UNIVERSIDADE DE SÃO PAULO

FACULDADE DE FILOSOFIA, LETRAS E CIÊNCIAS HUMANAS

DEPARTAMENTO DE HISTÓRIA

PROGRAMA DE PÓS-GRADUAÇÃO EM HISTÓRIA SOCIAL

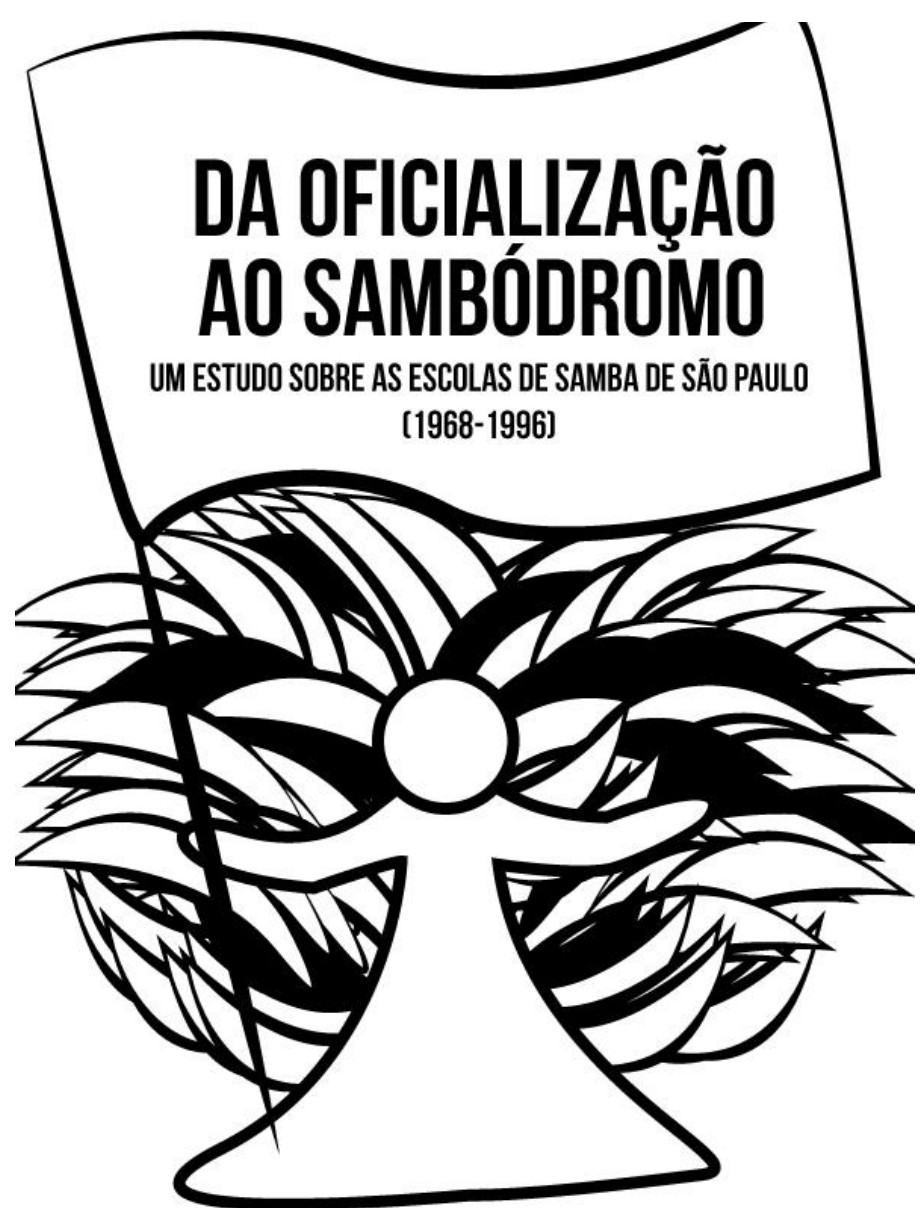

VERSÃO CORRIGIDA

São Paulo 
UNIVERSIDADE DE SÃO PAULO

FACULDADE DE FILOSOFIA, LETRAS E CIÊNCIAS HUMANAS

DEPARTAMENTO DE HISTÓRIA

PROGRAMA DE PÓS-GRADUAÇÃO EM HISTÓRIA SOCIAL

\title{
Da Oficialização ao Sambódromo: Um estudo sobre as escolas de samba de São Paulo (1968- 1996).
}

\begin{abstract}
Dissertação apresentada ao Programa de Pós-Graduação em História Social, da Faculdade de Filosofia, Letras e Ciências Humanas, da Universidade de São Paulo, como requisito para a obtenção do título de Mestre em História.
\end{abstract}

Orientador: Prof. Dr. Maurício Cardoso.

VERSÃO CORRIGIDA

São Paulo

2013 
Autorizo a reprodução e divulgação total ou parcial deste trabalho, por qualquer meio convencional ou eletrônico, para fins de estudo e pesquisa, desde que seja citada a fonte.

Catalogação da publicação

\section{BARONETTI, BRUNO SANCHES.}

Da Oficialização ao Sambódromo: Um estudo sobre as escolas de samba de São Paulo (1968-1996)/ Bruno Sanches Baronetti; orientador Maurício Cardoso. - São Paulo, 2013. 397 f;

Dissertação (Mestrado) - Universidade de São Paulo, 2013.

1. Carnaval; 2. Escolas de Samba; 3. Samba; 4. Cidade de São Paulo; 5. História Oral. 
Para Marcos dos Santos, Gabi, Dona China, Mestre Divino, Osvaldinho da Cuíca e Álvaro Casado, que viveram esta História. 
Samba-Enredo Camisa Verde e Branco (1982)

Achei uma bola de ferro

Preso a elos de corrente

Tinha um osso de canela

Deu tristeza em minha mente

Esse osso de canela

Veio de outro continente

De jeito nenhum

Não é preconceito

Negro ou branco tem direito

Nossa escola não faz distinção de cor

Pra falar sobre esse tema

Foi que surgiu o problema

E o dilema se avizinhou

$\hat{O} \hat{o} \hat{o}$, a nossa escola enaltece a negra gente

Que nunca ficou chorando

Sempre viveu cantando

Fingindo Contente

Negro paga imposto, negro vai à guerra

Negro ajudou a construir a nossa terra

Temos a pergunta não nos leve a mal

Por que só no tríduo de Momo que o negro é genial?

Ele é capitão, ele é general

Poderia ser tanta coisa

Dentro da vida real.

Talismã 


\section{Resumo}

\section{Da Oficialização ao Sambódromo. Um Estudo sobre as Escolas de Samba de São Paulo (1968-1996)}

Esta dissertação apresenta as principais transformações institucionais, estéticas e musicais das escolas de samba da cidade de São Paulo entre 1968 e 1996. O corte cronológico inicial se justifica a partir da oficialização do concurso de cordões carnavalescos e das escolas de samba pela prefeitura da cidade, em 1968, que introduziu novas regras que modificaram a estrutura dos desfiles, contribuindo para a extinção dos cordões nos bairros da cidade. Já o corte final é justificado pelas transformações ocorridas na década de 1990, quando os desfiles deixam o espaço público da rua e passam a acontecer em um espaço construído exclusivamente para esse fim, o Sambódromo. A pesquisa histórica se dá reconstruindo a atuação das duas principais federações carnavalescas da cidade de São Paulo: a União das Escolas de Samba Paulistanas (UESP), fundada em 1973 com o objetivo de reunir as escolas de samba e blocos carnavalescos e representá-las junto ao poder público, e a Liga Independente das Escolas de Samba de São Paulo (Liga), fundada em 1986 a partir de membros descontentes com a atuação da UESP e que representa as escolas de samba do Grupo Especial e Grupo de Acesso.

Palavras-Chave: Carnaval; Escolas de Samba; Cidade de São Paulo; História Oral; Imprensa da Cidade de São Paulo. 


\section{Abstract \\ From Formalization to the Sambadrome. A study about Samba Schools in São Paulo City (1968-1996)}

This master's degree dissertation presents the main institutional, aesthetic and musical changes of samba schools of São Paulo between 1968 and 1996. The initial chronological mark is justified starting from the official street carnival contests and samba schools organized by the City Hall in 1968, which introduced new rules that changed the structure of the parades and contributed to the extinction of the street carnival in city districts. The final period is presented by the changes occurred from 1991 on when the parades moved from street public space to an area built strategically for this purpose, the Sambadrome. The historical research is done assessing the performance of two main carnival representative institutions of São Paulo city: the UESP (Union of Paulistanas Samba Schools) founded in 1973 with the goal of bringing together the samba schools and the street carnival blocks and representing them before the government, and LIGA (Independent League of Samba Schools of São Paulo), which was founded in 1986 by members that were unhappy about the performance of the UESP, whose objective is to represent the samba schools of the Special Group and the Access Group.

Keywords: Carnival; Samba Schools; São Paulo City; Oral History; Press in São Paulo City. 


\section{AGRADECIMENTOS}

Quando se encerra uma dissertação, o pesquisador se depara com duas sensações: a primeira, de dever cumprido; a segunda, a de que agora que está começando a entender o seu objeto de pesquisa, deverá concluí-la. Apesar de aqui se encerrar uma etapa, o samba continua.

O decoro aconselha que a primeira menção de agradecimento seja dada ao Orientador. Tenho uma grande alegria de cumprir este preceito, não por dever, mas por prazer. Assim, agradeço profundamente ao Prof. Dr. Maurício Cardoso pela total confiança e paciência. O Professor Maurício apoiou e orientou com atenção intelectual, a direção deste trabalho. Foi um grande Mestre que aceitou o desafio de orientar este trabalho, mesmo quando fugia de sua área de especialidade, contribuindo sempre com ideias e pensamentos, além de ter acompanhado todas as reflexões de modo coerente e profissional.

Cabe agradecer, sem dúvida, ao CNPq, pelo financiamento na parte final da pesquisa, permitindo assim uma maior dedicação na redação da dissertação.

Também gostaria de mencionar o Professor Francisco Alambert (FFLCH-USP), historiador de notório saber e grande amigo que sempre me incentivou nas artes de Clio. Agradeço sua presença nesta banca de arguição. Ele também é responsável pelo sucesso deste trabalho, orientando e participando desde a gênese do projeto, durante a graduação.

À Professora Olga Rodrigues de Moraes von Simson, pela presença na banca de qualificação e na arguição de defesa, além de todo incentivo e ajuda dada durante toda a pesquisa, me recebendo por algumas vezes no LAHO e acompanhando as reflexões e o texto desta dissertação com uma atenção muito especial.

À Professora Maria Leda de Oliveira, pela presença na banca de qualificação e pela rigorosa leitura, que me ajudou na redação final da dissertação. 
O agradecimento mais que especial à minha família, em primeiro lugar, com muito orgulho, aos meus pais (Luvercy e Mariles), com quem posso contar em todas as horas. Obrigado mais uma vez pelo apoio, carinho e incentivo de toda uma vida. Agradeço também meu irmão Raul, meu grande amigo que tanto admiro, e a certeza de que sem o apoio incondicional, a compreensão e o amor de vocês eu nunca teria chegado até aqui.

À minha amada Karine, que tanto me ajudou neste trabalho, me incentivando desde o início. Sempre disposta a revisar os textos, ler o que eu havia escrito, a me acompanhar em entrevistas e pesquisa de campo, além de contribuir com ideias. Mas, acima de tudo, agradeço por ser uma grande companheira e amiga despertando tanta alegria e amor em minha vida.

À minha avó e madrinha, Adelina, que nutre amor, afeto e carinho por mim e ao meu avô Miguel (in memoriam), de quem tanto tenho orgulho e afeto, e que infelizmente não pôde ver este trabalho concluído.

À União das Escolas de Samba Paulistanas (UESP) e ao Centro de Documentação e Memória do Samba (CDMS), pelo apoio incondicional a esta pesquisa, por manter este precioso e importante acervo dedicado ao samba.

E em especial e que deveria vir em primeiro lugar, ao grande amigo e meu Mestre dentro do mundo do samba, Marcos dos Santos, pelas longas e animadas conversas sobre o samba e carnaval, me apresentando este maravilhoso universo com toda sua experiência e militância pelo samba de São Paulo. Sem seu apoio e parceria, me abrindo tantas portas, este trabalho nunca teria sido concluído. Obrigado, Mestre!

Ao grande compositor e sambista Adriano Bejar, que vive intensamente a paixão do Carnaval. Também agradeço ao Caio, Barroquinha, Nenê, Cíntia e a presidente Léia e ao presidente Kaxitu que sempre me acolheram com todo o carinho e afeto dentro da Matriz do Samba.

À Embaixada do Samba e a todos os "imortais" que me receberam com tanto carinho, dando preciosos depoimentos para este trabalho. Começo agradecendo ao 
maior mestre-sala e à maior porta-bandeira que já existiram no carnaval paulista, Mestre Gabi e Dona China, Embaixatriz Mestra, que me mostraram a elegância e a verdadeira magia do carnaval.

Também ao grande Mestre Divino que, com seu apito e com sua batucada, faz nossos corações baterem mais forte. Ao Osvaldinho da Cuíca e Álvaro Casado que abriram as portas de suas casas para mim, concederam importantes entrevistas e deram permissão para revirar seus arquivos.

Quero agradecer agora a todos os amigos e parentes que também foram importantes neste percurso.

À minha prima Tati, grande educadora e amiga de todas as horas, que durante toda a vida me apoiou e incentivou. À minha tia Lourdes pelo carinho e apoio de todos os dias, ao meu primo Paulo Henrique (in memoriam), que Deus levou tão cedo e que também não pôde ver este trabalho concluído.

Ao Francisco, meu primo, mas na verdade um grande tio e irmão e a querida Dorcas, por todo apoio e carinho. Agradeço por estarem presentes nos momentos mais importantes da minha vida.

Ao grande amigo Guto e a grande amiga Cássia pela grande amizade e vivência fraterna de mais de dez anos. E agradecer aos meus queridos amigos e amigas, Juliano, Danilo, Gabriel, Cleber, Maria Inez, Renata, Laura, Amelina e Caroline que sempre depositaram tanta confiança em mim e que também acompanharam este trabalho.

Ao querido amigo Marcus Baccega, companheiro de mística e perfeito cristão na vivência das virtudes teologais (fé, esperança e caridade), grande incentivador do meu trabalho, com quem aprendi muito nestes anos de diálogo, amizade e militância em prol da Teologia da Libertação, na luta por um mundo mais justo e fraterno.

À minha amiga Lígia Conti, companheira de pesquisa e também apaixonada pelo universo das escolas de samba, que também tanto contribuiu para este trabalho, 
pelos toques, dicas e parceria nas entrevistas. Espero que esta tabelinha renda mais frutos, contribuindo para contar esta história tão importante para a vida social do país.

Aos amigos Benito, Thomas e Roberta companheiros de militância política e de gosto pela cultura popular.

À Dona Silvânia e ao Seu Boero que me alegram com sua convivência e que me recebem como se fosse um filho.

Aos amigos da Rádio Juventude, Euzébio Jorge, Larissa Miho, Edson Figueiredo, Bruno Varoli e João pelo apoio e suporte na realização do programa "A hora e a vez do Samba”.

Ao amigo Paulo, grande conhecedor de cultura popular, músico, poeta, com quem tenho sempre ótimas conversas e que tanto ajudou indicando livros para esta pesquisa.

Aos amigos professores dos colégios por onde passei desde o início da dissertação: E.E. Nossa Senhora Aparecida, Santo Antônio de Lisboa, João e Raphael Passalácqua e São Vicente de Paulo.

Durante o tempo em que estive desenvolvendo este trabalho, tive o apoio e a colaboração de muitas pessoas, e infelizmente se torna impossível mencionar aqui todos os nomes. A todos estes minhas sinceras desculpas e meus agradecimentos.

E agradeço a Deus por mais esta graça e por ter permitido que eu chegasse até aqui. 


\section{SUMÁRIO}

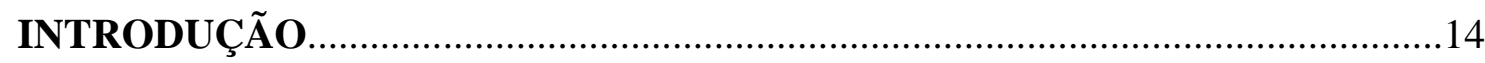

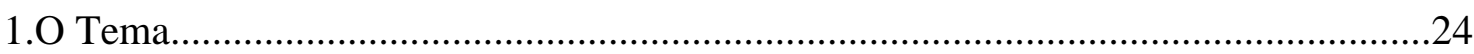

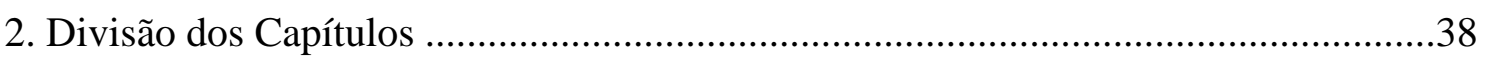

I. AS TRANSFORMAÇÕES INSTITUCIONAIS DAS ESCOLAS DE SAMBA DA

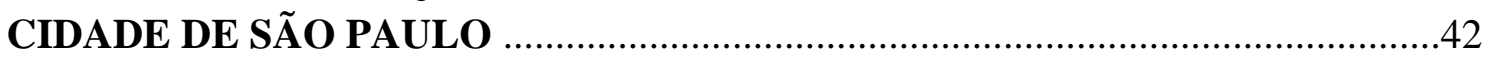

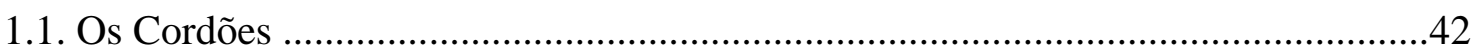

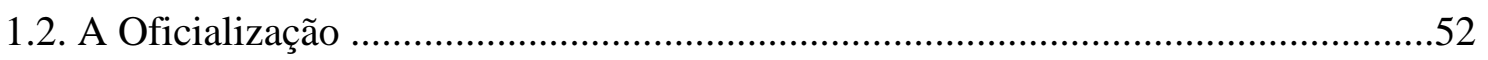

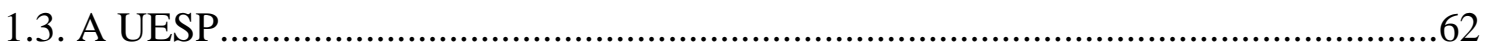

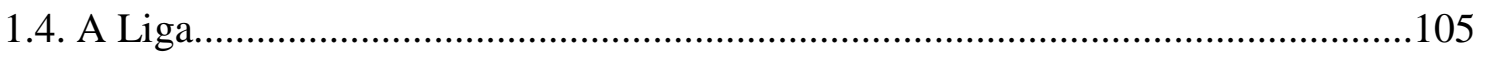

II. AS TRANSFORMAÇÕES ESTÉTICAS NO DESFILE DAS ESCOLAS DE SAMBA DA CIDADE DE SÃO PAULO ......................................................117

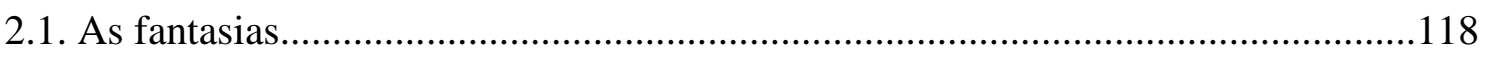

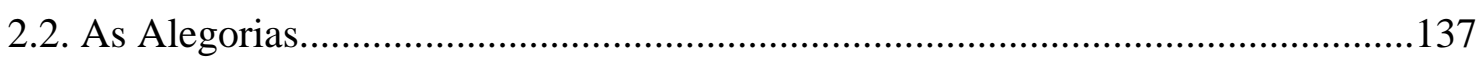

2.3. O Samba- Enredo (transformações musicais)..................................................143

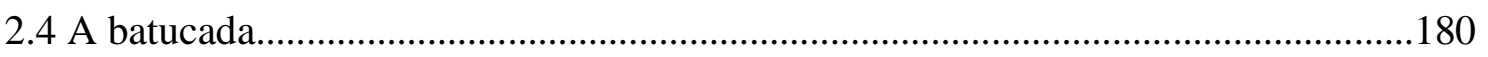

III. A CRIAÇÃO DO SAMBÓDORMO E AS TRANSMISSÕES

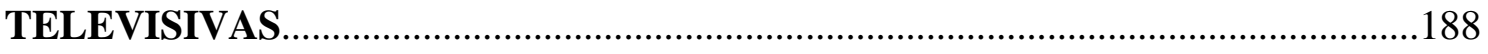

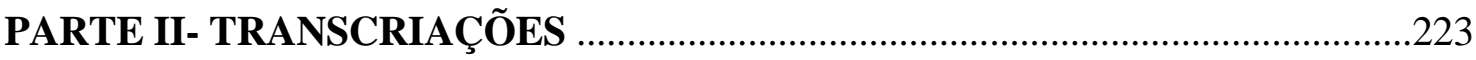

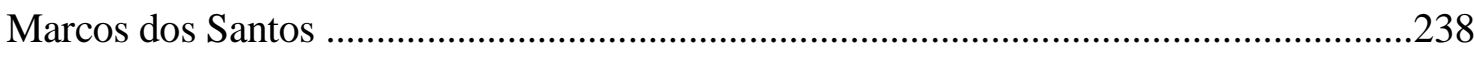

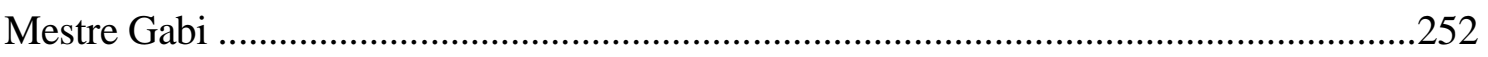




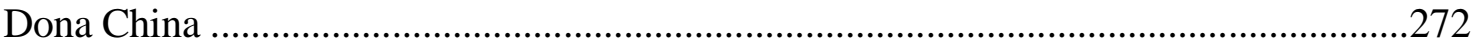

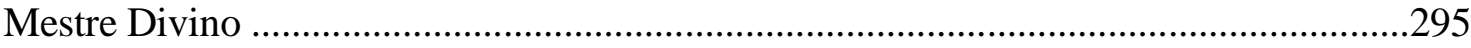

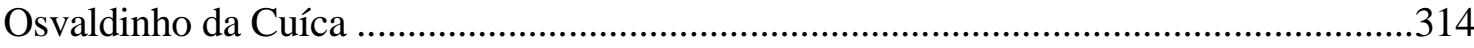

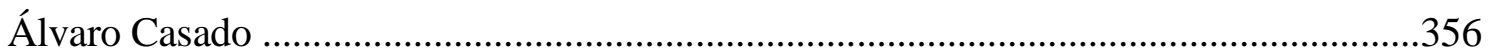

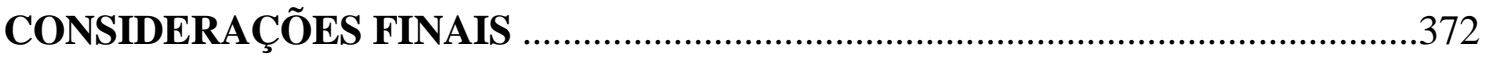

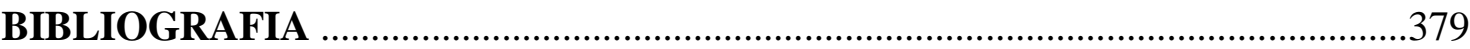

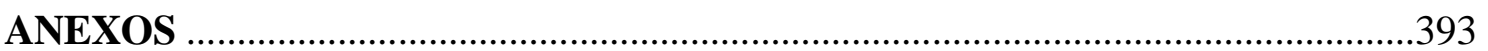




\section{INTRODUÇÃO}

A escolha de pesquisar as escolas de samba de São Paulo ocorreu por razões de ordem pessoal e historiográfica. Pessoal pelo fato de eu ser paulistano, ser simpatizante e participar do universo mágico das escolas de samba de São Paulo. O meu contato com a música popular vem desde a infância, quando ficava prestando atenção nas tristes letras das modas de viola escutadas por meu pai. Já com o universo das escolas de samba começou como espectador também na infância, quando eu ficava acordado até tarde da noite para assistir pela televisão aos desfiles das escolas de samba. Normalmente assistia apenas algumas escolas e dormia durante a apresentação das outras.

Este contato de espectador se modificou já na adolescência, quando fui pela primeira vez a uma quadra de escola de samba e vi o quanto a comunidade se esforçava para a realização dos desfiles e o quanto era animado o ensaio da escola. No ano de 2005, já como estudante do curso de História, assisti a uma reportagem televisiva que narrava algumas das atividades promovidas pela União das Escolas de Samba Paulistanas (UESP) no Dia Nacional do Samba, dia dois de dezembro, e que contava com a presença da Embaixada do Samba e de diversos membros das Velhas Guardas. Por causa da reportagem fiquei sabendo que a UESP possuía um acervo e que este era aberto ao público. Como eu morava na mesma rua em que está localizada a UESP, alguns dias depois, decidi conhecer a entidade.

Já estava próximo do Natal e o efetivo da UESP estava empenhado em organizar o carnaval, não pude ter acesso ao acervo. Após o carnaval de 2006, retornei à entidade e fui muito bem recebido por todos seus funcionários. Conheci então o acervo e percebi que havia muito a pesquisar sobre o tema. Comecei a pesquisar bibliografia a respeito do carnaval, inclusive lendo livros que estavam disponíveis na própria entidade. Após escrever um pequeno projeto que abarcava a história dos cordões carnavalescos e a passagem deles para escolas de samba, procurei o Prof. Dr. Francisco Alambert, de quem havia sido aluno do curso de História Social da Arte. Ele prontamente aceitou me 
orientar e muito contribuiu para o desenvolvimento de minha Iniciação Científica, que abordou aspectos estéticos dos desfiles carnavalescos na cidade de São Paulo.

Em 2007, fui convidado por Marcos dos Santos para realizar o curso de formação de jurados carnavalescos promovido pela UESP. Desde o ano seguinte sou membro do corpo de jurados da entidade, atuando como jurado dos desfiles oficiais da Prefeitura de São Paulo em diversas cidades do interior e nos desfiles realizados pela UESP, presenciando, desta maneira, um pouco, as tensões vivenciadas por esses dirigentes e sambistas dentro do carnaval paulistano; portanto, a motivação se deu pela necessidade de entender essas relações entre o poder público e as escolas de samba e como isso contribui para mudanças dentro do universo das agremiações, sejam elas comportamentais, organizacionais, ou mesmo estético-musicais.

Ao iniciar a pesquisa, visitei diversas escolas de samba, conversei com muitos membros das escolas e percebi que muitos deles estavam desiludidos com o carnaval atual, principalmente os membros das Velhas Guardas das escolas. Ao conversar com eles, percebi que eles eram fonte indispensável para minha reflexão sobre a história dos folguedos carnavalescos na cidade, visto que a memória coletiva e a trajetória desses velhos sambistas traziam novos elementos para a minha interpretação das relações entre o carnaval e o poder público, restando, ainda, muitas lacunas a serem percorridas para traçar a história das agremiações carnavalescas paulistanas.

O Brasil é tradicionalmente conhecido como o país do carnaval. Todo ano milhões de reais saem dos cofres públicos para o patrocínio de festas por todo o território nacional. São trios elétricos, desfiles de blocos, festas, bailes e a parte mais conhecida, tanto dentro como fora do país, que é o desfile das escolas de samba. A cada ano, um novo espetáculo é apresentado à sociedade brasileira. A modalidade dos desfiles das escolas de samba surgiu no Rio de Janeiro e aos poucos se tornou hegemônica em todo o Brasil (LEOPOLDI, 2009). A cada fevereiro, sempre surge a mesma pergunta: qual será a próxima inovação ou mistério que será revelado na avenida? Milhões de reais são gastos em um espetáculo que dura pouco mais de uma hora (tempo médio de desfile de uma escola de samba). 
Em um país com tantas carências em áreas essenciais como educação, saúde, transporte, infraestrutura, segurança e moradia, dentre outras, por que investir milhões de reais em uma festa? A pergunta é ainda mais pertinente por se tratar de dinheiro público.

No ano de 2012, a Prefeitura de São Paulo investiu mais de R 23 milhões de reais nos desfiles das escolas de samba (O ESTADO DE SÃO PAULO, 25/02/2012). Durante a apuração, um componente de uma escola de samba, inconformado com as notas dadas pelos jurados do concurso à sua escola, invadiu o local de apuração e rasgou as notas, sendo preso pouco tempo depois. Outro integrante de uma escola de samba ligada a uma torcida de futebol também foi preso, incitando um tumulto que resultou em um incêndio e depredação do Sambódromo. Para o público em geral, que não conhece as rivalidades e tensões que cercam uma apuração de desfile, fica sempre a pergunta: por que tanta violência empregada na definição do campeão de uma festa cujo objetivo inicial é o divertimento, a satisfação pessoal, a inversão de papéis?

O espetáculo dos desfiles promovido e patrocinado pela Prefeitura é uma competição entre as escolas, um concurso com premiação para as escolas vencedoras e punição para as escolas que não se enquadraram nos parâmetros de julgamento estabelecidos pelo regulamento, sendo, portanto, rebaixadas para um grupo com menor visibilidade, recebendo um prêmio muito menor em dinheiro. Logo, nenhuma escola quer perder, pois isso não se resume a uma questão de prestigio e visibilidade, mas principalmente financeira. Historicamente, durante várias apurações ocorreram discussões, brigas e tentativas de se impedir a leitura de nota. Mas, pela primeira vez, houve a retirada das notas das mãos do locutor oficial e depredações aos troféus e incêndio a carros alegóricos de escolas coirmãs.

Diante desse cenário em que são gastos anualmente milhões de reais de verbas públicas nos desfiles, transformando uma atividade de lazer em algo cercado de polêmicas, rivalidade, competição e até mesmo violência, nos parece fundamental entender como se deram as relações entre o Estado e as escolas de samba. O corte cronológico inicial da pesquisa se justifica, pois os desfiles das escolas de samba se tornam a forma hegemônica de se brincar carnaval na cidade de São Paulo, justamente a 
partir do momento em que se inicia uma relação permanente entre as escolas de samba e a Prefeitura de São Paulo, através da oficialização dos desfiles promovida pelas autoridades municipais já ocorrida em 1968, introduzindo novas regras que modificaram a estrutura dos desfiles.

Ao longo dos capítulos da dissertação, a pesquisa busca reconstruir as relações e as tensões entre o poder público e as escolas de samba. Essa relação não é feita de maneira direta, com o Estado negociando diretamente com as escolas de samba, mas através das federações carnavalescas, que são entidades civis que representam as escolas de samba nessas negociações. Mapeamos as grandes mudanças nos desfiles das escolas de samba na cidade de São Paulo a partir de 1968, tanto na perspectiva institucional (organização), quanto nas dimensões estéticas e musicais.

O corte cronológico final se dá em 1996, pois, a partir dessa data, julgamos que não houve transformações e mudanças significativas, sejam elas de ordem institucional, no relacionamento entre Estado e escolas de samba, sejam de ordem estética e musical. Ao assistirmos o famoso desfile da torcida organizada e escola de samba Gaviões da Fiel, de 1995, ou o da Vai-Vai, de 1996, percebemos claramente como a organização e a disposição das alas permanecem as mesmas; as fantasias e alegorias, feitas com o mesmo padrão estético e utilizando os mesmos materiais e os sambas-enredos seguindo as mesmas estruturas de divisão e o mesmo padrão rítmico, com as baterias mantendo as mesmas configurações de naipes de instrumentos.

Ao analisarmos essas mudanças percebemos que elas estão interligadas, fazendo com que surjam outras questões. Na produção bibliográfica de quem se dedicou ao tema, como Urbano (1987 e 2006), Rodrigues (1984), Queiroz (1992), dentre outros e também no discurso dos sambistas ligado às escolas de samba, principalmente os da Velha Guarda, percebe-se que as escolas sofreram um processo de “embranquecimento". O segmento negro, realizador histórico dos desfiles das escolas de samba perdeu espaço para novos dirigentes, ligados à classe média, que estabeleceram novas relações das escolas com o Estado, com empresários e patrocinadores e com o público em geral, abrindo o espaço das escolas de samba para demandas de políticos e empresas interessados em associar suas marcas às escolas. 
Outro ponto de confluência dos trabalhos acadêmicos sobre as escolas de samba é a "espetacularização" dos desfiles após a implantação das transmissões televisivas, o que levou as diretorias das escolas de samba a um comportamento "empresarial", que tem de lidar com várias questões, como patrocínios, financiamentos e subvenções de dinheiro público. Boa parte da bibliografia corrente e das narrativas registradas em áudio de sambistas históricos sugere que as mudanças foram todas impostas pelo Estado e pela indústria cultural, sem negociação, "de cima para baixo", para impor às escolas um modelo lucrativo de turismo e entretenimento, determinando assim a produção e realização dos desfiles. Essa perspectiva ignora que concessões e negociações foram feitas com a participação ativa das escolas, através das federações e dos diversos mediadores envolvidos no processo.

Existem estudos que relativizam este processo ao procurarem entender, de forma mais ampla, as relações sociais dentro e fora das escolas de samba, contribuindo com análises que se voltam a questões como solidariedade e gênero (OLIVEIRA, 2002), resistência (SIMSON, 1989 e 2006 e SOARES, 1999), trabalho e lazer (BLASS, 2007) e também as relações com o poder público e empresas (AZEVEDO, 2010). A importância desses estudos é fundamental para a presente pesquisa, pois eles permitem entender que as relações sociais envolvendo o Estado e as escolas de samba são mais complexas. No entanto, ainda não estão claros vários vetores dessas mudanças, sendo muitas delas listadas como naturais, como se mudanças estético-musicais, dentro dos desfiles das escolas de samba nos últimos quarenta anos, fossem uma evolução do carnaval. Algumas indagações nesse sentido são importantes. Essas mudanças são reflexos das mudanças institucionais dos desfiles? Ou, ao contrário, as mudanças estéticas, como um maior número de integrantes, fantasias e carros alegóricos mais luxuosos, atraíram uma maior atenção para os desfiles da capital paulista, sendo necessárias mudanças de ordem institucional para acompanhá-las, como o Sambódromo, por exemplo. Foi o crescimento do carnaval de São Paulo que gerou uma demanda para um espaço construído exclusivamente para esse fim, dentro da cidade, com investimento e manutenção do poder público? Ou, mais uma vez, procurou-se imitar um modelo externo, como o do Rio de Janeiro, ao construir um Sambódromo que 
permitisse a aplicação de um modelo, que já estava vigente lá, nas escolas da capital paulista? Qual o papel e a posição dos sambistas e dos dirigentes das escolas de samba que vivenciaram esse projeto? E qual o discurso que eles produzem a respeito?

A hipótese dessa pesquisa é o processo de oficialização do Carnaval que se constituiu por uma trama complexa de negociações entre o poder público e os agentes sociais envolvidos. Em outras palavras, a oficialização não ocorreu nem de "de cima para baixo", como se o Estado fosse uma instituição monolítica, desprovida de tensões, nem de "baixo para cima", como se os sambistas pudessem impor a sua agenda cultural ao Estado. Entendemos que apesar das tensões e diferentes interesses em jogo, foi um conjunto de demandas e interesses comuns que conduziram à normatização do desfile de Carnaval. Ao longo do trabalho, por meio da análise documental e bibliográfica e também através das entrevistas dos sambistas, procuramos defender que as transformações pelas quais os desfiles das escolas de samba da cidade de São Paulo passaram, entre 1968 e 1996, foi o resultado da reflexão conjunta e da negociação envolvendo de início os sambistas e o Estado e, posteriormente, a indústria cultural.

Um exemplo nítido da complexidade das relações entre o Estado, a indústria cultural e os sambistas é o do sambista Geraldo Filme, um dos maiores expoentes do carnaval paulistano, defensor das tradições do samba rural paulista e dos cordões carnavalescos e liderança do movimento negro. Filme esteve presente em todos os lados. Como sambista e líder do movimento negro, como dirigente de escola de samba (Unidos do Peruche e Vai-Vai), presidente de escola de samba (Paulistano da Glória) e também foi coordenador da Coligação das Escolas de Samba e presidente da UESP entre 1977 e 1979, sendo um dos responsáveis por fechar os contratos que mudou os locais dos desfiles, os quais eram historicamente, eram realizados no centro da cidade e foram para a Avenida Tiradentes, local que, até então, nunca recebera os desfiles ${ }^{1}$.

Nas décadas de 1980 e 1990, Geraldo Filme esteve do "outro lado", como funcionário da Anhembi Turismo (atual SP Turis), empresa ligada à Secretaria de Turismo, responsável por organizar o carnaval da cidade de São Paulo, em parceria com

\footnotetext{
${ }^{1}$ Documentos de reunião administrativa da UESP em 1977. Disponível no Centro de Documentação e Memória do Samba da União das Escolas de Samba Paulistanas (CDMS-UESP).
} 
as empresas patrocinadoras e os sambistas da Liga e da UESP. Sua atuação na Anhembi era na parte de coordenação de carnaval, ou seja, participar das negociações com as entidades carnavalescas, mais especificamente no setor de fiscalização, encarregado de monitorar e avaliar se as escolas cumpriam à risca o regulamento que ele próprio tanto criticava enquanto sambista.

Estas relações ambivalentes ou até mesmo contraditórias de Geraldo Filme são a tônica do comportamento dos dirigentes negros das escolas de samba, a partir da oficialização dos desfiles em 1968. Com a "tomada" da principal expressão cultural dos segmentos negros e pardos pobres da cidade, por pessoas ligadas às classes médias e altas, nos anos 1980 e 1990 as relações se dão, de uma maneira mais clara, "de cima para baixo", contudo não com a imposição do poder público, mas de demandas vindas dos patrocinadores e da indústria cultural televisiva que passam a ver o carnaval paulistano como uma possibilidade de investimento e lucros financeiros. Essa pressão financeira que culminou em uma divisão entre as escolas de samba em duas federações (Liga e UESP) e levou o poder público a necessidade de tirar o carnaval do espaço público e confiná-lo em um espaço fechado e monitorado, longe da agitação e da vivência democrática das ruas, para gerar lucros e consumir o carnaval como mercadoria e mera diversão e não como um espaço legítimo que os negros e pobres encontraram historicamente ocupando o espaço público das ruas, sempre negado pelas classes dominantes.

Para compreender satisfatoriamente os itens mencionados acima, a pesquisa se deu a partir de documentos produzidos pelas próprias instituições pesquisadas e a partir de depoimentos de dirigentes das duas federações de carnaval que atuaram no período, além da análise da produção bibliográfica sobre o tema do carnaval e das escolas de samba.

As fontes primárias de documentação utilizadas foram as Fichas Técnicas do Carnaval Paulistano, disponíveis no Centro de Documentação e Memória do Samba ${ }^{2}$. Estas fichas e os dados técnicos estabelecem um panorama a respeito dos desfiles dos

\footnotetext{
${ }^{2}$ Centro de Documentação ligado à UESP, localizada à Rua Rui Barbosa, nº588, na cidade de São PauloSP.
} 
blocos e escolas de samba de São Paulo. Suas principais informações são: a) nome das agremiações que desfilaram; b) número de componentes; c) horário do desfile; d) notas dos jurados e justificativa; e) enredo e letra do samba das principais escolas e blocos; e) croquis das alegorias; f) documentos burocráticos como atas de reuniões, fax entre a UESP e as escolas; g) depoimentos de sambistas.

As fichas técnicas estão disponíveis com interrupções. Há fichas dos seguintes anos: de 1969 a 1975 e de 1977 até 1990.

Para compreender o período a partir de 1990, são utilizados os arquivos da empresa que administra o carnaval paulistano, a Anhembi Turismo e Eventos da Cidade de São Paulo, hoje SP Turis. Os documentos da Anhembi nos permitem compreender as principais alterações ocorridas no Sambódromo no período estudado, no que tange a obras físicas, regimentos administrativos e mudanças de gestão da empresa que é a responsável por organizar o carnaval da cidade.

O último recurso de fonte primária utilizado na pesquisa e o mais importante para a reconstituição histórica proposta na pesquisa é o depoimento oral, isto é, a realização de entrevistas gravadas com pessoas que viveram ou testemunharam acontecimentos referentes ao universo das escolas de samba. Apesar do grande volume de documentação impressa sobre o carnaval de São Paulo, uma grande parte das consequências das relações entre as agremiações carnavalescas e o poder público municipal nos quase trinta anos que a pesquisa abrange só é possível de serem compreendidas a partir das entrevistas.

Constitui-se como grupo de pesquisa personagens do mundo do samba que participaram desse momento de transição dos cordões para escola de samba e da oficialização do carnaval e que aturaram como dirigentes das federações e das escolas, mas já falecidos; utilizamos os depoimentos colhidos na década de 1980 com o auxílio da equipe do Museu da Imagem e do Som (MIS), pela $\operatorname{Prof}^{\mathrm{a}} \operatorname{Dr}^{\mathrm{a}}$ Olga Rodrigues de Moraes von Simson, cujas transcrições estão localizadas no Laboratório de História Oral da Universidade Estadual de Campinas (LAHO-Unicamp). 


\section{O Tema}

Até o final da década de 1960, os estudos sobre carnaval e outras festas estavam reclusos às pesquisas dos folcloristas, sendo o tema pouco estudado, dentro do âmbito acadêmico.

A partir da década de 1970, os estudos sobre as escolas de samba ganharam cada vez mais força dentro da academia, principalmente dentro das ciências humanas. Sejam pesquisas no âmbito da historiografia, buscando a reconstituição dos folguedos e atores envolvidos; antropológico, nas relações entre seus participantes; sociológico, investigando as transformações e a posterior mercantilização e descaracterização das escolas de samba; estético-visual, analisando as fantasias e alegorias, materiais utilizados e o crescimento vertical do carnaval; linguístico, focado na temática dos sambas-enredos; dos estudos do corpo, visualizando as mudanças e permanências do samba, enquanto dança, dentro dos desfiles; da musicologia, dedicada às questões estético-musicais da bateria e sambas-enredos das escolas de samba. A relevância desses estudos dentro de diversos campos da pesquisa científica revela as múltiplas faces das manifestações ligadas à festa carnavalesca dentro da cultura brasileira.

Um dos primeiros teóricos a estudar a festa carnavalesca e fonte de inspiração para muitos outros trabalhos é o linguista russo Mikhail Bakhtin, cujo livro A Cultura Popular na Idade Média e no Renascimento: o contexto de Rabelais (1941) analisa a festa para entender o universo do escritor francês François Rabelais, do século XVI. Para isso, teceu importantes reflexões sobre o carnaval. Para Bakhtin, os festejos do carnaval, com todos os atos e ritos cômicos que a ele se ligam, ocupavam um lugar muito importante na vida do homem medieval. Esses ritos ofereceriam uma visão do mundo, do homem e das relações humanas totalmente diferentes, deliberadamente não oficial, exterior à Igreja e ao Estado. Durante a festa, os homens da Idade Média pareciam construir, ao lado do mundo oficial, católico e estamental, cheio de regras, um segundo mundo e uma segunda vida aos quais pertenciam em maior ou menor proporção, e no qual eles viviam em ocasiões determinadas. Isso criava uma espécie de 
dualidade de mundos, o mundo real e um mundo de aspirações ideais que vigorava apenas quatro dias, mas muito importante, pois, sem levá-lo em consideração, não se poderia compreender nem a consciência cultural da Idade Média nem a civilização renascentista. Como aponta Bakhtin, essas aspirações:

\footnotetext{
Estão mais relacionadas às formas artísticas e animadas por imagens, ou seja, às formas do espetáculo teatral. E é verdade que as formas do espetáculo teatral na Idade Média se aproximavam na essência dos carnavais populares, dos quais constituíam até certo ponto uma parte. Ele se situa na fronteira entre a arte e a vida (BAKHTIN, 2000, p. 3-4, grifo nosso).
}

As festas, para o escritor russo, são anseios de mundos ideais e de aspirações da sociedade humana, fugindo do rigor e das hierarquias da vida cotidiana. Elas seriam também um instrumento lírico e épico para os grupos participantes e funcionaria como um instrumento de ação, possivelmente de mudança para a sociedade em seu conjunto. É um momento à parte que se realiza de forma mais completa nas festas populares e públicas, como o carnaval. No espírito carnavalesco original, as hierarquias sociais são abolidas momentaneamente, e os participantes penetram num "mundo à parte", utópico, regido pela liberdade, pelos excessos e pela abundância, com uma inversão dos padrões sociais (BAKHTIN, 2000, p. 5 e 6).

Para o filósofo russo, o carnaval, em sua essência, ignora toda distinção entre atores e espectadores, já que neste evento todos seriam iguais, pois participam e se divertem da mesma forma. Também ignora o palco, mesmo na forma embrionária. Os espectadores não assistem ao carnaval, eles o vivem, uma vez que o carnaval, pela sua própria natureza, existe para todo o povo. Durante o período em que a festa está vigente, deve-se viver pela sua lei, que é a liberdade. O carnaval está associado ao tempo, pois ele representa a ideia de um retorno efetivo e completo (embora provisório) ao Éden, convertendo-se em uma segunda vida das camadas menos favorecidas do povo, penetrando temporariamente a sua entrada em um reino utópico da universalidade, liberdade, igualdade e abundância, contrastando com a exploração, desigualdade e carestia da realidade (BAKHTIN, 2000, p. 6 e 7). 
Apesar de o carnaval contemporâneo ser completamente diferente da festa realizada no final da Idade Média, objeto de estudo de Bakhtin, mas suas reflexões continuam sendo chave importante para se entender os diversos domínios da vida e da cultura. Hoje, no Brasil, existem duas modalidades de carnaval: o carnaval participativo, realizados em pequenas cidades do país e nas grandes cidades do Nordeste. O primeiro tipo se aproximaria um pouco mais da ideia de carnaval descrita por Bakhtin, pois os foliões participam efetivamente da festa, ocupando as ruas e se divertindo sem qualquer preocupação e organização de moldes competitivos. No entanto, um fenômeno recente que revela que a indústria cultural já se apropriou deste tipo de brincadeira de Momo é o dos chamados "abadás". É a cobrança de ingressos para as pessoas ocuparem locais públicos perto dos trios elétricos que conduzem a festa. Aqueles que compram os "abadás" ficam em um espaço separado, normalmente por cordas ou tapumes e vigiado por seguranças que impedem aqueles que não pagaram de se aproximar. Neste carnaval participação, vigente nos dias de hoje os que não possuem os "abadás" são chamados de foliões "pipoca" e acompanham, de longe, os cantores que animam a festa, ou vão "pipocando" em vários pontos da cidade para se divertir. Há ainda uma tímida reação iniciada na década de 2010 por parte de foliões na cidade de São Paulo que formam blocos para desfilar sem nenhuma preocupação, regra ou interdição e ocupam as ruas da cidade durante o carnaval. No ano de 2014, passaram a receber apoio por parte da Prefeitura, que envia banheiros químicos e acompanha com carros da CET (Companhia de Engenharia de Tráfego) o cortejo do bloco.

O carnaval das escolas de samba, realizado principalmente nas grandes metrópoles, como São Paulo e Rio de Janeiro, é uma modalidade de carnaval espetáculo. Esta modalidade não se configura como uma festa, mas como uma competição, com ganhadores e perdedores. Os participantes se dividem em dois tipos: atores e espectadores. Os atores são aqueles que se fantasiam e desfilam por suas escolas, cujo objetivo é sagrar-se campeã. Os espectadores, maior parte dos envolvidos, não participam de fato dos desfiles, apenas assistem e admiram o espetáculo. Tal modalidade de carnaval é a maior contradição de uma festa que originalmente representaria uma fuga utópica e provisória da vida cotidiana, como aponta Bakhtin. 
Um dos primeiros trabalhos do campo historiográfico sobre o tema foi escrito por Emmanuel Le Roy Ladurie, no livro O carnaval de Romans: da Candelária à Quarta-Feira de Cinzas 1579-1580. Publicado em 1979, a obra analisa o carnaval francês de Romans no século XVI. Ladurie inicia o texto com o carnaval de 1580, que se transformou em um massacre entre os habitantes do povoado, num contexto de lutas entre os católicos e os protestantes, a insatisfação contra a cobrança de impostos e a nobreza.

Para Le Roy Ladurie, o carnaval estaria no tempo cristão e corresponderia à última festa do calendário cristão, antes da Quaresma, período de penitência e abstinência (alimentar, sexual), culminando na festa da Ressurreição na Páscoa, que tem um significado de renascimento espiritual. O carnaval, assim, é visto como uma antítese da Quaresma, já que exalta o pecado, a gula, a lubricidade, a comezaina (preço invertido dos alimentos); ele permite que certos rituais anteriores ao cristianismo sejam resgatados, vividos e, posteriormente, negados. Para ele, a festa carnavalesca concebida dentro do ideário cristão católico busca "enterrar sua vida de pagão, entregar-se a um último desregramento paganizante, antes de penetrar nos tempos da ascese quadragesimal do catecúmeno, o qual conhecerá enfim na Páscoa, seu renascimento batismal e espiritual" (LADURIE, 2000, p. 320). Na medida em que quer "enterrar sua vida de pagão", a festa produz diretamente alguns ritos anteriores ao cristianismo que foram amalgamadas ao catolicismo quando da cristianização das áreas rurais da Europa, durante o primeiro milênio, em um processo de bricolagem cultural. Os ritos pagãos enterrados seriam especialmente as saturnais romanas, "as mascaradas animais e fustigações das lupercais, a cavalgada do asno, etc.” (LADURIE, 2000, p. 323-324).

O historiador francês enxerga o cristianismo como uma religião que tem como mito fundador da condição histórica da humanidade o pecado humano (a descida do Éden) e que se apropriou de certos ritos pagãos, tendo-os assimilado e os modificado. O carnaval de Romãs, bem como durante as festividades desenvolvidas pelos negros do Estado de São Paulo, no final do século XIX e início do século XX, situam-se no tempo cíclico dos rituais da Igreja Católica. Com o sincretismo, devoções, procissões e missas 
dedicadas aos santos da Igreja Católica foram amalgamadas com ritos folclóricos foram ligados à cultura popular.

Para além da problemática religiosa, o carnaval também é visto por Ladurie como ligado ao contexto agrícola, com raízes anteriores ao cristianismo. O carnaval seria a festa que representa o fim do inverno, fundamental para uma civilização ainda dependente da agricultura, trazendo esperanças de uma colheita melhor, capaz de proporcionar uma melhor alimentação durante o ano (LADURIE, 2000).

O ponto em que os dois autores se aproximam é de o princípio da festa carnavalesca ser uma permanência na história da humanidade. No carnaval, segundo Bakhtin, os valores da sociedade são invertidos, e, para Ladurie, tudo o que era usualmente reprimido pela Igreja torna-se permitido. Depois deste período de liberdade, segue-se a Quaresma, época de contenção e penitência. Com propriedade, o historiador Jacques Le Goff, parafraseando Bakhtin, afirma que "a civilização do Ocidente medieval é, no nível do símbolo, o fruto da tensão entre Quaresma e Carnaval" (LE GOFF, 2006, p. 60). De fato, a celebração do corpo e da carne se materializa no Carnaval, prática que se mantém e a enriquece.

$\mathrm{Na}$ antiga província francesa do Delfinado, na Savoia, o animal símbolo da festa era o urso. $\mathrm{O}$ animal anunciava o fim da estação mais fria, e tinha uma função de previsão: se ele retornasse para a sua toca, era sinal de que a estação fria deveria continuar por mais quarenta dias, para, então, começar o degelo e instaurar-se a primavera, símbolo da retomada da vida. Nos Pirineus, o urso Candelária-Carnaval era um ladrão de carneiros e, ao final da festa, é simulado o seu fuzilamento, para proteger simbolicamente os rebanhos (LADURIE, 2000, p. 325). Esta é uma tradição cíclica, sendo repetida todos os anos. A fantasia de urso é utilizada ainda hoje, e confeccionada com lã grossa ou peles de animais. Apesar de sua origem longínqua, a figura do urso está viva no carnaval brasileiro, principalmente em Recife, pois foi trazida por ciganos oriundos da Europa que dançavam de porta em porta, em troca de algumas moedas. Os ursos do carnaval de Recife são grupos de foliões que saem as ruas geralmente com um ou dois homens vestindo um velho macacão coberto de estopa, veludo, pelúcia ou agave com sua máscara de papel-machê pintada de cores variadas, preso por uma corda na 
cintura, segurado por outro que tem o papel simbólico de domador. O homem vestido de urso dança para alegria de todos ao som de músicas elaboradas pelos próprios grupos ou marchas carnavalescas, cujo ritmo pode variar entre baião, forró, xote e até polca. A parte instrumental do grupo, conhecida como "Orquestra do Urso", é geralmente formada por sanfona, triângulo, bombo, reco-reco, ganzá, pandeiro; há outras orquestras mais elaboradas, nas quais aparecem instrumentos de corda ou sopro, como violões, cavaquinhos, clarinetes e até trombones. O conjunto traz, por vezes, além do domador, do urso e da orquestra, o tesoureiro (com sua pasta de arrecadar dinheiro, uma espécie de "livro de ouro"), uma mulher como porta-cartaz ou porta-estandarte, balizas munidas de batutas de madeira e muitos foliões que acompanham e estão lá apenas para brincar o carnaval.

Julio Caro Baroja também se debruça sobre diversas manifestações carnavalescas europeias, como os "guirrios" da região das Astúrias e o próprio carnaval de Romans. Para o folclorista espanhol, o carnaval possui duas funções - uma função de ritual agrícola e biológico e uma utilidade social:

local:

O objetivo do Carnaval é assegurar o bom andamento da sociedade

1) Pela expulsão do mal (biológico, social ou pecaminosoanticristão) fora das fronteiras, na véspera da quaresma definitivamente purificadora;

2) Por reproduções do andamento normal da vida humana, obtida graças às figurações encadeadas do nascimento, da copulação, da morte e do renascimento (vejam-se os fantasmas canibalescos de Romans, que não são apenas uma ameaça em relação aos ricos, mas também um fantasma de transubstanciação);

3) Por imitações de trabalhos agrícolas ou outros, essenciais à sobrevivência do grupo (lavras aqui, e debulha alhures, especialmente em Romans); e por paradas militares;

4) Pela representação dos animais de interesse econômico maior (caça, carneiro, aves domésticas, cuja função simbólica, em Romans e fora de Romans, ultrapassa, de resto, este rasteiro utilitarismo); 
5) Por atos tais como as condutas de estrépito que são úteis à expulsão do mal, ao prosseguimento das atividades normais, etc. (BAROJA, 2006, p. 277).

Apesar de o carnaval contemporâneo das grandes cidades não possuir mais uma função ligada ao tempo da natureza e dos rituais agrícolas, ele possui uma utilidade social, de paralização momentânea dos acontecimentos cotidianos, para se viver um momento de festa e diversão com maior liberalidade, com regras menos rígidas e maior interação social.

No Brasil, a festa carnavalesca foi objeto de estudo de vários folcloristas desde o inicio do século XX até meados da década de 1970, quando passou a ser objeto de estudos de pesquisas universitárias. Como exemplos de trabalhos de folcloristas sobre o carnaval brasileiro, temos os do potiguar Luis da Câmara Cascudo, (1967); Rossini Tavares de Lima (1954); Eneida de Moraes (1958); Edison Carneiro (1961); Jota Muniz (1976), e Wilson de Moraes (1978).

A partir da década de 1970, os estudos sobre carnaval deixaram de ser objeto apenas dos estudos de folcloristas e passaram a receber maior atenção por parte das pesquisas universitárias, principalmente os temas relacionados ao carnaval do Rio de Janeiro, já tido como modelo consagrado ${ }^{3}$. Além de estudos sobre as escolas de samba cariocas, destacam-se, neste contexto, Carnavais, malandros e heróis (1983), do antropólogo Roberto DaMatta, e Carnaval brasileiro o vivido e o mito (1992), da socióloga Maria Isaura Pereira de Queiroz. São trabalhos pioneiros na pesquisa universitária brasileira que dedicaram uma análise teórica sobre o carnaval brasileiro de uma forma geral.

Os estudos de DaMatta têm como objetivo principal entender os dilemas brasileiros e os processos culturais que tornam nossa sociedade "diferente e única" (DAMATTA, 1996, p. 14). O antropólogo não realiza uma interpretação cronológica do carnaval brasileiro nem dedica uma análise sistemática sobre as escolas de samba ou

\footnotetext{
${ }^{3}$ A respeito dos trabalhos acadêmicos pioneiros sobre as escolas de samba do Rio de Janeiro destacam-se os trabalhos de Maria Júlia Goldwasser (1975); José Savio Leopoldi (1977); Roberto Da Matta (1983); Ana Maria Rodrigues (1984).
} 
sobre outras manifestações presentes no carnaval, mas elabora uma visão geral mais complexa. O carnaval, para ele, estaria - assim como para Bakhtin - enquadrado dentro daquelas instituições perpétuas que nos permitem sentir nossa própria continuidade como grupo social. $\mathrm{O}$ autor acentua a grande capacidade de organização e improvisação dos participantes das entidades carnavalescas, enfatizando a força desta atividade que seria o grande momento lúdico nacional. $\mathrm{O}$ carnaval reproduziria a sociedade brasileira não de forma direta, mas de forma dialética, com muitas autorreflexões, circularidades, dimensões e planos, sendo capaz de estimular mudanças que poderiam ocorrer nos padrões sociais estabelecidos (DAMATTA, 1996).

Já o livro de Maria Isaura Pereira Queiroz é formado por quatro ensaios que foram originalmente publicados separadamente na década de 1980 em revistas especializadas. A autora antes de escrever os ensaios vivenciou vários carnavais em cidades diferentes, como Salvador, São Paulo, Rio de Janeiro e São João del Rei, em Minas Gerais. O primeiro ensaio traça um paralelo entre os entrudos portugueses (uma festa regional) e a introdução e expansão dessas festas no Brasil dos séculos XVIII e XIX; o segundo ensaio analisa as escolas de samba do Rio de Janeiro; o terceiro ensaio dedica-se à temática dos grandes bailes carnavalescos; já o quarto ensaio, de análise mais teórica, estuda o surgimento e a construção do mito carnavalesco no Brasil. Ao fazer esse percurso, a autora pensa as diferenças do carnaval brasileiro ao longo do tempo, chegando inclusive a algumas generalizações como a que cita que "a uniformidade dos folguedos carnavalescos sempre existiu no país” (QUEIROZ, 1992, p. 12), revelando que a festa carnavalesca está presente em todo o país, cada região com as suas peculiaridades e regras próprias. A socióloga atribui o crescimento das escolas de samba ao "nacionalismo exacerbado", predominante na década de 1920 entre os intelectuais, destacando a geração modernista e a sua influência entre os populares, além do fato de que o Rio de Janeiro era a principal cidade do país e capital federal, fatores que contribuíram para tornar as escolas de samba a principal manifestação artística do carnaval brasileiro. ${ }^{4}$.

\footnotetext{
${ }^{4}$ Esse tema será retomado por VIANNA, Hermano. O mistério do samba. 6. ed. Rio de Janeiro: Jorge Zahar, 2008.
} 
Queiroz procura se alinhar à perspectiva de autores franceses dos anos 1970, como Mesnil (1974) e Faure (1978), tecendo análises a partir do "vivido" e não do "sentido", ou seja, a partir das experiências concretas observáveis e não a partir da memória coletiva de foliões. Assim, no carnaval atual ou no do passado, este tipo de análise, segundo a autora, demonstra que não há e que nunca houve oposição e incompatibilidade entre os folguedos carnavalescos e a sociedade nas quais estão inseridos: "Sociedade e Carnaval sempre caminharam emparelhados, guardando a mesma configuração e composição sociais, de tal modo que as modificações da festa correspondem sempre às mudanças que se verificam na sociedade urbana" (QUEIROZ, 1992, p. 218).

No desenvolvimento da presente pesquisa, a visão desses autores colabora para a identificação das mudanças estéticas e visuais pelas quais passaram o carnaval das escolas de samba nos últimos quarenta anos. Uma das condições essenciais para se brincar o carnaval é utilizar um disfarce carnavalesco, popularmente conhecido como fantasia. O trabalho de Queiroz revela que as fantasias carnavalescas, item essencial para se desfilar em uma escola de samba começaram a se popularizar no Brasil dentro dos bailes da Corte brasileira no século XIX e também nas festas populares, conhecidas como entrudos, trazidos pelos colonizadores portugueses nos séculos XVIII e XIX. Outra importante contribuição dos autores se dá na análise das relações entre escolas de samba e o Estado. No caso das escolas de samba paulistanas e cariocas esta relação é indissociável, devido ao modelo de concurso carnavalesco oficial promovido pelo poder público nas duas cidades. Tanto DaMatta quanto Queiroz observam que a festa carnavalesca funciona como uma inversão que objetiva a manutenção das hierarquias, como uma válvula de escape para as tensões do cotidiano, permitida, controlada e estimulada pelo grupo dominante, no caso brasileiro, as elites e o Estado, seja ele autoritário ou mesmo o democrático, constituindo em mais um recurso utilizado pelo “poder" para manipular e reforçar a ordem vigente, capitalizando em seu proveito os próprios excessos nele manifestados (SOIHET, 1999, p. 14). 
Com relação ao tema especifico das escolas de samba paulistanas, a bibliografia é bem menor e com trabalhos espaçados, pois a maioria das pesquisas dedica-se a analisar o carnaval do Rio de Janeiro.

As pesquisas sobre as escolas de samba de São Paulo, objeto de pesquisa deste trabalho, ainda são um território a ser descoberto com pouca produção bibliográfica. Destacam-se três trabalhos pioneiros e panorâmicos que mapearam as grandes mudanças pelas quais passaram o desfile das escolas de samba, desde a época dos cordões, no início do século XX, até as transformações, imediatamente após a oficialização dos desfiles em 1968.

Esses trabalhos, próximos aos realizados pelos folcloristas, fazem uma leitura das escolas de samba de São Paulo como manifestações folclóricas autênticas que foram corrompidas pela oficialização das escolas de samba na década de 1960, acabando com o que os folguedos carnavalescos de São Paulo tinham de autêntico, ao se estabelecerem regras e padrões inspirados no carnaval do Rio de Janeiro. São os trabalhos do pesquisador santista J. Muniz Jr., Do batuque à escola de samba (1976), de Wilson de Moraes, Escolas de Samba de São Paulo (1978) e Maria Apparecida Urbano, Arte em Desfile (1985) e Carnaval \& Samba em evolução na cidade de São Paulo (2006).

J. Muniz Jr. faz uma análise cronológica das escolas de samba, trazendo a sua filiação a musicalidade produzida pelos escravos do interior do Estado, a que ele chama, genericamente, de batuque. Após a abolição, muitos desses escravos migraram para as cidades em busca de melhores condições de vida, mas mantiveram a sua musicalidade. Eles formaram os cordões carnavalescos e posteriormente as escolas de samba. O livro também traz uma segunda parte com informações sobre a organização, os aspectos legais sobre o funcionamento de uma escola de samba e o regulamento dos desfiles de carnaval, sendo esta segunda parte uma espécie de manual a todos os interessados em como criar e administrar uma escola de samba.

Wilson Rodrigues de Moraes, folclorista, é o primeiro a reconstituir a história social dos cordões paulistas desde sua fundação até a extinção dos concursos em 1973. No período estudado, o autor enxerga os desfiles como uma manifestação espontânea 
dos segmentos mais pobres da sociedade paulistana, dotados de um espírito carnavalesco com grandes liberdades para inovação e improviso, sem regras fixas, e que sofreram uma mudança após a oficialização em 1968, quando os desfiles passaram a ter regras fixas e um controle por meio de um regulamento disciplinador, a partir de um modelo vindo do Rio de Janeiro. Além disso, Moraes aponta que os desfiles de carnaval de São Paulo ainda remetiam a uma festa popular, e não a um evento do município, baseado na ordem e nas regras do poder público.

\begin{abstract}
A partir de 1960, o prestígio das Escolas de Samba cariocas já em ascensão toma novo impulso e começa a motivar os grandes meios de comunicação. Elas passam a dominar o noticiário carnavalesco, inclusive dentro da Capital bandeirante. Os sambistas de São Paulo olhavam "esse sucesso" e procuravam no exemplo carioca um meio de sair da situação que, para eles, era considerada ostracismo. Para os dirigentes do samba paulista aquele 'sucesso' se devia principalmente ao apoio do poder público e o mesmo caminho teria que ser procurado para São Paulo. A oportunidade surgiu quando os sambistas notaram que o Brigadeiro Faria Lima era sensível aos problemas do carnaval. Ao conquistarem o almejado beneplácito das autoridades municipais, as escolas paulistanas envolveram-se numa série de ações e compromissos antes inexistentes, o que iria causar profundas e súbitas transformações em suas estruturas até então vigorantes (MORAES, 1978, p. 92).
\end{abstract}

A carnavalesca e pesquisadora Maria Apparecida Urbano, que segue a linha de folclore desenvolvida por Rossini Tavares de Lima, corrobora com a análise feita por Muniz e por Moraes. Urbano divide em três etapas as evoluções e mudanças que as escolas de samba vêm sofrendo. Apesar de a pesquisadora analisar o carnaval popular negro da cidade de São Paulo, ela tem como modelo de classificação as escolas de samba do Rio de Janeiro. De acordo com a classificação de Urbano, a primeira etapa seria a da "pureza", que marcaria a era dos cordões e algumas escolas de samba. Essas se destacariam pela espontaneidade, trabalho artesanal dependente da habilidade e da mão de obra da comunidade, que participava de forma voluntária. Urbano a classifica como verdadeira representação folclórica: um momento de arte "pura", verdadeira manifestação de arte popular, com estrutura flexível e desordenada.

A segunda etapa iria de 1940 até a década de 1960, época da "contaminação". Segundo esta visão, a espontaneidade desaparece por causa da ajuda dos órgãos 
governamentais à escola na forma de incentivos financeiros e da utilização de algumas regras das escolas de samba cariocas. É uma fase de transição na qual o Estado irá impor regras e normas para a existência legal das escolas e para o enredo. Este, a partir daí, deverá versar sobre fatos, personagens, heróis, lendas e datas extraídos do folclore e da história do Brasil.

A terceira etapa, apontada por Urbano, é a da "transformação", vista a partir dos anos 1960, objeto de análise da presente pesquisa. Neste período as escolas estão mais dinamizadas e transformam o desfile em espetáculo, ocorrendo uma tendência para a industrialização de toda mão de obra carnavalesca. Do folclore passa-se à arte de massa. Dentro dessa perspectiva, a visão de mundo do sambista vai perdendo espaço para a do espectador-patrocinador. Há uma imposição de regras baseadas no luxo e na riqueza da apresentação para o sucesso da escola na avenida, a exaltação de qualidades individuais em detrimento da coletividade. Com as regras rígidas para a composição do enredo, as críticas sociais vão desaparecendo e dando lugar aos enredos comprados, ou seja, grandes empresas, artistas, governos de cidades pagam para ter seu nome como tema de escola de samba. Outro grande problema narrado pelos sambistas decorre da venda de fantasias por altos preços para qualquer pessoa que queira desfilar, mesmo sem nunca ter ido à quadra da escola, gerando um excesso de componentes.

As principais obras sobre o carnaval de São Paulo foram escritas por Olga Rodrigues de Moraes von Simson, a sua dissertação de mestrado intitulada A burguesia se diverte no Reinado de Momo: sessenta anos de evolução do Carnaval na cidade de São Paulo (1855-1915), de 1984, e a tese de doutoramento Brancos e Negros no Carnaval Paulistano (1914-1988), de 1989, publicada em livro em 2006. Ambos os trabalhos foram realizados na área de Sociologia da Cultura, sob a orientação de Maria Isaura Pereira de Queiroz. Os dois trabalhos se complementam ao traçar um grande panorama sobre os folguedos carnavalescos populares desde a segunda metade do século XIX até as transformações ocorridas no final da década de 1980.

Em sua dissertação de mestrado, Simson apresenta o carnaval popular do século XIX, os caiapós e os entrudos. O carnaval popular que aparece no início do século XX em São Paulo é a junção da tradição do entrudo, trazida para o Brasil pelos 
colonizadores lusitanos com as danças e cantos dos escravos africanos que produz outro tipo de festa, que se renova ano a ano, com suas músicas, danças, disfarces e adereços leves, feitos de materiais que podem ser descartados. Assim, a cada ano, novos temas e novas músicas surgem, fantasias podem ser recriadas com materiais leves e flexíveis que permitem a dança e as inovações (SIMSON, 1984).

Os resultados de sua pesquisa foram possíveis através de um grande projeto de história oral desenvolvido na década de 1980, que reconstituiu a memória do carnaval paulistano ${ }^{5}$. As entrevistas transcritas estão disponíveis no Laboratório de História Oral (LAHO) do Centro de Memória da Universidade Estadual de Campinas (UNICAMP) e foram consultadas para reconstituir partes da presente dissertação, principalmente relativas ao processo de oficialização do carnaval da cidade em 1968, e ao processo de fundação da UESP, pois trazem depoimentos de sambistas, hoje falecidos que participaram ativamente destes processos.

Esse trabalho se estrutura em torno do contraste entre as brincadeiras de Momo dos brancos e negros na cidade de São Paulo. A primeira parte da tese discorre sobre os folguedos dos bairros operários da Lapa, Brás e Água Branca nas primeiras décadas do século XX e que desapareceram ao longo dele.

A segunda parte da tese é sobre o carnaval dos negros, remontado às suas origens rurais, dos caiapós, em Pirapora, passando pelos cordões carnavalescos até as escolas de samba. Os caiapós eram uma encenação feita durante os festejos de Momo, em que negros se vestiam de índio e dançavam o caiapó. Até o estudo de Simson, pouco se sabia sobre ele. Quem revelou essa modalidade de brincadeira de carnaval para a pesquisadora foi Dionísio Barbosa, também conhecido como Nhonhô da Chácara, fundador do primeiro cordão carnavalesco na cidade de São Paulo, em 1914. Ao entrevistá-lo, no final da vida, e ao mencionar que tinha interesse no carnaval dos anos 1800, Dionísio Barbosa disse que o carnaval dançado pelos negros no século XIX era o caiapó, e que o pai dele era grande dançarino de caiapó. Por conta do estado de saúde de

\footnotetext{
${ }^{5}$ Projeto Memória do Carnaval Paulistano, desenvolvido em parceria entre o Museu da Imagem e do Som de São Paulo (MIS-SP) e o CERU (Centro de Estudos Rurais e Urbanos) da Universidade de São Paulo. Os áudios das entrevistas estão disponíveis para a consulta no MIS e no LAHO (Laboratório de História Oral do CMU/Unicamp).
} 
Seu Dionísio, essa história dos caiapós não pôde ser contada por ele, e a pesquisadora recorreu às Atas da Câmara Municipal e a uma pesquisa em arquivos para conseguir registros sobre os caiapós.

Simson também descreve minuciosamente o processo histórico dos cordões carnavalescos, como eles vão crescendo, estruturando-se, estabelecendo laços comunitários sólidos e o seu contato com a "sociedade mais ampla" (SIMSON, 1989). O longo período estudado pela obra (1914-1988) possibilita abrir caminhos para novos trabalhos em questões que ficaram em aberto ou não tiveram a devida atenção, por conta da abordagem mais panorâmica dada ao período após 1968, já que a autora se debruça mais nas primeiras décadas do carnaval "heroico", deixando um pouco de lado a análise mais precisa do processo que levou à extinção dos cordões negros na cidade, que será discutido no presente trabalho.

Outra grande contribuição do trabalho de Simson é o mapeamento dos territórios e as transformações urbanas da cidade, ao longo do século XX, nos bairros onde se desenvolveram as brincadeiras de Momo, mostrando o carnaval estreitamente vinculado às modificações urbanas.

Ao analisar os cordões e posteriormente as escolas, Simson analisa a construção de um carnaval que adquire progressivamente uma escala metropolitana. A pesquisa no livro Carnaval em Branco e Negro (2006), desdobramento da tese de doutorado, também se destaca um álbum de fotos registrando os desfiles carnavalescos dos brancos e negros no carnaval de São Paulo. Este álbum também é um importante documento imagético para analisar os desfiles carnavalescos da cidade de São Paulo.

Dentre as produções mais recentes se destacam algumas pesquisas que optaram por realizar recortes específicos e históricos a partir de estudos de caso, como as dissertações de Reinaldo Soares da Silva, O Cotidiano de uma escola de samba paulistana: o caso da Vai-Vai (1999), e de Kelly Adriano de Oliveira, Entre o lúdico e a luta: Leandro de Itaquera, uma escola de samba na cidade de São Paulo (2002). Estes são estudos da área de Antropologia realizados na Universidade de São Paulo e que 
procuram retratar a vivência, a mística e a organização vigente dentro de uma escola de samba contemporânea.

O trabalho de Soares da Silva sobre o Vai-Vai analisa as atividades diárias promovidas pelos componentes das escolas de samba, ou seja, os ensaios, festas, batismos, seleção do samba-enredo, que são as atividades desenvolvidas na quadra da escola e na rua, já que a quadra do Vai-Vai é pequena e não comporta o grande número de participantes. $\mathrm{O}$ antropólogo diferencia as atividades realizadas na quadra da escola das desenvolvidas no barracão da escola de samba e nas oficinas de costura das alas, onde não predomina o trabalho voluntário e a diversão, mas o trabalho remunerado por produtividade, revelando a outra face do carnaval paulista, totalmente profissionalizado e mediado pelas relações do trabalho. Estes profissionais, incluindo o carnavalesco da escola, ficam isolados, distantes e separados fisicamente (já que o barracão fica a mais de $10 \mathrm{~km}$ da quadra da escola), da rede de sociabilidade e convivência estabelecida dentro de uma escola de samba (SILVA, 1999).

O trabalho de Kelly Adriano Oliveira observa os preparativos da escola de samba Leandro de Itaquera para o desfile do grupo Especial de 1999, tentando desvendar as relações entre as propostas políticas do movimento negro na cidade e as associações socioculturais como as escolas de samba, enquanto formas de sociabilidade desenvolvidas no cotidiano urbano de moradores da periferia da cidade. A autora questiona, de um lado, as oposições entre carnaval, ou festas em geral, e trabalho, assim como faz Soares da Silva; de outro lado, as relações predeterminadas entre a população negra da cidade e exclusão, mostrando que, sob o aspecto econômico e político, a identidade negra se afirma de modo negativo, porém, do ponto de vista cultural e social, essa identidade é avaliada positivamente.

Ainda nesta linha de contrapor carnaval e trabalho, há o livro Desfile na avenida, trabalho na escola de samba: a dupla face do carnaval (2007), da socióloga Leila Maria da Silva Blass, que procura desvendar os vários processos de produção e elaboração dentro de uma escola de samba, buscando compreender a "pluralidade de práticas de trabalho e do emprego que essa produção supõe" (BLASS, 2007, p. 36). Leila Blass irá mapear toda a produção profissional dentro das grandes escolas de samba que se 
desenvolve dentro do barracão e contrapor este trabalho profissional, com vínculo empregatício, mediante salário, e a exploração do capital ao trabalho lúdico que os sambistas desenvolvem dentro da quadra da escola.

Uma das poucas biografias feitas sobre os personagens das escolas de samba na cidade de São Paulo é a da jornalista Ana Braia, intitulada, Memórias de Seu Nenê da Vila Matilde (2000), sobre o Seu Nenê da Vila Matilde, reconstituindo a trajetória de vida desta importante personagem do carnaval de São Paulo. Através dessa trajetória, a presente pesquisa pode compreender determinadas mudanças internas no universo específico de uma escola de samba, a visão de mundo de um importante sambista da cidade, os desfiles mais marcantes da Nenê, seus principais sambas-enredos e as disputas de campeonatos.

Para compreender o carnaval do século XXI, há o livro de Christian Dennys Monteiro de Oliveira, Geografia do Turismo na Cultura Carnavalesca (2007), que investiga uma geografia do turismo das escolas de samba responsável por criar o Sambódromo, um lugar específico para os desfiles. O livro contribui para a dissertação ao descrever de maneira minuciosa o significado, a ocupação e os desafios do Sambódromo, bem como a carência de um projeto político e cultural que o vincule aquele à cultura do samba na cidade ao longo do ano.

Dos últimos cinco anos destacam-se algumas dissertações, como a de Vanir de Lima Belo, O enredo do carnaval nos enredos da cidade: dinâmica territorial das escolas de samba em São Paulo (2008), oriunda da área de Geografia Urbana e que trata da relação das escolas de samba com o espaço urbano da cidade de São Paulo, buscando ver as escolas dentro da dinâmica de ocupação dos espaços da cidade. A área de musicologia também vem dedicando alguns trabalhos ao tema das escolas de samba de São Paulo, como o produzido por Chico Santana no departamento de Musicologia do Instituto de Artes da Unicamp e intitulado A batucada da Nenê de Vila Matilde: formação e transformação de uma escola de samba paulistana (2009), que estudou a bateria da escola de samba Nenê de Vila Matilde, relacionando a trajetória musical da escola com a incorporação de elementos organizacionais, estéticos e musicais dos cordões carnavalescos paulistanos. Seu trabalho é importante por ser o pioneiro a 
realizar uma análise musical dos padrões rítmicos de uma bateria de escola de samba da cidade de São Paulo. A dissertação de Santana foi utilizada no segundo capítulo deste trabalho para compreender as mudanças trazidas pela incorporação de elementos musicais das baterias das escolas de samba do Rio de Janeiro.

Por fim, há a dissertação de mestrado de Clara de Assunção Azevedo intitulada Fantasias Negociadas. Políticas do Carnaval Paulistano na Virada do Século XX (2010), que trata das políticas do carnaval paulistano e de suas relações institucionais no final do século XX, mais especificamente a relação da Prefeitura de São Paulo e da Secretaria de Turismo com a empresa São Paulo Turismo (SP Turis), que é responsável por administrar o espaço do Sambódromo dentro do Complexo do Anhembi e estabelecer os contratos necessários para a realização dos desfiles a cada ano. O trabalho de Azevedo contribui com a presente dissertação, pois, também explora a relação desta com as federações carnavalescas, Liga e UESP, e, por último, e como as federações se posicionam frente às escolas de samba, destrinchando toda a estrutura hierárquica institucional dos desfiles oficiais das escolas de samba na cidade de São Paulo.

\section{Divisão dos capítulos}

No primeiro capítulo, buscamos reconstituir brevemente a trajetória dos cordões carnavalescos para entendermos as tensões e demandas dos sambistas ao reivindicar verbas do poder público, o que resultou na oficialização dos desfiles das escolas de samba e contribuiu com a extinção dos cordões carnavalescos nos bairros da cidade. Nos dedicamos a analisar as mudanças institucionais a partir das mudanças na forma e na organização dos desfiles de carnaval. Estas são referentes às mudanças na legislação municipal e à postura dos órgãos públicos frente aos desfiles carnavalescos. Durante o período estudado por esta pesquisa, a cidade de São Paulo teve mais de onze prefeitos, e a maior parte deles, no período entre 1969 e 1985, ou seja, durante a ditadura militar, foi nomeada pelo governador do Estado, sem eleição. Este período sem eleições municipais 
compreende a maior parte da nossa pesquisa. Apenas José Vicente Faria Lima (19651969), Jânio Quadros (1986-1988), Luiza Erundina (1989-1992) e Paulo Maluf (19921996) foram eleitos pelo voto direto.

São ainda muito importantes as mudanças institucionais dentro das federações carnavalescas, em especial, os regulamentos e as relações da UESP e da Liga com o poder público. A União das Escolas de Samba Paulistanas (UESP) foi fundada em 1973 com o objetivo de reunir as escolas de samba e blocos e representá-los junto ao poder público. Já a Liga Independente das Escolas de Samba de São Paulo (Liga) foi fundada em 1986, a partir de membros descontentes com a atuação da UESP, e hoje representa as escolas do Grupo Especial e do Grupo de Acesso (antigos Grupos I e II). A partir do diálogo sistemático entre as entidades e a Prefeitura é possível estabelecer como essas relações foram sendo articuladas, podendo ser visualizadas nas modificações e transformações que as escolas de samba sofreram. Essas federações de representantes das escolas de samba têm o papel de organizar, anualmente, em conjunto com a Prefeitura de São Paulo e a Secretaria de Turismo, os desfiles carnavalescos, além de intermediar e representar as escolas de samba junto aos órgãos públicos, como a Prefeitura e suas secretarias, e também se relacionar com as autarquias e a Justiça. A relação entre os órgãos administrativos municipais e as entidades carnavalescas variou de acordo com a administração, assim como a quantidade de verbas repassadas para as escolas e os locais destinados à realização dos desfiles.

No segundo capítulo são analisadas as principais transformações estéticas e musicais nos desfiles das escolas de samba, desde a oficialização até os primeiros desfiles ocorridos dentro do Sambódromo. Como parte das transformações estéticas, compreendem-se fantasias, alegorias, materiais utilizados para confecção, a evolução e profissionalização dos barracões e as mudanças na evolução e na dança dos desfiles. As transformações musicais compreenderão as principais mudanças nas baterias das escolas de samba e também as mudanças dentro dos sambas-enredos durante o período estudado. Neste capítulo optamos por uma abordagem panorâmica, na qual não serão analisadas todas as escolas e sambas, mas procuraremos destacar as mudanças profundas que influenciaram na transformação dos desfiles da cidade de São Paulo, 
levando-o a perder cada vez mais suas características originais para se buscar um padrão cada vez com uma maior aproximação das escolas de samba do Rio de Janeiro.

O terceiro capítulo discorre sobre as transformações ocorridas a partir de 1991, quando os desfiles das principais escolas da cidade deixam o espaço público da rua e passam a se realizar no Sambódromo do Anhembi. A partir da documentação da empresa Anhembi Turismo, será analisado o projeto do Sambódromo e as principais questões envolvendo sua construção, assim como a mudança nas relações e nas demandas dos sambistas com o poder público. Foi feito o esforço para analisar, do ponto de vista simbólico, o que significou a conquista de um local fixo para os desfiles, garantindo, com isso, que a mesma prática de desfile será realizada por muitos anos, e, por outro lado, quais as perdas que os sambistas tiveram ao deixar o espaço público para desfilar em um local privado. A partir dos anos 1990, as escolas de samba do Grupo Especial são administradas sob uma lógica empresarial, com várias fontes de financiamento, contudo, atentamos que essa lógica empresarial não reflete a realidade da esmagadora maioria das escolas de samba da cidade, já que as escolas menores dos outros grupos ligados à UESP (I, II, III, IV) permanecem apresentando características mais próximas dos desfiles dos períodos anteriores. Estas escolas não têm a visibilidade e os recursos das grandes entidades, e dependem, ainda, do trabalho voluntário e artesanal, utilizando, na maior parte das vezes, a casa dos próprios componentes para produzir e armazenar os instrumentos, fantasias, adereços, alegorias e realizar a maior parte de suas atividades ao longo do ano.

Por fim, concluímos o trabalho, lançando um olhar para o final desse processo iniciado em 1968, com a oficialização dos desfiles carnavalescos da cidade de São Paulo e concluído com a construção com verba pública de um espaço dedicado exclusivamente a esse fim. Também lançamos atenção para as transmissões televisivas dos desfiles das escolas de samba de São Paulo, quando são retomadas algumas questões relacionadas com o segundo capítulo, que, como já foi descrito, trata das modificações estéticas, mas tentando compreender o porquê dessas mudanças, já que elas atendem a demandas não apenas de acordos estabelecidos com o Estado, mas também de acordos estabelecidos com a indústria cultural, contribuindo para que os 
desfiles das escolas de samba se tornem cada vez maiores, sendo referência não só no Brasil, mas também no exterior e tentando alcançar seu objetivo de rivalizar com as escolas de samba do Rio de Janeiro. O outro lado dessa relação é que, para atender a essas demandas, as escolas devem seguir um "padrão", que as tornam cada vez mais semelhantes, sem características próprias através das quais o público em geral possa distinguir os desfiles de uma determinada escola, comparando-o com os de outra.

Na segunda parte do trabalho estão transcriadas na íntegra os depoimentos dos sambistas que nos concederam entrevista, seguindo os procedimentos metodológicos da História Oral. Sem estes depoimentos, muitas lacunas ficariam abertas, dentro da presente pesquisa. Foram escolhidas para colaborar com esta pesquisa pessoas que viveram e testemunharam as transformações pelas quais passou o carnaval da cidade de São Paulo durante o período estudado (1968-1996). 


\section{I - AS TRANSFORMAÇÕES INSTITUCIONAIS DAS ESCOLAS DE SAMBA DA CIDADE DE SÃO PAULO}

\subsection{Os cordões}

Os chamados cordões carnavalescos formaram o que chamamos hoje de escolas de samba, as organizações carnavalescas e artísticas paulistanas. Foi através desses cordões, que a população negra e pobre paulistana participava das Folias de Momo, no início do século XX.

Nessa época, ainda não havia desfiles populares organizados e as festividades realizadas pelos cordões ainda não contavam com o ritmo do samba. A parte musical dos cordões foi aos poucos recebendo influências desse ritmo, como o batuque e o samba-de-bumbo ${ }^{6}$. O batuque era uma denominação um pouco mais genérica dada a princípio pelos portugueses para designar a dança dos negros da África. Como mostra Luis da Câmara Cascudo, no final do século XIX e início do século XX, no Estado de São Paulo, nas regiões de Piracicaba e Sorocaba e mesmo na capital, o batuque era dançado com frequência, improvisando-se uma coreografia que seguia os ritmos do tambu, do quinjengue, da matraca e do guaiá. A partir dessa base instrumental, eram improvisados versos. O batuque era tido como uma dança de terreiro e também conhecido em cidades como Tietê, Porto Feliz, Laranjal Paulista, Capivari, Botucatu, Itu, Tatuí e em outros municípios que contavam com a presença de antigos escravos no Estado de São Paulo (CASCUDO, 2011).

Os folguedos do carnaval paulistano possuem grande influência rural e religiosa, proveniente dessas festas e procissões do interior do Estado. A maior parte dos componentes dos cordões convivia regularmente com o chamado Samba de Pirapora,

\footnotetext{
${ }^{6}$ Para o folclorista Luis da Câmara Cascudo, há duas variantes do samba tradicional em São Paulo, consideradas como o ancestral do samba cosmopolita. Elas guardam traços que os aproximam do jongo e do batuque, seus parentes próximos e por muitos considerados seus antecessores. A de Samba de Bumbo tem como ponto de aglutinação a Festa do Bom Jesus, em Pirapora; já a de Lenço, a devoção familiar do grupo a São Benedito. Apresentam letras e melodias singelas e funcionais, algumas tradicionais, outras estruturadas de acordo com as circunstâncias cotidianas.
} 
cuja característica principal era a presença do bumbo. Esse contato se dava principalmente durante as festas de Bom Jesus, realizadas no início de agosto, quando, em romaria, os negros iam até a cidade de Pirapora do Bom Jesus. A festa consistia em uma manifestação religiosa na cidade, e, paralelamente aos cultos e procissões, acontecia uma reunião de negros que cantavam e dançavam o ritmo do samba. Esses negros se reuniam nos barracões, que eram locais de hospedagem improvisada para os romeiros. E eram nesses espaços que se realizavam os encontros de sambistas, na cidade de Pirapora do Bom Jesus.

Para Osvaldinho da Cuíca, sambista e pesquisador do samba no Estado de São Paulo, o samba-de-bumbo recebe esta denominação a partir da inclusão do bumbo, instrumento utilizado pelas bandas marciais nas cantorias das festas religiosas do catolicismo popular em Pirapora. Estas festas tinham o acompanhamento de violas, cavaquinhos, chocalhos e percussão corporal feita por mãos e pés. Em outras regiões do Estado eram utilizados os primitivos tambus - tambores escavados em troncos de árvores -, comuns nos batuques paulistas, porém, o seu grande tamanho e peso, dificultavam o seu transporte. Por isso coube ao bumbo a função de realçar o caráter rítmico das canções, favorecendo a expressão dos vigorosos matizes musicais africanos (CUÍCA; DOMINGUES, 2009, p. 25).

As manifestações musicais de Pirapora do Bom Jesus receberam posteriormente contribuições de elementos musicais originalmente dispersos, como o jongo, a catira, a caninha verde e Folia do Divino, trazidas por romeiros de diversas regiões do Estado de São Paulo, do Sul de Minas, do Mato Grosso e do Norte do Paraná. Tendo como ponto de vista a composição, o repertório tocado pelo samba-de-bumbo era principalmente a improvisação de versos sobre uma base melódica/harmônica bastante simples em longos desafios. Os desafios musicais são disseminados em todo o país recebendo diversos nomes, como "duelo de viola", "partido-alto", "repente”, “embolada" etc. e destacam-se nestes desafios de improviso matizes ibéricos e africanos. No caso dos desafios do samba-de-bumbo, há predominância do canto africano, pois, somado à influência negra em sua síntese rítmica, costumavam ser realizados versos improvisados com grande uso de mensagens de duplo sentido, característicos da comunicação velada 
desenvolvida pelos escravos para driblar a vigilância dos senhores durante o período escravista (CUÍCA; DOMINGUES, 2009, p. 27).

Dona China, primeira porta-bandeira da escola de samba Vai-Vai relembra que, quando criança, ia com sua família para a festa:

Sempre no mês de agosto íamos pra Pirapora do Bom Jesus. (...) Era tão lindo! Tinha congada, catira, tinha a dança de roda, as mulheres com aquelas saionas, dançando e batendo aquele tambor, eu dancei até com menino pequenininho assim, menino bom pra dançar sabe, dançar umbigada, aquelas coisas lindas, depois também tem a dança de São Gonçalo, o pessoal vem dançando, e bate pra lá, bate pra cá, aquelas fitas, coisa maravilhosa.

Com a abolição da escravidão e o desenvolvimento e a expansão da cidade de Pirapora, muitos desses antigos escravos se mudaram para a cidade de São Paulo e trouxeram consigo o ritmo do samba:

\begin{abstract}
Como a cidade de Pirapora era muito pequena, não contando com hotéis e hospedarias, foram construídas nessa época grandes barracões para abrigar os romeiros. A parte profana da festa era realizada nesses barracões e ali se davam os grandes combates de samba entre grupos rivais, representando cada um a sua cidade. A romaria a Bom Jesus de Pirapora, apesar de ser uma devoção religiosa, propiciava, entretanto, uma ocasião de grande divertimento para os fiéis, com desafios de samba, passeios de barco pelo Tietê, desfile de rua, além de promover um encontro entre todos os romeiros (SIMSON, 1989, p. 98).
\end{abstract}

Outra data importante sempre comemorada pelo contingente negro da cidade era o dia três de maio - dia da Festa de Santa Cruz —, através de rezas e procissões junto à Igreja das Almas dos Enforcados, no bairro da Liberdade. Da mesma forma era sempre lembrado o dia de São Benedito.

Nesse primeiro momento, as manifestações musicais tradicionais negras eram discriminadas pela sociedade branca dominante, que frequentemente proibia os negros de utilizarem o espaço público para essas manifestações. Assim, para impedir o direito à reunião e à organização dos negros, prática exercida desde a escravidão, incitava-se os órgãos do poder público a reprimi-las. A única exceção era feita às festas inerentes ao 
calendário oficial católico, utilizadas pelos negros para cultuar suas raízes, através do sincretismo religioso.

Em 12 de março de 1914 nascia o primeiro cordão da cidade, o "Grupo Carnavalesco Barra Funda" (MORAES, 1978, p. 34). Fundado por Dionísio Barbosa e seus familiares no bairro de mesmo nome, ganhou nas ruas o apelido de "Camisa Verde" já em seu primeiro desfile, com doze pessoas vestidas com camisas verdes, calças brancas e chapéus de palha. Nessa época, os desfiles ainda não contavam com o ritmo do samba; os instrumentos musicais eram apenas pandeiros e chocalhos feitos com madeira e tampinhas de cerveja, e só no ano seguinte é que conseguiram um surdo.

Sobre esse cordão, o jornalista e sambista Jangada relembra:

\begin{abstract}
Em 1914, a cidade possuía três núcleos onde se realizavam festejos carnavalescos: Brás, Avenida Paulista e Centro. É neste ano que, liderado pelo negro Dionísio Barbosa, surge o grupo carnavalesco Barra Funda, o primeiro cordão carnavalesco de São Paulo, composto por apenas dez foliões, que animava as ruas por onde passava, chegando mesmo a ser convidado para abrilhantar os bailes da aristocracia na Av. Paulista. A coragem de Dionísio merece destaque, principalmente a considerar-se que, naquele tempo, era preciso muita fibra para sair às ruas, já que a polícia achava que diversão carnavalesca era privilégio de rico, o povo negro e pobre tinha mesmo é que trabalhar (ÚLTIMA HORA, 04/03/1976).
\end{abstract}

Apesar de ser o primeiro agrupamento criado por negros para os festejos de carnaval, já existiam diversos clubes, grêmios e associações formados por negros na cidade de São Paulo. Destacam-se o Club 13 de Maio dos Homens Pretos, fundado em 1902; o Centro Literário dos Homens de Cor, fundado em 1903; a Sociedade Propugnadora 13 de Maio, fundada em 1906; o Centro Cultural Henrique Dias, fundado em 1908 e, pouco tempo depois de terem fundado o Grupo Barra Funda, surgiram a Sociedade União Cívica dos Homens de Cor, fundada em 1915, e a Associação Protetora dos Brasileiros Pretos, fundada em 1917 (DOMINGUES, 2007).

A pesquisadora Regina Pahim Pinto contabilizou em sua pesquisa o número de 123 associações formadas por negros na cidade de São Paulo entre 1907 e 1937, incluindo os agrupamentos carnavalescos (PINTO, 1993, p. 84). A criação destas 
associações no mesmo período do surgimento do Grupo Barra Funda deixa evidente que esta não foi uma atitude isolada de Dionísio Barbosa, mas já utilizada pelos negros da cidade como forma de identidade para organizações assistenciais, políticas, literárias, culturais e mesmo para a construção de atividades de lazer.

Pouco depois de ser fundado o grupo carnavalesco "Camisa Verde", formou-se outro cordão nas imediações da Barra Funda: a agremiação "Campos Elíseos”. Esta nasceu da estrutura de um grupo menor, conhecido como "Bloco dos Boêmios", fundado em 1913 a partir de um grupo de fanfarrões que cantavam nos bares da região da Avenida São João, no centro, precisamente na Alameda Glete. Entre seus membros importantes estavam Alcides Marcondes e José Euclides Santos, que entraram no grupo em meados de 1915.

Os cordões se tornaram, durante a primeira metade do século XX, uma importante expressão de lazer dos negros e pobres paulistanos. Os primeiros surgiram em bairros distintos, mas com características sociais próximas: bairros operários da capital, com grande concentração de afrodescendentes e imigrantes, como Barra Funda, onde foi fundado o primeiro, Bixiga e Baixada do Glicério. Esses bairros tinham em comum o fato de se encontrarem próximos ao centro urbano e comercial da cidade. Além disso, havia bairros ricos nas suas proximidades, possibilitando empregos domésticos aos segmentos negros. Suas características geográficas, de "baixada", ou seja, locais alagadiços ou de encostas íngremes propiciavam o oferecimento de moradias a baixo custo (SIMSON, 2007, p. 84).

Em São Paulo, dois elementos motivavam o desfile dos cordões no carnaval: em primeiro lugar, a tradição; em segundo, o fato de as fábricas serem fechadas pelos patrões aos sábados, domingos e terças-feiras gordas, ou seja, terças-feiras de carnaval.

Como já mencionamos anteriormente, a partir do modelo desenvolvido pelo cordão da Barra Funda, os instrumentos dos primeiros cordões basicamente eram feitos com madeira e tampinhas de cerveja; em seguida entraram instrumentos típicos de bandas militares, o conjunto de sopros de metais e palhetas, como saxofone, trombone e 
clarineta e também conjunto de cordas ${ }^{7}$. Mais tarde, estes instrumentos de banda perderam importância e foram introduzidos instrumentos como cavaquinho, bandolim, surdo, caixa e chocalho; com estes instrumentos, os cordões adquiriram, aos poucos, o ritmo da marcha-sambada e, posteriormente, do samba (MORAES, 1995). Entre os instrumentos de percussão dos cordões predomina o bumbo que influencia o ritmo pesado do samba paulista, herdeiro também das marchas cantadas nos festejos dos "santos populares" em Portugal (BLASS, 2007). Essa presença relativamente grande de instrumentos melódicos e harmônicos explica, em parte, o pouco uso da percussão, pois o volumoso som desta fatalmente encobriria os demais.

Quanto à letra do samba — hoje samba-enredo, na época, as marchas-sambadas —, podemos observar que grupos como "Camisa Verde" utilizavam músicas próprias, compostas todos os anos pelos seus integrantes. Outros utilizavam marchinhas que tocavam no rádio, que se tornava o meio de comunicação mais popular da época. $\mathrm{O}$ cordão "Camisa Verde" continuou fazendo desfiles até 1939, mas, por falta de recursos, ficou sem desfilar até 1953, quando ressurgiu pelas mãos de Inocêncio Tobias, o Mulata, casado com uma sobrinha de Dionísio e morador do bairro da Barra Funda. Junto com os amigos Colombina, Feijó e Bagdá, pôs o cordão novamente na rua.

Através de um mapeamento que visa identificar a criação dos principais cordões entre os bairros da cidade, observamos que, em pouco tempo, a novidade se espalhou e foi adotada por inúmeras comunidades e bairros pobres. Essas festas eram o principal - e, muitas vezes, o único - lazer de seus moradores, operários e trabalhadores domésticos em sua maioria.

Sobre a estrutura dos cordões carnavalescos, Osvaldinho da Cuíca ressalta:

Os cordões eram pequenas turmas de familiares, vizinhos e amigos que saíam às ruas com figurinos simples, feitos em casa, e com formação musical muito reduzida e improvisada. Deve-se sempre desconfiar daqueles que descrevem um cordão como uma multidão de encher as ruas, vestida em trajes esplendorosos e dançando ao som de uma música ensurdecedora (CUÍCA; DOMINGUES, 2009, p. 44).

\footnotetext{
${ }^{7}$ Ficha técnica 1992. Centro de Documentação e Memória do Samba, FT, 1992.
} 
Até os anos 1930 seriam criados muitos outros cordões. Nessa década, os cordões caíram definitivamente no gosto das camadas populares paulistanas. Os principais estavam no bairro da Barra Funda, "Flor da Mocidade" e "Geraldino"; nos Campos Elíseos, o de mesmo nome; na Pompéia, "Esmeraldino"; na Casa Verde, "As Caprichosas"; na Liberdade, "Mocidade do Lavapés"; no Cambuci, os "Marujos Paulistas"; em Pinheiros, o "Caveira de Ouro"; no Bixiga, o tradicional "Vai-Vai"; além de outros, como "Termiano", "Metalúrgica Mar Rugerone", "Victoria Paulista", "Nacionalista", "Irmãos Patriotas" e "Diamante Negro". Até que, em 1934, surge o "Baianas Paulistas" — também chamado de "Baianas Teimosas" —, na região da Rua Lavapés, trazendo grandes inovações, como as "baianas" que davam nome ao cordão.

Alcides Marcondes, um de seus fundadores, juntou-se a Chico Pinga e outros habitantes do Glicério e Liberdade, formando uma bateria. Entre as mulheres, então encarregadas pela dança, estavam Jovina, Madrinha Eunice (fundadora da primeira escola de samba de expressão de São Paulo, a "Lavapés"), Nair, entre outras. O grupo estava localizado na rua Tamandaré, na Liberdade ${ }^{8}$.

Nesse tempo, o "Vai Vai" - fundado em 1930 no bairro da Bela Vista, por Benedito Sardinha, Frederico Penteado, Dona Casturina, Dona Iracema, Tino, Guariba, Livinho e Henricão - desfilava com cerca de cem pessoas, todas vestidas já nas cores branco e preto, com o pavilhão sob a responsabilidade de Dona Iracema, evidenciando o papel de destaque que as mulheres tiveram no carnaval paulistano. O símbolo escolhido foi uma coroa adornada por dois ramos de café (SOARES, 1999, p. 26).

As mulheres foram muito importantes para o crescimento dos cordões. Desde a sua formação, elas eram as responsáveis pelas fantasias, pelos panos e até por alas inteiras, e pela arrecadação de fundos com comerciantes e colaboradores. Também participavam dos desfiles, normalmente como amadoras (pastoras), apresentando-se em filas paralelas, fazendo várias evoluções.

Muitas delas levavam e incentivavam seus filhos a participarem dos desfiles. Seu Zezinho do Morro da Casa Verde, falecido baluarte do carnaval paulistano, relatou, em

\footnotetext{
${ }^{8}$ Depoimento de Deolinda Madre (Madrinha Eunice). Acervo MIS-SP (Museu da Imagem e do Som). Fita $\mathrm{n}^{\mathrm{o}}$ 112.23.24.
} 
depoimento para o Museu da Imagem e do Som (MIS), como se tornou integrante dos primeiros cordões negros, aos oito anos de idade:

Eu conheci o Barra Funda em 1918, a minha mãe me levou para uma festa que tinha em São Bom Jesus de Pirapora. (...) Foi lá que fiquei conhecendo o Barra Funda... Em 18 eu desfilei lá com eles, lá em Pirapora. Quando em 20, eu já comecei a desfilar aqui em São Paulo, ainda não tinha bem a noção da coisa ${ }^{9}$.

Desde o final da década de 1940 e início dos anos 1950, as escolas e cordões começaram a ganhar os bairros mais afastados do centro devido, sobretudo, ao encarecimento das moradias populares localizadas no centro da cidade. Com a eclosão da Segunda Guerra Mundial, houve um grande aumento no preço dos materiais de construção, dos aluguéis e terrenos. Além disso, houve grande especulação imobiliária nesse período, obrigando os moradores pobres, negros, em sua maioria, a migrar para bairros da periferia onde os aluguéis eram mais baratos. Nabil Bonduki explica esse fenômeno:

\begin{abstract}
O problema dos despejos se constituiu, no período do pós-guerra e no período populista, no mais importante e angustiante problema habitacional surgido nos bairros tradicionais e consolidados de São Paulo. O significado real desta questão é mais amplo do que a primeira vista poderia parecer: representa o processo concreto de expulsão da população de baixa renda das moradias de aluguel produzidas principalmente com capital privado em áreas urbanas relativamente bem equipadas e situadas próximas aos locais de emprego. É bastante difícil estimar o total de famílias despejadas durante o período mais agudo da crise de habitação, ou seja, entre 1945 e 1948. Em 1945 foram assinadas pelos juízes 2614 ações de despejo, número que subiu a $5.121 \mathrm{em} 1946$ e que atingiu somente em janeiro de 1947, 491 casos (BONDUKI, 1992, p. 7).
\end{abstract}

Os cordões paulistanos obedeciam a uma sequência própria e original durante suas apresentações. $\mathrm{O}$ desfile era aberto por um grupo de balizas ou contrabalizas que variava de dois a sete elementos, em sua maioria, jovens ágeis, munidos de capas de cetim e batutas de

\footnotetext{
${ }^{9}$ Depoimento de Seu Zezinho do Morro da Casa Verde. Acervo MIS-SP (Museu da Imagem e do Som). Fita ${ }^{\circ}$ 112.2. Data da Entrevista: 24/04/1981.
} 
madeira. O termo designa a pequena batuta de madeira que os jovens utilizavam para realizar evoluções e malabarismos. As batutas eram cuidadosamente confeccionadas com o dobro da medida do antebraço do baliza.

Esses balizas possuíam funções de abre-alas e defensiva ao mesmo tempo, pois não deixavam ninguém se aproximar do símbolo máximo do folguedo: o seu estandarte. Quem introduziu os balizas nos desfiles carnavalescos dos cordões foi Dionísio Barbosa, ao assistir uma parada militar no Rio de Janeiro ${ }^{10}$. No início dos cordões esta função era exercida somente por homens.

Tornaram-se comuns nos anos 1930 o acirramento das disputas físicas entre os cordões com a finalidade de pegar o estandarte do outro cordão rival. Para aquele que perdia o estandarte, era uma derrota desmoralizante; então, para evitar sua perda, surge, atrás das balizas, um grupo de batedores ("bastedores") composto por homens munidos de lanças, que ficavam à frente do porta-estandarte. Estes batedores não possuíam nenhuma função plástica ou musical, sendo apenas responsáveis por defender o estandarte e afastar os curiosos que ficavam na rua e atrapalhavam a passagem do cordão. A denominação "bastedores" aparece em uma antiga marcha do cordão Camisa Verde da década de 1920 que cita as diversas partes constitutivas do cordão:

\footnotetext{
Amadoras, estrelas do Verde

Marchemos, vamos marchar

Que a vitória deste ano

Nós queremos conquistar.

E a nossa porta-bandeira

Com o nosso pavilhão,

Convidemos as amigas

A florescer neste cordão,

E os nossos bastedores,

Cada um com seu bastão,

Convidemos todos,
}

\footnotetext{
${ }^{10}$ Depoimento de Dionísio Barbosa a Olga von Simson e a José Ramos Tinhorão. Laboratório de História Oral-Unicamp. Pasta D. Barbosa, p. 48.
} 
Na década de 1940, as disputas já não se davam na forma de confrontos e agressões físicas, e os concursos já eram organizados por emissoras de rádio, jornais e firmas comerciais. A competição se torna algo muito organizado e as mulheres passam a também ocupar os postos de baliza, devendo ter flexibilidade, agilidade e graça.

Além destas balizas, dos contra balizas e dos batedores, havia um mestre de cerimônias para proteger o pavilhão. Este nunca devia afastar-se da porta-estandarte, devendo se comportar como uma espécie de "mestre-sala". Seu Zezinho do Morro da Casa Verde descreve assim os mestres de cerimônias: "Na frente do estandarte tinha um diretor, que hoje eles 'diz’ mestre-sala. (...) Antigamente era mestre de cerimônias. Ele sambava em volta da porta-bandeira, sempre com um pauzinho na mão. Se você chegava lá, ele já cutucava. Não podia chegar perto da porta-estandarte"11.

Depois deles, na sequência de organização dos cordões vinha o grupo de instrumentos com forte influência do choro: violões, cavaquinhos, flautim, clarinete, saxofone, pandeiros e também chocalhos, sempre executados por homens. Em seguida, desfilavam as alas de fantasias e o reinado de Momo, com a corte carnavalesca, sempre com as fantasias mais luxuosas: o rei, a rainha e a princesa sempre como as grandes atrações dos cordões. A corte normalmente dançava "em cobrinha", fazendo ziguezagues - um provável legado do samba rural — sem pressa ou espalhafato, representando orgulhosamente a função nobre que desempenham naqueles dias de festa (CUÍCA; DOMINGUES, 2009, p. 47).

Nesse contexto, as mulheres do cordão perfiladas receberam o nome de amadoras ou pastoras: elas iam cantando as marchas-sambadas compostas especialmente para a ocasião e executando elaboradas evoluções típicas de bandas militares. $\mathrm{O}$ canto das pastoras normalmente era ensaiado sob as ordens do mestre de

\footnotetext{
${ }^{11}$ Depoimento de seu Zezinho do Morro da Casa Verde. Acervo do Museu da Imagem e do Som (MIS). Fita ${ }^{\circ}$ 112.2. Data da Entrevista: 24/04/1981.
} 
cerimônia ou do cantor oficial da agremiação. Por fim, o desfile era encerrado pela bateria, que não se destacava muito e servia para dar e manter o ritmo da apresentação.

A oficialização dos desfiles carnavalescos pelos órgãos públicos municipais, em 1968, acarretou grandes transformações para as escolas de samba. A partir deste ano, as escolas de samba e cordões carnavalescos passaram a receber uma subvenção financeira da Prefeitura de São Paulo para arcar com parte dos custos do desfile. Até 1967, os concursos de carnaval eram produzidos por diversas agremiações em vários locais, desde a prefeitura, até, por exemplo, o clube dos lojistas de algum bairro, os jornais e as emissoras de rádio - bastava que oferecessem patrocínio. Os desfiles não tinham normas nem regulamentos rígidos, eles variavam de acordo com as negociações entre as escolas participantes e a entidade patrocinadora; portanto, esses patrocínios poderiam ser oferecidos ou não, dependendo das condições econômicas da época. Além da verba

para as escolas, a Prefeitura de São Paulo, a partir do carnaval de 1968, passou a promover e organizar um concurso oficial, esvaziando assim os concursos promovidos por jornais e rádios.

\subsection{A oficialização}

Em 1967, dirigentes de várias agremiações, como Inocêncio Tobias (Camisa Verde e Branco), Pé Rachado (Vai-Vai), Seu Nenê (Nenê de Vila Matilde), Seu Carlão (Unidos do Peruche), Madrinha Eunice (Lavapés) e Xangô (Vila Maria), procuraram os radialistas Moraes Sarmento, Evaristo de Carvalho, Vicente Leporace e Ramon Gomes Portão, que já tinham experiência com transmissão e patrocínio dos desfiles, para uma reunião sobre como obter patrocínios para o carnaval do ano seguinte. Desse encontro surgiu a ideia de formarem uma comissão para solicitar ao prefeito de São Paulo, Brigadeiro Faria Lima, um patrocínio da prefeitura para a realização dos desfiles. Tinham por finalidade centralizar os desfiles em um único local, pois, antes, os locais variavam a cada ano, dificultando a logística e o planejamento das escolas, como 
transporte de alegorias, locais para a concentração dos integrantes das escolas, banheiros e outras questões de infraestrutura, como montagem de arquibancadas, que variavam de acordo com o local do desfile e o valor gasto pelo patrocinador (URBANO; NABHAN; SANTOS, 1987, p. 12).

O prefeito José Vicente de Faria Lima se reuniu com a comissão de sambistas e radialistas, gostou do projeto apresentado a ele e aceitou patrocinar os desfiles carnavalescos na cidade. Para realizar essa ação, enviou para a Câmara Municipal a Lei $\mathrm{n}^{\mathrm{o}} 7.100$, de 29/12/1967, na qual a prefeitura ficava autorizada a promover as festas de carnaval e financiá-las através de verbas orçamentárias próprias. No ano de 1968, a prefeitura investiu NC\$480.000,00 (quatrocentos e oitenta mil cruzados novos) provenientes do excesso de arrecadação previsto para o presente ano:

\section{LEI No 7.100, DE 29 DE DEZEMBRO DE 1967:}

Dispõe sobre as festas de cunho popular e festejos carnavalescos, e dá outras providências:

Art $1^{\mathrm{o}}$ - Fica a Prefeitura autorizada a promover, anualmente, festas de cunho popular e festejos carnavalescos no Município de São Paulo, visando incerementar o turismo, conservar e desenvolver tradições folclóricas brasileiras e contribuir para a recreação popular:

Parágrafo Único: A fim de atender ao disposto nesse artigo, o Executivo, na forma da legislação vigente e das normas estabelecidas poderá:

I - promover diretamente ou mediante concessão, observado nesse caso o princípio da concorrência:

a) a ornamentação das ruas, praças e outros locais de festejos populares, bem como a construção de arquibancadas, coretos, tablados e outras instalações necessárias;

b) bailes no Teatro Municipal, em outros próprios municipais e logradouros públicos;

II - conceder auxílios, instituir e outorgar prêmios, conforme regulamento a ser baixado por decreto.

Art. $2^{\circ}$ - Poderão ser constituídas comissões com a finalidade de coordenar e executar as providências necessárias à realização das festas e festejos que trata o artigo $1^{\circ}$, observado o disposto nesta lei. 
Parágrafo Único: A composição de cada comissão, suas atribuições específicas e normas de funcionamento serão estabelecidas por decreto.

Art. $3^{\circ}$ - Para atender às despesas com a execução dessa lei, em 1968, fica o Executivo autorizado a abrir, na Secretaria das Finanças, com vigência até 31 de dezembro do mesmo ano, crédito especial no valor de NC\$480.000,00 (quatrocentos e oitenta mil cruzados novos), que será coberto com recursos provenientes do excesso de arrecadação previsto para o corrente exercício, e nos anos subsequentes, pelas verbas orçamentárias próprias.

Art. $4^{\circ}$ - Essa lei entrará em vigor na data de sua publicação, revogadas as disposições em contrário $^{12}$.

Como se pode observar, a lei é genérica sobre "festas de cunho popular e festejos carnavalescos", não legislando especificamente sobre os desfiles de escolas de samba e cordões de carnaval. A motivação de sua publicação foi a reunião com os sambistas e radialistas. O objetivo do prefeito, como fica evidente no artigo $1^{\circ}$, é "incrementar o turismo" e "conservar e desenvolver as tradições folclóricas", sendo o primeiro com muito mais força que o segundo. O item que contempla as escolas de samba e cordões é o item II do Art. 1' , “conceder auxílios, instituir e outorgar prêmios, conforme regulamento a ser baixado por decreto", ou seja, o prefeito poderia conceder ou não prêmios e auxílios para as escolas. Já os recursos necessários para promover os desfiles, ou seja, a parte de infraestrutura e divulgação não estava determinada na lei e retirada, por exemplo, da Secretaria de Turismo ou Cultura, mas deveriam vir de verbas orçamentárias próprias, de iniciativa exclusiva do prefeito, através de um projeto de lei. Este projeto de lei é submetido ao Poder Legislativo, que o discute, modifica, aprova e submete novamente ao chefe do Executivo para sanção, como toda lei.

No início do ano seguinte, em 11 de janeiro de 1968, o decreto-lei de $\mathrm{n}^{\mathrm{o}}$ 7.348/68 cria a Comissão Organizadora do Carnaval, vinculada à Secretaria de Turismo e Fomento e submetida diretamente ao prefeito que, ao lado do secretário de Turismo, Tibiriçá Botelho Filho, foram os coordenadores do carnaval daquele ano, realizado no Vale do Anhangabaú. Esse conjunto de leis foi completado no final de 1970, com o

\footnotetext{
${ }^{12}$ Arquivo da Biblioteca da Câmara Municipal de São Paulo.
} 
decreto $\mathrm{n}^{\mathrm{o}} 9.051$ de 12/10/1970, assinado pelo prefeito Paulo Maluf, que instituía um "Calendário Oficial de Eventos", na cidade de São Paulo, sob a responsabilidade da Secretaria de Turismo e Fomento:

(...) Art. $7^{\circ}-\mathrm{A}$ inclusão no "Calendário Oficial de Eventos" dar-se-á por despacho do Secretário de Turismo e Fomento ex-officio, mediante requerimento do interessado.

Art. $8^{\circ}$ - São incluídos obrigatoriamente no "Calendário Oficial de Eventos” de cada ano:

a) As festividades da Semana da Pátria;

b) As festividades comemorativas da fundação da cidade de São Paulo;

c) Os festejos carnavalescos;

d) As festas de Natal, fim de ano e primavera;

Art. $9^{\circ}$ - A inclusão no "Calendário Oficial de Eventos" constitui uma condição necessária para a concessão de auxílio e a outorga de prêmios, nos termos do artigo $1^{\circ}$ do parágrafo único, item II, da Lei 7.100, de 29 de dezembro de $1967^{13}$.

O decreto $\mathrm{n}^{\mathrm{o}} 9.051$ reconhece, oficialmente, por parte da prefeitura, que o carnaval é um evento público de caráter municipal e que deve ser organizado e supervisionado pela Secretaria de Turismo e Fomento.

Apesar do incentivo recebido pelo poder público, os desfiles das escolas de samba se tornam hegemônicos dentro das brincadeiras de carnaval da cidade, já que eles foram contemplados com as verbas oficiais. Ao escolher o desfile das escolas de samba como festejos oficiais do carnaval da cidade de São Paulo, a prefeitura exclui várias outras manifestações de Momo que aconteciam na cidade, como os corsos que ocorriam no bairro do Brás e, que nos anos 1950, foram transferidos pela prefeitura para a Avenida São João e os bailes carnavalescos promovidos nos salões pela classe média em diferentes bairros da cidade, que não recebiam apoio nenhum e foram aos poucos acabando, com seus participantes se dispersando ou mesmo participando e fundando novas escolas de samba.

\footnotetext{
${ }^{13}$ Arquivo da Biblioteca da Câmara Municipal de São Paulo.
} 
Este apoio financeiro através da Lei $\mathrm{n}^{\circ} 7.100$, de 29/12/1967, e os decretos complementares exigiram que as escolas e cordões fundassem uma federação ou confederação, de personalidade jurídica, para que pudessem receber os incentivos da Secretaria de Turismo e Fomento. Dessa forma, foi reativada a Federação das Escolas de Samba e Cordões Carnavalescos de São Paulo, fundada em 1958 e que se encontrava sem nenhuma atribuição. Os desfiles de carnaval, a partir de sua oficialização, passaram a ser planejados pela administração municipal, como parte das atividades de turismo e entretenimento; os custos com a realização dos desfiles foram, assim, incorporados como parte dos investimentos necessários para aquecer um setor da economia urbana do município. As transformações institucionais vinculavam-se diretamente à atuação do poder público municipal como impulsionador de mudanças, a partir do momento no qual ele se tornou patrocinador e promotor dos desfiles carnavalescos.

Os integrantes das escolas viam, no apoio da prefeitura, uma etapa importante cumprida, pois as verbas representavam a valorização de sua atividade cultural como algo importante para a vida social da cidade e como um elemento potencializador de sua autonomia. Todos os anos até a oficialização, os cordões e escolas não tinham a certeza de que desfilariam por falta de patrocínio, pois quase todos os seus membros não dispunham de muitos recursos para investimentos. A quantidade de dinheiro empregada pelas escolas e cordões, até a oficialização era, basicamente, para comprar a fantasia segundo o tema daquele ano, que poderia ser de marinheiro, soldado, pirata e outros possíveis temas, e a da corte carnavalesca, que normalmente eram as mais caras, mas sempre recicladas a cada ano. E, por fim, possuíam gastos com os instrumentos, tanto para manutenção daqueles que apresentassem algum problema, como compra de novos, além do encouramento dos instrumentos de percussão.

Para os sambistas que participaram dessas negociações, o patrocínio da prefeitura iria garantir esses gastos mínimos, possibilitando a agremiação desfilar, mesmo que os dirigentes não conseguissem dinheiro suficiente dentro da própria comunidade. O arrecadado com o "livro de ouro", ou contribuição de membros, poderia ser gasto em fantasias mais luxuosas, para encantar o público e ganhar o desfile, ou até 
mesmo em passeios e atividades voltados para a comunidade das escolas, como excursões e piqueniques, além de outras eventuais despesas durante o ano.

Os cordões de carnaval, e mesmo as que se intitulavam "escolas de samba", até esse momento, não possuíam "quadras" para realizar seus ensaios, que eram feitos na rua, em terrenos baldios ou praças públicas. As festas principais, como o aniversário das agremiações, levantamento de fundos para o carnaval, ou ensaios gerais, também poderiam ocorrer em salões improvisados ou alugados. Os instrumentos mais caros, como os de sopro assim como as fantasias mais caras, as da corte carnavalesca, normalmente eram guardados na residência da família responsável pela agremiação.

Nesse período, da luta pela oficialização, os sambistas de São Paulo, que exerciam os ofícios menos valorizados e remunerados, já viam o carnaval e o samba como elementos potenciais para modificar as condições sociais de seus integrantes e da comunidade que vivia em torno das escolas. Viam, na aliança com o poder público, a esperança de uma vida melhor, de poder divulgar a sua agremiação, não apenas durante o carnaval, mas em eventos e festas ao longo do ano. Era comum a formação de grupos para apresentação de espetáculos de samba em teatros, bares e outros locais da cidade, ou mesmo em cidades do interior.

O primeiro desfile oficial realizado pela prefeitura de São Paulo ocorreu em 1968, em pleno ambiente de repressão imposto pelo regime militar brasileiro. Participaram desse primeiro desfile oficial as seguintes escolas e cordões: "Nenê de Vila Matilde"; "Unidos do Peruche"; "Lavapés"; o cordão carnavalesco "Vai-Vai"; o cordão Carnavalesco "Fio de Ouro da Bela Vista"; "Camisa Verde e Branco"; "Acadêmicos do Ipiranga"; "Mocidade Alegre"; "Príncipe Negro de Vila Prudente"; "Estrela Brilhante"; "Império do Cambuci"; "Unidos de Vila Maria"; "Acadêmicos do Tatuapé"; o "Grupo Folclórico Irmãs Ibejy"; "Acadêmicos do Parque Peruche"; "Folha Azul dos Marujos", "Morro da Casa Verde" e "Primeira de Santo Estevão. A campeã daquele ano, por sua vez, foi a "Nenê de Vila Matilde", tendo como tema o poema de Castro Alves "Navio Negreiro", em um samba puxado por Álvaro Rosa, o Paulistinha. 
O patrocínio oficial da Prefeitura de São Paulo previa a concessão de verbas para os custos de organização do concurso de carnaval, uma premiação para a escola campeã e verbas de participação para todas as escolas. Para a realização do concurso era necessário que a Prefeitura e as agremiações carnavalescas, através da Federação das Escolas de Samba, formulassem um regulamento para os desfiles. Evaristo de Carvalho foi até a cidade do Rio de Janeiro encontrar-se com Paulo Costa Lamarão, então presidente da Confederação Brasileira das Escolas de Samba (CBES), com o objetivo de Lamarão o auxiliar a produzir um regulamento para as escolas de samba e cordões de São Paulo. Então, o primeiro regulamento oficial dos desfiles da cidade de São Paulo é realizado tendo como modelo o da CBES. A mudança inicial prevista neste regulamento era a criação de um único palco para todos os desfiles que, normalmente, eram descentralizados, com as escolas e cordões participando de várias competições em vários palcos, normalmente organizados por jornais e rádios. O local escolhido para centralizar os desfiles foi a Avenida São João, que recebeu os desfiles entre 1968 e 1977. Um carnavalesco também foi trazido do Rio de Janeiro para auxiliar as escolas a se adaptarem às mudanças.

O secretário de Turismo, Tibiriçá Filho, viu nos desfiles do Rio de Janeiro um modelo mais acabado e mais rentável de desfiles e que foi encarado pelo poder público paulista como um sucesso. Decide importar o regulamento proposto por Lamarão, sem levar em conta as especificidades das agremiações paulistas, oriundas dos cordões carnavalescos (AZEVEDO, 2010). O secretário via as escolas e cordões como manifestações folclóricas que passavam a desempenhar um papel turístico na cidade. $\mathrm{O}$ patrocínio dos desfiles eram oportunidades de ampliação de uma atividade de lazer (que até então era negligenciada pelo próprio Estado) capaz de tornar a cidade mais atrativa para os visitantes. A oficialização veio ao encontro da posição do governo federal que procurava alavancar o turismo como uma potencialidade do país, para gerar divisas e empregos. Dois anos antes, em 1966, o marechal Humberto de Alencar Castelo Branco havia criado a Empresa Brasileira do Turismo (Embratur). A empresa estatal foi criada com o objetivo de desenvolver e normatizar o turismo no Brasil. 
Fazendo um paralelo com os desfiles da capital fluminense, a prefeitura do então Distrito Federal, já em 1936, começou a dar prêmios em dinheiro para os vencedores do concurso de escolas de samba, como forma de promover e incentivar os desfiles, assim como já fazia com alguns ranchos ou blocos (CABRAL, 2001, p. 114).

A decisão de contar uma história na avenida já era adotada por ranchos carnavalescos e foi admitida e utilizada pelas escolas de samba a partir de 1935. É o surgimento do enredo, dentro das escolas de samba. A partir desses prêmios e incentivos financeiros dados pelo poder público, começam a se estabelecer regras mais rígidas para as disputas. Com o golpe do Estado Novo, em 1937, o Brasil entra em um período ditatorial e o governo de Getúlio Vargas intensifica a censura e a propaganda nacionalista, criando o Departamento de Imprensa e Propaganda (DIP). A partir de 1938, com um novo regulamento proposto pela União das Escolas de Samba do Rio, os enredos deveriam versar sobre história e fatos, líderes e personagens do Brasil (PARANHOS, 2005, p. 138-143). Essa exigência continua vigente e está presente no regulamento, no momento da oficialização do carnaval de São Paulo ${ }^{14}$.

A penetração e a influência de soluções adotadas pelas escolas de samba do Rio de Janeiro já vinham sendo adotadas por alguns cordões e escolas de samba da cidade de São Paulo, muito antes da oficialização, como Nenê de Vila Matilde, Império do Cambuci e Unidos do Peruche, responsáveis por trazer para o carnaval da cidade diversas inovações que já estavam presentes nos desfiles do Rio de Janeiro.

Entre 1968 e 1971, a Prefeitura de São Paulo promoveu desfiles em duas categorias: escolas de samba e cordões carnavalescos. Sendo o prêmio recebido pelos cordões bem menor do que aquele oferecido às escolas de samba. Durante esses quatro anos, o número de escolas participantes aumentou e o número de cordões ficou reduzido para apenas três: Fio de Ouro, Vai-Vai e Camisa Verde e Branco. Os três decidiram se tornar escolas de samba, dando fim à tradição dos cordões, seguindo assim o padrão dos

\footnotetext{
${ }^{14}$ Essa exigência foi em parte flexibilizada na década de 1970 pelo talento estratégico e criativo do carnavalesco Joãosinho Trinta, no Rio de Janeiro, que, ao incluir o sonho e o imaginário em seus enredos, livrou os criadores do desfile da limitação imposta pelo regulamento.
} 
regulamentos trazidos do Rio de Janeiro, o qual se consolidava como modelo carnavalesco também em São Paulo.

O cordão Fio de Ouro, que tinha dificuldades de organização por dividir o público com o Vai-Vai, já que ambos são do mesmo bairro, Bela Vista, não conseguiu se manter como escola de samba e, no final dos anos 1970, decidiu encerrar suas atividades, quando se encerraram os desfiles dos cordões. É importante lembrar que a decisão de se tornarem escolas de samba partiu dos próprios cordões remanescentes que tinham décadas de existência e não queriam perder prestígio e membros para as escolas de samba. Outro fator muito importante para o fim dos cordões era que a quantidade de verbas distribuídas para os cordões era menor que aquela destinada às escolas de samba, mesmo alguns cordões sendo, como os dois acima mencionados maiores que as escolas de samba do período. A adaptação desses cordões históricos foi muito rápida, prova disso é o tetracampeonato conquistado pelo Camisa Verde e Branco entre 1974 e 1977 e o primeiro título do Vai-Vai como escola em 1978.

É interessante observar que os radialistas Evaristo de Carvalho, Moraes Sarmento, Vicente Leporace e Ramón Gomes Portão, além de auxiliar as escolas de samba, se tornaram os primeiros dirigentes da refundada Federação das Escolas de Samba, recebendo os recursos do Estado e os repassando para as escolas porque os próprios sambistas ainda eram vistos com certa desconfiança pelo poder público, pelo fato de serem pessoas de pouca escolaridade e baixa renda. Uma prova disso é a criação, em 1970, de uma Comissão de Carnaval, chamada COCAP, pela Secretaria de Turismo, encarregada de organizar e realizar o carnaval. Na comissão estavam presentes os radialistas acima citados, como representantes dos sambistas, além de pessoas ligadas à administração pública.

Para Seu Nenê da Vila Matilde, aquele era o momento de aglutinar o maior apoio possível e mostrar que os sambistas não estavam isolados, mas contavam com uma assessoria de profissionais universitários e respeitados no mercado de trabalho, que iria facilitar e mediar o acesso dos sambistas às autoridades municipais. Em seu livro de memórias, ele nos conta a importância dos jornalistas: 
Sabíamos que tínhamos que falar com o prefeito Faria Lima, mas não sabíamos como chegar a ele. No ano anterior tínhamos conversado com o deputado Egídio de Serrano sobre como chegar até o prefeito e ele disse: "Vocês têm que arrumar um cartucho". Nós não sabíamos que cartucho era esse. Aí parece que Deus ajudou, o cartucho estava ali mesmo: era o Moraes Sarmento, um radialista conhecido. Sabíamos que falar com o Faria Lima era difícil, porque já tínhamos tentado. Já tínhamos feito cartas, escrevíamos e quando chegávamos com a carta ao gabinete do prefeito, sempre tinha um secretário, porteiro, que pegava a carta e engavetava (BRAIA, 2000, p. 68).

Em 1971, como nos informa o ex-dirigente da federação e ex-presidente da UESP, Álvaro Casado, a Federação das Escolas e Cordões sofreu uma intervenção judicial, por rejeição das contas, por parte da Prefeitura:

\begin{abstract}
Na época do Moraes Sarmento, da Federação, andaram emitindo uns cheques sem fundo, porque chamava a escola e dava na mão do cara. Era o Mala que ia, eu ia com ele e a gente dava o cheque pra escola diretamente, pro presidente, tesoureiro. (...) Deixa eu te contar uma coisa que me veio agora. Teve uma escola de samba, veio lá da zona Leste. O presidente pegou o dinheiro e comprou carro, comprou geladeira, fogão pra nêga e pá pá pá [sons com a boca]. E aí não saiu a escola [risos]. O que você vai fazer com um cara desse? O que vai fazer com esse cara? [risos]. Assinou o recibo com o dinheiro e gastou e não pôs a escola na rua [risos]. Não lembro se foi da Casa Verde ou da zona Leste, mas esse cara fez isso. Teve processo, mas o cara tava ligando pra processo [risos]. Caiu no esquecimento. E com isso quem ficava sem crédito era a Federação. ${ }^{15}$
\end{abstract}

Somado a isso, houve um processo de "fritura" dos dirigentes da Federação por parte dos sambistas. Após apoiar a Unidos da Peruche em uma questão judicial para a concessão do terreno em que a escola ensaiava para agremiação, a Nenê de Vila Matilde, que também não tinha quadra, acusou Evaristo de Carvalho de trabalhar em favor da Peruche e de não ajudá-la na mesma questão. E havia também a rivalidade entre os remanescentes cordões Camisa Verde e Branco e Vai-Vai. Os cordões os acusavam de serem partidário de um ou do outro cordão.

Após as denúncias de alguns membros, ligados a uma escola acusando-o de desonestidade, dizendo que ele havia se apoderado de verbas destinadas às escolas,

\footnotetext{
${ }^{15}$ Entrevista com Álvaro Casado. Data: 01/05/2012.
} 
Evaristo de Carvalho abandonou a presidência da federação, deixando-a novamente sem atribuições. A prefeitura chegou a nomear a criação de uma Comissão Interventora, na Federação, até se conseguir chegar a um acordo. Os sambistas chegaram a sugerir uma nova composição da diretoria, mas, como esse acordo não foi possível, optou-se pela dissolução da Federação. Nos dois anos seguintes, a prefeitura organizou o carnaval sem a participação dos sambistas.

Em entrevista, Evaristo de Carvalho conta como se originou o boato, segundo o qual ele teria desviado dinheiro da Federação:

Em 1971 quando assumi a presidência do órgão, o Tribunal de Contas, que passou a funcionar em 1970, pediu à Federação a prestação de contas dos anos 68 e 69. Acontece que, nesses dois anos, a Secretaria de Turismo entregou a verba diretamente às escolas, razão pela qual a Federação não poderia fazer a prestação exigida pelo Tribunal. Foi aí que, os inimigos gratuitos, se aproveitando da ingenuidade dos sambistas, espalharam que eu estava em papos de aranha, perante o Tribunal de Contas (Notícias Populares, 17/03/1974).

Diante desse novo quadro de oficialização, mas sem participação efetiva na organização dos desfiles, outros radialistas, dirigentes de escolas, sambistas e jornalistas reúnem-se novamente para fundar uma nova federação representativa das escolas de samba. É importante destacar o papel dos radialistas como intercessores e mediadores desses primeiros contatos entre Estado e escolas de samba. Esses profissionais conferiam legitimidade e certa segurança aos desfiles, pois eles já tinham experiência anterior na organização de concursos de carnaval e gozavam bom trânsito junto aos sambistas.

\subsection{A UESP}

No ano de 1973 são criadas duas diferentes federações: a Associação das Escolas de Samba de São Paulo (AESSP), sediada na Avenida Rio Branco, e a União das Escolas de Samba Paulistanas (UESP), fundada por sambistas e radialistas (AZEVEDO, 2010, p. 91). Novamente, os sambistas buscam a mesma fórmula de 
negociação, congregando não apenas sambistas, mas atraindo intelectuais e profissionais de comunicação, buscando assim maior legitimidade e atenção por parte do poder público. Como escolas fundadoras da UESP estavam Vai-Vai, que nesse momento deixava de ser cordão e passava a se tornar escola de samba: Mocidade Alegre; Rosas de Ouro; Cabeções da Vila Prudente; Príncipe Negro; Flor da Vila Dalila; Paulistano da Glória; Pérola Negra; Acadêmicos do Chora Galo; Unidos do Peruche; Foliões da Vila Nova, Falcão do Morro Itaquerense e Folha Azul dos Marujos ${ }^{16}$.

No Estatuto de fundação da UESP, redigido pelo sambista Jangada, estavam elencados todos esses objetivos:

a) congregar as escolas de samba que tenham sede e foro no município de São Paulo;

b) defender e divulgar a música popular brasileira, principalmente o samba;

c) lutar pela igualdade social e racial;

d) assessorar, sempre que convocada, a Secretaria de Turismo e Fomento em todas as questões referentes aos desfiles de carnaval;

e) promover solenidades comemorativas do Dia do Samba;

f) lutar pela fundação da Federação das Associações de Samba do Estado de São Paulo, congregando as entidades associativas dos outros municípios, e pela fundação da Confederação das Federações Estaduais das Associações de Escolas de Samba, congregando as Federações de outros Estados (URBANO, 2006, p. 194).

Nesta ata de fundação que daria origem ao primeiro regulamento da UESP é possível observar objetivos distintos. O primeiro deles é ser uma associação para congregar as escolas de samba da cidade de São Paulo e representá-las nas negociações com o poder público. Também há uma preocupação social e cultural, pois ela chama para si o objetivo de defender e divulgar a música brasileira, em especial o samba, num contexto em que os sambistas de São Paulo estavam fora da indústria fonográfica e do entretenimento que no momento histórico era então dominado pelo iê, iê, iê, também conhecido como Jovem Guarda, que gozava de sucesso absoluto na mídia. Até mesmo as canções e sambas-enredos das escolas de São Paulo não eram gravados, sendo

\footnotetext{
${ }^{16}$ Fonte: Centro de Documentação e Memória do Samba. Documento: UESP 25 anos, p. 14.
} 
divulgadas apenas no interior das próprias comunidades e no momento do desfile. $\mathrm{O}$ terceiro ponto é de extrema importância, pois declara que a entidade tem como objetivo lutar por igualdade racial e social. Isso é muito expressivo pelo momento histórico vivido, em um contexto de ditadura e cerceamento de liberdade.

Os sambistas que, historicamente, sempre sofreram preconceito pelo fato de serem negros e pobres, viam na entidade um espaço de luta e de conquista de direitos sociais e consideravam as federações uma valorização de sua cultura, ou até mesmo uma possibilidade de melhores condições de vida. O quinto item, sobre as solenidades do Dia do Samba, visava criar uma agenda cultural com eventos relacionados ao samba na cidade. Dentre as iniciativas criadas pela UESP, destacam-se a eleição do Rei Momo e da Corte Carnavalesca da cidade de São Paulo e também o concurso do cidadãosamba, folião maior do carnaval da cidade, escolhido entre os representantes das próprias escolas de samba. A inspiração para o cidadão-samba foi novamente o exemplo das escolas de samba do Rio de Janeiro, que iniciaram um concurso semelhante no ano de 1935. No ano de 1937, Paulo Benjamin de Oliveira, o Paulo da Portela, foi o vencedor (URBANO, 2006, p. 184).

O último ponto é o desejo de interlocução com as Federações de outros municípios e a criação de uma Confederação de Escolas de Samba de todos os Estados, para troca de experiências e unidade de discursos, adoção de critérios únicos de julgamento, intercâmbio de jurados e o desejo de construir uma cultura de desfiles de escolas de samba no calendário carnavalesco para todo o Brasil.

Para Maria Isaura Pereira de Queiroz, a oficialização dos desfiles, por parte da prefeitura e a obrigatoriedade de uma federação ou associação dos sambistas, responsável pelo diálogo, tornaria as escolas submissas ao poder público:

Ao delegar à Associação das Escolas de Samba a função de distribuidora das subvenções dadas pelo governo, ao permitir-lhe nomear o júri dos concursos, o Estado transformou-a em verdadeiro vigia do bom comportamento das escolas, só receberiam subvenções, só poderiam aspirar ao prêmio as inscritas na associação, isto é, aquelas que haviam provado sua submissão (...). O Estado, representante legítimo das camadas superiores, dominava assim as 
sociedades recreativas inventadas pelos subúrbios e através delas, domesticava as massas (QUEIROZ, 1992, p. 109).

Mesmo que o Estado a visse como uma "vigia" do comportamento das escolas para a realização de um carnaval "domesticado", devemos relativizar isto. Os sambistas não foram "domesticados" simplesmente. Ao analisar as atribuições da UESP e como aconteceram as negociações e embates com o Estado ao longo dos anos, podemos perceber, na ata de fundação da UESP, que os sambistas tinham um projeto político e cultural em mente. Este projeto queria dar visibilidade para as escolas de samba e para os artistas anônimos das escolas, como compositores, bailarinos e artistas plásticos que não tinham espaço dentro da indústria fonográfica ou em outros espaços artísticos. Buscavam transformar o carnaval em um espetáculo rentável e sustentável e as escolas de samba como um grande espaço de discussão política, cultural e de lazer, fazendo muitas vezes o papel do poder público, sempre ausente dos bairros periféricos da cidade. As lideranças negras das escolas de samba, como Pé Rachado, Seu Carlão, Seu Nenê, Inocêncio Tobias e Jangada, responsáveis pela fundação da UESP, levantaram bandeiras que, historicamente, o movimento negro iria defender, de maneira mais veemente, apenas no final da década de 1970. Esses sambistas tinham o objetivo de lutar não apenas pela igualdade racial, mas também por uma sociedade socialmente igualitária. Muitas das demandas dos sambistas obviamente não foram possíveis de serem cumpridas, mas as escolas de samba cumpriram um importante papel de aglutinador popular dentro dos bairros periféricos da cidade e as negociações com o Estado não foram apenas impostas "de cima para baixo", sobretudo num processo em que tanto o poder público quanto os sambistas tiveram de ceder para ser possível a realização dos festejos carnavalescos em um contexto histórico de repressão e ditadura militar.

A UESP buscou inicialmente filiar um maior número de escolas e ter um reconhecimento do poder público. Depois do problema da intervenção judicial na Federação das Escolas de Samba, a Prefeitura de São Paulo passou a exigir que as escolas se regularizassem, tornando-se uma organização recreativa com personalidade jurídica. Isso foi fundamental para a legitimação da UESP, que auxiliou na legalização e 
na elaboração dos estatutos de suas filiadas. Também ficou a cargo da UESP a criação de uma comissão de fiscalização das escolas, para garantir que estas tivessem um vínculo com a comunidade em que estavam inseridas e evitar, com isso, o aparecimento de "escolas de fachada", que captavam os recursos necessários e não se apresentavam nos desfiles. Outra assistência jurídica prestada pela UESP nesse período visava resolver os problemas que as escolas tinham com a polícia, após serem acionadas por moradores dos bairros em que se localizavam insatisfeitos com o barulho dos ensaios. Era uma difícil negociação para realizar os ensaios nas ruas, já que as escolas ainda não possuíam quadras, restando a elas ensaiarem em praças e ruas de menor movimento e em horários que não incomodassem seus vizinhos.

Para a direção da UESP foram eleitos, ainda no final de 1973, como presidente o jornalista Renato Correa de Castro; vice-presidente, Dalmo Ferreira; vice-presidente de Finanças, João de Angelo; vice-presidente de Comunicação, Wanderli Salztiel; vicepresidente de Divulgação, Covas Júnior; vice-presidente Social, Aristides Barbosa; e vice-presidente de Patrimônio, Carlos Eugênio Panadis.

Uma das primeiras decisões tomadas pela diretoria da UESP foi tentar representar as escolas de samba nas negociações com o poder público para a elaboração do regulamento referente ao carnaval de 1974. Os sambistas passaram a interferir na elaboração do regulamento dos desfiles a partir de 1972, devido aos problemas relacionados ao carnaval de 1971. Segundo o regulamento desse ano, realizado pela Secretaria de Turismo, só permaneceriam no Grupo I para o ano seguinte as escolas que tivessem conseguido um número maior que $70 \%$ dos pontos disputados, e, caso tal regulamento fosse cumprido, teria levado ao rebaixamento da maioria das escolas. Como não era possível rebaixar mais de 50\% das escolas para o Grupo II, essa cláusula foi considerada sem efeito (FOLHA DE SÃO PAULO, 01/01/1974). Para o ano seguinte, foi chamada uma comissão de sambistas que elaborou um novo regulamento, em parceria com o secretário de Turismo.

Havia a preocupação de cumprir o acordo com as emissoras de rádio que transmitiam os desfiles e evitar o que havia acontecido em carnavais anteriores, quando os desfiles atrasavam horas, por não haver uma definição clara para afirmar que um 
determinado desfile estava encerrado e outro estava começando. O regulamento previa penalidades pesadas às escolas que não se apresentassem no horário. Após os desfiles, sete escolas foram desclassificadas de seus respectivos grupos, pelo não cumprimento do horário.

Como o regulamento foi elaborado pelos próprios sambistas, houve uma disputa entre eles, porque uma parte queria voltar ao regulamento antigo, que não previa punições por atraso, nem estabelecia tempo definido, e a outra parte (que contava com o apoio do então secretário, Edemir Machado) queria fazer valer o regulamento mais rigoroso. Prevaleceu a visão do secretário e diversas escolas perderam pontos na apuração e algumas foram inclusive rebaixadas. Como em 1972 muitas escolas sofreram punições, no carnaval de 1973 as escolas levaram a questão do tempo mais a sério, resultando na punição de apenas três escolas por atraso.

Por conta dos problemas enfrentados pela extinta Federação e pela divisão das escolas em duas organizações, a Secretaria de Turismo decidiu negociar a organização dos desfiles de 1974, diretamente com as escolas, o que provocou reações tanto da Associação, quanto da UESP. Na assinatura do contrato, sem a força de uma negociação em conjunto, a Secretaria tomou a iniciativa de modificar alguns itens do regulamento sem consultar as escolas, nem a UESP. As alterações nos dias de desfile e o tamanho dos carros alegóricos não foram aceitos pelas escolas de samba que, através da UESP, protestaram e ameaçaram não desfilar, caso o regulamento não fosse revisto. O jornal Notícias Populares, de 30 de dezembro de 1973, que noticiou as disputas, lançou as manchetes sensacionalistas: "Carnaval paulista pode acabar em 74" e "Carnaval paulista está ameaçado de desaparecer”.

Em nota, a entidade considerou "um absurdo as exigências da Secretaria de Turismo" e precipitada a atitude do órgão público de não convocar os sambistas para a discussão. O regulamento da Secretaria mudava de domingo para terça-feira os desfiles do Grupo I e os sambistas alegavam que a mudança a menos de dois meses para o carnaval, poderia causar prejuízos para as escolas que já haviam assumido diversos compromissos como o aluguel de equipamentos para o domingo e haviam firmado contrato com prefeituras do interior para desfilarem na terça-feira gorda. Diante do 
acordo, o secretário da entidade dos sambistas disse: "Se alguma modificação deve ser feita, a UESP deve ser consultada, além do que se devem estudar as possibilidades previamente, e dar um prazo para que as escolas se adaptem" (NOTÍCIAS POPULARES, 30/12/1973).

A respeito dos carros alegóricos a discordância era que a UESP sugeriu que se aumentasse o tamanho, liberando medidas maiores, já que os desfiles haviam sido transferidos do Vale do Anhangabaú para a Avenida São João, que possuía uma pista mais larga.

Poucos dias depois, surgiram novos impasses entre as escolas de samba e a Secretaria de Turismo. Durante a primeira reunião do ano, realizada no dia 2 de janeiro para solucionar os problemas no regulamento (GAZETA ESPORTIVA, 29/12/1973), o secretário negou ter elaborado o regulamento sem ouvir as escolas. O jornal Notícias Populares, que naquele momento dava ampla cobertura ao processo de negociação dos desfiles das escolas de samba, entrevistou o secretário, que reagiu à pressão dos sambistas: "A Secretaria remeteu a minuta do regulamento, anexa a um ofício convocando a UESP e a AESSP e todas as escolas filiadas ou não às entidades" e "se convoquei todas as escolas de samba é porque quero conversar diretamente com elas, devido às divergências existentes entre a Associação das Escolas de Samba de São Paulo e a União das Escolas de Samba Paulistanas" (NOTÍCIAS POPULARES, 04/01/1974).

Durante a reunião, o Secretário aceitou a mudança do dia de desfiles, a fim de que o desfile do Grupo I continuasse no domingo. O compositor B. Lobo, da Unidos do Peruche, pediu a criação de uma comissão especial para fiscalizar os jurados. O secretário informou ao sambista que os juízes são autônomos e que, para o carnaval, pretendia convocar pessoas conhecedoras do assunto e imparciais.

O presidente da UESP, Renato Correa de Castro, pressionou o secretário a revogar o item que proibia que as escolas desfilassem com as suas fantasias, antes do desfile oficial. Segundo Castro, as escolas assumiam diversos compromissos nos bairros de origem, já que a verba que a secretaria destinava às escolas não cobria todas as 
despesas. O secretário, no dia seguinte, então, respondeu: "se querem que eu retire o item, eu o retirarei, mas depois não venham culpar os jurados por perda de pontos" (NOTÍCIAS POPULARES, 05/01/1974).

Segundo o secretário, com os desfiles nos bairros e em bailes, duas ou três vezes antes do carnaval, as fantasias ficariam amarrotadas ou rasgadas para os desfiles oficiais. O presidente da UESP também queria que a secretaria proibisse as escolas não filiadas a qualquer das duas entidades de participar dos desfiles. O secretário, dessa vez, não cedeu e disse que a obrigação das escolas era ser registrada na Secretaria de Turismo e, mesmo que uma agremiação não fosse filiada a qualquer uma das entidades, não poderia impedi-las de desfilar, pois as mesmas poderiam entrar com um mandado de segurança.

Ficou decidido, ainda na reunião, que os prêmios teriam um aumento de $100 \%$ em relação ao ano anterior. Ficou acertado que para o Grupo I os prêmios seriam de 12 mil cruzeiros para o campeão e 10 mil para o vice-campeão. Para o Grupo II, Cr\$ 8 mil e Cr\$ 6 mil. O Grupo III, Cr\$ 4 mil e Cr\$ 2 mil, respectivamente. Por fim, o secretário anunciou um aumento de $10 \%$ nas verbas do carnaval, que seriam liberadas nos próximos dias. Juarez da Cruz, presidente da Mocidade Alegre, imediatamente se posicionou contra o aumento, considerando-o irrisório em relação ao aumento dos custos.

Ainda em processo de discussão com o secretário e percebendo que ele voltou atrás em sua decisão tomada na reunião do dia anterior, os sambistas passaram então a pressionar a prefeitura por um aumento de $20 \%$ da verba do ano anterior. As duas entidades de sambistas, a UESP e a AESSP, decidiram, por votação de seus representantes, na mesma reunião, encaminhar ao prefeito Miguel Colassuono três pedidos: o aumento da subvenção e o fortalecimento dos desfiles do Grupo II, aumentando, assim, o número de participantes desse grupo, subindo três escolas do Grupo III, e a incorporação das escolas desclassificadas por falhas na organização do carnaval de 1973 (Notícias Populares, 05/01/1974). 
Pelo regulamento haviam subido a Rosas de Ouro, campeã do Grupo III, e Príncipe Negro da Cidade Tiradentes, vice-campeã. Duas escolas desceram do Grupo I, o Fio de Ouro, em seu primeiro desfile como escola de samba, e Unidos de Vila Maria; as escolas Unidos do Bom Retiro e a Campos Elíseos foram desclassificadas e não poderiam desfilar; as federações queriam incluí-las no Grupo III e II, respectivamente, pois julgavam que elas foram desclassificadas por falhas na organização do carnaval e não por conta própria.

O secretário de Turismo, José Maria Mendes Pereira, então se comprometeu a encaminhar os pedidos para o prefeito, já que o aumento da subvenção dependia de decreto do prefeito, mas disse que as punições estavam previstas no regulamento anterior (NOTÍCIAS POPULARES, 05/01/1974).

Uma nota emitida pelas entidades, publicada na imprensa contendo diversas reivindicações dos sambistas, revelava que a questão central era o aumento de verbas para os desfiles:

\begin{abstract}
Motivados pela alta do custo de vida que encareceu sobremaneira o preço de todos os artigos utilizados na confecção de fantasias, carros alegóricos, alegorias e preparação para o desfile, desejam as escolas que o aumento dessa contratação seja da ordem de $20 \%$ sobre a contratação do ano de 1973 , e não de apenas de 10\%, como nos informou o Secretário de Turismo. O ideal seria que essas contratações obedecessem ao Plano de Equivalência Salarial, conforme já estabelecido no Salão Paulista de Belas Artes, por exemplo, e baseado ainda nos estudos da Fundação Getúlio Vargas, no tocante à alta do custo de vida (NOTÍCIAS POPULARES, 05/01/1974).
\end{abstract}

A última demanda dos sambistas na carta era receber os recursos da prefeitura com maior antecedência. Eles alegavam que o recebimento dos recursos a poucas semanas do carnaval e também o aumento de apenas $10 \%$ não refletiam o aumento do custo das mercadorias, motivado pela alta inflação do período. Como mostra Álvaro Casado, os sambistas também pressionavam o poder público:

Teve um ano lá, acho que foi em 75, que começou a atrasar; nós pegamos e fomos todo mundo lá. Todas escolas, lotou. Aí o cara viu a pressão. Passou 
uns dias e teve o dinheiro na mão. Porque teve ano que a verba saiu praticamente em janeiro, pô. Teve parcela que saiu em fevereiro. Já teve verba que saiu três dias antes do carnaval, a última parcela. Aí você pega um sábado e domingo a 25 de Março fechada, não dava tempo. Agora não, a verba já sai em setembro. ${ }^{17}$

Uma solução encontrada pelas agremiações para montar o seu desfile era encontrar algumas lojas e armazéns que se dispusessem a vender os materiais a prazo, com as escolas pagando apenas quando saísse a verba para o carnaval. ${ }^{18}$ Para evitar novamente esse tipo de negociação incerta, a UESP emitiu uma carta endereçada ao secretário de Turismo em nome de todas as suas filiadas, solicitando as verbas com maior antecedência:

O Carnaval de 73 ensinou muitas lições aos responsáveis pela Secretaria Municipal de Turismo, e a maior delas, foi sem qualquer sombra de dúvida, a de que as escolas de samba paulistanas, ainda em processo de implantação, teriam, obrigatoriamente, de merecer um firme apoio financeiro da Secretaria Municipal de Turismo, consubstanciado no pagamento do auxílio - ou subvenção, ou termo que se queira empregar - bem antes do carnaval, de preferência ainda em dezembro, para que as agremiações, a maioria delas sem meios próprios de renda, pudessem partir para a feitura de seus carnavais com um mínimo razoável de tempo ${ }^{19}$.

Isso comprova que as negociações entre a UESP, as escolas e a Prefeitura passaram por momentos tensos, com pressões de ambos os lados. O poder público ameaçava não liberar os recursos e as escolas ameaçavam não desfilar, caso suas reivindicações não fossem atendidas.

No caso das reivindicações do carnaval de 1974, a Prefeitura cedeu nos pontos mais importantes das exigências dos sambistas ao aumentar a verba para os desfiles em $20 \%$ e incluir três escolas do Grupo II no Grupo III, dividindo melhor o número de agremiações por grupo. Quanto ao dia de desfile, as escolas também foram atendidas e o desfile do Grupo I continuou a ser no domingo.

\footnotetext{
${ }^{17}$ Entrevista com Álvaro Casado. Data: 01/05/2012.

${ }^{18}$ Entrevista com Mestre Gabi. Data: 25/10/2010.

${ }^{19}$ Carta datilografada. Acervo pessoal de Álvaro Casado.
} 
Com relação ao aumento das verbas, como mostra o título "Um milhão para o carnaval de rua" de uma reportagem do jornal Notícias Populares de 18 de janeiro de 1974, ou seja, 13 dias após a reunião com a Secretaria de Turismo, o prefeito cedeu à pressão dos sambistas e aumentou em $20 \%$ o repasse das verbas em relação ao carnaval anterior. Segundo o jornal, com o novo acordo, as escolas do Grupo I receberiam 52 mil cruzeiros, as do Grupo II, 34 mil cruzeiros e as do Grupo III, 20 mil cruzeiros, totalizando um milhão e cem mil cruzeiros. A reportagem também discorre sobre outras reivindicações atendidas:

\begin{abstract}
Ainda durante o despacho com o Secretário Municipal de Turismo, o prefeito determinou o escalonamento das escolas de samba. Assim, o primeiro e o segundo grupos terão 10 escolas e o terceiro, 11. O terceiro grupo desfila no sábado à noite, abrindo os festejos carnavalescos; o primeiro grupo desfilará no domingo e o segundo, na noite de segunda feira, encerrando a parte dos desfiles oficiais (NOTÍCIAS POPULARES, 18/01/1974).
\end{abstract}

Essa negociação evidencia a força e a pressão que as escolas também colocaram na prefeitura, e que as decisões impostas de "cima para baixo" por esta, foram revistas após um posicionamento coletivo dos sambistas e a ameaça de não poder desfilar no concurso oficial.

Em 1975, devido aos vários impasses com os sambistas, a Secretaria de Turismo, responsável pela administração do carnaval, decidiu terceirizar a produção do carnaval, contratando a Jaraguá Promoções, uma empresa responsável em negociar com as escolas a realização do carnaval (AZEVEDO, 2010, p. 95).

Muitas escolas nesse período ainda contavam com uma administração bem amadora, sem possuírem, ao menos, conta em banco. Ainda não era comum a preocupação de exigir notas fiscais e prestação dos contas de seus gastos, o que evidentemente gerava alguns problemas. Por isso, nos carnavais de 1974 e 1975, quando ainda havia a divisão das federações, a prefeitura decidiu pagar apenas uma quantia de participação pela apresentação das escolas de samba nos desfiles - uma espécie de cachê artístico. Com esse artifício jurídico, a UESP e suas filiadas deixavam 
de sofrer uma pressão quanto a prestação de contas do dinheiro público, a qual já havia gerado muitos conflitos e interdições judiciais na própria Federação e em escolas que acabavam descredenciadas.

Com a contratação para a execução de um serviço, as escolas tiveram garantida a verba destinada ao financiamento da construção do desfile de carnaval. No caso de não conseguirem apresentar um bom desfile, o próprio regulamento se encarregava de punição, com o rebaixamento para o grupo imediatamente inferior. A UESP, no início, era a favor desse modelo jurídico de relação entre as escolas e a prefeitura, pois os repasses eram dados diretamente às escolas, que repassavam um percentual para a própria UESP.

Os protestos mais comuns das escolas após a realização do carnaval não eram destinados à UESP, mas à Prefeitura e, obviamente, ao corpo de jurados. Todos os anos, muitas escolas se posicionavam contra as notas recebidas por elas e não aceitavam o resultado oficial.

Em 1975, após a apuração do carnaval e confirmado o bicampeonato da escola de samba Camisa Verde e Branco, os componentes da escola Nenê de Vila Matilde realizaram um grande protesto, no qual, simbolicamente, "enterraram" o carnaval. Os alvos daquele ano foram a empresa Jaraguá, tida como ineficiente, a Comissão do Carnaval Paulistano (COCAP), ambas responsáveis por escolher o júri, e o secretário de Turismo, acusado de prejudicar a escola, que ficou em quarto lugar. O protesto consistiu na escola realizar um cortejo fúnebre com caixões pelas ruas centrais da cidade e realizar uma "cerimônia de sepultamento" na frente da Câmara Municipal. A indignação de Seu Nenê era com as seguintes notas: sete, de Mestre-Sala e Porta Bandeira, seis, de Comissão de Frente, e um nove de bateria, em um momento em que a bateria da escola era considerada a melhor da cidade (FOLHA DA TARDE, 18/02/1975).

No ano seguinte, em 1976, foi a vez de Mocidade Alegre, Rosas de Ouro e VaiVai não aceitarem o tricampeonato do Camisa Verde e Branco e protestarem contra a organização do carnaval, o tratamento dado aos sambistas e o resultado oficial. Segundo 
o colunista Jangada, do jornal Última Hora, a Jaraguá promoveu uma “apoteose de erros":

\begin{abstract}
Extremamente útil o desfile da Apoteose, porque ficou claro que a Secretaria de Turismo não pode mais entregar à empresa Jaraguá a organização de uma festa deste quilate. A ela e seus funcionários cabe a responsabilidade por várias escolas desfilarem em apenas duas faixas de trânsito existentes na Av. São João, como a eles cabe a responsabilidade pela falta de informação ao público, o incitamento aos policiais - desta vez de uma delicadeza digna de elogios - ao uso da violência, o que, em parte conseguiram. Mais especificamente, um funcionário de nome Gilberto Oliveira - que logo se tornou conhecido de todos pela falta de um mínimo de consideração com o povo e todos os demais presentes que não fossem autoridades - se imbuiu de ares de autoridade e foi um dos destaques no incitamento aos desmandos, tentando, quase nunca conseguindo, se investir de poderes de polícia (ÚLTIMA HORA, 04/03/1976).
\end{abstract}

Eduardo Basílio, presidente da escola Rosas de Ouro, exigia a anulação dos votos de um jurado de bateria, Walter Silva, que possuía uma coluna no jornal Folha de São Paulo e na qual revelou seus votos antes da apuração. O secretário indeferiu o pedido e argumentou que o jurado emitiu opinião após ter colocado seus votos na urna, e que isso não alterava o resultado (FOLHA DA TARDE, 05/03/1976). A Mocidade Alegre promoveu, na quadra de sua escola, a "noite da choradeira", contra o resultado dos desfiles. (FOLHA DA TARDE, 15/03/1976). A UESP, através do boletim "Recado do Samba", de abril de 1976, relata às suas filiadas o caos que foi o desfile daquele ano $^{20}$. Das 23 escolas inscritas no Grupo III e pleiteantes, apenas 13 se classificaram. Dez escolas foram desclassificadas por não apresentarem 200 componentes, número mínimo exigido, ou por terem se atrasado, norma vigente desde 1973. Essas normas rígidas com o número de componentes era para desestimular a criação de dezenas de escolas pequenas, sem uma estrutura mínima que se esperava dos participantes de um carnaval oficializado. Uma das estratégias para tentar burlar o regulamento é descrita por Maria Apparecida Urbano, em entrevista a Vanir Belo: "Por exemplo, quem estava lá no começo mudava a camiseta e ia lá pra trás ser contado de novo. Tinha uma série de coisas assim, engenhocas para que a escola saísse" (BELO, 2008, p. 59).

\footnotetext{
${ }^{20}$ Boletim Recado do Samba. Edição no 2 . Abril de 1976. Acervo UESP.
} 
A justificativa das escolas de samba para o atraso foi a seguinte: a empresa Jaraguá não ofereceu suporte para as escolas estacionarem as alegorias com antecedência e elas tiveram que trazê-las de suas quadras e terrenos utilizados para a sua construção. Como os desfiles eram no centro da cidade e a grande maioria das escolas vinha de bairros periféricos, o transporte dos carros alegóricos comprometeu a apresentação das escolas de samba em seus respectivos horários.

Alguns membros da diretoria do Vai-Vai, após a apuração do carnaval, chegaram a coletar assinaturas para entregar aos deputados do MDB um documento pedindo para eles pressionarem o prefeito a demitir o Secretário de Turismo. O presidente do Vai-Vai, Chiclé, ameaçou novamente não participar do próximo carnaval, mas, obviamente, no ano seguinte, estava desfilando novamente:

Essa é a nossa vontade geral. Nós vamos sair na avenida, desfilando porque é a nossa obrigação com o povo, mas não vamos desfilar para competir. A verba que eles dão não nos faz falta. Neste ano nos deram Cr\$ 60 mil. Ora, vendemos cada apresentação da escola por Cr\$30 mil. Assim, se nos apresentarmos dois dias, já temos a mesma verba. Quando chegou o dinheiro deles, a escola já estava toda pronta para sair, apenas com o dinheiro dos integrantes (FOLHA DA TARDE, 05/03/1976).

Outra voz dissonante que criticava duramente a organização do carnaval foi a do escritor e dramaturgo Plínio Marcos, que trabalhou em 1976 como comentarista da rádio Tupi. Em sua coluna no Jornal Folha de São Paulo, ele disse:

Para quem acredita que 300 mil pessoas apinhadas em arquibancadas que mal comportam 20 mil pessoas assistindo ao desfile de 12 mil sambistas, é algo genial, o carnaval em São Paulo foi um sucesso (...) Para quem acredita no paternalismo da Prefeitura, dando subvenções para as escolas de samba; para quem acredita que não tem importância que das 40 escolas de samba, apenas quatro ou cinco possam sair à rua com seus próprios recursos, o carnaval de São Paulo foi um sucesso (...) Para quem gosta de bateria tocando no melhor estilo fanfarra de pelotão naval, o carnaval de São Paulo foi um sucesso. Porém e sempre tem um porém, para quem tem olhos de ver e viu, o carnaval de São Paulo, onde tudo se resumia na mal iluminada e mal decorada avenida São João e no estardalhaço do Trio Elétrico, lixão sonoro - o carnaval foi um fracasso. Para quem percebeu que não havia por parte das autoridades, nenhuma preocupação em preservar aspectos culturais do carnaval e nem o 
esforço dessas autoridades em promover outros eventos carnavalescos além dos desfiles das escolas de samba, que a Prefeitura é obrigada a realizar por lei, o carnaval de São Paulo foi um fracasso (FOLHA DE SÃO PAULO, 06/03/1976).

O próprio prefeito Miguel Colassuono não gostou da condução da Jaraguá à frente dos desfiles das escolas de samba e tentou implantar, no carnaval de 1976, um "carnaval metropolitano", que iria ser realizado em toda a extensão do Vale do Anhangabaú e parte da Avenida Prestes Maia. Seria metropolitano, pois o prefeito tentou costurar um acordo com outras dez prefeituras da região do $\mathrm{ABCD}$, Osasco e outras, para que elas participassem do carnaval da capital. Com a saída de Miguel Colassuono da Prefeitura e de José Maria Mendes Pereira da Secretaria de Turismo, o projeto foi abandonado.

O governador Paulo Egydio Martins nomeou em 1975, o banqueiro Olavo Setúbal para o cargo de prefeito. As escolas de samba viram que era uma oportunidade de pressionar o recém-nomeado prefeito e pediram, em documento elaborado por Alberto Alves da Silva, o Seu Nenê da Vila Matilde, a nomeação de Paulo Henrique Meinberg para a Secretaria de Turismo. Meinberg já havia sido secretário de Turismo na gestão do prefeito Faria Lima, auxiliando na consolidação da parceria escolas e prefeitura e tinha a proposta de criação do "palácio do carnaval", um local destinado a abrigar as atividades das escolas de samba e servir para preparação do carnaval. A proposta contou com o apoio e o entusiasmo dos sambistas, que tentaram emplacar Meinberg na secretaria. O projeto, segundo o seu autor: "É a criação de uma sede em que se possa tratar de tudo que se relacione ao carnaval. Onde técnicos no assunto, elaborem as promoções pré-carnavalescas e carnavalescas propriamente ditas. A Secretaria de Turismo criaria uma infraestrutura organizada, integrando tudo referente ao carnaval” (FOLHA DA TARDE, 11/03/1975).

O prefeito não cedeu ao apelo das escolas e nomeou Armando Simões Neto para a secretaria. Simões Neto já era um político experiente, ex-vereador e havia passado pelo Departamento de Trânsito na gestão Colassuono. O novo secretário endureceu as posições da secretaria e não levou adiante a proposta do "palácio do carnaval". Durante 
as negociações para a realização do carnaval de 1976, a ameaça de não realizar o carnaval partiu do próprio secretário, que decidiu suspender as negociações para a distribuição de verbas e também sobre as alterações no regulamento para o carnaval de 1976, após mais um impasse entre a secretaria e as escolas, que não conseguiam chegar a um acordo.

Simões Neto deu um prazo de 15 dias para que uma única entidade representasse as escolas de samba e vencesse os impasses. Por conta do curto prazo de tempo, a AESSP, liderada por Pedro Guilharde, decidiu se incorporar à UESP, pois a última possuía maior estrutura e o mandato de sua diretoria estava se encerrando, com a possibilidade de uma nova direção se formar congregando sambistas das duas federações. ${ }^{21}$ Como os custos para realização dos desfiles carnavalescos aumentaram em 1976, Simões Neto também decidiu que a secretaria assumiria novamente a administração do carnaval, agora juntamente com a UESP, única entidade a representar as escolas e blocos nas negociações com o poder público.

Durante a preparação para o carnaval de 1976, a UESP entrega ao secretário um documento com uma análise dos principais problemas verificados no carnaval anterior e também questões de infraestrutura que prejudicaram o desenvolvimento das escolas de samba. Em síntese, o documento trazia seis questões principais: 1) representatividade da própria UESP; 2) quadra de ensaios; 3) ajuda financeira; 4) reformulação do programa do carnaval paulistano; 5) aperfeiçoamento do concurso, adotando-se novos critérios de julgamento; 6) participação das escolas de samba em outras atividades ao longo do ano (GAZETA ESPORTIVA, 18/05/1975).

A UESP, como única entidade representativa das escolas, reivindicava um papel mais ativo na organização do carnaval. Julgava ser seu papel auxiliar na fiscalização dos desfiles oficiais para impedir erros que prejudicassem suas filiadas. A direção também desejava atuar em outras frentes, como a elaboração de uma revista do carnaval paulistano contando a história das escolas de samba, que não foi editada por falta de recursos.

\footnotetext{
${ }^{21}$ Fonte: Centro de Documentação e Memória do Samba. Documento: UESP 25 anos, p. 16.
} 
A entidade também se colocava na defesa dos lamentáveis acontecimentos que ocorreram na quadra da Unidos do Peruche, como a invasão do terreno em que a escola ensaiava pela polícia. Para ela, a invasão de ensaios das escolas era motivada pelo fato de a maioria das escolas não possuírem quadras com estrutura adequada. Algumas escolas ensaiavam em praças públicas, alugavam clubes e terrenos cedidos por amigos ou pela própria Prefeitura, mas a título precário, o que as impedia de planejar e realizar as obras necessárias para um melhor conforto dos seus associados e visitantes. A solução proposta pela UESP, no documento, seria a secretaria elaborar um plano que permitisse a posse de terrenos ociosos para as escolas e financiamentos para melhorias.

A entidade realizou uma nova eleição buscando novamente a reunificação das entidades representativas das escolas de samba. Seu Juarez da Cruz, Seu Nenê, Pé Rachado e Seu Carlão do Peruche procuraram o publicitário e artista plástico Álvaro Casado e o convidaram a assumir a presidência da UESP. Casado já tinha experiência em desfiles desde 1953, quando fundou a escola de samba Acadêmicos do Tatuapé e desde então atuava na organização das escolas e nas negociações do carnaval com as rádios e com os órgãos públicos. Foi ele também quem confeccionou a primeira bandeira da UESP e contribuiu para que a entidade se instalasse em um prédio na Avenida Brigadeiro Luiz Antônio, esquina com a Rua Rui Barbosa, na Bela Vista, bairro no qual se localiza, até os dias de hoje, a sede da UESP. Com o apoio dos principais “caciques" do samba de São Paulo, que julgavam que ele poderia desenvolver um bom trânsito com a prefeitura, Álvaro Casado foi eleito. A diretoria ficou assim constituída: Álvaro Casado, presidente; Derly Marques da Silva, vice-presidente administrativo; Arnaldo Mathias, vice-presidente de Finanças; Dárcio Pauperio Serio, vice-presidente de Comunicações; Nelson Crecibeni Filho, vice-presidente de Divulgação; e Paulo Soares de Almeida, vice-presidente de Patrimônio. Novamente, dentro dos nomes da diretoria da UESP, nesse momento, não há a figura de nenhum "cardeal" do samba. Como não havia ainda a unidade entre os sambistas, a solução encontrada foi colocar, na linha de frente, dois profissionais liberais e universitários com laços de amizade e ligação com as escolas de samba: Álvaro Casado, publicitário, e Derly Marques, jornalista. 
Em entrevista, Álvaro Casado diz que a principal dificuldade enfrentada em seu mandato foi a unificação das escolas de samba em torno da UESP, conseguida apenas por Geraldo Filme, seu sucessor. A oposição, em parte, segundo Casado, era determinada pelos mesmos motivos que fizeram os "cardeais" convidá-lo a disputar a eleição e assumir a presidência: o de ele ser branco e profissional universitário.

\footnotetext{
Você sabe que no samba, a maioria é de negros. E quando viam o branquinho aqui, alguns já torciam o nariz. (...) Mas eu tinha o apoio das principais figuras que confiavam no meu trabalho. A partir de setembro, toda sexta-feira eu estava lá comandando as assembleias e ajudando as filiadas no que fosse possível $^{22}$.
}

Na década de 1970, muitas escolas de samba foram fundadas em diversos locais da cidade. Como elas não possuíam muita experiência, o próprio presidente da UESP, Álvaro Casado, era quem desenhava os figurinos, as alegorias, fazia a pesquisa dos enredos e entregava para que suas filiadas tivessem uma espécie de "roteiro a ser seguido". Outros membros da diretoria, como Silvio Modesto e Jangada, frequentemente faziam os sambas-enredos de escolas filiadas, para que eles cumprissem as exigências dos regulamentos e passassem, sem problemas, pela apreciação da censura prévia, instituída após a promulgação do Ato Institucional Número 5 (AI-5) pelo regime militar. Todos os sambas-enredos escolhidos pelas escolas deveriam ser aprovados pelo Departamento de Censura da Polícia Federal.

Muitas vezes as escolas vinham aqui e diziam: "a gente vai vir de corte portuguesa", eu perguntava: "vocês têm o dinheiro, vocês sabem como são os figurinos, as alegorias, quanto de tecido vai gastar?" Eu fazia os cálculos junto com eles, e dava um valor que a escola não ia conseguir arrecadar. Então, eu ajudava a organizar o enredo com fantasias mais simples, com alegorias pequenas, para que as escolas pudessem desfilar. $(. . .)^{23}$

\footnotetext{
${ }^{22}$ Entrevista com Álvaro Casado. Data: 01/05/2012.

${ }^{23}$ Idem.
} 
Ainda sobre a censura, esta se tornou ainda mais implacável com os desfiles carnavalescos a partir da Portaria $\mathrm{n}^{\mathbf{0}}$ 006/76, de 19 de janeiro de 1976. A portaria abrangia não apenas os desfiles das escolas, realizados nas ruas e que já necessitavam de aprovação da polícia para ocorrer, mas todos os bailes carnavalescos, inclusive os realizados em espaços privados. A medida assinada pelo coronel José Guimarães Barreto, superintendente regional do Departamento da Polícia Federal, dizia, em seu Art. $1^{\mathrm{o}}$ :

1 - Nenhum BAILE CARNAVALESCO poderá ser realizado em teatros, cinemas, parques, clubes, associações recreativas ou esportivas, salões, hotéis ou dependências adequadas, sem a devida aprovação do respectivo programa pelo Serviço de Censura de Diversões Públicas da Superintendência Regional do D.P.F em São Paulo ou pelos órgãos competentes da Divisão de Santos e das Delegacias de Bauru e Lorena. ${ }^{24}$

Essa era mais uma medida imposta pelo regime para controlar qualquer reunião ou aglomeração de pessoas, mesmo que essas tivessem como finalidade a diversão. Além das canções, notoriamente censuradas, os enredos e os croquis da decoração dos salões e das alegorias e fantasias a serem feitas também deveriam ser enviadas previamente para aprovação do órgão da Polícia Federal. É possível observar, em todos os sambas-enredos depositados pelas escolas nos arquivos da UESP, um carimbo emitido pela Polícia Federal, atestando que a letra musical foi examinada e liberada para gravação e divulgação pública ${ }^{25}$.

Como a UESP assumiu de vez o desafio de organizar os desfiles das escolas de samba da capital paulista, como única entidade, ela também participou das discussões que resultaram na transferência do local dos desfiles, que ocorriam desde 1968 na Avenida São João, para a Avenida Tiradentes, ocorrida em 1977.

\footnotetext{
${ }^{24}$ Anexo 1. Portaria n ${ }^{\circ}$ 006/76. Departamento da Polícia Federal de São Paulo encaminhada ao Sr. Álvaro Casado, presidente da UESP. Acervo pessoal de Álvaro Casado.

${ }^{25}$ Anexo 2. Samba-enredo da Sociedade Carnavalesca Corujas da Vila Esperança de 1979. Acervo UESP.
} 
Em entrevista, Álvaro Casado nos conta a preocupação da Prefeitura com a mudança do local de desfiles:

Saía lá da Duque de Caxias e ia até o Correio. Foi o melhor carnaval que eu vi o da São João. Era tradicional. Mas tinha o problema de trânsito, de trilho. Ali era vazão de tudo, pô. Quem ia pra Lapa, Pinheiros, Vila Madalena, não tinha acesso. Parava os bondes, os ônibus, entendeu? E virava uma bagunça ali no centro. Tanto é que nós fizemos vários... Desfiles e os palanques ficavam ali no Largo do Paiçandu. Em frente a igreja. E era corda, não tinha arquibancada, o carnaval era na corda. E dava uma mão de obra danada. E aí optamos pela Tiradentes. Eu era presidente da UESP e falamos, vamos mudar" 26 .

Como ficou evidente, a grande preocupação da Prefeitura era resolver o problema no trânsito da região central da cidade, que era interrompido por cinco dias para a realização dos festejos carnavalescos. Além disso, havia uma reclamação das escolas de samba, que alegavam uma dificuldade em manter o ritmo, devido à ladeira existente na avenida (FOLHA DE SÃO PAULO, 09/05/1975). As escolas se concentravam na Avenida Duque de Caxias, entravam na Avenida São João perfiladas para o desfile e seguiam em direção ao Vale do Anhangabaú, local de dispersão.

Em matéria do jornal Folha de São Paulo, o último desfile da Avenida São João foi descrito como um caos para os moradores da região e inseguro para os populares que estavam interessados apenas em prestigiar sua escola de samba:

O empurra-empurra durante os desfiles de ontem na Avenida São João
próximo à praça Júlio Mesquita. foi violento. Eram mulheres e crianças no
meio da multidão, que gritavam aos policiais, pedindo ajuda. A confusão
ocorria principalmente nas proximidades do edifício Andraus, onde foram
colocados cordões de isolamento muito próximos às calçadas, deixando
apenas um pequeno corredor no passeio para os passantes. Moradores do
edifício São José, na avenida São João, 856, reclamaram das autoridades
afirmando que não conseguiriam sair para fazer compras, pois a porta do
prédio ficou totalmente congestionada. Do alto do edifício os moradores
vaiavam, enquanto a multidão, embaixo se comprimia assustada, todos com
medo de cair no chão e serem pisoteados. Também ao lado do Cine Oásis,
onde existia um estacionamento, foi colocado um grande tapume sobre a
calçada, deixando apenas um metro de passeio para os populares. Ali
chegaram mesmo a acontecer algumas brigas entre passantes que tentavam

${ }^{26}$ Entrevista com Álvaro Casado. Data: 01/05/2012. 
utilizar-se daquele pequeno corredor (FOLHA DE SÃO PAULO, 03/03/1976).

A sugestão da Avenida Tiradentes surgiu por ela ser próxima à Marginal Tietê, portanto, de fácil acesso, próxima ao centro da cidade e da estação da Luz. Com essa mudança de local, as escolas poderiam construir alegorias maiores e levar um maior número de componentes para os desfiles. A escolha do local agradou aos sambistas, pois o lugar era amplo e permitia às escolas levar suas alegorias e pelo fato de a avenida ter grande comprimento e também pela possibilidade de todas as agremiações montarem as suas alas em sequência antes da apresentação, permitindo, assim, corrigir erros de posicionamento. Para testar a avenida foram realizados dois desfiles no ano de 1976. No feriado de Primeiro de Maio, cerca de trinta escolas e blocos desfilaram em comemoração ao Dia do Trabalho. E no dia quatro de setembro as escolas voltaram a desfilar em comemoração à Independência do Brasil, contando inclusive com um concurso que escolheu o melhor samba-enredo sobre o tema (BELO, 1971, p. 71).

Para acomodar o público que ia assistir aos desfiles, eram montadas arquibancadas tubulares de metal, cujo acesso era dado pela venda de ingressos. A prefeitura também instalou um moderno sistema de arquibancadas móveis e um sistema de som que proporcionava a todos ouvirem os intérpretes das escolas ${ }^{27}$. Mesmo aqueles que não tinham condições financeiras de adquirir os ingressos poderiam assistir aos desfiles pelas brechas entre os módulos das arquibancadas e também era possível acompanhar a dispersão das escolas ao final do desfile. ${ }^{28}$

Ainda no ano de 1976, inspirados pela iniciativa do Rio de Janeiro, que gravava os sambas-enredos desde o final da década de 1960 e alcançava vendagens expressivas, as escolas de São Paulo também passaram a lançar o LP com os sambas-enredos do Grupo I. A gravação do LP ficou a cargo de ritmistas selecionados por Osvaldinho da Cuíca, como Branca de Neve, no surdo; Xixa, no cavaquinho e violão, e contou também com a presença dos próprios puxadores das escolas, acompanhados por um grande coro

\footnotetext{
${ }^{27}$ Entrevista com Osvaldinho da Cuíca. Data: 20/01/2012.

${ }^{28}$ Entrevista com Mestre Gabi. Data: 25/10/2010.
} 
de vozes masculinas e femininas. A produção do LP foi realizada pela UESP e pela gravadora Crazy e promovido pela revista Amiga, além da divulgação nas rádios Nacional, Record, Gazeta, Capital e da Rede das Emissoras Coligadas, que contava com 16 emissoras no interior do Estado. ${ }^{29}$

Apesar de todas as inovações, algumas indefinições geraram atritos entre a Secretaria de Turismo, a Jaraguá e as escolas de samba. Os sambistas consideravam curto o tempo determinado para os desfiles. As Escolas de Samba dos Grupos I, II, III e IV teriam, respectivamente, $60,40,30$ e 30 minutos para os desfiles. ${ }^{30}$

Apesar de vários outros entraves, a maior polêmica novamente se deu pela questão da liberação dos recursos. A prefeitura estava impedida de liberar a verba por conta de um processo em andamento no Tribunal de Contas do Município contra a antiga Federação das Escolas de Samba, que deveria prestar contas à secretaria sobre os recursos gastos no carnaval de 1971 (ÚLTIMA HORA, 03/11/1976).

Por conta disso, até o dia 30 de dezembro de 1976 as negociações sobre as verbas do carnaval 1977 ainda estavam em curso, sem uma solução. Nesse dia, Álvaro Casado emitiu uma nota encaminhada ao prefeito sugerindo a adoção de algumas medidas que contornariam tais problemas, aumentando em $20 \%$ os recursos para as escolas de samba e pedindo para a secretaria retomar a organização do carnaval, pois o contrato firmado com a empresa Jaraguá "além de não resolver o problema das agremiações onerou ainda mais os cofres da municipalidade, com o pagamento de comissões e verbas de administração à empresa contratante" 31 .

Mesmo com a mudança de pista e a necessidade das escolas apresentarem um carnaval maior e a solicitação de um aumento de $20 \%$, a Secretaria de Turismo do município diminuiu as verbas em relação ao ano anterior (FOLHA DA TARDE, 31/12/1976). A verba orçamentária foi a mesma, mas com a terceirização do carnaval, organizado pela empresa Jaraguá, o montante destinado às escolas de samba foi

\footnotetext{
${ }^{29}$ Boletim Recado do Samba. $\mathrm{n}^{\mathrm{o}} 2$, abril de 1976.

${ }^{30}$ Regulamento para os desfiles do ano de 1977. Acervo UESP.

${ }^{31}$ Ofício encaminhado pela UESP para a Prefeitura de São Paulo. Data: 30/12/1976. Acervo pessoal de Álvaro Casado. Data: 01/05/2012.
} 
reduzido em 40\%. Também havia um prêmio em dinheiro, mas apenas para as três escolas melhores classificadas de cada grupo. A campeã do Grupo I ganharia Cr\$ 24.000,00, a do Grupo II, Cr\$ 18.000,00, e a do Grupo III, Cr\$ 9.600,00 (GAZETA ESPORTIVA, 31/01/1977). ${ }^{32}$.

Como mostra a matéria do jornal Folha da Tarde, de 02 de janeiro de 1977, além de reduzir o valor recebido pelas escolas, a Jaraguá só liberou as verbas destinadas para o $2^{\circ}$ e $3^{\circ}$ grupos na semana entre o Natal e o Ano-Novo. Quanto ao primeiro grupo, deveria ter sido paga naquele dia. O redator Paulo Valentim, da coluna Roda de Samba, aponta:

\begin{abstract}
Na realidade as entidades que estavam aguardando a verba para armar seus carnavais podem considerar-se candidatas a uma péssima classificação. Quem não se "virou" não terá mais tempo de seguir e nem encontrar bons preços em tecidos, alegorias, adereços, tintas, sapatos, chapéus e até mesmo instrumentos musicais. Não existe uma costureira ou alfaiate milagroso que consiga em 15 dias fazer uma fantasia de destaque com aplicações em pedrarias diversas, nenhum cenógrafo pode arriscar-se a montar um carro alegórico em 10 dias e o veículo não desmantelar na passarela. É isso aí, minha gente, vamos aproveitar tudo aquilo que já estiver pronto e desfilar com fantasias de carnavais passados. Podem estar certos que nós que estaremos cobrindo o carnaval-77, mostrando o sacrifício de cada sambista, que com o seu suor leva à avenida a alegria para o povo paulista (FOLHA DA TARDE, 02/01/1977).
\end{abstract}

Uma crítica também feita ao carnaval daquele ano, o primeiro realizado na Avenida Tiradentes, foi a não implantação do projeto original que previa a extensão dos desfiles por uma segunda pista, a da empolgação. Nessa segunda pista, que deveria ter sido localizada ao longo da Avenida Prestes Maia, as escolas terminariam o desfile permitindo ao público excedente das arquibancadas apreciar um desfile descontraído. Mas o que aconteceu foi o contrário, as escolas tiveram que virar à direita na Rua Mauá, congestionando a área próxima a cabine do jurado de Comissão de Frente, prejudicando a sua avaliação.

\footnotetext{
${ }^{32}$ Jornal Gazeta Esportiva. Data: 31/01/1977.
} 
O desejo real dos sambistas, já em 1977, era a construção de um espaço construído especialmente para os desfiles e que durante o ano funcionaria como um polo de cultura popular. Como afirma o presidente da UESP, Álvaro Casado, em entrevista ao jornal Gazeta Esportiva:

Corrigidos os defeitos, a Tiradentes será durante alguns anos o local ideal para os desfiles, mas a UESP pretende oferecer estudos para a localização definitiva dos desfiles em local construído especialmente, o que virá diminuir os gastos com montagem e desmontagem de arquibancadas e as escolas terão o local para guardar alegorias e até vestir as fantasias. O local dos desfiles funcionará durante o ano como um verdadeiro centro de cultura popular com apresentação de folclore, concursos de fanfarras e festas cívicas (GAZETA ESPORTIVA, 05/03/1977).

Como afirma Osvaldinho da Cuíca ${ }^{33}$, alguns sambistas ligados principalmente ao movimento negro estavam descontentes com a atuação da UESP enquanto entidade cultural do samba de São Paulo. Além da questão dos recursos que chegavam sempre atrasados, havia uma insatisfação com o departamento cultural da UESP. Reuniram-se e fundaram a Coligação das Escolas de Samba. Dentre eles estavam Geraldo Filme e Ciro Nascimento, preocupados em preservar a herança africana e rural do samba em um momento de grande crescimento das escolas de samba, que contavam com maiores recursos financeiros e se inspiravam nas inovações ocorridas nas escolas do Rio de Janeiro.

As reuniões da Coligação eram normalmente na sede da escola de samba Paulistano da Glória, agremiação presidida pelo próprio Geraldo Filme. A escola de samba recebeu este nome por sua sede se localizar na Rua da Glória, no bairro da Liberdade. Foi fundada por empregadas domésticas que trabalhavam para famílias abastadas da região da Avenida Paulista como um espaço de lazer e de reuniões políticas. Era uma espécie de "sindicato" informal das domésticas da região. Além dos desfiles realizados primeiro como cordão e posteriormente como escola de samba, o Paulistano possuía um dos mais conhecidos salões de baile, reunia os negros da cidade e

\footnotetext{
${ }^{33}$ Entrevista com Osvaldinho da Cuíca. Data: 20/01/2012.
} 
era apelidado de "oficina do samba". Uma das fundadoras do cordão foi a mãe de Geraldo Filme, que, em depoimento ao programa Ensaio, da TV Cultura, disse sobre o Paulistano:

\begin{abstract}
O Paulistano da Glória pra mim representa muito porque me faz lembrar minha mãe. A velha trabalhava com a família dos Penteado, no Jardim América, Cerqueira César, Alameda Santos, 25, por aí, 25, 26. Ela fez uma viagem para a Europa com uma dessas famílias e lá viu um movimento de operários, um movimento sindical, e ela gostou da coisa: "Dá até pra organizar as cozinheiras lá embaixo". Quando voltou pra cá, ela pensou em sindicalizar as domésticas, aquelas coisas todas, uma organização em defesa da doméstica. Aí tinha um barracão velho lá, que guardava carruagem, ela pediu, emprestaram pra ela e aí fundaram o Paulistano. Não era Paulistano da Glória. Havia surgido o Paulistano dos bacanas lá embaixo e ela fundou aqui em cima, na cabeceira, o Paulistano das cozinheiras. Mas até 41, o Paulistano ainda era um clube. O Bitucha e o Juca procuraram manter com associados e tudo. Depois, com o tempo, tornou-se uma empresa dançante e eu com o Bitucha, bom carnavalesco, e seu Juca, que conheceram os carnavais do passado, fui funestamente com eles pra lá e fizemos coisas bonitas com o cordão Paulistano e com a escola de samba também (BOTEZELLI; PELÃO; PEREIRA, 2000, vol 2: 82).
\end{abstract}

Participaram das reuniões da Coligação nomes importantes do samba paulistano, como Inocêncio Tobias, do Camisa Verde e Branco, Pé Rachado, ex-presidente do VaiVai e fundador da Barroca Zona Sul, e Seu Nenê da Vila Matilde. Como a preocupação da Coligação era a preservação cultural, organizando reuniões, bailes e eventos musicais $^{34}$, fez com que ocasionasse alguns atritos com a UESP, pois havia várias escolas e sambistas participando das duas federações. Segundo o sambista Jangada, diretor da UESP:

Não bastaram a União das Escolas de Samba Paulistanas e a Associação das Escolas de Samba do Estado de São Paulo. Para que a desunião das escolas ficassem bem caracterizada surge a Coligação - cujo nome chega a ser irônico, pois ela apenas divide mais uma casa recheada: o nosso samba. E tal como suas similares, a Coligação não sabe das coisas ou informa errado de propósito. A primeira da Vila Itaim permanece filiada à União. E agora? (ÚLTIMA HORA, 05/05/1976).

\footnotetext{
${ }^{34}$ Entrevista com Álvaro Casado. Data: 01/05/2012.
} 
Como as experiências anteriores das várias federações não haviam dado certo e sempre havia o medo de divisão, isso poderia ser mal interpretado pelo poder público, que só aceitava negociar com uma única entidade.

A UESP buscou apoio na Confederação Brasileira das Escolas de Samba, sediada no Rio de Janeiro, que reconhecia a UESP como entidade representativa das escolas na capital e convidou o presidente Álvaro Casado para a função de diretor do Departamento da Região de São Paulo e o estimulou a criar uma Federação Estadual para São Paulo auxiliar os outros municípios a promoverem desfiles de escolas de samba (NOTÍCIAS POPULARES, 15/06/1976). Casado, seguindo essa recomendação, estimulou as escolas de samba de cidades vizinhas a criar associações para exigir das prefeituras a oficialização do carnaval. O caminho inverso também foi seguido, já que a UESP prestou assessoria também para as prefeituras interessadas em organizar um concurso. A coluna Roda de Samba, do jornal Folha da Tarde, deu destaque às reuniões de Derly Marques com Décio Chiappa, diretor da Divisão de Turismo e Recreação de Osasco, e do presidente Álvaro Casado com Sergio Delfiol, assessor de Relações Públicas de Suzano (FOLHA DA TARDE, 18/03/1977).

A saída encontrada pelos dirigentes para não dividir novamente o samba paulistano foi incorporar as discussões da Coligação na própria UESP. Para Geraldo Filme e os dirigentes da Coligação, a função de uma entidade das escolas de samba não deveria ser apenas de negociação com os órgãos públicos, jurídica e economicamente, mas desempenhar uma função cultural, também, de valorização e preservação do samba e da cultura negra de uma forma geral. Este pensamento ia de encontro às decisões tomadas pelo movimento negro que começava a se reorganizar no ano de 1978, com a criação do Movimento Unificado contra a Discriminação Social (MUCDR), que lutava por uma melhor inserção do negro na sociedade.

No mês de março ocorreu uma reunião com a participação de boa parte dos dirigentes da UESP e da Coligação, escolas e blocos para efetivamente selar a unificação dos sambistas em torno de uma única entidade (FOLHA DA TARDE, 19/04/1977). 
O sambista Juarez da Cruz, fundador da Mocidade Alegre, declarou, quando começaram as articulações para essa reunião: "Somamos atualmente a média de mais de 40 mil sambistas espalhados por toda São Paulo. Muitos sindicatos não possuem a soma de sócios que nós podemos possuir dentro de uma só sociedade representativa". Para Juarez, a única forma de os sambistas lutarem e conseguirem respeito, era a união. O grande objetivo do sambista era a independência e a desvinculação das escolas do poder público:

\begin{abstract}
Queremos e podemos viver independentes dos setores públicos, que muito têm realizado a favor das escolas de samba. Entretanto a liberdade é de suma importância para o nosso desenvolvimento. Dado a este motivo, havíamos programado uma reunião com almoço para o próximo dia 20, domingo e cada entidade se faria representar por dois diretores. (...) Não estou, portando bandeira de nenhuma das atuais entidades, julgo isso errado, não importa qual delas sobreviva, o que é importante é que somente uma delas seja nossa legítima representante. Da forma que está é que não pode continuar (GAZETA ESPORTIVA, 18/03/1977).
\end{abstract}

Defendendo essa plataforma de união, Geraldo Filme de Souza, que era líder da Coligação e filiado à UESP, bem como presidente da escola de samba Paulistano da Glória, foi alçado à condição de candidato a presidente da UESP, sendo eleito no mês de abril, e tomado posse no mês de maio de 1977. A proposta de Geraldo Filme, descrita pouco acima, era de incorporar à agenda pública da UESP a luta pela preservação da cultura e das tradições africanas na sociedade paulista e paulistana. A gestão de Filme representará o inicio da virada que as escolas de samba de São Paulo irão ter, a partir do início dos anos 1980, com a abertura política da ditadura militar. Com o fim da censura prévia e a rearticulação dos movimentos sociais, muitas escolas de samba iriam promover seus desfiles como forma de luta e denúncia da situação dos negros no país. O ano de 1982 marca essa virada com várias escolas trazendo temas ligados a este programa sociocultural.

A diretoria tinha como membros Evaristo de Carvalho, um dos líderes da antiga Federação e um dos responsáveis pela oficialização dos desfiles em 1968, como vicepresidente administrativo; além de Arnaldo Mathias Seraphim, vice-presidente de 
Finanças; João Carlos de Carvalho Camargo, vice-presidente de Comunicações; Derly Marques da Silva, vice-presidente de Divulgação; Nelson Crecibeni Filho, vicepresidente Social; e Pedro Gilardi Filho, vice-presidente de Patrimônio. Para o conselho fiscal foram eleitos: Luiz Carlos Ribeiro Silva, Norival Romão e Orlando Alves Bittencourt. Como suplentes: Sebastião Eduardo Amaral, João da Silva e Osvaldo Vilaça, o Mala.

Desde 1973, como mencionado, após a interdição da antiga Federação, as escolas recebiam as verbas diretamente da prefeitura, e então repassavam o percentual destinado à manutenção da UESP. As principais despesas da UESP, nesse momento, eram com encargos de contabilidade, advogado, telefone, almoxarifado e o aluguel da sala em que se localizava a entidade, na Avenida Brigadeiro Luiz Antônio. Não havia funcionários dando expediente. Eram contratados apenas temporariamente, a partir de setembro até o carnaval. As reuniões ocorriam semanalmente a partir dos meses de setembro ou outubro. A diretoria da UESP não tinha remuneração, sendo o trabalho voluntário ou remunerado apenas pelos serviços prestados durante o carnaval. Como afirma Álvaro Casado:

Era um tempo que eu dedicava, por amor, depois que eu saía do meu trabalho. Sempre as noites de sexta-feira, e alguma outra noite da semana eram para a UESP. Trabalhava em uma agência de publicidade na praça da República e depois ia até a galeria na Brigadeiro ${ }^{35}$ ".

Dentre outras parcerias realizadas pela UESP, além daquela feita com a Confederação Brasileira das Escolas de Samba, estava um acordo com o Ministério da Educação e Cultura (MEC) e a Embratur para a montagem de duas salas ocupadas pela empresa brasileira no Museu Internacional do Carnaval e da Máscara, na cidade de Binche, na Bélgica, famosa por ter um dos carnavais mais antigos da Europa (FOLHA DA TARDE, 22/03/1977).

\footnotetext{
${ }^{35}$ Entrevista com Álvaro Casado. Data: 01/05/2012.
} 
Para efetivamente cumprir a promessa de uma entidade preocupada com a parte operacional, financeira e também cultural das escolas, a UESP promoveu, em abril de 1977, em uma parceria da antiga diretoria liderada por Álvaro Casado e a nova diretoria liderada por Geraldo Filme, o primeiro curso sobre escolas de samba, com o intuito de divulgação cultural e de instruir os dirigentes mais novos a respeito da história, da parte cultural e também da montagem de um desfile. $\mathrm{O}$ curso teve duas fases. A primeira com a duração de seis horas divididas em três dias.

A primeira aula, mais panorâmica, abordou a história da escola de samba desde sua origem, desenvolvimento, organização, seu relacionamento com as autoridades e os aspectos jurídicos relacionados à criação de um Grêmio Recreativo e Escola de Samba. A segunda aula abordou o lado cultural e a importância de uma escola de samba para sua comunidade. A terceira aula dedicou-se aos aspectos técnicos da montagem de um desfile, incluindo a formação da bateria, o samba-enredo, os componentes obrigatórios e a evolução.

A segunda parte do curso, de caráter prático, teve como objetivo a formação técnica dos alunos que frequentaram a primeira fase. A duração foi de 12 horas, incluindo exercícios e observação nas quadras e ateliês das escolas de samba. A primeira de três aulas objetivou mostrar como se constrói um enredo, base de todo desfile de escola de samba. Os alunos tiveram orientação sobre como utilizar elementos da História, do folclore, das lendas e costumes do Brasil para a montagem do enredo e a oportunidade de montá-lo na prática para, posteriormente, os apresentarem às suas respectivas escolas. Na segunda aula foi desenvolvido o processo de criação das fantasias, utilizando materiais e técnicas artesanais. A terceira e última aula do curso, de duração de quatro horas, foi um misto de técnicas de escultura, carpintaria e serralheria necessárias para a produção de carros alegóricos (GAZETA ESPORTIVA, 07/04/1977).

As inscrições eram gratuitas e o corpo docente composto pelo folclorista Wilson de Morais, também mestre-sala da Barroca Zona Sul; pelo músico e jornalista Jangada; pelo publicitário e artista plástico, Álvaro Casado, dentre outros. O curso foi uma espécie de manual sobre escola de samba. Tinha como objetivo mostrar que qualquer um poderia montar uma escola de samba. Ao contrário de muitas atividades, guardadas 
sempre como segredo pelos que detêm seus códigos, os sambistas gostavam de dividir seus conhecimentos e experiências com outras pessoas de fora do meio, que também gostavam de samba e tinham vontade de entrar, ajudar ou até mesmo criar uma escola de samba em seu bairro, mas não sabiam como.

Outra atitude tomada pela nova diretoria, desde a sua posse, foi a criação de festas e atividades ligadas às escolas de samba durante todo o ano, como forma de divulgação, aumento da sociabilidade e da arrecadação de recursos para custear parte dos desfiles. A primeira festa foi a "Festa do Abacaxi", realizada na quadra de ensaios do Bloco Gaviões da Fiel, no Bom Retiro. Segundo o próprio Geraldo Filme: "Com esse pagode, a UESP inicia sua programação, que tem por objetivo incrementar o samba da Pauliceia, com encontro direto dos sambistas com a população" (FOLHA DA TARDE, 17/06/1977). As escolas também organizavam diversos eventos em parceria com a UESP, como as 24 horas de samba, evento musical promovido pela Mocidade Alegre em sua quadra e que contava com 24 horas de atrações musicais (FOLHA DA TARDE, 27/09/1977), algo semelhante à proposta da atual Virada Cultural.

A UESP também estava atenta ao que acontecia fora das escolas de samba, como prestar apoio, ao lado da escola de samba Quilombo, do Rio de Janeiro, a um ato público contra o racismo realizado no dia 7 de julho de 1978, com duas mil pessoas nas escadarias do Teatro Municipal. $\mathrm{O}$ ato contra o racismo e em solidariedade a quatro jovens discriminados durante uma competição no Clube de Regatas Tietê e ao jovem Robson de Oliveira Cruz, negro, trabalhador e pai de família, torturado até a morte no $44^{\circ}$ Distrito Policial de Guaianazes, após ser confundido com um ladrão. Durante o ato foi distribuída, por parte dos organizadores, uma Carta Aberta, dirigida à população, que incitava a população afro-brasileira a criar "Centros de Luta" nos bairros, nas prisões, nos terreiros de candomblé e umbanda, nos locais de trabalho e nas escolas de samba, a fim de organizar um movimento de luta contra a opressão racial, a violência policial, o desemprego, o subemprego e a marginalização da população negra (DOMINGUES, 2007, p. 114).

A Secretaria de Turismo, interessada em manter um calendário de atividades ligada às escolas de samba, tentou promover, em 9 de abril 1977, um Campeonato 
Brasileiro de Escolas de Samba. O evento ocorreria no estádio do Morumbi às 20:00 horas e iria contar com diversas escolas da capital, de Santos e o encerramento ficaria a cargo da escola carioca Beija-Flor de Nilópolis. Mas, devido à forte chuva que havia caído no campo, o evento foi adiado para o dia seguinte, às 16:00 horas. Os sambistas do Rio de Janeiro até chegaram a vir para São Paulo para a apresentação. Mas com a péssima alimentação, estrutura e alojamentos oferecidos pela Secretaria, os sambistas das escolas Beija Flor, Mocidade Independente de Padre Miguel e do bloco Cacique de Ramos decidiram voltar para o Rio de Janeiro na mesma noite de sábado. Devido às baixas das principais atrações o evento foi cancelado, mesmo com milhares de pessoas que compareceram ao estádio no domingo à tarde. Algumas pessoas iniciaram um quebra-quebra na tentativa de ter seu dinheiro de volta. O jornal Folha de São Paulo colocou como capa de seu caderno cultural: "Vexame! O túmulo do samba". Alguns dirigentes queriam receber o cachê acordado, como o presidente do Camisa Verde e Branco, Inocêncio Tobias: "Se quiserem saber tudo direitinho, apareçam amanhã às 15 horas na Secretaria de Turismo. Eu estarei lá e vou querer acertar umas coisas com o Secretário" (FOLHA DA TARDE, 11/04/1977).

O diretor da empresa contratada pela secretaria para realizar o espetáculo se explicou na tentativa de isentar a secretaria da responsabilidade pelo ocorrido:

\footnotetext{
A promoção foi toda nossa e a Secretaria apenas estava colaborando. O que ocorreu foi que a chuva atrapalhou o espetáculo no sábado e, por volta das 23h30 levamos o pessoal (cerca de 1200 pessoas para o Pacaembu). Compramos comida e cigarros. Conseguimos alojamento para uma parte no estádio, mas a outra teria que dormir no ônibus. Dessa forma, todos decidiram regressar e tentamos avisar pelas emissoras de rádio que o espetáculo havia sido suspenso (FOLHA DA TARDE, 11/04/1977).
}

Após o fracasso do concurso, a secretaria procurou a UESP a fim de negociar um novo projeto de divulgação dos compositores e cantores ligados às escolas de samba. Foi criado, então, um projeto chamado "Samba vai aos Parques". O projeto consistiu na apresentação de espetáculos de samba em parques públicos nos finais de semana. Por exemplo, no dia 03 de setembro, Jangada, Silvio Modesto, Geraldo Filme, 
Zeca da Casa Verde, Talismã e Tuniquinho Batuqueiro se apresentaram no Jardim da Luz, e, no dia 04, no Parque do Morumbi (GAZETA ESPORTIVA, 03/09/1977).

Já os populares ensaios realizados pelas escolas passaram a contar com novas regras. De acordo com uma portaria assinada pelo coronel Erasmo Dias, secretário de Segurança Pública, os ensaios deveriam ser realizados em recintos fechados, no horário das 19 às 22 horas. Aos sábados poderiam prolongar-se até às 4 horas de domingo. Aos domingos, deveriam iniciar-se às 15 horas e encerrar-se às 18 horas (FOLHA DA TARDE, 10/01/1978). Essa medida prejudicou inúmeras escolas que ainda não possuíam quadras e dependiam do espaço da rua para ensaiar, assim como as que tinham quadras, mas estas eram insuficientes para o número de pessoas que compareciam aos ensaios.

Algumas escolas só conseguiam realizar o ensaio geral na véspera do carnaval, na própria Avenida Tiradentes, prejudicando a harmonia e a coreografia das alas. $\mathrm{O}$ jornal Última Hora relatou um incidente ocorrido a poucos dias do carnaval, com a manchete: "Polícia impede ensaio da escola". A matéria relata que a escola de samba Pérola Negra foi impedida de ensaiar na rua. A quadra da escola estava ainda em fase de construção e, por isso, não ofereceria condições para a realização do ensaio geral. Segundo os policiais, a escola estava "infringindo uma portaria da Secretaria de Segurança Pública, que proíbe ensaios de escolas de samba em vias públicas”. A diretoria da escola e a UESP, diante do ocorrido, enviaram uma carta ao secretário, solicitando providências para evitar esse tipo de constrangimento. Para o presidente da UESP, Geraldo Filme, era um absurdo tentarem confinar uma arte que nasceu nas ruas. "Com surpresa, fomos informados que o samba, que nasceu e cresceu nas ruas, passava a ficar confinado. Tivemos que acompanhar as autoridades a duas delegacias de polícia e recebemos uma intimação para comparecer à Delegacia de Diversões Públicas" (ÚLTIMA HORA, 24/02/1978).

No ano de 1977, durante as negociações para o carnaval de 1978, a Prefeitura escutou a reclamação dos sambistas, não renovou o contrato com a Jaraguá e criou uma autarquia chamada Paulistur, espécie de Embratur da cidade de São Paulo (AZEVEDO, 
2010, p. 95). A empresa passou a ser a responsável pela organização dos principais eventos turísticos da cidade, como o carnaval, as corridas de Fórmula 1 e de outras categorias, os desfiles de 7 de Setembro e as festas de Réveillon. A Paulistur criou um departamento exclusivo para o carnaval, o Departamento de Coordenação Organizadora de Carnaval (COC). A partir desse momento, até 1986, havia duas entidades que organizavam o carnaval, o COC e a UESP. O COC era responsável pela infraestrutura, por negociar o fechamento do trânsito, pela contratação da empresa para montagem, iluminação, sistema de som e etc, isto é, cuidava das bases concretas para a realização dos festejos.

As reuniões do COC com a direção da UESP eram mediadas e dirigidas pela Comissão de Carnaval da Prefeitura. Nas negociações para a realização do carnaval de 1978 foi nomeado o general Moacyr Gaia como presidente da comissão. O militar tinha a ideia de vender espaços nas arquibancadas para empresas privadas, como maneira de arrecadar verbas e diminuir os gastos públicos (ÚLTIMA HORA, 24/02/1978).

Pelo acordo assinado entre as partes houve um reajuste com relação a verba do carnaval do ano anterior, que havia reduzido em $40 \%$ o montante gasto. Os desfiles ocorreriam em dois locais da capital: na Avenida Tiradentes, pelo segundo ano, entre a Praça da Luz e a Avenida do Estado, além dos desfiles de carros alegóricos realizado na Vila Esperança. Trinta e nove escolas foram inscritas para a participação nos desfiles. Inicialmente, a Paulistur queria alterar o regulamento para realização de um carnaval maior. A empresa queria estabelecer, no mínimo, mil componentes fantasiados para as escolas de samba do Grupo I, 700 do II e 400 do III. E o Grupo IV não desfilaria na Avenida Tiradentes nem teria apoio da secretaria. Outra proposta apresentada pela Paulistur era a inclusão de mais um jurado por quesito, totalizando dois jurados para evitar as confusões e reclamações envolvendo as escolas que ganhavam notas muito baixas em um quesito e perdiam o campeonato ou, às vezes, eram até mesmo rebaixadas (FOLHA DA TARDE, 11/03/1977). Para o presidente da Paulistur, o ex-secretário de Turismo, Armando Simões Neto, era necessário aumentar o número de componentes das escolas, já que a nova pista era maior e era necessário preenchê-la por inteiro. Isso seria possível depois das medidas que fariam o reajuste no valor da verba recebida pelas 
escolas e da decisão do prefeito Olavo Setúbal de conceder a isenção do imposto de $35 \%$ que incidia sobre os serviços oferecidos pelas escolas de samba e pelas prestadoras de serviços responsáveis pela organização do carnaval ${ }^{36}$ (FOLHA DA TARDE, 16/08/1977).

Após seis meses de negociação, ficou estabelecido que as escolas de samba do Grupo I deveriam se apresentar com um mínimo de 800 componentes fantasiados. As escolas do Grupo II, com 500 e as do III com 200, respectivamente (FOLHA DA TARDE, 30/09/1977).

Algumas escolas do Grupo III subiram para o II. Para o desfile ficou acertado que os Grupos I e II contariam com doze escolas cada e o Grupo III com quinze. O Grupo IV, como não receberia o apoio da Secretaria, deixou de existir formalmente. As escolas pequenas, pretendentes a entrar no Grupo III, conseguiram organizar um desfile informal patrocinado pelo Clube dos Lojistas do Ipiranga, no mesmo bairro. O corpo de jurados foi formado por sambistas voluntários que pertenciam às escolas do Grupo I. As duas melhores colocadas do desfile do Ipiranga ganharam o direito de serem incluídas no Grupo III no ano seguinte. E as piores colocadas do Grupo III passaram novamente a condição de pretendentes, sem direito a nenhuma remuneração (FOLHA DA TARDE, 15/11/1977).

No contrato, as escolas passavam a ser tratadas com os mesmos direitos e responsabilidades de qualquer instituição jurídica. O regulamento previa diversas penalidades, que iam desde a suspensão até a extinção das escolas que não cumprissem as cláusulas do contrato.

Ao eliminar o Grupo IV, a Secretaria de Turismo e a Paulistur tinham uma estratégia que era a de diminuir o número de escolas vigentes na cidade para melhorar o nível das exibições. Ao não receberem mais verbas oficiais, essas escolas não teriam como sobreviver e tinham dois caminhos: a extinção ou a fusão com outra escola maior do mesmo bairro ou de localidades próximas. A posição da empresa era clara:

\footnotetext{
${ }^{36}$ Ofício enviado por Geraldo Filme de Souza para o gabinete do prefeito Olavo Setúbal em 10/07/1977.
} 
(...) a Paulistur pretende dar mais apoio para as escolas que vem se destacando nos desfiles, porque elas terão mais responsabilidade no próximo carnaval. As pequenas escolas de samba serão absorvidas pelas maiores, tendo em vista a localização dos bairros e a simpatia dos componentes pelas cores das agremiações que exercem maiores influências em cada região da capital. A primeira medida será a extinção do Grupo IV, que foi criado no carnaval passado, mas não correspondeu às expectativas, pois as escolas de samba se apresentaram mal nos desfiles. ${ }^{37}$

No ofício enviado pela UESP para as escolas de samba no dia 26/12/77 38 , o diretor Derly Marques revela que esse apoio descrito no documento acima se concretizou. Até o Natal de 1976, as escolas já haviam recebido $80 \%$ da remuneração para o carnaval do ano seguinte, anulando assim o problema que afetava as escolas nos anos anteriores. O presidente Geraldo Filme relembra que os atrasos prejudicavam muito as escolas, dificultando seu planejamento e a compra dos produtos utilizados. Segundo Filme, com a antecipação dos recursos era possível procurar produtos e preços melhores, principalmente das fábricas de tecido das cidades do interior do Estado.

A UESP e os sambistas julgavam necessária a criação de um seminário para os jurados das escolas de samba. Os próprios sambistas, que julgariam o desfile do Ipiranga, ainda tinham algumas dúvidas. Além do que, no Grupo I, a opinião dos dirigentes era que apenas a nomeação de mais um jurado não era garantia suficiente de uma apuração mais técnica e justa.

Desde a oficialização até o carnaval de 1976, na Avenida São João, os jurados eram normalmente personalidades, professores universitários e maestros convidados da prefeitura e não recebiam nenhum cachê por isso. Mas, muitas vezes eram convidadas pessoas que não tinham grandes conhecimentos sobre as escolas de samba. Na coluna "Assim cantam os tamborins", do jornal Gazeta Esportiva, é relatado um caso de uma jurada que perguntou a um sambista o que significavam as figuras vestidas todas iguais que vinham à frente das escolas e que paravam aguardando a entidade passar, depois seguiam atrás. O sambista quase caiu de costas ao perceber que a jurada não conhecia

\footnotetext{
${ }^{37}$ Ofício UESP informa. Data: 12/09/1977. Acervo UESP.

${ }^{38}$ Idem. Data: 26/12/1977. Acervo UESP.
} 
sequer o que era a Comissão de Frente de uma escola de samba (GAZETA ESPORTIVA, 14/02/1978).

Por esse motivo, a UESP cobrava da secretaria a realização de um seminário, com um curso básico de formação, já que os jurados a partir de 1977 passaram a receber um cachê para julgar dos desfiles. Mesmo com o apelo dos sambistas, a prefeitura não aceitou financiar o seminário e ele não foi realizado. A saída encontrada foi incluir os quesitos de julgamentos nos cursos de formação de escolas de samba, promovidos pela entidade. Além dos dirigentes e membros das escolas de sambas, os jurados eram convidados para algumas aulas, a fim de aprender e explicar para os sambistas os pontos de balizamento para as notas, sempre motivo de briga entre as escolas perdedoras.

A grande novidade para esse carnaval foi a cobrança de ingressos para ter acesso às arquibancadas, o que, até o ano anterior havia sido gratuito (FOLHA DA TARDE, 10/01/1978).

A partir daí, o carnaval de São Paulo entra em uma nova fase. Deixa de ser diversão gratuita, que atraía principalmente os menos favorecidos que desfilavam em suas escolas e aqueles que apenas gostavam de assistir aos desfiles, e passa a atrair as classes médias e altas, que compravam um ingresso e exigiam maior comodidade e um espetáculo de qualidade.

Com o montante arrecadado por meio da cobrança de ingressos foi possível a Paulistur arcar com custos maiores, além de aumentar a potência da sonorização e iluminação da avenida. Para o carnaval de 1979, a Paulistur procurou explorar espaços de merchandising na avenida com a inserção de textos e exibição de marcas comerciais. Para o secretário: "Pagando as taxas exigidas, as empresas poderão divulgar tudo" (FOLHA DA TARDE, 10/01/1978).

A ideia já havia sido debatida desde o ano anterior. Segundo o mesmo secretário, as mudanças minimizariam os custos do carnaval de São Paulo, além de possibilitar um aumento do repasse para as escolas. Além disso, foi estendida a extensão das arquibancadas, permitindo a colocação de ingressos populares na área de concentração. Ao todo foram oferecidos 17 mil lugares, instalados em 34 módulos de estruturas 
tubulares com capacidade para 500 pessoas e com grande parte coberta, a exemplo do Rio de Janeiro. As estruturas ofereciam a capacidade para alojamento de seis câmeras de televisão, para que as emissoras tivessem a possibilidade de tomadas aéreas, obtendo assim uma melhor perspectiva de transmissão. As cabines de rádio tinham a possibilidade de instalação de equipamentos e transmissores. A imprensa escrita também contou com uma cabine com telefones e máquinas de datilografia (GAZETA ESPORTIVA, 11/01/1979). Para o carnaval do ano de 1980, foram construídas arquibancadas tubulares para 30 mil pessoas, evidenciando o crescimento do carnaval paulistano, em termos de público.

Ainda durante a década de 1970, ocorreu a formatação atualmente vigente dos desfiles das escolas de samba e de blocos, com a divisão das escolas e dos blocos em grupos, dado o grande número de agremiações filiadas e as diferentes estruturas e tamanhos apresentados por elas. Dessa separação por grupos, formou-se uma divisão hierárquica: Grupo I (Posteriormente chamado de Especial), Grupo II (posteriormente chamado de Acesso) e Grupo III. O Grupo IV foi criado nos anos 1980, assim como na década de 1990 foi criado um grupo de vagas abertas para as novas escolas que eram fundadas e que quisessem participar do grupo. Além do grupo dos desfiles de blocos, sagrava-se campeã a escola que tivesse alcançado o maior número na soma das notas de todos os quesitos. Apesar da divisão hierárquica do desfile, necessária para haver certo equilíbrio no concurso, cada escola possuía o mesmo peso em assembleias e discussões dentro da UESP. Na eleição para presidente, deliberações de verbas e contratos, as escolas do Grupo I e do Grupo IV possuíam o mesmo direito a voz e voto.

Uma reportagem do extinto jornal Última Hora, do ano de 1976, revelou como a imprensa já vinha alertando a população para o fato de o desfile carnavalesco da cidade estar subordinado a uma empresa que não conseguia cumprir com o seu objetivo, que era o de atrair turistas para o carnaval. A solução correta, para o jornalista, seria se os desfiles carnavalescos voltassem novamente a serem assumidos pela Secretaria de Cultura: "Seria interessante entregar-se o Carnaval a outra pasta: a Secretaria de Cultura. Afinal, o Carnaval paulista, pobre imitação do Carnaval carioca, perdeu as suas 
raízes. Portanto, nem atrai turistas, nem diverte o povo. Ao contrário, afugenta um e outro" (ÚLTIMA HORA, 04/03/1976).

Entre 1977 e 1986, a UESP conduziu as negociações na organização dos desfiles de carnaval, ocupando um espaço cada vez maior para os sambistas. No ano de 1977, a UESP recuperou o direito de gerir as verbas do carnaval. Nesse período, a UESP possuiu três diferentes presidentes: Geraldo Filme (1977-1979), Osmar César de Carvalho, com dois mandatos (1979-1983), e Alberto Alves da Silva Filho (Betinho) (1983-1985), até a nova divisão das federações com a fundação da Liga, em 1986.

Com a transferência do local dos desfiles, negociados entre a Paulistur, a prefeitura e os sambistas, estes passaram a ter uma maior visibilidade, pois os desfiles eram realizados em uma avenida com uma pista ampla, contavam com arquibancadas e apresentando envolvimento mais responsável, por parte das escolas de samba, que passaram a atrair membros de todas as classes sociais. Para Ana Maria Rodrigues (RODRIGUES, 1984), essa entrada de membros brancos, oriundos das classes médias e altas, fez com que o carnaval negro se tornasse cada vez mais "pálido", pois atraiu a presença cada vez maior de brancos das classes médias e altas nos ensaios e, principalmente, na direção das escolas e federações. As escolas de samba, segundo Rodrigues, passaram a dar os cargos mais importantes na direção a integrantes brancos, pelo fato de eles serem mais escolarizados e, portanto, partir da ideia de que eles administrariam melhor a escola. Com isso, as escolas de samba deixaram de ser símbolo apenas de negros e pobres e passaram a entrar em um processo de caráter nacional, nomeado como "domesticação da massa urbana" pela socióloga Maria Isaura Pereira de Queiroz, ao analisar esse fenômeno dentro do carnaval carioca (QUEIROZ, 1992).

É preciso ressaltar que a iniciativa de oficialização, por parte do poder público, partiu dos próprios sambistas, que viam no reconhecimento oficial do desfile a valorização de suas atividades. Não podemos entender o poder público como destruidor da manifestação popular, pura e espontânea, atuando de forma repressora e alienante. $\mathrm{O}$ processo foi de negociação, com uma parte significativa das demandas dos sambistas sendo atendidas pela prefeitura da cidade. Em São Paulo, a oficialização dos desfiles era a oportunidade para se constituir um evento oficial do calendário do turismo municipal, 
a semelhança daquele que já ganhara, no Rio de Janeiro, a adesão das classes médias e altas do país. Com isso, o poder público municipal passou a ser o promotor e o controlador do desfile das escolas de samba de São Paulo, a cidade economicamente mais importante e com o maior número de habitantes e trabalhadores do país. Mas, para atender essa demanda, ela impôs algumas condições aceitas pelos sambistas.

Para Olga von Simson (SIMSON, 2007), a oficialização foi, ao mesmo tempo, uma possibilidade de ampliação e uma estratégia de sobrevivência e triunfo da festividade criada pela população negra paulistana. É inegável que formas, modelos e valores socioculturais foram modificados no interior das escolas de samba para que elas atraíssem a participação das classes mais elevadas. Antes disso, os bailes da elite aconteciam nos grandes clubes como o Iate Clube, no Rio de Janeiro, o da Ilha Porchat, em São Vicente, ou em teatros, como os Municipais do Rio e de São Paulo, com grande repercussão nas maiores revistas de atualidades da época como O Cruzeiro, Manchete e Fatos e Fotos. Estas revistas, até meados dos anos 1970, dedicavam um pequeno espaço para o desfile das escolas de samba, e, quando o faziam, era com o conteúdo sobre as cariocas. As escolas de samba paulistanas passaram a ter um espaço, mesmo que reduzido, nas grandes revistas de circulação nacional somente a partir de 1977, quando os desfiles cresceram e passaram a serem realizados na Avenida Tiradentes.

Os bailes de carnaval do Teatro Municipal do Rio de Janeiro, por exemplo, eram verdadeiros espetáculos das elites, aos quais somente tinham acesso os ricos e famosos. Como evidencia a "fotográfica" revista carioca Manchete, em 1970:

\footnotetext{
Para o povo, a chegada dos convidados é a primeira atração. Desde o anoitecer de segunda-feira, milhares de pessoas concentram-se diante do municipal para assistir à entrada dos convidados e ao desfile das fantasias premiadas. $\mathrm{O}$ interesse popular, sem falar nos 6000 que participam do baile, demonstra mais uma vez que a tradicional festa da segunda-feira é o maior show carnavalesco a portas fechadas do mundo. A passarela armada em frente ao teatro permite que vejam à vontade o cortejo de celebridades, e de certa forma, participem um pouquinho do grande espetáculo ${ }^{39}$.
}

\footnotetext{
${ }^{39}$ MANCHETE. Rio de Janeiro: 21 de fevereiro de 1970, ano 17, ed. no 931, p.19. Grifo nosso.
} 
Durante a década de 1970, as escolas de samba possuíam um espaço permanente na imprensa paulistana, contando com diversas colunas em jornais populares de grande circulação. Dentre elas, destacam-se “Assim Cantam os Tamborins”, do jornal Gazeta Esportiva, elaborada pelo jornalista Evaristo de Carvalho, ex-presidente da Federação das escolas de samba; "Quadra de Ensaio e NP no samba", do jornal Notícias Populares, elaborada respectivamente por Edmundo Andrade e J. Muniz Jr; "UH no Samba", do jornal Última Hora, elaborada pelo sambista Jangada, e "Roda de Samba", do jornal Folha da Tarde, elaborada por Edmundo Andrade e, posteriormente, por Paulo Valentim. As colunas traziam informações relacionadas ao carnaval e ao universo das escolas de samba, como o calendário de eventos realizados pelas escolas, disputas de samba-enredo, informações relativas à preparação e aos bastidores das escolas, eleições etc. Esse espaço conquistado dentro da imprensa pelas escolas de samba, poucos anos após a oficialização evidencia a consolidação dos folguedos carnavalescos dentro da agenda cultural da cidade. Os quatro jornais, que foram extintos, até os anos 2000, disputavam o público trabalhador das classes mais baixas, também público-alvo das escolas de samba. As colunas saíam em dias alternados para não trazerem as mesmas informações, portanto, era possível, quase que diariamente, saber os acontecimentos das escolas de samba, por meio dos dados dos jornais. Até os dias de hoje, as escolas de samba de São Paulo não tiveram tanto espaço na grande imprensa escrita como na década de 1970. Algumas colunas, como a da Folha da Tarde, avançou nos anos 1980. Essas colunas se constituíram como uma memória das próprias escolas de samba e formaram um material muito importante para a presente pesquisa.

Com da criação da Paulistur e a designação de que a empresa seria responsável pela gestão do carnaval, a UESP tornou-se uma parceira estratégica, como por exemplo, na escolha do corpo de jurados. Estes poderiam ser jornalistas, professores e até mesmo sambistas de outras cidades, como do Rio de Janeiro e de Santos. A partir da década de 1980, a UESP conseguiu o direito de escolher os jurados e organizar um curso de formação ${ }^{40}$.

\footnotetext{
${ }^{40}$ Fonte: Centro de Documentação e Memória do Samba. Documento: UESP 25 anos, p. 20.
} 
O curso de formação foi importante para melhorar a capacidade de julgamento, pois muitos vinham de outras cidades, com regulamentos diferentes; outros julgavam pela primeira vez e evitava-se assim a utilização de critérios discrepantes, pois o momento de apuração sempre foi de grandes conflitos, com as escolas discordando das notas dadas e das justificativas apresentadas. Os membros da UESP criaram a "Cartilha do Samba", um livreto contendo todos os quesitos e pontos de balizamento (URBANO, 2006, p. 195). A cartilha era usada como material de apoio aos jurados e também era entregue a todas as filiadas, para que as diretorias de escolas de samba estivessem a par dos quesitos e critérios adotados para a concessão das notas. Um dos objetivos da própria UESP ao conduzir a escolha e formação dos jurados era evitar esse tipo de desentendimento, que sempre deixava rusgas nas reuniões e no ambiente interno da própria entidade. Esse direito de escolha e formação dos jurados representou uma maior autonomia na organização dos desfiles da capital paulista, possibilitando que os próprios sambistas determinassem a escolha dos jurados e os critérios de julgamento. Nesse momento, nem as escolas cariocas havia conseguido tal autonomia, permanecendo a escolha dos julgadores, prerrogativa da prefeitura da cidade do Rio de Janeiro (LEOPOLDI, 2009).

Também em parceria com a Paulistur, a UESP adquiriu o direito de credenciamento dos dirigentes das escolas de samba para ter livre trânsito em todas as áreas de desfile, pois o impedimento dos diretores de harmonia e outros dirigentes de circular em alguns locais da pista geravam alguns atritos entre a UESP e as escolas de samba. A parceria entre a empresa municipal e a entidade das escolas de samba se tornou mais sólida, a partir do ano de 1983, na gestão do prefeito Mário Covas. O prefeito nomeou João Dória para presidência da Paulistur. Dória nomeou um sambista para a direção do COC, Eduardo Joaquim de Oliveira. Este, após ocupar o cargo na Paulistur, foi eleito presidente da UESP, entre 1986 e 1990.

Durante sua gestão no COC, houve um atrito entre os sambistas e a Paulistur envolvendo a questão dos ingressos de cortesia para os desfiles. A empresa limitou drasticamente a distribuição de ingressos de cortesia para o carnaval de 1984, seguindo uma orientação do Tribunal de Contas do Município e do gabinete do prefeito, para 
evitar que se repetisse uma prática comum nos últimos anos, quando até oito mil ingressos eram oferecidos como cortesia. Pelas novas regras, nem o cerimonial da prefeitura poderia emitir convites especiais para as autoridades; e os vereadores deveriam solicitar por escrito à empresa a inclusão de seu nome na lista do camarote da prefeitura (FOLHA DA TARDE, 16/02/1984).

Com o objetivo de montar mais de quatro mil ingressos nas arquibancadas, a Paulistur eliminou a maioria dos camarotes, inclusive o da própria UESP, que recebeu 800 ingressos para as quatro noites de desfile e 85 credenciais de trabalho com livre acesso à pista. Os sambistas acharam este número diminuto e pressionaram a direção da empresa para conseguir mais ingressos. A justificativa dada foi que eles, após desfilarem, não tinham como guardar as fantasias e voltar para as arquibancadas. A empresa não cedeu aos apelos e disse que aquela era uma posição do Tribunal de Contas do Município.

Ainda na gestão de João Dória, um importante acordo foi assinado na Paulistur. O governador André Franco Montoro aprovou o patrocínio do governo do Estado para os desfiles da capital. $\mathrm{O}$ acordo previa que o montante que o governo destinava aos desfiles seria encaminhado a UESP, que o distribuiria para as escolas filiadas. Com mais esse recurso, as escolas puderam dar um salto em termos de apresentação visual e na qualidade geral das apresentações. A organização dos desfiles, por outro lado, também passava a ser mais cuidadosa. Vários sambistas foram contratados para a coordenação da empresa, já que o carnaval era o maior evento de samba realizado durante o ano. Dentre os sambistas estavam, por exemplo, Geraldo Filme, que cuidava da parte de fiscalização. Vários sambistas aproveitaram a sua experiência na organização dos desfiles para, posteriormente, auxiliar a prefeitura nas negociações com as escolas. Somado a isso estava o já mencionado direito de escolher os jurados. Percebe-se portanto, que, a partir da década de 1980, os sambistas estão à frente do processo, tendo uma maior autonomia e um maior poder de decisão.

Em 1983, após dois mandatos de Osmar César de Carvalho à frente da UESP, Seu Nenê da Vila Matilde se organiza com antigos sambistas e com membros das escolas recém-fundadas e lança seu filho, Alberto Alves da Silva Filho, o Betinho, para 
a presidência da federação. Betinho vence a eleição, mas enfrenta, durante todo o seu mandato, uma oposição muito grande.

Uma parte dos antigos dirigentes decide sair da UESP e fundar a Federação das Entidades Carnavalescas do Estado de São Paulo (FESEC), buscando congregar agremiações distintas de todo o Estado de São Paulo (SIMSON, 2007, p. 224). Em seu programa político para a entidade, Betinho queria promover uma "revolução cultural". Para ele, as escolas de samba "apesar de ser a mais autêntica manifestação da cultura do nosso povo, não é devidamente valorizada [sic]. Os museus, pinacotecas, sinfônicas e grupos de balé recebem verbas e atenção muito superiores dos órgãos de Estado e dos meios de comunicação" (FOLHA DE SÃO PAULO, 07/09/1983).

A UESP, na visão de seu presidente, possuía 70 filiadas que congregavam mais de cem mil sambistas e meio milhão de frequentadores, ao longo do ano, e em muitos bairros periféricos as escolas eram o único espaço social e opção de lazer, devendo, portanto, serem mais valorizadas pelas autoridades. Para iniciar essa mudança, Betinho pretendia visitar os "órgãos de cultura e de comunicação" e seu grande desejo era: "Vamos lutar pela implantação de cursos de cultura popular como matéria obrigatória nas escolas públicas e privadas" ${ }^{41}$. Essa postura de cobrança por parte em relação aos poderes públicos mostrava que a UESP tinha uma plataforma sólida e uma certa autonomia de trabalho. Infelizmente, a ideia de criar uma matéria relacionada à cultura popular não teve apoio na Secretaria Municipal de Educação, nem na Prefeitura de São Paulo. Uma parceria importante foi estabelecida por Betinho, no início de seu mandato, com o Serviço Social do Comércio, o SESC, para uma série de apresentações com os "cardeais do samba", os membros fundadores das escolas de samba, em um espetáculo que contava a história do samba de São Paulo.

Esta autonomia trouxe benefícios e também alguns conflitos. Com a estabilidade financeira proporcionada pelos subsídios do Estado, a UESP estabeleceu parcerias com empresas e lojas para que suas filiadas pudessem comprar o material necessário para a montagem de seus desfiles, podendo pagar a dívida através da UESP, que se

\footnotetext{
${ }^{41}$ Idem.
} 
comprometia com o estabelecimento comercial, a descontar o montante devido do dinheiro, que a escola receberia das verbas para o carnaval ${ }^{42}$. Por outro lado, não existe escola de samba cuja prioridade não seja o desfile carnavalesco, então, em muitos casos, essas novas demandas culturais foram colocadas em segundo plano, pelos dirigentes, com os sambistas gastando energia prioritariamente para colocar suas escolas na avenida.

Até o início da década de 1980, o carnaval de São Paulo era transmitido integralmente apenas pelo rádio. As emissoras de televisão mostravam trechos, ou até alguns desfiles das entidades paulistanas, mas as escolas não recebiam direitos de imagem. No ano de 1984, duas emissoras, a RTC e o SBT, televisionaram os desfiles diretamente da Avenida Tiradentes, com uma transmissão completa, mostrando flashes de outros Estados, processo inverso ao que vinha acontecendo em anos anteriores, quando os desfiles do Rio de Janeiro eram transmitidos na íntegra e eram mostrados apenas flashes de São Paulo e de outros Estados (FOLHA DA TARDE, 09/02/1984). Do patrocínio oferecido para as transmissões televisivas, as escolas receberam $30 \%$. Após o sucesso de audiência alcançado pelo SBT, outras emissoras também se interessaram pela transmissão dos desfiles.

\subsection{A Liga}

No ano de 1985, a extinta TV Manchete (canal 9) propôs um contrato de exclusividade para a transmissão dos desfiles do Grupo I da cidade de São Paulo (AZEVEDO, 2010). Em troca da transmissão, a emissora pagaria os direitos de imagem diretamente para a UESP, que os repassaria às escolas de samba. Este contrato era apenas para a transmissão do Grupo I. Para não conflitar com as transmissões do Rio de Janeiro, a emissora solicitou a troca do dia de desfile. As escolas dos grupos menores aceitaram trocar o dia de desfile e viam, no montante arrecadado pela UESP com a

\footnotetext{
${ }^{42}$ Fonte: Centro de Documentação e Memória do Samba. Documento: UESP 25 anos, p. 26.
} 
televisão, uma oportunidade de receberem uma verba maior e produzirem um carnaval melhor.

Para exibir o Carnaval de 1986 no Rio de Janeiro e nas principais cidades do país, a Rede Manchete investiu Cr\$ 8 bilhões e mobilizou 870 profissionais. Em contrapartida, com a venda de seis cotas de patrocínio nacional e duas locais, faturou Cr\$ 15 bilhões. A Rede Globo, que também transmitia os desfiles, arrecadou Cr\$20 bilhões em publicidade, segundo a revista de marketing ADM (FOLHA DA TARDE, 12/02/1986). Era, portanto, um negócio muito rentável e com alto potencial de crescimento.

As escolas do Grupo I não aceitaram dividir a verba recebida pelo canal de televisão com as escolas menores, cujos desfiles não atraíam interesse de transmissão. Marcos dos Santos, que era secretário da UESP no período, relata:

\begin{abstract}
Os presidentes dos grupos inferiores cresceram o olho, e disseram que mudavam, mas exigiam uma compensação financeira das maiores que iriam receber da televisão. E o presidente da UESP, na época, não teve esse jogo de cintura de conseguir uma solução. Isso começou a dificultar a negociação, e o que eles fizeram? Fundaram a Liga com nove escolas do então Grupo I, e mudaram o nome para Grupo Especial. Só teve uma escola que resistiu, que foi a Nenê de Vila Matilde, que disse que iria continuar na UESP ${ }^{43}$.
\end{abstract}

Como o estatuto da UESP previa que cada escola tinha direito a um voto na assembleia da UESP, independentemente do seu tamanho, ganhou a proposta de divisão dos recursos provenientes da emissora de TV para todos os grupos. O Grupo I receberia $50 \%$ e o restante seria distribuído para os demais grupos ${ }^{44}$. As escolas do primeiro grupo se sentiram prejudicadas e decidiram abandonar a UESP e fundar uma nova federação de carnaval que congregasse apenas as escolas do Grupo I, para que essa nova entidade pudesse assinar o contrato de transmissão dos desfiles com a emissora interessada. Para os dirigentes das escolas menores, valia o principio da democracia,

\footnotetext{
${ }^{43}$ Entrevista com Marcos dos Santos. Data: 06/08/2010.

${ }^{44}$ Entrevista com Mestre Divino. Data: 24/09/2011.
} 
com votos iguais para todas as escolas filiadas, já que todas pagavam as mesmas taxas de filiação.

A ideia de formar uma nova liga já havia surgido após a apuração do carnaval de 1985. Nesse ano, alguns dirigentes ficaram insatisfeitos com a vitória da Nenê de Vila Matilde, já que Alberto Alves da Silva Filho, o Betinho, era presidente da escola e da UESP. O grande trunfo da escola, segundo o próprio fundador da escola, Seu Nenê, era o samba-enredo intitulado "Quando o cacique rodou a baiana, aí, ó" (BRAIA, 2000). A disputa foi acirrada durante toda a apuração e a Nenê levou o carnaval no último quesito: fantasia, justamente o ponto fraco da escola da zona Leste e o ponto forte das escolas concorrentes. Soma-se a isso o fato da escola campeã ter sido chamada para desfilar no Sambódromo do Rio de Janeiro, representando o samba de São Paulo, a convite da Riotur, órgão de turismo da cidade do Rio de Janeiro, mesmo sob os protestos do vice-governador carioca, o antropólogo Darcy Ribeiro, que, ao saber do desfile da escola paulistana, alimentou a velha rivalidade entre São Paulo e Rio de Janeiro, principalmente dentro do mundo do samba; e a exemplo de Vinicius de Moraes, (que chamara São Paulo de "túmulo do samba"), soltou este comentário totalmente infeliz: "O que estão fazendo com o carnaval carioca é importar samba de segunda classe. Seria bem melhor importar o frevo de Recife" (CABRAL, 2011, p. 250). Até os dias de hoje, a Nenê é a única escola paulistana que pode se orgulhar de ter desfilado no Sambódromo da Marquês de Sapucaí.

A inspiração para a fundação da Liga, mais uma vez, veio do exemplo bemsucedido do Rio de Janeiro, que havia fundado a Liga das Escolas de Samba do Rio de Janeiro (Liesa). Após a fundação da Liesa, as escolas do Rio conseguiram diversos patrocínios de empresas privadas e também recebiam anualmente os direitos de imagem pagos pelo canal de televisão para a transmissão dos desfiles. A polêmica do campeonato da Nenê de Vila Matilde, em 1985, também contribuiu para deixar diversos dirigentes insatisfeitos. Isso tirou um pouco do prestigio da UESP como entidade representativa e a legitimidade de Betinho como presidente.

Uma das justificativas para a nova divisão dos sambistas após nove anos de unificação foi a confusão envolvendo o carnaval de 1986, desde a sua organização até a 
apuração. No final do ano de 1985 houve uma proposta de patrocínio de um grupo de empresários portugueses que queria comprar os direitos de organização e transmissão do carnaval de São Paulo. Para efetivar o patrocínio, queriam mudar os desfiles de São Paulo de domingo para sábado, a fim de não concorrer com os desfiles do Rio de Janeiro, que já ocorriam no domingo (AZEVEDO, 2010, p. 100).

Quase às vésperas do carnaval, o secretário de Cultura, Hélio Dejitiar, assinou um contrato com uma incorporadora imobiliária, liderada por um grupo de empresários portugueses, chamada Respaldo, passando para a empresa toda a administração, receitas e custos do carnaval de 1986. A empresa cobriria todos os custos de montagem e desmontagem das estruturas de arquibancadas, decoração, limpeza, etc., e fecharia os contratos com a emissora de televisão e patrocinadores, além de arrecadar com a venda de ingressos e alimentação. O contrato foi assinado pelo recém-eleito prefeito Jânio Quadros em regime de urgência e dispensou licitação pública. Seguindo a lei municipal $\mathrm{n}^{\mathrm{o}} 8248$, de $1975^{45}$, a qual dizia que, em assuntos urgentes e de relevância para o município, o prefeito poderia assinar acordos sem a necessidade de licitação pública.

Em São Paulo, os desfiles dos blocos e, algum tempo depois, das escolas de samba se iniciavam no domingo de carnaval na Avenida Tiradentes. Na segunda aconteciam os desfiles dos grupos menores e, na terça, o desfile da apoteose (desfile das campeãs) com as escolas mais bem avaliadas. A proposta do grupo português era transmitir pela televisão as escolas do Grupo I, e essas receberiam uma verba maior para estruturar seus desfiles. O interesse dos empresários era de investir apenas no topo da hierarquia das escolas, pois são elas as que possuem maior visibilidade e destaque. As verbas para os grupos menores seriam dadas, apenas para a viabilização do negócio e para garantir a dinâmica dos concursos na qual as piores colocadas são rebaixadas para o grupo inferior e as mais bem colocadas passam do grupo inferior para o grupo superior. Após várias rodadas de negociação das escolas de samba com a empresa e atritos entre as escolas do Grupo I com as escolas menores, que não queriam trocar os dias de desfile, o negócio não foi viabilizado e, poucos dias depois, a prefeitura reassumiu a organização do carnaval. Segundo o empresário Miguel Carlos Castro, da

\footnotetext{
${ }^{45}$ Arquivo da Biblioteca da Câmara Municipal de São Paulo.
} 
Respaldo, em entrevista ao jornal Folha de São Paulo, em 1986, "o carnaval terminou se tornando um mau negócio". Após não cumprir o prazo dado pela prefeitura para que a empresa apresentasse um documento bancário garantindo que possuía os $\mathrm{Cr} \$ 8$ bilhões necessários para viabilizar o negócio. Em nota distribuída à imprensa, a empresa explicou o episódio:

\begin{abstract}
A empresa recuou e não apresentou o documento, pois as escolas de samba não puderam adiar compromissos assumidos em cidades do interior e recusaram a proposta de transferir os desfiles do primeiro grupo para sábado. Sem a alteração do desfile, a Respaldo perdeu o grande trunfo que tinha para negociar com as televisões - que preferem, no domingo os desfiles do Rio. Tudo isso prejudicava também a venda dos espaços publicitários de arquibancada a que a empresa tinha direito (FOLHA DE SÃO PAULO, 01/02/1976).
\end{abstract}

Com a saída da empresa, a organização do carnaval, pela quarta vez, mudou de direção naquele ano. Através da portaria $n^{\circ} 78$, decretada no dia 03 de fevereiro de 1986, o prefeito destituiu a Comissão Organizadora do Carnaval, nomeada para substituir a Paulistur que estava sendo extinta. A empresa mista comandada pela prefeitura que detinha 77\% das ações passou a se chamar Anhembi Centro de Feiras e Congressos S.A, a partir de fevereiro de 1986. As atribuições da nova empresa ficaram restritas à administração do Complexo do Anhembi, na zona norte da cidade, e à organização do carnaval. A proposta do prefeito foi aprovada pelos 15 acionistas minoritários. Com a nova empresa, o prefeito reduziu o staff da nova empresa de 330 para 200 funcionários. (FOLHA DA TARDE, 31/01/1986).

Jânio Quadros ainda montou uma comissão composta por alguns secretários municipais, pelo presidente da Anhembi e por presidentes de escolas e blocos para levantar os gastos feitos pelos cofres públicos e viabilizar uma parceria com empresas privadas. Em memorando enviado aos secretários indicados para a comissão, o prefeito afirmou que não estava disposto nem mesmo a ceder ônibus para os sambistas (o que ele também havia negado, mas depois voltou atrás). Ele considerava os contratos assinados na gestão Mário Covas uma "invasão de mandato e desperdício de dinheiro público" (FOLHA DE SÃO PAULO, 10/01/1986). 
A confusão terminou somente no dia de carnaval, quando os desfiles aconteceram. Os ingressos foram liberados apenas quatro dias antes do carnaval, após várias tentativas frustradas dos foliões de comprarem suas entradas:

Com relação aos ingressos, centenas de paulistanos compareceram durante a madrugada e início da manhã de sábado no Anhembi e Galeria Prestes Maia para garantir uma vaga. E frustrados, pela quinta vez, não conseguiram comprar os bilhetes. Apenas um papel informava a transferência da data e dos locais de venda. Agora, parece que a coisa é séria e tanto na Galeria Prestes Maia, Anhembi, como nas Administrações Regionais, a venda será realizada e o paulistano poderá garantir seu ingresso nos festejos de Momo na Avenida Tiradentes (NOTÍCIAS POPULARES, 03/02/1986).

No ano seguinte e nos próximos de seu folclórico mandato, Jânio Quadros patrocinou os desfiles carnavalescos, aumentou as verbas e liberou gratuitamente as arquibancadas dos desfiles dos grupos menores. E, inclusive, iniciou algumas discussões para a construção do que ele chamou de "desfilódromo" (FOLHA DA TARDE, 10/02/1986).

Para efeito de comparação de gastos sobre os valores investidos no carnaval, no ano de 1986, a empresa Riotur arrecadou Cr\$ 58 bilhões - principalmente com patrocinadores, direito de transmissão às emissoras nacionais e estrangeiras e com a venda de ingressos para os desfiles. Segundo a empresa, os gastos foram de $\mathrm{Cr} \$ 40$ bilhões, portanto, o carnaval deu um lucro de Cr\$ 18 bilhões (FOLHA DE SÃO PAULO, 13/02/1986).

As escolas Beija-Flor, Padre Miguel, Portela e Salgueiro declararam terem gasto Cr\$ 4 bilhões cada para se apresentar no Sambódromo. Os números de São Paulo são bem menores. Para armar a passarela da Avenida Tiradentes e cobrir outros custos como a subvenção das escolas, a Prefeitura de São Paulo investiu Cr\$ 8,5 bilhões e arrecadou Cr\$ 1,9 bilhão com a venda dos ingressos (FOLHA DE SÃO PAULO, 14/02/1986).

Uma das principais escolas da capital, a Camisa Verde e Branco, teve um orçamento de Cr\$ 600 milhões, sendo Cr\$ 109 milhões dados pela prefeitura (GAZETA ESPORTIVA, 13/09/1985). A quantia total gasta pela escola paulistana é menor que a 
subvenção oficial de Cr\$ 800 milhões que cada uma das quinze escolas do Grupo I-A receberam da Prefeitura do Rio.

Betinho deixou a presidência da entidade no final de 1985 e em seu lugar entrou Eduardo de Oliveira, visto pelas escolas de samba como uma continuidade da gestão anterior. Questões políticas também motivaram a fundação da Liga. Eduardo Basílio, presidente da Rosas de Ouro e historicamente ligado ao malufismo, não aceitava a nomeação de Percival Maricato, membro da associação de bares e restaurantes e membro do PT como vice-presidente administrativo. O próprio Eduardo de Oliveira era visto com desconfiança pelos malufistas, por causa de suas ligações com o PMDB do então governador Orestes Quércia e do antigo prefeito Mário Covas.

Durante a gestão de Paulo Maluf como governador, Basílio foi diretor da Embratur e da Comgás. Também foi administrador regional (atual Subprefeitura) de cinco regiões da cidade: Vila Mariana, Butantã, Capela do Socorro, Pinheiros e Casa Verde.

O que também enfraqueceu ainda mais a UESP foi a escolha dos jurados para os desfiles do carnaval de 1986. O corpo era composto pelo estilista Ronaldo Ésper (Fantasia); pelo ator e diretor Cacá Rosset (Enredo); pelo artista plástico e presidente do Conselho de Museus do Estado de São Paulo Zélio Alves Pinto (Alegoria); pela jornalista e quadrinista Cecília Vicente de Azevedo Alves, a Ciça; pela jornalista da Rede Globo, Rose Nogueira (Mestre-Sala e Porta-Bandeira); pelo artista plástico e vicepresidente da Associação de Artistas Plásticos de São Paulo, Ivald Granato (Evolução); pelo maestro e regente titular da Orquestra Sinfônica do Teatro Municipal, Júlio Medaglia (Melodia); pela cantora Célia (Harmonia); pelo primeiro percussionista da Orquestra Sinfônica Municipal de São Paulo e professor da ECA-USP, Cláudio Stephan (Bateria); e pelo crítico musical e diretor de arte do jornal Estado de São Paulo, Adones de Oliveira (Letra do Samba).

A ideia da UESP era criar um conselho de notáveis e que estivesse acima de qualquer suspeita, convidando para tal, grandes nomes conhecidos do público e respeitados em suas áreas. A ideia foi apoiada inicialmente por algumas escolas e 
rejeitada por outras, que alegaram que a maioria dos jurados não conhecia a realidade de uma escola de samba. Esse coro ganhou todas as vozes, quando a apuração começou. Houve tumultos, brigas, violência policial e indecisão da diretoria da UESP quanto à validade do resultado.

A apuração havia começado às 11 horas no ginásio de esportes do Pacaembu, mas foi interrompida 40 minutos depois com a entrada do presidente da escola Camisa Verde e Branco, Carlos Alberto Tobias, na área reservada à mesa apuradora. A confusão se formou após uma nota 9,2 de Alegoria dada à escola da Barra Funda. Como o regulamento previa apenas notas inteiras, o presidente da escola queria arredondar para 10 e os demais queriam arredondar para 9. Após o dirigente ter pulado a grade que separava sambistas da mesa apuradora e rasgado o formulário com a nota, instaurou-se a confusão. Depois de 40 minutos de discussão, decidiu-se que todas as notas fracionadas seriam arredondadas para mais. A próxima nota lida foi o quesito Melodia. O presidente do Camisa ficou novamente descontrolado e inconformado com a nota cinco dada à sua escola pelo maestro Júlio Medaglia, jurado desse quesito. Para ele, o maestro não tinha competência para julgar o quesito Melodia. Já o presidente da escola Rosas de Ouro, Eduardo Basílio, acusou o maestro de prejudicar sua escola, por conta de questões político-partidárias. Basílio acusava Medaglia, membro do PT, de chamar jurados petistas. O maestro argumentou que, antes do carnaval, recebeu voto de confiança de todos os dirigentes para a seleção do júri dos desfiles dos Grupos I e II. Em entrevista ao jornal Folha de São Paulo, Medaglia disparou: "não sou tão desinformado como pensam. Fui diretor cinco anos do programa 'A hora e a vez do Samba', na rádio Roquete Pinto no Rio. Conheço melodia desde a Renascença. São seiscentos anos de música" (FOLHA DE SÃO PAULO, 14/02/1986).

Ricardo Kotscho, que cobria o evento e fez a matéria para o jornal Folha de São Paulo opinou sobre a confusão envolvendo a apuração:

O espetáculo deste primeiro Carnaval sob os auspícios do neo-janismo não poderia ter sido mais autêntico. Depois de intermináveis reuniões nos banheiros do ginásio do Pacaembu, enquanto do lado de fora milhares de desocupados passavam o dia tomando cachaça e cerveja, os dirigentes do 
samba paulista apelaram para a velha saída: chamaram a polícia e levaram as urnas para o quartel do $2^{\circ}$ Batalhão de Choque da PM, na rua Jorge Miranda, bairro da Luz, zona central da cidade.

A confusão toda começou quando a Prefeitura anunciou o fechamento da Paulistur e depois ficou sem saber como organizar o Carnaval, em tantas idas e vindas que até a véspera nem se sabia se iria sair o desfile das escolas de samba na avenida Tiradentes. Mas a União das Escolas de Samba Paulistanas (Uesp) também foi responsável pelo vexame que se consumou ontem, ao demonstrar que não consegue andar com as próprias pernas. Durante muito tempo, os carnavalescos se queixaram da interferência do poder público na organização desta festa popular. E no momento em que este poder se omite, todos voltam correndo para o quartel. (FOLHA DE SÃO PAULO, 14/02/1986).

O jornalista critica a posição da UESP de não conseguir controlar suas filiadas e de pedir socorro para a polícia, já que depois de mais de três horas de brigas e indecisão, o presidente da UESP determinou, por medidas de segurança, que as urnas ainda não abertas fossem levadas para o Batalhão de Choque da PM. O presidente do Camisa propôs que as dez escolas do Grupo I fossem sagradas campeãs e disse que "se uma escola for declarada campeã, fundará uma liga com as "coirmãs dissidentes". As escolas Vai-Vai e Mocidade, escolas bem colocadas na apuração, não concordaram. Após a apuração acontecer dentro do batalhão da PM, o Vai-Vai sagrou-se campeão.

As disputas eram muito maiores do que as brigas recorrente em apurações de carnaval. Na verdade eram dois grupos que queriam demonstrar sua força dentro da UESP, como parte da luta pelo poder político na cidade. Um ligado ao malufismo e outro ligado ao petismo. Além desses grupos também existiam escolas ligadas ao janismo e ao quercismo, que questionaram muito mais a opção ideológica dos jurados, do que o seu trabalho de análise técnica.

Kotscho conclui:

Para começar, as escolas não conseguiram se entender na escolha dos jurados e acabaram dando carta branca ao maestro Júlio Medaglia para que o fizesse. Depois começaram a acusar Medaglia de ser ligado ao vice-presidente administrativo da Uesp, Persival Maricato, da Colorado do Brás. Como os dois são petistas, foram colocados sob suspeita de procurar prejudicar a Rosas de Ouro, tradicionalmente ligada ao malufismo - e por aí foi o samba do crioulo doido que antecedeu a apoteose da apuração. 
O estopim já estava aceso quando foi anunciada a nota 5 para a melodia da Camisa Verde, que serviu de senha para que quase todos virassem a mesa. 'Cada um quis puxar a brasa para sua sardinha e, no fim, não sobrou sardinha nem brasa para ninguém', constatava desolado, o crítico carnavalesco Paulo Valentim, ao ver as urnas sendo levadas novamente para o quartel (FOLHA DE SÃO PAULO, 14/02/1986).

As escolas fundadoras perceberam que, caso se unissem, poderiam negociar diretamente com a televisão os direitos de transmissão, sem a necessidade de acordo com as escolas menores e com a prefeitura. Portanto, a Liga Independente das Escolas de Samba (Liga) nasce com funções semelhantes às da UESP, sendo a responsável pela negociação das escolas com patrocinadores e com o poder público. O Estatuto da Liga foi assinado no dia 19 de junho de 1986, por Camisa Verde e Branco, Rosas de Ouro, Mocidade Alegre, Vai-Vai, Águia de Ouro, Imperador do Ipiranga, Acadêmicos do Tucuruvi e Unidos do Peruche. Quem assina a ata de fundação como representante das escolas é Eduardo Basílio, nomeado primeiro presidente da Liga. Segundo o documento, a Liga define como seus objetivos sociais:

a) Congregar escolas de samba, sediadas no Estado, defender seus interesses e reivindicações, representá-las perante as autoridades e entidades particulares e prestar-lhes assistência cultural;

b) Colaborar com as autoridades, visando o incremento e o brilhantismo das manifestações culturais e folclóricas, sobretudo aquelas ligadas ao samba;

c) Promover eventos, cursos, conferências, debates, reuniões/espetáculos, excursões, desfiles e festivais de natureza cultural, social, folclórica, desportiva e de lazer;

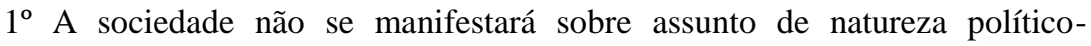
partidária, nem se engajará em campanhas de tal teor;

$2^{\circ}$ A sociedade não admitirá distinções por motivo de raça, cor, sexo, religião, profissão e nível econômico ${ }^{46}$.

Com a fundação da Liga, a divisão dos sambistas estava novamente instaurada. No início, apenas as escolas do Grupo I eram aceitas como filiadas da Liga. Os grupos menores, que não tinham visibilidade, não despertaram o mínimo interesse.

\footnotetext{
${ }^{46}$ Estatuto da Liga Independente das Escolas de Samba de São Paulo. Acervo UESP.
} 
Posteriormente, a Liga aceitou também as escolas do Grupo II, hoje, respectivamente, Grupo Especial e Grupo de Acesso. A primeira medida da Liga, para atender ao canal interessado em pagar pela transmissão dos desfiles, foi a mudança do dia dos desfiles do principal grupo de domingo para sábado, mudança negada pelas escolas no acordo com a empresa Respaldo, para não coincidir com o desfile do Rio de Janeiro, também transmitido pelas emissoras de TV.

A partir desta divisão entre a Liga e a UESP, em 1986, os desfiles paulistanos organizados pela primeira passaram a ser transmitidos pelas emissoras de televisão, inicialmente a Manchete e posteriormente a Rede Globo. O primeiro desfile organizado pela Liga foi o do carnaval de 1987, sob a coordenação da Anhembi e de uma série de empresas interessadas em patrocinar apenas o carnaval das escolas maiores, comprando uma cota de publicidade nos espaços da avenida. Era a oportunidade para divulgarem suas marcas para as 25 mil pessoas que assistiam na Avenida Tiradentes e para outros milhares que assistiam via Rede Manchete, emissora que transmitia os desfiles. Se antes, com a UESP, qualquer acordo deveria ser referendado por mais de 70 escolas, afastando os patrocinadores que não tinham interesse em patrocinar as escolas pequenas, com a Liga bastava negociar com quem realmente interessava. A UESP continuou organizando com a prefeitura o carnaval de bairro na cidade.

Com a entrada do aporte financeiro das emissoras de televisão e dos patrocínios de empresas privadas, o concurso virou uma disputa profissional. Os prêmios para os vencedores passaram a ser cada vez maiores. Essa disputa levou a uma dinâmica de mutação dentro das direções das escolas de samba, com a saída de fundadores e membros históricos das escolas das funções de direção e a entrada de novas lideranças, ligadas a uma administração mais empresarial das escolas, que passaram a lidar com um orçamento cada vez maior, produzindo também um desfile grandioso, sempre na expectativa de superar o Rio de Janeiro (OLIVEIRA, 2007, p. 69).

Neste modelo instituído a partir da Liga e que ainda está vigente nos desfiles da atualidade, a direção da nova entidade é escolhida a partir de uma eleição, na qual os dirigentes das agremiações concorrem e passam muitas vezes a acumular o cargo de dirigente de escola e de federação. Para conseguir realizar esse carnaval, que se tornou 
tão grandioso em tão pouco espaço de tempo, os três principais canais de financiamento das escolas se tornaram os seguintes: as verbas oficiais recebidas pela Liga, através de convênio com a prefeitura, as verbas de direitos de transmissão do canal de televisão que detém os direitos de televisionar o desfile e o repasse de uma parte do total arrecadado com a venda de ingressos.

Em suma, a Liga trabalha dentro de um parâmetro empresarial capaz de negociar contratos com as emissoras de comunicação, com o poder público, buscando uma maior fatia do bolo para as escolas (BELO, 2008, p. 202). Já a UESP permaneceu como a entidade de organização das pequenas agremiações, de comunidades mais afastadas, longe dos holofotes, trabalhando dentro do parâmetro tradicional de desfiles que as escolas realizam, desde a oficialização dos mesmos. Vale lembrar que, desde a oficialização, em 1968, o principal canal de financiamento das escolas de todos os grupos já era a verba da Prefeitura, portanto, é o dinheiro público que mantém as escolas de samba, seja de qual grupo for. ${ }^{47}$ Esse dinheiro, no entanto, é insuficiente para cobrir os gastos totais das escolas, pois os desfiles estão se tornando a cada ano, mais luxuosos, e as escolas têm na sua comunidade e na criatividade de seus membros as soluções para que o desfile aconteça, somados a patrocínios pontuais de empresas que podem eventualmente ser negociados.

Para a UESP, a saída das escolas do Grupo I representou a perda da maior parte de sua receita e de seu prestígio nas negociações com o poder público, pois tanto a prefeitura como os patrocinadores estavam interessados apenas nas escolas maiores ao destinar a maior parte das verbas para elas, criando, a partir daí, uma espécie abismo praticamente intransponível relativo à estrutura dos desfiles carnavalescos das escolas pequenas para as escolas grandes. As verbas que a UESP passou a receber, depois da divisão, representavam apenas uma pequena parte do montante anterior dado pela prefeitura para organização de desfiles dos grupos menores. Os desfiles dessas escolas que permaneceram sob a organização da UESP apenas sobrevivem com o patrocínio oficial e por meio do esforço da própria comunidade, e não atraem a atenção de patrocinadores e investidores de maior vulto financeiro.

\footnotetext{
${ }^{47}$ Fonte: Documentos de prestação de contas das escolas filiadas à UESP. Ano: 2007.
} 


\section{II - AS TRANSFORMAÇÕES ESTÉTICAS NO DESFILE DAS ESCOLAS DE SAMBA DA CIDADE DE SÃO PAULO}

Este segundo capítulo apresenta as principais transformações visuais e musicais pelas quais pasosu o carnaval de São Paulo durante o período estudado na presente dissertação (1968-1996).

No capítulo anterior pudemos observar as mudanças institucionais no carnaval de São Paulo, os debates entre as federações, entre os dirigentes e as relações deles com o poder público e com outros agentes da indústria cultural. As mudanças abordadas neste capítulo são mais visíveis para aqueles que acompanham o universo das escolas de samba, pois são as mudanças nos desfiles propriamente ditos. Mudanças que aconteceram nas fantasias, nos carros alegóricos, nos sambas-enredos e na bateria das escolas de samba.

Ao observarmos tais mudanças, podemos perceber que elas não se explicam por si só, mas que são fruto das negociações e das transformações institucionais pelas quais passou carnaval de São Paulo. Mantendo-se fiel à tese da presente dissertação de que as transformações não ocorreram "de cima para baixo" - com a atuação do Estado ou da indústria cultural impondo novas regras e padrões que as escolas eram obrigadas a aceitar e a eles se adequarem, tese também defendida por Ana Maria Rodrigues (1984) e Maria Apparecida Urbano (1987) — nem de "baixo para cima", pois as mudanças estéticas das escolas de samba paulistanas são decorrentes apenas da capacidade de inovação de seus membros. Elas foram negociadas, tanto com agentes externos quanto internos. Transformações de naturezas diferentes foram mapeadas. Houve aquelas transformações criadas pelas próprias escolas de samba para os desfiles, que acarretaram uma mudança ou adequação por parte dos regulamentos e uma ação das federações de carnaval e de outras escolas de samba para legitimar ou deslegitimar tais inovações, e aquelas mudanças que foram decorrentes de transformações institucionais mais amplas, ou seja, foram as relações políticas e financeiras com agentes externos, como o Estado ou as demandas da indústria cultural que as originaram. No caso das 
últimas, foram exercidas com mais pressão em dois momentos: na oficialização, na qual o Estado, para patrocinar a festa e se resguardar como avalista, prefere adotar um modelo pronto, oriundo das escolas de samba do Rio de Janeiro, e adaptado pelas escolas de samba de São Paulo, nos anos 1980, com a ação da entrada da televisão nos desfiles; e na mudança dos locais de apresentação, que deixam as ruas e passam a acontecer no Sambódromo, iniciando-se uma nova dinâmica de desfile, trazendo tanto perdas como ganhos, do ponto de vista estético.

\subsection{As fantasias}

Para participar de um desfile de escola de samba, é necessário vestir uma fantasia. Essa palavra, na Língua Portuguesa, possui um duplo sentido, pois ela se refere tanto às ilusões e idealizações da realidade quanto às roupas e adereços utilizados somente no carnaval (DAMATTA, 1996, p. 60). As máscaras e os costumes são fundamentais para a festa carnavalesca. Os costumes são chamados de fantasia, pois, ao utilizá-los, se dá a troca de identidade, passa-se a vivenciar a inversão de papéis cotidianos, idealizando uma nova realidade, e vivendo-se o momento da fantasia.

O carnaval traz a ideia de retorno efetivo e completo (embora provisório) ao país da Idade do Ouro. Ao se fantasiar e ocupar o espaço das ruas há uma fuga provisória dos moldes da vida ordinária (isto é, oficial). É o contrário da festividade oficial na qual as identidades estão preservadas e, com elas, a estabilidade, a imutabilidade e a perenidade das regras que regem o mundo: hierarquias, valores, normas e tabus religiosos, políticos e morais correntes. Neste tipo de festividade há uma evidência da condição dos participantes: sua condição social, sua fortuna, seu emprego, idade e relação familiar (BAKHTIN, 2000, p. 9).

No Brasil, as brincadeiras de disfarces se popularizaram nos bailes de máscaras da Corte no século XIX e também nos entrudos populares das ruas, folguedo do período 
carnavalesco trazido pelos colonizadores portugueses para o Brasil e que consistia no desfile de um boneco chamado Entrudo ou João, acompanhado de outro boneco chamado Dona Quaresma que passeavam nas ruas manipulados por populares entoando modinhas burlescas. Também eram comuns as batalhas de arremessos de laranjas de cheiro feitas de cera e cheias de líquido perfumado ou ainda o arremesso de farinha, cinzas e lama, principalmente em escravos que carregavam as bandejas e serviam de vítimas, sem poderem esboçar qualquer reação. Também havia grupos de mascarados, danças e bailes que coroavam os festejos (QUEIROZ, 1992, p. 39).

Entre os escravos e negros brasileiros era comum a festa da Coroação do Rei do Congo, presente até hoje em algumas localidades, principalmente da zona rural. Consistia em uma festa com dança e música que celebraria a coroação do rei do Congo, rei africano que teria sido deposto, escravizado e mandado para o Brasil. O cortejo era composto pela coroação do rei e da rainha do Congo, pelo agradecimento a estes governantes, pelo culto aos antepassados, com cavalgadas, música e celebração de santos católicos reverenciados pelos negros como São Benedito e Nossa Senhora do Rosário. Os principais instrumentos musicais utilizados nessas festas eram cuíca, caixa, pandeiro, além de vários instrumentos improvisados feitos pelos negros (MAZOCO, 1993).

No carnaval paulistano, desde o primeiro cordão fundado por Dionísio Barbosa, em 1914, os participantes sempre desfilaram uniformizados e fantasiados com calça branca, camisa verde e chapéu de palha na cabeça, gerando, a partir daí, o nome popular do Grupo Carnavalesco Barra Funda, que ficou conhecido como "Camisa Verde e Branco”. A importância da fantasia era fundamental, pois uma vez que não havia um tema ou enredo orientador, a ideia de conjunto e harmonia nas apresentações era transmitida pelas fantasias (SIMSON, 2007, p. 164).

$\mathrm{Na}$ era dos cordões normalmente os foliões faziam suas próprias fantasias, utilizando diversos materiais, ou seja, aqueles que cabiam no orçamento, sempre respeitando as cores da agremiação. Essas começaram a ser feitas com maior cuidado a partir da entrada das mulheres nos cordões, no final da década de 1910 e início da década 1920. As mulheres, chamadas de amadoras, utilizavam fantasias coloridas, 
femininas (de holandesas, camponesas, princesas, etc.). Também havia sempre nos cordões uma preocupação com o calçado a ser utilizado durante o desfile. Nunca desfilaram descalços, pois isso fazia referência à época da escravidão, quando os escravos eram obrigados a andar descalços, portanto, calçar sapatos significava que o negro era liberto. Normalmente utilizavam sapatos ou botinas feitas em couro, especialmente confeccionadas por sapateiros contratados pela agremiação.

Por exemplo, o Vai-Vai ${ }^{48}$ saía desde seus primeiros desfiles ainda como cordão, com suas fantasias em branco e preto. Outras cores também eram utilizadas, mas sempre as cores da agremiação eram predominantes. Dona China do Vai-Vai recorda este tempo e lembra o processo artesanal de confeccionar as fantasias. Elas eram realizadas de acordo com as condições econômicas da época, havia uma precariedade material e, com isso, várias improvisações. Dona China recorda também que cada integrante podia confeccionar a sua própria fantasia:

\begin{abstract}
Antigamente, com a minha comadre bordando, eu cheguei a pegar uma lantejoula do chão, para não fazer falta no meu vestido, porque não podia comprar, não. Hoje em dia, a pessoa chega e já tem tudo pronto, quer dizer que nós antigamente lutávamos, a gente comprava o tecido ou a escola dava um tecido vagabundo e você tinha que fazer ele, coberto e forrado com lantejoula; quando não tinha dinheiro pra comprar lantejoula, a gente colocava plástico. O primeiro vestido meu que eu saí no Vai-Vai, o Pé Rachado, que era presidente naquela época, deu só cetim preto e falou: 'Olha, China, te dou o cetim e você vê o que você pode fazer'. Então ele me deu e eu mandei uma colega minha que mora aqui fazer, ela fez e eu falei: 'e agora, como eu vou comprar lantejoula', porque a situação financeira não era boa, aí eu comprei um plástico, ela recortou toda a bandeira do Vai-Vai num plástico, ela colocou no vestido preto de cetim, e nossa, quando eu cheguei na avenida, esplandeceu! $!^{49}$
\end{abstract}

\footnotetext{
48 Somente a título de explicação: quando nos referimos às agremiações "Camisa Verde e Branco" e "Vai-Vai", o correto é utilizarmos o Camisa, o Vai-Vai, e quando nos referimos a escolas de samba como "Nenê de Vila Matilde", "Lavapés" e "Unidos do Peruche", devemos utilizar a Nenê, a Lavapés, a Peruche, porque o artigo masculino antes dos nomes das escolas de samba informa suas origens históricas como cordões de carnaval.
}

${ }^{49}$ Depoimento de Dona China do Vai-Vai. Data: 09/07/2011. 


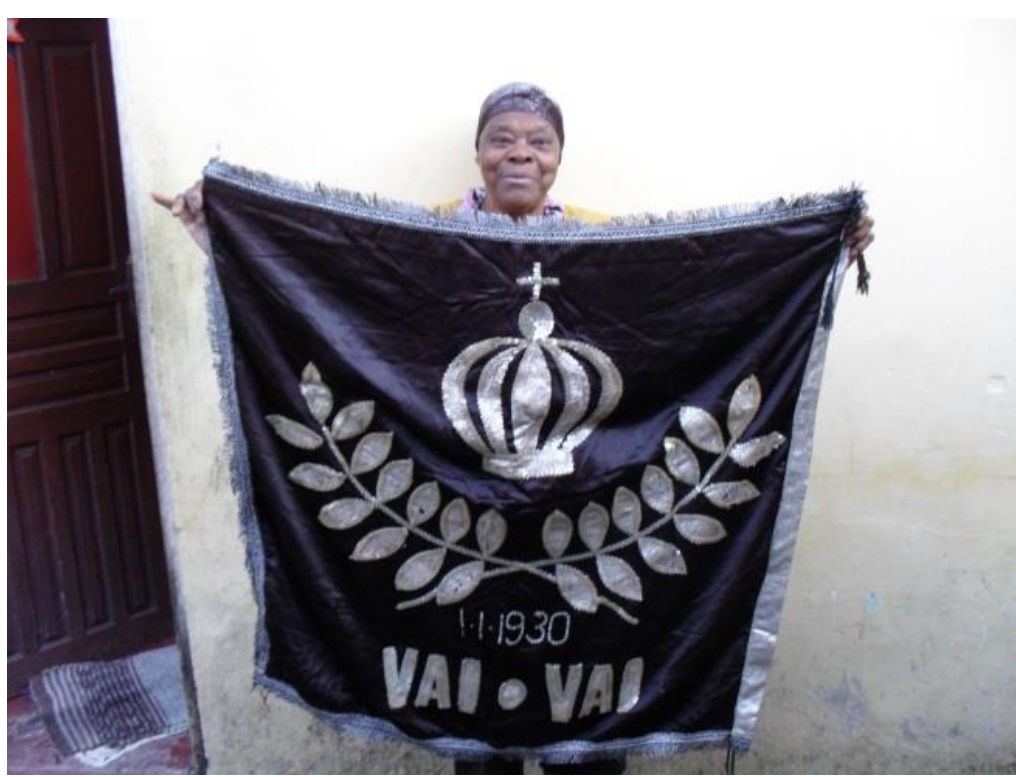

Legenda: Dona China, primeira porta-bandeira da escola de samba Vai-Vai, com o primeiro pavilhão da escola. Crédito: foto do autor.

Álvaro Casado, em sua trajetória como presidente da UESP, descreve o processo artesanal e coletivo de confecção das fantasias carnavalescas:

Usávamos cetim, lamê. Usava muita renda. A costura era feita na casa do cara. A casa dele virava um barracão. A verdade é essa. A mulher fazendo o arroz aqui, e a outra com a máquina de costura ali. E eu visitava cada muquifo, em cada beco da cidade. As pessoas faziam pelo amor, pelo samba. Tanto é que a Rosalina, eu fiz até enredo pra ela, ela ficava de setembro até o dia do carnaval, costurando direto, todo dia. Junto com aquela sobrinhada, um costurava, outro alinhavava. Três máquinas de costura, direto. Era amor mesmo! $!^{50}$

Como uma memória coletiva do carnaval deste tempo, Mestre Gabi relembra a divisão entre o trabalho masculino e feminino, com os homens realizando os trabalhos mais pesados, como a confecção de alegorias, e as mulheres se dedicando ao processo de confecção das fantasias, e o sentimento que isso trazia ao observar, por exemplo, as fotos de desfiles antigos dos quais ele participou:

${ }^{50}$ Entrevista com Álvaro Casado. Data: 01/05/2013. 
Veja bem, antes eram os homens que faziam as alegorias. E nós tínhamos as costureiras, e quem eram as costureiras? Era a minha mãe, era a mãe de outro sambista, não era a profissional costureira, eram pessoas comuns, que sabiam costurar um pouco, então vamos fazer fantasia. E nós confeccionávamos as nossas fantasias. Talvez por isso a gente seja muito saudosista. Porque você olhava depois em uma fotografia a sua fantasia, e olhava com um sentimento. Este aqui foi a última conta que eu coloquei, este aqui foi a última unha que eu coloquei, então, para nós, era uma coisa assim magnífica, e a gente curtia muito isso. Quantas noites eu não fui para a escola para ficar no barracão, ajudando, pregando. Eu não sou marceneiro, mas quantas vezes eu não ia lá pregar os carros alegóricos, eu ia pintar, também não sou pintor, mas pintava, decorava, então era um trabalho de todos da comunidade, a gente não tinha aquilo como profissão ${ }^{51}$.

As fantasias que mais se destacavam nos cordões eram as da Corte Carnavalesca, que encerravam o cortejo, composta sempre pelo rei e pela rainha (de Momo), as princesas e os príncipes e, eventualmente, por duques, duquesas e pajens. A rainha normalmente se apresentava com fantasias à Luís $\mathrm{XV}$, com longos vestidos de cetim, peruca branca empoada e com a coroa e joias feitas com metal brilhante. Uma parte dos recursos arrecadados durante as atividades realizadas pelos cordões, ao longo do ano, era destinada à confecção das fantasias da corte carnavalesca (SIMSON, 2007, p. 167). As fantasias, tanto as masculinas quanto as femininas, sempre tiveram bastante decência e elegância, cobrindo a maior parte do corpo, sem qualquer nudez. Para driblar a falta extrema de recursos, as fantasias dos cordões, muitas vezes, possuíam apenas a frente de cetim ou outro tecido colorido, e a parte de trás era feita com papelão pintado. Normalmente eram escolhidas, a partir de modelos de revistas e recriadas pelas próprias costureiras dos cordões.

A fantasia dos integrantes da parte instrumental foi aos poucos sendo padronizada, como um "terno carnavalesco" (SIMSON, 2007, p. 167), isto é, uma roupa masculina confeccionada com um tecido vistoso ou brilhante, evidenciando o papel de destaque que os músicos tinham dentro dos cordões.

\footnotetext{
${ }^{51}$ Entrevista com Mestre Gabi. Data: 25/10/2010.
} 
Osvaldinho da Cuíca nos conta que eram as fantasias do instrumental dos cordões que normalmente mudavam a cada ano e destaca as fantasias da Corte descrita acima:

O primeiro tema de fantasia da batucada do Vai-Vai foi de marinheiro. Teve um ano em homenagem aos russos, as fantasias de 'sordadinho' Fritz. Fritz por quê? Existia uma propaganda no jornal que era bomba de Frit pra matar inseto. Eles falavam Frit, né? Tinha a propaganda de um 'sordadinho' que tinha um chapéu russo, aquele chapéu comprido, de russo. Só que em vez dele ter uma carabina aqui na mão, ele tinha uma bomba de Fritz na mão, isso nos anos trinta, quarenta. Eu me lembro disso aí. Até os anos cinquenta tinha a propaganda do soldadinho com uma bomba de Fritz da mão. Normalmente era a bateria que vinha com fantasia diferente todo ano. A corte vinha igual. A mesma coroa, a capa de rei, rainha, os súditos atrás. As crianças segurando a capa da rainha, do rei. Era bonito, mas sempre a mesma coisa ${ }^{52}$.

A partir do momento em que as escolas de samba passaram a desfilar seguindo um enredo, contando uma determinada história, todas as fantasias passaram a se modificar anualmente, pois estas deveriam fazer parte e ajudar a contar este enredo. As escolas então começaram a se organizar por grupos de fantasias iguais, chamadas alas, passando a ter um certo nível de responsabilidade, por parte dos participantes, da ala que antes não se exigia.

Para Roberto DaMatta:

As alas podem aumentar, diminuir, criar suas regras e estilos, ter nomes próprios (...). Por isso, as escolas de samba podem congregar ricos e pobres, pretos e brancos, patrões e empregados, sambistas e sambeiros (os de dentro, que participam do dia-a-dia da escola de samba e os de fora, que compram a fantasia apenas para desfilar). De fato, toda a organização da escola de samba era fundada nessas unidades semiautônomas e poderosamente articuladas (DAMATTA, 1997, p. 103).

Com a instituição do modelo carioca de desfile na década de 1960, via regulamento da oficialização, abordado no primeiro capítulo, ruiu toda a organização de desfile tradicional dos cordões carnavalescos. As fantasias trazidas todos os anos, de

\footnotetext{
${ }^{52}$ Entrevista com Osvaldinho da Cuíca. Data: 21/01/2012.
} 
duques, condes, príncipes, reis, fidalgos e princesas, deram lugar a um novo modelo em que as fantasias eram modificadas a cada ano, de acordo com o tema trazido pela escola.

A partir da oficialização dos desfiles em São Paulo, houve a introdução da figura dos carnavalescos para coordenar a montagem dos desfiles das principais escolas de samba. Com o fim dos cordões de carnaval após 1973, essa corte carnavalesca deixou de existir, por conta da obrigatoriedade de personagens que explicitassem o enredo de cada ano, utilizado nos desfiles das escolas de samba. Com isso, o modelo de organização e elaboração das fantasias e do próprio desfile foi alterado.

O processo descrito pelos entrevistados de um fazer artesanal, como Mestre Gabi e Dona China, ou coletivo, no caso de Dona Rosalina, descrita por Álvaro Casado, foi substituído nas escolas de samba pelas fantasias realizadas praticamente em escala de "manufatura", com divisão social do trabalho e espaços dedicados especialmente para este fim, com costureiras com oficinas próprias e cuja elaboração das fantasias é feita em série, com a presença de bordadeiras, complementando a realização da tarefa. Há até a presença de chapeleiros com função especializada para essa tarefa. Tanto as costureiras, bordadeiras e até os chapeleiros permanecem, normalmente, nessa atividade de confecção de fantasias de julho, quando são lançadas as "fantasias-piloto" até a véspera do dia de desfile, quando são finalizadas e retocadas as últimas fantasias.

Para o carnavalesco Joãosinho Trinta, a própria expansão do capitalismo urbano criou a demanda por profissionais especializados. Em entrevista concedida a Betty Milan em 1980, ele explica:

\footnotetext{
Quem morava no morro do Salgueiro vivia ali por perto e colaborava na alegoria; ele mesmo fazia sua fantasia. (...) Mas a cidade cresceu, o cara que mora no morro do Salgueiro hoje trabalha no Leblon, então tem que acordar cedo, quatro cinco horas da madrugada e se deslocar para outro lugar. Quando volta tarde da noite, não tem mais tempo de fazer alegoria, faixa, bonecos. A grande cidade acabou com a participação do componente e surgiu então o carnavalesco (MILAN, 1994 apud BLASS, 2007, p. 63).
}

Se por um lado, esta nova demanda abre a possibilidade de empregar mão de obra para a confecção das fantasias, por outro há o lucro que limita o acesso ao desfile 
das grandes escolas apenas para aqueles que possuem condições de comprar a sua fantasia, que apenas consomem o desfile como um produto, sem manter vínculos com a agremiação na qual desfila. A lógica citada por Trinta de que as pessoas não têm mais tempo na cidade para se dedicar a um trabalho não remunerado, ao qual se converte em lazer, não se aplica à lógica de organização das escolas dos grupos inferiores, que ainda mantém o processo artesanal, realizando a reciclagem e distribuindo as fantasias gratuitamente para os membros da escola, normalmente localizada em lugares pobres e periféricos de pequeno poder aquisitivo e que mantêm acesa a chama do carnaval comunitário. Nesses locais, a lógica da construção da mercadoria visando lucro ainda não se aplica.

O jornal $O$ Estado de São Paulo apresentou uma extensa matéria sobre a preparação de algumas escolas de samba para o carnaval de 1976, intitulada “Costureiras, operários - os anônimos personagens". A reportagem exalta o trabalho artesanal e gratuito dos membros das escolas, que utilizam suas horas de lazer e até faltam ao trabalho, diminuindo sua renda mensal para conseguir realizar as tarefas necessárias para a escola se apresentar no desfile, contrastando esse tipo de trabalho com o remunerado, exercido por trabalhadores assalariados do carnaval, que, naquele momento, já representava grande parte da mão de obra das grandes escolas. Para esses trabalhadores há o reconhecimento de poderem se dedicar integralmente ao que mais gostam de fazer, preparar o desfile das escolas de samba, e, por outro lado, ele representa a oportunidade de viverem dignamente com este ganho. E há ainda uma terceira classe, propriamente de artistas, como passistas, músicos e compositores, que aproveitam o clima de carnaval para gravarem canções, marchinhas e as verem executadas nas rádios, pelo país afora, além de se apresentarem em diversos shows, casas noturnas e festas, e, com isso, ganharem algum dinheiro, através de sua arte.

Os sambistas passam por dificuldades, ao realizar seu grande sonho mas muitos acabam desempregados e passando por diversas dificuldades por não se dedicarem aos seus empregos formais, em prol da preparação e, claro, da vivência do momento mágico da festa: 
Há três meses Janete Silva, primeira dama da escola de samba, Morro da Casa Verde, sai do trabalho às quatro da tarde para sentar-se à máquina de costura até as primeiras horas do dia seguinte. Durante essas nove ou dez horas diárias, ela costura as fantasias que a escola vai apresentar na avenida, no carnaval.

"É muita canseira para três dias. Mas como é de gosto, a gente faz com satisfação". Janete é uma das muitas pessoas que fazem desses três dias algo que justifique a preparação que a festa exige. Ela é mulher de Zezinho Nazareth, o presidente da escola, e em sua tarefa reúne na casa pequena, construída nos fundo do quintal, as netas e filhas: Valderez corta o pano; Solange, Yara, Sandra e Janete costuram.

Yara, filha do diretor de bateria, o Macuco é overloquista. Mas só trabalha até dezembro: "Quando pego o serviço, já aviso que de janeiro em diante só costuro para a escola". Essa rígida posição, na maioria das vezes cria um sério impasse para o sambista: sair no carnaval ou perder o emprego? Maria Inês Braga, porta-bandeira da Nenê de Vila Matilde, por exemplo, sabe que será suspensa por faltar uma semana ao serviço, na Tecelagem Matarazzo. Ela sabe que falta sem justificativa dá suspensão, mas não se importa: "Uma semana de folga é até melhor, para curtir a ressaca".

Nas escolas pequenas, como a Unidos do Bom Retiro, que desfila no terceiro grupo, o desprendimento é ainda maior. Dona Maria Rosa Henrique da Silva, por exemplo, mudou-se do Bom Retiro para a Casa Verde porque a casa anterior estava pequena demais para conter as fantasias e os instrumentos da escola, que ela ajudou a fundar há oito anos. E há três meses a escola recebe todas as atenções da família, que enfrenta o desconforto de ver a casa invadida, dia e noite, pelas pessoas que vêm ensaiar, provar a fantasia ou simplesmente sonhar com os três dias da avenida.

Na verdade, o poder econômico, a mentalidade empresarial, não conseguiu atingir a todos os sambistas e passistas, sobretudo os mais humildes, que nem por isso deixam de perceber a pressão a que estão sendo submetidos, como revela o desabafo de um ritmista da Rosas de Ouro, referindo-se aos dirigentes da escola: "Eles administram, mas a gente é que faz o samba". Se para os sambistas e passistas das escolas o lucro maior é "ganhar na avenida", o carnaval tem outros personagens para quem os quatro dias podem representar o pagamento das prestações da casa ou da televisão, a entrada para um carro usado, o cumprimento de promessas feitas no Natal, ou simplesmente a garantia, por algum tempo, para a feira ou o supermercado. Esses personagens são $80 \%$ dos 30 mil músicos registrados em São Paulo, que durante o carnaval vão conciliar as mais diversas ocupações que exercem normalmente, com a possibilidade de tocar, em média, 34 horas, em busca de qualquer uma das coisas acima. (...) Companheiros de aventura dos músicos de ocasião, os chamados autores de carnaval concentram suas esperanças na eventual boa vontade dos programadores musicais, que pode determinar o êxito ou o malogro de uma composição. O êxito, por si só, não assegura uma gratificação maior do que a simples satisfação pessoal. Para obtê-la, o compositor também depende da eficiência com que a sociedade de direitos autorais, à qual está filiado, vai recolher as taxas pagas pelos executantes das músicas.

Integrante da escola de samba, Unidos de Vila Maria, o compositor Xangô não vê muitas oportunidades para os autores desconhecidos. "Antes era preciso pagar o programador das músicas nas estações de rádio. Agora, por menos de 30 mil cruzeiros ninguém consegue 'trabalhar' direito uma marcha 
de carnaval no rádio e na televisão. E ainda precisa correr os clubes para convencer os conjuntos a tocar: como é mais fácil tocar velhos sucessos, quem quiser colocar uma música nova no ar precisa até ajudar os conjuntos a decorá-la (O ESTADO DE SÃO PAULO, 29/02/1976).

Assim como atesta Dona Janete e outros sambistas citados nas matérias, outra das principais dificuldades dos sambistas é conseguir materiais de boa qualidade para a confecção das fantasias. Os materiais utilizados para delas variavam, dependendo da quantidade de recursos empregada na construção de cada fantasia. Muitas escolas driblavam a falta de recursos com criatividade, utilizando materiais reciclados e baratos como palha, sisal, sementes, franjas em tecidos tingidos, bordados coloridos e macramês enfeitados. Existiam também outros materiais mais caros, utilizados até hoje por escolas mais luxuosas, como espelhos, paetês, matelassês, cirê, rolotês, galões, strass, veludos, cetins, marabu, lurex, etc. (CAVALCANTI, 1999, p. 193).

A partir da década de 1970, com a introdução da figura do carnavalesco, ele passa a ser o responsável por desenhar e montar os protótipos das fantasias. O que antes era feito de maneira espontânea, seguindo uma ideia geral, nesta década passa a ser centralizado nas mãos do carnavalesco. Ele desenha os modelos de fantasia para aprovação da diretoria da escola. Depois de aprovadas, as fantasias saem do papel e ganham vida com a confecção dos protótipos, as primeiras fantasias prontas. Estas são entregues para os chefes das alas em uma festa, que costuma se chamar "Lançamento dos Pilotos".

O carnavalesco André Machado é um dos que utilizam este processo criativo de desenhar as fantasias no papel para então elas ganharem vida. Seguem abaixo dois modelos de fantasias criadas por ele para os desfiles da escola de samba Barroca Zona Sul, no ano de 2012. O enredo homenageava a cantora Alcione, ícone do samba brasileiro, e sua escola de samba, a Mangueira. A primeira é um cisne, com notas musicais destacando a famosa lenda antiga do "canto do cisne". Segundo esta lenda, o cisne branco seria um animal mudo e que só cantaria no momento anterior à sua morte. No enredo, o carnavalesco quis homenagear as composições feitas por Cartola, fundador da escola de samba Mangueira, no fim de sua vida, após passar por um 
período de mais de vinte anos de ostracismo. A segunda é a fantasia utilizada pela Ala de Baianas da Barroca, com as baianas em verde-e-rosa, cores da Mangueira, com o símbolo da agremiação carioca na saia e a presença de rosas no turbante.

Esses modelos feitos à mão e os protótipos são de grande importância para o carnavalesco ter um maior controle sobre a execução das fantasias por parte das alas. As fantasias da ala de Baianas, Mestre-Sala e Porta-Bandeira, Bateria e Comissão de Frente não são repassadas para os chefes de ala, mas são confeccionadas pela própria escola de samba e supervisionada diretamente pelo carnavalesco. 


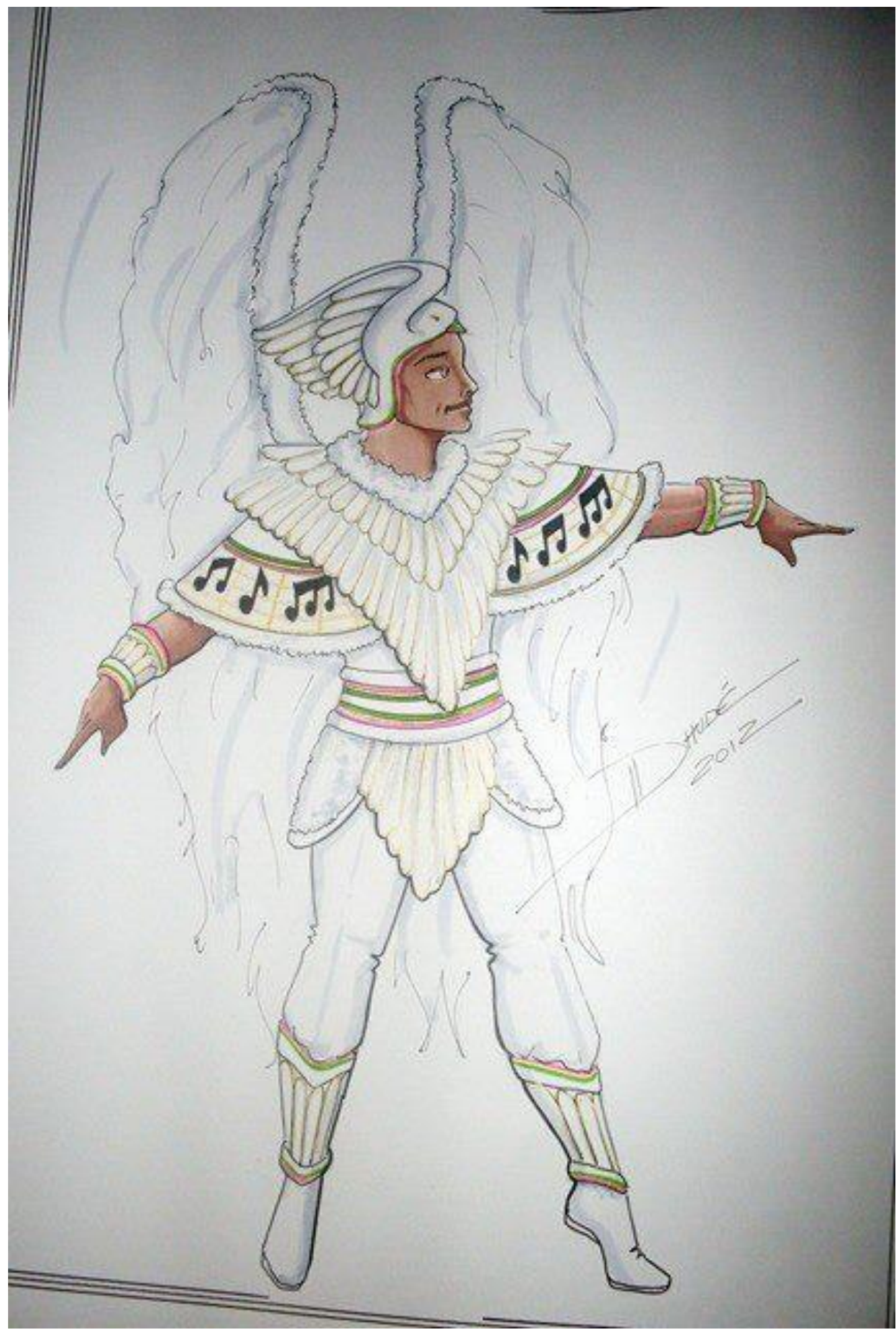

Desenho de André Machado: Escola de Samba Barroca Zona Sul (2012) 


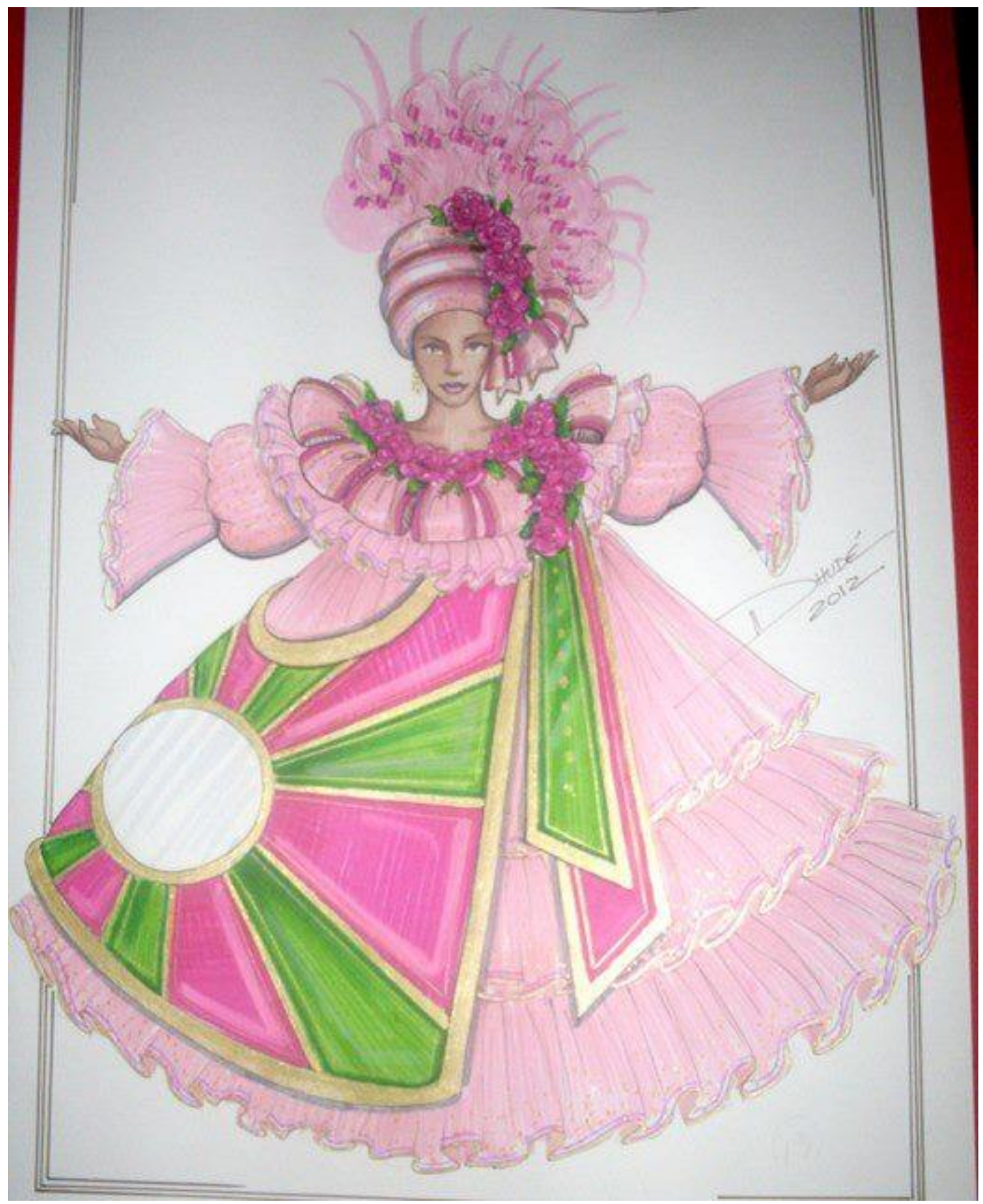

Desenho: André Machado. Escola de Samba Barroca Zona Sul (2012). Ala de Baianas

Depois desse dia, cada ala segue seu caminho autônomo, e as fantasias podem ser confeccionadas em oficinas contratadas para este fim ou mesmo na casa dos "chefes 
de ala", que é o responsável pela comercialização das fantasias e por reunir o número de foliões necessários para o desfile, conforme descrito acima (SOARES, 1997, p. 63).

As alas descentralizam a escola de samba reunindo pessoas de diferentes bairros, e, em alguns casos, de diferentes cidades. Cada ala tem um nome permanente, que foi escolhido por seu chefe ou por parentes e amigos. Normalmente fala de um desejo, de uma admiração, de uma característica da própria comunidade que concentra a maioria dos participantes.

Uma ala muito importante dentro de uma escola de samba é a ala de Baianas. Foi introduzida como ala obrigatória pelo regulamento criado a partir da oficialização carnaval da cidade de São Paulo em 1968. No Rio de Janeiro, a presença da ala de Baianas foi iniciada no ano de 1933, através de um decreto-lei do então prefeito do Rio de Janeiro, Pedro Ernesto, como forma de homenagear as baianas quituteiras vendedoras de doces e acarajé nas ruas e líderes religiosas das casas de santo do Rio Antigo, as "tias baianas".

Apesar de terem sido criadas de forma artificial por um decreto, ao longo do tempo, a Ala de Baianas se tornou um elemento indispensável para as escolas de samba. Composta por elementos femininos, normalmente senhoras, é uma ala de evolução. Estas senhoras, muitas delas mães de santo da umbanda e do candomblé, fazem, todos os anos, diversos trabalhos religiosos de proteção, pedidos de licença e reverência aos orixás.

Todos os sambistas entrevistados demonstraram profundo respeito e admiração pela Ala de Baianas. Para eles, a Ala de Baianas é um "fundamento", ou seja, algo inerente à própria concepção de uma escola de samba. A palavra tem, além de uma implicação de algo imprescindível, uma conotação religiosa, pois conhecer os fundamentos da religiosidade da umbanda e do candomblé é a base para manter uma relação bem estabelecida com os orixás. Cada orixá recebe oferendas de diferentes alimentos e bebidas, é importante saber, por exemplo, qual a cor das velas a serem acesas, qual o período do culto em que o médium de incorporação receberá o ponto do orixá, dentro do terreiro. Para Marcos dos Santos: “As baianas não são acessório, são 
parte fundamental de uma escola de samba". ${ }^{53}$ Mestre Gabi compartilha da mesma opinião e vai além:

É obrigatório, vocês sabem que é obrigatória uma Ala de Baianas em uma escola de samba, estavam querendo tirar, mas quem queria tirar? A modernidade. Sabe essas senhoras aí já estão muito cansadas, e além do mais atrasam o desfile. Quê isso? Baiana é fundamento de escola de samba! E neste fundamento estão os pavilhões, as baianas. Tem sempre aquela baiana que é chefe de terreiro, que faz os trabalhos de proteção da escola de samba, tudo em cima do pavilhão, porque ele representa toda aquela comunidade, toda aquela nação. Então é por isso que a gente vai lá e cumprimenta com muito respeito ${ }^{54}$.

Como as demais alas da escola, a Ala de Baianas é julgada pelo quesito Fantasia. Além das fantasias, muito apreciadas, possuem um lugar especial dentro das escolas, e, no desfile, possuem uma dança peculiar, girando de tempos em tempos em torno do próprio corpo, rodando as suas amplas saias no centro da avenida.

A partir do início da década de 1990, várias alas foram perdendo sua função original como, por exemplo, a Comissão de Frente ${ }^{55}$, passando a incorporar características típicas do teatro e do balé, tornando-se uma espécie de introdução ao grande espetáculo, sendo responsável pela apresentação da escola. No entanto, qualquer mudança na Ala de Baianas é veementemente rejeitada por todos os sambistas, por conta não apenas do significado histórico, mas principalmente religioso desta ala dentro dos desfiles. Marcos dos Santos narra em sua entrevista que um carnavalesco queria retirar o turbante da ala de baianas e coloca-las para desfilar de boné e óculos escuros, demonstrando assim um grande desconhecimento do imaginário e das práticas de uma escola de samba. O resultado foi que esse carnavalesco teve que modificar as fantasias, colocando novamente turbantes nas baianas. Mas uma parte da escola não ficou satisfeita, pois o turbante foi considerado uma verdadeira "escultura" na cabeça das baianas, prejudicando a evolução da ala:

\footnotetext{
${ }^{53}$ Entrevista com Marcos dos Santos. Data: 10/08/2010.

${ }^{54}$ Entrevista de Mestre Gabi. Data: 25/10/2010.

${ }^{55}$ A Comissão de Frente tem como principal função a obrigatoriedade de apresentar a escola e de saudar o público durante a apresentação do desfile. Deve manter uma postura gentil, comunicativa e graciosa.
} 


\begin{abstract}
A Ala das Baianas tem um negócio na cabeça que não é um turbante e esconde o rosto. Tira toda a cosmogonia e o significado da ala de Baianas para o carnaval. As baianas não são mero acessório, são parte fundamental de uma escola de samba. Mas o que é isso? É o padrão visual, porque a televisão precisa de coisa grande, então os costeiros das alas cresceram, ficou absurdamente pesada (sic) ${ }^{56}$.
\end{abstract}

Para Mestre Gabi, a Unidos do Peruche foi a escola de samba que introduziu este novo modelo de fantasias, mais pesadas e elaboradas, no final da década de 1980, quando trouxe o carnavalesco Joãosinho Trinta para assinar o seu desfile. A escola teve um relativo sucesso com essas inovações trazidas por Trinta. Alcançou o vicecampeonato e ter tirou 10 nos três quesitos visuais: Enredo, Fantasia e Alegoria. Após isso, no carnaval seguinte, de 1991, outras escolas também passaram a adotar este modelo, com o objetivo de melhorar suas notas nos quesitos visuais:

\begin{abstract}
O carnaval de São Paulo começou a mudar não foi nem quando ele saiu daqui da Tiradentes para lá, prô Sambódromo. Ele mudou quando Joãosinho Trinta veio pra Peruche. A Peruche saiu com costeiro, as alas saíram com costeiro, todo mundo falou: -Nossa, olha o Peruche, todas as alas vêm com costeiro. E todo mundo ficou maravilhado. Joãosinho Trinta veio lá do Rio. E o cara é uma cabeça, eu tiro o chapéu pra ele, é sumidade. Sim, a Peruche começou a trazer do Rio, trouxe o Jamelão, trouxe o Joãosinho. E depois todas as outras escolas vieram atrás. ${ }^{57}$
\end{abstract}

Este tipo de embate entre carnavalescos e membros das Velhas Guardas das escolas, guardiões de uma tradição, tornou-se mais frequente a partir dos desfiles no Sambódromo, na década de 1990. As transformações iniciadas na década de 1970, com a "invenção" de novas tradições para as escolas de samba, passam por um processo de descaracterização na década de 1990, oriundo de pressões externas, ou seja, do principal patrocinador da festa, a emissora de televisão, que, segundo Marcos dos Santos, "precisa de coisa grande", de espetáculo para mostrar na avenida. Os carnavalescos que realizam os desfiles, visando o título, preferem descaracterizar estas tradições, como no

\footnotetext{
${ }^{56}$ Entrevista de Marcos dos Santos. Data: 10/08/2010.

${ }^{57}$ Entrevista com Mestre Gabi. Data: 25/10/2010.
} 
caso analisado das fantasias da ala de Baianas, e "comprar briga" com os membros mais velhos da escola. Os carnavalescos não desejam se adequar a este novo modelo e correr o risco de sua escola ao final da apuração, não ter um desempenho bom no quesito Fantasia, dando argumentos para a sua demissão por parte da diretoria da escola.

As pioneiras a modificar a forma de apresentação tradicional da Comissão de Frente foram, novamente, as escolas de samba do Rio de Janeiro: a Imperatriz Leopoldinense, em 1979, e, posteriormente, a Mocidade Independente de Padre Miguel, em 1991, com um enredo intitulado “Chuê, chuá: as águas vão rolar!”, de Renato Lage e Lilian Rabello.

Nesse ano, a Comissão de Frente foi composta por bailarinos vestidos como escafandristas, com armaduras verdes e que se moviam em câmera lenta, como se estivessem andando no fundo do mar. Apesar deste tipo de apresentação contrariar o regulamento para julgar o quesito - que proibia coreografias e dizia que a obrigatoriedade da Comissão de Frente era apresentar a escola e saudar o público ao longo do desfile —, esta inovação recebeu nota dez de todos os jurados. O episódio provocou a mudança das regras no ano seguinte, possibilitando às escolas de samba utilizarem destes recursos para engrandecer o espetáculo; as comissões coreografadas se tornaram tendência, passando a desfilar com fantasias inusitadas e apresentando coreografias e passos dentro do enredo proposto.

A introdução da Ala de Baianas e da Comissão de Frente coreografada mostra que a configuração dos desfiles sofreram diversas influências e modificações por diferentes motivos. A Ala de Baianas foi introduzida no regulamento a partir de um decreto e a Comissão de Frente coreografada teve o caminho inverso, primeiro surgiu dentro dos desfiles e então foi permitida e incorporada pelo regulamento, evidenciando a "via de mão dupla", por onde normalmente as inovações são introduzidas nos desfiles carnavalescos paulistanos. Ou por decretos e regulamentos, como em 1968, que introduziu a Ala de Baianas, a exemplo do Rio de Janeiro, ou através da perspicácia de seus próprios membros que trazem algo novo e rapidamente isso é disseminado para outras escolas, caso da Comissão de Frente. Em São Paulo, algumas escolas resistiram 
em trazer a Comissão de Frente coreografada, mas, depois de várias notas baixas, acabaram se adequando ao novo padrão de julgamento do quesito.

As fantasias, como já foi mencionado, se tornaram mais luxuosas nos anos 1990, dentro das grandes escolas, perseguindo um ideal de beleza que é criticado pelo sambista Marcos dos Santos, principalmente por causa do peso. Algumas fantasias chegam a pesar mais de $10 \mathrm{~kg}$ e, em grande parte, são descartadas após o momento efêmero do desfile.

Hoje é porta-costeiro, isso é o padrão visual, porque a televisão precisa de coisa grande, então os costeiros das alas cresceram. (...) Esse ano minha escola teve uma Ala de Baianas muito pesadas, coisa de chorar, fiquei enlouquecido, as senhoras não conseguiam suportar o peso. Se chovesse não saía do lugar ${ }^{58}$.

Por outro lado, as escolas menores ligadas à UESP utilizam normalmente fantasias mais leves, com materiais mais simples e, consequentemente, mais baratos. Algumas escolas grandes também se valeram da criatividade e adaptação dos materiais utilizados em momentos de dificuldade econômica e que acabaram por se tornar a prática costumeira da escola. Uma saída utilizada por muitas escolas é a reciclagem para reaproveitarem os materiais para o carnaval seguinte e, para as escolas pequenas, é também o uso de sobras de materiais das grandes escolas em seus desfiles ${ }^{59}$. Outra saída é a substituição de penas naturais por materiais sintéticos, muito mais baratos.

Em 1992, diante da grave crise econômica que passava o país e, consequentemente, as escolas de samba, a Rosas de Ouro encontrou na reciclagem e na adaptação de novos materiais - a solução para um carnaval criativo e mais barato. Seu

\footnotetext{
${ }^{58}$ Entrevista de Marcos dos Santos. Data: 10/08/2010.

${ }^{59}$ Quem promove o enxerto de fantasias já utilizadas e o uso de sobras nas escolas menores são as chamadas "escolas madrinhas". Geralmente é uma escola do Grupo Especial que tem escolas afilhadas nos grupos menores. Por se valerem das mesmas cores no desfile, as menores podem reaproveitar fantasias, materiais e alegorias cedidas gratuitamente ou por um baixo custo pela escola madrinha. A contrapartida oferecida pelas escolas afilhadas é ceder elementos para completar o número mínimo exigido pelo regulamento quando a escola madrinha não alcança este número.
} 
carnavalesco, Tito Arantes Filho, em entrevista ao jornal O Estado de São Paulo, revelou as adaptações que a escola faria para não encerrar o carnaval com dívidas.

\begin{abstract}
A Rosas de Ouro encontrou fôlego para produzir as fantasias, alegorias e adereços que serão utilizados no desfile com a reciclagem de materiais utilizados no desfile do ano passado, quando a escola dividiu o título com a Camisa Verde. Novos materiais, mais baratos, também serão usados: vareta de solda de PVC, hastes de guarda-chuvas velhos, panos de limpeza, papelcigarro e acetato. As plumas, que de acordo com Arantes Filho, custam $\mathrm{Cr} \$ 3$ mil a unidade, forram preteridas em favor de material sintético de preço dez vezes menor.

Os trunfos da escola, garante o carnavalesco, são a Comissão de Frente, e principalmente, as alegorias. Cada um dos carros alegóricos transportará cerca de 20 destaques. "Vamos misturar o luxo com a realidade" (O ESTADO DE SÃO PAULO, 02/02/1992).
\end{abstract}

Álvaro Casado nos conta que essa prática é recorrente desde os anos 1970, quando ele era presidente da UESP. As escolas utilizavam materiais reciclados e também utilizavam os materiais das escolas madrinhas, permitindo que as escolas menores usassem suas fantasias já utilizadas em outros desfiles ou em dias diferentes no mesmo desfile. Ele denomina esta prática de "enxerto": "Quantas escolas de samba não enxertavam. O Acadêmicos do Tatuapé com a Nenê já enxertou. A Tatuapé desfilava em um grupo a Nenê em outro, como eram todos sambistas ali da área, tudo azul e branco, aproveitamos as fantasias". 60

\footnotetext{
${ }^{60}$ Entrevista com Álvaro Casado. Data: 01/05/2012.
} 


\subsection{As Alegorias}

As alegorias são a expressão de uma ideia ou conceito através de uma imagem. Dentro do carnaval essa imagem é realizada através de um "carro alegórico" que conta parte importante da história desenvolvida na avenida, seguindo o enredo proposto por uma escola de samba. As alegorias são formas espaciais - estruturadas, organizadas, ordenadas - criadas para serem vistas e, no caso do carnaval, integralmente consumidas neste ato.

Ferreira Gullar (GULLAR, 1998) menciona a escola de samba como uma manifestação barroca, por conta da primazia visual do desfile. Baseado na obra Origem do drama barroco alemão, de Walter Benjamin, Gullar vê a alegoria como a forma, por excelência, da expressão do barroco enquanto visão de mundo. Nas escolas de samba haveria alguns traços barrocos que soariam particularmente carnavalescos: a substituição do absoluto pelo relativo; a valorização do incompleto ou do desconexo em formas que "parecem poder continuar em todas as partes que transbordam de si mesmas" (GULLAR, 1998). O firme e o estável entram em comoção. Para Hauser, "a intenção artística do barroco é em outras palavras, 'cinematográfica'; o estímulo ao novo, ao difícil, ao complicado" (HAUSER, 1997, p. 101 e 102). Gullar vê estes elementos citados por Hauser presentes dentro das escolas de samba e, em especial, através das alegorias carnavalescas.

Para Maria Laura Viveiros de Castro Cavalcanti, parafraseando o filósofo francês Merleau-Ponty, as alegorias carnavalescas são um dos elementos principais do carnaval brasileiro contemporâneo:

São feitas para serem vividas, apreciadas e consumidas no ato mesmo de sua apresentação festiva; existem para a fruição daquilo que fazem acontecer de modo eficaz. São enormes objetos que operam como verdadeiras entidades em seus contextos rituais, deslocando o sentido e os limites do humano em direções inesperadas. São, em especial, uma festa dos olhos; solicitam o olhar, um olhar sinestésico e integrado à corporalidade (CAVALCANTI, 2011:233). 
Os carros alegóricos já eram elementos essenciais dos desfiles das sociedades carnavalescas burguesas desde o século XIX e eram elementos presentes nos ranchos e nas grandes sociedades carnavalescas que precederam a formação das escolas de samba no Rio de Janeiro nos anos 1920. Eram carroças enfeitadas, puxada por animais, e posteriormente substituída por automóveis. Também estavam presentes no carnaval paulista, principalmente dentro dos desfiles de carnaval na Avenida Paulista e no bairro do Brás nas primeiras décadas do século XX. Os desfiles com os carros eram chamados de corso, típicos dos carnavais burgueses, em que eram utilizados automóveis enfeitados que desfilavam pela avenida, com seus ocupantes fantasiados (SIMSON, 2007).

A participação da família neste tipo carnaval era uma forma de mostrar prestígio social entre os imigrantes em rápido processo de ascensão social, pois possuir um automóvel era uma dessas formas (SIMSON, 2007, p. 76). No bairro do Brás, por exemplo, de origem operária e de pequena classe média, os veículos eram muitas vezes alugados.

A primeira escola a utilizar carros alegóricos dentro do desfile carnavalesco em São Paulo foi a Nenê de Vila Matilde em 1956, como apontamos no primeiro capítulo. Nesse ano, a Nenê trouxe outras inovações: foi a primeira também a apresentar-se com um samba-enredo intitulado "Casa grande e senzala", baseado no título da obra de Gilberto Freyre. Na ocasião utilizaram-se pequenas alegorias de madeira ajudando a ilustrar o enredo. Uma delas trazia um livro grande e decorado, com o nome "Casa Grande e Senzala" que vinha escrito nele. Naquele ano, como prova de que as inovações surtiam efeito, a escola da zona Leste sagrou-se pela primeira vez campeã do carnaval. A responsável por introduzir as alegorias animadas (com movimentos) foi a escola de samba Unidos do Peruche, em 1962, em um enredo sobre Castro Alves. O criador destas alegorias foi o compositor e carnavalesco Benedito Lobo, parceiro de Talismã na montagem de carnavais em muitas escolas.

A partir da oficialização em 1968, as escolas passaram a receber uma quantia maior de recursos, oriunda da Prefeitura, e isso permitiu que as escolas e os cordões fizessem alegorias mais luxuosas e bem acabadas. Em 1969, o Vai-Vai construiu um 
carro alegórico representando uma igreja barroca mineira, ilustrando o enredo que homenageou o escultor mineiro Aleijadinho. Ela foi construída em madeira e papelão, e era ladeada por imagens ampliadas dos profetas retratados em Congonhas do Campo. As maiores alegorias dessa época eram construídas todas em madeira e forradas com panos, papelão e papéis brilhantes. Eram empurradas inicialmente por membros do próprio cordão e, mais tarde, por pessoas remuneradas, devido ao grande esforço físico e ao fato de os empurradores não poderem desfrutar e brincar os folguedos carnavalescos (SIMSON, 2007, p. 164).

A partir da fase de expansão das escolas de samba do Rio de Janeiro, nos anos 1960 e 1970, cujo modelo foi seguido pelas escolas da capital paulista, as alegorias passaram a ter um papel cada vez maior dentro dos desfiles carnavalescos, sendo apresentadas em proporções maiores e com grande riqueza de detalhes cênicos. Esses aumentaram também em número, pois as escolas possuíam várias alegorias em um desfile, dependendo do grupo em que a escola estava classificada. As alegorias normalmente representam os maiores gastos dentro de uma escola de samba, já que as fantasias normalmente são vendidas e o dinheiro reinvestido na própria escola. Com a ampliação das escolas de samba, principalmente a partir da inserção da classe média e com a crescente mercantilização da festa, que passou a ser consumida na avenida e também via transmissão televisiva, era necessário apresentar um produto atraente e belo.

\footnotetext{
A força crescente das alegorias no desfile pode ser atribuída ao fato de elas possibilitarem a expressão da experiência fragmentada de vida dos habitantes da grande cidade que as apreciam e aplaudem. Elas correspondem a uma das formas encontradas pelas escolas de samba para a expressão das transformações do seu tempo e da sua cidade (CAVALCANTI, 1999, p. 180).
}

As alegorias têm a função de ilustrar o enredo, e, por sua própria natureza visual, em geral apresentam muito mais coisas do que o próprio samba-enredo. Para o carnavalesco Renato Lage, o samba-enredo é apenas a "trilha sonora" para o desfile, pois o grande encantamento vem da parte visual. O encanto das fantasias e alegorias 
vem do fato se serem obras de arte popular, únicas e mutáveis e, portanto, é impossível decifrá-las totalmente. Esse é seu poderoso encanto. Impossível compreendê-las totalmente. As esculturas, por exemplo, feitas por Rosa Magalhães para a escola de samba Salgueiro, em 1990, participaram, no ano seguinte, da XXI Bienal de Artes de São Paulo. Elas foram consideradas obras artísticas pelo curador João Cândido Galvão, que as incluiu na prestigiada mostra internacional de arte.

É o carnavalesco quem concebe a ideia dos carros alegóricos. Ele o faz a partir de um conceito principal e desenha as partes que o integram. Depois de aprovado o desenho e realizado o orçamento, dá-se inicio ao trabalho de "barracão", com a confecção das alegorias. O barracão, como é popularmente conhecido nas escolas, é o local onde são realizadas as alegorias. Nunca é na quadra da escola, normalmente em locais afastados, mais próximos do local de desfile, para facilitar o transporte. Até a década de 1980, as estruturas dos carros alegóricos eram realizadas apenas em madeira, e o principal chefe do barracão era o carpinteiro (URBANO; NABHAN; SANTOS, 1987, p. 62).

Como analisa Leila Blass, existem dois tipos de tempo dentro de uma escola de samba: o tempo da festa e o tempo do trabalho. Se no início dos folguedos as relações eram voluntárias, fazendo parte das atividades de lazer dos envolvidos, a partir da entrada do dinheiro do Estado e do financiamento obtido através dos meios de comunicação eletrônica, dos turistas e das chamadas classes médias no interior das escolas de samba, essas relações tornam-se profissionais, com trabalhadores contratados especificamente para a produção do desfile, na qual se destacam tanto "o pessoal do barracão" como o carnavalesco (BLASS, 2007, p. 24).

A partir da década de 1980, há a necessidade de se contratar outros profissionais especializados, que não precisam ter relações com a quadra da escola, como artesãos, serralheiros, soldadores, marceneiros, escultores, pintores, vidraceiros, mecânicos, iluminadores, eletricistas, especialistas em efeitos visuais, etc. (BLASS, 2007, p. 53). Com a entrada de um dinheiro maior vindo dos patrocinadores e da verba da televisão e, mais tarde, com a realização dos desfiles no Sambódromo, os carros passam a ser maiores, mais luxuosos e mais duradouros. A estrutura dos carros das grandes escolas, 
antes feitas em madeira, passa a ser realizada sobre os eixos de carros ou caminhões, com a colocação de ferragem e com tantas rodas quantas forem necessárias para um movimento equilibrado.

Uma vez pronta, essa base inicial é forrada de madeira. Além do forro, a madeira é um elemento cênico decorativo. Sobre essa base erguem-se então as grandes esculturas em isopor ou fibra de vidro. Um aspecto peculiar da escultura em isopor é o seu caráter oculto e efêmero dentro da preparação do carnaval. As formas esculturais em isopor são raramente vistas: o escultor que trabalha com o isopor é como um artista escondido: exceto o caso de peças únicas, presentes na decoração dos carros, as peças em isopor não fazem parte da composição do carro alegórico. Ou melhor, é uma espécie de "molde do molde", porque uma vez esculpida, a peça de isopor é integralmente forrada com papel-machê de modo a se tornar bem lisa para a moldagem feita através de mistura de gesso e sisal (CAVALCANTI, 1999, p. 163). Este é um processo semelhante ao utilizado pela escultura artística tradicional, mas especificamente a escultura em bronze, que também supõe a moldagem como fase decisiva. $\mathrm{O}$ nome do modelador às vezes pode ser mencionado, no entanto, a autoria da peça pertence claramente ao artista que a concebeu. No carnaval, o escultor transpõe para o isopor o desenho do artista, isto é, do carnavalesco.

Citando novamente Maria Laura Cavalcanti:

\footnotetext{
As esculturas são o elemento expressivo central dos carros, e apenas depois de seu posicionamento, se inicia a decoração, com os mais diversos materiais: tecidos, plásticos, acetatos, pinturas, espelhos. Quando é o caso, instalam-se, nessa última fase, os mecanismos já previstos para o movimento e iluminação, e posiciona-se o volante para a direção das rodas. O núcleo expressivo de um carro alegórico são as esculturas, normalmente feitas em gesso, fibra de vidro e isopor (CAVALCANTI, 1999, p. 157).
}

Também é importante destacar o trabalho dos carpinteiros dentro da confecção de um carro alegórico, pois apesar de ele não ser mais o chefe do barracão e coordenar todo o processo de feitura do carro, ele continua presente, mas agora coordenando a fase intermediária entre a base do carro (serralheria) e a decoração dele. A madeira forma 
necessariamente a base, mas pode participar também, com inusitados recortes, da cenografia de um carro. Depois de encerrado o carnaval, as escolas dos grupos de destaque normalmente passam parte do material utilizado (fantasias, alegorias, pedaços de alegorias) para as escolas menores montarem seu carnaval do próximo ano e, assim, o ritual cíclico se mantém.

Em seguida, entra um mecânico para o posicionamento das rodas, dos pneus e do volante do carro, pois este deve ficar em uma posição central, facilitando, assim, as manobras que os carros têm de fazer para entrar na avenida. São proibidos motores para empurrar os carros alegóricos, devido a riscos de incêndio, e é permitido apenas o gerador responsável por iluminar o carro.

Além destas transformações na parte estrutural houve diversas transformações estéticas nos carros alegóricos, trazidas no final da década de 1980 e intensificadas com os desfiles do Sambódromo. O marco da mudança dos carros alegóricos em São Paulo foi no inicio dos anos 1990, quando houve uma competição entre as escolas para ver qual traria o maior carro alegórico para a avenida. Mestre Gabi se mostra crítico desta disputa pelo maior carro alegórico:

O Juarez da Cruz, na Mocidade Alegre, viu no Rio as alegorias e se tocou. Também começou a colocar na avenida carros alegóricos maiores, aí foi nessa crescente. As escolas competiam pra ver qual era o maior carro, até chegar naquele tigre que a Império trouxe que era uma monstruosidade, mas que adianta? O que adiantou um tigre daquele tamanho? Pra quebrar a harmonia da escola, quebrar em que termos? Você tem um tigre de 50, 60 metros de comprimento e ali não tem ninguém. Então a escola termina o canto lá e recomeça aqui atrás, quebra a harmonia da escola, o canto e mesmo que não quebre, com toda essa tecnologia de som que nós temos aí, mas a escola tem que estar muito bem ensaiada para não quebrar o canto, a harmonia. E foi assim, começaram vir as pessoas do Rio de Janeiro e padronizar tudo. ${ }^{61}$

É importante destacar não apenas a influência do modelo de alegorias das escolas de samba do Rio de Janeiro, mas a troca e a incorporação de elementos de outras festividades como o boi-bumbá do Festival Folclórico de Parintins, realizado na

\footnotetext{
${ }^{61}$ Entrevista com Mestre Gabi. Data: 25/10/2010.
} 
ponta da ilha Tupinambara, no estado do Amazonas, fronteira com o Pará, no final do mês de junho. Foram os "bois" Caprichoso e Garantido que iniciaram os carros articulados com movimentos nos desfiles. O desfile de Parintins não é em cortejo linear, como no caso dos desfiles das escolas de samba, mas em uma arena circular, e elas não têm o mesmo significado que os carros alegóricos nas escolas de samba. As escolas de samba contribuíram no Festival de Parintins com a introdução nas alegorias na festa, e Parintins contribuiu com o nosso desfile modificando e dando um novo significado para as alegorias, adicionando movimentos que posteriormente foram incorporados pelos carros alegóricos das escolas de samba. Nesse processo, semelhante ao analisado pelo antropólogo Franz Boas, “os elementos tomados emprestados são inteiramente transformados e ressignificados" (BOAS, 1966).

\subsection{O samba-enredo (transformações musicais)}

Em São Paulo, o desfile dos cordões antes da popularização do samba-enredo não era exatamente feito ao ritmo do samba. Eles desfilavam com um ritmo chamado marcha-sambada, que é uma fusão da marcha militar europeia ${ }^{62}$ com o samba de bumbo, do interior do estado de São Paulo, descrito abaixo e marcado pela sua sonoridade grave característica. Para o sambista Geraldo Filme:

O Cordão do Vai-Vai! Eu gostava de ver o Cordão do Vai-Vai. Cordão é uma modalidade diferente. Por sinal, só teve em São Paulo e Rio Grande do Sul. (...) É batuque pesado, mas a divisão na boca é marcha. A gente chamava de marcha sambada. O carioca está fazendo hoje, mas a gente já fazia antigamente. É a marcha sambada (BOTEZELLI; PELÃO; PEREIRA, 2000. Volume 2: 80).

Apesar de ser um consenso entre os pesquisadores que estudam o tema a denominação marcha-sambada para definir musicalmente o tipo de samba feito pelos

\footnotetext{
${ }^{62}$ Notada, por exemplo, no uso de instrumentos de sopro característicos das bandas militares e que iria se popularizar com as marchinhas de carnaval.
} 
cordões carnavalescos, Mestre Divino, presidente e diretor de bateria da escola de samba Imperial, não concorda com essa denominação. Para ele, o correto seria samba marcheado:

O som que a Vai Vai fazia ou que o Fio de Ouro fazia como cordão era diferente da Nenê. Era diferente. Muita gente chama esse ritmo dos cordões de marcha sambada. Presta atenção, nunca houve marcha sambada. O que há é samba marcheado. Era um samba muito mais pesado. É melodicamente o compasso mais alongado. A gente tem que falar assim porque em primeiro lugar vem o samba. Era marcheado para as pessoas poder desfilar andando, indo em uma direção seguindo aquele ritmo. ${ }^{63}$

Dionísio Barbosa, fundador do Cordão Carnavalesco Barra Funda, em entrevista a Olga von Simson e a José Ramos Tinhorão ${ }^{64}$, disponível no MIS e no Laboratório de História Oral da Unicamp, diz que a inspiração musical dos cordões não vem apenas do batuque, mas também da boa impressão em relação às bandas militares, cujos desfiles foram assistidos por ele no Rio de Janeiro.

Esse fato talvez possa explicar a importância musical da marcha no pioneiro cordão paulistano, o que influenciaria as agremiações subsequentes. Também diz que na bateria dos cordões fazia-se a marcação com os surdos, produzidos com barrica e a partir de tambores de azeitona, que eram de madeira, e de carbureto de cálcio, feitos em lata. Normalmente era utilizado o couro de cabrito para fazer o encouramento do tambor.

Mestre Divino, presidente e diretor de bateria da escola de samba Imperial, nos mostra como eram feitos esses instrumentos improvisados:

Era tudo em couro, não existia bordão de aço. A sobra de couro a gente molhava bem, esticava, torcia, torcia, pegava de lado, pegava do outro e depois fazia aquele bordão com aquela corda de cima. Era do próprio couro, tudo era de madeira, tudo era encourado. A gente montava... Fazia agogô!

\footnotetext{
${ }^{63}$ Entrevista com Mestre Divino. Data: 15/10/2011.

${ }^{64}$ Entrevista de Dionísio Barbosa a Olga von Simson e a José Ramos Tinhorão. Laboratório de História Oral-Unicamp. Pasta D. Barbosa, p. 53.
} 
Você comprava nesses ferro velho e com uma serra circular, montava, ia na morsa e tirava os dente, soldava e saía o agogô. Tudo artesanal. É... O surdo era de latão de carbureto ${ }^{65}$. Sabe o que é carbureto, né? Tudo de latão de carbureto. Fazia a borrachinha de fixação, o estirante. Era tudo nós mesmo que fazíamos, a rosca, achatava a parte de baixo. E tinha mais o chocalho com vara. E outra coisa que a gente fazia era reco-reco de bambu. Tinha um cabo fino. É o reco-reco estriado, estriado porque tem uma chave de alumínio, ela era estriada, né? Então ela virava aqui e tinha uma alça pro dedo segura aqui e culungundum, caxitundum, culugundum. Hoje tenho recoreco, mas é de mola, né? ${ }^{66}$

Divino ressalta ainda que até hoje produz seus próprios instrumentos e esse é um dos trunfos de sua bateria ser tão reverenciada.

Agora que inventaram a pele de nylon, porque era tudo couro. Deixava no sol depois fazia a barba dele, pra deixar lisinho. Tenho ainda couro bruto aí. Isso hoje. Eu mesmo faço meus instrumentos. Eu gosto. Faço cambito. Eu mesmo faço meus cambitos. Agora os mestres de bateria compra tudinho. É só ligar pra loja e pedir pra entregar. (...) Dá uma olhada nos meus instrumentos. É tudo de couro! Isso ninguém sabe, cara! Cê sentiu, ouviu a vibração no chão? Pega uma chave lá qualquer, se você aperta algum instrumento aqui não faz mais barulho. Vai nas escolas por aí é tudo de náilon. ${ }^{67}$

Osvaldinho da Cuíca, que também desenvolve a atividade de luthier até os dias de hoje, relembra este processo e aponta as transformações pelas quais passou o processo de realização dos instrumentos. Assim como as fantasias, os instrumentos eram feitos pelos próprios integrantes dos folguedos carnavalescos, com suas nuances e experiência sonora. Hoje, a exemplo das fantasias, são feitos em fábricas de instrumentos especializadas que os produzem em série, todos padronizados com o mesmo som.

65 O Carbureto de Cálcio é aplicado em geradores, reage com água e produz o Acetileno. O Acetileno produzido é amplamente aplicado em processos de aquecimento, solda, corte de metais e produção de resinas como PVC, PVA, etc.

${ }^{66}$ Entrevista com Mestre Divino. Data: 15/10/2011

${ }^{67}$ Entrevista com Mestre Divino. Data: 15/10/2011 
Então saía um regional com dois, três cavacos e um banjo. Porque o banjo grita mais alto. E violões, um pandeiro e poucos bumbos. Um ou dois, como eu falei pra vocês. Pra não encobrir os violões e a voz. Então era muito mais sonoro, mais bonito. De longe já se ouvia aquele grupinho, que vinha cantando, balançando, espontâneo. Sem aquele compromisso de ganhar um título, dinheiro e tal... Aí veio a televisão e começou a mudar muito. Foi com a entrada da televisão e o crescimento muito acelerado das escolas que começou a industrialização dos instrumentos, porque antes era artesanal, né? Agora são trezentos, quatrocentos ritmistas, não tem como fazer como antigamente. Você fazia primeiro com barrica, depois veio o processo de evolução e fazia com madeira compensada. Tinha aquele tamborzão de madeira compensada e que parecia um surdo. Era só pregar um couro ali e virava um surdo. O surdo é de madeira compensada até hoje. Então a gente inventou aquilo. Depois veio tambor de carbureto. Era um tamborzão de lata assim do tamanho do tronco de uma pessoa, bem grande. A gente mandava para o ferreiro ferrar uma argola aqui e quatro tarraxas. Aí já esticava e apertava o surdo, não era mais esquentado na fogueira. Que aqueles compensados de barrica. Cê tinha que esquentar e esticava. Dali dez minutos esfriava, aí ficava pior. O sereno molhava e aí ficava pior. Esquentava durante uns dois minutos e depois começa a bater, tum, tum, tum, tum, tum, tum, até ficar na afinação correta. Dali a pouco já começava de novo. Os caras falam, endeusam muito isso. Pega um tambor murcho, esquenta ele e começa a tocar no sereno pra ver quanto tempo ele dura. Entendeu? Aí inventamos a tarraxa. Aí não precisava mais esquentar, era só apertar que a pele esticava. Isso já representou um grande avanço. Aí depois começou a industrializar. Por tarraxa nos instrumentos. Você sabe a capa do meu livro? Tá o Germano Mathias com a primeira cuíca que eu fiz pra ele. Ele já tinha comprado uma e não deu certo. Aí ele foi até a minha casa para eu entregar a cuíca pra ele. Ele foi com o Padeirinho lá. E aí tiramos a foto, com o Germano e a cuíca. ${ }^{68}$

Eram estes mesmos tambores improvisados que seus integrantes utilizavam na festa de Bom Jesus de Pirapora. O próprio Dionísio possuía formação musical europeia, tendo tocado em banda regida por maestro italiano.

Quanto às letras das músicas apresentadas durante os desfiles, podemos observar que grupos como o pioneiro "Camisa Verde" utilizavam músicas próprias, normalmente com oito versos divididos em duas quadras, de autoria de seus integrantes. Em 1915, o cordão desfilou com uma canção composta pelo próprio Dionísio Barbosa e por seu irmão Luiz Barbosa, uma marcha-sambada de duas quadras, sem título, que tinha como tema "chamar a todos para ir à janela ver o grupo que desfilava". Este tipo de música desenvolvido por esses primeiros cordões era em sua grande maioria composto de

\footnotetext{
${ }^{68}$ Entrevista com Osvaldinho da Cuíca. Data: 21/01/2012.
} 
marchas curtas e que ficou conhecido posteriormente como samba-exaltação, justamente pela temática ser de divulgação, entusiasmo e glorificação dos feitos da própria agremiação:

\author{
Minha gente saia fora \\ Da Janela venha ver \\ O Grupo da Barra Funda \\ Tá querendo aparecer \\ $2^{\mathrm{a}}$ Parte \\ Cantamos todos \\ Com voz aguda \\ Trazendo vivas \\ Ao Grupo da Barra Funda ${ }^{69}$
}

Como nenhuma dessas marchas-sambadas, ou sambas marcheados, como quer Divino, foi registrada em disco, é muito difícil fazer uma reconstituição fiel de como elas eram executadas. A gravação feita em discos e em apresentações ao vivo por músicos como Osvaldinho da Cuíca e pelo grupo Kilombolo Dia Piratininga são baseadas em depoimentos de sambistas antigos, como Dionísio Barbosa, Seu Zezinho do Morro da Casa Verde, Geraldo Filme e outros membros que ainda lembravam tais músicas. E a partir do canto, da melodia, das entonações e acentos colhidos nessas entrevistas, que se dá a tentativa de se reproduzir a marcha-sambada, o mais próximo possível de sua melodia original.

Em 1928, o grupo Barra Funda já apresentava canções mais elaboradas, com letra e melodia mais próximas de um samba de quadra, mas com forte marcação no surdo, instrumento típico dos cordões. Esta canção tem como tema a exaltação da batida

\footnotetext{
${ }^{69}$ CD. História do Samba Paulista I. Narrada e contada por Osvaldinho da Cuíca. CPC UMES. Faixa 05, 1999.
} 
e dos instrumentos utilizados pelo cordão, temida pelos outros grupos, dada sua qualidade.

O meu cordão vem batendo sem rival

Deixa passar meu carnaval

Meu chocalho vem falando e vem chorando

E o tamborim vem batucando

O cavaquinho vem fazendo a harmonia

Com o violão e a bateria

Refrão:

Ô abre-alas/abre-alas, por favor

Nossa batida

É temida, é do amor

$2^{a}$. Parte:

Nosso pandeiro vem falando e vem chorando

E o tamborim vem batucando

O cavaquinho vem fazendo a folia

Com o violão e a bateria ${ }^{70}$

Infelizmente quase nada sobrou desses cordões, apenas algumas fotos amareladas, não se conservando as canções cantadas por eles no carnaval. Para preencher esta lacuna, um trabalho amplo ainda precisa ser feito com eventuais foliões dessas agremiações que ainda estão vivos e que possam se lembrar das músicas compostas por esses cordões, para que eles sejam finalmente registrados em áudio.

Desde o primeiro desfile, o Vai-Vai, seguindo os demais cordões, também saiu com músicas próprias; no ano de 1930, apresentou-se nas ruas com uma canção típica dos cordões, de exaltação à própria agremiação, feita pelo compositor Henricão, com

\footnotetext{
${ }^{70}$ Cantado por membros da escola de samba Camisa Verde e Branco no documentário Samba à paulista.
} Fragmentos de uma história esquecida, Diretor: Gustavo Mello. Produção: TV Cultura, 2007. 
duas "quadrinhas" com três versos, e conclamando todos a saírem de suas janelas para “espiar o Vai-Vai passar" e intitulando o cordão como "Turma do amor".

Saiam à janela, venham espiar

O Vai-Vai passar, gente de valor

Turma do amor, rei do carnaval $2^{\mathrm{a}}$ Parte:

O Vai-Vai na rua faz tremer a terra

Quem está ouvindo e não vê

Chega a pensar que é guerra

(BOTEZELLI; PELÃO; PEREIRA, 2000. Volume 5: 108)

Estes versos chamando as pessoas a irem às suas janelas eram muito recorrentes nos temas dos cordões, porque eles desfilavam nas ruas do bairro de origem e uma das formas de se obter patrocínio era passar o chamado "Livro de Ouro" para comerciantes e moradores da localidade da escola. No livro as pessoas assinavam e davam uma pequena contribuição financeira para compra de materiais para o desfile do cordão, que devia assim dar um retorno aos patrocinadores locais, fazendo um desfile no próprio bairro, antes ou após o desfile oficial no centro da cidade. Seu Nenê da Vila Matilde, por exemplo, em entrevista a Olga von Simson, diz que nunca descia para o centro sem antes desfilar no seu bairro, mesmo com chuva, como forma de agradecer a todos que contribuíram financeiramente e também como forma de manter o apoio da comunidade $^{71}$.

Em 1935, o Vai-Vai desfilou com um samba-exaltação de autoria de Tino e Guariba que já não convidava as pessoas para saírem às ruas, mas lamentava aqueles que não "aprontaram" a sua fantasia para desfilar no cordão. O samba revela que nesse

\footnotetext{
${ }^{71}$ Depoimento de Seu Nenê da Vila Matilde a Olga von Simson. Laboratório de História Oral-Unicamp (LAHO). Pasta Nenê.
} 
momento o grupo estava organizado e todos os seus integrantes já desfilavam fantasiados:

Agora que eu quero ver
Você chorar
Você Vai entristecer
Quando o Vai-Vai passar...

Bem que eu lhe avisei

E você sabia

Porque não aprontou

$$
\begin{aligned}
& \text { A sua fantasia } \\
& \text { Se você não sai } \\
& \text { É por culpa sua }
\end{aligned}
$$

Pra te consolar o Vai-Vai está na rua ${ }^{72}$

Uma marcha-sambada feita por Filme para o cordão na década de 1950, composta por três quadras, também tem a mesma temática dos cordões apresentados acima, exaltando a primavera e chamando as pessoas para saírem "às janelas".

Saiam às janelas, venham ver

Que lindas flores

E o Paulistano vem cantar

Primavera Estação, estação das flores

$2^{a}$ Parte:

É isso vem ver mocidade

Vem ver nosso jardim

${ }^{72}$ CD. História do Samba Paulista I. Narrada e contada por Osvaldinho da Cuíca. CPC UMES. Faixa 10, 1999. 
Vem ver o cravo beijar a Rosa

A violeta brigar com o jasmim

$3^{\mathrm{a}}$. Linda Jardineira

Não fuja de mim

Eu vou regar as flores

Que plantei no jardim ${ }^{73}$.

O grupo carnavalesco que introduziu o chamado samba-tema no carnaval paulistano foi a escola Nenê de Vila Matilde. Fundada em 1949, na zona Leste da capital paulista, a partir de um grupo de serenatas e de uma roda de tiririca (a capoeira paulista). Este grupo era liderado por Nenê do Pandeiro, que posteriormente se imortalizaria no carnaval como Seu Nenê da Vila Matilde. Depois de ver os desfiles das escolas cariocas em 1955 junto com outro integrante da escola, eles notaram que apesar de adotar o nome "escola de samba", a Nenê, na verdade, era um cordão, pois desfilava com a corte, possuía balizas, estandartes e não possuía samba-enredo.

No carnaval de 1956, a escola da Vila Matilde inovou trazendo um tema de orientação geral para o desfile, intitulado "Casa Grande e Senzala", baseado no livro de Gilberto Freyre e um samba que narrava essa história ${ }^{74}$. Este samba trazia a temática da escravidão e do sofrimento da população negra, inaugurando no carnaval paulista uma tradição de enredos de temas ligados às tradições afro-brasileiras, imortalizando o verso "É banzo que negro tem". O samba-tema de autoria de Álvaro Rosa, o Paulistinha, e Popó, apelido de Mário Protestato dos Santos, jornalista do jornal O Dia, era:

Aruanda ficou

O mar separou

Senhor!... Meu Senhor!...

\footnotetext{
${ }^{73}$ Depoimento de Geraldo Filme a Olga von Simson. Laboratório de História Oral-Unicamp (LAHO). Pasta G.Filme, p.71.

${ }^{74}$ Depoimento de Seu Nenê da Vila Matilde a Olga von Simson. Laboratório de História Oral-Unicamp (LAHO). Pasta Nenê, p.142.
} 


\title{
Nego tudo deixou
}

É banzo que negro tem

É banzo que negro tem

Na casa grande tudo é alegria

Na casa grande tudo é festança

Na senzala negro chora

Que nem criança

É banzo que negro tem

É banzo que negro tem (BRAIA, 2000).

Seu Nenê da Vila Matilde, em depoimento a Olga von Simson, relembra como foi ganhar esse campeonato:

\begin{abstract}
Chegamos um pouco de caminhão, um pouco de bonde, outro pouco de trem... Passamos pela rua Direita, Largo de São Francisco, viramos à esquerda, pela rua Dublas do Nascimento, subimos a Brigadeiro Luiz Antônio... Vínhamos cantando e dançando, com aquelas sombrinhas azuis e brancas... E o povo já começou a olhar... A Comissão de Julgamento ficava num coreto, na Praça da Bandeira, e quando chegamos perto já olhou com interesse... Éramos mais ou menos uns cem e formávamos cinco alas, entre baianas, damas antigas, lordes, escravos. Levávamos uma árvore sobre rolimã, feita de sarrafo, papelão bem pintado, uns galhos bem feitos. Eram alegorias pequenas, feitas pelo carnavalesco da época, o Coruja, que mais tarde formou o "Corujas" da Vila Esperança. Foi um sucesso tremendo, aquilo era uma novidade em São Paulo, além do tema, que também entusiasmou o pessoal. Esse foi um dos primeiros ataques que fizemos, com enredo, com sistema, organização ${ }^{75}$.
\end{abstract}

A principal diferença entre o samba-tema e o samba-enredo está na simplicidade do primeiro. Ele é composto a partir da ideia ou tema que a escola está apresentando na avenida, como por exemplo, o livro de Gilberto Freyre, ou sobre a cidade de São Paulo, mas sem um compromisso de ser um samba, de cuja letra saiam os elementos que

\footnotetext{
${ }^{75}$ Depoimento de Seu Nenê da Vila Matilde a Olga von Simson. Laboratório de História Oral-Unicamp (LAHO). Pasta Nenê, p.118-119.
} 
estruturam o desfile de uma escola de acordo com o respectivo enredo. As inovações fizeram sucesso e, nesse ano, a escola venceu seu primeiro campeonato.

Em 1961, a escola ganhou seu segundo campeonato com um samba-tema em homenagem à Marquesa de Santos e que já se aproximava mais do samba-enredo que estava sendo produzido pelas escolas cariocas no momento. Vale lembrar que este é o período da parceria Silas de Oliveira e Mano Décio da Viola na escola de samba Império Serrano no Rio de Janeiro, formatando o modelo considerado "clássico" do samba-enredo no carnaval carioca. O samba de Paulistinha retrata os motivos pessoais e políticos que levaram D. Pedro I a não se casar com Domitila de Castro, a Marquesa de Santos, como as guerras enfrentadas por D. Pedro I em seu período como Imperador do Brasil, a Guerra da Cisplatina e a Confederação do Equador. E a renúncia feita por Domitila de não se casar com o Imperador para não separar a jovem nação:

Renunciou o Imperador

Pelo amor que consagrava

À nossa pátria querida

Domitila de Castro, Marquesa de Santos

Para não ver a nossa terra dividida

Não se casou com D. Pedro e o Norte não se separou

Diz a história

Vamos reverenciar a sua memória!

Brasil... Brasil amado

Quanto civismo no passado

A campanha Cisplatina

A doação de Domitila

Renunciando, o seu amor teria falado:

Parta-se o meu coração

Por minha causa não haverá separação

Não, não, não 
O Norte não vai separar-se da União ${ }^{76}$

Em 1968, com a oficialização do carnaval em São Paulo, analisada no capítulo anterior, houve a mudança no regulamento de desfiles com inúmeras inovações. Uma das inovações trazidas foi a obrigatoriedade de se desfilar com o ritmo do samba e de se adotar um samba-enredo, o que já vinha sendo adotado por algumas escolas. Segundo o regulamento o enredo, a história que a escola apresenta na avenida deveria tratar apenas de fatos históricos e folclore de cunho nacional. Consolida-se em São Paulo o modelo que já estava presente nos desfiles do Rio de Janeiro, desde meados dos anos 1930. Com este regulamento, as escolas de samba fizeram no carnaval de 1969 a passagem do samba-tema para o modelo do samba-enredo, pois a música apresentada deveria estar obrigatoriamente ligada ao enredo apresentado pela escola de samba. A maioria das escolas já apresentava neste momento músicas relacionadas ao seu tema de desfile. $\mathrm{O}$ que houve foi uma adaptação para a realização de um samba com uma letra mais complexa e com um número maior de versos.

O carnaval de 1969 foi o primeiro carnaval realizado após ser outorgado o Ato Institucional Número 5 (AI-5) pela ditadura militar. O AI-5 instituía que as músicas registradas e gravadas em território nacional deveriam passar pela censura prévia. Isso incluía as músicas de carnaval. Portanto, qualquer crítica ao regime, uma leitura mais progressista da História ou mesmo social, mesmo que bem-humorada, era sinônimo de samba censurado.

Mestre Gabi, antes de se tornar mestre-sala, foi compositor da escola de samba Barroca Zona-Sul e nos conta sobre seus sambas censurados:

Um período que não podíamos falar. Eu fiz samba-enredo que foi pra censura. Tudo tinha que passar pela censura. Essa palavra aqui não, tem que tirar. Era complicado. Até 1970 e poucos, mas até mesmo até 1985 ainda

\footnotetext{
${ }^{76}$ CD. História do Samba Paulista I. Narrada e contada por Osvaldinho da Cuíca. CPC UMES. Faixa 14, 1999.
} 
tinha censura velada. Certas coisas não podiam falar. Senão era preso. Eles queriam que a gente fizesse esse sambinha água com açúcar $^{77}$.

A censura valia para todas as novas composições dentro dos meio musical e fonográfico brasileiro e não apenas para os sambas-enredos. Esta aberração durou de 1969 até o ano de 1986, quando o ministro da Justiça, Fernando Lira, promulgou uma lei acabando com a censura no país. As escolas de samba já estavam dispensadas de censura prévia dos enredos, sambas-enredo, alegorias, adereços e figurinos desde setembro de 1985, quando uma portaria da Polícia Federal as liberava ${ }^{78}$.

Nos documentos em anexo está uma cópia do samba-enredo $O$ cancioneiro do Estácio de Sá realizado pela escola de samba Corujas da Vila Esperança, em 1979. No documento é possível visualizar o carimbo do Departamento da Polícia Federal liberando a canção para "gravação e divulgação pública" ${ }^{79}$ ".

Para que as escolas de samba recebessem a verba oficial, era necessário que seu samba-enredo estivesse aprovado pela censura. Como os sambas deveriam tratar de fatos históricos de cunho nacional, as escolas de São Paulo também passaram a utilizar, a partir de 1969 e em toda a década de 1970, um estilo de composição conhecido no Rio de Janeiro como "samba-lençol”. Essa expressão é pelo fato de o samba ter que "cobrir" o enredo em sua "totalidade" e não poder contradizê-lo em nenhum aspecto.

Este estilo de composição tem seu início no samba realizado por Silas de Oliveira para a escola Império Serrano em 1961, intitulado: "Sessenta e um anos de República”. Esta canção deu ao gênero uma nova forma que é utilizada até hoje no samba-enredo, o "samba-lençol", uma das modalidades de sambas-enredo mais conhecidas $^{80}$. Caracterizada por melodias solenes, por jogos rítmicos frequentes (às vezes fazendo com que a sílaba tônica não coincida com o acento musical, o que

\footnotetext{
${ }^{77}$ Entrevista com Mestre Gabi. Data: 25/10/2010.

${ }^{78}$ Anexo 3. Ofício No 1509/85 - GAB/DCDP Departamento de Polícia Federal de São Paulo encaminhada a Eduardo de Oliveira, presidente da UESP. Acervo UESP.

${ }^{79}$ Ver novamente Anexo 2. Samba-enredo da Sociedade Carnavalesca Corujas da Vila Esperança de 1979. Acervo UESP.

${ }^{80}$ Este estilo teve seu apogeu na década de 1960, diminuiu sua importância nos anos 1970 e 1980 , aparecendo novamente nos anos 1990 e "revitalizado" nos anos 2000. São obras de caráter histórico que, no entanto, esboçavam versões idealizadas de passagens da História do Brasil.
} 
aumenta o efeito da sincopa). Também é caracterizado por letras extensas com muitos versos e por um vocabulário sofisticado, que se afasta definitivamente da linguagem popular e dos sambas de terreiro e de quadra.

Passou a ser um tipo de samba feito exclusivamente para ilustrar o enredo que a escola desenvolverá durante o seu desfile. É comum também, no “samba-lençol", expressões e palavras eruditas da língua portuguesa, distantes do cotidiano dos sambistas como, no caso do já citado samba "Sessenta e um anos de República", de Silas de Oliveira, que utiliza: "glória opulenta", "eminente estadista" e "vitória altaneira" ${ }^{81}$. Se, em termos de letra, os sambas-enredo foram ficando cada vez mais "eruditos" e até mesmo artificiais, em termos de melodia os compositores foram desenvolvendo recursos cada vez mais sofisticados para se poder cantar facilmente essas letras de uma formalidade discursiva muito grande (MUSSA; SIMAS, 2010, p. $57)$.

Além desta exaltação a personagens históricos, que iam dos grandes líderes militares da História do Brasil, passando pelos grandes homens das ciências e das artes, os sambas-enredo também tratavam de cenas e paisagens naturais do Brasil, como no samba-enredo mais conhecido de todos os tempos, "Aquarela Brasileira", também composto por Silas de Oliveira em parceria com Mano Décio da Viola, e que se tornou um grande sucesso do cancioneiro popular. Composto por versos mais simples e com passagens poéticas muito mais ricas e melódicas, este samba apresentado pela escola Império Serrano no ano de 1964 ganhou nota 8, porque o enredo da escola falava dos Estados brasileiros e citava Minas Gerais, mas o samba-enredo não cita o Estado. Em São Paulo, também era comum enredos sobre as riquezas da terra, como "Rei Café", realizado pela Unidos do Peruche em 1970.

Geraldo Filme, atento a essas mudanças, compôs um samba-lençol para o VaiVai, em 1969, com um enredo intitulado “Aleijadinho", mas que, na prática, era uma mistura com um enredo sobre Chico Rei. É um samba que não possui grandes qualidades estéticas, evidência desta transição rápida pela qual as agremiações

\footnotetext{
${ }^{81}$ Samba-enredo. "Sessenta e um anos de República". Autor: Silas de Oliveira.
} 
carnavalescas passaram, com uma letra artificial, descritiva e uma poesia pobre, pouco elaborada e contando com a presença de várias palavras eruditas que não fazem parte do vocabulário corrente dos sambistas apresentando uma melodia que mal consegue encaixar os versos, muito longos. Percebe-se que a melodia e a letra foram inspiradas diretamente nos sambas-enredo realizados por Silas de Oliveira nos desfiles do Rio de Janeiro:

Na era de 1730,

Quando o preto era importado,

Atracou o navio negreiro,

Chico Rei desceu descalço

Com sua tribo acorrentado

Vindo diretamente a Vila Rica

Terra do ouro e do pinho,

Onde residia o estatuário

Antônio Francisco Lisboa

O famoso Aleijadinho

Lá lá lá lá lá (...)

$\mathrm{Na}$ gravação original ainda percebe-se a presença dos instrumentos de sopro como o trombone, típico dos cordões paulistanos.

Apesar das limitações impostas pelo regulamento para os desfiles oficiais do Grupo I, as escolas não abandonaram as tradições africanas nem a cosmogonia da cultura negra, que permeia não só o samba, mas todo universo das escolas de samba. $\mathrm{O}$ próprio samba descrito acima apresenta, de forma crítica, a questão escrava no Brasil. Esta era uma das maneiras de driblar as restrições impostas pelo regulamento e pela censura, utilizar temas históricos nacionais para contar a importância dos negros na história do Brasil, como os enredos relacionados a Zumbi dos Palmares, como fez a Mocidade em seu título do grupo 2, em 1970, e também pelo Acadêmicos do Ipiranga, 
em 1972, dentre outras escolas. Também deve-se destacar a importância dos enredos relacionados a temas afro-religiosos ou da cultura afro-brasileira. Nesses enredos é possível ver com um pouco mais de clareza o discurso do negro reprimido, que, na maioria das vezes, tenta ser anulado pelo repressor, apresentando-se no enredo das escolas de samba sob as mais diversas formas e disfarces: fuga ao problema; alienação aparente; uso de símbolos, metáforas e metonímias, embora algumas vezes mostre-se abertamente beligerante e de oposição. Sobre a história do Brasil, as escolas de samba também procuravam falar sobre a história dos negros no Brasil. Por exemplo, a recémfundada Mocidade Alegre foi campeã do Grupo II no ano de 1970 com um enredo sobre Zumbi dos Palmares, inspirado no famoso enredo de mesmo nome realizado por Fernando Pamplona na Acadêmicos do Salgueiro, em 1960.

$\mathrm{O}$ pioneiro a escrever enredos e também compor sambas-enredo ligados às temáticas de matizes africanas em São Paulo é Geraldo Filme. Destacam-se, na década de 1970, diversos sambas realizados para a escola de samba Paulistano da Glória. Como “Tebas", "Histórias de um Preto Velho" e "Que gente é essa".

No samba-enredo "Tebas", de 1974, em um enredo intitulado "Praça da Sé, sua lenda, seu passado e seu presente", sobre um dos principais redutos de sambistas da primeira metade do século XX, Geraldo Filme faz um verdadeiro trabalho de microhistória, resgatando a história de um escravo trabalhador da construção civil do século XVIII, completamente ignorado pela História oficial. Segundo as pesquisas de Geraldo Filme, ele encontrou a história deste escravo devido ao fato de "Tebas" ser um termo utilizado pelos negros paulistanos no século XIX com o significado de alguém muito bom em sua área de atuação, algo como "Pelé", para os dias de hoje. A origem do termo é o nome de um escravo que conseguiu ser alforriado, por ser um grande conhecedor das áreas de alvenaria e hidráulica. Segundo Geraldo Filme, Tebas, apelido do escravo Joaquim Pinto de Oliveira, era um dos responsáveis pela construção das torres da antiga igreja da Sé e da canalização dos esgotos da região central da cidade. Ele, que dominava a técnica de taipa de pilão, teria construído as torres sob duas condições: ganhar sua carta de alforria e que seu casamento fosse o primeiro celebrado na igreja após a 
construção das torres. Após a construção da igreja da Sé, também construiu a torre do Recolhimento de Santa Teresa e o primeiro chafariz em pedra da cidade.

A história se parece com a de Chico Rei, negro que conquistou sua liberdade trabalhando nas minas de ouro de Vila Rica, durante o ciclo aurífero do Brasil e também tema de diversos enredos em escolas de samba de todo o Brasil. Assim como a história de Chico Rei, a história de Tebas carece de fontes para comprovar sua existência, mas foi difundida pela tradição oral.

Tebas, negro escravo

Profissão alvenaria

Construiu a Velha Sé

Em troca da carta de alforria

Trinta mil ducados que lhe deu padre Justino

Tornou seu sonho realidade

Daí surgiu a velha Sé

Que hoje é o marco zero da cidade

Exalto no cantar de minha gente

A sua lenda, seu passado, seu presente

Praça que nasceu do ideal

E praça feita por escravos é praça do povo

Velho relógio

Encontro dos namorados

Me lembro ainda do bondinho de tostão

E engraxate batendo a lata de graxa

E camelô fazendo pregão

O tira-teima do sambista do passado

Bexiga, Barra Funda e Lavapés

O jogo da tiririca era formado

O ruim caia e o bom ficava em pé 
No meu São Paulo, oi lerê, era moda

Vamos na Sé que hoje tem samba de roda

No meu São Paulo, oi lerê, era moda

Vamos na Sé que hoje tem samba de roda

(BOTEZELLI; PELÃO; PEREIRA, 2000. Volume 2: 76)

No samba-enredo "Que gente é essa”, também feito por Filme para o Paulistano da Glória, já é possível perceber uma crítica mais contundente à escravidão, com a escola descrevendo na avenida a história da escravidão no Brasil, desde a travessia dos navios negreiros até a situação do negro contemporâneo, vivendo excluído nos "morros e favelas". No samba também há a citação de várias entidades espirituais africanas, da cultura e da religiosidade do candomblé e, por fím, a presença de várias expressões e versos em língua africana:

Que gente é essa

De pé no chão

Que tem no canto

Sua forma de expressão?

Cantou na travessia

O seu triste lamento

Para amenizar

Tanta dor e sofrimento

Que canto lindo na plantação

O rei escravo cantou na mineração

Rezou cantando

Ao Pai Oxalá

Agô-gegê e iorubá

Eparrei!

Oiá oiá vem nos ajudar 
Kaô Kaô Kaô iorubá

Depois surgiu Palmares

Sua confederação

E um canto livre

Vem lá do sertão

Cantou na capoeira

No tronco cantou e gemeu

Ela cantando embalava

Um filho que não era seu

Hoje essa gente sofrida

Vem dos morros e favelas

Mas traz um canto divino

Que ilumina a passarela. Quem é?

É o canto negro, sinhô.

(BOTEZELLI; PELÃO; PEREIRA, 2000. Volume 2: 83)

O samba apresenta uma melodia lenta e bem marcada, para facilitar o canto e a evolução da escola na avenida.

De autoria também de Geraldo Filme, a escola do bairro da Liberdade apresentou "Oração em Tempos de Festa", de 1977, exaltando a luta dos negros para manter a sua cosmogonia e as suas crenças durante o período opressor e violento da escravidão. Nesse samba são lembradas as funções dentro do candomblé de vários Orixás como: Oxossi, Ogum, Omolú, Oxumarê, Yansã e Iemanjá:

Meu povo pede licença

Pra contar essa história

Do negro e seus Orixás

Canta Paulistano da Glória 
Além de compor para a sua escola de samba, como já citado, Geraldo Filme também compôs diversos sambas-enredo para a escola de samba Vai-Vai. Fiel à sua linha de escrever sobre temas ligados à cultura negra, em 1976 escreveu a canção para o enredo em homenagem ao poeta negro recifense Solano Trindade.

A partir da década de 1970 acontecem os primeiros esforços para a gravação dos sambas-enredo de São Paulo em discos. Foi realizada, de forma sistemática, a gravação das músicas apresentadas pelas escolas do Grupo I (atual grupo Especial) somente a partir de 1977, quando os desfiles foram transferidos para a Avenida Tiradentes.

Outras escolas também apostaram em enredos de inspiração africana e de denúncia social. Dentre elas destacam-se Unidos do Peruche, Nenê de Vila Matilde e Camisa Verde e Branco.

A década de 1970 é o período de hegemonia do Camisa Verde e Branco, com a agremiação alcançando a marca de seis títulos de campeã do carnaval paulistano. A agremiação conquista o título do último desfile dos cordões carnavalescos em 1971 e, no ano seguinte, desfila pela primeira vez como escola de samba, alcançando o terceiro lugar. A partir daí, a agremiação mostra que conseguiu uma rápida adequação para a linguagem dos desfiles das escolas de samba. Em 1973 fica com o vice-campeonato e a partir daí a escola conquista um tetracampeonato consecutivo (de 1974 a 1977). No ano seguinte e em 1980 a escola ficou novamente com o vice-campeonato, sagrando-se campeã novamente em 1979.

A escola não apostou em enredos ligados a personagens históricos, mas aqueles relacionados à natureza, como "As quatro estações do ano" (1973), ao mundo da música, cinema e artes plásticas, como "Tropicália” (1975), "Atlântida e suas chanchadas" (1976), "Semana de Arte Moderna e os contemporâneos do futuro" (1978), além de uma lenda indígena "Narainã, a alvorada dos pássaros" e um enredo sobre o gênero feminino, “Acima de Tudo Mulher” (1980).

Outra maneira encontrada pelas escolas de samba para fugir dos temas históricos solicitados pelo regulamento são aqueles relacionados a temas oníricos, circenses ou ligados ao universo fantástico da imaginação. No Camisa-Verde e Branco destaca-se 
“Sonho Colorido de um pintor" (1971), de autoria de Talismã. É, na verdade, um enredo sobre o trabalho artístico de um pintor e como ele transforma a tinta em beleza:

Sonhei que pintei

Minhas noites de amarelo

Lindas estrelas no meu céu eu coloquei

$\mathrm{O}$ feio que era feio ficou belo

Até o vento do meu mundo eu perfumei

Numa apoteose de poesia

Um conjunto de harmonia

Uma lua roxa pra iluminar

As águas cor de rosa do meu mar

Meu sol eu pintei de verde

Que serve pra enxugar

Lágrimas, se um dia precisar

A dor e a tristeza fiz virar felicidade

Aproveitei a tinta e pintei sinceridade

Pintei de azul o presente, de branco eu pintei o futuro

O meu mundo só tem primavera

$\mathrm{O}$ amor eu pintei cinza escuro

Pra lá eu levei a bondade, dourada é sua cor

Aboli a falsidade, o meu povo é incolor

$\mathrm{Na}$ entrada do meu mundo, tem um letreiro de luz

Meu mundo não é uma esfera

Tem o formato de cruz

No mesmo ano, a Nenê de Vila Matilde apresentou o enredo "O Brasil em festa no sonho de Aladino", de Edson Conceição, misturando ficção literária e história:

Viveu nos tempos bem distantes,

Quando o circo era alegria sem idade

Aladino, que com as mãos e com seus versos

Transformava ilusão em realidade,

Ele era rei dos saltimbancos 
Que "nas sete cartas loucas"

Afonso Schmidt imortalizou...

Esses tipos de enredo tornam-se muito mais recorrentes, a partir da segunda metade da década de 1970, com as escolas de São Paulo, como no próprio Camisa Verde e Branco em 1979, de autoria de Ideval Anselmo e intitulado "Almôndegas de Ouro":

Venham ver, para crer

Os seus olhos nunca mais verão

Luzes, é festa no palacete

Muita gente no banquete

Catas-Altas se engalana sim

Loucos, hoje é festa para o povo

Têm almôndegas de ouro

É o convite de um sacristão

Mandou vir escravos ornados

Tesouros lesados, do seu sogro capitão

$\mathrm{Na}$ dança a mente criança

Valsava alegre, pelo salão

Queria ser nobre um dia

A dor que trazia no coração

Louco, quebram taças de cristais

Foi chamado aquela hora

De rei do ouro, senhor das Minas Gerais

Era chegado o momento

Mas eis que um dia

Chegava a romaria, com ela o imperador

Como presente ofertou uma baixela de ouro

Mas em troca do tesouro

Foi nomeado barão

Como na vida tem sempre seus altos e baixos

Ele caiu no fracasso, logo virou um plebeu 
Louco, lindas festas nunca mais (nunca mais)

$\mathrm{O}$ destino emudeceu

O Rei do ouro, senhor das Minas Gerais.

O samba-enredo acima é inspirado nos enredos desenvolvidos por Joãosinho Trinta nessa década para as escolas de samba Salgueiro e Beija-Flor. Joãosinho é o carnavalesco pioneiro a desenvolver enredos totalmente voltados à imaginação, narrando de uma maneira ficcional fatos históricos. Seu enredo pioneiro neste tema é "O Rei da França na Ilha da Assombração" (1974), campeão com a escola de samba Salgueiro. O enredo que narra as Pretas Velhas Maranhenses conta para o público uma história literária. O enredo narra que durante a infância de um dos reis da França, nosso país provocava um enorme alvoroço na corte francesa, por suas belezas naturais e culturais. Tanto o Rei da França quanto a Ilha da Assombração, que, no caso, é a cidade natal do carnavalesco, São Luís do Maranhão, são produtos da imaginação do narrador (CUNHA JÚNIOR, 2010, p. 19).

A partir de 1979, com a extinção do AI-5 e o processo de abertura política conquistado pela população durante o governo Geisel, as escolas de samba ganham uma liberdade maior para tratar de temas sociais e políticos. O ano de 1982 é particularmente rico nesse aspecto, consolidando a virada nos temas de enredos do carnaval de São Paulo, que passou a focalizar vários elementos de denúncia social, em especial a situação do negro e do pobre no país.

Como foi discutido no primeiro capitulo, impulsionados pelo momento político do país, começam a surgir, dentro das escolas de samba, reuniões de pessoas interessadas em participar do processo político do país. Vários grupos de discussões foram formados, inserindo-se principalmente dentro das lutas do movimento negro que começou a se rearticular naquele momento e procurou apresentar o negro como bravo, forte e guerreiro.

Destacam-se nesse carnaval os enredos escolhidos por Nenê de Vila Matilde, Mocidade Alegre e Camisa Verde e Branco. A escola de samba da zona Leste apresentou "Palmares, raízes da Liberdade". Apesar de muitas escolas sempre 
encenarem o tema da Guerra de Palmares, a Nenê traz em seu desfile apenas o aspecto da luta contra a escravidão, com uma mensagem de alerta para a situação dos negros na contemporaneidade. O samba-enredo de Armando da Mangueira e Jangada contribui para a transmissão da mensagem proposta pela escola ao apresentar o refrão "Se cuida branco que o negro não tem senhor". O samba transcende a luta pela liberdade como não sendo apenas dos negros, mas a luta de classes, de todos os pobres. A escola de samba é apresentada como um "novo Quilombo", ou seja, um espaço de lutas e diversão de todos os marginalizados e "escravizados" pelo sistema capitalista.

\section{Oiá Princesa}

Oiá Zumbi

A nobreza de Palmares viemos recordar

$$
\text { É claridade }
$$

Brilha a raiz da liberdade,

Zumbi lutou

Até que a morte o libertou

E uma nova aurora conquistou

Ôôô, Ôôô se ouvia um feroz clamor

Ôôô se cuida branco

Que o negro não tem senhor

No terrível horror do cativeiro

Ao esplendor

Palmares o quilombo pioneiro

Superou a dor

O negro soube se unir ao índio e ao branco pobre

Eram três raças a sorrir

Era um Brasil mais nobre

Olha o tombo

É samba de conga 
E tem dendê

Chegou novo Quilombo

E seu nome é Nenê

A escola de samba Mocidade Alegre apresentou o enredo "Malungos, guerreiros negros", sobre o mesmo tema da escravidão. A escola apresentou os sobreviventes dos navios negreiros como verdadeiros guerreiros, metáfora aplicada para a situação do negro no país. Malungo é uma palavra africana, que significa companheiro (aquele que divide o pão). Era a forma de tratamento mútua que os negros de diferentes tribos davam àqueles que vinham no mesmo navio negreiro.

\author{
Malungos irmãos verdadeiros \\ De uma raça guerreira \\ Que a natureza criou... \\ Com força e suor \\ O negro procurou \\ O seu valor
}

Na mesma linha da Nenê de Vila Matilde, mas com uma mensagem de denúncia explícita e radical da situação do negro no país, o Camisa Verde e Branco apresentou o enredo "Negro Maravilhoso Mútuo Mundo Kitoko". No desfile, a escola trouxe a saga do povo negro, trazido à força do continente africano para ser escravo no Brasil e que mesmo depois da abolição, continuou como o grupo mais marginalizado e com menos oportunidades. O Camisa Verde e Branco chama a atenção de que os negros devem se destacar na sociedade brasileira em geral e não apenas no carnaval, no qual já são tradicionalmente reconhecidos.

O samba-enredo, de autoria de Talismã, é um dos únicos da história do carnaval paulistano que pode ser classificado como música de protesto, com uma letra 
questionadora e provocativa e uma melodia que se aproxima dos sambas feitos pelo Camisa Verde e Branco durante sua fase como cordão.

Achei uma bola de ferro

Preso a elos de corrente

Tinha um osso de canela

Deu tristeza em minha mente

Esse osso de canela

Veio de outro continente

De jeito nenhum

Não é preconceito

Negro ou branco tem direito

Nossa escola não faz distinção de cor

Pra falar sobre esse tema

Foi que surgiu o problema

E o dilema se avizinhou

Ô ôô, a nossa escola enaltece a negra gente

Que nunca ficou chorando

Sempre viveu cantando

Fingindo Contente

Negro paga imposto, negro vai à guerra

Negro ajudou a construir a nossa terra

Temos a pergunta, não nos leve a mal

Porque só no tríduo de momo que o negro é genial?

Ele é capitão ele é general

Poderia ser tanta coisa

Dentro da vida real. 
A Nenê de Vila Matilde trouxe, em 1985, "O dia que o Cacique rodou a baiana", de Paulinho da Matilde, também um samba-enredo de protesto; mas, ao contrário do "Negro Maravilhoso", do Camisa Verde e Branco, no qual a mensagem é forte, explícita e contundente, a Nenê optou por realizar a crítica social através de sátira política e de costumes. O samba trata da luta do cacique Juruna, primeiro indígena a ser eleito deputado federal dentro do Congresso para aprovar os projetos de interesse de seu povo. Também faz uma crítica aos meios de comunicação, alienantes, que destroem a "arte e a imaginação" dos negros e índios para veicular cultura de massas. Por fim, o samba da Nenê sugere aos negros, público original das escolas de samba e também explorado historicamente pelo branco, para "rodar a baiana" e lutar por seus direitos dentro da política tradicional elegendo seus representantes.

\author{
Vai, Nenê \\ Embalando a alegria \\ E no canto \\ Da águia guerreira \\ Toda altaneira \\ Cai na folia
}

Quando o cacique rodou a baiana

O Juruna vestiu a camisa, gravata e paletó

Mas o branco soberano

Só explorando

Até que o índio disse ó

Ó ó ó

Até que o índio disse ó

Macobeba

No rádio e televisão

Destrói a arte

E a imaginação

Negro também quer

Poder falar alto

Rodar a baiana

Chegar no planalto 


\title{
Hoje
}

\author{
Para orgulho de nossa nação \\ Negros e brancos \\ E índios são irmãos \\ Reivindicando seus direitos \\ Se unindo em mutirão! \\ Oh! meu senhor... \\ Devolva minhas terras \\ Por favor \\ Nosso canto e dança \\ Desponta nossa alegria \\ Driblando a inflação \\ É o nosso dia-a-dia.
}

A partir da década de 1980 há uma aceleração rítmica na forma de compor os sambas-enredo, que ficam com andamentos mais rápidos, descaracterizando-os, aproximando-os da marcha. Este fenômeno se inicia no Rio de Janeiro em algumas escolas e se intensifica nos sambas apresentados pelas escolas de sambas da cidade de São Paulo nos anos 1990.

Uma das justificativas da aceleração dos sambas-enredo é para eles se adaptarem ao crescimento do número de pessoas que desfilam nas escolas de samba. Se até a década de 1970 as agremiações desfilavam com centenas de pessoas, a partir da década de 1980 e 1990 passam a desfilar com milhares de pessoas, no mesmo período de tempo ou até mesmo em um espaço de tempo menor.

Portanto, para as escolas não perderem pontos, as pessoas precisam passar rápido pela passarela e uma música mais rápida facilitaria isso. Para Mestre Gabi, este processo em que a música deve ditar o ritmo dos passos das pessoas que se apresentam atualmente na avenida não é um samba-enredo, mas uma marcha-enredo ${ }^{82}$. Os ritmistas, para conseguir sustentar estes sambas na avenida, são obrigados a tocar mais de 150 toques por minuto, medidos no metrônomo.

${ }^{82}$ Entrevista com Mestre Gabi. Data: 25/10/2010. 
Osvaldinho da Cuíca apresenta outra justificativa para o aceleramento dos sambas-enredo a partir da década de 1980. Para ele, o fenômeno se dá pela concorrência do desfile das escolas de samba com os blocos de carnaval de rua da cidade do Rio de Janeiro:

\begin{abstract}
Você sabe qual a razão dos sambas-enredos acelerarem tanto? Enquanto as escolas limitaram seus componentes, os blocos, como o Bafo da Onça e Cacique de Ramos aumentaram. Então você vê, teve uma época que quiseram fechar o Sovaco do Cristo, porque saíam duzentas mil, cem mil pessoas. Aonde vai caber essa quantidade de gente? Não cabe. Aí que dá o vandalismo, porque vai pela cidade andando, quebra carro e atrapalha o trânsito. Cem mil pessoas pela cidade atrapalha o trânsito. E os blocos estavam indo nesse caminho. Por causa do Bafo da Onça e do Cacique de Ramos. Então o que aconteceu? As músicas dos blocos eram mais empolgantes, contagiavam mesmo. Tinha aquela:
\end{abstract}

Essa onda que eu vou, olha a onda, iaiá.

E acelerar, acelerar. E as escolas vinham:

Vejam essa maravilha de cenário

É um episódio relicário.

Tava tudo quietinho, né? Balanceado. E os blocos já metendo o pau. O maior número era dos blocos. Porque antigamente era o contrário. Migraram para os blocos, o pessoal de escola de samba, pra encher os blocos. É mais empolgante o bloco com samba de embalo. E aí o samba-enredo passou a ser samba de embalo. Embalo de embalar mesmo. Essa é a verdadeira história. Não isso que contam por aí, tem que acelerar porque tem que desfilar em uma hora ${ }^{83}$.

Como mostram Luiz Simas e Alberto Mussa (SIMAS; MUSSA, 2010), os sambas-enredo começam a ficar estruturalmente semelhantes. É adotada uma espécie de "fórmula" pelos compositores para dar conta deste novo modelo. A "fórmula" criada no Rio de Janeiro e transportada para São Paulo é o samba-enredo "Peguei um ita no norte", que contagiou a avenida com o refrão: Explode coração, na maior felicidade é lindo o meu Salgueiro, contagiando e sacudindo essa cidade, de autoria de Demá Chagas, Arizão, Celso Trindade, Bala, Guaracy e Quinho.

A partir deste samba, muitas escolas de samba passaram a exigir de seus compositores sambas-enredo que tivessem refrões fortes, alegres e que exaltassem a

\footnotetext{
${ }^{83}$ Entrevista com Osvaldinho da Cuíca. Data: 21/01/2012.
} 
escola, como o citado acima. Como evidencia Leila Blass, o refrão desempenha um papel importante no samba enredo, "expressando o que está internalizado por todos e preparando a passagem para o conteúdo a ser tratado nas estrofes seguintes" (BLASS, 2007, p. 68). Já para Rachel Valença, o refrão seria "um recurso precioso para captar a simpatia e a participação das arquibancadas" (VALENÇA, 1996, p. 87).

Os sambas-enredo passam a ter uma divisão diferente com uma primeira parte, seguida de um refrão de oito versos (16 compassos) e de uma segunda parte, seguida de um segundo refrão também com oito versos. Este segundo refrão, na verdade, é o "refrão principal", que tem como função "levantar e empolgar a avenida", mencionando sempre, de forma entusiástica, o nome da escola, às vezes até fugindo da temática do enredo. Esta parte deve ter uma melodia também mais empolgante, para todos cantarem. Apesar de estas músicas serem grandes em extensão, os seus versos são cada vez mais curtos, porque, como apontam Mussa e Simas, é difícil para os foliões, em geral, conseguirem entoar mais de oito sílabas, em quatro compassos (MUSSA; SIMAS, 2010, p. 118).

No geral, a primeira parte destes sambas-enredo tem em torno de dez versos e predomínio do tom maior; já a segunda tem a mesma extensão, mas um predomínio do tom menor em sua primeira parte para, no fim, dar entrada ao "triunfal refrão principal" (MUSSA e SIMAS, 2010, p.117).

Coração, amor, emoção, galera, luz, brilhar, resplandecer, irradiar... Esses são substantivos e verbos que mais aparecem nos sambas-enredo das escolas do Grupo Especial do Rio e de São Paulo, a partir da década de 1990, quando os desfiles passam a ocorrer no Sambódromo. Como atesta Osvaldinho da Cuíca ${ }^{84}$, sambas que fogem a essa regra não têm chances dentro das eliminatórias promovidas pelas escolas. Prova dessa nova condição é que Osvaldinho concorreu com sambas na escola de samba Vai-Vai e Gaviões da Fiel e foi tachado de ultrapassado, porque seus sambas não seriam adequados para o andamento do desfile:

\footnotetext{
${ }^{84}$ Entrevista com Osvaldinho da Cuíca. Data: 21/01/2012.
} 
Agora virou inferno samba-enredo. Dá saudades do Jamelão. Ele não permitia gritaria no samba. Houve meu samba aí, meu samba-enredo tá aí nesse cd que eu te dei. Pode por aí pra vocês ouvirem, ele empolga pela letra, pela melodia, pela sequência lógica. Não tem gritaria. Qualquer samba meu você entende. Salvo aquele de 82, o Oluayê, que era uma filosofia africana. É difícil você entender uma filosofia brasileira, quanto mais uma africana, né? Então, tudo bem. Mas quando eu faço samba você entende. Você começa pelo fio, ele vem em ordem cronológica, contando a história até o fim. Esse ano eu fiz, tá aí. Só que não deixaram ganhar, lá na Gaviões. O enredo era pra contar a saga do povo nordestino, o sofrimento do sertão, vindo pra São Paulo e um representante maior que chegou a ser presidente da nação, representando todo esse povo, com seu folclore, sua história e seu sofrimento. Vindo pra São Paulo e vencendo, que é o Lula. Ele conseguiu um monte de patrocinadores pra Gaviões falar dele. Cinco milhões. Muito bem, tá aí. Você pega meu samba você entende. A primeira parte é ficção. Você vai ver o maior escorpião da avenida, é o abre-alas da escola. Porque ele é do signo de escorpião. Esse escorpião se transforma num gavião, porque é a Gaviões da Fiel e ele é corintiano. E vem pra São Paulo, aí que começa a luta dele que todo mundo conhece, no $\mathrm{ABC}$ até ser presidente da república. Aí vêm os processos de viajar pro Nordeste, fazendo as caravanas da cidadania, aqueles negócios, muito bem. Esse é o enredo, agora pega o samba-enredo que ganhou. Agora você pega o meu pra você ver. Só tem rimas pobres, um senso comum. Eu tenho percepção. Que eu sempre fui de conjunto vocal, sempre gostei de vocalizar. Então eu peguei o pessoal da Vela, umas meninas que cantam pra caramba. Peguei o Washington do Vai-Vai, o Odilon que é um irmão meu também, desfilava comigo nos cordões. E gravamos o samba. Eu falei pra eles, a música é essa só que aqui vai fazer uma oitava e aqui vai vocalizar. No palco fizemos igual a gravação. Ensaiamos a divisão. Não quero harmonia, quero voz. Quando chegou na quadra e eu entrei com aquela turma. Violão, cavaco tudo ensaiado, coro. Tinham uns oito no coro. Quando abriu o vocal, o Renê Sobral começou:

Nasceu na terra seca do sertão/pau-de-arara pés no chão/ o retirante nordestino/ Viveu o sofrimento do lugar/E na cultura popular fortaleceu o seu destino/ Cresceu sob a influência de escorpião/ Acreditando no poder da transformação/ Bateu asas e voou/E foi assim que tudo começou/Mãe coragem abençoa pra vencer/ Vem pra terra da garoa a perder/Operário consciente é cidadão/ É o braço forte da nação/ Mãe coragem abençoa, pra que?/ Pra vencer, vem pra terra da garoa. ${ }^{85}$

Outro fenômeno criticado por Osvaldinho é a poluição visual dentro dos sambasenredo, com mensagens para a escola, para a comunidade, para o presidente da escola, diretoria etc. Nesta safra de sambas-enredos surgidas a partir da década de 1990 há a presença de uma grande exaltação à própria escola, principalmente nos refrões, e a não descrição de todo o enredo ao longo da música, o que ocasiona a perda de pontos. Para

\footnotetext{
${ }^{85}$ Entrevista com Osvaldinho da Cuíca. Data: 21/01/2012.
} 
ele, isso alimenta o "ego da comunidade", mas não se traduz em vitória na avenida, nem em sambas elaborados:

A questão de você exaltar a escola na primeira parte do samba. É tudo balela! Não precisa. O Silas de Oliveira dificilmente falava da escola, nominalmente. Eu ganhei o maior carnaval da Vai-Vai, Amado Jorge. Quando estava fazendo o samba meu parceiro meu falou:

- Mas não tem Saracura? Não tem Vai-Vai e não tem Bexiga? Eu disse a ele:

- Não tem Bixiga, mas tem o mais importante, todo o enredo. Quando anuncia lá não fala assim. Agora a escola de samba Vai-Vai. Tem o meu pavilhão escrito Vai-Vai, você quer o que mais? Não tem o abre-alas escrito Vai-Vai?

- Mas e a comunidade nós não vamos ganhar. Mas o samba começa baixo?

- Vamos ganhar sim. Vai lá escutar os sambas do Silas de Oliveira. Ele começa o samba dele com Vejam essa maravilha de cenário é um episódio relicário e vai subindo? Eu comecei assim:

Bahia o seu nome principia/Com o canto e a magia/Que o negro sopra pelo ar/Cantando sua terra sua gente/Seu passado presente. Resultado. Ganhei o carnaval e fui tricampeão com o Amado Jorge. Neste ano a Mocidade vem com o mesmo tema, Jorge Amado e com a tenda dos milagres, daquele herói, Pedro Arcanjo. (...)

Então não precisa essa exaltação toda. Botar uma linha ou duas eu ponho. $\mathrm{Na}$ maioria das vezes eu ponho, é uma questão de satisfazer o ego da comunidade, mas não tem necessidade. Certas coisas são vícios. Não é regulamento e não é tradição. Veja essa gritaria toda. O Jamelão não permitia na Mangueira que viesse caco. Caco é quando quebra telha pra lá. O velho dizia:

- Aqui não tem caco, não, aqui tem samba!

E é verdade mesmo tem que cantar. Você pega a gravação você não consegue entender o samba com tanta gritaria em cima. Ô, meu presidente. Que meu presidente. Ô, minha ala de baianas. Que ala de baianas. Deixa a ala de baianas cantar que o papel dela é esse. Todo ano é meu presidente. Presidente entra e sai todo ano. Às vezes é uma porcaria esse presidente, afundou a escola e o cara tá puxando o saco lá na gravação. Não tem que estar gritando não. Você tem que apresentar o samba-enredo, mostrando a letra e a música. Aí o cara sai gritando em cima. É moda agora. Chega pô! Samba é música não é gritaria! Outra coisa que me deixa nervoso. Soltam fogos pra caramba. No meu tempo fogos era na festa junina. Você tá cantando e pum, pum, pum. Aquela barulheira, ninguém escuta o samba.

\footnotetext{
${ }^{86}$ Entrevista com Osvaldinho da Cuíca. Data: 21/01/2012.
} 
Para Maria Apparecida Urbano, esta mudança no caráter dos sambas-enredos é decorrente da própria expansão dos desfiles das escolas de samba e da sua inserção na grande mídia. Por conta disso é necessário que as escolas se adequem, produzindo canções que representem o cotidiano ou os valores comuns à sociedade para a qual está sendo apresentado o samba-enredo (URBANO; NABHAN; SANTOS, 1987, p. 51). Além disso, podemos perceber que a preocupação dos compositores em incluir em suas canções, palavras genéricas como sabedoria, vida, poesia, amor, beleza, felicidade, alegria, etc., como estratégia para a composição de diversos sambas-enredos para serem disputados em diversas escolas em um curto espaço de tempo. Seria uma técnica estabelecida para a realização de várias canções, cada uma com tema diferente, o que demandaria tempo de elaboração e estudo para se entender a mensagem do enredo. Para facilitar esta tarefa, vários compositores com "manha de avenida" se juntam e realizam a tarefa.

Este é outro fenômeno recorrente nos sambas-enredo realizados em São Paulo a partir da década de 1990 e visto, por exemplo, no "Peguei um ita no norte", do Salgueiro, é a presença de vários compositores na autoria do samba. Alguns chegam a contar com dez nomes. Os sambas são feitos por dez pessoas? A resposta é não. O que acontece é que as escolas abriram a disputa de samba-enredo para compositores que não são da escola. Isso gerou a formação de grupos de compositores que inscrevem músicas em quase todas as escolas, para aumentar a chance de vitória. Normalmente os compositores realizam sozinhos ou em dupla um samba, somado a outros sambas de outras pessoas do grupo que são inscritos com o nome de todos em uma espécie de "consórcio", nas eliminatórias promovidas pelas escolas. Como a qualidade dos sambas apresentados não apresenta grande variação, já que os mesmos compositores concorrem em várias escolas, outras questões como a qualidade da gravação, a preferência da torcida presente na quadra da escola ou mesmo o desempenho ao vivo do intérprete podem influenciar no resultado.

Por isso há os chamados "parceiros investidores" que não compõem os sambas, mas também assinam a parceria, porque investem financeiramente neles. Pagam parte dos custos de registro e gravação em estúdio, além do cachê de intérpretes que vão 
"defender" o samba nas eliminatórias, já que um bom intérprete aumenta as chances de a canção cair nas graças dos jurados. Há casos de "investidores" que patrocinam bebidas e ônibus para os integrantes irem às quadras das escolas torcerem por seus sambas. Obviamente, em caso de vitória, parte do dinheiro ganho com a gravação do disco, direitos autorais e de exibição no desfile pela emissora de televisão vai para o investidor recuperar seu capital e ter algum lucro.

Esta é uma crença já enraizada entre os próprios compositores que já fazem sambas "funcionais", ou seja, que atendem a esses parâmetros do grupo de compositores e dos "sambistas investidores", e quem não se adapta tem poucas chances de vitória:

Há uns dois anos, na Vai-Vai, infelizmente, foi a mesma coisa. Perdi o samba-enredo. O carnavalesco era o Chico Espinosa. Esse ano ele tá lá na Vila Maria. Ele queria meu samba. Tanto é que ele ficou um mês afastado do Vai-Vai, brabo. Porque quando ele viu meu samba ele mudou até o enredo. Ele inspirou-se no meu samba pra fazer a escola de asas. Quando ele me viu, perguntou:

- De onde você tirou essa ideia do anjo?

Eu falei: - Você não pesquisou direito.

Eu fui no enredo lá na Vila Prudente. Conheço a orquestra Baccarelli, o símbolo da orquestra é um anjo. Não podia falar Baccarelli, porque seria propaganda. Então pus o seguinte verso:

Um anjo que desceu lá na favela

E traz pra passarela um lindo sonho a realizar.

A proposta do enredo é que música e a arte acabavam com a miséria. Vê se alguém falou? Eu falei. Aí o que o Chico Espinosa fez e botou o Vai-Vai toda alada do começo ao fim. Alegoria, ala, destaque, tudo com asa. Porque eu coloquei no meu samba, do anjo que desceu lá na favela. Nenhum samba, nem mesmo o que ganhou não fala. Fazer o quê se os caras têm muito dinheiro. Pra ganhar samba-enredo tem que investir pesado. O samba que ganhou de mim fez uma coisa inédita na história da disputa de samba-enredo. Nem no Rio nem em São Paulo. Puseram três puxadores, o Wander Pires, Tinga e outro, os melhores do Rio pra defender. Você costuma ver, normalmente um puxador e seis apoios. Agora pegaram os três melhores do Rio, pagaram onze ônibus da Heliópolis e do Jardim Elba. Uma torcida forte pra caramba! E puseram o som e iluminação pra eles. Essas coisas eu não posso nem falar! $!^{87}$

\footnotetext{
${ }^{87}$ Entrevista com Osvaldinho da Cuíca. Data: 21/01/2012.
} 
Outro motivo para este "tecnicismo", que gera não apenas uma padronização sonora, mas também uma padronização visual, tornando os desfiles cada vez mais semelhantes, é que as escolas de samba optam por levar para a avenida sambas que têm mais chances de tirar nota 10 , pois os jurados dão nota aos sambas-enredo sem um maior envolvimento afetivo, sem uma avaliação mais apurada da qual uma obra artística necessita, ou dão nota máxima para sambas horríveis do ponto de vista estético-poético, mas que cumprem estritamente sua função dentro do quesito.

Grande parte destes sambas-enredo produzidos após o início dos desfiles realizados no Sambódromo do Anhembi é efêmera. Seja do Grupo Especial, Grupo de Acesso ou Grupo I. Alguns meses depois, ou mesmo ao final do desfile, eles são esquecidos por todos, não se cristalizando na memória da música popular brasileira. Muitos são patrocinados por empresas, cidades ou Estados que desejam utilizar os desfiles para divulgarem suas marcas ou características de suas localidades para todo o Brasil. Também há uma grande concentração de enredos abstratos, como "mundo da imaginação", ou reflexivos, tornando as letras cada vez mais previsíveis e cheias de lugares-comuns.

As decisões das diretorias das escolas de samba de buscar enredos patrocináveis para conseguir o montante de dinheiro necessário para pôr a escola na avenida (e que não é pouco, na casa dos milhões de reais!) faz com que sambistas tradicionais das Velhas Guardas se desencantem com esta situação de mercantilização do carnaval e se ressintam, pois não conseguem enxergar-se como integrantes do atual mundo do carnaval, uma vez que, inicialmente, a escola de samba se apresentava de forma simples e espontânea, e hoje é um verdadeiro produto da indústria cultural e televisiva. Prova disso são as entrevistas realizadas durante a realização desta dissertação. Essa avaliação é unânime por parte de todos os entrevistados. Alguns têm opiniões críticas mais fortes, como é o caso de Marcos dos Santos e Mestre Gabi, outros procuram tentar quebrar essa lógica, o que é o caso de Mestre Divino, persistindo com sua escola de samba, a Imperial, realizada de modo artesanal, com trabalho familiar e que traz uma batucada com a presença de diversas crianças para tentar manter em atividade instrumentos em 
desuso pelas escolas tradicionais, preocupadas apenas em tirar nota dez e serem campeãs ao final do desfile.

Na conversa entre Paulinho da Viola e Elton Medeiros, em entrevista a Fernando Faro, em 1990, é nítido o tom saudosista com que falam das escolas de samba:

PAULINHO: Se você fosse o presidente de uma escola de samba hoje, o que você faria?

ELTON: Eu não seria.

PAULINHO: Mas vamos supor que você assumiu a presidência.

ELTON: De jeito nenhum.

PAULINHO: Com o apoio de toda a comunidade.

ELTON: Paulo há uma incompatibilidade de meu temperamento como fazedor de samba com o clima que existe hoje lá. O perfil da escola de samba não condiz com o meu perfil de sambista. Você sabe que hoje os novos ricos tomaram conta da escola de samba, já começa mal, porque eles ditam as regras, eles são donos das escolas de samba, eles não são presidentes, têm um título de presidente de honra, mas isso na realidade quer dizer que eles são donos da escola de samba, mandam e desmandam, pagam para um sambista varrer a quadra. Então, um bom tamborinista às vezes está varrendo a quadra, está trabalhando como garçom, enquanto um camarada que não sabe bater tamborim está na bateria, outro que não sabe fazer um samba está entrando na parceria de um samba. Eu sei que você também não seria presidente de uma escola dentro desse contexto (BOTEZELLI; PELÃO; PEREIRA, 2000. Volume 3: 144).

Alguns sambas-enredo do final do período analisado conseguiram virar exceção. Apesar de serem realizados sob a fórmula da estrutura definida por Mussa e Simas como "funcional", eles possuem letras belíssimas que realmente empolgam os foliões e caem na boca do povo, sendo cantados até os dias de hoje, não apenas nas quadras das escolas, mas em vários espaços destinados ao samba na cidade. Esses são os casos dos sambas-enredo da escola Gaviões da Fiel de 1995, "O que é bom é para sempre”, de autoria de Grego. Ou do Vai-Vai do ano seguinte, "A Rainha, a Noite tudo transforma", de Wagner Santos e Borrão, ambos campeões.

Para que a festa carnavalesca continue crescendo do ponto de vista da qualidade artística, é fundamental que os artistas consigam inovar e se desprender deste atual 
modelo que transforma as apresentações das escolas em um espetáculo visual, sonoro e performático, repetitivo e padronizado. 


\subsection{A batucada}

Com a adoção do samba executado pelas baterias, a marcha-sambada foi aos poucos se extinguindo, sendo hoje até difícil de ser reconstituída, com precisão na forma como era tocada. Sabe-se que tinha uma forte influência do bumbo, com um som grave, reminiscência do samba de batuque ou do samba rural praticado nas fazendas de café do interior do Estado de São Paulo, em instrumentos feitos com troncos de árvore cobertos por couro de animal.

Algumas gravações de época, como alguns sambas gravados pela escola de samba Unidos do Peruche, no final dos anos 1960, com a presença de instrumentos de sopro e metais, podem nos indicar um caminho. Essas mudanças promoveram a extinção definitiva dos cordões carnavalescos e também dos instrumentos de sopro no instrumental das escolas, que passaram então a desfilar apenas com percussão.

Osvaldinho da Cuíca é um dos que evidenciam este processo de mudanças e perda de uma parte da identidade instrumental dos cordões paulistanos, que não foram incorporados pelas escolas de samba:

Tinha trombone, clarins, tinha muitos clarins, todas essas coisas bonitas se perderam e virou tudo escola de samba de padrão carioca. Por exemplo, assim como no Sul, aqui em São Paulo a batida do surdo era diferente. Não tinha nada igual ao Rio, absolutamente nada. (...) Não falava bateria era batuque. Bateria era Rio de Janeiro. Aqui era batuque. Na frente do batuque tinha uma rumbera. Sacudindo aquele vestido encarnado, rodando no chão. (...) A percussão do cordão era bem pesada. Além desses instrumentos de corda e de sopro que eu falei tinha surdo e bumbo, muito bumbo de banda. Não confundir com zabumba, porque muito historiador põe zabumba. Zabumba é nordestino é fininho, é um bumbo magro, e o bumbo é aquele gordo mesmo de banda, aquele que nem o dos fuzileiros navais. Bum, bum, bate de um lado e do outro. Então em São Paulo tinha muito bumbo e a batucada era bem diferente. Como tinha muito harmônico, o bumbo é um grave pesado, e ele tem muito harmônico. O som é assim: - Bum! O harmônico fica retumbante. O importante dele era a função de batida, não é repique. Quem repicava era um surdinho pequeno. Era um samba socado que o carioca dava risada da gente. Falava que era um samba duro. Então era assim, o bumbo ele vinha sempre dois ou quatro atrás, depende do cordão. ${ }^{88}$

${ }^{88}$ Entrevista de Osvaldinho da Cuíca: Data: 21/01/2012. 
Com isso, as características oriundas do samba-de-bumbo e da marcha-sambada foram se extinguindo, pois, apenas com a percussão, a "batida" das escolas de São Paulo foi se aproximando cada vez mais das baterias das escolas do Rio de Janeiro ${ }^{89}$.

O responsável pela parte instrumental dos cordões carnavalescos é o chamado de “apitador". Era ele quem ensaiava os ritmistas e músicos que preenchiam a parte musical dos desfiles. Eram chamados de apitadores pelo fato de realizarem a regência com o auxílio de um apito. Os apitadores tinham que bolar os criativos breques, já que a qualidade deles era fundamental para o renome do apitador e do cordão. Os apitos da época eram maiores e mais graves do que os que se usam hoje nas escolas de samba, por isso permitiam que se atingisse um extenso leque de notas. Mas para que essas notas saíssem afinadas, os apitadores precisavam ter enorme habilidade com os dedos e com os lábios (CUÍCA; DOMINGUES, 2009, p. 48 e 49). Osvaldinho da Cuíca, ainda adolescente, foi um dos apitadores do cordão "Garotos do Tucuruvi”. O cordão Vai-Vai possuiu famosos apitadores, como Walter Gomes de Oliveira, o Pato'N'Água e Mestre Feijoada, seu último apitador.

Pato'N’Água, mítico malandro da primeira metade do século XX na cidade de São Paulo, comandou diversas agremiações da cidade, sendo campeão em todas elas. Além do Vai-Vai, passou por Acadêmicos de Santa Isabel, que depois viria a ser Acadêmicos do Tatuapé, Unidos do Peruche e também um grupo carnavalesco ligado ao clube do Corinthians, do qual era funcionário. Foi assassinado no município de Suzano em 1969. Geraldo Filme, grande admirador do trabalho de Pato à frente dos cordões e que o homenageou com um samba intitulado "Silêncio no Bexiga", comenta:

Pato N’Água (...) conseguia dirigir uma bateria com perfeição, instrumento, afinação, aquelas coisas todas. (...) Me parece que ele era roupeiro do Corinthians, ele e o Caldeirão, irmão dele, qualquer coisa assim, mas tinha ligação direta com o clube. Como bom sambista, ele tinha aquele monte de

\footnotetext{
${ }^{89}$ Carlos Sandroni identifica a "batida" aplicada à execução do samba no violão como "um modelo rítmico de acompanhamento, suscetível de certo grau de variação, utilizado quando a canção a ser acompanhada pertence ao gênero samba". In: SANDRONI, Carlos. Feitiço decente. Transformações do samba no Rio de Janeiro (1917-1933). Rio de Janeiro: Jorge Zahar, 2001, p. 45.
} 
"comadre", então tinha que fazer as visitas. Um belo dia, ele saiu para fazer a visita na casa das comadrinhas e tomou um café da manhã, parece que era dia de pagamento, alugou um táxi e foi embora, passa ali, toma um café, passa lá, bate um papo. Foi parar em Suzano. Chegou em Suzano, o motorista ficou meio cabreiro. A última coisa que se sabe é que o motorista falou: "Tem um cidadão que está no carro desde manhã". Passaram a mão no rapaz e levaram pra dentro da delegacia. Depois disso a notícia que chegou para nós foi que o rapaz estava morto. Encontraram morto numa lagoa em Suzano. Trouxeram o corpo pra São Paulo, o Wadi Helu que comandou fez todo o enterro. Estava como enfarto. De susto não morreu, porque ele era bravo, afogado também não, porque chamavam de Pato N'Água porque nadava bem demais. $O$ motorista do carro funerário falou pra gente, o Carlão do Peruche, eu e a falecida Cininha: "Dá uma olhada na japona dele, ela está com uns furos meio estranhos". Quando o Carlão pegou a japona, o dedo dele já entrou num buraco. Fomos tirar a roupa dele pra ver e não aparecia marca de furo. Aí explicaram pra gente que, se for baioneta ou punhal, na água fecha. Aí passou e a única coisa que restou foi a homenagem a ele através de um samba (BOTEZELLI, PELÃO e PEREIRA, 2000. Volume 2:80).

Dona China, prima de Pato N'Água sobre a estranha morte relembrou:

Quando eu comecei no Vai-Vai, o mestre de bateria era o Feijoada, depois entrou o Tadeu. Antes deles teve um primo meu, o Pato'N'água. Quando nós soubemos que ele tinha morrido, já tinha passado um mês ou dois, morreu lá em Suzano, a gente nem sabe como foi direito. Falaram que mataram ele, mas até hoje a gente não sabe. Cada um conta uma história diferente ${ }^{90}$.

Os instrumentos musicais dos cordões carnavalescos já foram descritos no início do primeiro capítulo. A bateria da escola de samba é composta apenas por instrumentos de percussão organizados em naipes de timbres variados: agudíssimos, agudos, médios e graves dos grupos dos idiofones e dos membranofones. ${ }^{91}$ São instrumentos obrigatórios em uma bateria de escola de samba e que são julgados durante os desfiles: surdo (naipe grave), repinique (naipe agudo), caixa (naipe agudo), cuíca (naipe agudo), tamborim (naipe agudíssimo), chocalho (naipe agudíssimo). É através destes instrumentos que os jurados têm referência para a análise rítmica da bateria e o intérprete pauta seu canto. $\mathrm{O}$ andamento de uma bateria é analisado através da pulsação do surdo e de seus complementos descritos acima. Como atesta o Manual do Avaliador

\footnotetext{
${ }^{90}$ Entrevista de Dona China do Vai-Vai. Data: 09/07/2011.

${ }^{91}$ Segundo a classificação de Hornbostel \& Sachs.
} 
das Escolas de Samba produzido pela $\operatorname{UESP}^{92}$, no que diz respeito ao ritmo, o funcionamento de uma bateria assemelha-se a uma orquestra; devendo manter inalterável o sincronismo de sons e o ritmo emitido pelos diversos instrumentos, cuja distribuição dentro do conjunto fica a critério de cada agremiação.

Os idiofones são os instrumentos cujos materiais soam como os sinos, gongos, chocalhos e etc. Nas baterias de uma escola de samba, além dos instrumentos obrigatórios, é comum estar presentes outros instrumentos idiofônicos: agogô, prato e reco-reco. O prato é um instrumento que hoje está em desuso, com pouca presença, enquanto os outros (agogô, reco-reco e chocalhos) continuam em destaque (MENISTREL, 2009, p. 89).

Os tambores, cuja percussão é dada por uma pele de animal ou sintética são chamados de membranofones. Na bateria de uma escola de samba estão presentes os seguintes membranofones: cuíca, tamborim, pandeiro, repinique, caixa, surdo e timbau; eles são tocados com diferentes tipos de baquetas ou com as mãos, a exceção da cuíca, vibrada pela ação de um pano umedecido esfregado por um arame (MENISTREL, 2009, p.90).

Os surdos apresentam normalmente três variações: a primeira é de marcação, a segunda é de resposta e a terceira de corte. O surdo de primeira é, em geral, o mais grave dos três. Tem normalmente de 24 a 29 polegadas, e é o alicerce rítmico da batucada, pois é executado no segundo tempo do compasso binário (tempo forte do samba). O surdo de segunda é um pouco menor, tem em geral de 22 a 26 polegadas, e responde a batida do surdo de primeira, tocando no primeiro tempo do compasso. $\mathrm{O}$ surdo de terceira mede entre 16 e 20 polegadas e é o mais agudo dos três sendo executado junto com o surdo de primeira, porém executando figuras sincopadas (a marca rítmica do samba) (MENISTREL, 2009, p.101).

A escola de samba Nenê de Vila Matilde ao lado do Vai-Vai destacou-se nos anos 1960 e 1970 por sua bateria, sendo a escola que introduziu alguns dos instrumentos

\footnotetext{
92 Segundo o Manual do Jurado produzido pela União das Escolas de Samba Paulistanas (UESP) em 2007 com os critérios e pontos de balizamento vigentes.
} 
agudos e agudíssimos de percussão nas escolas de São Paulo. Estas tradicionalmente se caracterizam por uma afinação mais grave e um andamento mais lento. Esta inovação se deu a partir do diálogo e intercâmbio feito com baterias de escolas do Rio de Janeiro, como a escola de samba Mangueira e Mocidade Independente de Padre Miguel, e, com essa nova formação instrumental, a escola fazia uma batucada cheia de "breques" ${ }^{93}$, que empolgavam a avenida. As escolas que surgiram neste contexto também buscaram adotar esse modelo rítmico, marcando a festa carnavalesca a partir daí. Os instrumentos leves de percussão são: tamborim, repique, ganzá, agogô, cuíca - que dialogam entre si e com o surdo de marcação.

Nove anos antes da oficialização, em 1959, a bateria da Nenê adicionava aos seus desfiles o ritmo e as batidas cariocas, aprendidas pelo próprio Nenê em visita ao morro da Mangueira e posteriormente ensinados por mais de dois anos, aos ritmistas paulistanos. Essa influência carioca provocou diversas mudanças dentro do instrumental da Nenê. Inicialmente, os ritmistas tiveram dificuldade em entender a batida carioca, mais leve e mais rápida, pois estavam acostumados a uma batida mais pesada e a uma dança mais lenta dos cordões, originárias do jongo e das danças religiosas do interior do Estado trazida pelos negros que imigraram para a capital, ao longo do século XX (SIMSON, 2007, p. 218).

Após a oficialização, o então diretor de bateria da Vila Matilde, Mestre Divino, aperfeiçoou essas mudanças e introduziu outras dentro da bateria da escola da zona Leste:

Mudamos coisas simples como a altura e largura dos instrumentos, a afinação
caixa e tarol combinando com o corte, atrelado à combinação ou com surdo e
bumbo, bumbo com bumbo, surdo com surdo ou surdo com bumbo invertido
cada um, resultando em uma afinação. Mas o padrão, obtivemos das caixas e
taróis e no corte, assim, para um grave e agudo, um corte. Montamos uma
linha de surdo para fazer a primeira e uma linha de bumbo para dar a
resposta. No caso da primeira tudo bumbo, surdo é só corte e centralizador.
Então temos: primeira e segunda que são de bumbos e surdos (terceira e
centralizador), onde temos que ter surdo só na terceira, o corte, e na quarta

93 "Breque" ou "Bossa" é uma parada repentina ou inesperada, executada quando a percussão está no seu ponto mais animado, permitindo floreios rítmicos e coreográficos que empolguem a assistência. 
que será o contra tempo - combinação. Atentamo-nos ao uso de agogôs, pois são quatro campanas: dó-ré-mi-fá, usando-os com moderação, porque dentro de uma batucada não apresenta tanta utilidade e efeito e, se não bem utilizado, no momento exato atrapalhará no andamento do conjunto no ritmo. Costumava tocar os instrumentos com os batuqueiros, individualmente, fazendo-os cantar porque o batuqueiro que canta não atravessa ${ }^{94}$.

Como os instrumentos de corda e de sopro caíram, a bateria ficou sendo a referência musical da escola e é chamada por muitos como "coração da escola". Para Mestre Divino, o nome deveria ser a "batucada" de uma escola e não "bateria", pois bateria seria apenas uma junção de poucos instrumentos percussivos, montada como instrumento individual, a "bateria de conjunto", tocada por apenas um músico, enquanto a batucada pode ter centenas de ritmistas. Para ele, "a bateria tem padrão e a batucada tem estilo":

\begin{abstract}
A bateria tem padrão e a batucada tem estilo. O que eles chamam de bateria de escola de samba tem apenas nove instrumentos a batucada dezenove. Bateria tem surdo de primeira, segunda e terceira. Repinique e caixa, certo? Tamborim, agogô, chocalho e cuíca. O que eu faço é batucada e tem surdo de primeira, segunda, terceira, quarta e quinta. O bumbo do tamanho certo que faz a marcação junto com as primeiras. E dá sempre dois ou quatro compassos. Tem que ser par, não pode ser ímpar. Essa é a quinta e combina em resposta com a quarta. Combinação, por isso tem a quarta e a quinta, na batucada. Aí na batucada você tem caixa de guerra, caixa, tarol e tarolzinho. Nove. Repinique e malacacheta. Onze. Tamborim, agogô, chocalho, recoreco e prato, certo? Ai você tem, a cuíca e pra fechar o ganzá. Esses são os instrumentos que compõe uma batucada (...)Bateria pra mim é de eletricidade. Bateria de conjunto! O instrumento bateria assim, com caixa, prato. Pega uma bateria. O que a negrada faz é batucada. Vem do batuque feito antes pelos negros que trouxeram a percussão pra cá, né? ${ }^{95}$
\end{abstract}

O surdo de quarta é o mais agudo de todos e toca uma variação da batida do surdo de terceira, completando-a. Já o surdo de quinta é o mais grave de todos e toca uma variação do surdo de primeira, alternando a marcação em contratempos de quatro ou oito compassos (MENISTREL, 2009, p. 205).

Outro instrumento tradicional dos cordões que praticamente "desapareceu" nos anos 1980 e 1990 e que foi retomado como "inovação" nos anos 2000 é a frigideira. Na

\footnotetext{
94 Depoimento de mestre Divino ao site do Camisa Verde e Branco. Disponível em: <www.camisaverdebranco.net>. Acesso em 26/09/2011.

${ }^{95}$ Entrevista com Mestre Divino. Data: 15/10/2011.
} 
verdade é um utensílio doméstico utilizado como instrumento percussivo nos cordões devido ao seu timbre metálico agudíssimo:

\begin{abstract}
Tinha frigideira. Tocava-se muita frigideira. Sabe o instrumento que acabou com a frigideira? $\mathrm{O}$ tamborim, porque tudo o que o tamborim faz, era a frigideira que fazia. Frigideira era tocada virando. Igual ao tamborim hoje. Além de São Paulo no carnaval de Santos tinha muita frigideira. Santos era campeã. Brasil de Santos, X9, escolas muito boas. Os tamborins que tiraram as frigideiras. Entrou o tamborim e caiu a frigideira. Os últimos desfiles com frigideira acho que foi em $1974,1975^{96}$.
\end{abstract}

No discurso de Mestre Divino podemos perceber também uma integração e troca cultural entre as escolas de samba da capital paulista com as escolas de samba da cidade de Santos, algumas até mais antigas que as de São Paulo. Dona China também relembra que desfilou várias vezes ostentando o pavilhão de escolas de samba da cidade litorânea: "Também desfilei na escola Império do Samba de Santos, todo ano eles vinham me buscar. Eu tenho as medalhas que eu vou mostrar, de 1970 a 1974 . Ganhei elas como melhor porta-bandeira de Santos" ${ }^{97}$. As escolas de Santos possuíam uma maior influência do Rio de Janeiro, pois o porto de Santos contava com muitos estivadores que vinham da então capital federal, e vice-versa, muitos saíam de Santos ia trabalhar no porto do Rio e depois retornava, com novas ideias que haviam aprendido com as escolas de samba cariocas.

Mestre Divino ressalta que foram abolidos das baterias das escolas de samba estes surdos de quarta e de quinta tradicionais do samba paulista e os quais ele fez questão de manter à frente da Nenê de Vila Matilde. A saída desses surdos está relacionada a uma das mais significativas perdas das escolas de samba da capital paulista: a sua identidade sonora. Para ele, qualquer pessoa com um mínimo de conhecimento musical conseguiria distinguir e identificar facilmente a bateria das escolas, pois cada uma possuía sua própria identidade, timbre e sonoridade. Isso teria ocorrido por tentar apenas copiar o modelo das baterias das escolas cariocas. Ele próprio

\footnotetext{
${ }^{96}$ Entrevista com Mestre Divino. Data: 15/10/2011.

${ }^{97}$ Entrevista com Dona China: Data: 09/07/2011.
} 
utilizou diversos padrões rítmicos que já eram utilizados em escolas de samba do Rio de Janeiro, em especial da Mocidade Independente de Padre Miguel, da qual foi ritmista. O mestre de bateria analisa que, ao utilizar esses recursos, as baterias regidas por ele não perderam sua identidade e cadência, pelo contrário, preservam uma sonoridade que as próprias escolas cariocas já não têm.

\begin{abstract}
Eu dou umas paradas na avenida. No Rio várias escolas fazem paradas. Faço aquilo que a Padre Miguel fazia. Hoje não consegue fazer, cara! Parar e voltar sem chamar. Só no sincronismo. Quando eu via a Padre Miguel fazer isso era bonito pra caramba! Tem que todo mundo parar junto e voltar junto pra dá certo. É no compasso certo. O que a gente faz aqui na Imperial, os caras não conseguem mais fazer. Eu fico puto, por isso... Poxa vida! Por isso que eu falo que a banana comeu o macaco; a linguiça colocou o cachorro pra corre. Gozado, né? ${ }^{98}$
\end{abstract}

Sérgio Cabral confirma a fala de Divino: “As baterias tiveram que se adaptar à correria da música e sem condições de manterem as antigas características de cadência, timbre etc., ficaram todas muito parecidas, como se houvesse uma só bateria para todas as escolas" (CABRAL, 2011, p. 259).

Outro fator que também contribuiu para a perda da qualidade sonora das baterias é a diminuição do número de diferentes instrumentos dentro das mesmas. Houve um aumento no número de ritmistas, dificultando o trabalho do mestre de bateria, ocasionando uma diminuição na quantidade de instrumentos diferentes. Com medo de perder pontos, as escolas optam por levar apenas os instrumentos obrigatórios para a concessão de notas, utilizando poucos, ou quase nenhum instrumento musical diferente. Diversos instrumentos foram praticamente esquecidos como: frigideira, tarol, malacacheta, etc.

Apesar de estes instrumentos estarem em desuso na maior parte das escolas de samba, eles permanecem na Imperial, fundada por Mestre Divino em 1983 e que mantém os 19 instrumentos da batucada em sua formação musical.

\footnotetext{
${ }^{98}$ Entrevista com Mestre Divino. Data: 15/10/2011.
} 


\section{III - A CRIAÇÃO DO SAMBÓDORMO E AS TRANSMISSÕES TELEVISIVAS}

Este capítulo analisa as intensas modificações ocorridas a partir de 1991, ano em que os desfiles das principais escolas da cidade de São Paulo deixaram o espaço público da rua e passaram a ser realizados no Sambódromo, nome como ficou popularmente conhecida a passarela fixa construída para abrigar os desfiles. Trata-se de um capítulo de fechamento que pretendeu interpretar as decorrências do processo de oficialização do carnaval paulista.

O jornalista carioca Sérgio Cabral, em seu livro Escolas de Samba do Rio de Janeiro (2011) questiona se o uso do sufixo grego “dromo" é aplicado ao local, já que o mesmo designa local de corridas, como autódromo. Mas ele mesmo responde, com ironia: "Mas o desfile das escolas não se transformara numa corrida de samba, depois que elas se agigantaram, e mesmo assim continuaram obrigadas a desfilar no tempo estabelecido pelo regulamento?" (CABRAL, 2011, p. 243).

Procuramos ao longo do capítulo interpretar a história do Sambódromo a partir da documentação da empresa Anhembi Turismo, responsável pela administração e gestão do local, onde encontramos um conjunto de documento sobre as negociações entre os agentes envolvidos na construção de uma passarela fixa de desfiles - cujo projeto foi doado por Oscar Niemeyer à cidade de São Paulo. Nessa direção foi possível identificar mudanças nas demandas dos sambistas em relação ao poder público e nas relações com a indústria cultural.

A questão central a ser debatida é: o que significou a conquista de um local fixo para os desfiles? Por um lado, o Sambódromo garantiu a realização dos desfiles em situação de competição por muitos anos, por outro expressou a perda por outro representou a perda do espaço público e aberto para os desfiles. Como os sambistas e agentes sociais envolvidos nesse processo compreenderam essas mudanças e atuaram sobre elas? A construção deste espaço fechado converge, em muitos sentidos, com a 
estrutura da maioria das escolas de samba do Grupo Especial a partir dos anos 1990, administrada sob uma lógica empresarial, com várias fontes de financiamento. Ao mesmo tempo contrária a dinâmica vivida pela esmagadora maioria das escolas de samba da cidade, isto é, as escolas menores dos outros grupos ligados à UESP (I, II, III, IV) que apresentam características mais próprias dos períodos anteriores. Essas escolas não têm nem a visibilidade nem os recursos das grandes escolas dependendo ainda fundamentalmente do trabalho voluntário e artesanal, concentrado, na maior parte das vezes, na casa dos próprios componentes onde produzem e armazenam os instrumentos, fantasias, adereços, alegorias e realizam a maioria de suas atividades ao longo do ano.

A Prefeitura de São Paulo procurou modernizar a administração e os órgãos responsáveis pela organização dos desfiles a partir de 1977. Nesse ano, a coordenação da Secretaria de Turismo e Fomento criou um departamento exclusivo para o carnaval, o Departamento de Coordenação Organizadora de Carnaval (COC), subordinado à Paulistur, órgão da Secretaria de Turismo. Com isso, a pista de desfiles também mudou. Com as escolas trazendo um número cada vez maior de integrantes, alegorias cada vez maiores e mais complexas, decidiu-se tirar os desfiles do espaço descentralizado do centro da cidade (Anhangabaú, Rua Direita, Avenida São João) e centralizá-lo em uma região da cidade. O local escolhido foi a Avenida Tiradentes, na zona Norte da capital.

A escolha agradou aos sambistas, pois o lugar era amplo e de fácil acesso, permitindo às escolas levar suas alegorias e também porque a avenida tem grande comprimento. Com isso, era possível para as escolas montarem todas as suas alas em sequência antes da apresentação. Para acomodar o público que ia assistir aos desfiles, arquibancadas tubulares de metal eram montadas, cujo acesso era dado pela venda de ingressos. Mesmo aqueles que não tinham condições financeiras de adquirir os ingressos poderiam assistir aos desfiles pelas brechas e também era possível acompanhar a dispersão das escolas ao final do desfile ${ }^{99}$

A partir de 1983, a organização do carnaval ficou também a cargo dos sambistas representados pela UESP (União das Escolas de Samba Paulistanas) e, posteriormente, pela Liga (Liga Independente das Escolas de Samba de São Paulo). Este crescimento e

\footnotetext{
${ }^{99}$ Entrevista com Álvaro Casado. Data: 01/05/2012.
} 
maior profissionalismo do carnaval de São Paulo, envolvendo um número cada vez maior de participantes e espectadores, chamou a atenção das emissoras de televisão, que então passaram a comprar os direitos de transmitir o desfile (AZEVEDO, 2010, p.100).

Durante o governo do prefeito Jânio Quadros (1986-1989) começaram as primeiras discussões dentro das escolas de samba e na Prefeitura de São Paulo para a construção de uma Passarela do Samba nos mesmos moldes do Rio de Janeiro, com um projeto do arquiteto Oscar Niemeyer. O prefeito havia chamado a atenção em diversas entrevistas que pretendia construir um "desfilódromo" na cidade. No entanto, por conta de diversas restrições orçamentárias e da falta de clareza política, o projeto não foi em frente (BELO, 2008, p.70).

A discussão durante a construção do Sambódromo e o seu posterior uso geram diversas opiniões entre os sambistas. Lideranças ligadas à Liga e à UESP se entusiasmaram com um local fixo para a realização dos desfiles como havia sido feito no Rio de Janeiro. Para elas era o coroamento das boas relações entre as escolas de samba e o poder público. Por conta da fragmentação e disputa entre as entidades, os sambistas da Liga tiveram um papel mais atuante na elaboração e discussão do projeto com a Prefeitura. Como o espaço seria construído para abrigar os desfiles das grandes escolas, nada mais lógico que a entidade que as representasse estivesse nas negociações. Uma parte da direção da Liga, politicamente mais conservadora e de direita, liderada por Eduardo Basílio, da Rosas de Ouro, ligado ao janismo e ao malufismo, não ficou satisfeita com os resultados da eleição para a Prefeitura de São Paulo, em 1988, na qual Luiza Erundina, do PT, primeira mulher eleita prefeita da cidade, venceu o ex-governador Paulo Maluf.

A prefeita anunciou a intenção da construção do Sambódromo, logo no discurso de abertura do carnaval de 1989, quando ela estava há pouco mais de um mês no cargo. A promessa poderia ter ficado apenas no palanque, pois não era usual o prefeito realizar um discurso antes da abertura oficial do carnaval da cidade.

A prefeita Luiza Erundina anunciou que pretende construir em São Paulo um "sambódromo", local exclusivo para desfiles de escola de samba, semelhante ao Rio de Janeiro. A declaração foi feita no sábado à noite, pouco depois de ter aberto o Carnaval paulistano com um 
discurso - prática costumeira em festas populares de pequenas cidades do interior do país, mas inédito em São Paulo.

Erundina chegou à av. Tiradentes pouco antes das 20h. Logo após o discurso, caminhou pela avenida a passos apressados. No rápido desfile pela avenida, acompanhada de seguranças pessoais, ouviu aplausos misturados a vaias e gritos de "Maluf". De acordo com a prefeita, o sambódromo paulista ainda é uma ideia em estudos, e o local ainda não foi definido: "Pode ser na Av. Tiradentes (centro) ou no autódromo de Interlagos (zona sul)".

(FOLHA DE SÃO PAULO, 06/02/1989).

Mesmo anunciando a intenção de construção do Sambódromo, já no inicio de seu mandato a prefeita enfrenta uma oposição justamente das lideranças dos sambistas politicamente mais conservadoras. Como resposta a esta oposição é possível perceber uma postura populista de Erundina, que fez o anúncio sem nenhum cuidado ou estudo, sem discussões com as partes envolvidas, nem com consulta à população, (OLIVEIRA, 2007, p. 78) mas apenas para "jogar para a plateia" e garantir o apoio dos sambistas num momento em que parte deles vinculados à Liga fazia oposição à sua gestão, e outra parte, comandada por Percival Maricato, a apoiava. Os que a apoiavam, a partir de 1990, já não estavam mais na direção da UESP. Com a nova gestão, Mestre Divino, então presidente procurava se afastar de disputas partidárias, mas apoiou o projeto liderado por Eduardo Basílio, da Liga de cobrar da prefeita mais benefícios para as escolas de samba. Este alinhamento se deu após a realização do seminário São Paulo Samba e Carnaval ${ }^{100}$ promovido pela Anhembi em junho de 1989 no qual a UESP e a Liga redigiram um documento conjunto com as demandas do samba, por não terem da prefeita um posicionamento claro na campanha sobre a forma como ela conduziria o carnaval e a construção do Sambódromo. Analisando o documento escrito pelos sambistas ao final do seminário $^{101}$ pudemos observar que os sambistas tomaram posição e reivindicaram maior atenção ao carnaval. Na visão dos presidentes das grandes escolas o carnaval de São Paulo não conseguiria alcançar a importância adquirida no Rio de Janeiro sem a construção de uma passarela fixa para a realização de seus desfiles e passaram a fazer um forte lobby para convencer as autoridades a viabilizar a sua construção.

\footnotetext{
${ }^{100}$ PASTA ANHEMBI TURISMO 1989. Centro de Documentação e Memória do Samba, AHB 1989.

${ }^{101}$ Idem.
} 
Apesar de anunciar a intenção de construção do Sambódromo, a prefeita não estabeleceu um diálogo imediato com esses sambistas. Eles então organizaram alguns atos e passeatas, cobrando da prefeita um melhor tratamento e o atendimento às suas demandas ${ }^{102}$. Mais uma vez, a questão central era a reivindicação de mais verbas para os desfiles, num momento histórico em que a inflação estava na casa dos dois dígitos mensais, o que fazia com que os sambistas perdessem poder de compra durante o processo de tramitação e liberação do dinheiro, o que levava alguns meses. Além de este orçamento ser incerto, apesar de ele ser concedido todos os anos, a quantidade de dinheiro disponibilizada dependia sempre de negociações exaustivas com o prefeito ou secretário. Tal orçamento não possuía lei específica, já que a lei de 1967 e o decreto de $1970^{103}$ eram genéricos e não especificavam de onde sairia o dinheiro (CRECIBENI, 2000, p. 116 e 117).

Mestre Divino conta que participou dessas reivindicações iniciais por melhores condições do carnaval como presidente da UESP. A entidade apoiou a posição da Liga de partir para um enfrentamento com a Prefeitura para esta se posicionar de forma mais clara sobre sua política para as escolas de samba, e, em seguida, narra as frustrações decorrentes do uso da obra e do cenário do carnaval atual:

A gente fazia passeata, manifestação. Oh, nós juntamos mil e quatrocentas pessoas, mil e quatrocentos batuqueiros na escadaria da Praça da Sé. Eu tenho várias fotos na escadaria da Praça da Sé. Esses tempinhos atrás aí o Leandro Lehart disse que colocou mil e quatrocentas pessoas num evento que ele fez. Nós colocamos isso em uma manifestação. Pra reivindicar um carnaval melhor pra cidade. O problema da Tiradentes era o monta e desmonta. Ficava muito caro. Era muito trânsito, né? Então a prefeitura arrumou um lugar fixo pra gente mudar... Eu tenho a foto da pedra fundamental do lançamento do Sambódromo. As pessoas meio que apagam o passado, porque hoje não me convidam nem pra passar na porta. Não que eu tô fazendo questão. O importante é a minha escola estar lá. Pra falar a verdade, em vinte anos, depois que eu larguei a presidência da UESP só no ano passado que o Serginho que é o presidente da Vila Maria e da Liga, mandou o convite pra mim $^{104}$.

\footnotetext{
${ }^{102}$ Entrevista Mestre Divino. Data: 15/10/2011.

${ }^{103}$ Lei N 7.100 de 29/12/1967 e Decreto No 9.051 de 12/10/1970.

${ }^{104}$ Entrevista Mestre Divino. Data: 15/10/2011.
} 
Diante deste cenário hostil à Prefeita, das duas entidades carnavalescas e de boa parte das escolas de samba, ela procurou cooptar os sambistas e entidades carnavalescas para sua base de apoio. Sabendo que as lideranças do samba eram muito influentes na periferia da cidade, região prioritária na estratégia política adotada por Erundina, ela aceitou negociar as duas demandas dos sambistas: uma lei que protegesse e garantisse as verbas para o carnaval e a construção do Sambódromo.

Ainda não havia sido definido o local e a prefeita adiantou que este poderia ocorrer em uma área próxima da própria Avenida Tiradentes (Centro) ou em uma área específica dentro do complexo do Autódromo de Interlagos (zona Sul), cujo custo seria menor, pois parte das arquibancadas e a pista já existia. O presidente da Liga, Eduardo Basílio, da Rosas de Ouro, defendia, no seminário, a construção do Sambódromo do Parque Anhembi. Em entrevista à revista Veja, que realizou uma matéria sobre a possibilidade da construção do Sambódromo, Basílio declarou: "Por que não aproveitar o terreno do estacionamento do Anhembi? Já imaginei até um projeto de passarela, que deixaria espaço para estacionar os carros alegóricos nos outros dias do ano" (OLIVEIRA, 2007, p. 80).

A ideia da construção do Sambódromo na zona Norte obviamente beneficiaria Basílio, já que sua escola estava localizada próxima ao parque. A ideia foi bem aceita na administração municipal. Como mostra reportagem publicada no jornal Folha de São Paulo, o presidente da Anhembi Turismo, Paulo Itacarambi, após realizar alguns estudos preliminares sobre os locais mais adequados na cidade para receber o Sambódromo, também sugeriu a área do Parque Anhembi, na zona Norte da cidade, como o melhor lugar para se realizar a construção:

Paulo Itacarambi, presidente da Anhembi, empresa municipal que organiza o Carnaval da Cidade, afirmou que o assunto deve começar a ser discutido ao final de semana e depende de fontes para obtenção de recursos do interesse da população. Ele citou outros locais onde o sambódromo paulistano poderia ser instalado: na área do Parque Anhembi (zona norte) e nas avenidas do Estado e 23 de maio (centro). A vice-presidente da Anhembi, Dulce Pereira, declarou que "conseguimos colocar essa ideia na cabeça da prefeita, mas não sei se vai dar tempo de fazer isso para o ano que vem. O projeto seria viável se pudéssemos contar com a colaboração de uma iniciativa privada" (FOLHA DE SÃO PAULO, 06/02/1989). 
No ano de 1989, portanto a liderança da Liga e o presidente da Anhembi já tinham o Parque Anhembi como o "melhor" lugar para a construção do Sambódromo, mesmo sem levar em consideração que este local não tinha nenhuma ligação histórica com o samba da cidade. No Rio de Janeiro, por exemplo, o Sambódromo foi construído na Avenida Marquês de Sapucaí, no centro da cidade, local que já era utilizado para realização dos desfiles.

Passado o ano inicial de governo, a prefeita Luiza Erundina começava a atender às demandas dos sambistas, ao promulgar, no dia quatro de janeiro de 1990, a lei $\mathrm{n}^{\mathrm{o}} 10.831$, ditando que desfiles e eventos carnavalescos passariam a ser de competência da Prefeitura e parte do calendário oficial da cidade. Esta lei veio substituir o decreto $\mathrm{n}^{\circ}$ 9051, de 12 de outubro de 1970, que não condicionava de forma clara as verbas para o carnaval nem o seu caráter de importância para a cidade. O decreto apenas delegava funções para a Secretaria de Turismo e Fomento através da Paulistur, que foi extinta durante a gestão do prefeito Jânio Quadros, dando lugar à empresa Anhembi Turismo e Eventos, da cidade de São Paulo (CRECIBENI, 2000, p. 44).

A preocupação da prefeita era atender às demandas dos sambistas, mas em conjunto com a Anhembi Turismo procurava meios para que os sambistas não dependessem exclusivamente do dinheiro público para a realização do carnaval e buscar, ao lado das escolas, uma arrecadação de forma mais eficiente, com um maior investimento do setor televisivo e também dos patrocinadores no carnaval. A ideia inicial era realizar parcerias com a iniciativa privada ${ }^{105}$. Esta já era uma diretriz seguida pela administração municipal durante o governo Jânio, que extinguiu a Paulistur e a transformou em Anhembi, a fim de transmitir uma feição mais empresarial e explorar de forma mais eficiente os eventos culturais da cidade, proporcionando maiores lucros para os investidores e menores investimentos por parte da Prefeitura.

No texto da lei promulgada pela prefeita Luiza Erundina, logo no art. $1^{\circ}$, é possível perceber este direcionamento, pois os desfiles são vistos como um evento da cidade,

\footnotetext{
${ }^{105}$ Circular intitulada "Um projeto onde todos ganham", distribuído pela Anhembi Turismo. Pasta Anhembi Turismo 1990. Centro de Documentação e Memória do Samba, AHB, 1990.
} 
realizados sob a gestão da prefeitura ${ }^{106}$. Nesse contexto, já era pensado, segundo Christian Oliveira, (OLIVEIRA, 2007, p.50) como uma forma de agradar aos turistas e como mostram os documentos da Anhembi Turismo, em parceria com as empresas de televisão, que iria patrocinar grande parte do espetáculo.

A Anhembi Turismo formou uma Comissão de Estudos para viabilizar o projeto de construção do Sambódromo e o melhor local de sua execução. Após alguns trabalhos iniciais, constatou-se que o melhor local seria aquele estacionamento de veículos dentro do Complexo do Anhembi. A discussão então seguiu para a Câmara dos Vereadores, onde foram apresentadas propostas de dois vereadores para mudanças dos locais do desfile. No mês de março, o vereador Pedro Dallari, do PT, apresentou a proposta do Executivo de construção no Anhembi, enquanto o vereador Bruno Feder redigiu um projeto paralelo, que indicava uma parte do Campo de Marte, área da Aeronáutica, como o local mais adequado para a construção ${ }^{107}$, pois atendia melhor aos interesses televisivos. Segundo o parecer do vereador:

Visa esta propositura, estabelecer a área municipal denominada de Campo de Marte como o local para a realização dos desfiles das escolas de samba do município de São Paulo (...)

A mudança para o local pretendido, implicará em sensível redução de custos, solucionará definitivamente o caos provocado no trânsito, facilitará o acesso aos sambistas com seus carros alegóricos, como a população em geral, que terá melhores condições para participar dos cortejos de Momo, com segurança e comodidade (...)

Por derradeiro, a nova localização também possibilitará maior cobertura das redes de televisão que para nossa felicidade, agora acreditam na importância e na tradição do carnaval paulista ${ }^{108}$.

\footnotetext{
${ }^{106}$ Lei $\mathrm{n}^{\circ} 10.831$ de 4 de janeiro de 1990. Oficialização do Carnaval na Cidade de São Paulo, e dá outras providências.

Luiza Erundina de Souza, Prefeita do Município de São Paulo usando das atribuições que lhe são conferidas por lei.

Faz saber que a Câmara Municipal, em sessão de 13 de dezembro de 1989, decretou e promulgou a seguinte Lei:

Art $1^{\circ}$ - O Carnaval paulistano, bem assim as manifestações artístico-populares que o compõem, constitui-se em vento oficial da Cidade, com o apoio e sob a gestão da Prefeitura.

Art $2^{\circ}$ - Para efeito desta Lei, são consideradas manifestações artístico-populares, entre outros os concursos, desfies, festas, bailes realizados no período do carnaval, com o apoio e administração da prefeitura (...).

${ }_{107}^{107}$ PL 41 de 06/03/1990. Arquivo da Biblioteca da Câmara Municipal de São Paulo.

108 Idem.
} 
Os dirigentes das federações de carnaval também exerciam pressão na Câmara dos Vereadores para uma rápida aprovação do projeto, mas não viam o Campo de Marte como um bom local para os desfiles, assim como a Prefeitura que não queria entrar em disputa e compra da área que pertencia a Aeronáutica. Para justamente ganhar mais força política, uma das estratégias dos sambistas era pressionar os vereadores que haviam sido eleitos com o apoio das escolas de samba, em seus respectivos bairros. Mas como o momento econômico era muito ruim, em razão da inflação galopante, os vereadores temiam uma reação negativa da população ao destinar uma soma tão grande de dinheiro público na construção de algo que beneficiaria uma pequena parte da população (OLIVEIRA, 2007, p. 83).

Esta postura dos vereadores era compreensível, principalmente após as consequências para a população do famigerado Plano Collor. Nesse mês de discussão do projeto na Câmara (março de 1990), o presidente Fernando Collor de Mello tomou posse como presidente e anunciou seu plano econômico, chamado de Plano Collor, com o objetivo de controlar a inflação e conter os gastos públicos. Dentre as medidas tomadas pelo presidente estava o congelamento dos salários e o confisco do dinheiro das contascorrentes e cadernetas de poupança durante 18 meses.

Como forma de garantir um apoio popular ao projeto, o secretário de governo, José Eduardo Martins Cardozo, declarou à população que os investimentos públicos no Sambódromo paulista seriam menores do que os realizados na construção do seu homônimo da cidade do Rio de Janeiro, e que a Prefeitura buscaria parcerias com empresas privadas para viabilizar a obra e tudo seria feito mediante licitação pública. Esta informação era para tranquilizar parte do legislativo municipal e o Tribunal de Contas do Município, que não havia concordado com os gastos e com a contratação de empresas sem licitação que havia sido feita em outra obra da Prefeitura na cidade, a reforma do Autódromo de Interlagos, a fim de trazer a Fórmula 1 de volta à cidade. Nas palavras do próprio Cardozo: "O Sambódromo paulista será mais simples que o do Rio, e a participação das empresas na construção (com direito a troca de publicidade e direito de transmissão será feito com licitação)" (FOLHA DE SÃO PAULO, 31/03/1990). 
A viabilização do Sambódromo foi realizada de fato após a doação do projeto para a cidade feito pelo arquiteto Oscar Niemeyer. Pelo desenho do projeto e suas dimensões, o Campo de Marte e outras regiões da cidade foram descartadas e optou-se por construí-lo no estacionamento oeste do Parque Anhembi. O Instituto de Arquitetos de São Paulo se posicionou contra a realização da obra de forma tão acelerada e sem uma discussão mais profunda com a comunidade. As justificativas dadas pela Prefeitura de que o Sambódromo de São Paulo custaria menos que o do Rio de Janeiro ou que o projeto arquitetônico seria doado por Niemeyer não poderia ser colocado acima dos resultados finais desejados. O Sambódromo não seria um espaço utilizado para os sambistas e pelos sambistas, mas um modelo paradoxal no qual deveria atender aos sambistas, mas que pertence à Prefeitura e é utilizado segundo os critérios adotados por ela nos outros 361 dias do ano (OLIVEIRA, 2007, p. 85).

Mesmo com as críticas dos arquitetos e de parte do legislativo municipal, as obras tiveram início, precisamente, em 10 de novembro de 1990 e o Polo de Arte e Cultura da Cidade de São Paulo foi inaugurado no Parque Anhembi, na zona Norte da cidade, de forma provisória, já no carnaval de 1991. Havia apenas a pista, com pouca estrutura, mesmo assim, os sambistas desfilaram pela primeira vez no Sambódromo, ainda que de forma precária. O jornal Folha de São Paulo, uma semana antes do desfile, trouxe a seguinte manchete: "Erundina inaugura Sambódromo em obras e com alagamento". A reportagem alertava que as obras estavam incompletas e, caso houvesse chuvas, com certeza a pista alagaria, pois, no dia anterior, ela estava alagada e o sistema de ralos e escoamento de água estava entupido com entulho. Os problemas não tiraram o entusiasmo dos sambistas. Seu Nenê da Vila Matilde demonstrava que estava satisfeito com o andamento das obras: "O local é ideal para o samba. Se chover, vamos enfrentar os mesmos problemas que tínhamos na Avenida Tiradentes" (FOLHA DE SÃO PAULO, 02/02/1991).

A justificativa para sua construção de maneira tão rápida era defendida principalmente pelos sambistas vinculados à Liga, pois a ideia era acabar com os transtornos para o trânsito da região da Avenida Tiradentes, que ficava cerca de dez dias interditadas, e os altos custos para montagem e desmontagem das arquibancadas (FOLHA 
DE SÃO PAULO, 15/02/1990). Este argumento é muito próximo ao utilizado pelos sambistas cariocas para a construção da passarela fixa no Rio de Janeiro, inaugurada em 1984 durante o mandato de Leonel Brizola, sob o comando do vice-governador, o antropólogo Darcy Ribeiro. Outro ponto era o prestígio que as escolas adquiriam dentro da cidade com um local construído especialmente para os desfiles. Mas ao contrário da construção carioca, que ao longo do ano funcionava como escola, chamada CIEPS, e utilizava seus camarotes como salas de aula (com 210 salas ao todo), o Sambódromo paulista, desde sua origem, é utilizado apenas para a realização dos desfiles e esporadicamente para eventos de entretenimento.

Após os desfiles do carnaval de 1991, teve início a segunda fase da Construção do Sambódromo, já batizado pela Anhembi Turismo como Polo de Arte e Cultura. Nesta parte foram construídas as arquibancadas de concreto ao lado da pista da Marginal Tietê. As arquibancadas de concreto possuem oito degraus, com três metros de altura e 500 metros de extensão, com capacidade para cerca de 10 mil espectadores. Ao lado da Avenida Olavo Fontoura foram montadas as tradicionais arquibancadas em estrutura tubular (dez módulos com capacidade para aproximadamente 11 mil pessoas) ${ }^{109}$. A empresa entregou as arquibancadas uma semana antes do carnaval, ao custo de 500 mil dólares. O total gasto do início das obras até a conclusão da segunda fase do Sambódromo, segundo a Anhembi Turismo, era de 1,3 bilhão de cruzeiros. Além da arquibancada de alvenaria, a Prefeitura investiu em um novo sistema de drenagem, devido aos alagamentos ocorridos no carnaval anterior, em rede elétrica, telefonia, cronometragem e urbanização da área em volta do Sambódromo ${ }^{110}$.

A montagem das arquibancadas tubulares, mesmo após a construção de uma parte de alvenaria, se deu pela indefinição da Câmara dos Vereadores, que precisava aprovar uma mudança na Lei de Zoneamento da região da Avenida Olavo Fontoura, que impedia a construção de arquibancadas definitivas. Como o governo Erundina não tinha uma maioria sólida, a oposição trancava a pauta da Câmara dos Vereadores, não permitindo a

\footnotetext{
${ }^{109}$ Relatório do Carnaval. 1992. Realizado pela Anhembi Turismo. Pasta Anhembi Turismo 1992. Centro de Documentação e Memória do Samba, AHB, 1992.

110 Documento Anhembi Informa. Sinopse de Imprensa. Pasta Anhembi Turismo 1992. Centro de Documentação e Memória do Samba, AHB, 1992.
} 
aprovação imediata de projetos de interesse do Poder Executivo. A Lei de Zoneamento é referente ao planejamento urbano da cidade, regulamentando o uso e a ocupação dos terrenos para todo tipo de construção. A primeira legislação desse tipo em São Paulo surgiu em 1973, quando o então prefeito Figueiredo Ferraz lançou o primeiro Plano Diretor sob o discurso de que São Paulo deveria parar de crescer desordenadamente. Com esse plano, em algumas regiões da cidade só poderiam ocorrer obras e modificações com a aprovação do município.

Havia ainda neste projeto a construção de dois fossos laterais, separando as arquibancadas da pista de desfile. Um arquiteto ligado à escola de samba Vai-Vai percebeu a gravidade e os perigos de acidente que poderiam ocorrer com a construção deste fosso. Ele entrou em contato com a professora Olga von Simson, acadêmica estudiosa do carnaval paulistano, com bom trânsito entre as escolas de samba e lhe apresentou o projeto. Ambos convocaram uma reunião com as lideranças da Liga, a fim de orientá-las a pedir uma mudança na proposta do arquiteto Oscar Niemeyer para o Sambódromo paulista. Após uma negociação das lideranças do carnaval com a Prefeitura, com a Anhembi Turismo e desta com o escritório do arquiteto, o projeto do fosso foi substituído pela construção de um setor de mesas e cadeiras no local de separação entre as arquibancadas e a pista de desfile. A solução agradava aos sambistas e também a Anhembi, que ganhava a possibilidade de exploração de um novo setor para espectadores, com preços obviamente menores que os camarotes, que são cobertos e contam com uma infraestrutura melhor, mas superiores aos da arquibancada, pelo fato de ser o local mais próximo da pista $^{111}$.

Após a definição do projeto e dos prazos para a construção do Sambódromo, os dirigentes das escolas de samba continuaram a pressionar o poder público para a realização de uma nova divisão de receitas entre a Anhembi Turismo e a Liga em 1992. No ano anterior, a divisão do total arrecadado com a bilheteria do Sambódromo havia sido $50 \%$ para as escolas de samba e 50\% para a Anhembi Turismo. Após diversas rodadas de negociação e com a promessa de realizar o "melhor carnaval da história de São Paulo" (O ESTADO DE SÃO PAULO, 02/02/1992), os sambistas conseguiram

${ }^{111}$ Entrevista com Olga Rodrigues de Moraes von Simson. Data: 29/11/2011. 
fechar um excelente contrato. Nele estava definido que as escolas de samba ficariam com 90\% do total arrecadado da bilheteria e a Anhembi Turismo apenas com 10\%. Depois de ter conseguido o novo acordo com a Prefeitura, as escolas passaram então a pressionar o governador do Estado para liberação de mais recursos a serem aplicados no carnaval. Em uma audiência com o governador Luiz Antônio Fleury Filho, o presidente da Liga, José Júlio Teixeira Filho, pediu CR \$ 1,6 bilhão de incentivos para as escolas, demonstrando claramente a pressão das escolas no poder público e deu um recado claro para o governador de que queria o dinheiro "para anteontem" (O ESTADO DE SÃO PAULO, 02/02/1992).

O governador Fleury, após se reunir com diversos secretários, negou inicialmente liberar qualquer quantia em dinheiro para as escolas sob a justificativa de que estes gastos não estavam previstos no orçamento. Os sambistas não ficaram satisfeitos e passaram a se posicionar publicamente contra o governador, acusando-o de boicotar o carnaval da cidade. Em ano eleitoral, a saída encontrada pelo governador foi o Banespa, Banco do Estado de São Paulo, entrar como patrocinador dos desfiles, contribuindo com Cr\$ 360 milhões em troca de placas de publicidade no Sambódromo. O presidente da Liga, Júlio Teixeira Filho, declarou, em entrevista ao jornal Diário Popular, que, apesar de conseguir apenas $20 \%$ do valor pretendido, ficou satisfeito com o empenho do governo do Estado em patrocinar os desfiles. Segundo ele, o custo das 76 escolas de samba e dos 32 blocos carnavalescos ficou em Cr\$2,06 bilhões em 1992. E “como a prefeita Luiza Erundina contribuiu com $\mathrm{Cr} \$ 404$ milhões, ficou faltando, para cobrir o custo, $\mathrm{Cr}$ \$ 1,6 bilhão. $\mathrm{O}$ ideal seria que o Estado e Prefeitura cobrissem o custo total, mas eles contribuíram com o que puderam e nós estamos satisfeitos" (DIÁRIO POPULAR, 04/02/1992).

Com a declaração do presidente da Liga é possível perceber que os dirigentes viam apenas o poder público como canal de financiamento dos desfiles. Após as contas não fecharem e as escolas terem que buscar financiamento próprio para conseguir se apresentar de maneira competitiva na avenida, passaram a pressionar os canais de televisão que transmitiam os desfiles. As emissoras de rádio e a imprensa escrita apenas cobriam os desfiles, não realizando nenhum pagamento para as escolas. A ampliação dos gastos das escolas e a necessidade criada pela mídia da realização de um desfile cada vez 
mais grandioso e luxuoso gerou uma defasagem que impediu que os desfiles se tornassem economicamente viáveis.

Os dirigentes paulistanos buscam integrar-se a essa dinâmica da indústria cultural. Esta coopta a manifestação cultural popular com o objetivo de incorporá-la à cultura dominante, já inserida no mercado de consumo. Mas o carnaval paulistano estava, nesse momento, em uma espécie de transição. Há tempos deixara de ser uma festa espontânea, mas ainda não se tornara um evento turístico ou de entretenimento economicamente viável que se paga apenas com a venda de ingressos e verba de patrocinadores privados, necessitando de dinheiro público para cobrir grande parte de seus gastos.

Porém, em 1993, o governo do Estado liberou uma quantia dez vezes maior: Cr\$ 3,97 bilhões, que foram repassados pela Secretaria de Esportes e Turismo do Estado às entidades carnavalescas. Mais uma vez o poder público estava pressionado pelos sambistas, que viam os custos do carnaval aumentar pela alta inflação do período. A verba foi dividida em Cr\$2,45 bilhões para a Liga, Cr\$ 1,30 bilhão para a UESP organizar o carnaval das escolas dos grupos inferiores e dos blocos especiais e $\mathrm{Cr} \$ 221$ milhões para a Associação das Bandas Carnavalescas de São Paulo para a promoção de eventos com as bandas carnavalescas da cidade. Valor semelhante foi distribuído pelo governo para promoção dos desfiles carnavalescos no interior do Estado. Foram distribuídos Cr\$ 4,2 bilhões para as 44 cidades classificadas como Estância Turística ${ }^{112}$.

Os dirigentes pensaram que as verbas oriundas do governo do Estado e do Banespa se tornariam uma fonte fixa de entrada de recursos, assim como as verbas da Prefeitura. Com o término do mandato de Luiz Antônio Fleury Filho, assumiu o governo do Estado Mário Covas, do PSDB, eleito no ano anterior. Covas, que já havia sido prefeito de São Paulo e estabelecido uma boa relação com os sambistas, no início de seu mandato como governador, estabeleceu o fim dos gastos com o carnaval da cidade de São Paulo, destinando apenas parcos recursos para a realização do carnaval das cidades classificadas como Estância Turística, a título de fomento ao turismo.

${ }^{112}$ Pasta Anhembi Turismo 1993. Centro de Documentação e Memória do Samba, AHB 1993. 
Os dirigentes das escolas pequenas, que dependiam unicamente da verba oficial para realizar seus desfiles, ficaram descontentes. Todas as escolas e blocos filiados à entidade vieram com faixas em protesto à falta de recursos para a realização dos desfiles carnavalescos de 1995. Algumas delas eram pretas, símbolo de luto, e outras mais irônicas, como uma que estava escrito “Obrigado Maluf”. Uma das escolas apresentou um carro intitulado "Carro dos Sonhos" como resposta ao posicionamento do governador, que estaria "acabando com os sonhos" dos sambistas pobres. Para Robson de Oliveira, presidente da UESP, o carnaval da entidade foi:

\begin{abstract}
Uma festa pobre de brilho e luxo por falta de verba suplementar da Prefeitura e por parte do Governo do Estado, que não deu um centavo para o carnaval. No entanto, se vem pobre as fantasias e alegorias vem rico no samba no pé e criatividade dos sambistas, já que todos não estão medindo esforços para apresentar um grande espetáculo e mostrar para os governantes que o samba não vive de ilusão ou joguinho de empurra-empurra (HORA DO POVO, 24 e 28/02/1995).
\end{abstract}

Se as escolas de samba recebiam verbas do poder público, dos patrocinadores e da televisão, todas buscavam maneiras de tornar os desfiles mais atrativos para suas demandas. O poder público estava interessado em tirar proveito político dos desfiles e os patrocinadores e a televisão em divulgar suas marcas e lucrarem economicamente com o espetáculo. No carnaval de 1994, o então presidente da Liga, Sólon Tadeu Pereira, inovou chamando diversas pessoas famosas, como atores e atrizes, cantores populares e celebridades para serem jurados dos desfiles carnavalescos. Esta decisão mostra como os sambistas não tinham uma ideia clara de como conciliar seus interesses aos da indústria cultural. Concluíram que ganhariam mais visibilidade trazendo jurados "VIPs" para avaliar a disputa. Se, no início, quando foi anunciada a proposta, já gerou polêmicas e divergência entre os sambistas, após a apuração se transformou em revolta contra o presidente da Liga, que pediu demissão após o episódio. Criou-se nesse ano duas modalidades de júri. Um júri técnico e outro "artístico". Ao contrário dos jurados técnicos, que normalmente possuem ligação com as escolas, ficavam em cabines de madeira, tomando chuva e se preparavam para julgar os desfiles em cursos promovidos 
pelas próprias entidades, os jurados "VIPs" tiveram, na ocasião, todos os privilégios possíveis: ficaram em camarotes especiais com bebida (alcoólica) e comidas disponíveis. Este pequeno gesto evidencia que, com o crescimento dos desfiles e das escolas de samba - e estas passaram a ganhar cada vez mais destaque nos meios de comunicação até a possibilidade das transmissões televisivas integrais dos desfiles no início dos anos 1980 —, criou-se uma falsa ideia de que "qualquer um" entende de carnaval. Todos assistiam aos desfiles, estavam familiarizados com termos e com a estrutura dos desfiles e, portanto, estavam aptos a dizer qual escola foi melhor. Processo semelhante ao que acontece com o futebol, do qual o Brasil possui 200 milhões de treinadores.

O sentimento de revolta entre as escolas foi maior porque dois anos antes, em 1992, a entidade formatou e promoveu um curso para preparação de jurados. Na ocasião, a entidade constituiu uma comissão de sambistas de várias escolas, que se juntou em um seminário e elaborou um livro contando brevemente a história do samba paulista, do carnaval na cidade e, principalmente, esclarecendo os quesitos e os parâmetros de balizamento para os jurados. Os autores do livro e do curso sentiram-se prejudicados pelo esforço feito para a formação de jurados, porque esses só foram utilizados em um carnaval.

Com algumas exceções, como a do compositor Paulo Moura, a maior parte dos famosos não tinha conhecimento mínimo para julgar quesitos técnicos. Muitos simplesmente não deram notas para as escolas, ou, como aponta o jornal Hora do Povo, "não estavam sóbrios quando algumas escolas desfilaram" (HORA DO POVO, 23/02/1994). Como forma de protesto, no dia do desfile das campeãs a escola de samba Leandro de Itaquera apresentou um carro alegórico, com cerca de 30 componentes, representando os jurados "VIPs" completamente bêbados e sonolentos. E os diretores da Gaviões da Fiel desfilaram com nariz de palhaço contra as notas que não foram atribuídas.

O processo de substituição dos jurados nesse ano foi semelhante ao que aconteceu ao longo da década de 1980 e 1990, com a substituição de sambistas anônimos por pessoas famosas nos lugares de destaque dos desfiles. A entrada dos jurados "VIPs" e a 
ocupação total dos espaços simbólicos do carnaval por pessoas estranhas representam a realidade das escolas de samba. O sambista, que vinha num processo crescente de exclusão, não pode nem consumir e julgar a sua própria arte que é consumida e também julgada por outros. Com isso, o carnaval, que se constitui essencialmente como festa da inversão, não cumpre mais a sua essência. Ao vestir as máscaras e fantasias durante o carnaval, o sambista busca justamente o contrário da vida cotidiana. É o triunfo de uma espécie de liberação temporária da verdade dominante e do regime vigente, de abolição provisória das relações hierárquicas, privilégios, regras e tabus (BAKHTIN, 2000, p. 89). Para Roberto Da Matta, a ruptura da festa não acaba com as hierarquias nem com a desigualdade social, mas a irreverência do carnaval permite uma relação mais livre e menos fatalista com o status quo (DAMATTA, 1996, p. 30). As configurações dos desfiles carnavalescos na lógica empresarial não cumpre esta inversão característica, vista por Bakhtin, nem permite hierarquias e relações mais livres, segundo Da Matta. Os sambistas que sempre tiveram o sonho de "se sentir rei por um dia", como diz Mestre Gabi, já não o são, pois os meios de comunicação dão destaque apenas para o que acontece em seu próprio meio.

Esta leitura é visível na leitura das entrevistas realizadas no âmbito desta dissertação. Marcos dos Santos, fundador da escola de samba Tom Maior, diz:

Desfilar em escola de samba é sinônimo de status. Ainda mais que aparece na Rede Globo, fora à invasão dos artistas que eu acho uma aberração que a própria escola de samba faz consigo mesma, uma falta de autoestima. Porque rainha de bateria e congêneres eu acho que tem que sair da comunidade. Eu tenho certeza que os grandes artistas, o grande elenco é a comunidade, era a única vez que a pessoa comum se sentia artista, todo mundo virava artista no carnaval, isso era muito bom. Hoje os verdadeiros artistas são os atores mesmos, o sambista virou coadjuvante desses artistas que tem destaque na passarela, o sambista virou coadjuvante desses artistas principais que são da televisão. Não existe mais aquela coisa romântica de o sujeito simples ser rei, artista por um dia que era muito legal para autoestima da comunidade ${ }^{113}$.

Essas novas posturas geram um sentimento de deslocamento, principalmente nos sambistas mais antigos que vivenciaram outras relações humanas e profissionais dentro

${ }^{113}$ Entrevista com Marcos dos Santos. Data: 10/08/2010. 
do carnaval. Como mostra Marcos dos Santos em todo o seu depoimento, os membros de sua geração se sentem coadjuvantes dentro de suas escolas de samba.

Na mesma linha de análise de Marcos, há o depoimento de Jamelão, intérprete nonagenário da escola de samba "Mangueira". Ele destaca essa intervenção no modelo de apresentação das escolas: estas devem seguir o modelo imposto pelo canal de televisão que transmite o desfile, como parte de um processo de negociação que trouxe perdas e ganhos. A televisão levou o desfile para o horário nobre, mas ditou as novas regras. Algumas absurdas, como a de que uma escola de samba do Grupo Especial desfile com 4000 componentes em uma hora, prejudicando completamente qualquer manifestação artística.

Hoje as escolas de samba têm um lugar certo de desfile, vai para o Sambódromo, fica uma coisa mais certa mais correta com horário, mas o que acontece lá no Rio é que tem um horário marcado e o samba tem que acabar naquela hora certa enquanto eles poderiam deixar a escola desfilar mais a vontade não naquela correria porque é uma correria para marcar hora certa porque a televisão quer. Hoje o samba sofre as consequências de ter se encostado com a televisão. A escola tem que fazer tudo que a televisão quer para receber. A escola de samba na televisão não é nada daquilo que é na avenida, eles apresentam uma figura aqui outra ali um porta-bandeira, mas o que acontece ao vivo pela televisão não é sentido como na avenida, você vê coisas aí que em casa no sofá você não vê. Infelizmente o samba está entregue a televisão São eles que mandam, determinam, mas tudo bem, como diz o outro é o moderno ${ }^{114}$.

A construção do Sambódromo, com tanto dinheiro público empregado, levanta algumas questões: por exemplo, como uma diversão anual inicialmente envolvendo negros das baixas classes sociais conseguiu construir um lobby, organizar lideranças e conseguir do poder público, a construção de um local fixo para os desfiles? O interesse do poder público, no contexto da ditadura militar, em controlar manifestações que ocorriam nas ruas, a organização dos sambistas em entidades como a UESP e a Liga, a

\footnotetext{
114 Entrevista de José Bispo Clementino dos Santos, popularmente conhecido como Jamelão. Data: 06/01/2006.
} 
força das escolas de samba nas comunidades e bairros e, por fim, a presença da indústria cultural e do capital possibilitaram o desenvolvimento e o lobby das escolas de samba.

Com o Sambódromo está garantida a manutenção do carnaval das escolas de samba por anos a fio. A construção desse espaço fixo para os desfiles carnavalescos representou o que podemos chamar de "metropolização" de uma cultura tida como provinciana (OLIVEIRA, 2007). O espaço destinado aos seus eventos não é mais a avenida (espaço público), mas um espaço privado, de cunho mercantil, com fins lucrativos e politicamente centralizado, pelo fato de ser uma passarela definitiva.

Nestor Garcia Canclini, ao analisar o processo de transformação das culturas populares na América Latina, faz o seguinte questionamento: “É preciso perguntar-se agora em que sentido e com quais fins os setores populares aderem à modernidade, buscam-na e misturam-na a suas tradições?" (CANCLINI, 2011, p. 205). Podemos aplicá-lo no caso das escolas de samba paulistanas. Com quais fins os sambistas aderiram a esse processo de transformação nos desfiles carnavalescos para atender às suas necessidades e demandas? Ao negociar com o poder público por mais de duas décadas, os dirigentes das escolas de samba conseguiram não apenas o reconhecimento e o financiamento de suas atividades de lazer, objetivo inicial, como conseguiram que seus desfiles se tornassem oficiais e hegemônicos dentro das festividades carnavalescas, com a construção de um espaço na cidade construído especificamente para este fim.

Segundo Canclini, "a preservação pura das tradições não é sempre o melhor recurso popular para se reproduzir e reelaborar sua situação" (CANCLINI, 2011, p. 236). A maior visibilidade e as transformações das escolas de samba no Brasil estão inseridas em um fenômeno de alcance global de valorização e modificação de atividades folclóricas por parte do Estado e da indústria cultural. Elas funcionariam como agentes de inovação, que as modifica com o objetivo de transformá-las em cultura de massa, para serem consumidas por um maior número de pessoas e gerar retorno financeiro. As escolas de samba - que tinham ganhado difusão e legitimidade social através da ação do Estado e dos meios de comunicação de massa, inicialmente o rádio e o cinema, e posteriormente com a televisão e na atualidade a internet - se reinventaram em virtude de um novo público de classe média que passou a participar das escolas de samba. São 
pessoas que não necessariamente frequentam a quadra da escola e seus eventos, não participam da comunidade em que a escola está inserida, mas participam somente do "grande ato" que são os desfiles. E pagam por isso.

Se por um lado essas transformações deixam os membros das Velhas Guardas desconfortáveis e sem uma voz ativa para enfrentar esse processo de modernização e de feição empresarial dentro das escolas, por outro foram importantes para legitimar novas lideranças que deram continuidade e conseguiram a ampliação dos folguedos e também atraíram novos recursos para eles, que são investidos na própria escola e no pagamento de todos que contribuíram profissionalmente para a confecção e execução dos desfiles.

A visão de desfile da Liga, mais integrada a uma visão empresarial, conseguiu realizar esse novo tipo de desfile carnavalesco, consolidando um processo que ocorria desde a oficialização, chamado por Olga von Simson de "carnaval-show-mercadoria", pois era produzido pelos sambistas, com a mediação da indústria cultural para ser consumido no país e no exterior. O carnaval rentável não é uma festa popular e folclórica promovida por negros e pobres, mas uma apresentação grandiosa e mercadológica, transmitida pela TV em grandes pistas fixas, com milhares de pessoas nas arquibancadas apenas assistindo ao grande espetáculo, enterrando de vez o carnaval participação oriundo da época dos cordões em que o "brincar e o divertir-se que também estavam integrados à apresentação da agremiação carnavalesca, havia deixado de existir" (SIMSON, 2007 p. 366).

Como os desfiles se tornaram cada vez maiores, mais luxuosos e disputados, as escolas também procuraram novas estratégias de crescimento, desenvolvimento, obtenção de recursos, tendo a diretoria da escola adotado uma postura cada vez mais empresarial. Atualmente, a estrutura organizacional de uma escola de samba é semelhante à de uma empresa de médio porte, contando com presidente, vicepresidente, diretor de carnaval, coordenador-geral, carnavalesco, assessores, secretários, coordenadores de projetos, relações públicas, tesoureiro, diretor-geral e de finanças, departamento cultural, social, de marketing, de patrimônio, diretor de barracão, mestre de bateria e diretores de bateria, chefes de ala, dentre outros, como operários (ferreiros, 
marceneiros, escultores, vidraceiros, etc.), que compõem a rede de pessoas envolvidas em uma escola de samba.

Antes mesmo do final de todas as obras previstas no projeto do Sambódromo terminar, a Prefeitura já queria "se livrar" do Sambódromo privatizando-o. No ano de 1995, além do Sambódromo, o prefeito Paulo Maluf queria, através de um projeto de lei, ceder para particulares os principais palcos de eventos administrados pelo Estado. O projeto elaborado por técnicos do Executivo previa a concessão do estádio Paulo Machado de Carvalho, popularmente conhecido como Pacaembu, por 40 anos e de todo o Complexo do Anhembi, incluindo o Palácio das Convenções, o Palácio de Exposições, estacionamento e o Sambódromo. Os custos de manutenção e de finalização das obras seriam pagos pela iniciativa privada que deveria ficar com $65 \%$ dos lucros obtidos pela exploração dos espaços, ficando os $35 \%$ restantes com a Prefeitura.

O secretário municipal do Planejamento, Roberto Paulo Ritcher, afirmava que, ao transferir para a iniciativa privada os "elefantes brancos", a Prefeitura iria economizar, pois, segundo ele, esses espaços traziam prejuízos aos cofres públicos. Com a privatização, a Prefeitura deixaria de investir aproximadamente $\mathrm{R} \$ 10$ milhões por ano em obras, financiamento de projetos e carnaval e com o Fundo Municipal de Turismo. O jornal $O$ Estado de São Paulo defendia abertamente a privatização, com o argumento de que a Prefeitura não conseguia manter a estrutura adequadamente:

\footnotetext{
Um jovem de 25 anos com cara de 100. E mais ou menos assim que o Parque Anhembi comemora, hoje, um quarto de século desde a sua inauguração com o Salão do Automóvel, em 1970. Sem investimentos em manutenção e expansão, o quinto maior centro de eventos do mundo não consegue mais atender a demanda. Várias feiras têm de ser recusadas por falta de espaço. Há goteiras, déficit na rede elétrica, sujeita a sobrecargas, piso irregular, estrutura de serviço ruim.

São tantos problemas que a Prefeitura quer se livrar do Anhembi. O projeto de privatização está na Câmara. O sambódromo não seguirá o mesmo plano. Para deixar de ser um monstro ocioso fora do carnaval, ele deve ser palco de shows para 10 mil pessoas com a entrega da arquibancada monumental, em janeiro.
}

Segundo o secretário do Planejamento, que acumula a pasta da Saúde, Roberto Paulo Ritcher, a concorrência será nacional e internacional. Ele acredita que será possível lançar a licitação em fevereiro ou 
março. "Temos vários grupos estrangeiros querendo investir no Anhembi” (O ESTADO DE SÃO PAULO, 20/11/1995).

O prefeito tinha ainda a intenção de extinguir a empresa Anhembi e criar uma nova com uma estrutura menor, semelhante à extinta Paulistur. Segundo o secretário, com sua visão liberal e privatista, a única função a ser desempenhada pelo Estado era a de fomento e divulgação dos principais eventos da cidade, como a Fórmula 1 e o Carnaval (O ESTADO DE SÃO PAULO, 05/06/1995).

A privatização não conseguiu se realizar devido à oposição das federações de carnaval, UESP e Liga, e dos vereadores da cidade. Para os vereadores, as festividades populares, como o carnaval, poderiam ficar sem o apoio necessário para sua realização e o estádio poderia ser descaracterizado. O líder da oposição, vereador José Eduardo Martins Cardozo, ex-secretário de Governo na gestão anterior de Luiza Erundina e um dos interlocutores da construção do Sambódromo, disse que o projeto era absurdo e lutou com o apoio de outros partidos, como o PMDB e o PSDB, para sua derrubada. Segundo Cardozo: "A partir do momento que a Prefeitura transfere essas administrações para a iniciativa privada, a cidade perde dois equipamentos importantes para a realização da política de esporte, lazer e recreação. O Anhembi não é usado apenas para feiras e exposições, mas tem uma função social como o empréstimo de aparelhos para festas populares organizadas por associações de bairro" (O ESTADO DE SÃO PAULO, 05/06/1995). Outro argumento que prejudicava os defensores da privatização foi o apurado pelos vereadores. Ao contrário do que dizia o jornal O Estado de São Paulo, não havia prejuízo, mas o lucro estimado do Complexo do Anhembi para o presente ano era de R \$ 3,9 milhões. O calendário de feiras estava lotado até 1997 e 15 dias de aluguel no Palácio de Exposições, de 67 mil metros quadrados, não custavam menos que 690 mil dólares.

A privatização afetaria diretamente as escolas de samba. A preocupação dos dirigentes das federações era com a diminuição de seus recursos e uma limitação de sua atuação. A Liga recebia 90\% do total arrecadado com a venda de ingressos do carnaval. Com a privatização teria que ser feito um novo acordo com a concessionária e obviamente 
seria menos vantajoso para os sambistas. Para Robson de Oliveira, então presidente da UESP, o governo agia com autoritarismo ao submeter um projeto dessa magnitude sem escutá-los. Assim que foi divulgado o projeto de lei da privatização, Oliveira convocou uma reunião com 110 entidades carnavalescas, entre escolas e blocos filiados à UESP, e se posicionaram contra o projeto, solicitando uma audiência com o prefeito. Após a oposição de sambistas e vereadores e a derrubada do projeto, o Executivo desistiu de enviar projeto substitutivo e manteve o estádio do Pacaembu e o Complexo do Anhembi, sob sua administração (O ESTADO DE SÃO PAULO, 07/06/1995).

Como a Liga ficava com $90 \%$ do total arrecadado da bilheteria, ela estipulou os preços do carnaval de 1995. E para cobrir os gastos com o carnaval, houve um aumento de $841,74 \%$ em relação ao ano anterior. A justificativa para tamanho aumento foi a conversão da antiga moeda, cruzeiro real, para a atual, o real, e ao aumento dos custos. Para ele, o material utilizado para a confecção de alegorias e carros subiu muito. No ano passado, cada agremiação do Grupo Especial gastava, em média, 60 mil dólares. Hoje gasta de R\$ 700 mil a 1 milhão" (DIÁRIO POPULAR, 03/02/1995). Mesmo a preços exorbitantes, os 22 mil ingressos foram vendidos. Muitos reclamaram do preço do ingresso, pois o mais barato custava $\mathrm{R} \$ 20,00$, cerca de $30 \%$ do valor do salário mínimo de $\mathrm{R} \$ 70,00$ na época. Obviamente, o presidente da Liga exagerava e muito, já que o câmbio da época estava congelado e um real equivalia a um dólar. Com essa medida, há uma nova exclusão dos sambistas pobres. Se para participar dos desfiles das escolas do Grupo Especial custava muito caro, ser apenas espectador também passa a representar um gasto que muitos não podem assumir. $\mathrm{O}$ objetivo era atrair turistas e pessoas mais abastadas, não o sambista pobre que quer participar, assistir, mas o faz apenas pela televisão. Para essas pessoas estão reservados os desfiles dos grupos inferiores, que ainda são realizados em avenidas da cidade com cobranças simbólicas ou distribuição gratuita de ingressos.

Um fato mais grave ainda e que mostra a exclusão dos sambistas dentro do Sambódromo eram os "penetras de carteirinha". No ano em que os ingressos aumentaram mais de $800 \%$, cerca de quatro mil pessoas assistiram aos desfiles sem pagar, apenas com credenciais e "carteiradas" oficiais. Ao contrário do espaço público, no espaço do 
Sambódromo aqueles que entravam sem pagar eram servidores públicos. Para o diretor de infraestrutura do Anhembi, José Pedro Elmadjian Sobrinho: "Houve um abuso de credenciais e carteiras de políticos, policiais militares, oficiais de justiça e outros" (O ESTADO DE SÃO PAULO, 30/01/1996). A saída encontrada pelos organizadores foi a implementação de cartões magnéticos e catracas eletrônicas, além de controlar e estipular a validade de credenciais oferecidas a prestadores de serviço.

Christian Oliveira traz a analogia de que a construção do Sambódromo não representa a "casa do sambista", mas o "túmulo do samba", pois não é permitido ao pobre o acesso ao local nos dias de desfile, pelo preço dos ingressos e fantasias e porque nos demais dias do ano não há nenhuma outra atividade ligada ao samba, com exceção dos ensaios técnicos das escolas, mas também inseridos no contexto dos desfiles (OLIVEIRA, 2007, p. 144).

As obras do Sambódromo terminaram definitivamente em 1996, pelo então prefeito Paulo Maluf, que inaugurou o Polo Cultural e Esportivo Grande Otelo. Contou com um investimento municipal muito maior que o previsto no contrato de licitação pública, inclusive com a contratação de diversos serviços de emergência, que dispensa processo licitatório $^{115}$, modelo seguido por muitas obras da gestão de Maluf à frente da Prefeitura. Recentemente, o ex-prefeito foi condenado pela justiça das Ilhas Jersey, paraíso fiscal próximo ao Canal da Mancha, a devolver para os cofres públicos R $\$$ 57,9 milhões referentes a desvios e superfaturamento em obras de sua gestão como prefeito da cidade. O maior montante desviado foi da obra da Avenida Água Espraiada, atual Jornalista Roberto Marinho (FOLHA DE SÃO PAULO, 19/01/2013).

Ainda houve uma última tentativa de se desfilar pelas ruas da cidade. Em 1996, após a apuração do carnaval, as escolas de samba mais bem classificadas do Grupo Especial e do Grupo I desfilaram em diversos locais da cidade. Foi uma tentativa de aproximar as escolas de samba do grande público. A escola Gaviões da Fiel desfilou na Avenida dos Metalúrgicos, na Cidade Tiradentes. O público compareceu e nem esperou a apresentação acabar para se misturar aos passistas durante o desfile. A Polícia Militar,

\footnotetext{
${ }^{115}$ Pasta Anhembi Turismo 1992. Relatório do Carnaval. 1992. Centro de Documentação e Memória do Samba, AHB 1992.
} 
percebendo que o cordão de isolamento feito por ela foi rompido, soltou então bombas de gás lacrimogênio para dispersar a multidão. Segundo o jornal Diário Popular: "Um gás, de cheiro forte, asfixiante e efeito lacrimejante, tomou conta do ambiente. As pessoas ficaram desorientadas e caíram no chão. Integrantes da Gaviões gritavam que se tratava de bombas atiradas pelos PMs, na tentativa de conter o tumulto". O jornal tentou justificar a ação da Polícia com a manchete sensacionalista "Desfile vira arrastão" (DIÁRIO POPULAR, 22/02/1996). O “carnaval-show-mercadoria" só é pensado para se acompanhar de longe. Qualquer tentativa da população pobre de se divertir é confundida com assalto e desordem. Para o jornal, a ação da Polícia Militar não foi apenas justificada, mas parabenizada, pois rapidamente conseguiu controlar o "tumulto e confusão" causados por pessoas que não queriam apenas olhar, mas participar da festa e desrespeitaram o cordão de isolamento feito pela polícia.

Reações semelhantes ocorreram nos bairros de Vila Maria, onde desfilou a VaiVai, campeã de 1996, e Freguesia do Ó, onde desfilou a Rosas de Ouro. Nesses locais, a multidão não só ficou observando o desfile, como entrou no meio das alas e atrás, na tentativa de não ser apenas espectador, mas novamente participar dos desfiles.

Depois dessa tentativa de levar a apresentação das escolas de samba para os diferentes bairros da cidade não ter sido aprovada pelas autoridades, elas passam a acontecer apenas em seu monumento, a Passarela do Samba. Local visto pelo poder público e pelas emissoras de TV como local mais adequado, afinal este possuía uma pista com 530 metros de comprimento por 14 metros de largura, dez setores com arquibancadas de concreto e mais um módulo especial para a imprensa e TV. E ao contrário dos pobres que estavam nos bairros periféricos da cidade, querendo participar do desfile, no Sambódromo isso não ocorre, pois a pista é totalmente ladeada por camarotes, alugados por multinacionais, proporcionando grande conforto para seus “convidados especiais". A área total é de $33.975 \mathrm{~m}^{2} 116$.

A partir desse ano ficou acertado que os desfiles ocorreriam em dois dias (sexta e sábado) para serem transmitidos integralmente pela Rede Globo de Televisão e não

\footnotetext{
${ }^{116}$ Pasta Anhembi Turismo 1992. Relatório do Carnaval. 1992. Centro de Documentação e Memória do Samba, AHB 1992.
} 
coincidir com os dias do desfile do Grupo Especial do Rio de Janeiro. A emissora inicialmente era contra os desfiles do Grupo Especial em dois dias, chegando inclusive a não transmitir o carnaval de São Paulo, mas após ser batida com larga margem na disputa pela audiência pela TV Manchete, que transmitiu os desfiles ao vivo, a emissora carioca não deixou mais de transmiti-los.

Como é possível observar na planta baixa do Sambódromo, o televisionamento já estava previsto em sua arquitetura. Todos os que assistem ao desfile de dentro dele possuem uma visão lateral do desfile, inclusive os jurados. A transmissão da TV é a única que tem uma visão frontal, pois sua cabine está em uma torre acima das arquibancadas, além dos diversos blimps e câmeras posicionadas ao longo da avenida. Os blimps são balões flutuantes a base de gás hélio, ideal para visualização a distância. Coloridos e iluminados, os blimps garantiam grande visibilidade aos produtos anunciados no Sambódromo.

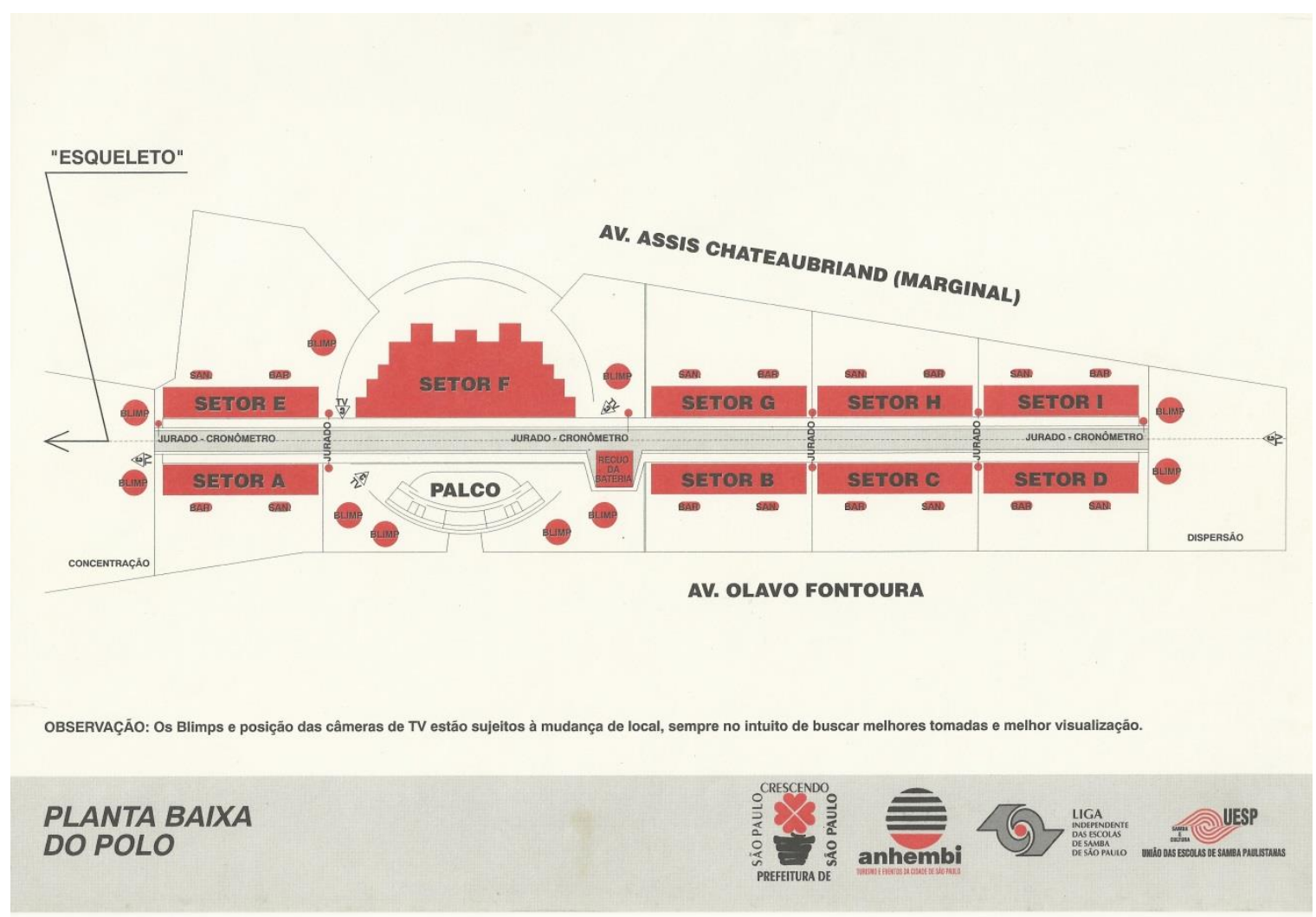


Planta baixa do Sambódromo. Pasta Anhembi Turismo 1996. Centro de Documentação e Memória do Samba, AHB, 1996.

O documento "São Paulo, Samba de Cara Nova", produzido pelo Departamento de Marketing da Anhembi Turismo, em 1996, após o encerramento das obras do Sambódromo e direcionado a empresas interessadas em patrocinar o carnaval, revela que o desfile das escolas de samba é um evento com alto potencial lucrativo, portanto atrativo para investimentos. Segundo a Anhembi, o desfile das escolas de samba no Sambódromo de São Paulo seria um excelente investimento publicitário, pois conta com "mais de dez horas de transmissão ao vivo pela televisão" e "é manchete dos principais jornais por mais de dez dias". E convida explicitamente os empresários: "Por ser um evento muito divulgado e de grande concentração de público, oferece várias e variadas oportunidades de retorno de mídia indireta e merchandising local, o que otimiza em muito (sic), o custo de seus patrocinadores"117. A opção política do Estado brasileiro associado à indústria cultural de eleger o samba como a musicalidade brasileira central não impede e até estimula as potencialidades de convivência instantânea com os mais modernos veículos de comunicação e empresariais.

Para Marcos dos Santos, a visibilidade do Sambódromo só é boa para quem está nos camarotes assistindo aos desfiles. O Sambódromo é ruim do ponto de vista do espectador comum de arquibancada e de quem desfila. Para Marcos, quem está desfilando não consegue sentir uma interação com o público, além de ser localizado em uma área de difícil acesso, por não contar com metrô e trem próximos. Apenas poucas linhas de ônibus atendem ao destino:

O Sambódromo do Anhembi foi construído para a linguagem televisa. A proposta arquitetônica do Anhembi é de ser bem iluminada, uma arquibancada distante das escolas, é horrível desfilar você não sente o público. A não ser que você tenha grana para comprar camarote você não vê direito. Ele é muito mal localizado, não se oferece condição do público chegar até lá ${ }^{118}$.

\footnotetext{
${ }^{117}$ Documento São Paulo, samba de cara nova. Pasta Anhembi Turismo 1996. Centro de Documentação e Memória do Samba, AHB, 1996.

${ }^{118}$ Entrevista com Marcos dos Santos. Data: 10/08/2010.
} 
Dona China, primeira e eterna porta-bandeira do Vai-Vai, atualmente com 82 anos e mais de 70 carnavais disputados, analisa o Sambódromo do ponto de vista de quem assiste ao desfile, denunciando a ausência de conforto para os sambistas. Para ela, a infraestrutura provisória e o monta e desmonta dos desfiles da Avenida Tiradentes era melhor do que a do Sambódromo:

\begin{abstract}
Nós gostávamos da Tiradentes, sabe por quê? Na Tiradentes tinha onde o pessoal fazia a concentração, tinha mais liberdade, tinha bar aonde você poderia ir em um banheiro, você podia comer uma coxinha, uma empadinha, você tinha a liberdade de usar os barzinhos dali, e veja bem, lá no Anhembi você não tem, tinha no começo algumas barracas que ficavam ali no começo, mas de uns tempos para cá, terminou, não tem mais nada.
\end{abstract}

A nova estrutura dos desfiles no Sambódromo fomentou inovações no desfile, pois as escolas passaram a contar com uma pista maior e mais ampla, possibilitando um aumento significativo no tamanho dos carros alegóricos, que passaram a ser construídos em barracões próximos ao Sambódromo, facilitando o transporte e possibilitando alegorias maiores. Por outro lado há uma significativa perda, pois traz um distanciamento da comunidade do processo de produção material do carnaval, algo que fazia parte do cotidiano da escola (BELO, 2008, p. 94).

Ao transmitir os desfiles, as emissoras de TV passaram a pagar direitos de imagem para as escolas de samba. Novamente, o modelo do carnaval de São Paulo se espelhou no carnaval do Rio de Janeiro que, naquele momento, já estava perfeitamente adaptado, e que exige das escolas de samba: agilidade, riqueza, beleza, tempo definido e rigorosamente controlado, além de adequação à grade de programação da emissora. Uma das penalidades mais rigorosas impostas às escolas de samba durante os desfiles são os atrasos. Um minuto a mais de desfile pode significar a perda do campeonato ou o rebaixamento de uma escola. A punição varia de acordo com o regulamento. No ano de 1996, a pena para cada minuto atrasado era a perda de um ponto, podendo uma escola perder o título ou mesmo ser rebaixada pelo atraso de um minuto. 
Muitos sambistas criticam este modelo engessado de competição. Para eles, ao criar regras tão rígidas, a competição tira quase toda a possibilidade diversão de se "viver o espírito do carnaval", nas palavras de Jamelão. Para o eterno intérprete da Mangueira é uma ignorância o desfile ser tratado como se atendesse somente aos requisitos exclusivos de um programa de televisão, fazendo parte de uma construção cenográfica com horário demarcado para início e fim.

\begin{abstract}
O samba mudou mais porque apareceu esse negócio de televisão que antigamente não tinha e a escola tem que estar com o horário marcado. Eles querem aquilo ali em tempo e hora não pode atrasar, porque tem que acabar cedo, por conta do horário da programação, daí que eles mesmos embolam tudo, já que tem a passarela, e muitas vezes acontece de um carro de alegoria quebrar e daí é um bolo. Até consertar. Isso aí imprevisível e como tem horário marcado, não tem conversa, atrasou perdeu pontos. (...) É mais do que um desfile militar, que num desfile militar você vê um ritmo e no samba é mais acelerado, porque a escola tem um contingente maior, quem dera que a escola tivesse o mesmo número que um batalhão, mas a escola leva uma nuvem de seis mil, e agora tem escolas que levam turistas que vêm de fora que gostam de samba querem participar, chega muito turista, e eles acham que não podem participar. Poder pode mas eles têm que entrar no andamento, o diretor de harmonia tem que ser muito sagaz, de olho no relógio, porque quando dá o apito tem que ficar atento pra todo mundo ir embora." (...) "Antigamente era um pouco mais cadenciado, o samba acabava com o dia claro, agora eles correm um pouco mais porque a televisão quer e fica em cima, então tem essa coisa, sabe que perde ponto então põe a escola para correr $^{119}$
\end{abstract}

A questão do tempo, crucial nos concursos realizados pelas escolas de samba, impede as pessoas de aproveitarem plenamente o carnaval. Há a criação de um paradoxo. O carnaval é uma festa que exige um tipo de tempo especial, vazio, sem trabalho. O tempo do carnaval é cíclico e cósmico, marcado pelo relacionamento entre Deus e os homens, adquirindo, com isso, um sentido universalista e transcendente. Como aponta Roberto Da Matta, não é possível determinar quando se iniciou o carnaval, porque ele está ligado a toda a humanidade, e pensar em seu tempo é pensar em termos de categorias abrangentes como o pecado, a morte, a salvação, o sexo e seu abuso ou sua moderação (DAMATTA, 1996, p. 54).

\footnotetext{
${ }^{119}$ Entrevista de José Bispo Clementino dos Santos, popularmente conhecido como Jamelão. Data: 06/01/2006.
} 
Com a limitação do tempo e a punição para quem não seguir essa regra, os desfiles carnavalescos saem do tempo cósmico e entram no tempo do capital, com estruturas rígidas impostas a todos que participam dos desfiles. Para o folião comum, o tempo dos desfiles era o de lazer, ou seja, do não trabalho. Ao se padronizar e limitar o tempo dos desfiles são reafirmadas as relações da sociedade capitalista, em que o tempo do lazer é limitado para apenas refazer as energias dos trabalhadores e para o consumo, necessários para um novo ciclo de trabalho. Não existe a possibilidade de inserção de uma nova sociedade baseada no lazer dentro do sistema capitalista de produção. $O$ filósofo húngaro István Mészáros analisa em sua obra, Para além do capital, que, para superar superação da lógica do capital e de seus meios de dominação, é necessária a destruição do sistema hierárquico de divisão do trabalho que subordina as atividades vitais dentro do trabalho ao capital. Com esta mudança passaria a ser verdadeiro o princípio em que o tempo fora do trabalho teria um caráter emancipador. Caso contrário, o trabalho continuará reproduzindo o poder do capital sobre si próprio (MÉSZÁROS, 2002, p. 892).

As relações capitalistas de tempo impedem que o carnaval seja vivido em sua plenitude. Mestre Gabi observa isso na relação da cidade com o carnaval. Para ele não há nenhuma evidência nos espaços públicos da cidade de São Paulo indicando o tempo de carnaval. Uma das poucas coisas que remete a esse tempo são os desfiles das escolas de samba, vistos como apenas mais um evento da cidade e que, na atual configuração, poderia acontecer em qualquer época do ano, não necessariamente no carnaval.

É duro o que eu vou dizer, eu, Gabi. Não vejo mais o carnaval, pelo menos na nossa cidade. Não se vive o carnaval. Você vive um desfile de escola de samba lá no sambódromo. Se você sair daquele meio ali você anda pela cidade normal como se tivesse num dia comum. Até com menos gente, porque muita gente aproveita pra viajar. Entra em uma escola de samba e vá desfilar. Vá como componente da escola mesmo, de ônibus, faça a via sacra. Quando você descer do ônibus, entra no corredor polonês, naquele espaço, aí fica lá parado esperando porque tem que concentrar duas escolas. Aí vai entrar, mas se sua ala for uma das últimas está frito, porque vai ficar lá atrás. Depois que entrou, em 20, 25 minutos você passa a pista toda. Quando menos, porque às vezes a escola tá grande, gasta menos tempo. Quando acaba o desfile já vem o segurança e coloca vocês pra entrar no ônibus e você vai embora e acabou o seu carnaval. É carnaval? Não é carnaval, você não vê 
ninguém fantasiado nas ruas como antigamente a gente via. (...) Agora o sambista pobre desfila pela sua escola e vai embora. Acabou o carnaval. É só 20 minutos de avenida. Lá você não pode entrar nem com uma garrafa d'água. Então tudo você tem que comprar. Você quer água? Você tem que descer lá e comprar. Então isso restringiu demais os sambistas. E aí eu digo a comunidade sambística que é a comunidade pobre, né? Então elitizou demais. Ficou tudo caro. ${ }^{120}$

A dinâmica de disposição dos camarotes ao longo da pista evidencia apenas as grandes empresas com os ricos, chiques e famosos protagonizando a descaracterização do carnaval original, negro e popular, acirrando a ideia de "carnaval espetáculo"

A lógica das escolas business faz parcerias com o futebol, como é possível observar principalmente com o surgimento das escolas ligadas a torcidas organizadas, como a Gaviões da Fiel, ligada ao Corinthians; Mancha Verde ao Palmeiras, Dragões da Real ao São Paulo e Torcida Jovem ao Santos. Também é financiada por políticos que prometem benefícios e patrocínios em troca de votos das comunidades e por representantes de atividades informais e ilegais como o "jogo do bicho" (RODRIGUES, 1984).

A definição de um local permanente e fora do espaço público das ruas levou as escolas do atual Grupo Especial e até mesmo do segundo grupo, chamado Grupo de Acesso, uma nova forma de utilização dos espaços vizinhos ao Sambódromo. Elas transferiram seus barracões (local onde as alegorias são construídas) para áreas mais próximas do Anhembi, com a finalidade de facilitar o transporte de alegorias, em especial as escolas de bairros mais afastados, que sempre tinham problemas com carros alegóricos que quebravam durante o transporte até o Sambódromo ou que ficavam presos em viadutos. Por outro lado, como alerta Vanir Belo, "o distanciamento da produção de alegorias da sede da escola, distancia também a comunidade de parte da produção material do carnaval, que fazia parte do cotidiano do bairro" (BELO, 2008, p. 107).

Como atesta o texto produzido pela SP Turismo, o Polo Cultural Grande Otelo não possui nenhuma ligação ou fomento às escolas de samba e adquiriu a finalidade de

${ }^{120}$ Entrevista de Mestre Gabi. Data: 25/10/2010. 
ser mais uma opção de entretenimento e local de eventos da cidade, sendo o carnaval apenas uma das atividades que ele realiza ao longo do ano.

\begin{abstract}
O Polo Cultural Grande Otelo, projetado pelo arquiteto Oscar Niemeyer, é um dos maiores espaços para grandes eventos ao ar livre na cidade de São Paulo. Também conhecido como Sambódromo, tem abrigado em média 30 grandes eventos por ano, além da maior festa popular paulistana, o Carnaval. Inaugurado em 1991, nos últimos anos uma diversificação da utilização dos seus espaços fez do Polo um local para eventos de diferentes estilos, tanto esportivos quanto apresentações artísticas. O local possui 10 módulos de arquibancadas ao longo de uma pista de 530 metros de comprimento por 14 metros de largura, com acomodação para 26.246 pessoas sentadas. Distribuídas pelos diversos setores/arquibancadas estão instalados 138 camarotes, com tamanhos variados que acomodam entre 10 e 50 pessoas. Todos os setores possuem infraestrutura completa para bares. A arquibancada monumental do Polo, com capacidade para 7749 pessoas sentadas, fica situada em frente a um palco de $900 \mathrm{~m}^{2}$. Além das arquibancadas, a monumental, possui 10 amplos camarotes em frente ao palco com ótima visibilidade. Nos bastidores do palco estão disponíveis três grandes camarins e amplas áreas de serviços. Local ideal para shows de médio porte, como foi o caso do Sampa festival, que abrigou mais de 10 mil espectadores neste espaço. O Polo também possui duas grandes áreas abertas, denominadas concentração e dispersão (denominações extraídas do mundo do samba) ideais para grandes shows musicais. No espaço da concentração foi construída a ARENA ANHEMBI, o primeiro espaço para megaeventos com estrutura fixa do país. A São Paulo turismo aplica uma política de comercialização de seus espaços para ações de Marketing Profissional. O Polo Cultural e Esportivo Grande Otelo que pode ser comercializado de forma exclusiva nos seus, $93 \mathrm{mil} \mathrm{m}^{2}$, considerando-se os espaços da Arena, Dispersão e Pista. Ou ainda é possível a utilização de espaços específicos, adequando as necessidades de construção do seu evento.
\end{abstract}

Após a entrega do troféu para a campeã do carnaval, na Quarta-Feira de Cinzas, nos próximos 360 dias do ano o Polo fica subutilizado para eventos de uma marca de cerveja, patrocinadora e mantenedora do espaço, que não tem nenhuma ligação com o mundo do samba. São muito pouco significativas as atividades realizadas ao longo do ano ligadas ao universo do samba ou das escolas de samba. Isso revela que a ligação que as escolas de samba têm com o espaço do Sambódromo se resume ao do período carnavalesco.

\footnotetext{
${ }^{121}$ Extraído de: 〈http://spcarnaval.com.br/sambodromo.php〉. Apud: BELO, Vanir de Lima. O enredo do carnaval nos enredos da cidade: dinâmica territorial das escolas de samba em São Paulo. Dissertação de Mestrado. São Paulo: FFLCH/USP, 2008, p. 105-106.
} 
Como diz Ana Maria Rodrigues, as consequências da Passarela do Samba para o grupo negro, sempre identificado com o dia a dia das escolas, são funestas:

\begin{abstract}
O indivíduo que participava diretamente das manifestações culturais de seu grupo dando formas plásticas e estéticas ao seu poder criador, independente do grau de sofisticação dessa criação teve solapada tal oportunidade. Atualmente encontra-se na situação de mero espectador, sem quaisquer gratificações advindas da capacidade de criar enredos, pensar nas fantasias, construir seus carros alegóricos utilizando papelão molhado, dançar enfim, solando o corpo no espaço, deixando-se instintivamente conduzir pela força do batuque. Isso porque os desfiles atualmente são programados passo a passo por pessoas estranhas à sua realidade social, à sua identidade racial, ficando para os negros apenas a parte pesada da execução dos projetos e a efetiva massa desfilante que dá corpo à escola nos desfiles (RODRIGUES, 1984, p. 42).
\end{abstract}

Dona China, em depoimento ao autor, também vê o mesmo processo de exclusão e afastamento das camadas mais pobres da sociedade dos desfiles das escolas de samba do Grupo Especial, seja como protagonista, desfilando, pois o preço de uma fantasia possivelmente passa de um salário mínimo, seja como mero espectador, pois os preços dos ingressos para assistir aos desfiles também são altos.

\begin{abstract}
Antigamente você vivia o carnaval porque não precisava pagar para assistir, você estava em uma avenida ela já lotava, já vinham às escolas de samba aquela coisa linda. Hoje em dia, para assistir o carnaval tem que pagar e não tem liberdade, já que você está lá na arquibancada. Se você quiser levar uma comida, um lanche, já não pode, tem que comprar tudo lá. Então o carnaval mudou nesses aspectos, porque a pessoa que gosta de carnaval vai porque quer assistir, mas o carnaval hoje é mais para os ricos, porque eu não vou lá pagar $\mathrm{R} \$ 400,00$ em um camarote, e eles pagam, e os camarotes estão superlotados.
\end{abstract}

Novamente comparando a situação dos desfiles das décadas de 1970 e 1980 na Avenida Tiradentes com os atuais no Sambódromo do Anhembi, Dona China enxerga mudanças significativas nos desfiles:

Mudou, ali para ficar bom tinha que desfilar direto (Anhembi), porque você tem aquela curva que engole muita coisa, você vem e a curva tem que fazer 
isso, você não vê a escola inteira, depois da curva que vem vindo as alas e isso eu acho que prejudica um pouco, porque o bonito é você ver a escola quando ela vem você vê aquela emoção, aquela coisa, tem que sair uma para entrar a outra, não cabe a escola inteira na pista. É nisso que eu acho que mudou, na Tiradentes cabia direitinho.

Em São Paulo, as escolas se profissionalizam quando o poder público financiador dos desfiles carnavalescos exigiu das mesmas, em contrapartida, um comportamento mais empresarial, de suas diretorias. A princípio, estas eram escolhidas de acordo com a tradição e importância dos membros dentro da comunidade, mas a interferência externa faz com que sejam criadas regras cada vez mais rígidas na organização do carnaval, afastando cada vez mais o simples sambista das decisões tomadas pelas escolas.

Esta lógica empresarial não reflete totalmente a realidade das escolas de samba, mas apenas as escolas dos principais grupos (Especial e Acesso), já as escolas menores dos outros grupos ligados à UESP (I, II, III, IV) permanecem apresentando características mais próximas dos desfiles dos períodos anteriores. Estas escolas não têm a visibilidade e os recursos das grandes escolas e dependem ainda do trabalho voluntário e artesanal, utilizando, na maior parte das vezes, a casa dos próprios componentes para produzir e armazenar os instrumentos, fantasias, adereços, alegorias e realizar a maioria de suas atividades ao longo do ano. O processo histórico de se fazer samba sempre esteve vinculado às classes subalternas. Mesmo sendo hegemônicos dentro dos festejos carnavalescos, os símbolos originais do samba não deixaram de ser comunitários e provincianos, nem se perdeu a mística do batuque e da comunicação com as entidades espirituais. É possível ver isso nas rodas promovidas pelas escolas de samba para batismos de sambistas, apresentação dos novos sambas ou em pedidos de proteção para que tudo ocorra bem durante os desfiles. Para as camadas mais pobres da sociedade estão reservados estes desfiles das escolas de samba menores, ligadas a vários bairros periféricos da cidade, que saem todos os anos disputando concursos promovidos pela UESP em grupos inferiores, em datas diferentes dos dias reservados ao desfile principal. Estes eventos atraem milhares de pessoas e não têm nenhuma cobertura por parte da 
grande mídia e da indústria cultural, permanecendo ligados à essência do carnaval como festa genuinamente popular. 


\section{PARTE II}

TRANSCRIAÇÕES 
Nas páginas seguintes serão apresentadas as transcriações das entrevistas realizadas pelos sambistas que colaboraram com este projeto. Para colaborar com esta pesquisa, foram escolhidas pessoas que viveram e testemunharam as transformações pelas quais o carnaval da cidade de São Paulo passou durante o período estudado (19681996). Apesar do grande volume de documentação impressa sobre o carnaval de São Paulo, inclusive com entrevistas já realizadas para outras pesquisas, julgamos fundamental respondermos, de forma satisfatória, a pergunta inicial da presente dissertação: "Quais foram e como ocorreram as transformações institucionais e estéticas que o carnaval da cidade de São Paulo vivenciou a partir de sua oficialização até o advento do Sambódromo?" Era necessário entender como os sambistas sentiram, vivenciaram e interpretaram essas mudanças. Grande parte das consequências sentidas pelos sambistas a partir das transformações e hibridizações das relações entre as agremiações carnavalescas e o poder público municipal - e, posteriormente, entre os meios de comunicação eletrônica nos quase 30 anos que esta pesquisa abrange — só é possível ser compreendida a partir das vozes deles próprios, frente a essas mudanças.

E como escolher os sambistas que participariam? Escolhemos para entrevistar alguns membros da Embaixada do Samba, entidade cultural ligada à União das Escolas de Samba Paulistanas (UESP), que reúne os baluartes do samba da cidade de São Paulo. Os embaixadores e embaixatrizes são muito respeitados dentro do "mundo do samba" e desempenham uma função pedagógica, com a finalidade de preservar as tradições do samba paulistano, através de rituais, como os realizados anualmente no dia 2 de dezembro, Dia Nacional do Samba, ou em palestras, no interior de suas agremiações, ou gentilmente cedendo entrevistas, como as realizadas para este trabalho. O conhecimento desses baluartes é transmitido oralmente para as novas gerações, principalmente às ligadas ao cotidiano das escolas de samba. Para ser membro da Embaixada do Samba, é necessário ter, no mínimo, 25 anos como membro atuante de alguma escola de samba. Normalmente, os nomes mais proeminentes das Velhas Guardas das Escolas de Samba são escolhidos Embaixadores.

Todos os membros da Embaixada possuem mais de 60 anos e vivenciaram as transformações ocorridas a partir da oficialização do carnaval paulistano, em 1968, e a 
perda do espaço público com a transferência dos desfiles das ruas para o Sambódromo, em 1991. Como a Embaixada possui, atualmente, mais de 50 membros, procuramos entrevistar aqueles mais atuantes, que ocuparam cargos de direção em escolas de samba, federações e associações carnavalescas.

Vivemos em um sistema no qual o passado é cada vez menos importante e a velhice é uma categoria social rejeitada pela sociedade industrial, pois não participa da produção de mercadorias. Para Eclea Bosi, é nesse momento de sua vida que o idoso deve desempenhar a "alta função da lembrança [...] cresce a nitidez e o número das imagens de outrora, e esta faculdade de relembrar exige um espírito desperto, a capacidade de não confundir a vida atual com a que passou, de reconhecer as lembranças e opô-las às imagens de agora" (BOSI, 2009, p. 81).

Seguindo a linha proposta por Bosi (2009), além de uma justificativa histórica, ao darmos voz aos membros das Embaixadas, temos uma justificativa social para a realização deste trabalho. Pretendemos, assim, reconstruir, através do envolvimento dessas personagens com o mundo do samba, as vozes que historicamente não são ouvidas. Personagens que dedicaram boa parte da vida em prol dos folguedos e, apesar da popularidade atingida hoje pelas escolas de samba, estão excluídas dos meios de comunicação de massa e da indústria fonográfica.

O primeiro entrevistado e nosso ponto de partida é Marcos dos Santos, fundador da escola de samba Tom Maior e atual diretor do Centro de Documentação e Memória do Samba (CDMS). Marcos participa há mais de 45 anos de cordões carnavalescos e escolas de samba. Sempre foi um militante das escolas de samba de São Paulo, travando diversas lutas dentro da entidade que dirige, o CDMS, a fim de preservar e divulgar a arte produzida pelas agremiações.

Meu primeiro contato com Marcos ocorreu em 2006, quando eu fui conhecer o acervo do Centro de Documentação. Ele soube do meu interesse por carnaval e escolas de samba e me convidou para participar do curso de formação de jurados da UESP, no módulo visual. Em 2007 eu realizei o curso e Marcos foi um dos professores. A relação professor-aluno logo se desenvolveu em uma longa amizade, a qual perdura até hoje. 
Antes de ingressar no Programa de Pós-Graduação, na época em que estava redigindo o projeto, trocamos muitas ideias e ele me esclareceu diversas dúvidas. Quando a pesquisa de fato iniciou e a História Oral tornou-se uma de minhas fontes principais, Marcos foi um dos maiores entusiastas. Dispôs-se a ser o primeiro entrevistado e me apresentou a inúmeros sambistas-membros da Embaixada do Samba. A entrevista realizou-se no dia 10/08/2010 e, depois disso, Marcos me indicou dois nomes Mestre Gabi e Álvaro Casado. A entrevista foi revista por Marcos no início de 2011 e, após ajustes de alguns nomes, que não estavam compreensíveis, e a retirada de algumas denúncias mais contundentes feitas pelo entrevistado, a entrevista foi aprovada. O tom da entrevista de Marcos é marcado pela denúncia e pela defesa de um carnaval popular realizado para o sambista pobre. Para Marcos o público a quem o carnaval deveria se dirigir é o das classes menos privilegiadas. Ele optou por retirar algumas críticas a pessoas, pois, apesar de serem fatos verídicos, não tinha documentos para prová-las. A entrevista foi validada em maio de 2012, a fim de constar no exame de qualificação.

Marcos e todos os outros sambistas entrevistados se orgulham de fazer parte da Embaixada do Samba e de serem membros de uma Velha Guarda. Para eles, ser membro da Velha Guarda é ter a responsabilidade de ensinar as gerações mais novas os valores de uma geração anterior que realizava um carnaval artesanal, tornando-se uma voz que não se molda às exigências do carnaval do atual modelo televisivo.

O tom é de crítica ao modelo atual de desfile e organização das grandes escolas. Em alguns trechos, isso aparece em todas as entrevistas como uma questão de geração. Todos os entrevistados, com exceção de Dona China, possuem idades aproximadas e veem seu passado como algo nostálgico e bonito do qual se orgulham, e analisam as modificações trazidas pelo presente como algo que não os beneficiou e os excluiu, apesar de todos fazerem parte da Embaixada do Samba, possuírem prestígio e ocuparem cargos em federações, caso de Marcos e Mestre Gabi.

O segundo entrevistado foi Gabriel de Souza Martins, o Mestre Gabi. Eleito pelo jornal Folha de São Paulo o melhor mestre-sala do século XX, Mestre Gabi defendeu os pavilhões de Barroca Zona Sul e Camisa Verde e Branco. Foi fundador e presidente 
da Associação de Mestres-Salas, Porta-Bandeiras e Estandartes do Estado de São Paulo (AMESPBEESP), professor em diversos cursos para formação de mestre-sala e também para formação de jurados. Atualmente é dirigente da Federação das Escolas de Samba e Entidades Carnavalescas (FESEC), responsável por organizar e julgar diversos concursos no interior do Estado. Mestre Gabi também foi eleito, no ano de 2011, cidadão-samba e membro da corte carnavalesca dos desfiles oficiais.

Eu não o conhecia pessoalmente, mas após um breve contato telefônico, Mestre Gabi se dispôs a ser entrevistado na mesma hora. Marcamos para uma semana depois, em 25/10/2010, às 16:00, na sede da FESEC, próxima à Avenida Tiradentes. Mestre Gabi estava muito à vontade, apesar de não me conhecer. A entrevista foi conduzida por mim, filmada por meu irmão e contou com a participação de Lígia Nassif Conti, também pesquisadora do samba na cidade de São Paulo. Foi uma entrevista franca e emocionada, que nos possibilitou conhecer e, no mesmo instante, admirar uma pessoa fantástica.

As críticas de Mestre Gabi ao atual modelo das escolas de samba são corroboradas por Marcos dos Santos, que as inclui na organização da escola de samba Tom Maior, da qual é fundador. Esses sambistas viveram em sua geração um paradoxo: defenderam um ideal de autenticidade, de construção de um espaço de lazer e sociabilidade para seus pares e a maior parte não vê com alegria as consequências do sucesso do modelo criado por eles. Para eles, o atual modelo das escolas de samba e do Sambódromo privilegia mais as pessoas "de fora" do mundo do samba - que podem investir muito dinheiro para participar — do que os sambistas "de dentro", os quais, historicamente, são pobres e não têm condições de investir dinheiro, mas que investem o principal: o seu tempo e o seu "amor" pela escola.

A visão dos dois dirigentes paulistanos se aproxima do discurso dos portelenses Paulinho da Viola, Candeia e João Nogueira nos anos 1970. O processo pelo qual as escolas de samba do Rio vivenciaram naquela década, as escolas de São Paulo vivenciaram nas duas décadas seguintes.

Em 1975, um grupo de compositores da Portela, encabeçados por Candeia, André Motta Lima, Carlos Monte, Cláudio Pinheiro e Paulinho da Viola, enviou ao 
presidente da escola de samba um documento com críticas às decisões tomadas pela diretoria da agremiação. Esse grupo defendia um projeto "tradicionalista" para a Portela, que, naquele momento, estava cedendo às intervenções e "espoliações" de pessoas ligadas às classes mais abastadas e que começavam a ter poder dentro da escola (RODRIGUES, 1984).

A diretoria defendia a integração da Portela ao novo modelo de carnaval que havia se configurado na década anterior, com a entrada de carnavalescos e patronos ligados às classes mais altas. No documento, Candeia diz: "escola de samba é povo em sua manifestação mais autêntica. Quando se submete às influências externas, a escola de samba deixa de representar a cultura do nosso povo". E mais à frente: "O sambista, a princípio, viu isso como uma vitória do samba, antes desprezado e até perseguido. $\mathrm{O}$ sambista não notou que essas pessoas não estavam na escola para prestigiar o samba. $\mathrm{E}$ aí que as escolas começaram a mudar" (BUSBÁCIO, 2008, p. 288).

O grupo não encontrou espaço dentro da Portela e, no final de 1975, o grupo de compositores deixou a agremiação e fundou a escola de samba Quilombo. Este é o mesmo dilema que vivem algumas pessoas da Velha Guarda, como podemos perceber claramente nas entrevistas de Marcos dos Santos e Mestre Gabi. No caso, eles preferem permanecer dentro de suas escolas, mas como uma voz dissonante e respeitada, apesar de não terem forças políticas e econômicas para reverter esse processo. Após a entrevista, Gabi me apresentou a Nicéia, funcionária da FESEC e filha de Dona China, que me passou o número de sua mãe.

Emília Feliciana Ferreira, a Dona China do Vai-Vai, foi nossa terceira entrevistada. É uma das mais antigas foliãs do carnaval paulistano, que desfila desde 1936. Participou de vários cordões carnavalescos e foi a primeira porta-bandeira do VaiVai, quando o mesmo deixou de ser cordão, nos anos 1970. Também atuou como presidente da escola de samba Unidos da Vila Carrão e foi fundadora, ao lado de Mestre Gabi, da AMESPBEESP. Atualmente possui uma barraca de quitutes, que vende um delicioso cuscuz nos ensaios da escola de samba Vai-Vai. Liguei para Dona China após o carnaval de 2011, e ela pediu para marcarmos a entrevista posteriormente, já que estava se recuperando de um AVC sofrido poucas semanas antes. Tentei novamente o 
contato no início de julho e marcamos a entrevista para uma tarde de feriado, no dia 09/07/2011. Dentre vários biscoitos e cafés e rodeados por centenas de fotos dos carnavais antigos, permanecemos conversando por mais de três horas. Na entrevista pudemos observar o orgulho que Dona China tem de ser membro da escola de samba Vai-Vai e o profundo respeito e reverência que a escola tem por ela. Contou sua trajetória e os percalços pelos quais passou, por ser mulher, negra, pobre e sambista em uma sociedade machista e racista, que durante muito tempo criminalizou o samba e qualquer atividade de lazer dos negros da cidade, pois, para muitos, a mentalidade escravocrata ainda estava presente e o papel do negro na sociedade seria apenas trabalhar sem reclamar. Na entrevista de Dona China, percebemos algo marcante que, apesar de todas as adversidades, inclusive de perder a mãe e o marido em um intervalo de dois meses, ela nunca desistiu de continuar no samba. Uma frase sua sintetiza a entrevista: "Vou desfilar até meu último dia".

Em maio de 2012, retornei para conversar com Dona China e, mais uma vez, me emocionei. Ela chamou o filho, alguns netos e vizinhos para sua casa e queria mostrar a todos a transcriação, dizendo que ali estava registrada a sua história. Após alguns ajustes, a entrevista foi validada no mesmo dia.

O nosso quarto entrevistado foi Valdevino Batista da Silva, o mestre Divino. Um dos maiores mestres de bateria de todos os tempos, foi diretor de Nenê de Vila Matilde e Camisa Verde e Branco. Também foi presidente da UESP, fundador e atual presidente da escola de samba Imperial, localizada na Vila Ré. Seu nome surgiu em uma conversa informal com Adriano Bejar, membro da Comissão de Carnaval da UESP. Lamentamos a morte de Mestre Lagrila, grande diretor de bateria do carnaval de São Paulo, com passagens por Camisa Verde e Branco, Nenê de Vila Matilde e Leandro de Itaquera. Concordamos que, se eu estava estudando as transformações estéticas do carnaval de São Paulo, seria fundamental conversar com Mestre Divino, pois ele possuía um estilo único e sua bateria tem a maior quantidade de instrumentos diferentes de todas as escolas de São Paulo.

Depois de um contato prévio por telefone, agendamos a entrevista para um sábado, dia 15/10/2011. Chegamos à quadra da escola no bairro da Vila Ré, zona Leste 
da cidade, perto das 14:00. Mestre Divino não estava e nos informaram de que ele estava no barracão da escola. Fomos até lá e aguardamos por quase duas horas no barracão da escola, já que Mestre Divino, junto com alguns netos, faziam a confecção de um carro alegórico de sua escola. A espera valeu a pena, converteu-se em mais de três horas de conversa, com Divino apresentando diversos instrumentos de sua "batucada", como ele mesmo se refere, como tarol, tarolzinho, malacacheta, caixa-deguerra, frigideira e muitos outros. O tom da entrevista foi muito agradável, de grande franqueza nas respostas, e Divino se comportava como alguém que quer passar adiante o seu legado; por isso, seus filhos e netos aprendem praticamente juntos a falar, sambar e batucar.

Ao visitar uma escola de samba pequena e familiar como a Imperial, pudemos ver como os processos de confecção de fantasias e alegorias ainda continuam coletivos e artesanais. Mestre Divino também compartilha da visão de que o sambista perdeu espaço dentro da direção das grandes escolas. Para ele, o sambista continua dentro dos cargos, mas é obrigado a fazer diversas concessões para arrecadar o montante necessário para colocar a escola na avenida, ficando refém do atual modelo. Por não concordar com este modelo, Mestre Divino preferiu se ausentar das grandes escolas e fundar a sua própria. Mas o sonho de que sua escola se torne grande, um dia, continua. Durante a entrevista, queixou-se diversas vezes sobre a direção da UESP, de que está endividada e não tem forças nem para manter os próprios regulamentos, já que eles são constantemente alterados devido a pressões tanto das escolas quanto do poder público.

A transcriação da entrevista de Divino foi a mais complexa. Como o mestre utiliza uma linguagem técnica e faz sons com a boca ou com os próprios instrumentos o tempo todo, para exemplificar as transformações musicais vivenciadas por ele no carnaval, no processo de passagem da oralidade para a escrita, infelizmente, isso se perdeu. Alguns sons também estão incompreensíveis por conta da qualidade do gravador, que não conseguiu captar diferenças sutis de batidas tocadas por Mestre Divino. Após a transcrição, Divino aprovou o processo de transcrição no final de 2012 e de transcriação às vésperas do carnaval de 2013, inclusive nos convidando a pegar uma fantasia e desfilar em sua escola de samba no evento, o que, infelizmente, não foi 
possível, devido a compromissos assumidos com a UESP, onde atuei na transmissão dos desfiles.

O nosso quinto entrevistado foi Osvaldinho da Cuíca, primeiro cidadão-samba da cidade de São Paulo, fundador das escolas de samba Acadêmicos do Tucuruvi e Gaviões da Fiel e membro da ala de compositores do Vai-Vai. É também pesquisador do samba e escreveu um livro sobre o tema. Eu sempre fui um fã do trabalho de Osvaldinho como intérprete e assisti a diversas apresentações feitas por ele e sua banda, no circuito SESC e outros espaços dedicados ao samba. Quem iniciou os contatos com Osvaldinho foi Lígia Nassif Conti. Ele aceitou nos receber prontamente em uma sextafeira, 21/01/2012, um mês antes do carnaval. Apesar de ser uma figura muito atarefada e, na ocasião, estar com vários problemas de saúde em decorrência de uma infecção que havia contraído durante uma viagem a Cuba, realizada semanas antes, nossa conversa se estendeu por quase quatro horas e Osvaldinho nos mostrou seu acervo, com muitas fotos e documentação sobre o samba na cidade de São Paulo e ainda, ao final, presenteou Lígia e a mim com seus CDs e DVDs.

O tom da conversa foi professoral, com Osvaldinho explicando vários momentos do samba como estilo musical e a trajetória dos cordões e escolas de samba na cidade. Em alguns momentos, ao contar suas memórias, não sabíamos se Osvaldinho presenciou determinados fatos ou se os conhecia por também ser um pesquisador do tema. Uma das maiores frustrações de Osvaldinho no momento era não ter conseguido bons resultados como compositor de sambas-enredos e isso influenciou a sua análise, crítica ao modelo atual de organização das escolas de samba. Osvaldinho, assim como Marcos dos Santos e Mestre Gabi, define suas opções dentro do samba como uma "missão", um compromisso quase religioso que pauta suas ações e escolhas de vida, e que, por conta disso, até de oportunidades financeiras para permanecer fiéis aos ideais que acreditam e defendem.

Por causa de sua agenda de shows e constantes viagens, retomamos o contato com Osvaldinho no início de 2013, e, passada a fase inicial de transcrição, estamos aguardando a validação. 
Para fechar o ciclo de entrevistas, decidi buscar o nome indicado por Marcos dos Santos e entrevistar Álvaro Ribeiro, o Casado. Fundador da escola de samba Acadêmicos do Tatuapé, foi também presidente e diretor cultural da UESP. Álvaro Casado é a antítese da análise que alguns autores fazem sobre a entrada de membros da classe média dentro das escolas de samba. Branco, dono de uma agência de publicidade ao lado do escritor, professor e dramaturgo Carlos Queiroz Telles, a Fator Publicidade, Casado adquiriu o respeito e a admiração dos "caciques" do samba, como ele mesmo define. Está envolvido com carnaval desde a década de 1950, quando, ao lado de seu cunhado, Álvaro Vilaça, o Mala, participou da fundação da escola de samba Acadêmicos do Tatuapé. Casado é compositor, venceu com diversos sambas-enredos em escolas de samba e também atua como artista plástico e escritor de enredos para diversas agremiações. Em 1975 foi convidado pelas principais lideranças negras do samba, como Inocêncio Mulata, Seu Juarez, Seu Nenê e Seu Carlão do Peruche para assumir a presidência da UESP, criada dois anos antes. A estratégia de colocar profissionais universitários como jornalistas, radialistas e publicitários nos cargos de direção da UESP pode ser entendida por alguns como uma entrega de postos-chave para pessoas "de fora" do mundo do samba. Mas, na própria entrevista, Casado diz que foi o contrário: os sambistas precisavam naquele momento dos jornalistas para alcançar o seu fim, que era receber patrocínio da Prefeitura de São Paulo; ele próprio não se enquadra nessa categoria, pois, no momento em que foi indicado para a presidência da UESP, tinha 20 anos de atuação dentro das escolas de samba. O que os dirigentes queriam, ao nomear essas pessoas, era um melhor trânsito com as autoridades e, de certa forma, "legitimar" a nova federação, pois ela contava não apenas com sambistas pobres e negros, mas com diversos profissionais universitários e respeitados em suas áreas.

Após um contato inicial por telefone em abril de 2012, marcamos a entrevista para o feriado de $1^{\circ}$ de maio em sua casa, no município de Poá. Meu pai, que conhece bem o município, me acompanhou e chegamos pela manhã na casa de Seu Álvaro. A área é uma chácara, com uma grande área verde e diversos cachorros que queriam interagir com os visitantes. O entrevistado mudou-se para lá com sua esposa após se aposentar. Durante a entrevista, fez questão de mencionar a sua amizade com Mano 
Décio da Viola, um dos maiores sambistas do Império Serrano, e, inclusive, produziu o primeiro disco de Mano Décio. O tom da entrevista é de um apaixonado pelo carnaval e por sua escola de samba que, pelo fato de ser um profissional universitário e com certo tempo livre, foi procurado pelos "caciques" do samba para presidir e coordenar as negociações do carnaval com a prefeitura num momento de instabilidade e desavenças. A sua condição ímpar de branco e profissional liberal bem-sucedido foram os principais argumentos dos que o defendiam, dizendo que, além de dirigente de escola de samba, Álvaro tinha experiência e bons contatos com o poder público. Eram também os principais argumentos daqueles que o criticavam, já que algumas lideranças achavam que um negro deveria estar à frente da UESP. Após a gravação da entrevista, ele nos contou que possuía uma série de documentos sobre o carnaval de São Paulo em sua casa. Uma parte ele entregou para compor o acervo do CDMS e outra parte ainda estava em seu poder, guardada em um arquivo na parte anexa de sua casa. Como havia uma pessoa morando nesse anexo e ele não queria acordá-la, ficou acertado de que veríamos na próxima visita. No feriado de 12 de outubro de 2012, retornamos com a entrevista transcrita para Seu Álvaro ler e levei o disco de Mano Décio que ele havia produzido, mas não o tinha. O seu acervo ainda não estava disponível e ele me emprestou um jornal e uma revista que continha uma reportagem e uma entrevista que ele havia concedido. A autorização para uso e a validação ocorreu em abril de 2013.

Com a finalização da entrevista de Álvaro Ribeiro, julgamos ter reunido um bom número de entrevistas e uma pluralidade de opiniões. Entrevistamos dois dirigentes de federações e fundadores de escola de samba (Marcos e Álvaro), um mestre-sala e uma porta-bandeira, que também tiveram experiências à frente de federação e escola de samba (Mestre Gabi e China), e dois músicos profissionais (Osvaldinho e Divino), sendo o primeiro atuante exclusivamente como compositor e cantor e o outro que atua também como dirigente, foi presidente de Federação e atualmente exerce a atividade de presidente de escola. Álvaro e Divino foram os dois ex-presidentes da UESP entrevistados e, durante seus mandatos, houve mudanças dos locais de desfile na cidade. Álvaro participou das negociações que envolveram a mudança do tradicional centro da 
cidade, para a Avenida Tiradentes em 1977, e Divino, da Avenida Tiradentes para a mudança definitiva para o Sambódromo em 1991.

Todas as entrevistas foram realizadas na modalidade História Oral. O caminho metodológico adotado pela pesquisa segue a linha de pesquisa do Núcleo de Estudos de História Oral da USP (NEHO/USP), em particular os modelos criados por José Carlos Sebe Bom Meihy, que define:

História oral é um conjunto de procedimentos que se inicia com a elaboração de um projeto e que continua com o estabelecimento de um grupo de pessoas a serem entrevistadas. O projeto prevê: planejamento da condução das gravações com definição de locais, tempo de duração e demais fatores ambientais; transcrição e estabelecimento de textos; conferência do produto escrito; autorização para o uso; arquivamento e, sempre que possível, a publicação dos resultados que devem, em primeiro lugar, voltar ao grupo que gerou as entrevistas (MEIHY; HOLANDA, 2007, p. 15).

A modalidade de História Oral escolhida é a Temática; contudo, para o uso dessa opção, entendemos por História Oral Temática a utilização de entrevistas de um determinado grupo sobre um assunto específico. Essa entrevista do tipo documental não abrange necessariamente a totalidade da vida do informante, apesar de as entrevistas abordarem também partes importantes da vida do entrevistado não ligadas ao carnaval e elas constarem no escopo final fundamental, pela oportunidade de recuperar testemunhos relegados pela História.

A metodologia empregada busca reconstituir acontecimentos e cenas presenciadas pelos entrevistados a respeito do universo das escolas de samba, analisando os diferentes momentos e transformações vivenciados por eles, sem atribuir juízo de valor às decisões tomadas pelos dirigentes, enquanto indivíduos, mas apenas buscando enxergar as transformações obtidas a partir das decisões e negociações das escolas de samba com outras instâncias como a indústria cultural e o Estado. Também é utilizada como ação para complementar ou promover o diálogo e o confronto com as demais fontes. Dessa maneira, os depoimentos podem ser mais numerosos, resultando em maiores quantidades de informações, o que permite uma comparação entre eles, apontando divergências, convergências e evidências de uma memória coletiva dos entrevistados. Nesta recuperação, os registros de reminiscências orais se destacam, pois 
permitem a documentação de pontos de vista diferentes sobre o mesmo fato, os quais, omitidos ou desprezados pelo discurso do poder, estariam condenados ao esquecimento (MEIHY, 1996 e 2007).

$\mathrm{Na}$ busca por características de uma coletividade, a realização destes depoimentos orais nos possibilitou captar, a partir das reminiscências, o que as pessoas vivenciaram e experimentaram em mais de 40 anos de participação em folguedos carnavalescos.

A memória, para Walter Benjamin, constitui na mais importante contribuição para que as lembranças continuem vivas e atuais, não se transformando em exaltação ou crítica pura e simples do passado, mas em meio de vida, em procura permanente de escombros, que possam contribuir para estimular e reativar o diálogo do passado com o presente. Tanto a História como a memória, apesar de distintas, têm substâncias comuns: são as antíteses do esquecimento. São fontes de perpetuação (BENJAMIN, 2000). Em consequência disso, como afirma Jacques Le Goff, são também espaços de poder (LE GOFF, 1990). A historiadora mineira Lucília Delgado vê a memória como base construtora de identidades e solidificadora de consciências individuais e coletivas. Ela funcionaria como um elemento constitutivo do autorreconhecimento como pessoa e/ou como membro de uma comunidade pública, como as comunidades das escolas de samba, uma nação privada ou uma família (DELGADO, 1996, p. 31). Já para Margarida de Souza Neves, assim como para Benjamin, também tem como objeto de sua reflexão a memória:

O conceito de memória é crucial porque na memória se cruzam passado,
presente e futuro, temporalidades e espacialidades; monumentalização e
documentação; dimensões materiais e simbólicas; identidades e projetos. E
crucial porque na memória se entrecruzam a lembrança e o esquecimento; o
pessoal e o coletivo; o individuo e a sociedade, o público e o privado; o
sagrado e o profano. Crucial porque na memória se entrelaçam registro e
invenção; fidelidade e mobilidade; dado e construção; história e ficção;
revelação e ocultação (NEVES, 1999, p. 218).

Para a historiadora oral Sônia Maria de Freitas, metodologia de utilizar depoimentos orais abre novas perspectivas para o entendimento do passado recente, reconstruindo, através do envolvimento dessas personagens com o mundo do samba, a 
possibilidade e o conhecimento de diferentes "versões" sobre as transformações dentro das escolas de samba. Os depoimentos ainda podem apontar continuidade, descontinuidade ou mesmo contradições no discurso do depoente (FREITAS, 2006).

Todas as entrevistas foram gravadas em áudio e posteriormente transcritas, buscando, em um primeiro momento, uma reprodução fiel, sem cortes, nem acréscimo; inclusive tentando reproduzi-las de forma coloquial, com as mesmas expressões e vocabulários utilizados pelos entrevistados para torná-los mais próximos possíveis de suas ideias originais. Após essa etapa inicial, os textos da entrevista foram devolvidos para os sambistas. Nomes foram corrigidos e algumas passagens foram suprimidas a pedido de alguns entrevistados, outros autorizaram a utilização da íntegra da entrevista, que passou por um processo de textualização, fundamental para que o narrador se reconheça no texto. Nesta etapa foram suprimidas as perguntas realizadas pelo entrevistador (ou entrevistadores), produzindo, assim, um texto de fácil leitura e análise, dando ao leitor uma ideia do ambiente da entrevista, seu ritmo e a comunicação não verbal, típica da oralidade, que se perdem na transcrição do texto. Incluem-se através das palavras as emoções do entrevistado, a entonação, gestos faciais e corporais, mantendo o clima coloquial e de cumplicidade que se estabelecem nas entrevistas (MEIHY; HOLANDA, 2007, p. 156, e MEIHY, 1991, p. 30-1).

A textualização é fundamental para que o narrador se reconheça no texto. Para conseguir realizar essa tarefa, nos valemos do conceito de transcriação, desenvolvido por Meihy (1990, 1991 e 2007) e Evangelista (2010). Para os autores, a transcriação é uma necessidade de reformular a transcrição literal para tornar a leitura compreensível. Como observa Meihy:

Na transcrição literal há inúmeras frases repetidas, enquanto outras são cortadas pelo entrevistado ou pela qualidade da gravação; há muitas palavras e expressões utilizadas incorretamente, devido à própria dinâmica da fala, da conversa informal - que é o que tentamos fazer nas entrevistas (2007, p. 156).

Os depoimentos orais serão mais que arquivo de gravações: implicam a elaboração de um documento que pode ser, num primeiro momento, a transcrição do testemunho e, em outra etapa, a sua análise. Como observa novamente Meihy, o primeiro estágio implica objetividade, e o segundo admite graduações dependendo mais de quem interpreta (MEIHY, 1996). 
O uso da transcriação justifica-se também do ponto de vista social, já que visa não apenas a utilização dela para a presente pesquisa, mas principalmente para voltar ao grupo de sambistas que as gerou, por meio de um apêndice ao final deste trabalho, contendo a transcriação de todas as entrevistas concedidas ao autor, registrando uma parte importante da história de vida de todos aqueles que, gentilmente, deram depoimentos para a pesquisa.

Após a realização da transcriação, os textos foram novamente entregues aos sambistas para a validação das entrevistas. Feito esse percurso, reconstituímos os passos de uma história cultural e artística fundamentais para entendermos aspectos da temática social, artística, política e urbana da cidade de São Paulo, e, em alguns momentos, até do Brasil, durante o século XX, procurando compreender a evolução histórica dos desfiles, que, em três gerações, transformou uma variante do batuque africano, perseguido pela polícia e pelas elites, em um espetáculo conhecido mundialmente. 


\section{Marcos dos Santos}

Nome: Marcos dos Santos

Data de nascimento: $12 / 07 / 1948$

Local: São Paulo

Profissão: Arquivista

Escola de samba: Tom Maior

Data da entrevista: 10/08/2010

Local da entrevista: Sede da UESP

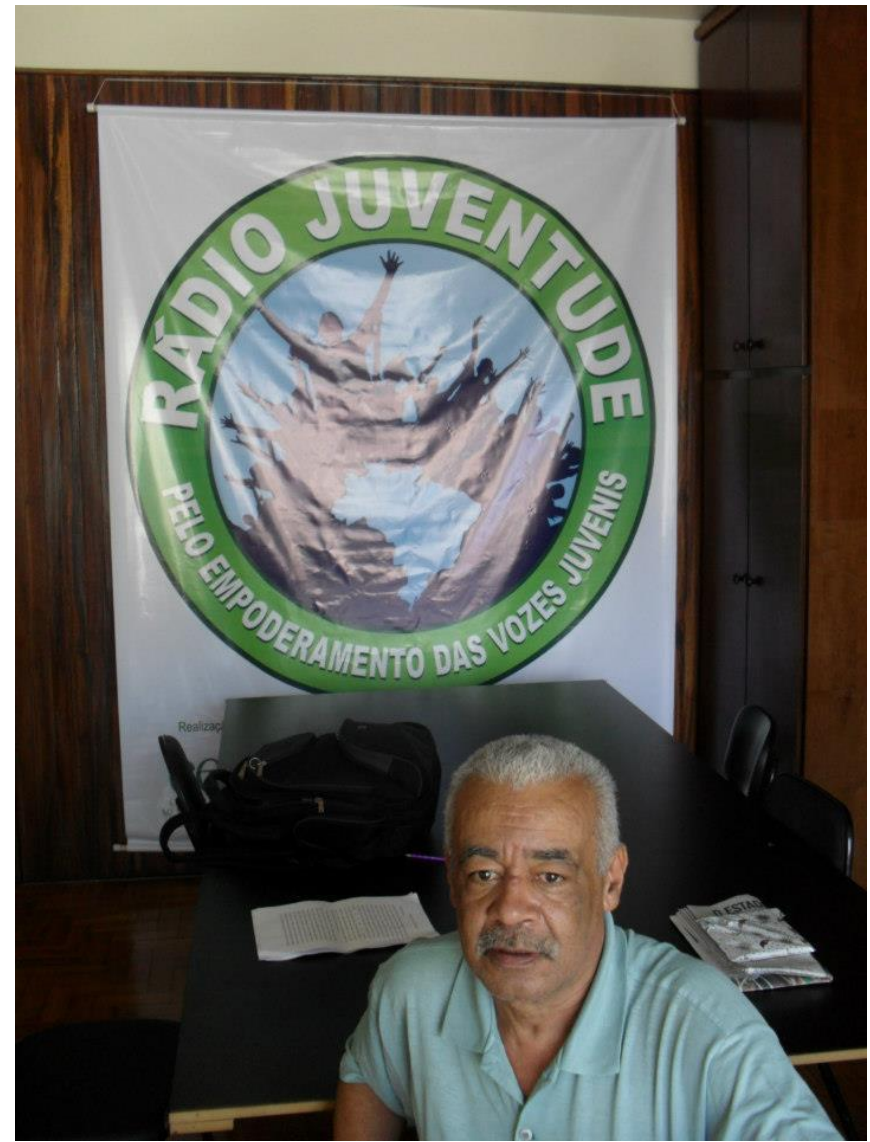

Figura 1 - Marcos dos Santos

Fonte: Foto tirada pelo autor. 


\section{"Nosso papel aqui na UESP é preservar o carnaval de comunidade"}

“Meu nome é Marcos dos Santos. Nasci em 1948, aqui em São Paulo. Tenho 41 anos de samba. Recebi, no ano passado, a minha faixa de Embaixador do Samba. Atualmente, sou coordenador do Centro de Documentação e Memória do Samba, aqui na UESP.

Eu considero que estou no samba desde 1969, ano do meu primeiro desfile pelo Cordão Carnavalesco Mocidade Camisa Verde e Branco, na Barra Funda. Desfilei quatro anos no Camisa, e depois participei da fundação da escola de samba Tom Maior. As origens do Tom Maior são três grupos que se juntaram. Existia um grupo de festeiros que eu liderava na Vila Madalena. Era Maria Helena, eu, Antonio Carlos e a sua mulher. Tinha um conjunto em que a gente tocava, era o Chic Samba Show. Além de nós, tinha um grupo de universitários que frequentava o São Paulo Chic, casa de show que a gente tocava. Aí nos juntamos, com o apoio da Família Miranda e de algumas outras famílias, junto com a gente e esses universitários da USP e da FEI.

Nessa época, quem realizava as rodas de samba eram as famílias. Íamos nas casas das famílias de amigos nos finais de semana. Aí eu comecei a namorar uma moça da família Miranda, a Maria Elisa. Nós nos encontrávamos sempre na casa do Hélio, em alguma festa, samba. E resolvemos fundar a escola de samba Tom Maior.

Uma coisa que não é verdade: a gente não é dissidência do Camisa Verde e Branco, tanto é que a maioria continuou no Camisa; era uma experiência nova que nós queríamos ter, uma escola com algumas coisas diferentes. Queríamos estar coordenando um novo processo. O Aníbal e eu contestávamos muita coisa do Seu Inocêncio, que era então presidente do cordão. Mas no dia em que a Tom Maior desfilou pela primeira vez, eu falei com o Aníbal o seguinte: O Seu Inocêncio tinha razão em um monte de coisas, a gente tava sonhando. E aí foi fundada em 14 de fevereiro de 1973.

O nome Tom Maior é por causa de uma música do Martinho da Vila. 'Vai ter que amar a liberdade/só vai cantar em tom maior/na felicidade de ter um Brasil melhor'. Foi inspirada nessa música, foi o Hélio Bagunça que sugeriu o nome Tom 
Maior. As cores vermelho e amarelo quem sugeriu foi o grande Talismã, que participou do grupo fundador.

A primeira sede foi na minha casa na Rua Cristiano Viana. A segunda sede foi na Rua Oscar Freire. Aí nós mudamos para o bairro do Campo Limpo, porque a gente achou que aqui estava muito elitizado. Foi uma tentativa de se tornar mais popular, mas foi uma experiência horrível. Acabamos depois de dois anos lá, e aqui a Tom Maior já começou brilhando. Em nosso primeiro carnaval existiam apenas três grupos de escola de samba.

No começo a gente chegou até se reunir com o pessoal da Pérola Negra, que também é do bairro, e com a Boca da Bruxa, que era um bloco que costumava sair sempre da Praça Benedito Calixto e descer a Rua Teodoro Sampaio. E nos reuníamos com o pessoal de uma escolinha que tinha desfilado somente na Vila Madalena, a Acadêmicos de Vila Madalena.

Nos juntamos para ver se conseguíamos unir em uma escola só. Mas também já nasceu a rivalidade que temos com a Pérola Negra. Nesse primeiro ano, saímos com 180 pessoas, fizemos questão que a conta fosse 180. Queríamos que saíssem somente pessoas que participavam do Tom Maior.

Nessa época, 74, 75, ainda existiam os cortiços ali na Oscar Freire, na Capote Valente. Por incrível que pareça, naquela região também tinha moradores negros e pobres. A gente começou a divulgar a escola no Largo de Pinheiros, onde tem o terminal de ônibus do Largo da Batata. Passamos a panfletar lá, e isso surtiu efeito; no carnaval, uma ala inteira já saiu lá do bairro do Campo Limpo.

No nosso primeiro desfile, em 74, saímos no terceiro grupo, e subimos para o segundo, ficamos um ano e passamos para o primeiro, que equivale hoje ao Grupo Especial, aí caímos em 1977.

É muito difícil administrar o carnaval de uma escola de samba. Fui diretor-geral do Tom Maior durante uns dez anos. Depois, em 1981, quem era presidente era o Wilson, mas a escola sempre teve muita disputa interna, então, durante os primeiros doze anos tivemos onze presidentes. Nenhum conseguia completar o mandato de dois anos, renunciava, saía. 
Aí, em 1981, ninguém queria pegar, e para evitar que a escola acabasse, então virei presidente e fiquei um ano. Também não consegui terminar o mandato como era praxe [risos]. Quando eu saí entrou o Claudinho, que ficou só um carnaval. Mas ele foi o único que quis sair e tinha o apoio de todo mundo, todos estavam fechados com ele, fizemos um carnaval legal, mas ele não quis continuar. Peguei de novo, fiquei mais um ano e fui derrubado de novo e entrou a Amélia, que era costureira do Tom Maior desde o primeiro ano.

Mas quem já estava tocando mesmo era o Marko Antonio, um rapaz jovem que dava uma força muito grande e eu mesmo fiz pressão para ele ficar na presidência, e ele assumiu. Ele era moleque, mas era apaixonado. Porque a maior dificuldade dos presidentes é a grana. Mesmo com a grana pouca é possível fazer um bom trabalho. As verbas vêm da quadra, da televisão e outras atividades.

Pessoalmente, eu acho que as escolas são mal administradas, mal planejadas. Por exemplo, eu nunca vou acusar o Marko de roubar, de tirar dinheiro do Tom Maior, como eu fui acusado várias vezes. Sei o quanto isso é pesado para a gente. O Marko mesmo chegou a me acusar, quando eu era presidente. Ele fez parte do movimento que me derrubou. Depois que ele assumiu, passaram três anos ele me chamou e falou:

— Ó, cara, desculpe; não é mole, você fez milagre.

Quando eu fui presidente não tinha verba de televisão. Era só a verba que vinha da prefeitura para o carnaval. E a gente não tinha sede; veio a ter a primeira sede, nem bem sede, uma pequena quadra improvisada debaixo do viaduto Paulo VI.

Eu sou péssimo para lembrar data, mas eu lembro que conseguimos essa concessão enquanto eu era presidente. Mas eu não sei o que aconteceu. Uns anos depois, eu me afastei por um período e acabaram perdendo esta concessão. Continuamos lá porque invadimos e ficamos até sermos despejados. Então ficamos na rua de novo, ensaiávamos no Sumaré, na Oscar Freire, mas sempre na rua, até que o Marko Antônio alugou uma sede na Avenida Doutor Arnaldo, que ficamos três anos, mas não tinha grana para pagar aluguel.

Ele já está há bastante tempo como presidente. Com ele, a escola adquiriu estabilidade que antes não tinha. Aí começou a crescer. Tem um pessoal, que eu 
considero pequeno, mas que continua lá desde a fundação até hoje. O pessoal da Velha Guarda e algumas famílias, como por exemplo, a minha família que continua até hoje, meu primo e eu, a família do Marko Antônio, a família do Seu Otto, a do Seu Caju. Continuam algumas famílias, como a do Caloi. Mas cresceu muito, hoje estamos com duas mil, três mil pessoas, um absurdo. E não é um público cativo, há uma rotatividade enorme, o pessoal aparece um ano, desfila e não aparece mais.

Eu costumo dizer para minha tristeza que o Tom Maior é, hoje, uma escola de baladeiro, que não é do povo; é tudo classe média universitária, bacana, uma escola branca, mesmo com pouquíssimas exceções. É negra a nossa porta-bandeira, a maioria das senhoras da ala de baianas, que ainda continua nas mãos do sambista mesmo, mas o resto já se perdeu. Estamos hoje no terreno do antigo Projeto Equilíbrio, e apareceram alguns patrocinadores. Um grupo fez a reforma, outro grupo arrendou por dez anos a quadra, então a gente está muito bem instalado numa das quadras mais simpáticas de São Paulo. Porque falta o tino comercial, de negociador para o sambista. Na verdade, a gente tem plena consciência de que até hoje só existem duas escolas de São Paulo que são bem administradas, e por sambistas. Rosas de Ouro, com a família do falecido Seu Basílio, e a outra a Mocidade Alegre, com a Solange, da família do falecido Seu Juarez. São escolas bem administradas, não tem dívidas, não montam só enredo em cima de patrocínio, conseguem fazer bons carnavais com o dinheiro que tem. É sempre muito bem planejado.

Já tem escola que tem dinheiro, como, por exemplo, o Império da Casa Verde. Não é que ela é bem administrada, é que tem muito dinheiro mesmo, então faz a diferença. A X9 também é bem organizada, mas as outras, as tradicionais, como a Nenê, Vai-Vai, Camisa, têm problemas de administração. Eu jamais penso que por desonestidade. Eu nunca vi ninguém roubando. Eu entendo que é mal administrado por ingenuidade, até. Eu mesmo sou um péssimo administrador, eu não sei administrar nem minha vida.

Quando eu era presidente do Tom Maior, era uma loucura, era muito mal administrado: tinha dívida, cheque sem fundo. Mas tem sambistas que são bons administradores. Uma coisa que eu fui aprender muito depois, quando comecei a 
trabalhar com artesanato, é a importância de almoxarifado, que é de primeira necessidade, e também reciclagem, já que o pessoal tira o costeiro e joga lá. Esse ano eu voltei para a quadra depois do desfile e fiquei recolhendo as fantasias, porque o pessoal começa a jogar a fantasia já na dispersão, no ônibus e na quadra. Isso é mal administrado. Tem que conscientizar que, depois do desfile, tem que devolver a fantasia. O que foi jogado de pluma, se fosse guardado, a gente gastaria metade no ano que vem, porque tudo se aproveita. E não é só no Tom Maior, na maioria das escolas não há um bom trabalho de reciclagem. Se a pessoa não quiser guardar a fantasia depois do carnaval, deve devolvê-la à escola.

Em minha opinião, quando houve a oficialização do carnaval em São Paulo e a fundação da UESP, havia a seguinte presunção: 'Em dez anos vamos passar o Rio de Janeiro', e com essa preocupação somente com espetáculo visual, a comunidade acabou ficando cada vez mais em segundo plano e, quando veio a televisão, aí prejudicou tudo. O sambista acabou excluído do mundo do carnaval, como ele é excluído como artista, do teatro, do cinema. Ele não tem acesso a lazer e cultura, porque pra isso tem que ter grana. Infelizmente, cultura, lazer é uma coisa cara e escola de samba, para mim, é o maior exemplo.

O verdadeiro sambista já não tem mais espaço, porque ele não tem dinheiro para pagar fantasia e ele não tem dinheiro para comprar o ingresso para a família toda assistir o desfile, aquele ingresso familiar do tempo da São João, Tiradentes já não existe mais. Eu ia com minha família, levávamos lanche, assistíamos aos desfiles, hoje já não dá mais, antigamente tinha encontros de carnaval. Eram famílias de sambistas que só se encontravam no carnaval, eu vivi muito isso, de parentes meus que a gente só encontrava no carnaval.

E como eu disse, ficou muito nessa de superar o Rio de Janeiro e acabou não olhando para dentro e nisso inflacionou, porque para ser melhor que o Rio precisa muita grana e muito planejamento. Só que no Rio ou é bem planejado ou tem muita grana. Tem a verba da televisão, quadra, do governo, de bicheiros, dizem por aí, que tem até coisas mais pesadas, mas eu, particularmente, nunca vi. 
Não acho que exista dinheiro de tráfico financiando escolas, eu não sei de escola nenhuma que recorra a esse tipo de recurso. É com certeza uma maneira de denegrir a imagem do coletivo dos sambistas, já que a fama ruim sobra sempre para nós. A imagem do carnaval melhorou muito, depois que incorporou a classe média. Mas você sabe que incorporou porque é moda.

Hoje, desfilar em escola de samba é sinônimo de status. Ainda mais que aparece na Rede Globo, fora a invasão dos artistas, que eu acho uma aberração que a própria escola de samba faz consigo mesma, uma falta de autoestima. Porque rainha de bateria e congêneres eu acho que tem que sair da comunidade. Eu tenho certeza que os grandes artistas, o grande elenco é a comunidade; era a única vez que a pessoa comum se sentia artista, todo mundo virava artista no carnaval, isso era muito bom.

Hoje os verdadeiros artistas são os atores mesmos, o sambista virou coadjuvante desses artistas principais que são da televisão. Não existe mais aquela coisa romântica de o sujeito simples ser rei, artista por um dia, que era muito legal para autoestima da comunidade.

Tem uma história de uma menina do Mackenzie que veio aqui na UESP para produzir um documentário para o Mackenzie. Ela queria fotos ou reportagens de revistas ou jornais que mostrassem a polícia batendo nos sambistas. Eu falei que não tinha, e perguntei por que ela estava insistindo tanto nisso. Ela disse que iria sustentar no documentário que, com a chegada da classe média, o sambista parou de apanhar, que hoje nós somos aceitos devido ao ingresso da classe média. Pra mim é justamente o contrário, essa chegada significa a exclusão do negro sambista das decisões, dentro da escola. Tivemos uma grande discussão em que eu falei que ela estava totalmente equivocada.

Quanto à televisão, tem um aspecto que a gente não pode negar: levou o carnaval de São Paulo para mídia, divulgou o nome dos bairros e das escolas, mas, financeiramente, eu não sei se esse modelo é viável e sustentável.

Eu preferiria que fosse sem televisão, porque, se não tivesse televisão, não teria tanto turismo, os baladeiros não iriam lá, entendeu? A linguagem do carnaval hoje é ditada pela televisão, então tem que ser coisas grandes, enormes. A porta-bandeira hoje 
é porta-costeiro, o costeiro dela é maior que a bandeira, uma coisa absurda. A ala das baianas tem um negócio na cabeça que não é um turbante e esconde o rosto.

Tira toda a cosmogonia e o significado da ala de baianas para o carnaval. As baianas não são mero acessório, é parte fundamental de uma escola de samba. Mas o que é isso? É o padrão visual, porque a televisão precisa de coisa grande, então os costeiros das alas cresceram, ficou absurdamente pesada. Esse ano minha escola teve uma ala de baianas muito pesada, coisa de chorar; fiquei enlouquecido, as senhoras não conseguiam suportar o peso. Se chovesse não saía do lugar. Estava muito linda, embora incompleta. Mas é isso que ganha o desfile do padrão televisivo. A ala de baianas do Tom Maior estava incompleta, faltando chapéu, sem pano das costas e turbante; isso não é só fantasia, baiana é fundamento. Mas turbante já era, hoje eles põem alegoria em cima das cabeças das baianas. Eu monto as baianas do Tom Maior, e você tem que amarrar essas fantasias pesadas e machuca as senhoras, é uma tragédia. Não é privilégio da minha escola. Isso é em todas as escolas.

Uma das coisas que eu tenho certeza que a televisão contribuiu foi essa imposição do visual, porque tem que ter visual não para quem está lá assistindo, mas para quem está na televisão, em casa. Para a Rede Globo, tanto faz que se for mil ou 50.000 pessoas no desfile, para ela, se estiver vazio, é a mesma coisa, porque o que interessa é o público assistir em casa com o saquinho de pipoca. Porque tudo gira em torno dos patrocinadores. É tudo gira em torno dos patrocinadores.

No Rio eu não sei, mas, com relação a São Paulo, é um contrato cruel, irrisório, uma coisa horrível. Cada escola do Grupo Especial recebe por volta de 150.000 reais, isso é o valor de uma chamada de propaganda no horário nobre do desfile; com isso, você vê o quanto que a Rede Globo ganha em cima do carnaval. E tem essa questão do monopólio, que eu acho antidemocrático. Ela não permite que outras emissoras transmitam. A Rede Globo, no final das contas, mais atrapalha que ajuda. Porque, mesmo no Rio, já teve carnavais que foi a Globo e a Manchete que transmitiram, e me parece que, mesmo em São Paulo, aconteceu isso. Então não tinha monopólio, hoje tem.

Sem monopólio poderíamos discutir melhor o preço, mas ela comprou a exclusividade e nós vendemos. O sambista vira refém, não pode fazer nada, ela paga 
quanto quiser, e eu acho muito pouco, tendo em vista as exigências do padrão visual que ela mesma impôs para o desfile que dizem é mostrado para o mundo inteiro, mas o carnaval de São Paulo só passa aqui. O mundo inteiro é o Rio de Janeiro, eu não sei como rola esse contrato lá, mas é uma boa grana, bem maior que a de São Paulo.

O Sambódromo do Anhembi foi construído para a linguagem televisiva. A proposta arquitetônica do Anhembi é de ser bem iluminada, uma arquibancada distante das escolas, é horrível desfilar, você não sente o público. A não ser que você tenha grana para comprar camarote, você não vê direito. Ele é muito mal localizado, não se oferece condição do público chegar até lá.

Você teve a Virada Cultural: foi metrô a noite inteira, no carnaval não se tem isso. Eu estive com o Mercadoria, que era diretor de carnaval do Anhembi, e propus que ele entrasse em contato com a administração do metrô e das empresas de ônibus que passavam por aqui, para fazer um esquema diferente no carnaval. O sambista Mercadoria respondeu:

- O Anhembi é para quem tem carro e para quem tem dinheiro para pagar no estacionamento e nos ingressos.

Tudo bem que se ganhe dinheiro, mas, e para o sambista pobre que não tem carro? Por isso o Anhembi contribuiu muito para a descaracterização do carnaval popular, de sambista pobre mesmo.

A divisão entre as federações, com a criação da Liga, também foi por culpa da televisão. Essa divisão foi uma história que eu acompanhei bem. Eu frequentava a UESP, na época, e prestava assessoria na coordenação do carnaval. Foi quando a Globo quis comprar o carnaval de São Paulo. Para comprar, ela solicitou uma mudança no calendário, para não coincidir com os dias do Rio.

A partir dessa mudança de calendário, nunca mais lotou a Avenida Tiradentes. Eram mais de 50.000 pessoas. Depois dessa mudança, enquanto foi na Tiradentes, nunca mais lotou. Porque na sexta-feira é dia normal, todo mundo trabalha e chega cansado. Desfile deveria ser no sábado e no domingo. Mas a Globo propôs mudar o calendário do Grupo Especial, esse teria que vir para a sexta e para o sábado, quando desfilava o terceiro grupo da UESP. Aí tiveram que jogá-los na segunda ou na terça. 
Os presidentes dos grupos inferiores cresceram o olho, e disseram que mudavam mais, exigiam uma compensação financeira das escolas maiores que iriam receber a verba da televisão. E o presidente da UESP na época não teve esse jogo de cintura de conseguir uma solução. Isso começou a dificultar a negociação, e o que eles fizeram? Fundaram a Liga com nove escolas do então Grupo I, e mudaram o nome para Grupo Especial. Só teve uma escola que resistiu: foi a Nenê de Vila Matilde, que disse que iria continuar na UESP.

O Betinho era presidente aqui na UESP e quem mandava na escola era o pai dele. O Seu Nenê não foi na reunião de fundação da Liga e perguntou quem iria impedir a Nenê de desfilar. E desfilou. Ele comprou mesmo sendo uma luta inglória, de sambistas contra o dinheiro da televisão.

A cisão se deu aí, em 1986. Eles gostaram da ideia de organizar independente da UESP. A ideia inicial era administrar o grupo de elite e as outras escolas ficariam com a UESP. Eles colocaram em prática, de cada ano trazer um grupo. No ano seguinte levaram o Grupo de Acesso. Tudo consequência da televisão, quando as grandes escolas foram embora a maior entidade que ficou aqui o bloco Gaviões da Fiel, que era um senhor bloco. O que fez a Liga? Convidou os gaviões para se filiar à Liga e abriu o Grupo de Acesso para eles virarem escola. Seu Juarez era o presidente, esse pecado ele tem e sabe disso. Transformaram o Bloco Gaviões em escola e quebraram a UESP, que era então ainda a entidade mais forte.

Só que também revela um erro de avaliação e prepotência deles em pensarem que levavam a Gaviões, no outro ano o Grupo II, depois o III e fechavam a UESP. No outro ano houve resistência aqui na UESP, o Grupo II permaneceu e acabou aí essa história. E a Gaviões começou a ganhar carnaval. Porque a Liga agiu com prepotência quando levaram eles, pensaram: 'Esses daí não vão longe, não.' E virou uma potência.

A Gaviões inflacionou o carnaval, assim como a Império está inflacionando. Para correr atrás, tem que ter muito dinheiro, e para pegar torcida também, porque eles possuem muito dinheiro. Todos querem ganhar carnaval, meu presidente quer ganhar carnaval e, para ganhar, ele precisa gastar muito mais. Patrocinar o visual imposto pela Globo. A Gaviões tem 50.000 sócios para financiar. Eu penso que é irreversível, não há 
volta. Esse discurso que eu faço hoje, o Paulinho da Viola fazia no Rio junto com Elton Medeiros há 20 anos. Ano retrasado, o Paulinho passou um dia aqui com a gente, almoçou aqui. Ele falou que era irreversível, não tem jeito, tomaram conta de tudo mesmo. Eu brinco sempre com a Léia que, daqui alguns anos, vão deixar ela, o Caio e eu para empurrar carro alegórico.

Eu não vou pagar 300 reais numa fantasia; mesmo que eu tiver, acho ofensivo! Não eu, Marcos, eu sambista. O absurdo que é presidente chegar na concentração e bater no peito dizendo que tem quinhentas fantasias da comunidade. É uma inversão de valores. São quinhentas da comunidade e três mil pagas. Deveriam ter 500 convidados para colocar os artistas, os japoneses, e cobram 30.000 uma fantasia, para poder financiar e subsidiar a comunidade. Parece utópico, mas seria o justo.

Eu faço questão de dizer que sou contra torcida de times. Sou contra carnaval de segmentos, carnaval é de sambista, não é de segmento ou de torcida. Agora estão inventando um carnaval universitário, uma coisa horrível. Eles podem pular carnaval à vontade, mas escola de samba deve ser de sambistas. Tive uma péssima experiência aqui com um cara que falou tanta besteira, o presidente dos Acadêmicos de São Paulo. São uns rapazes de uma arrogância e prepotência absurda. Eles esquecem o que a Velha Guarda representa para uma escola, o que nós, sambistas, já fizemos.

Por que se cria vários desfiles e vários carnavais? Temos dois carnavais, o da elite e do pobre, das comunidades. Esse não é divulgado. Mas o carnaval das comunidades, bem ou mal, ainda resiste, nas escolas menores que estão em ascensão. As pessoas desfilam porque gostam, não para aparecer na televisão. A fantasia não é cara, normalmente é cedida gratuitamente. Quem vai lá é porque gosta, não porque dá prestígio, ao contrário, desfilar em escola pequena não é recomendável. Em termos de estigma, é visto até hoje como coisa de maloqueiro. Mas resistimos, e um dos motivos de eu estar aqui na UESP é esse porque a minha escola já foi embora faz tempo. Perdemos a origem.

Estou meio descrente. Tanto é que, tirando o carnaval de comunidade, eu não quero mais mexer com carnaval. Eu estou agora no Centro de Documentação e Memória do Samba, vou desfilar na minha escola, amo a Velha Guarda, a ala das 
baianas que está há anos com a gente. Mas é triste, tenho certeza que, quando eu for ao ensaio do enredo desse ano, metade do elenco já são outras pessoas. Existe aquela turma que são: Rosas, Nenê, Vai-Vai tem muito, mas são poucos. Tem uma escola rival do Tom Maior e tem muito mais comunidade: a Pérola Negra.

A minha escola, hoje, não tem nada a ver com o que eu penso sobre escola de samba. O padrão imposto pela mídia não é o que eu penso. Eles alegam que houve uma profissionalização, mas eu não acho que a escola se profissionalizou, eu acho que a escola se comercializou. Virou algo meramente comercial, não é profissional. Profissional em que sentido? Comprar mestre-sala, porta-bandeira e o compositor? O carnavalesco, por exemplo, antigamente ele tinha uma ligação com a escola de samba de vários anos, hoje o carnavalesco não passa dois anos dentro da mesma escola, com puxador de samba acontece a mesma coisa, tudo sem bandeira.

Perdeu o amor, com raríssimas exceções. Carnavalesco, das escolas grandes, eu não conheço nenhum que esteja mais de três anos. Nas pequenas estão lá o carnavalesco ou comissão de carnaval que é o pessoal da comunidade. Eles dizem que é profissionalismo, eu acho que é comércio. Eu tive um exemplo muito duro na minha escola, o nosso mestre-sala e porta-bandeira, considerado por muitos o melhor de São Paulo. Eles eram da Pérola Negra, era o terceiro casal lá. Ele teve um princípio de namoro com a moça, ela, com muita vontade de desfilar no Tom Maior; aí eu conversei com os dois, passou um tempo, a menina aqui do Tom Maior ficou grávida, aí eu trouxe. Vieram para o Tom Maior para ser primeiro casal. Foi muito bom, e eles eram Tom Maior mesmo, a família toda, filhos, primos tia, mãe, todo mundo era Tom Maior. Mas, há três anos, o Marko Antônio me falou que eles foram para o Império de Casa Verde, eles compraram o passe.

Deu-me uma tristeza tão grande, porque esse ano o Império achou que o casal do Vai-Vai era mais interessante e mandaram eles embora três meses antes do carnaval. Desfilaram na nossa escola como convidados, mas agora fica difícil de recuperar o destaque de primeiro casal, porque o Vaguinho é um bom mestre-sala e está lá há bastante tempo. Isso é profissionalismo? Não, é um comércio barato que a escola fez com eles. Bem, eu não me venderia, mas não é por isso que as pessoas não possam 
buscar algo melhor financeiramente. O casal recebeu 12 mil reais, é um ótimo dinheiro, ela é doméstica e ele balconista de loja. No Tom Maior não ganhavam nada, apenas a fantasia. Seria profissional se eles recebessem no Tom Maior. Quando o meu presidente ligou desesperado para contar essa história, eu perguntei quanto eles ganhavam? Ele me respondeu:

- Nada. Só ajuda de custo com a passagem.

— O que mais você quer?

Eles recebiam somente nota dez e é difícil conseguir outro casal assim. Hoje está todo mundo comprando todo mundo, a escola poderia dar uma ajuda de custo para eles. O puxador de samba da Rosas de Ouro também é do Tom Maior, temos muita gente espalhada por aí em outras escolas que pegam nossos talentos e pagam mais. Essa troca é principalmente entre as grandes. Porque a pessoa pode desfilar em uma escola grande do Grupo Especial e continuar no Grupo II com a escola dele, o que acontece muito. E também a Velha Guarda, que desfila por amor.

Mas hoje existe ala de Velha Guarda não pelo respeito com os antigos de escola ou sonho do meu presidente, mas porque Velha Guarda virou quesito, tem prêmio em dinheiro para a escola. Então, Velha Guarda, é status. Há alguns anos, o que aconteceu no Rio foi um dos maiores crimes contra a cultura, não foi contra o carnaval somente.

A Velha Guarda da Portela não poder desfilar, e não é qualquer Velha Guarda, não, é a da Portela. Desfilaram depois, sozinhos, no chão, para a Escola não perder pontos, fecharam o portão em cima deles. Um dos maiores desrespeitos que eu já presenciei contra a cultura. Tinha fundador da Portela lá. É errado o carnavalesco colocar a Velha Guarda por último, se atrasar, é eles que têm que correr, é irracional você colocar pessoas de 70, 80 anos correndo. No meu conceito, a Velha Guarda vem atrás da Comissão de Frente. Se for para correr, no final do desfile coloca os mais jovens.

Nosso papel aqui na UESP, principalmente depois da chegada da Léia aqui, é preservar o carnaval de comunidade. E formar escolas, para que, quando ela sair daqui e vá para Liga, ela vá com uma boa formação cultural, essa é nossa preocupação. E preservar, porque preservando você tem história, se você tem história, tem futuro. Por 
isso foi criado esse centro aqui, e disponibilizando principalmente para escolas suas origens. São três eixos: formação, informação e preservação. Formação porque as escolas da UESP formam sambistas.

As grandes escolas já não formam mais, apenas compram. Enquanto que as escolas da UESP são obrigadas a formarem seus passistas, compositores. A criar os artistas. Por exemplo, a Nenê de Vila Matilde, que é uma escola de 1949 e já teve grandes puxadores, como Armandinho da Mangueira, Paulistinha, e criados lá, será que a Nenê não consegue formar um puxador bom lá?

Esse ano o presidente da Nenê falou comigo:

- Olha, roubamos seu puxador, que é o Royce do Cavaco.

Eu disse a ele:

- Muito obrigado. O Royce não tem nada a ver com a Vila Matilde.

É o caso do Tom Maior. Tem grandes puxadores, como o Jadir, Maradona, Darlan, e agora temos o René Sobral, que começou aqui na UESP. Mestre de bateria é a mesma coisa, uma escola tirando da outra. Minha escola não tem a melhor bateria de São Paulo, e tem condições de conseguir cinco mestres de bateria. Do Nenê saem muitos e ela contratou outro mestre agora.

Ainda bem que o regulamento brecou, porque o pessoal vinha do Rio pra coordenar desfile aqui. Então a escola perdeu todo o seu projeto que é formar e ensinar. O nome não é escola, então tem cuidar da formação do sambista. Essa é a grande luta da UESP e a minha luta. Tenho mais de 40 anos de samba e essas são as minhas impressões sobre o que está acontecendo no mundo do samba hoje." 


\section{Mestre Gabi}

Nome: Gabriel de Souza Martins

Data de nascimento: 08/11/1947

Local: São Paulo

Profissão: Desenhista Industrial

Escola de samba: Camisa Verde e Branco

Data da entrevista: 25/10/2010

Local da Entrevista: Sede da FESEC

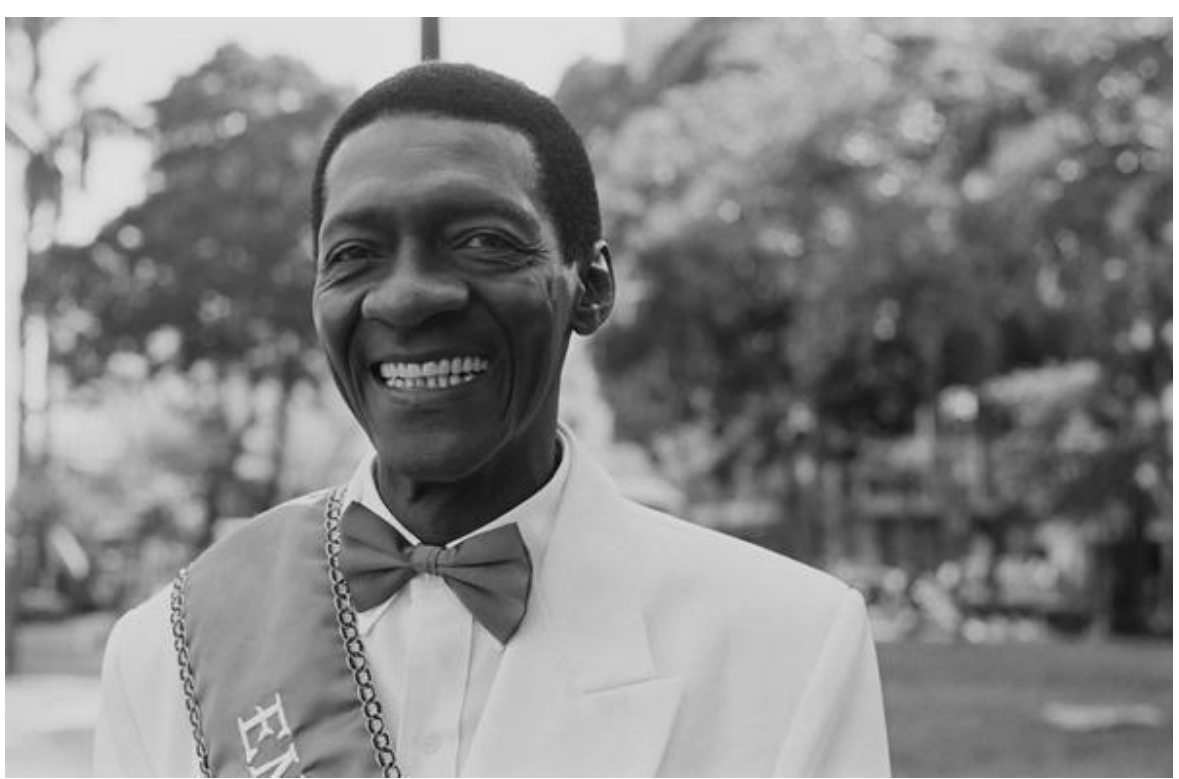

Figura 2 - Gabriel de Souza Martins, o "Mestre Gabi":

Fonte: http://amespbeesp.blogspot.com.br/

"O amor pela escola, a gente, que é sambista da Velha Guarda, nós sentimos demais!" 
“Meu nome é Gabriel de Souza Martins, Nasci no dia oito de novembro de 1947, no antigo Hospital Matarazzo, na Avenida Paulista. Mamãe e papai moravam no Jardim Paulista nessa época.

Com cinco anos fomos morar na Zona Leste, onde passei toda minha infância. E de lá, até hoje, moro no mesmo lugar. Minha casa era muito alegre e sempre tinha festas. Os primos do meu pai faziam serenata, faziam samba e a gente foi se acostumando sempre com isso. E foi indo, indo, indo... Mas, por incrível que pareça, eu fui para mundo do samba sozinho, e depois levei meu pai.

O samba surge na vida da gente assim, como uma coisa que você já nasce com ele. Tinha lá no bairro tinha uma escola de samba que era a Estrela Brilhante. Mas eu nem participava muito, porque eu, na época, eu não me interessava muito por escola de samba. Eu me interessava mais em curtir, só. Aí, depois que o tempo foi passando, aí sim, eu comecei a participar mais.

Minha primeira escola foi Barroca Zona Sul. Mas, antes de participar da Barroca, participava das bandas que tinham aqui na cidade. Algumas ainda existem, como a Banda Redonda, a Banda do Cantinho e a Banda Bandalha. Então eu tava no meio. Comecei a participar de carnaval nas bandas.

Lá tocavam músicas de meio de ano, das rádios e sambas também, além de marchas. Eram marchas que hoje a gente já não tem mais. A resistência ainda foi até uns anos atrás. O Sílvio Santos era um dos que faziam essas marchinhas de carnaval. Depois acabou. Não se faz mais hoje...

Fora do período de carnaval, meus amigos e eu íamos muito em barzinho. Foi quando eles começaram a dar espaço a grupos de samba: grupo aqui, grupinho ali, quando chega o... Como é o nome? É... Fundo de Quintal e deu um boom, assim, nesses grupinhos que foram se formando. Então a gente começou ali no bar, no campo de futebol e nas bandas.

Quando eu cheguei, o samba já tava popularizado. Mas teve a geração que veio antes de mim. Muita gente boa, e que foram muito importante pro samba chegar onde chegou. Aprendi muito com eles. Na Praça da Sé era um dos locais onde mais se curtia samba em São Paulo. Se você vê hoje na Praça da Sé alguém jogando capoeira, até vai 
formar um pessoalzinho ali. Mas antigamente isso era comum, sabe? Tá jogando capoeira, tá jogando tiririca, e tal.

Os engraxates que faziam o movimento. Não era uma coisa assim do outro mundo que ficava todo mundo, ali olhando. O pessoal olhava, mas era uma coisa mais normal na cidade, ali, na Praça da Sé, antes da reforma que também não era dessa magnitude que é hoje, era uma coisa menor. A Praça da Sé de antigamente era cheia de ponto de ônibus e bondes. Era muito diferente de hoje. Ao lado da Praça da Sé existia a Praça Clóvis que, eu não sei nem se vocês conheceram, acho que nem conheceram a Clóvis. Então, tinha a Clóvis que era logo de onde os sambistas também se reuniam.

A gente tinha muito espaço em vários pontos da cidade pra ficar se divertindo, na Zona Leste tinha o largo do Peixe e na Barra Funda o Largo da Banana. Era uma diversão que acabou! A gente perdeu o uso do espaço público e pra conquistar aquele espaço foi uma luta. E depois a gente perde esse espaço público porque aí você tem: 'Ah, não pode fazer barulho aqui, não pode fazer barulho ali, não sei o quê...' Agora tem mais ainda, agora tem a lei do silêncio. Então nós temos escolas de samba que são obrigadas a fazer os seus ensaios à tarde, no máximo até às dez horas e aí acabou. As festas nos bares, as rodas de capoeira. Você não pode mais. Então a coisa vai se fechando muito, e a gente, fio, perdendo os espaços.

Em escola de samba eu comecei a participar mesmo como integrante, como componente, na década de 70. Depois virei chefe de ala. Aí desfilei em ala, depois desfilei em ala-show, com o pandeiro, tal fazendo aqueles malabarismos, como diretor, como um monte de coisa, como compositor, tudo na Barroca Zona Sul, e depois, aí sim, como mestre-sala. Então eu digo que a Barroca foi minha escola de samba de coração e de formação, de raiz.

Eu sou desenhista de profissão, trabalho em um escritório de arquitetura. Nunca vivi do carnaval, este negócio de muita gente viver do carnaval, é de agora, pouco tempo. Primeiro no Rio de Janeiro e depois aqui em São Paulo, lá começou bem antes.

Nós estamos mais ou menos 30 anos de defasagem com o Rio de Janeiro, de verdade. Nosso carnaval está grandioso, está, mas nem um pouquinho assim para se comparar com o carnaval do Rio, com o profissionalismo do Rio de Janeiro. Por isso, 
quando eu falo de carnaval, falo regional, falo do carnaval da nossa cidade, porque se formos comparar, estamos engatinhando ainda em termos de profissionalismo. Tanto que muitos vêm de lá para cá, puxador de samba, diretor de bateria, compositores e até casal de mestre-sala e porta-bandeira. Também de Parintins, eles estão vindo para São Paulo.

É a cidade do dinheiro, quer ganhar dinheiro, venha pra São Paulo. Eles mesmos falam: 'Quer ganhar dinheiro, vá pra São Paulo.' Eles vêm aqui e ganham dinheiro mesmo. Agora tem puxador de samba, tem chefe de barracão, diretor de bateria, mestresala e porta-bandeira, vem todo mundo para cá. Mas fazer o quê? E não é que somos piores do que eles, não é isso!

Aqui nós temos sambistas de primeira linha, como lá também, aqui nós temos nosso jeito, da nossa região. E estas profissões aí que surgiram, como marceneiro, serralheiro, decoradores, aderecistas de carnaval, que agora virou profissão. Aqui em São Paulo também está acontecendo isso, o pessoal tá trabalhando. Você, integrante, chega lá no barracão, de repente, você não pode nem entrar, tem segurança na lá porta, aquela coisa toda. Antes vinha todo mundo da escola, vamos ajudar e tal...

A gente colocava a escola na rua. Hoje não, hoje tem o segurança, fulano aqui pode entrar? Esse pode, aí entra, e só olha: Ó...ó...ó...e pronto. Eu não sei se é esta grandiosidade que tirou o romantismo ou o profissionalismo, ou o profissionalismo que tirou o romantismo que não tem mais.

Veja bem, antes eram os homens que faziam as alegorias. E nós tínhamos as costureiras, e quem eram as costureiras? Era a minha mãe, era a mãe de outro sambista, não era a profissional costureira, eram pessoas comuns, que sabiam costurar um pouco, então vamos fazer fantasia. E nós confeccionávamos as nossas fantasias.

Talvez por isso a gente seja muito saudosista. Porque você olhava depois em uma fotografia a sua fantasia, e olhava com um sentimento. Este aqui foi a última conta que eu coloquei, este aqui foi a última unha que eu coloquei, então para nós era uma coisa assim magnífica, e a gente curtia muito isso. E a família inteira pegava aquela calça, um bordava em uma perna o outro bordava a outra, era uma coisa de comunidade, sabe? Quando a gente diz escola de samba, comunidade era isso. 
Quantas noites eu não fui para a escola para ficar no barracão, ajudando, pregando. Eu não sou marceneiro, mas quantas vezes eu não ia lá pregar os carros alegóricos, eu ia pintar, também não sou pintor, mas pintava, decorava, então era um trabalho de todos da comunidade, a gente não tinha aquilo como profissão.

Hoje eu não vejo o carnaval como eu via antigamente. Eu vejo o carnaval hoje muito... É, como que eu posso dizer pra você? É duro o que eu vou dizer, eu, Gabi. Não vejo mais o carnaval, pelo menos na nossa cidade. Não se vive o carnaval. Você vive um desfile de escola de samba, lá no Sambódromo. Se você sair daquele meio ali, você anda pela cidade normal, como se tivesse num dia comum. Até com menos gente, porque muita gente aproveita pra viajar.

Entra em uma escola de samba e vá desfilar. Vá como componente da escola mesmo, de ônibus, faça a via sacra. Quando você descer do ônibus, entra no corredor polonês, naquele espaço, aí fica lá parado esperando porque tem que concentrar duas escolas. Aí vai entrar, mas se sua ala for uma das últimas está frito, porque vai ficar lá atrás. Depois que entrou, em 20, 25 minutos você passa a pista toda. Quando menos, porque às vezes a escola tá grande, gasta menos tempo. Quando acaba o desfile já vem o segurança e coloca vocês pra entrar no ônibus e você vai embora e acabou o seu carnaval. É carnaval? Não é carnaval, você não vê ninguém fantasiado nas ruas como antigamente a gente via. Hoje, se eu falar pra você:

— Põe a tua fantasia lá na sua casa e vem pro Sambódromo. Você não vai vir.

- Ah, cê acha que eu vou andar fantasiado aí na rua?

Não vem, ninguém vem. Vem com a fantasia no carro, chega lá no Sambódromo, aí, sim, que põe a fantasia. Chega no final, joga tudo lá e vai embora. Então, isso não é mais carnaval.

Até nos clubes, a gente não tem mais aquela alegria. Você não tem mais matinê pras crianças, então ficou muito restrito ao Sambódromo. Até quando era aqui na Tiradentes, era melhor, porque aí a cidade vivia o carnaval. Quando era na São João, no Anhangabaú, a cidade vivia ainda mais o carnaval. Agora lá, não, você ficou confinado. Chego ali, saio dali, acabou. Então é um pouco triste pra gente que é de outra época. De outro século. 
Claro que as coisas mudam, mas tem que mudar sempre pra melhor. Essa mudança cresceu o carnaval, mas nos exclui um pouco enquanto sambista mesmo... Por exemplo, essa ida dos desfiles... Não vou nem te dizer da São João. Da São João aqui pra Tiradentes já foi um feito, né? Nossa, o carnaval cresceu! Mas da Tiradentes lá pro Sambódromo excluiu o povão, sabe? Aí você me pergunta:

- Por que excluiu?

- Porque aqui se pagava bem menos pra entrar.

E, além disso, você tinha esse pedacinho onde nós estamos nessa altura da avenida. É o local onde começava o desfile. A pista de desfile, que era 750 metros, ia até lá em cima. Então daqui até o viaduto lá embaixo, no rio, era perto, então o povão podia assistir as escolas subindo, pra entrar na pista. Então era muita gente, mas muita gente mesmo, que ficava aqui nesse espaço que não se pagava. E depois a pista pra baixo, quase chegando lá na Praça do Correio, na dispersão. Então era muita gente mesmo.

E o povo que ficava andando aqui nas imediações. Então, nós perdemos isso. Lá no Sambódromo, ou você entra ou você não entra. Não adianta ficar de fora, fazer o quê lá fora, você não vê nada? Não tem ninguém. Só portão e muro. Então a gente perdeu com isso. A gente, eu digo, a comunidade, os sambistas que não podem pagar, lá é uma nota pra se entrar e pra assistir, né. Uma diferença: aqui você trazia seu lanche, você trazia seu café, você trazia sua garrafinha de chá e assistia as outras escolas nas arquibancadas. Você desfilava e depois ia assistir às outras.

Agora o sambista pobre desfila pela sua escola e vai embora. Acabou o carnaval. É só 20 minutos de avenida. Lá você não pode entrar nem com uma garrafa d'água. Então tudo você tem que comprar. Você quer água? Você tem que descer lá e comprar. Então isso restringiu demais os sambistas. E aí eu digo: a comunidade sambística, que é a comunidade pobre, né? Então elitizou demais. Ficou tudo caro.

O samba ficou elitizado. Hoje, Nossa Senhora, hoje é uma coisa assim... Lá embaixo você vê que as alegorias nossas hoje são imensas, né? O dinheiro chegou e a comunidade negra e pobre foi sendo excluída do carnaval. 
Outro fator: Quando você coloca uma torcida junto com as pessoas comuns, é complicado. Então muita gente não vai ao Sambódromo por esse fato. Medo por causa das torcidas. Porque lá nós temos a do São Paulo, do Palmeiras, do Corinthians, e agora tá chegando a do Santos também. Então é muita briga e muito descaso. Teve um ano aí que parecia um estádio, o pessoal da Gaviões estendeu uma bandeira em um setor e ninguém mais sentou ali, só eles. O lugar é comum a todo mundo. Botaram o bandeirão lá e tomaram conta. E aí chegou todos eles, sentaram. As escolas que passavam, eles ficavam de costas, não estavam nem aí. Só quando passou a Gaviões que aí eles se manifestaram da melhor forma, tudo bem. Mas é um desrespeito pra um pavilhão você estar ali fazendo um desfile com o público de costas. Isso daí foi muito repudiado.

Hoje eles já melhoraram. Tão melhorando. Parece que entenderam um pouco que carnaval, desfile de escola de samba é uma coisa, clube de futebol é outra. Porque ali é um lugar onde não tem só duas torcidas ou três. Ali tem torcidas de todas as agremiações. Cada um defende o seu bairro. Eu sento do teu lado, você é Camisa, você é Nenê, você é Vai-Vai; quando passa a minha escola, eu vou aplaudir. Você não vai ficar bravo porque eu tô aplaudindo a minha escola e nem eu vou brigar porque você tá lá aplaudindo a sua. Às vezes até aplaudo junto porque tá fazendo um trabalho bonito.

O samba sempre foi assim. Era uma integração e lá no Sambódromo, com as torcidas de futebol, a coisa ficou meio estranha. Então tem muita coisa que, se a gente for botar mesmo no papel, nossa... A grandiosidade acabou com a emoção.

O carnaval hoje, pra nós, não tem muita emoção mais, aquela coisa de coração, de você chorar pelo teu pavilhão, como acontecia. A gente, nossa, eu já chorei quando minha escola foi mal... A escola passa mal, passa bem, você sente. Hoje, não. Eu falo pra você:

— Você quer sair na escola? - Aí você fala:

- Ah, qual escola?

— Ué, na minha. Ah, mas é Palmeiras.

- Não, não é Palmeiras, é o Camisa Verde, não tem nada que ver com Palmeiras.

- Ah, mas eu sou corintiano. 
— Ah, então sai na Gaviões.

— Ah, mas Gaviões, não sei... Vai sair num horário ruim.

— Então sai lá no Caminho da Vila. — Aí você fala:

- Então quem sabe eu vou lá.

Você chega lá e sai, sem comprometimento nenhum. E nós estamos num concurso, tem que ter o comprometimento. Poxa, se eu vou sair lá é porque eu quero que a minha escola ganhe. Hoje se compra fantasia pela internet. O que mudou no Carnaval? Essas coisas...

Eu me emociono até, falando, porque a gente já não sente mais, sabe, aquela garra do povo contente, chegar aqui vai, ah, dessa vez nós vamos ganhar, e vamos pra cima, e tal, sabe? Perdeu tudo isso. Ganhou? Não ganhou? O ano que vem eu saio na que ganhou e tá tudo certo. $\mathrm{O}$ amor pela escola, a gente, que é sambista da Velha Guarda, nós sentimos demais! Demais da conta mesmo. Você vai na quadra... Olha, domingo passado eu fui no ensaio, tive lá na quadra. Rapaz, eu fiquei olhando assim, de braço cruzado. Cê já imaginou, eu, na minha escola, ficar olhando de braço cruzado? Deus me livre, jamais! Eu estava lá, mas você não sente mais o calor, aquela... Sabe, aquela coisa, aquele amor nos componentes. Eles estavam ensaiando como se fosse qualquer coisa.

Sinto que hoje, nas escolas de samba, muito poucas são as pessoas que pertencem à escola de samba. Porque a gente perde identidade, vocês sabiam? Perdia identidade. Eu, por exemplo, quando estive na Barroca, eu era o Gabi da Barroca. Então não sabiam meu nome completo, mas sabiam que eu era o Gabi da Barroca.

Quando eu vim pro Camisa, que ainda foi uma vinda assim, meio conturbada. Eu não ia sair mais de mestre-sala, porque a minha porta-bandeira da Barroca passou mal aqui na Tiradentes. Aí, em solidariedade, eu falei:

— Beth, eu não vou sair mais também.

Porque ela passou mal do coração. Eu pensei: 'Caramba, já pensou essa menina aí me vê dançando com outra porta-bandeira. Ela é capaz de morrer, coitada, né?' Aí, eu pensei: 'Eu também não vou sair mais.'

— Não, Gabi, sai sim. Puxa, que é isso? — Falei: 
— Não, não, não, não vou sair. - E não saí. Não saí mais como mestre-sala na Barroca. Aí, num outro ano, a minha esposa Vivi foi convidada pra ir pro Camisa Verde, assim, em janeiro. E aí, como o mestre-sala de lá não quis desfilar com ela porque ela não era porta-bandeira, ela era destaque. E aí ele falou:

— Não, você não é porta-bandeira, eu não vou desfilar com você.

E ele é meu amigo, nós somos amigos. Eu disse:

— Não, pode desfilar com ela que ela sabe, ela ensaia comigo.

Lá em casa a gente ensaiava. Aí, ele:

— Não, não só saio com a minha antiga porta-bandeira.

Aí a presidente, que era a Magali, falou:

— Ah, você não vai sair? Ah, tá, então tudo bem. Gabi vem cá. — Me pegou assim, levou lá no palco:

- A partir de hoje o Gabi e a Vivi são oficiais do Camisa Verde e Branco.

Eu falei:

— Que é isso, eu nem pertenço a essa escola, eu sou do Barroca.

Aí, já foi. Pronto, foi assim a minha vinda pro Camisa. E aí ficamos aí até hoje. Hoje eu não desfilo mais como mestre-sala, mas eu pertenço à escola, né? Vou, brigo, falo, mas é a minha escola de coração também. Fiquei mais de dez anos desfilando pelo Camisa, ganhei todos os prêmios que você pode imaginar. Aí a idade veio chegando e eu passei o bastão. Eu tenho duas escolas, a de raiz e o Camisa.

O carnaval de São Paulo começou a mudar não foi nem quando ele saiu daqui da Tiradentes para lá pro Sambódromo. Ele mudou quando Joãosinho Trinta veio pra Peruche. A Peruche saiu com costeiro, as alas saíram com costeiro, todo mundo falou: 'Nossa, olha o Peruche, todas as alas vêm com costeiro.' E todo mundo ficou maravilhado. Joãosinho Trinta veio lá do Rio. E o cara é uma cabeça, eu tiro o chapéu pra ele, é sumidade. Sim, a Peruche começou a trazer do Rio, trouxe o Jamelão, trouxe o Joãosinho. E depois todas as outras escolas vieram atrás.

Mas, antes dele, quem trouxe primeiro foi a Mocidade Alegre, que trouxe o Edson Machado, grande carnavalesco, fez dois carnavais maravilhosos na Mocidade Alegre, fez carnaval na Barroca da Zona Sul, maravilhoso. 
O Juarez da Cruz, na Mocidade Alegre, viu no Rio as alegorias e se tocou. Também começou a colocar na avenida carros alegóricos maiores, aí foi nessa crescente. As escolas competiam pra ver qual era o maior carro, até chegar naquele tigre que a Império trouxe que era uma monstruosidade, mas que adianta? O que adiantou um tigre daquele tamanho? Pra quebrar a harmonia da escola, quebrar em que termos? Você tem um tigre de 50, 60 metros de comprimento e ali não tem ninguém. Então a escola termina o canto lá e recomeça aqui atrás, quebra a harmonia da escola, o canto e mesmo que não quebre, com toda essa tecnologia de som que nós temos aí, mas a escola tem que estar muito bem ensaiada para não quebrar o canto, a harmonia. E foi assim, começaram vir as pessoas do Rio de Janeiro e padronizar tudo.

Hoje não tem muita diferença entre uma escola de São Paulo e do Rio. Mas deveria ser nítida, já que aqui é um ritmo que veio do batuque, que veio de outra vertente, né? Não foi aquele samba do Rio de Janeiro, que é diferente. Porque a nossa batida vem de cordão.

Porque em São Paulo, antes das escolas, o que mais tinha eram cordões. O cordão Barra Funda, que era o Camisa Verde, você tinha o Vai-Vai, você tinha o Fio de Ouro, você tinha um aqui da Liberdade... O Campos Elíseos. Então eram muitos cordões... Era uma coisa mais simples. Não era como a escola de samba. Então a escola realmente começa lá no Rio de Janeiro.

E depois é que vem pra São Paulo. E veio pra São Paulo, trazida por Evaristo de Carvalho, que trouxe a Portela pra desfilar no estádio do Pacaembu. Primeira vez que veio escola de samba aqui fazer um desfile. E aí os moldes são os mesmos, tanto que os quesitos são iguais. Agora lá... Eles mudam lá, aí nós mudamos aqui também. Pra copiar, né? Claro... Lá os desfiles são muito parecidos, você vê pra diferenciar uma escola da outra pra ver qual que vai ser campeã, é difícil. Aí vai essa transformação.

E começou a vir esse pessoal de Parintins, com os movimentos dos carros. É isso que nós temos ainda hoje. Mas às vezes a coisa muito grandiosa não surte o efeito desejado, mas a diferença foi assim fenomenal, lá nós temos 16 por 12 de pista, de largura por altura, acho que é 12 metros aquele portal, é muito alto. Todo mundo ficou refém da grandiosidade. A televisão só quer mostrar coisa grande. 
É a grandiosidade, e por causa da programação da Globo, é tudo cronometrado. Se você atrasar já perde ponto. Nossa, eu já saí dessa Avenida Tiradentes meio-dia. Era ruim, era, mas nós éramos felizes e não sabíamos. Mas estávamos curtindo o carnaval, quando terminava, ia todo mundo fantasiado, era aquele orgulho da sua fantasia, entrava para assistir as outras que estavam faltando, entrava fantasiado, mas hoje não é mais.

Quando você via uma fantasia jogada? Nunca, agora vai lá, no fỉm da avenida, se você não vê um monte de fantasias, tudo jogado. As pessoas não levam mais para casa, guardar pra quê? Mas se você quer saber, ainda tem gente mais velha do que eu que ainda tem fantasia guardada, e vai te falar: 'Com essa aqui eu desfilei na Tiradentes, com essa aqui eu desfilei na São João', tem gente que tem.

Eu não tenho porque as minhas fantasias eram de mestre-sala e as escolas do interior compravam as nossas fantasias para usarem, porque senão eu queria as minhas fantasias. Fantasias que eu ganhei como melhor mestre-sala e tal, eu guardei um tempo, mas depois vendi, porque a escola pedia pra vender e trazer dinheiro.

Hoje está todo mundo refém, não tem muito pra onde correr, se você quiser disputar o título como escola de samba. Na minha época, a coisa era mais tranquila de se levar. Porque o valor era bem menos. Se eu te dou mil reais pra você administrar, olha você vai ter que fazer o seu carnaval com mil reais, aí você vinha aqui comprava tecido, ia ali comprava as sandálias, sapatilhas. Nossa! Eram poucas as coisas que você tinha que comprar, as outras, você ia reciclando, procurando com alguém, não dá pra você me dar?

Vê o caso da Lavapés, que é uma escola de 1937, que é a primeira escola de São Paulo. A primeira escola de São Paulo foi fundada em 1935, que é a Primeira de São Paulo, e o seu presidente é o Elpídio de Faria, mas ela logo acabou. A Lavapés é a escola que de 1937 até hoje está desfilando, e é uma escola de família. Aí é o que eu digo pra vocês, quanto à resistência, ela continua sendo uma escola de família é a neta da Madrinha Eunice, que é a presidente hoje. Mas o que é que falta? Administração.

Nós pecamos muitas vezes por isso. Eu não sou contra alguém te ajudar na administração. Olha, você é formado em administração, conhece bem, vocês vêm pra minha diretoria, mas eu comando, eu não preciso dar a minha escola pra você. Você me 
auxilia, mas eu participo. O valor é muito alto, aí quando eu digo o nosso povo, é o nosso povo sambista, nosso povo negro, que tem menos instrução, ele não consegue sozinho, vê a situação da Lavapés hoje.

Com exceções, porque toda regra tem 'suas exceção', mas, se você hoje dar 50 milhões, olha, você vai ter que colocar a sua escola na rua, com 50 milhões. Olha, primeiro ele vai ter que trazer alguém pra fazer isso com ele, pra administrar isso com ele, porque ele não tem noção de administração de juros, de tabelas, de desconto. Você chega lá, pechinchar é uma coisa, um desconto que você pode adquirir com uma boa conversa, tratativas mesmo, é diferente, tem que ter uma pessoa mais experiente.

Aí o sambista foi perdendo o seu espaço, eu digo, enquanto presidente de escolas de samba, negros. Antigamente todos eles eram negros, não era? Nas escolas de samba, até porque não era bem visto pela sociedade, aquela coisa toda. A partir da oficialização a coisa foi mudando, e essa administração foi passando pra um pessoal profissional. Fulano é formado em administração, então é melhor trazer ele pra compor a nossa diretoria, porque ele conhece. Depois temos que prestar conta pra prefeitura, pros patrocinadores. Essa pessoa era uma pessoa branca e sem coisa de discriminação, porque somos todos iguais, mas você vai entregando os cargos.

Porque os sambistas não perderam, não, entregaram! Que tomar é difícil. Vai tomar a escola, não se toma, a gente dá. Perderam seus espaços, entregaram. Entregando você passa a de repente nem mais fazer parte da diretoria. Eu conheço fundador e expresidente que chega hoje na escola e perguntam:

— Quem é o senhor?

E o cara era presidente da escola, veja bem, fundador e presidente da escola, chega lá, tem os seguranças na porta, o cara fala cadê os ingressos? Não, mas eu era presidente. O cara tá lá, não conhece ninguém, não vai deixar entrar. Aí vem um, e diz: 'Nossa, mas é você, libera ele aí.' É humilhante, eu já presenciei, nossa! De ver alguém que já foi presidente daquela escola, daquela agremiação, chegar e pedirem para ele o ingresso. E ele ficar ali, aí o Gabi podia entrar porque o Gabi é mais conhecido, todo mundo me conhece, o pessoal fala: 'Ô, Gabi, faz favor, mas e fulano, não vai entrar?' Então, estas coisas que deixa a gente magoado, porque a gente presencia muito isso. 
O cara chega, muda tudo na escola e depois vira até presidente, porque estudou, tem uma graninha a mais. Mas não pense que porque ele estudou ele vai administrar bem. Por exemplo, os presidentes de escolas fizeram um contrato com a Globo, veja bem, de 14 anos. Vê se pode uma coisa dessas. Um contrato de exclusividade com a Globo de 14 anos. Isso não é um exagero? Pô, é brincadeira! O que você acha que eles colocaram nas cláusulas? Que não pode outra emissora entrar, não pode. 'Olha, nós vamos pagar esse dinheiro, mas vocês vão ter que desfilar na sexta-feira.' 'Na sextafeira?' 'É, mas a grana é boa'. 'Então, tá, vamos mudar pra sexta-feira, até pra não concorrer com o Rio, vamos mudar'. No primeiro ano do Sambódromo, em 1991, 1992, por aí que mudou. A direção da Rede Globo falou:

- Olha vocês vão desfilar na sexta-feira, mas só depois do Super Cine, nós não vamos televisionar nada antes do Super Cine.

Então as escolas desfilam na sexta-feira depois do Super Cine. Por que a grade da Globo não pode ser mexida, e no sábado? No sábado, pode começar um pouquinho antes, depois da novela. Então a gente foi ficando amarrado a eles, simplesmente.

A Rede Globo que comanda tudo. Percebe como a gente foi envolvido, uh, pronto e fomos sendo envolvidos. Aí nós estamos aí até 2014, porque assinamos em 2000, até 2014. O contrato é da Globo, vê se pode, 14 anos de contrato. É demais, não é? Você acha que se fosse um povo esclarecido ia fazer isso? Não iria. Em sã consciência, ia pesar os prós e os contras e não ia fazer uma coisa dessas. Jamais. Tanto que, agora, duvido que eles vão botar até 2028. Cê acha? Não, agora é mais três anos, vamos entrar com outra emissora, vamos dividir, porque eles fazem o que eles querem. Porque eu já briguei demais contra isso. Aí veja bem, eu já briguei demais com eles, por quê?

A televisão deveria estar aí para mostrar a beleza, o lado cultural da escola de samba, falando dos seus enredos, mostrar o que é e o que a escola tá trazendo. Quando é um enredo futurista, da cabeça do carnavalesco, a gente nem discute, mas quando é um enredo histórico, poxa, a gente coloca tanta coisa naquele desfie, que a maioria das pessoas não sabe. 
Pra você fazer um desfile, tem que pesquisar, e pesquisar muito. A televisão ignora isso. Teve um ano que o Camisa Verde e Branco veio falando da fotografia, então, nossa, quanta coisa importante nós tivemos naquele enredo. Que Dom Pedro que trouxe a máquina fotográfica. Muita gente não sabia. E aquela de foto sépia, preto, colorido, como é que se fazia. Então, muitas coisas importantíssimas que poderiam ser ditas durante o desfile da escola, não foi dito. O que passava? As meninas nuas, seminuas, né, porque nuas não pode vir, as coisas erradas. O mestre-sala e a portabandeira que ostentam o pavilhão, que é o ponto mais alto de uma escola de samba, passavam assim, ó, três segundos. Você acha que eu não vou reclamar? Fui reclamar!

- Vocês fazem coisa que não é pra fazer. Passa um casal, vocês dizem que é outro, totalmente errado.

Eu era presidente da Associação de Mestre-Sala e Porta-Bandeira do Estado, a AMESPBESP. Preparei um dossiê, com todas as escolas, todos os pavilhões. Mandei pra eles. Com o nome de todos os casais, sequência dos desfiles pra eles não errarem. 'Ah, mas isso não dá pra gente fazer, como não dá, tem que dar.' Aí o diretor da Globo falou pra mim:

- Gabi, deixa eu falar uma coisa pra você: você não quer ficar no carro de imagem, aí, quando passar o casal, você indica e a gente fala? — Eu falei:

— Eu não, não ganho nada com isso, vou perder meu carnaval pra ficar no carro de imagem, vocês que têm que se orientar.

Já reclamei demais com eles. Agora que eles estão colocando umas câmeras ali onde os casais evoluem mais, porque eles deveriam evoluir na pista inteira, mas quando vai chegando os jurados eles querem evoluir um pouco mais, fazendo as graças deles.

Agora de uns anos pra cá que eles estão colocando uma câmera ali, pra mostrar esse lado. Estão melhorando, até 2014 é capaz de melhorar um pouquinho mais.

A Leci Brandão é criticada nos seus comentários pela direção da Globo. Eu tô contando uma coisa que eu sei, ela me falou, porque a gente tem amizade. Porque ela fala, não sei se vocês já ouviram, quando ela entra pra falar, ela só pode falar uma coisinha assim. Ela fala:

— Olha lá a Fulana da ala das baianas. 
- Ah, Leci, você vai falar isso, olha a crítica.

Mas ela tem que falar isso. Para nós, que somos sambistas, que estamos com nossas famílias assistindo, já pensou? Sua mãe passando, e a Leci Brandão falando:

— Olha lá a Dona Carmem passando ali na ala das baianas. - Não é uma coisa fantástica que valoriza o samba? Mas ela não pode falar. Percebeu que ela não fala mais no carnaval do Rio, não é ela quem está fazendo as intervenções no carnaval do Rio, porque lá ela conhecia todo mundo, então ela anunciava:

- Vem aí a Dona Coisa, o Seu Fulano, da Velha Guarda - e tal. A direção da emissora diz:

— Não precisa falar isso.

Ela veio embora aqui pra São Paulo e tá disputando pra deputada aqui. Ela é muito boa a Leci. Teve um dia que eu estava na casa dela e a gente conversando, a Leci, eu e a mãe dela, ela disse pra mim que em São Paulo ainda pode falar, mas já estava sendo podada também. Então você vê que a direção se intromete muito, tem coisa que você não pode falar.

Eu questiono mesmo, já questionei com o Chico Pinheiro, porque você chega lá, vamos falar do quê, Chico? Teve uma que foi no carnaval desse ano, não teve o Botequim do Samba? Esquina do Samba? Eu fui convidado pra Esquina do Samba e tava lá. Aí eu de costas pra avenida e a câmera aí me filmando aí, e eu de costas pra avenida, aí eu olho assim, vem vindo o pavilhão, você acha que eu vou ficar de costas pra um pavilhão que está passando, não vou. Eu levantei e fui aplaudir, tem coisas que nós sambistas não podemos fazer, a gente tem que ensinar que não é assim, eles têm que aprender. Aí o Chico:

— Gabi, tá filmando. — Eu disse:

—Tá filmando, filma lá o pavilhão que tá passando, eu não sou o problema, tem que filmar lá, olha aí o pavilhão, tem que aplaudir.

Aí a Leci também virou, virou todo mundo, aí todo mundo ficou olhando. Veja bem, não me chamaram mais pra comentar na Esquina do Samba. Mas eu dei meu recado. As pessoas que estão chegando têm que se informar primeiro pra falar alguma 
coisa, ou exigir alguma coisa, né? Eu acho que a cultura do samba é diferente, precisa se orientar primeiro. Vou ficar de costas para um pavilhão, nunca!

O pavilhão é o mais importante de uma escola. Atrás desse pedacinho de pano aqui, desse pavilhão que existe desde 1984, quando foi fundada a Federação, isso é a Federação, uma coisa que é além de uma escola de samba, é um pavilhão que foi fundado por pessoas responsáveis que, com muito carinho elaborou, fundou tudo isso. É em respeito a essas pessoas é que a gente cumprimenta os pavilhões todos, é em respeito aos antepassados, aos nossos ancestrais.

E atrás de um pavilhão desses, se você soubesse o quanto de mística tem, principalmente de escola de samba, né? Esse eu não falo, porque é Federação. Tem muita coisa, muito misticismo que tem atrás de um pavilhão. Você vê que todas as escolas de samba têm uma ala de baianas, não tem?

É obrigatório, vocês sabem que é obrigatória uma ala de baianas em uma escola de samba, estavam querendo tirar, mas quem queria tirar? A modernidade. Sabe essas senhoras aí já estão muito cansadas, e além do mais atrasam o desfile. Que isso? Baiana é fundamento de escola de samba! E neste fundamento estão os pavilhões, as baianas. Tem sempre aquela baiana que é chefe de terreiro, que faz os trabalhos de proteção da escola de samba, tudo em cima do pavilhão, porque ele representa toda aquela comunidade, toda aquela nação. Então é por isso que a gente vai lá e cumprimenta com muito respeito. Sempre que vocês chegarem em uma escola de samba, você vai ver que o pavilhão está lá. Sempre está. Se não estiver está errado, ele sempre vai estar lá em algum lugar, pode chegar lá tranquilamente, pega o pavilhão, é um cumprimento só. É como se você estivesse chegando na minha casa e me cumprimentando: 'Oi, como vai, tudo bem?' Estes são os fundamentos da escola de samba, que eu acho que a gente peca muito em não passar isso para toda a comunidade.

Eu dei uma palestra na semana retrasada pra um grupo de jurados. E aí eles chegaram, todo mundo chegou, 150 pessoas, todo mundo sentou. E aí, a hora da minha palestra que é módulo dança, aí eu falei:

— Estou impressionado. Vocês chegaram aqui e ninguém foi lá cumprimentar o pavilhão. - Era o do Camisa Verde, porque foi feito lá. Aí, na saída, foi todo mundo lá. 
Ué, se eu não falo, não é todo mundo que fica sabendo. Tem que saber por quê. Se eu não falo alguém um dia ia falar, mas e se não fala? Eu, como membro da Embaixada, tenho que falar.

Esse é o carnaval hegemônico. Mas estou pensando nas escolas grandes. Se vamos falar das escolas da UESP, ainda tem, mas elas estão confinadas, coitadinhas. Você vê onde eles põem o pessoal para desfilar, lá no autódromo. Fala a verdade, onde não tem ninguém, pode? Não pode, então vai sendo excluído. Escola lá da Vila Matilde tem que desfilar lá no autódromo. Que dor de cabeça como é que o pessoal vai levar alegoria pra lá, não pode. A escola do bairro põe lá no bairro.

Sabe, antigamente a gente fazia isso. Quantas vezes eu desfilei na Vila Prudente, na Lapa, ali em cima em Santo Amaro, onde tinha gente. Agora, na Politécnica, não tem ninguém, e olha a dificuldade que é pra chegar. A UESP tinha mais de 120 escolas, só está com 68, não era para ter muito mais? Tá acabando, o pessoal tá desistindo. Vai acabando, o que eu digo de romantismo, é o tempo quando a gente fazia fogueirinha pra esquentar o tamborim, sabe? Acabou tudo isso.

Quantas vezes eu não fui lá em Santa Cruz, no Rio de Janeiro, buscar couro pra encourar os surdos do Camisa Verde. A gente ia lá no curtume, vocês morrem, é um cheiro horrível! E a gente ia sabe? Encourava tudo, ia todo mundo com aquela garra, hoje não. Você liga: ‘Ô, Fulano, tem couro aí, manda dez, manda 50.' O cara entrega na quadra e pronto. É tudo muito simples, não tem mais a ansiedade de você fazer, ver se está legal, chegar no dia do desfile, aí sim, tá tudo pronto.

Nós chegamos na avenida já está tudo pronto, olha que legal, mas você não viu nada, não acompanhou nada, porque não pode ir no barracão. A comunidade não pode ir no barracão. Então você não vê nada. Tem gente que chega para desfilar e não vê a sua escola. Você chega lá e é tudo muito rápido, já posiciona, sua ala é aqui, e aí soa a campainha e já desfilou. Aí vem o segurança, põe todo mundo pra fora, entra no ônibus, foi embora. Você não pode ficar ali pra ver sua escola chegar ou sair. Não tem como, você não vê a sua escola.

O samba é um instrumento de denúncia, temos que voltar a usá-lo. Aqui em São Paulo não temos muita tradição de escola que vem com sátira, mas no Rio tinha mais. 
Hoje quase não tem mais. A Ilha do Governador, Estácio, eles eram bem críticos, com questões políticas. Aqui em São Paulo lembro que o Camisa trouxe como o Negro Maravilhoso e era verdade! Vê só:

Tinha uma bola de ferro, preso nela uma corrente/Esse osso de canela veio de outro continente/De jeito nenhum não é preconceito/Preto e branco tem direito nossa escola não faz distinção de cor/E pra falar sobre esse tema/Foi que surgiu o problema/E o dilema se avizinhou/Ô ô ô, a nossa escola enobrece a negra gente/Que nunca ficou chorando/Sempre viveu fingindo contente/ Negro paga imposto/Negro vai à guerra/Negro ajudou a construir a nossa terra/Temos a pergunta não nos leve a mal/Porque só no tríduo de momo que o negro é genial?/Ele é capitão/Ele é general/Ele poderia ser tanta coisa dentro da vida real. [cantando]

É uma crítica forte e foi feita no tempo da ditadura. Um período que não podíamos falar. Eu fiz samba-enredo que foi pra censura. Tudo tinha que passar pela censura. Essa palavra aqui não, tem que tirar. Era complicado. Até 1970 e poucos, mas até mesmo até 1985 ainda tinha censura velada. Certas coisas não podiam falar. Senão era preso. Eles queriam que a gente fizesse esse sambinha água com açúcar.

Mas depois veio a democracia, e parece que quando você pode falar, perde a graça, quando você não pode falar que você fala. Eu tinha um professor de português, o dia que a gente queria matar aula era só falar de política. Ele já tinha sido preso como subversivo, quando a gente falava, ele saía no corredor, olhava, fechava a porta e começava a discutir política. Só que a gente não podia falar alto, tinha que falar baixinho e ele sempre com medo de alguém dedurar.

Agora vê os enredos desses últimos carnavais, quase todos eles giram em torno de patrocínio. Um fala de uma cidade, outro fala de outra. Nós vamos falar da Avenida Paulista, o centro financeiro, os barões do café, tal, rende alguma coisa? Vai render, mas seria melhor falar algo mais cultural, do nosso povo, as crianças não sabem mais nada, outro dia perguntei quem descobriu o Brasil, me falaram que foi Cristóvão Colombo. A criançada não sabe nada da nossa História. O samba-enredo poderia ensinar isso.

Com tudo isso, o futuro do carnaval paulistano é muito incerto. Eu vejo com muita preocupação... Em questões... De segurança. De segurança pelas escolas que a 
gente tá vendo subir. Tão chegando aí, essas escolas de torcida... Eu não sou contra as escolas de torcida, mas eu tenho uma preocupação. Eu já dei aula lá na Mancha Verde, e aí eu estava lá dando aula de mestre-sala e porta-bandeira na Mancha Verde... Peguei o CD e botei lá, tá tocando assim, quando tocou um samba da Gaviões que estava no CD...

- Puxa vida, não, não, não, não, Gaviões, não.

— Uai, por que não? É um samba.

— Não, Deus me livre, os caras passam aí na rua, vê nós tocando um samba do Gaviões. — Eu falei:

- Eu não quero saber, eu tô dando aula aqui e eu vou tocar. É um CD das escolas de samba de São Paulo, eu tenho que tocar.

Olha, eu parabenizo a Gaviões todo desfile e a Mancha também... Os carros que eles trazem, sempre maravilhosos, o acabamento, muito bonito... As fantasias são sempre nota dez! São mesmo caprichosos, eles fazem, eles têm condição e mostram que têm. Mas aí falta um pouco. Eles podiam ganhar o carnaval todo ano, poderiam mesmo.

Mas é que aí falta um pouco de maturidade de avenida em questões de desfile, falta um pouco... Porque aí, os componentes não são componentes da escola de samba, é torcida. Então pra eles, eles tão ali, mais preocupados em divulgar o time de futebol do que com as regras. Outros querem mais é curtir. E não é assim, as escolas de samba têm regras, e aí eles infringem as regras e por isso que eles perdem. Na evolução, por besteira que eles fazem... Perdem ponto por trazer bandeirona, que não pode, né. Então eles vão perdendo, assim, perdem pra eles mesmos. Mas, se eles vierem como uma escola de samba mesmo, ninguém segura.

A Mancha teve um carnaval aí que eles saíram lá da quadra montadinhos. Eles atravessaram o viaduto desfilando, desfilando a escola inteira, eles têm um poder de... de... aglutinação impressionante. Eu olhei e pensei: 'Caramba, ninguém vai segurar esses meninos'. Entraram, fizeram um desfile lindíssimo, com muita organização, perfeito, eles fizeram um desfile maravilhoso. Mas pecam em alguns aspectos, nesses aspectos de torcida, né? Aí é que empobrece. Mas se não fosse isso... Eles trouxeram uma grandiosidade pro nosso carnaval. 
Eles são responsáveis também por essa grandiosidade que a gente tem. Então, a gente critica, mas não pode só criticar, tem que falar as coisas boas que eles trouxeram também. Porque eles trouxeram muitas coisas boas, por que as outras não vão querer ficar pra trás, né? Então também vai ter que melhorar.

Eu sou o Gabi, mestre-sala do Camisa Verde e Branco e da AMESPBSP. Participei, lutei e continuo lutando por um carnaval popular feito pelos negros e pobres. E é isso... Se quiser falar de carnaval, venham aqui. Vocês vieram ao lugar certo!" 


\section{Dona China}

Data de nascimento: 04/08/1929

Profissão: Operária e comerciante

Escola de Samba: Vai-Vai

Data da entrevista: 09/07/2011

Local: Residência da Dona China

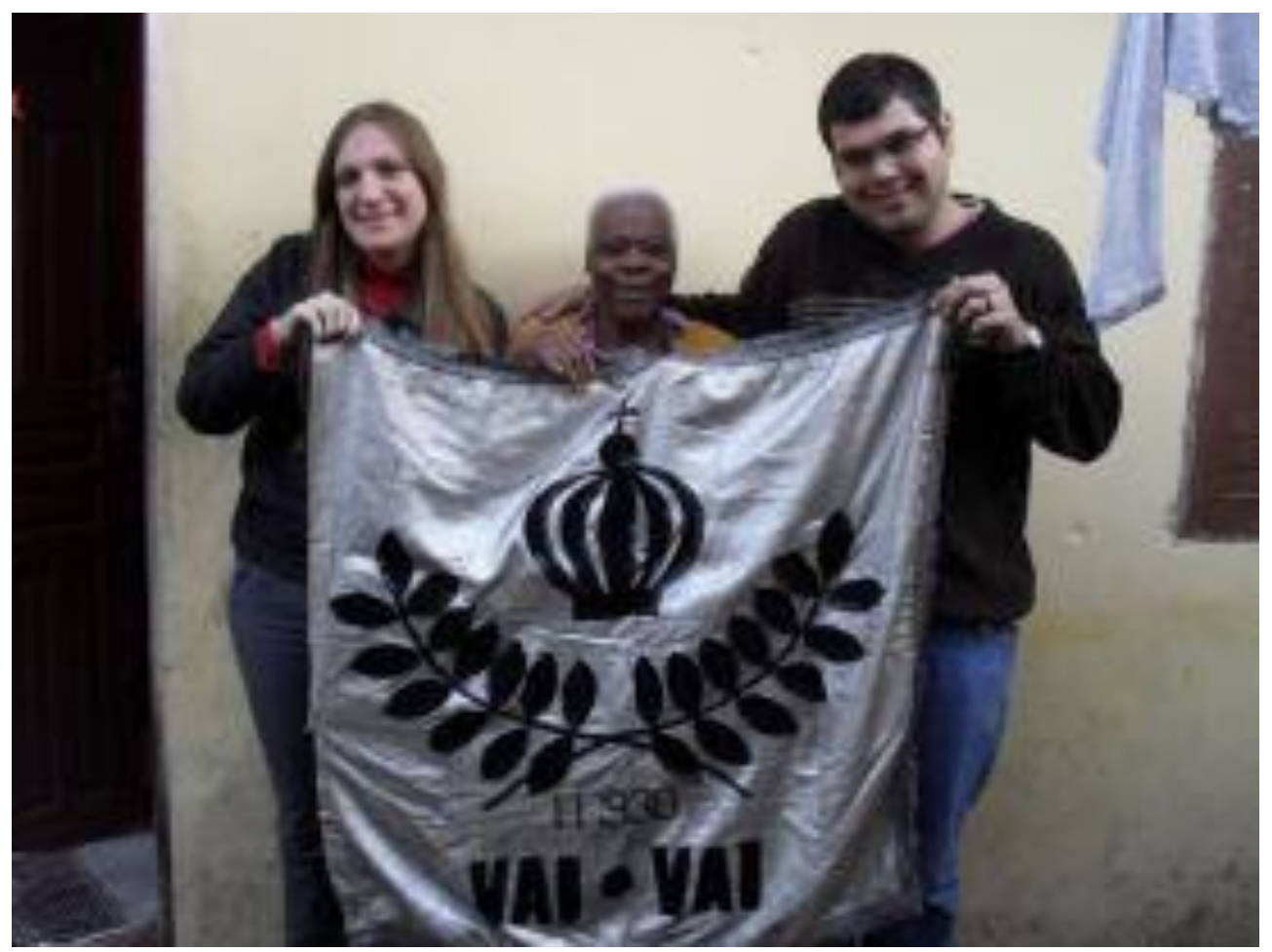

Figura 3- Dona China, ao centro, Karine Rio a esquerda e Bruno Baronetti a direita. Fonte: Foto do Autor

"Quero desfilar até o meu último dia." 
"Meu nome é Emilia Feliciano Ferreira, me conhecem no samba por China. Desde pequena sou conhecida por China. E estou no samba desde os 5, 6 anos, mais ou menos, ou sete. Lembro que entrei no samba e logo comecei a estudar.

Eu estou no samba de 1936 até hoje. Quem me levava nos desfiles quando eu era menina era meu avô. Ele que me chamava de guaxinim, porque eu tinha muito cabelo, como a calda do guaxinim, e eu fui indo até que eu virei Chininha.

Meu avô era assim, ele tinha três blocos, calça azul, camisa branca, calça verde, camisa branca, camisa amarela e calça branca. Cada dia se apresentava em uma fazenda, então nessa fazenda ele pegava um ramo de café e dava pra eu vir na frente. E aí eu vinha na frente, cada dia eu vinha na frente de um bloco. Quando terminava o carnaval, o bloco que ganhava, ganhava o troféu, e sabe o que era o troféu? Era saco de laranja, mexerica, café, meu Deus, era um divertimento!

Aí que eu comecei a gostar, gostava muito de cantar, participar da igreja e foi indo. Aí, viemos pra São Paulo, morar no Ipiranga, e lá eu comecei a sair no cordão Juventude como contrabaliza. Participava das festas da igreja, aquela festa que a meninada sai pra pegar flor pra colocar na rua onde passa o padre, de tudo isso eu participei. Tinha canto nas barracas, eu participava, era uma líder nos festejos.

E assim meu avô veio me trazendo, ele era rezador, rezava, participava de congada, de roda de samba, de festa de samba. E tudo isso eu fui aprendendo com ele e tomando aquele gosto e, quando chegamos aqui em São Paulo caí, de vez no samba! Meu pai também era músico, tocou na orquestra do Bem Conrado.

Também fui do circo, eu fiz algumas apresentações, tava aprendendo. Só não continuei porque, depois do Ipiranga, o circo vinha aqui pra zona Leste e, nesse tempo, era como se fosse fora da cidade e a minha família achava que era interior, que iam me roubar, então parei de me apresentar no circo, senão até hoje eu tava no Rapa-Rapa, tava no circo, já era velha, mas estava no circo! Acho que dessa época deve ter alguém, porque estou com 83 anos, e eles eram mais velhos que eu. É possível ter alguém, ou não tem, não sei.

Sempre no mês de agosto íamos pra Pirapora do Bom Jesus. Esse ano que eu não fui, mas eu vou. Era tão lindo! Tinha congada, catira, tinha a dança de roda, as mulheres 
com aquelas saionas, dançando e batendo aquele tambor, eu dancei até com menino pequenininho assim, menino bom pra dançar sabe, dançar umbigada, aquelas coisas lindas, depois também tem a dança de São Gonçalo, o pessoal vem dançando, e bate pra lá, bate pra cá, aquelas fitas, coisa maravilhosa!

Faz pouco tempo que nós participamos de um show junto com o Netinho na festa de Pirapora, ai, foi tão bom, você tinha que ver! Fora da festa, eu estive em Pirapora pra inaugurar o busto do Geraldo Filme, que fizeram em um salão, colocaram o busto dele em cima e nós que fomos inaugurar o busto dele.

Também participei das festas de Nossa Senhora Aparecida no Parque da Água Branca. Os bombeiros trouxeram e nós fomos receber a Nossa Senhora Aparecida, ali foi uma festa enorme. Fomos todos da UESP uniformizados, foi uma festa grande, muito boa.

No ano passado que eu não fui e esse ano que já me convidaram e que eu não fui por problemas de saúde, mas eu participo da festa de São Benedito, eu vou pra Santos com o Durval nas festas de São Benedito, participo de tudo. Agora a Embaixada, o pessoal da Velha Guarda, nós, da Velha Guarda, sempre participamos quando tem festa, participo de tudo isso.

Antes de entrar no Vai-Vai, eu participei de outras escolas, como Folha Azul e Tatuapé. Foi assim, do Ipiranga eu fui morar na Penha. Morei um pouco na Penha e viemos aqui para o Carrão. Nos mudamos pra cá em 1947. Aí começamos a sair no Folha Azul dos Marujos, era uma escola boa, mas aí morreu o presidente, os diretores, e eles não souberam levar a escola para frente porque ela estava muito boa. Também desfilei um ou dois desfiles do Tatuapé, escola do Mala e do Casado.

Eu saía nessa escolinha do Folha Azul e o Ivo veio me convidar para fazer uma noite no Vai-Vai, porque não tinha porta-bandeira para desfilar nesse evento que a escola ia fazer no Sábado de Aleluia. E eu fui na noite de sexta na casa da Dona Paula, que arrumou a roupa para mim direitinho. E quando foi no Sábado de Aleluia, eu estava no Pacaembu. Fiz o desfile eles gostaram, e quando fui para casa dela, na Avenida Angélica, décimo terceiro, aí os repórteres todos, em cima de mim, todos me adotaram, me pegaram como uma criança, e eu fiquei até hoje. 
A Dona Paula ajudava na parte de carnavalesco. Era assim, por exemplo, na época do cordão, a escola se reunia e cada fazia um pouco e saía tudo, mas quando passou a ser escola de samba, no Vai-Vai foi o Caio que passou a ser carnavalesco. Ele, a mulher dele, a Beatriz, e o Minoro, que é um japonês. Eu lembro que meu figurino de porta-bandeira era o Caio que fazia.

Era assim para ele fazer o figurino, tinha uma lista e era aquilo ali, não tinha que tirar, era tudo na íntegra, o que ele fazia tinha que sair como ele fazia, e hoje em dia o carnavalesco dá o figurino, mas se ela não gostar, 'ai tira isso, tira aquilo'; antigamente, não, era a coisa feita ali mesmo, na íntegra.

Hoje você vê, se o enredo for africano e tiver que sair de africano, sem camisa só de turbante, eles não querem, eles querem roupa que brilham plumas e paetês, se não tiver plumas e paetês ninguém quer, percebeu isso?

O carnaval é bem diferente, porque antigamente o enredo vinha de acordo, se era enredo afro, tinha que vir vestido de africano, tinha que vir vestido direitinho. As alas eram contadas e hoje em dia, não.

Nossa, no meu tempo, não era assim. Junto com a minha comadre, eu cheguei a pegar uma lantejoula do chão, para não fazer falta no meu vestido, porque não podia comprar, não. Agora a pessoa chega e já tem tudo pronto, quer dizer, que nós, antigamente, lutávamos, a gente comprava o tecido, ou a escola dava um tecido vagabundo e você tinha que fazer ele, coberto e forrado com lantejoula, quando não tinha dinheiro pra comprar lantejoula, a gente colocava plástico.

O primeiro vestido meu que eu saí no Vai-Vai, o Pé Rachado que era presidente naquela época deu só cetim preto e falou: 'Olha, China, te dou o cetim e você vê o que você pode fazer', então ele me deu e eu mandei uma colega minha que mora aqui fazer. Ela fez e eu pensei: 'E agora, como eu vou comprar lantejoula?' Porque a situação financeira não era boa, aí eu comprei um plástico, ela recortou toda a bandeira do VaiVai num plástico, ela colocou no vestido preto de cetim, e, nossa, quando eu cheguei na avenida, esplandeceu!

Ai, meu Deus do céu! Quando eu subi a São João, meu coração parecia que ia sair pela boca. Aí, lá na avenida que eu recebi o pavilhão, a bandeira, esta bandeira que 
tá aqui comigo. Quando eu ia subindo com ela na mão assim, vi a roupa do Ivo igual, a mesma roupa que era minha, era do Ivo Branco, o mestre-sala. Ele era enfermeiro do hospital municipal, depois foi para as Clínicas e passou a ser escrivão de polícia em Sorocaba, e de Sorocaba o Silvio me falou que ele tinha morrido. Mas o Ivo era uma pessoa muito grande, ele era louro dos olhos azuis, altão, usava sapatos brancos, então o pessoal chamava ele de homem do sapato branco. Era um mestre-sala de primeira, você tinha que ver, ele era meu mestre-sala e trabalhava com dois leques, e era uma coisa maravilhosa, quando ele caía na avenida, é uma coisa que a gente não esquece. Quando ele punha o leque assim e me chamava na avenida, e fechava o outro, a avenida vinha abaixo! Então sempre, graças a Deus, tive muita proteção dele, e ele, onde estiver, que Deus o proteja.

Quando o Vai-Vai passou a ser escola de samba, eu fui a primeira portabandeira. Fui primeira porta-bandeira do Vai-Vai, de 1972 até 1983. Vim para desfilar um dia e eu estou há 43 anos. Eu também já desfilei com estandarte. $\mathrm{O}$ ano que eu parei de sair de porta-bandeira eu passei a sair com o estandarte. O Vai-Vai é de 1930, mas não era escola de samba, era cordão.

Era diferente, porque no cordão tinha rancho, tinha rei, rainha, princesa, tinha todos esses adereços, tinha estandarte. A batida do cordão também é diferente porque o samba de cordão era uma batida, agora de escola de samba é outra. Então o samba de cordão era cantado em seguida, agora não. E tinha cavaquinho, tinha aquele bem grandão que bate. Hoje em dia mudou bastante, tem cuíca, tem reco-reco, agogô, frigideira. E o samba modificou muito.

Quando eu comecei no Vai-Vai, o mestre de bateria era o Feijoada, depois entrou o Tadeu. Antes deles teve um primo meu, o Pato’N'água. Quando nós soubemos que ele tinha morrido, já tinha passado um mês ou dois, morreu lá em Suzano, a gente nem sabe como foi direito. Falaram que mataram ele, mas até hoje a gente não sabe. Cada um conta uma história diferente.

Eu desfilei com a fantasia aí da fotografia, esse foi um dos meus primeiros anos como porta-bandeira. Você veja que era tudo diferente, até as plumas; antigamente, era 
o baile da gente que valia a pena, hoje em dia é só pluma e paetês, elas balançam e acabou, os concursos todos que eu ganhei, foi na raça, ganhei ali.

Quando eu deixei de sair de porta-bandeira, ela foi ofertada para mim pelo Chicle. Eu sou a única porta-bandeira que teve o pavilhão ofertado pela escola. Teve uma festa para mim no Palácio Mauá, e, nessa festa, eles me ofertaram o pavilhão que está aqui comigo. E durante esse tempo todo eu fiquei desfilando para o Vai-Vai, era muito bom!

Também desfilei na escola Império do Samba de Santos, todo ano eles vinham me buscar. Eu tenho as medalhas que eu vou mostrar, de 1970 a 74. Ganhei elas como melhor porta-bandeira de Santos. Tenho essas e outras medalhas. Uma das mais importantes foi a da inauguração da Praça Roosevelt, que o prefeito Faria Lima me deu. Tenho muitas outras medalhas e prêmios.

Ano passado, ganhei da Câmara Municipal. Eu tenho esses prêmios, mas eu acho que a política não devia entrar no carnaval. A política é uma coisa social, de governo, do Brasil. As escolas fazem homenagem aos políticos, mas eu acho que tinha que ser mais pro samba, mais enredos antigos, tinha que vir mais sobre escravidão, Baía de Todos os Santos, o enredo lá do Nordeste, um enredo que trouxesse a origem do povo brasileiro.

O Vai-Vai pra mim é uma segunda família, todos me respeitam, me querem bem. A diretoria é desse menino aí, agora ele é o presidente. Quando conheci, ele era uma criança, hoje ele é o meu presidente, o Neguitão. Tem também o Clarício...

O enredo do Vai-Vai desse ano são as mulheres maravilhosas, não li a sinopse ainda, mas deve vir muita coisa, nesse enredo, em minha opinião, eu ainda não li não sei o que o carnavalesco vai por, mas, nesse enredo, em minha opinião, vem muitas pessoas importantes, mulheres maravilhosas, isso é um enredo que traz as mulheres pra frente; agora, se fosse nesse enredo homenagem a Getúlio Vargas, já não seria bom, porque ele é um governador, então acho que não tem que misturar as duas coisas. Agora pode homenagear artista, como nós homenageamos ano passado o maestro, e a história do maestro é triste e feliz! 
Muitos artistas frequentam o Vai-Vai, o Cafu, jogador de futebol. Quem não sai de lá é o Douglas do Pixote. Todos vão lá na minha barraca. Se você soubesse o que de policial que vai lá. Tem uns que saem do serviço correndo para comer o meu cuscuz, ali eu trato bem, já tenho aquele jeito, também são 30 anos que eu tenho barraca ali. Quando algum bêbado chega pra atrapalhar, eu falo:

- Olha, não coloca a mão em mim e nem chega perto de mim porque meus colegas da polícia tão tudo aqui.

Eles falam assim:

— Ninguém mexe com você, Chininha. Pode ficar sossegada.

Ali eles comem, bebem, me tratam bem, se tem alguma coisa, eles me falam, se eu preciso de alguma coisa, eu falo com eles, tem o Pé, ele é fiscal de bateria. Ele ajuda o Tadeu na bateria, ele é investigador e têm muitos outros lá assim: tem médico, médica, advogado, todos apaixonados pelo samba.

Também tem o pessoal do Teatro Maria Della Costa e de grupo de pagode. Recebia até aquele que faz show com as meninas, o Compadre Washington. Daí você vê, eu tive aqui na minha casa também, no café da manhã, o Tramontina, o Chico Pinheiro, todos eles vieram aqui, quando eu cheguei aqui de um carnaval que eu desfilei, a minha cozinha já estava pronta e eles todos sentados esperando eu chegar. Foi muito bom, eles fizeram uma entrevista comigo que passou no jornal. Tudo isso acabou, não tem mais, esse negócio de café, não tem. A última matéria que eu fiz foi na Bandeirantes, que eu estava de embaixatriz, contando minha história. Eles me perguntaram:

- O que a senhora acha de artista no samba?

Eu falei:

- É bom. Ajuda o nome da escola, e, depois, eu não tenho nada para falar, porque eu sou da Velha Guarda e não tenho o que reclamar, a única que eu não gosto é que a gente luta, luta o ano inteiro pra fazer uma roupa e quando chega na hora do desfile o artista já tem roupa pronta pra sair, do contrário, quanto mais artista no samba, melhor é. E na reportagem eles puseram que a Velha Guarda não queria artista no 
samba. Que a gente da Velha Guarda não queria ela, a Tiazinha, quando ela veio desfilar no Vai-Vai.

Eu gosto, eu adoro e acho bonito o modo deles falarem, deles estarem participando. Tem a Leci Brandão, ela falou muito bem do carnaval de São Paulo. Tem uns artistas que têm talento também no samba. Esse ano teve um que participa da novela que foi mestre-sala da Gaviões da Fiel, o Wilson, não lembro o nome da novela. Aquele que aparece na novela, que tem um bar e está sempre de camisa listrada.

Uma das queixas que eu tenho é que a Globo não passa na íntegra o nosso carnaval. Tem ala que o povo nem vê, já no Rio de Janeiro, eles começam desde a concentração até aqui na dispersão, tudo. O pessoal está na concentração, eles estão mostrando e vem até aqui em cima na dispersão. Já nós aqui, da Velha Guarda, não aparecemos, você pode ver, outras alas também não apareceram. É uma crítica que eu pus na minha cabeça e você pode ver que é isso aí mesmo, né? É uma coisa certa, eu acho que eles deveriam dar mais valor ao nosso carnaval aqui de São Paulo. Você pode ver a Bandeirantes depois, quando passa lá os pedacinhos direitinho.

Acho que o carnaval, antigamente, ele não era, assim, falado; era público, e eu, muitas vezes, desfilei para o público, que não tinha cabine, então eu era aplaudida pelo público, quando falavam: 'A Vai-Vai vem vindo, a China vem vindo'. Nossa, meu Deus do céu, era aquele corre-corre, eles isolavam a pista com corda, aquela coisa era maravilhosa. E hoje em dia é tudo mais reservado. Ninguém pode chegar perto, não é que eu não acho o carnaval de hoje muito bom, são organizados de modo diferente. Quando eu comecei, era pela tradição.

Eu passei por Anhangabaú, Avenida São João, Líbero Badaró, também na Praça Roosevelt, onde eu inaugurei a praça, na Rua Direita. Mais isso foi muito antes de eu sair no Vai-Vai, ali, na Rua Direita era assim, um cordão tinha que passar por dentro do outro para poder ganhar. Eu vinha dançando e a outra porta-bandeira me ultrapassava, eu tinha que passar ela para poder chegar até o final, então a escola ganhava.

$\mathrm{Na}$ Rua Direita tinha a sua escola e tinha a minha, uma tinha que passar dentro da outra pra chegar na Praça da Sé. Também participei da Praça da Sé, dos dois tablados, da boneca de piche que o Grande Otelo encenava. Veja bem, a minha mãe 
trazia meus irmãos e eu para gente assistir o tablado, ela trazia uma coberta, punha a gente nas escadarias, e a gente ficava ali até terminar, porque quando terminava, ela vinha pegar a gente para ir embora pra casa, veja bem que ano que foi isso, foram assim por muitos anos. E acho que isso por uns dez anos, eu vinha para a Praça da Sé pra assistir o desfile de 25 de janeiro ou desfilar no carnaval.

Peguei todos os anos da Tiradentes, peguei todos os anos do Anhembi e vou até eu parar.

Nós gostávamos da Tiradentes, sabe por quê? Na Tiradentes tinha onde o pessoal fazia a concentração, tinha mais liberdade, tinha bar, poderia ir em um banheiro, você podia comer uma coxinha, uma empadinha, você tinha a liberdade de usar os barzinhos dali.

Veja bem, lá no Anhembi você não tem. No começo tinha algumas barracas que ficavam ali no começo, mas, de uns tempos para cá, terminou, não tem mais nada. No sambódromo, ali, para ficar bom, tinha que desfilar direto, porque você tem aquela curva que engole muita coisa, você vem e a curva tem que fazer isso, você não vê a escola inteira, depois da curva que vem vindo as alas e isso eu acho que prejudica um pouco, porque o bonito é você ver a escola quando ela vem, você vê aquela emoção, aquela coisa, tem que sair uma para entrar a outra, não cabe a escola inteira na pista.

É nisso que eu acho que mudou, na Tiradentes cabia direitinho. Lá não tem um bar, só dentro, lá fora não pode ter nada, mudou muita coisa.

Antigamente, a gente tinha amor no samba, amor à bandeira. Quando eu deixei o samba foi por doença. Passei uma fase muito difícil. Faleceu minha mãe e o meu marido em dois meses. No dia que ia fazer a missa de dois meses de falecimento da minha mãe, meu marido faleceu. Então eu desacorçoei, porque eu ia muito para o interior, passava vários dias fazendo shows no interior, aí, quando foi nesse último ano, eu falei assim:

— Olha, Chicle, minha mãe está muito mal.

Eu saía de dois hospitais, saía daqui do 21 de Abril, que a minha mãe estava ali, e ia lá para o Municipal ver meu marido. Entrava lá, tomava banho, as moças me davam sopa, e, depois de tudo isso, eu descia a pé pra Bela Vista e ensaiar no Vai-Vai. Quando 
minha mãe faleceu, eles vieram todos aqui, e, depois de dois meses, meu marido. Eu falei: 'Eu posso fazer esse carnaval, mas depois eu não quero mais.'

Meu marido morreu dia 17 de janeiro, enterrou dia 18. No dia 20 de fevereiro tinha que estar na avenida, porque antigamente era de domingo, não era de sábado; olha, a lágrima caía. Eu estava na avenida dançando, eu pensei: 'Nossa, é o último ano que eu vou sair', aí, quando teve na quinta-feira a reunião, eu entreguei minha carta de demissão. Mas eles não me deram. Falaram pra mim que eu continuaria para sempre sendo a porta-bandeira da escola. Mas já não dava mais pra continuar como primeira porta-bandeira, indo a todos os ensaios. Então passei o pavilhão. Dançava com o pavilhão em algum evento, em shows. Eu prometi que eu não ia desfilar contra o meu pavilhão, não ia disputar contra ele, e ia ser sincera a minha bandeira, que é a do VaiVai.

Em todos esses anos nunca saí por outra escola, participei sim, ajudei sim, porque eu sou fundadora e porta-bandeira da Associação de Mestre-Sala e PortaBandeira do Estado. Então, se eu estiver em uma quadra e um diretor ou presidente pedir pra segurar o pavilhão da escola, caso a porta-bandeira não estiver e precisar receber alguém, dá para você fazer isso, aí eu posso, mas desfilar contra o meu pavilhão, não!

E ele está aí, é uma relíquia, eu vou passar ele como falei pra vocês, eu quero em um pedestal ou então em algum museu, como o Museu do Disco. Teve uma exposição lá no Ibirapuera, museu afro e tinha umas fotografias minhas. Eu não fui lá ver, mas me falaram que tinham fotografias minhas.

Fui muito feliz na minha carreira, fui muito feliz mesmo. Algumas vezes têm alguns tropeços, como no serviço, você está no serviço e tem um que quer puxar o seu tapete, escola de samba é assim, mas quando um queria puxar o tapete meu daqui, eu saía pra lá, quando brigavam comigo aqui, eu rezava para aquela pessoa, para não fazer nada com outras pessoas. Fulana falava:

- China, ela é sua inimiga.

- Que Deus ajude ela, para não fazer para outro o que ela está fazendo comigo, porque eu não estou ligando pra isso. 
Então foi assim que eu fiquei todos esses anos nas escolas de samba. Se você chegar pra qualquer um e perguntar: 'E a China, porta-bandeira aqui, como que era?' Pergunta se eu tenho algum passado ruim. O meu passado é lindo, maravilhoso, limpo e eu posso chegar no aeroporto, dar meus documentos e vou para onde eu quiser, sou feliz da vida, e assim é.

Então, antigamente você vivia o carnaval porque não precisava pagar para assistir. Vinham às escolas de samba, aquela coisa linda. Hoje em dia, para assistir o carnaval, tem que pagar e não tem liberdade. Você está lá na arquibancada, longe. Se você quiser levar uma comida, um lanche, já não pode, tem que comprar tudo lá.

Então o carnaval mudou nesses aspectos. A pessoa que gosta de carnaval vai porque quer assistir. Mas o carnaval hoje é mais para os ricos, porque eu não vou lá pagar R \$ 4.000,00 em um camarote. E eles pagam e os camarotes estão superlotados. Eu fui fazer um show no Brahma ali na São João e tinha de tudo, serviram a gente muito bem. Eles querem resgatar alguma coisa de carnaval, sempre tem atrações, com artistas antigos, mas resgatar o carnaval como era na São João no Anhangabaú, na Tiradentes, não tem mais.

A gente desfilava ali no desfile oficial e dali mesmo saía e desfilava em outro canto, então você era carnavalesca a noite toda e era uma coisa que pra mim fez diferença. Agora, você veja bem, eu, com 82 anos, o que eu passei, bons carnavais, maus carnavais e agora? E assim é a vida, e vamos ainda ter muitas mudanças, né, porque do jeito que estão as coisas. Se por acaso os nossos dirigentes forem mais maleáveis, o carnaval pode melhorar.

Hoje o carnaval perdeu a essência, nós perdemos toda essência, porque, antigamente, se eu pusesse uma roupa de chita e um turbante, ih! Você era carnavalesca já tava desfilando, se os homens pusessem uma calça e alguma coisa na cabeça já era fino e hoje em dia, não, se um homem colocar uma calça de cetim e colocar um lenço na cabeça, o pessoal diz olha lá, imagina uma escola de samba sair com aquilo, não é verdade?

A diferença é muito grande, porque, antigamente, você fazia uma saia de chitão bem feitinha, de um paninho bem-feito, você saía e todo mundo admirava, uma queria 
comprar chitão mais bonito do que a outra, uma queria comprar estampado, para ser mais bonito que a outra, então o chitão fazia o carnaval, os homens faziam o carnaval, eles se vestiam de mulher, as mulheres se vestiam de homem. Então era um carnaval que alegrava o povo. Você vai nos bairros, como na Vila Esperança, e você vê o carnaval, você tá ali, você vê o carnaval. Agora lá, no Anhembi, não dá, é tudo fechado, o pessoal das escolas de samba só tem aquele trecho para desfilar, terminou o desfile, ônibus e quadra.

O samba traz alegria, traz tristeza, traz falsidade, mas muito mais alegrias. Eu, então, depois disso, mesmo triste, eu nunca parei. Continuei no samba, principalmente fazendo seminários fora com o Gabi, ensinando. Eu ensinei muitas porta-bandeiras. Todos os mestres-salas e porta-bandeiras no Vai-Vai, os que estão na escola passaram tudo na minha mão, aliás, todas as escolas de samba têm um pouco do meu dedinho. Eu não posso nem julgar ninguém. Dizem pra mim:

- China, porque você não faz o curso pra julgar?

Eu não preciso fazer curso, eu sou professora nesse quesito, só que eu não posso, porque geralmente as que estão desfilando passaram pela minha mão. Agora, as portabandeiras de hoje, algumas não querem obedecer, seguir o currículo, porque, hoje em dia, elas colocam uma sainha curta, gira, gira e aparece tudo, a porta-bandeira têm que ter o peito coberto.

Hoje, elas colocam tomara-que-caia e fica o tempo todo ajeitando assim. Se eu estou na avenida, eu não dou nota, porque a porta-bandeira tem que ser lisa, ela não tem que estar toda hora ajeitando aqui. Eu expliquei pra Paulinha, filha do Penteado, que é nossa porta-bandeira. Eu a ensinei desde pequena, ela é uma porta-bandeira que sabe dançar. Quando ela está em julgamento, ela não mexe em nada, ela só dança. E nesse ano que passou, ela perdeu ponto. Eu não li a súmula porque não gosto de me envolver em coisas de diretoria. Só quando eu era responsável pelo casal.

Isso não é um erro meu que ensinei. É um erro dela, ela quis mexer na roupa e o jurado fica em cima, se fosse eu que estivesse julgando, eu puniria também, ajeitou a blusa ou o pavilhão tem quer tirar nota. Foi no ano passado, que ela tirou nove e meio. Eu ensino para as minhas porta-bandeiras, que isso não pode. Pra você ver, o melhor 
trio de porta-bandeiras de São Paulo é o do Vai-Vai, é difícil o Vai-Vai ficar trocando.

Os casais da Império de Casa Verde eu que orientei, a Fabíola e Renatinho, do Camisa Verde, sabe, são mestres-salas que também passaram na minha mão, e hoje, se eles fazem alguma coisa errada, é porque eles querem aparecer. O mestre-sala e a portabandeira, eles são casais visados. Em uma escola de samba tem três, quatro mil pessoas e por causa de um erro da porta-bandeira, a escola pode perder um campeonato ou ser rebaixada. Ela tem a maior responsabilidade.

Dentro de uma escola de samba, o que mais a gente reverencia, o que você mais procura é a bandeira, é o mais visado. Não tem outro, o importante é a bandeira. Nós existimos para carregá-la. Hoje, quando eu vou a uma quadra e vejo caindo alguma coisa, eu até chamo atenção, chamo de lado a menina e explico assim, assim, assim. Porque tem algumas que a blusinha vem só até aqui. Usando tomara-que-caia, outras com o braço tudo de fora, não é assim, eu acho que a porta-bandeira é respeito. Ela é uma deusa da beleza e deusa da dança, ela é uma bailarina clássica. Ela é uma bailarina que não pode falhar, e muitos veem a porta-bandeira apenas pelo vestuário, e eu acho muito bonito o vestuário, mas o mais importante na porta-bandeira são os passos.

Quando eu vejo uma porta-bandeira dançando, se ela vem vindo lá na esquina pelo girado da bandeira, eu sei se ela vem certo ou se ela vem errado. Sei porque quando eu dava aula as minhas porta-bandeiras, meninas, moças que estavam aprendendo, eu ensinava elas, um pra fora dois pra dentro, assim, pra não tontear o pensamento. Porque tem muitas que só vai girando, girando, girando, não pode ser assim, a porta-bandeira tem que ter os passos dela, direitinho, olha é uma classe. Eu ganhei muitos concursos por causa da minha classe.

A primeira porta-bandeira que ganhou o concurso da Prefeitura fui eu. Ganhei um troféu dessa altura, quase um metro. Um troféu pra mim e o outro o Serginho, troféu azul, como a gente mudou de casa pra cá, mudou pra lá, então foi quebrando as partes do troféu que eu ganhei. Também teve um prêmio de cento e cinquenta cruzeiros para dividir em dois. Fomos receber, Serginho e eu no Banco Banespa que tinha na 25 de Março quando você sobe a ladeira. 
Quando eu ganhei, todos os outros casais estavam todos emplumados, cheios de coisa, e eu estava com este vestido da foto. Preto com pedrinhas, que eu tinha usado no desfile. Na tribuna dos jurados estava o Nelsinho que é presidente da FESEC, estava o Haroldo Lobo, compositor que faleceu, estava o Manezinho, Ciro, falecido, Geraldo Filme, todos os cobras estavam na tribuna, para julgar, porque era um concurso da prefeitura. Eram dezoito casais, tinha a Império do Cambuci, que era o Nivaldo e a Glória, que morreu, morreu a Olga da Mocidade Alegre, todas elas morreram, sabe? Eu que estou aqui, de enfeite.

Veja bem o que é a dança! Eu era a porta-bandeira mais pobre no visual, e elas estavam cheias de plumas e paetês, aquelas coisas todas e foram chamando os casais, aquela coisa toda. Eles dançaram. Aí, quando foi a minha vez de dançar, o Serginho perguntou quantos minutos eu ia querer. Eu falei:

— Olha, Serginho, pra mim, dois. - O Serginho falou:

- Não, vamos dançar em cinco, três pauleira e dois pra apresentação oficial.

Chegou a nossa vez, chamaram, quando nós entramos, não tinha ninguém pra bater palmas pra nós. O pessoal do Vai-Vai, eles estavam em uma festa na CMTC, no clube no Tietê do lado de baixo, então não poderiam ir para assistir as apresentações. Até tinha uns gatos pingados, mas nós entramos com raça.

E quando pisamos o pé e o Serginho abriu o leque, fomos passando, girando, fizemos dois minutos. Aí fizemos pauleira, ganhamos com classe e foi com a classe que nós ganhamos o troféu. Porque a minha roupa é essa, simples, mas foi a dança que diferenciou os casais e eles vinham só virando, e eu falei 'não', e fomos entrando nos nossos passos, e eu fui sentindo a música do surdo, tamborim, porque você tem que ir no compasso da música, direitinho, foi o que nós fizemos, nós ganhamos. Os meus dois pares, eles foram os melhores mestres-salas do Estado de São Paulo, foi uma pena que o Serginho morreu, e o Ivo morreu também, ficou só eu.

Eu sempre nas reportagens que faço, falo que a porta-bandeira que me orientou, eu falo assim, porque ninguém ensina ninguém, você orienta, quem me orientou foi a Neide da Mangueira. Ela ia pra Santos nos desfiles e me dava as dicas. Cada vez que 
faço uma reportagem, eu falo o nome dela em primeiro lugar, infelizmente ela já morreu. Então, tem que ter isso, respeito a quem nos orientou.

Só que, hoje em dia, você faz o bem e eles não olham a quem, quantos casais que fazem reportagem e não colocam meu nome, e eles sabem que saíram daqui dessa mão, eles não falam, por exemplo, esses meninos, Fabíola e Renatinho, dois irmãos, eu quase perdi trinta anos de Vai-Vai por causa deles, porque eu ia pedir demissão.

Eu sabia que eles não eram ainda casal suficiente para ir para avenida, que não estavam prontos. Mas eu acreditei neles. Discuti até com o Espinosa, que era nosso carnavalesco, na reunião geral. Me chamaram aqui na minha casa, porque eles me levavam e me traziam para eu ir nessas reuniões. A diretoria queria tirar o casal, porque era minha responsabilidade, eu falei não, falei para o Tadeu, que era o presidente. Para o doutor Miguel: 'Vocês não vão tirar esse casal e eu não vou dar aval para vocês tirarem eles, porque se eu estou cuidando dos casais é porque eu sou responsável. Agora em cima do carnaval vocês querem tirar, faltando três meses, eu disse não, se vocês tirarem eles a minha demissão está aqui.'

Nossa, foi um horror, um clima muito chato, muita gente de olho na vaga, mas eu bati o pé e o casal ficou. Eu fiquei ensaiando com esse casal, inclusive com esse menino que está agora na Vila Maria, o Ligeirão, que era da harmonia. Ele falou:

- China, você precisa tirar esse casal.

Eu falei para ele cuidar da harmonia que eu cuido do meu casal, olha foi o ano que eu lutei com eles, três vezes na semana, falei pro Gabi:

- Vou tirar um sábado para o Vai-Vai, um sábado para você.

Porque o Tadeu queria que eu ficasse apenas lá todos os sábados e também durante a semana eu vinha pra ensaiar o casal, porque eles saíram de terceiro para primeiro casal, é um pulo grande, e tinha mesmo que orientar, aí, quando chegou o carnaval, eles foram muito bem, deram entrevista e nem agradeceram meu nome. Olha menino, a ingratidão do samba é muito dura, você sabe que eu tenho 75 anos de samba, mas o que eu já sofri no samba, com essa ingratidão.

A única coisa que eu acho é que todos os mestres-salas e porta-bandeiras que passaram por mim deveriam ao menos em alguma reportagem falar assim: 'Eu tive 
instrução com a China. Eu fui a primeira que montou escolinha no Vai-Vai.' Era uma escolinha e uma ala que eu tinha no Vai-Vai. Eu tenho até fotografia d'eu dando aula, olha, era show.

Ano passado o presidente falou pra mim fazer onde eu queria a minha fantasia. Eu fui comprar o tecido lá na Avenida Tiradentes. Tava lá parada assim, e alguém me cutucou. Quando eu viro as costas, vejo aquele sargento, tenente, bateu nas minhas costas. Vi aquele homem todo fardado e falei:

— Olha, tenente, o senhor me desculpa, só quero atravessar. - Ele falou:

- A senhora assustou?

— Eu assustei, poxa, estou aqui parada e o senhor chega assim, me desculpa. Ele disse:

- Eu não desculpo não, China.

- Como China, o senhor me conhece?

— Claro que te conheço! Não lembra mais de mim, não se lembra do Marcos?

O Marcos era meu aluno de mestre-sala lá no Vai-Vai ele era tenente e ele me conheceu, não adianta esse cabelo branco nada, a fisionomia é a mesma. Aí os outros soldados me cumprimentaram, foi aquela festa. Ali na Tiradentes. Sabiam que eu frequentei muito o Tobias Aguiar, que a minha filha é filha de tenente, meu marido foi tenente. Eu ia lá pra fazer papel, ia pra tirar compra quando tinha a cooperativa. Conheço tudo ali, o capitão e todos eles. É uma festa, você tem que ver. Se eu for contar todas as histórias, você não sai daqui hoje, nem amanhã, nem depois.

A ala de passista do Vai-Vai sempre foi muito bonita, quem coordenava é o Crei, neto da Dona Olímpia. Pra sair lá tem que ter samba no pé. Antigamente tinha tanta coisa boa, muita criança, passo marcado, tinha destaque de chão, que hoje dificilmente tem.

Todas as alas era de sambista. Hoje tiraram, era o destaque que separava as alas, pois cada ala tinha seu destaque, para harmonia dirigir era melhor, e você já sabia, a ala de fulano já está montada, mas hoje é uma ala de sambista e quase todas de turista, pra você achar um destaque de ala, eu não sei como o Vai-Vai faz. Nesse ano que passou, 
colocou aquela escurinha, aquela professora de afro, eu esqueci o nome dela, ela vinha vestida como mata com uma roupa verde. Que espetáculo!

Já saí muitos anos de destaque, saí de destaque principal, saí de destaque de ala e depois eu falei: 'Agora eu vou pra Velha Guarda. Lá eu levo o estandarte.' Já tem bem uns dez anos que eu saio com a Velha Guarda. E é o lugar que eu sinto melhor, mas agora eu não quero mais participar de diretoria, quero só chegar e sair. Porque até o ano passado, eu cheguei a fazer Simpósio, fiz o Simpósio do Carnaval no Rio de Janeiro, no Projac, eu tive participação no ano retrasado na vinheta da Globo, ali perto de Pinheiros, na gravação no Credicard Hall, cantei no coro do disco desse ano, e uma porção de participações que, se eu vou falar, você não consegue nem escrever.

No ano retrasado, eu saí no carro alegórico no abre-alas, numa cabana, eram três cabanas que vinham na frente, eu fiquei satisfeita com isso.

Ano passado, eu voltei para trás, porque meu lugar agora é ali, eu só saio no carro de novo se minha perna não tiver boa. Se eu puder continuar, porque no carro não tem problema pra mim, mas não tem jeito, vamos ver esse ano, porque que eu não queria parar com o samba, não queria. Quero desfilar até o meu último dia.

Mas para sair no chão não dá mais. Porque meu lugar é o chão, adoro evoluir, eu fico cega, eu vou pro Rio de Janeiro todo fim de ano, vamos para Imperatriz, esse ano não fomos porque estavam em reforma, fomos pra Grande Rio. Meu Deus do céu, eu fui uma das porta-bandeiras homenageadas. Fomos muito bem recebidos, precisava de ver, o pessoal de Santa Catarina que trouxe escola de samba de lá ia na nossa mesa, tirava fotografias, que coisa linda.

Eu comecei a ir para o Rio com o pessoal do Vai-Vai. O Ivo Branco, que foi meu mestre-sala e eu fomos à segunda festa de inauguração da Quadra da Mangueira. Fomos convidados para inaugurar a Mangueira, também foi e o Seu Penteado, fomos para a Mangueira, naquele tempo ainda tinha a Mocinha, o Wilson, agora morreram eles todos, o Delegado ainda está vivendo, tá fininho. Cheguei perto dele e falei:

— Nossa, como você tá fininho, você lembra de mim? - Ele falou:

- É claro, Chininha, que eu me lembro de você. 
Eu fui a primeira porta-bandeira de São Paulo que dancei com o Delegado. E ele falou que a única porta-bandeira de São Paulo para dançar com ele era eu. Era ele que orientava os casais da Mangueira na quadra, porque no Rio de Janeiro não é como aqui, que ensaia em qualquer lugar, na rua, lá cada um tem um horário para ensaiar na quadra, vai uma, depois outra, terminou de ensaiar, vem outros componentes, a dele é a última que é mestre-sala e porta-bandeira, os casais entram e ele ensina, é igualzinho ao Gabi.

E agora que eu tô meio assim, depois do carnaval pra cá que eu parei um pouco porque a perna minha não quer ajudar e, se eu esforçar, chega no dia do carnaval não dá pra eu ir daqui até ali. Eu me trato no Hospital das Clínicas também, tomo remédio para o coração, e eu tiro sangue quase todos os meses. A doutora falou que agora meu sangue tá fino, que eu estava com sangue grosso, ela falou que agora tá fino, tá bom, conforme vai afinando o sangue que eu vou tomando o remédio. E eu falei para ela da minha perna, depois que eu tive derrame que eu fiquei assim, eu fiquei três meses internada no Tatuapé, e essa mão aqui eu podia mandar cortar a mão, não mexia.

Nossa, se você soubesse o que eu passei, não podia comer, e eu não aguento ouvir gemido, aquela gente gemendo, chorando, eu precisava tomar calmante para poder dormir. Então você veja bem, daqui da cintura pra cima eu não posso, não vai, porque é o braço que eu colocava o pavilhão, eu se tiver que pegar um pavilhão tem que segurar ele na mão, não posso porque daqui pra lá, não vai.

Sofri muito, e tive muito apoio do Vai-Vai, todos eles vieram no hospital me visitar, vinham aqui na minha casa, tinha o pessoal da diretoria. Não podia ir trabalhar na barraca. Vocês sabem que eu tenho uma barraca no Vai-Vai? Minha barraca é aquela pegada ao palco. Aquela barraca de cuscuz é minha e a outra em frente é a da Baiana. Aí quem ficou tomando conta foi a minha filha e as duas netas minhas, eu fazia as coisas e as netas tomavam conta pra mim e eles davam muita atenção para as meninas, olhavam elas, então eu não posso ter queixa que eu não tive atenção deles.

E eu estou aqui, mas você pensa que eles não estão preocupados, que desde o carnaval eu não apareço mais? Eles ligam pra cá, a Nilde liga, a Zulmira liga pra saber como eu estou. 
Eu que fiz a feijoada do Vai-Vai por três anos, era uma das melhores da cidade, saiu no jornal tudo. Eu saí da feijoada porque a Marília ficou doente um ano. Faz dois meses que ela está em coma, saiu do hospital, mas tá em casa em coma, o hospital mandou pra casa. Também ajudava a Dita que é a costureira a Benê que mora ali na Paim. Era nós quatro e o Raí, que era ajudante nosso. Então nós carregamos aquela cozinha nas costas três anos. Depois a Marília ficou doente e ficou tudo pra mim, e eu falei agora eu vou parar.

A diretoria arrumou outra equipe; arrumou a Baiana, não sei se ela vai continuar, se ela vai parar, não sei. Eu sei que tive a minha vez, saí com glória, nossa, aquilo ali recebia artista que não acaba mais. Tem horas que eu falo, eu vou largar mão do samba, mas eu fico pensando, quando eu olho na televisão eu falo,: 'Ai, meu Deus do céu, é pra eu ir porque, pra eu deixar o Vai-Vai, só se eu não estiver andando mais, mas enquanto der pra botar um pezinho no chão, eu tô lá no samba!'

E assim foi minha vida, já fiz de tudo dentro de uma escola de samba. Já fui presidente de uma escola de samba, a Unidos de Vila Carrão. Fora as baianas, que eu não gosto de sair de baiana, eu fiz tudo. Comissão de frente, harmonia, tudo, tudo, contrabaliza, porta-bandeira, quer dizer, que nessas alturas, a única coisa que eu não desfilei foi de baiana. Ajudava também a costurar, eu ajudava a fazer, mas eu não gostava de bordar, a minha comadre que era bordadeira, tinha a nossa costureira, da Vai-Vai, que era a dona Benê, também conhecida por Dita. Ela costura até hoje. Tá veinha, mas tem um ateliê na Rua São Domingos. Costura ela, o Lucas, e a Sula. Tem a Madalena que também faz roupas pra Gaviões da Fiel, então, quando eu preciso de alguma coisa de carnaval, eu peço pra elas, agora tem uns dois anos que eles me dão a roupa, mas antes sempre eu que confeccionei tudo.

Antes havia um pouco de preconceito quando eu assumi a Vila Carrão, mas muitos aceitaram. Eu fui a presidente da escola de samba aqui da Vila Carrão, ela desfilava aqui. Eu saí, eu deixei a escola não por preconceito, porque quando você luta por uma agremiação, você deve ser honesta, e eu sou muito honesta. Cheguei a tirar dinheiro de casa para fazer roupa para o pessoal sair na escola de samba. $O$ vice- 
presidente, que estava junto comigo, ele não era assim. Quando começou a ter um pouquinho de dinheiro, ele desviou e eu falei: 'Não quero, não vou sair mais.'

Porque antigamente saíamos com o livro de ouro, e, nesse ano que eu saí, eu falei: 'Não vamos sair com o livro de ouro. Não precisa, já temos o dinheirinho necessário. A prefeitura liberou o dinheiro antes.' E ele tirou o livro de ouro e eu não sabia. Eu falei: 'Não quero mais saber da escola.' Mas olha o que aconteceu: ele estava tirando livro de ouro em meu nome; e eu já tinha desistido da escola, e o pessoal estava esperando a escola.

Ele falava para as pessoas é o livro de ouro da escola de samba Unidos de Vila Carrão, da China, e eu já estava fora, me desgostei, mas, nesse ano, eu precisei batalhar para não ficar feio pra não perder minha moral, meu nome, já que ele tirou o livro no meu nome, coloquei a escola na rua e no clube do Carrão. Então eu disse para o presidente do clube:

— Esse ano eu estou aqui, mas ano que vem eu não sou mais presidente. — Ele falou:

— China, quer saber de uma coisa? Já que você não vai estar aqui eu não quero mais saber de organizar carnaval, vou acabar com o carnaval aqui no Carrão.

E acabou tudo, ninguém desfilou mais.

Porque tem que ter organização pra ser presidente de uma escola de samba. A Lavapés da Dona Eunice não teve bons dirigentes, porque quando uma escola é bem dirigida, ela não cai à toa, mas quando tem um tropeço por conta de briga de diretoria, aí quando que acontece isso, citando o exemplo do que eles fizeram comigo. Saí fora e acabou; eu era a líder ali. Quando eu comecei a ver desonestidade, eu larguei mão e parou. No outro ano a Unidos de Vila Carrão já não desfilou.

Então é assim eu acho que na Dona Eunice. Já saí com ela também. Teve um ano que eu saí, primeiro tinha aquele pessoal durão. Ela era durona, tinha o Chico Pinga. Aí veio vindo essa molecada, que não tem a firmeza dos mais velhos, aí a escola foi caindo. Agora parece que eles tão querendo levantar, mas tem que levantar com pessoas de capacidade, de gabarito. A Rose, que é a presidente lá, está sempre no VaiVai. 
O Folha Azul acabou por quê? Desleixo! A diretoria não age, porque se a diretoria age bem, a escola vai pra frente. Veja lá o Império da Casa Verde. Com pouco tempo eles já estão bem. Essa menina que agora está na Mocidade Alegre, a Solange, não está indo bem? A Angelina não pegou o Rosas de Ouro no lugar do pai dela, o meu compadre Basílio, não está indo bem? A X9 não tá indo bem?

Porque ali eles percebem que um diretor não está bem e vão trocando. O Vai-Vai mesmo saiu o Tadeu, depois do Tadeu fizeram a reunião veio o Tobias. Agora veio o Neguitão, que está indo bem, mas eles têm uma assessoria, não estão sozinhos. Tem o Claudinho, o Maluf, Clarício, eles são uma equipe e um tem que ajudar o outro e eu acho que a equipe sendo assim vai bem; agora, se deixar tudo para o presidente resolver não dá, os que tão em volta têm que ajudar. Eu acho que, nessa gestão, ele está indo bem, pelo menos eu não tenho queixa, o pessoal da escola também não.

Um grande parceiro meu no samba foi o Eduardo Nascimento. Ele é relaçõespúblicas do Estado de São Paulo, o Eduardo Nascimento, ele é embaixador comigo lá na UESP, ele também participou desses festivais em Santos, porque antigamente era Santos, Jundiaí, São Paulo e Rio de Janeiro, então tinha a Cidade do Samba, e daqui íamos para lá. Ele, o Gabi, Eu, o Penteado somos batizeiros, nós que batizamos as escolas, e era o Buiú também. O Penteado me liga:

- China, tem escola de samba pra batizar.

Eu falo:

— Ó, Penteado, eu não posso ir.

Ele fala:

— Você pode, a gente vai buscar você, sim.

Eu que batizei a escola de samba Paulistano da Glória, do Geraldo Filme. O que você disser de escola de samba daqui de São Paulo, geralmente eu batizei quase todas, eu, Eduardo Nascimento que eu te falo, Penteado, Buiú e Gabi. Se eu falar a escola de samba lá do Sapopemba, se eu não fui, é mentira.

Na Mocidade Alegre, nos festivais, era a gente que ajudava, ia com três, quatro ônibus. Não era que nem agora, eu e Juarez éramos muito amigos, e ele era embaixador na UESP junto comigo, o Juarez da Cruz. O Seu Basílio era meu compadre, dono da 
Rosas de Ouro. Essas meninas, a Angelina e a Solange, eu vi elas nascerem, conheci as mães delas. Tem a mãe de um menino que faz costeiros, Valdir, conheci a mãe dele. O Murilo, dancei muito com o Murilo, que não é do seu tempo, vocês não vão conhecer, ele era mestre-sala da Mocidade Alegre, eu ganhei também o anel de mestre-sala e porta-bandeira do Nenê, com o Jorginho da Rosas de Ouro, quando eles entregaram o pavilhão deram o anel para mim. Ele morreu. Isso daí foi na quadra da Rosas de Ouro. Eu frequentei muito tempo ali na Brasilândia, participei também do Morro da Casa Verde, do seu Zezinho, onde tinha a Dunga.

Eu também fui uma vez em um festival em Campos no Estado do Rio. Nossa, lá era um mato, só você precisava ver, participei também desse evento, fui desfilar para o Morro da Casa Verde. O Peruche, também, eu fiz a campanha do cimento, para arrumar a quadra do Peruche, junto com o Manezinho.

No Nenê da Vila Matilde eu só era visita, porque o Nenê foi meu namorado quando a gente era jovem. Então a mulher dele tinha ciúmes. Então a gente ia a todos os aniversários. Ele mandava ofício para o Vai-Vai e a gente vinha. A Nenê é aqui perto de casa. Quando ele faleceu eu fui. A mulher dele, apesar do ciúme, era minha amiga. Os filhos dele são meus colegas, é uma família. No dia que ele morreu, os filhos dele disseram assim:

- Vamos cantar aquela música que o meu pai gostava de cantar pra você, China.

E, na beira do caixão, cantaram aquela música que o Nenê, quando me via, cantava pra mim.

Nós fomos todos de uniforme da Embaixada da UESP e fizemos a última homenagem para ele, foi uma coisa muito linda. Quando morreu também o Xangô da Vila Maria, fui lá na Vila Maria fazer homenagem.

Quando eu recebi a faixa de Embaixatriz-Mestra, eu recebi na Barroca da Zona Sul, eu não esperava, eu recebi lá e foi a maior festa. Eu sou a primeira EmbaixatrizMestra, porque nunca havia tido uma Embaixatriz-Mestra. Só os Embaixadores. Então, na reunião de diretores e presidentes, eles resolveram colocar uma Embaixatriz Mestra e eu fui a escolhida. Coisa maravilhosa! E até hoje eu sou feliz com isso. Também recebi 
outra homenagem no ano passado, mas não pude comparecer. $\mathrm{O}$ telefone tocou, $\mathrm{O}$ Neguitão ligou pra mim e falou:

- China, a gente quer que a senhora venha para receber o prêmio, pois a senhora foi escolhida a mulher do ano do Vai-Vai. - Mas como, eu estou aqui, não posso mexer as pernas, acabei de ter um derrame. Ele falou:

- Não se preocupe, a gente manda um carro pra buscar a senhora, e manda levar.

— Mas eu não me sinto bem assim, eu estou mal mesmo, com a perna, vê se vocês recebem o prêmio pra mim, coloca uma pra receber.

— Ô, meu Deus do céu, não vai dar pra senhora vir mesmo?

Não deu, por causa da minha saúde. Então eu fui homenageada como Mulher do Ano. A festa foi na Avenida Paulista, na FIESP, lá onde foi os 80 anos do Vai-Vai. Não pude ir, mas ele se comunicou comigo, pedi desculpas, estou faltando nos encontros.

O pessoal da Camisa Verde me convida, todas as escolas convidam para inauguração, samba-enredo, tudo, mas eu não posso ir, estou com a perna desse jeito, tem que ficar me apoiando, tem que ir com uma pessoa, tem que andar de carro, eu não posso, é ruim porque estou aqui parada.

Tem muita coisa no samba que precisa ser muito bem esclarecida para a pessoa saber, porque às vezes a pessoa fala: 'A China, quem é a China?' Se eu for pegar do fiozinho lá de baixo até aqui, fica três, quatro dias a gente conversando. Mas com detalhes.

Então é assim. Fui fazendo seminário com o Gabi. Recentemente fiz uma peça ali no Centro Cultural São Paulo, ali na Rua Vergueiro, foi maravilhoso. Agora que eu parei um pouco de estar participante, porque eu tive derrame, então é chato, porque eu entrava de peito aberto andando e agora entrar de bengala. Não é que eu não quero usar, eu sei que eu vou precisar; se não, como é que eu vou andar, mas é uma coisa minha, eu acho que é cedo pra eu usar bengala." 


\section{Mestre Divino}

Nome: Valdevino Batista da Silva

Local de Nascimento: São Paulo-SP

Data de Nascimento: 1948

Profissão: Metalúrgico

Escola de Samba: Imperial

Data da entrevista: 15/10/2011

Local: Quadra da Escola de Samba Imperial

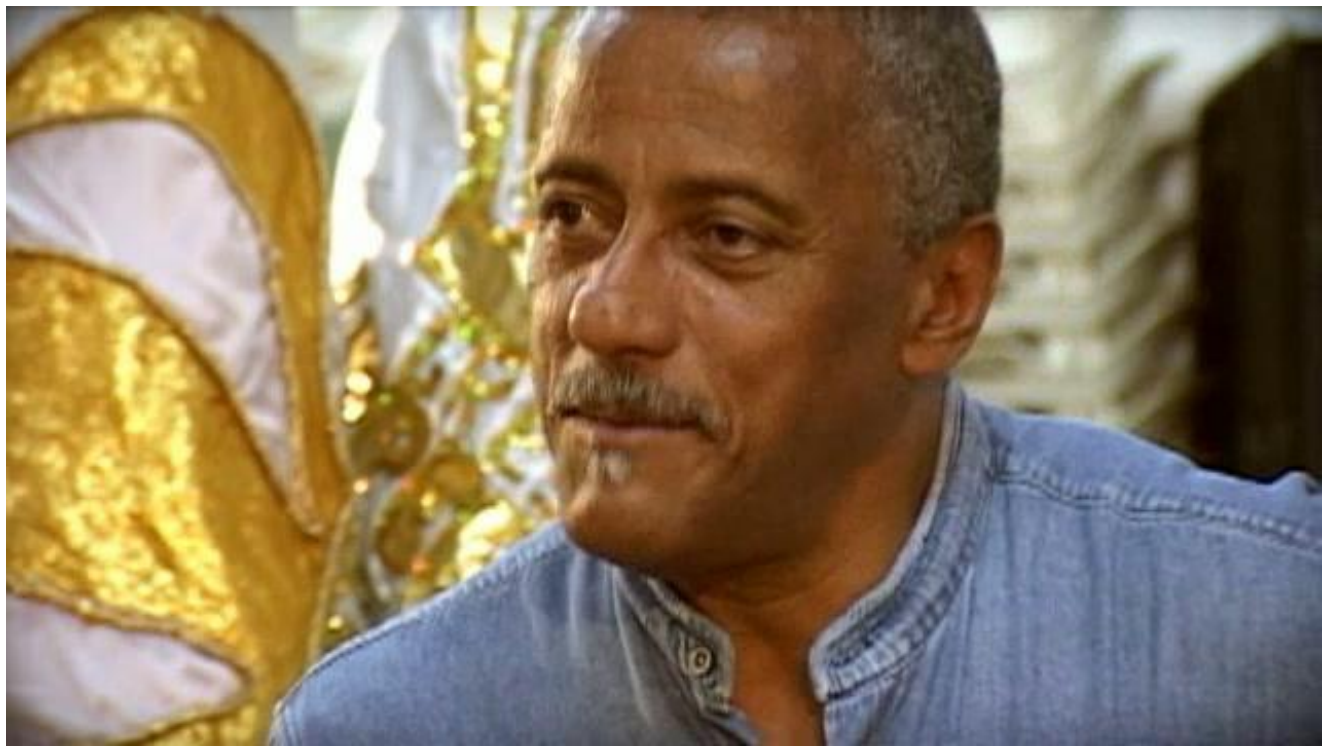

Figura 5 - Valdevino Batista da Silva, o "Mestre Divino" Fonte: http://vimeo.com/11989982

"Não sou mestre, sou batuqueiro". 
"Meu nome é Valdevino Batista da Silva, mas todos me conhecem como Divino. Nasci em 1948. Sou batuqueiro e estou presidente da Imperial. Não sou, estou! Já passei por várias escolas de samba. As principais: Nenê, Camisa e a escola que eu fundei, que é a Imperial.

Eu comecei no samba, na realidade, por influência dos meus irmãos. Eu sempre gostei de samba! Por influência do meu pai, eu sempre gostei de música caipira. Eu não gosto de música sertaneja. Eu gosto de música caipira mesmo, né? Mas, com o tempo, eu acabei pendendo para o lado dos meus irmãos, que eram do samba. Desde moleque. Eu fazia pandeiro de lata de marmelada. Eu lavava as tampinhas, amassava as latinhas e fazia o pandeiro de lata de goiabada ou de lata de manteiga. Enchia, pendurava com bexiga, esticava uma parte da bexiga em cima. E com isso eu me divertia...

Aí depois fui pra beira de campo. Às vezes, eu falo assim pras pessoas:

- Cê tá batendo igual beira do campo.

Não é pejorativo, nem nada. É que dentro do campo é sem compromisso. A torcida pulando, todo mundo gritando e vamo que vamo, né? Não pejorativo. Eu também tive na beira do campo. Tocando sem compromisso. E depois, em 1966 pra 67, que eu fui pra Nenê de Vila Matilde. Aí um amigo meu, que era de lá, me levou, o finado Zóio. Veja bem, isso é do tempo se tomava baquetada. Pra saí ali no meio tinha que ser batuqueiro mesmo...

Tomei baquetada lá na Nenê. A maior vergonha que eu passei na vida foi nessa escola de samba! Vergonha! Quando Jair Rodrigues e Martinho da Vila, quando eles começaram a despontar, lá na época dos Festivais da Record. Então, uma noite eles vieram na quadra da Nenê da Vila Matilde. E nesse dia, metade da batucada foi tocar no clube Tietê pra defender um dinheirinho. E geralmente iam os melhores, né? Os piores ficaram aqui e um dos piores, era eu, fio! E só tinha eu de malacacheta. Imagina. O apitador deu o toque pra eu fazer 'turugudum' e eu não fiz. Aí me esculachou, me tirou o instrumento e jogou a malacacheta lá de cima do palco. Olhei pras nega e as nega 'cuá, cuá'. Nesse dia, chorei de raiva, e pensei: 'Se esses caras aprenderam, também 
vou aprender. Se você quer saber, eu triturei todos eles. Sem sacanagem, o que eles sabiam, eu aprendi quatro vezes a mais. Tem pessoa que fala assim:

- Pô, o Divino dá baquetada. Nunca dei baquetada em ninguém. Eu passei por isso e sei o quanto eu chorei nesse dia. Aqui não admito que ninguém tire sarro da cara de quem erra... Aqui é uma escola de samba. Escola é pra se aprender, ninguém chega sabendo. Se soubesse, ninguém iria, não é verdade?

Sou do tempo que a gente desfilava no Ibirapuera. Na Rua Direita. O carnaval em São Paulo era feito na corda, cara! Cê imagina alegoria pra entrar no Ibirapuera. Na Rua Direita, as rádios que organizavam davam resultado na hora. O couro comia... Os caras lutavam um com o outro de vez em quando. Mas num tinha covardia. Arma, essas coisas. O negócio é pra quem fosse bom de briga. De murro, rodo, chinela, cabeçada, o couro comia, entendeu?

É... Eu fugia de casa pra assistir carnaval. Tomava cada cassete que cêis num tem noção. Naquele tempo de janela de veneziana. Todo mundo dormia, eu levantava, abria, pulava e encostava. Voltava no dia seguinte na ponta do pé e ia dormir. Meu pai era daquele jeito assim, ele não falava nada. No outro dia, quando você tomasse banho já tivesse dormindo, ele, oh! Eu apanhei muito de cinta de couro cru. Muito. Nego usava tamanco, eu sou do tempo de tamanco, cara. Todo mundo que era moleque usava tamanco. E assim, eu fugia pra assistir, fazer samba na beira do campo, de ir pro Ibirapuera, ir pra Praça da Sé.

Pra ter uns pixulé, catei papel, papelão, alumínio, gastei sola de sapato e fiz carreto na feira. É... Não era fácil. Era aquele tempo que num tinha pãozinho, nem bengala. Era filão e broa. Hoje, tá tudo aí. A vida sempre ensina tudo de bom e muito mais coisa ruim. Hoje aprende muita coisa ruim na televisão. A maioria desses programas deveria ser pra maior de 16 anos. Tão tirando a pureza da criança, não tem mais. Antes criança tinha pureza, andava de calça curta, o suspensório. Outra coisa, num se misturava moleque com adulto. Hoje é uma misturação danada! Então quando que uma roda de adulto lá, jogando capoeira, tiririca era eles que jogavam. Moleque não se metia! A molecada ficava do lado de cá imitando eles! Quem era bom de tiririca era o finado seu Nenê da Vila Matilde, né? Eu já li uns três ou quatro livros da história do 
carnaval de São Paulo e nenhum deles cita isso. Não cita. Quando tem que falar o que é. Porque existe parente dessas pessoas, existem pessoas que cuidam dessas pessoas. Existem pessoas que nem são parentes, mas que conhece isso e gostaria que fosse divulgado.

Pra colocar o carnaval na rua, passava o livro de ouro. Cada um segurava a ponta da bandeira, pros nego jogar as moedinhas pedindo dinheiro pra fazer o carnaval. Então o primeiro prefeito a apoiar o carnaval foi o carioca Faria Lima. Ele foi o primeiro a se interessar em fazer o carnaval direito aqui na cidade de São Paulo. Se o carnaval em São Paulo é hoje o que é, tem quem começou também, né? Tem gente que num lembra, num lembra nada! Tem pessoas que nem sabem. Vamos colocar como é. Foi o Faria Lima, o carioca que foi prefeito da cidade de São Paulo. Ele que passou a ajudar e financiar as escolas. Tem um radialista que, infelizmente, morreu que divulgou também bastante o carnaval de São Paulo. Quando tudo era rock, ele tinha lá o programa de samba, o Moraes Sarmento. Ele foi o presidente da primeira Associação de Escola de Samba de São Paulo! Essas pessoas que encaminharam tudo...

Além dos cordões, teve escola que se formou de blocos. O primeiro bloco, antes de formar a Mocidade Alegre, era o bloco do Pegue e Pague, que era Juarez da Cruz e os irmãos dele lá do bairro do Limão. Aí depois o bloco tornou-se a Mocidade Alegre. Isso em 70, 71, 72. Os cordões e os blocos passaram a ser escola de samba. O Vai-Vai fala que tem 90 anos, né? Pode ter 90 anos de agremiação, de escola de samba, não! Tem 40 de escola de samba.

Porque o samba antes era socado. Ele não tinha divisão de primeira, segunda e terceira, né? O primeiro instrumento a dar o contratempo de tudo aquilo que eu disse, se chama duff. Paulinho da Viola usa muito nas gravações dele. Mas já era usado antes do Paulinho e era socado. O cordão tinha o samba mais socado. Pesado. Com surdo e caixa também. A gente andava com o jornal no braço pra esquentar o tamborim, que também era de couro. Hoje é de plástico.

$\mathrm{Na}$ batucada não tinha repinique. Existia malacacheta. Era completamente diferente. $\mathrm{O}$ som é diferente. A tocada é diferente, batia até com duas baquetas. Não existia surdo de primeira, bumbo de primeira. Não existia. Era com duas baquetas. 
Depois que implantou. Porque esse "tum-tum-tum" era puxado do europeu. Foi igual o que o lundu fez. Ele puxou a percussão pra ele.

Outro instrumento que se usava quando eu comecei é o chocalho de vara. Prato, muito prato e cuíca. Cuicona! Tenho uma cuicona aí de catorze polegadas, que até busco ela lá em casa depois. O som é completamente diferente. A cuíca é o único instrumento que você toca com o tato, precisa de inteligência e a coordenação. Você passa um tempinho sem tocar e já pesa a mão. Tanto que tem o ditado: 'Cuíca, carro e mulher que não se empresta pra ninguém.' Mulher sai pra lá, o carro bate, e a cuíca não precisa nem falar, que sem ela acaba o samba. É o único instrumento que ocupa a tiara de fronteira no espaço vazio. Ele é como um sopro dentro da percussão...

Agora que inventaram a pele de náilon, porque era tudo couro. Deixava no sol, depois fazia a barba dele, pra deixar lisinho. Tenho ainda couro bruto aí. Isso hoje. Eu mesmo faço meus instrumentos. Eu gosto. Faço cambito. Eu mesmo faço meus cambitos. Agora os mestres de bateria compram tudinho. É só ligar pra loja e pedir pra entregar.

Não existia bordão de aço. A sobra de couro a gente molhava bem, esticava, torcia, torcia, pegava de lado, pegava do outro depois fazia aquele bordão com aquela corda de cima. Tudo encourado. Tudo a gente que montava... Fazíamos agogô. Você comprava serra circular. Pegava uns retalhos no ferro-velho e montava. A gente pegava, prendia a morsa e tirava os dentes, soldava e saía o agogô. A maioria era tudo artesanal. Tinha surdo de latão de carbureto. Tubo de latão de carbureto. Fazia a borrachinha de fixação, o estirante... A gente mesmo fazia a rosca e achatava a parte de baixo.

Os caras das antigas sabem mexer com isso. Hoje já leva tudo prontinho. É tudo de náilon. Chocalho com vara... Reco-reco de bambu. Era um reco-reco de cabo fino. Acho que você pegou o finalzinho disso aí. Reco-reco estriado. Estriado porque tem uma chave de alumínio e ela era estriada. Então ela virava e tinha uma alça pro dedo segurar aqui e o som comia solto. Hoje tenho reco-reco, mas é de mola.

Foram acrescentadas outras coisas também. Algumas se perderam e outras foram acrescentadas. Acrescentou a marcação de primeira. E, por outro lado, a escola deixou de tocar com duas baquetas. Começou tocar com uma. Observa aquele quadro ali. Duas 
baquetas. É da época de ouro e tem tudo o que era usado na batucada original. Usava bumbo de 36 polegadas! Fixado. Uma base de tronco de árvore em cima e uma menor aqui embaixo. $\mathrm{O}$ instrumento é 60 de altura por 36 polegadas de boca, véio! Era um tamborzão! Com dois suportes lateral, cravado aqui. Quem tocava ele, na Nenê, era um negão careca que era cabo do exército.

Tinha agogô. Tinha frigideira. Tocava-se muita frigideira. Sabe o instrumento que acabou com a frigideira? O tamborim, porque tudo o que o tamborim faz, era a frigideira que fazia. Frigideira era tocada virando. Igual ao tamborim hoje. Além de São Paulo, no carnaval de Santos tinha muita frigideira. Santos era campeã. Brasil de Santos, X9, escolas muito boas. Os tamborins que tiraram as frigideiras. Entrou o tamborim e caiu a frigideira. Os últimos desfiles com frigideira, acho que foi em 1974, 1975. Tinha pandeiro. Você tem um pandeiro diferente pra cada tipo de samba. Cada tipo de samba usa uma afinação diferente. É difícil um bom pandeirista. Às vezes você vê um bom malabarista e é péssimo ritmista. O malabarista é aquele joga e dá chaleira, faz tudo e rebola. E o bom ritmista, já viu o cara que é bom ritmista de pandeiro ficar jogando o pandeiro, já? Eu me considero um bom ritmista de pandeiro, péssimo malabarista!

O som que a Vai-Vai fazia ou que o Fio de Ouro fazia como cordão era diferente da Nenê. Era diferente. Muita gente chama esse ritmo dos cordões de marcha sambada. Presta atenção, nunca houve marcha sambada. O que há é samba marcheado. Era um samba muito mais pesado. É melodicamente o compasso mais alongado. A gente tem que falar assim porque, em primeiro lugar, vem o samba. Era marcheado para as pessoas poderem desfilar andando, indo em uma direção seguindo aquele ritmo. Pra você entender como funcionava. Vamos colocar a Mangueira, que é tempo e contratempo [sons com a boca]. Isso é meio bumbo e até a Mangueira perdeu isso... Você vê lá, até o Cordão do Bola Preta perdeu o jeito original de tocar. Até a Mocidade Independente de Padre Miguel perdeu. Você acredita? É bateria nota dez! Bateria que tinha uma marcação de 40 anos atrás, cara! 50 anos atrás. Esses que tão lá agora aniquilaram o surdo de quarta. O surdo de quarta deixa a caixa à vontade [sons com a boca]. Tiraram da Padre Miguel. Lamentável. Tô falando de lá porque eu conheço. 
Conheço muito lá. Eu sou do tempo do Waldomiro da Mangueira, do Marcelo da Portela, do André da Mocidade Independente de Padre Miguel. Desfilei três anos na Padre Miguel. Eu sou do tempo dessas pessoas aí. Sempre fui convidado lá na Padre Miguel. Eu tive na batucada do Pato N'água. Caraca, o cara batia em todo mundo aqui. Conheci Nicolau. Vê se alguém fala do Nicolau? O último desses aí que começaram a coisa foi o Nicolau! Oh, o nego apaga o passado. E guia o presente cum bando de mentiroso. Nicolau foi um dos maió diretor de bateria da Nenê! Um dos maió! Baixinho, pequenininho, bom. Batuqueiro mesmo! Pra você ter ideia, dava de 50 a zero no Lagrila. O falecido Lagrila veio na aba dele.

Dá uma olhada nos meus instrumentos. É tudo de couro! Isso ninguém sabe, cara! Cê sentiu, ouviu a vibração no chão? Pega uma chave lá qualquer, se você aperta algum instrumento aqui não faz mais barulho. Vai nas escolas por aí, é tudo de náilon. Eu dou umas paradas na avenida. No Rio várias escolas fazem paradas. Faço aquilo que a Padre Miguel fazia. Hoje não consegue fazer, cara! Parar e voltar sem chamar. Só no sincronismo. Quando eu via a Padre Miguel fazer isso, era bonito pra caramba! Tem que todo mundo parar junto e voltar junto pra dá certo. É no compasso certo. O que a gente faz aqui na Imperial, os caras não conseguem mais fazer. Eu fico puto, por isso... Poxa vida! Por isso que eu falo que a banana comeu o macaco; a linguiça colocou o cachorro pra correr. Gozado, né?

A bateria tem padrão e a batucada tem estilo. O que eles chamam de bateria de escola de samba tem apenas nove instrumentos, a batucada 19. Bateria tem surdo de primeira, segunda e terceira. Repinique e caixa, certo? Tamborim, agogô, chocalho e cuíca.

O que eu faço é batucada e tem surdo de primeira, segunda, terceira, quarta e quinta. O bumbo do tamanho certo que faz a marcação junto com as primeiras. E dá sempre dois ou quatro compassos. Tem que ser par, não pode ser ímpar. Essa é a quinta e combina em resposta com a quarta. Combinação, por isso tem a quarta e a quinta, na batucada. Aí, na batucada, você tem caixa de guerra, caixa, tarol e tarolzinho. Nove. Repinique e malacacheta. Onze. Tamborim, agogô, chocalho, reco-reco e prato, certo? 
Aí você tem a cuíca e, pra fechar, o ganzá. Esses são os instrumentos que compõem uma batucada!

A caixa e a caixa de guerra são dois instrumentos tocados por um talabarte na cintura. O tarol e o tarolzinho são instrumentos tocados sem talabarte, no apoio do braço, na altura do queixo. E o som dos quatro é completamente diferente. A caixa bate na altura da cintura... Não é todo mundo que sabe, não. Quando o tarol e o tarolzinho fazem, a caixa de guerra não faz. Quando a caixa de guerra faz, os tambores num fazem. Pra dar a combinação. Veja o som da malacacheta e do repinique [tocando], é completamente diferente. Olha como o som da malacacheta é alto. Olha o tamanho! Todo mundo já passou perto da umbanda, quimbanda, candomblé, num passou? Você pode imagina atabaque tocando, tirando a percussão dos pontos lá do samba, né? Então, esse aqui é a mesma coisa. É pra num perder o alinhamento do estilo.

Antigamente, pelo estilo, você sabia que escola de samba que era. Pelo estilo da arte, pelo som da batucada, você sabia qual a escola que tava desfilando. Hoje, se você não tivesse o papel, não sabia quem era a terceira, oitava e nona. Só tem floreado e enfeite de tamborim, mas aquele som, que é característico da escola, ninguém mais faz. Também troca mestre de bateria todo ano. Os ritmistas não aguentam bater dez minutos, já ficam cansados. Vê a musculação que eu faço com essa idade. Toco duas horas se for preciso, sem nem cansar as mãos.

Você identificava pelo estilo da nossa batucada. Batucada, entendeu? Bateria, pra mim, é de eletricidade. Bateria de conjunto! O instrumento bateria assim, com caixa, prato. Pega uma bateria. O que a negrada faz é batucada. Vem do batuque feito antes pelos negros que trouxeram a percussão pra cá, né? Aí, depois assim, aquelas, aquelas ladainhas de cantigas de senzalas, de tudo. Depois da abolição, começou a sair do interior e vem pra cá pra São Paulo, nos cordões nas festas religiosas, quando esse batuque foi pra rua. Por isso o samba não morre. A gente ocupava a rua. Era diferente, a alta sociedade tinha os bailes de salão.

Tem 30 anos que fundei a Imperial. Estou presidente, não sou. E eu tô concentrado aqui. Já tentei fazer outras coisas, mas não deu certo. Por que a Imperial ainda não tá no Especial? Por causa do Divino. Arrumei confusão já com muita gente. 
Eu fiquei seis meses na Vila Maria. Foram seis meses felizes para eles e feliz para mim. Seis meses. Mas depois o caldo engrossou! A Vila Maria merece uma batucada, merece. Porra, meu, é Vila Maria! Eu não sou salvador da pátria. Eu não sou artista, num sou empregado de samba, eu sou sambista. Eu não assino contrato com ninguém, porque quem assina contrato é artista. Eu num vivo no samba, eu vivo do meu trabalho e vivo para o samba. Mas, na Vila Maria, tudo me respeita... Todo mundo... Principalmente os mais velhos... Pela minha atitude. Os caras pressionando: 'Assina contrato.' Falei:

— Não! Não vou assinar contrato, não sou artista.

— Quanto você quer ganhar?

- Não, quanto vocês acharem que mereço, eu aceito. - O presidente perguntou:

— Cê tá sem carro?

- Eu tô.

— Então toma o carro. Um Renault importado. Passa no seu nome. Pagamento pelo seu trabalho.

— Não. Quando acabar o carnaval, se eu for merecedor, eu passo no meu nome. E se eu for merecedor de mais coisas, eu vou aceitar.

Só que falta de respeito eu não admito. Na final do samba-enredo, eu sempre acompanhei legal, cara. Faço de tudo pra acertar. Alcança o êxito quem está tentando fazer a coisa direito, concorda? Eu saí de lá porque briguei com o carnavalesco. Na disputa do samba-enredo. O carnavalesco discutindo por causa do samba-enredo. Eu cheguei e disse que ele tava enganado. Que o outro samba-enredo era melhor, a batucada também tinha achado. E aí começamos a discutir e ele jogou uma lata de cerveja no meu peito. Pô. Falta de respeito não admito. Peguei minhas coisas, uns instrumentos que levei pra lá, deixei a chave do quarto dos instrumentos e a chave do carro que me deram e não voltei mais. Eu adoro o povo da Vila Maria, mas falta de respeito eu não admito. O trabalho que eu fiz lá, num foi $5 \%$, faltava $95 \%$. Camarada, num sábado, numa hora dessas, juntava 160 pessoas pra ensaiar. Juntava o bloco das crianças, o bloco feminino e os adultos. Quem começava a tocar eram as crianças, passava para o feminino e depois os adultos. Mas deixa pra lá. Deixa ele carregar a cruz 
dele, né? Todo mundo que faz uma cruz, tem que carregar, não vai dar a cruz pra outro carregar, né?

Eu não preciso disso. Já passei por Ibirapuera, Rua Direita, Anhangabaú, São João, Tiradentes e Anhembi. Desfilei em todos esses lugares. Eu fui secretário, presidente e vice-presidente da UESP. Já briguei muito pelo samba. Eu era o presidente da UESP na época da Erundina, quando mudou da Tiradentes para sambódromo. Deu um passo pra frente no carnaval de São Paulo. Faz 20 anos isso. Porque, antes do Sambódromo, não tinha ninguém que tinha interesse em transmitir o nosso carnaval. Às vezes era a Gazeta, às vezes era a Cultura, de favor. Depois que inaugurou o Sambódromo... Choveu proposta. Eu fiz parte disso aí. Porque eu fui secretário e vicepresidente e presidente da UESP, né? Isso foi na primeira vez que o PT ganhou a prefeitura aqui em São Paulo, com a Luiza Erundina, que era assistente social, uma das pessoas que eu acho honestíssima. Votei nela umas duas vezes já. Ela governou a cidade com remanejamento de $1 \%$. Não sei você se recorda disso, $1 \%$ do orçamento! Hoje são 15, 20, e acho que o Kassab tem 25. Um por cento e a câmara toda contra ela.

A gente fazia passeata, manifestação. Oh, nós juntamos 1400 pessoas, 1400 batuqueiros na escadaria da Praça da Sé. Eu tenho várias fotos na escadaria da Praça da Sé. Esses tempinhos atrás aí, o Leandro Lehart disse que colocou 1400 pessoas num evento que ele fez. Nós colocamos isso em uma manifestação. Pra reivindicar um carnaval melhor pra cidade. O problema da Tiradentes era o monta e desmonta. Ficava muito caro. Era muito trânsito, né? Então a prefeitura arrumou um lugar fixo pra gente mudar... Eu tenho a foto da pedra fundamental do lançamento do Sambódromo.

As pessoas meio que apagam o passado, porque hoje não me convidam nem pra passar na porta. Não que eu tô fazendo questão. O importante é a minha escola estar lá. Pra falar a verdade, em 20 anos, depois que eu larguei a presidência da UESP, só no ano passado que o Serginho, que é o presidente da Vila Maria e da Liga, mandou o convite pra mim. Mas eu não fui, porque eu tenho um carnaval na segunda-feira pra sair. E eu não vou ficar sexta, sábado lá no Sambódromo. Tenho que descansar. Mas tem que me mandar até por uma questão de respeito. 
Eu não vou falar nada contra o Grande Otelo, meu patrício, que batiza o Sambódromo. Mas, sinceramente, o que ele fez de samba por São Paulo? Vamos falar a verdade?! Uma cidade que você tem Adoniran Barbosa, Geraldo Filme, Inocêncio Tobias, Dionísio Barbosa, Alberto Alves da Silva e Germano Mathias... Você tem um monte de pessoas que poderiam batizar melhor o Sambódromo. O que o Grande Otelo fez? Você tá entendendo? Eu não tenho nada contra ele... Que descanse em paz. E quando chegar a minha vez, eu também vou descansar.

Todas as escolas que estão na Liga passaram pela UESP. A Liga se vangloria, mas quem fez o trabalho foi a UESP. Mas deixa eu falar o que aconteceu. Antes da formação da Liga, esse interesse todo no carnaval daqui não existia. Começou a crescer mesmo depois do Sambódromo, que tem 20 anos. A Liga tem 25 anos. E só foi criada por causa de interesse de empresários no carnaval. Aí que foi quando houve o interesse de criar outra associação. Pra não ter que dividir o dinheiro com todos. A realidade é essa! Eles seguiram o que tinha acontecido no Rio de Janeiro. Mas lá fundaram a Liga pra doze escolas de samba. Esse ano tá com treze porque não desceu ninguém por causa dos incêndios. Ano que vem vai descer duas e vai continuar com doze. Não se fundou a Liga pra 22 escolas como aqui. Então, o que aconteceu aqui em São Paulo, é esse afastamento de unidade e fundaram a Liga. Porque, vamos falar, é interesse comercial. Todo mundo tá de olho onde a mídia tá, cara! Num tem como! E as escolas grandes não queriam dividir a grana da televisão com a gente, que é de escola pequena. Mas é a lógica. Eu não posso ser da série $\mathrm{C}$ ou da série $\mathrm{B}$ e querer ganhar o que ganha a série $\mathrm{A}$ ! E com as verbas e a estrutura que eles conseguiram com isso aqui em São Paulo, os maiores sempre vão ser os maiores, num tem como.

Amanhã ou depois, nós, da Imperial, vamos estar lá entre os maiores. Tem que enxergar, tem que enxergar a gente como uma das que têm qualidade e comunidade pra estar entre as maiores. A pessoa tem que ter consciência disso. O que não pode é o que acontece com muitas pessoas, que elas esquecem que elas já foram pequenas e médias. Elas num imagina que, um ano depois, elas podem descer pra média pra tentar refazer o caminho, né? Vê a Lavapés: era grande e hoje ficou pequena, vê a Barroca: era grande e hoje é media. 
Quem tá no especial tem muito mais verba e estrutura. Você tem Globo, bilheteria... Tem mais condições de captar patrocínio, recursos... Infelizmente a realidade é essa, véio, entendeu? Não tem como competir. As empresas só se interessam pelas escolas que tão lá no primeiro time, cara! Os outros não são vistos. 'Nós tamo' lutando pra ir para o Acesso. Com acesso é outra coisa, cara! É diferente. O prefeito recebe você junto com as escolas do Grupo Especial. A UESP virou o resto das escolas de samba. Você tira pela base de público que vai ao Sambódromo pra assistir o Grupo I. A gente desfila na segunda-feira pra cinco mil pessoas, se muito. No Grupo Especial colocam 30.000 na sexta e 30.000 no sábado.

E nem todas as escolas têm estrutura pra apresentar um desfile bem-feito. Vamos falar a verdade, 63. Vamos fazer, vamos, mas num comporta, cara! Têm algumas que só investem a verba oficial, e pronto. Vê o Grupo um. Nós somos doze escolas de samba no grupo. Então, vem só oito legal. Do jeito que tem ser, dentro do regulamento, vêm duas capengando e vêm duas pior que capenga. O poder público vai analisar por onde? A mídia vai divulgar qual? As que estão capengando, né? Então... Vai analisando tudo isso aí... Outra coisa, aquilo que eu falei pra você, regulamento é pra ser respeitado. Não pode passar a mão na cabeça. Trazer 60 mil pessoas pra esse desfile ruim? Não traz. $\mathrm{O}$ que fazer pra melhorar? Igual no Rio. Vamos diminuir o número de participantes. Dar mais condição pras outras, com menos escolas sobra mais dinheiro. O Grupo Especial tem 14 escolas. O ideal é 12 . Seis na sexta e seis no sábado.

Tem muita escola que, infelizmente, não tem condição. Pra você receber dinheiro público, qualquer entidade ou escola de samba, tem que ser legalmente constituída. Todo ano eu vou lá pegar um monte de certidão. FGTS, INSS, declaração de imposto de renda, tributos municipais, CADE, tributos federais. Tudo isso aí. Tem escola que não cumpre. Passa cheque sem fundo, não paga fornecedor, funcionário, imposto. Tenho falado muito com o Camilo isso. O Camilo, diretor jurídico da UESP, é um puta advogado... É o advogado da gente, pra defender a gente de várias questões aí. Como eu te falei, como é que pode aquele negócio de mexer com dinheiro público sobre um projeto e depois não prestar conta... Muitas escolas fazem isso aí, ligam para o Camilo consertar. Eu estou afastado da UESP. Enquanto o resto da panela daquela 
mulher estiver lá, eu num vô, cara. Eu lembro de todos os anos que.... Perdi carnaval na secretaria... Assim, de bobo alegre e ter desfile já vendido, cara. Cê já viu isso? Cê tem um regulamento, né? Você entrega a documentação, tem data, tem coisa estatutária, quantidade e tudo e... Perde antes de bobo alegre. Você faz tudo certo, tem aqueles que não fazem nada, não tão nem aí e, no final, dá tudo certo. A UESP passa a mão na cabeça de todo mundo. As escolas desrespeitam o regulamento e ainda ganham campeonato. A gente, que faz tudo certinho, acaba perdendo sempre.

A última da UESP foi ter subido terceiro e quarto colocado fora do regulamento. Esse ano agora [falando alto indignado], véio, o Kaxitu subiu o terceiro. Para, vai. Tem que seguir o regulamento. Tem escola que as cores são verde, rosa e branco, mas veio de branco e preto, véio. Estava na cara que era enxerto. E não aconteceu nada com a escola. O Kaxitu teve um carnaval que, na véspera, abandonou tudo. Ele sabia que tinha coisa errada aí, o cara jogou tudo pro alto e caiu fora. Depois, com muito custo, convenceram o Kaxitu voltar. Então são essas coisas que a gente fica triste. Não tem nada melhor que ser sambista e não tem nada que dê mais dor de cabeça que ser presidente de escola de samba. Quando você só é sambista, todo mundo é seu amigo, todo mundo te respeita; agora, você virou presidente, pode crer que, se você brigar mesmo pela sua escola, você vai arrumar muita confusão.

Eu não tenho medo de falar, não. Eu conto um monte de coisas e as pessoas torcem o nariz. A maioria das pessoas só ouve o que querem ouvir. Elas não querem ouvir o que você tem pra falar de verdade. A verdade não dói, como dizem por aí, mas causa rancor. Rancor. $\mathrm{O}$ rancoroso é pior que o cagueta. $\mathrm{O}$ cagueta entrega um cara e pronto. O rancoroso fica dos dois lados... Fica esperando pra dar o bote. Enfrentei muito rancoroso na minha vida. Como dirigente da UESP, de escola, sempre lutando pelo samba, o que aconteceu? Me expus muito, briguei, bati a cara, discuti...Tem um monte de vaquinha de presépio lá... Eu já sou diferente, brigo mesmo. Teve um ano que em enredo um jurado me deu dez, outro nove e meio, e o último deu sete no enredo! Fala a verdade, colega! Não vou ficar quieto. Ou o cara é burro e não pode ser jurado, ou tem maldade nisso daí. 
Mas vamos levando da vida, né, véio? Uma hora vai chegar o momento da Imperial. Eu espero conseguir mais essa alegria, passar por mais essa emoção, entendeu? A Imperial chegar lá no Grupo Especial comigo! Tendo a oportunidade de apresentar uma batucada de verdade. Me chamam de macaco por aí. Porque quando eu condo a bateria, eu venho pulando muito, fazendo macaquice! E eu tenho que vir igual a um tan-tan? Um joão-bobo? Um boneco de Olinda? Como é que pode? Olha, eu sou sambista! Enquanto eu tiver condição de dançar, cantar, pular, tocar, eu vô fazer mesmo! Primeiro de tudo, é um negócio muito pejorativo. Segundo, isso é racismo; terceiro, isso é preconceito; quarto, isso é inveja!

Eu quero viver isso. Eu fugi do hospital pra desfilar. Eu fiquei 70 dias morrendo, não morrendo, cara! Eu subi pra cobrir a alegoria, porque choveu pra dedéu. Então, nós compramos uma bobina de lona de oito metros de largura por sete de comprimento. Fomos lá, cortamos e enrolamos. Eu já subi na parte mais alta pras pessoas num subir lá. Justamente pra nêgo num cair, porque se cai no chão, piriri, pororó. Puxamos do lado direito do lado direito e, quando me vi, eu caí lá de cima, de costas. Caí naquele cimento preto lá, caí lá de costas... Tum! Nunca pedi tanto socorro na minha vida. Falaram pra mim, não pode se mexer. E aí chegou o carro da polícia, polícia militar e depois o carro do SAMU, o resgate. Eu estava consciente até chegar no hospital. Mas com muita dor. Eu fiquei três dias em coma. Três dias depois, eu voltei. Aí eu voltei na UTI, intubado, cheio de tubo. E lá nessa UTI tinha umas dez pessoas, eu era o décimo primeiro. Aí eu lembrei o que tinha acontecido. Aí vieram os netos e tal. E eu fui ficando mais calmo.

Isso mostrou outra coisa que eu já sabia, mas mostrou mais vivamente. O que esse país paga pra professores, educadores e pessoal do hospital, é muito pouco. Perto do trabalho que esses profissionais fazem. Agora você sabe o que é esquerda, o que é direita, o que é dia, o que é noite, o que é claro, o que é escuro, consegue ir ao banheiro sozinho. Porque a hora que você num souber e precisar de outra pessoa pra fazer com você, é terrivelmente terrível. Aquele barulho da maquininha de sugar da sonda não sai da minha cabeça até hoje. Tudo bem. Cheguei lá na sexta, no domingo saí do coma e me levaram da UTI pro quinto andar. Aí o que aconteceu: no quinto andar, estava cheio de maca, e eu lá, internado. Um dia tinha um senhorzinho lá com cateter assim, pra lá e pra 
cá, e um rapaz novo e uma senhorinha que parecia até a esposa dele, né? O filho brigou tanto com ele, mas tanto, falou até palavrão e depois foi embora com a senhora que ficava lá com ele. Passou um tempo e o veinho levantou e foi para o lado da janela. A janela num tinha grade, cara, e ele tentando se jogar pela janela. Eu levantei de lá e falei:

- Senhor, pelo amor de Deus, não faça isso. Venha pra cá.

Consegui colocar ele na maca, na cama dele. Fui lá e apertei o botão de emergência, num veio ninguém. Fui me arrastando até a porta: 'Oh, moça...' Eu estava há uns 30 metros da recepção. Quando eu voltei, o veinho de novo na janela. Ele arrancou o cateter e foi sangue pra tudo lado. Voltei lá de novo: 'Oh moça, oh moça...' Sabe o que eu fiz? Arranquei tudo o meu negócio e pensei: 'Esse senhor vai se jogar'. Eu tomei pancada na cabeça, vão falar... Será que não foi o senhor que jogou ele? Arranquei tudo o negócio, tinha uma blusa minha lá, botei a blusa, fui saindo, quando vê me vi, eu já estava na rua. Aí o hospital ligou. Minha esposa:

— Chegou, chegou, tá aqui.

Aquela noite eu num preguei os zóio... De dor. Dor, dor, dor! Terrível, terrível... Na cabeça. Que dor, que dor. Segunda-feira me levaram no hospital, aí ligou pro capitão e o capitão me levou daqui na viatura e me devolveu no andar que eu estava. Eu fui pra lá como preso. Quando chego lá... Um monte de exames, num acusou nada. Na quintafeira eu tive alta. Quinta-feira era o outro penúltimo ensaio da escola, o que que fiz? Tinha agitado, comecei a pôr a luz, arrumar e comecei a ficar quente, fervi igual uma chaleira. Não vim nem na batucada, vim na frente da ala das crianças. Criança na escola dá mais trabalho, sabe? Vim, vim, quando virou pra cá, fui me sentindo mal. Quando entrei aqui dentro, dei umas volta. Vim aqui, sentei me sentindo mal e o pessoal falando:

— Joga água na cabeça dele, água na cabeça dele! E traz sal e traz açúcar! Aí me levaram carregado pra casa. - O médico falou:

- O senhor não vai, não pode desfilar. Não pode, não tem condições.

Você acha que depois de 50 carnavais, eu não ia desfilar, mas tudo bem. Fiquei internado até na véspera do último ensaio. Antes do ensaio, saí. Saí, desacelerei, fiquei 
na minha. Ainda estava me sentindo bem mal, fazendo força pra me sentir bem, né?! Não era pra desfilar, mas fui desfilar. Desfilei, tirei mó barato, mas quando chegou do recuo da bateria pra frente, eu comecei a sentir dor no peito. Senti mal. Quando chegou lá no fim, que chegou o último carro, fiquei meio desesperado. Pra mim tinha caído uma pessoa lá do carro assim: tum. Eu virei pra batucada e disse olhando o fluxo de saída: 'Parece que uma pessoa caiu lá de cima do carro.' Eu fui lá e olhei assim, era meu filho. Aí eu comecei a me sentir mal e apaguei. Mais dois dias em coma no Mandaqui. Saí quatro dias depois. E aquela dor de cabeça que não passava. Voltei pro hospital. Mas não tinha neuro. Tive que voltar no outro dia. Tiraram até líquido da espinha, o que é terrível, cara! Quando vieram os resultados, acusou coágulo. Aí fez essa cirurgia aqui. Abriu daqui do meio da cabeça até o outro lado. Dá pra vê aqui. Mais 22 dias internado. Sai de lá. Cheguei em casa, no outro dia, voltou aquela dor de cabeça. Eu chorava de urrar, cara! Tentava tudo e não passava. Aí foi quando foi lá pra tirar de novo o líquido da espinha. Meningite bacteriana. Peguei no ato da cirurgia... Mais 19 dias internado! Tudo isso eu passei, agora. Antes, durante e depois do carnaval. Você me vê aqui trabalhando no sol é porque eu não sou um cara parado. Se fosse outro, tava deitado.

O meu outro problema agora é o peso. Eu pesava 82, 84 quilos. Agora eu estou com 97. Soro engorda? Não, porque é água. Mas os medicamentos que vão misturados com o soro que engordam. E eu, assim, acho que... Tem coisas que é pra alguns. Eu só de estar vivo aqui hoje, por Deus. Já fui baleado, por causa de samba. Já fiquei 27 dias em coma, cara! Eu sô todo costurado, cara! Eu tenho bala aqui. Tenho bala aqui. Eu sô todo costurado mesmo, por causa de samba! Com todo respeito, só pra você dar uma olhadinha. Eu sou todo costurado. Mas eu não me rendo, a minha cabeça... Enquanto isso daqui funcionar e comandar o resto, eu estou legal!

Última coisa, vocês vão entrar no site da Imperial. Nós estamos colocando no site seis estilos de batucada, justamente isso que eu tô falando pra você. Primeiro vamos registrar o som de todos os instrumentos que compõe, com a chancela em cima, do que significa cada tamanho. Aí depois os estilos! Vamos gravar quatro estilos! Gravado por toda essa molecada aqui! Não tem ninguém profissional! Toda terça e quinta tem 
ensaio. Pode aparecer aí. No site nós já colocamos a música do Gato da Vizinha, Antes da Vitória, essas duas são minhas. E o samba-enredo da Imperial 2012. É assim:

Vamos mandar matar o gato da vizinha/Que comeu minha sardinha/E fugiu para o quintal/E esse gato não vai mais me aborrecer/Pois dele eu vou mandar fazer /Tamborim pro Carnaval/Eu vou mandar/Eu vou mandar matar o gato da vizinha. E tem um breque. Percebe? Vou mandar matar o gato da vizinha/Que comeu minha sardinha/e fugiu para o quintal/E esse gato não vai mais me aborrecer/Pois dele eu vou mandar fazer/Tamborim pro Carnaval. Ó a segunda: E a vizinha é que vai pagar o pato/Porque tem amor/na amizade demais desse gato/E a vizinha é que vai pagar o pato/Porque tem amo/Na amizade demais desse gato/Eu vou mandar/Eu vou mandar matar o gato da vizinha/Que comeu minha sardinha.

Presta atenção nessa, se chama Antes da Vitória:

Antes da vitória não se deve cantar glória/Você criou fama, deitou-se na cama/E eu que não estou dormindo/Vou subindo, vou subindo/Enquanto você vai decaindo/Antes da vitória não se deve cantar glória/Você criou fama, deitou-se na cama/E eu que não estou dormindo/Vou subindo, vou subindo/Enquanto você vai decaindo/Quero a minha independência/E com calma e paciência me preparo para o futuro/Tudo isso resolvido/E você também sentindo/Entre nós o páreo é duro/Aguentei muita indireta/Mas andei na linha retal Não maldiga a minha sorte/Vou agir em tal cadência/Sei que a minha independência/há de ser a tua morte, Vitória/Antes da vitória não se deve cantar glória/Você criou fama, deitou-se na cama/E eu que não estou dormindo/Vou subindo vou subindo/Enquanto você vai decaindo, agora/Antes da vitória não se deve cantar glória/Você criou fama, deitou-se na cama/E eu que não estou dormindo/Vou subindo, vou subindo/Enquanto você vai decaindo.

A segunda: Sua voz só me não serve/Meu humilde te recebe/Sua entrada ninguém veta/Gozas de maior ventura/Mas quem vive em grande altura/Leva sempre grande quedal Sei que fiz papel bonito/Não tenho medo de grito/O que fala sem pensado/Não aceites carapuça/Só aceita a carapuça/Quem se sente melindrado, Vitória. 
E o hino nacional da Imperial: Chegou minha escola guerreira/Tu és majestosa no asfalto/Sou mais a sua bandeira/És voz que fala mais alto/Chegou/Chegou minha escola guerreira/Tu és majestosa no asfalto/Sou mais a sua bandeira/És voz que fala mais alto/Em nós, lindas cores de seu porte divinal/E faz pulsar forte o coração imperial/Não é pra desfazer/Mas tenho que falar/A nossa batucada ninguém pode segurar/Não é pra desfazer/ Mas tenho que falar/A nossa batucada ninguém pode segurar/Lá laiá, lá laiá/Nossa batucada ninguém pode segurar/Lá laiá, lá laiá/Sou imperial e vou cantar/Mas chegou, chegou... Muito bonito.

Eu me preocupo muito com o ambiente aqui na Imperial. Aqui é família. Frequenta a criança, o adulto e o velho. Meus filhos e netos estão aqui. Tem criança, adolescente, tudo mundo. Todo mundo sai! Os pais e mães deixam todas as crianças vir aqui. Então isso é meu prazer. Tem uma molecada agora que prefere o funk. Pelo amor de Deus, né, cara. Minha filha foi, chegou em casa, tomou banho, dormiu. No outro dia foi trabalhar e, quando voltou, ainda estava cheirando fumo o cabelo dela. Você imagina se ela num ficou tri louca de tabela, né? Pelo amor de Deus. Falei para o marido dela:

- Oh, marido, sério, num deixa mulher ir nessa parada, não. Principalmente sozinha. Você sabe que de louco e maluco, todo mundo tem um pouco, mas você num precisa endoidar, ficar debiloide, num é verdade? Pode falar o que quiser, mais esse negócio de funk não é bom para os jovens, não.

$\mathrm{Na}$ Imperial prefiro pegar criança... Adolescente... E ensinar! Pra pessoa aprender a tocar, primeiro tem que aprender a bater. Quando a gente começa a engatinhar, depois não dá o primeiro passo? É devagar... Então é a mesma coisa, né? Tem que aprender a bater dentro do andamento de audição, que ela consegue. Devagarinho, no começo e um pouquinho mais acelerado. Ela vai pegar o sentido da audição. Eu sempre pergunto, quando chega o pessoal aqui:

- O que cê toca?

— Oh, toco tudo! Caixa, repinique, chocalho.

— Não, porque você bate em tudo e não toca nada.

O primeiro instrumento a ser feito pra pessoa aprender a tocar percussão, para trabalhar o sentido da coordenação motora, é o chocalho. Vai balançando o braço 
assim... E chacoalha. Vai pegando ritmo [sons de chic chic chic com a boca]. Aí vai balançando até conseguir tocar junto com os outros instrumentos. É o primeiro instrumento. Se o cara não toca esse, na verdade não toca nada. Não tem segredo. Primeiro aprende a bater pra depois aprender a tocar. Qualquer instrumento. Todo mundo não bate palma? Devagar... Acelerado... Mesmíssima coisa. É pra mentalizar. Tem uma coisa. A pessoa só aprende, tem facilidade de aprender quando ela se sente bem no lugar. Ela se sente respeitada, se sente tratada como um todo. Tem pessoa que tem mais facilidade pra assimilar as coisas. Tem gente que tem mais dificuldade! Só que você tem que tratar todos iguais... Respeitar quem tem dificuldade. Como se nada de diferente tivesse acontecendo.

Aqui a gente não permite que ninguém dê risada de ninguém. Não existe isso aqui, não existe! Não tem nada...! Não existe gozação, aqui é escola e a palavra escola é para se aprender. E se você quiser, você aprende. Qualquer coisa. Tem escola do crime, colega! Tem escola até de malfeitor, então, né? Fala verdade? Tem gente que num presta no Pentágono, tem gente que num presta em Roma, tem gente que num presta em Brasília. Na escola de samba também. Tá sendo boa a conversa? Fala muito!

O que você imagina de percussão dentro de uma bateria, eu toco! E ensino. Entendeu? Mas eu já sô tirado de velho. Esse cara já era. Já é passado. Você num tem noção. Mas na batucada eu me garanto. Toco e ensino. Crianças de quatro anos a velhos de 80. Agora, no dia 12, é Dia das Crianças. A Secretaria de Educação do Estado chamou a batucada mirim da Imperial pra tocar lá no Memorial da América Latina. Será um prazer. Ali vai ter um monte de gente... Vai sê um prazer ver as crianças tocando ali... O negro, o branco, o cabeludo, o carrapinho, a menina e a mocinha... Todo mundo vai estar ali junto! E eles tocam muito. Com prazer. Samba é prazer, isso é o meu prazer. Isso contenta muito o meu ego. A única coisa que eu pretendo, se Deus me ajudar, é viver mais uns 15 anos! Pra ver esse meu neto aí, pequenininho, maior. Se Deus quiser. Vou fazer de tudo pra viver mais uns 15 anos." 


\section{Osvaldinho da Cuíca}

Nome: Osvaldo Barro

Data de nascimento: 12/02/1940

Profissão: Policial militar aposentado e músico profissional

Escola de Samba: Vai-Vai

Data da entrevista: 21/01/2012

Local: Casa de Osvaldinho da Cuíca

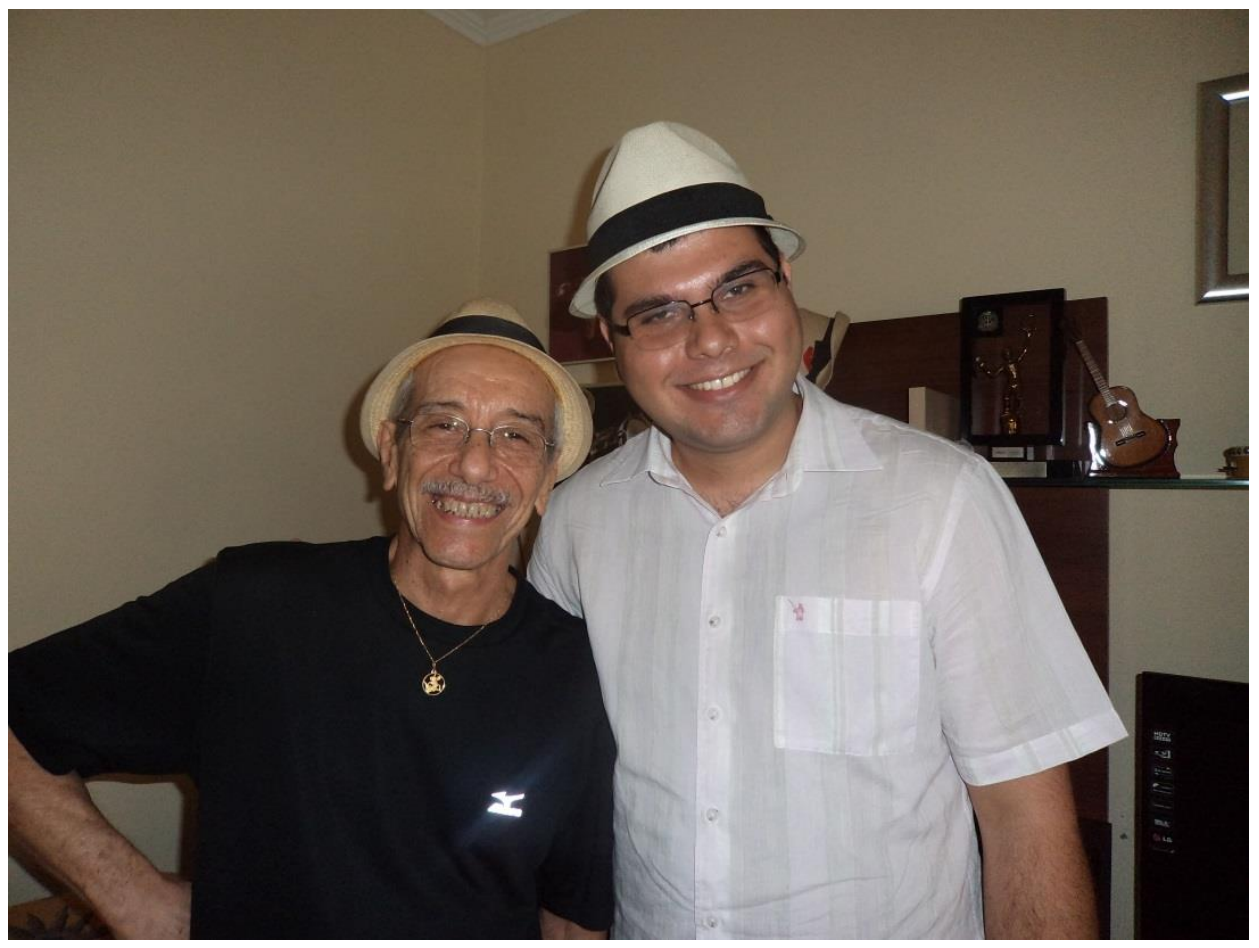

Figura 6 - Osvaldo Barro, o "Osvaldinho da Cuíca", e Bruno Baronetti. Fonte: Foto do autor. 


\section{"A melhor coisa que a gente tem é isso. Divulgar o nosso}

"Meu nome é Osvaldo Barro, nasci no dia 12 de fevereiro de 1940, numa terçafeira de carnaval. Nasci no bairro do Bom Retiro, na Rua Anhaia, antigo nº 123. Meus pais são Domingos Barro e Benedicta de Almeida Barro.

Minha mãe era de Mogi das Cruzes, e, quando meu pai estava no exército, ele serviu no quartel da cidade e conheceu minha mãe. Se casaram no dia 8 de abril de 1939. Dez meses e quatro dias depois, eu nasci. Minha mãe adorava assistir aos desfiles dos cordões carnavalescos no Parque da Água Branca, na São João e no bairro de Campos Elíseos, próximo ao Bom Retiro. Na terça feira de carnaval, ela estava assistindo ao desfile de um cordão roxo e branco, provavelmente era o Campos Elíseos, quando percebeu que estava na hora de dar à luz. Já nasci ao som da batucada. Meu pai, depois de dar baixa no Exército, se tornou fiscal da saúde, viajando o interior levando material para combater pragas, como mosquitos e ratos. Por causa da profissão, meu pai viajava muito, por isso moramos em Tabatinga, Itanhaém, Campinas, Jundiaí, Araraquara e Santos.

Meus pais se separaram pouco depois de minha irmã Yara nascer. Minha mãe, para nos sustentar, teve que trabalhar como empregada doméstica. Naquele tempo, empregada dormia no serviço e não podia ter filhos, pois achavam que não se dedicaria ao trabalho. Não tinha lei trabalhista. Então ficamos na casa de parentes, como da minha tia Cristina e da minha avó materna, Leobina, na cidade de Poá. Lá foi muito bom, não tinha luz elétrica, mas tinha uma fartura de comida, muitas frutas e como havia também um rio, a gente pescava. Com sete anos, fui estudar no Grupo Escolar Padre Eustáquio, em Poá, na frente do Abrigo Batuíra, de crianças carentes. Esse abrigo existe até hoje.

Com oito anos, vim morar aqui em São Paulo, na casa de minha tia Cristina, que era casada com um português chamado João. Ela tinha uma casa na Avenida Cabuçu, no bairro do Jaçanã. Com doze anos, comecei a engraxar sapatos e me envolver com a turminha que batucava. Minha tia brigava muito comigo por causa disso e fugi algumas vezes de casa. Fui morar num barraco com essa turminha da pesada e arrumei um 
emprego colando cartazes nas ruas durante a noite. Mas a realidade da rua é muito dura, tinha que brigar até para conseguir um lugarzinho pra dormir. Percebi o quanto estava perdendo e decidi voltar pra casa da minha tia, que só trabalhava.

Já estava com treze anos e decidi arrumar um emprego. Consegui como carregador de latões de ferro em caminhão. Era muito difícil, minha mão ficava toda cortada e depois decidi trabalhar na feira livre, carregando mercadoria e vendendo. Fui um bom vendedor, todo mundo gostava de mim, porque eu sempre fui muito alegre e folião. Com quinze anos, a nossa turminha se integrou ao Cordão Garotos do Tucuruvi, que desfilava todo carnaval lá na zona Norte, as cores eram preto e branco. Comecei como baliza e depois tocando apito. Aí fui evoluindo dentro do cordão, fui passista e fazia malabarismos. Depois passei a coordenar a batucada como apitador. Em 1959, com meu amigo Nelson Gaya, compus meu primeiro samba, para o Garotos do Tucuruvi. Esse samba se tornou muito conhecido no bairro por muitos anos. Era assim: Minha gente/Quem vem lá/Escuta-se a bateria daqui/Êêêê já vi/São os garotos do Tucuruvi (bis)/Eles vão abafar/já estão brilhando/Cadência de bateria marcando/Cabrochas assim eu nunca vi/Êêêe, São os garotos do Tucuruvi (bis). Belo samba! É de 58, com o Nelson Gaya, crioulo do Tucuruvi. Gente finíssima e educadíssima. Estudou, mas nunca trabalhou. Então ele vivia numa pindaíba danada. Então nós fizemos esse samba. Garotos do Tucuruvi, que é uma exaltação. Naquele tempo era exaltação, não tinha samba-enredo.

Quem segurava o samba aqui em São Paulo eram os engraxates e os abnegados do rádio. Porque o rádio era, na época, a comunicação de massa, a formadora de opinião. Além do rádio, tinha uma coisa muito importante, que quase se esqueceram de escrever, que quase apagaram da história nossa, as gafieiras. Eu, em gafieira, nunca fui bom dançarino. Aprendi a dançar sozinho e fui campeão em todas as escolas de dança. Dancei todo tipo de coisa. Com o Solano Trindade, com o Barbosa Lessa, gaúcho, e fazia folclore, o Lessa ajudou muito a preservar a tradição das danças do sul. Era maracatu, era qualquer coisa. Frevo e samba. Dançando samba fui campeão em todas as modalidades, mas nunca fui um campeão de dançar a dois. Sempre fui ruim. Nunca fiz escola pra isso. Mas o samba era tocado muito nas gafieiras que o manteve, com seus 
conjuntos, regionais e orquestra, foi a que sustentou mais... Esses sambas. Foi um dos responsáveis pela preservação e popularização.

É claro que os engraxates tiveram uma pequena parcela. Há uma mistificação muito grande disso. Porque o engraxate estava ali trabalhando, somente nas horas de folga ou nos finais de semana, quando reunia os caras que cantavam que iam pras gafieiras. Mas a maioria ia pra trabalhar. Eu mesmo fui engraxate em porta de gafieira. Nos finais de semana que tinha mais público... Vinham os carregadores, as empregadas domésticas com os vestidos das patroas. E eu ficava conhecendo os cantores, os músicos que tocavam samba nas gafieiras. Ficava lá de mansinho, com minha caixa e perguntava:

— Aí, meu, quer dar um traquejo aí no buti?

Aí o cara falava pra mim:

— Pô, mano, eu vou lá na Victor Costa, que era da Rádio Nacional.

Muitos tinham chance na Victor Costa. Até o Joãozinho Boa Pinta, que era batedor de carteira, apresentou samba lá. Boa pinta mesmo. O cara, se disputasse com o Ataulfo Alves, ele ia empatar com o Ataulfo Alves. Conheci ele no Tucuruvi. Ele andava com colete, gravata, pérola, aquelas pérolas na gravata, sabe? Aquelas pérolas, anel de ouro e era um tremendo batedor de carteira, era um mulato de nariz fino. Por isso que era boa pinta, olhinho assim amendoado e chapéu coco ou chapeuzinho preto de nome.

Se ele disputasse com o Ataulfo, que era considerado o mais elegante diversas vezes, ele até poderia ganhar. Onde havia uma aglomeração, lá estava o Joãozinho Boa Pinta para bater carteiras. Ele chegava fazendo festa, cantando. Eu me lembro de um samba dele que ele cantava:

A emissora Victor Costa está chamandolos calouros contemplados no programa que passou/Passei no teste e não sou mais calouro/minha voz vale um tesouro/Sou sambista de valor/Na minha casa certo rádio está ligadoleles não acreditavam/Que um dia eu fosse cantor. A cara deles há de rolar pelo terreiro/Cada vez que anunciar/Mais um novo cartaz brasileiro. 
Tem uma gíria da época, aquele negócio de cair a cara, a cara deles há de rolar pelo terreiro. Caiu a cara do cara, quer dizer, ficou decepcionado. Então tinham esses encontros, fazia-se batucada quando não tinha nada pra fazer, principalmente de noite, os caras batucavam...

O circuito que os engraxates faziam era o do centro, onde havia as empresas, escritórios. Na esquina da Rua Direita. O samba que se fazia na Rua Direita mesmo eu não me lembro. Pode ser que antes tinha, mas não era do meu tempo. Porque tinha emissora de rádio ali na esquina. Tinha a Rádio Record lá em cima. Tinham várias... Era um ponto de encontro ali. Na João Mendes tinha muito. Que a turma fala Praça da Sé, mas, depois que implodiram ali, modificou a Praça da Sé, aí mudou bastante. A turma fala Praça da Sé, mas era mais atrás.

Na João Mendes que era a batucada braba dos engraxates. Onde tinha mais, o ponto mais famoso era o Anhangabaú com a Avenida São João. Pra baixo do Banco do Estado, naquela esquina, onde tinha uma salsicharia ali com dois porquinhos, ficavam dois porquinhos assim, acendia e apagava. Essas luzes comum vermelha, dois porquinho com a salsicha assim, um pra lá e outro pra cá. Com a salsicha na boca, acendia e apagava. Aquilo era atração, era novidade. Chamavam o lugar de prainha. Era ponto de encontro. Não tinha praia nenhuma. Acho que era alguma gozação com o Rio de Janeiro, prainha. Em frente à Praça do Correio. Então ali também tinha bastante. Mas o lugar próprio mesmo de samba eram as gafieiras. Como tinha que pagar pra entrar, a gente ficava na porta engraxando os sapatos do pessoal que frequentava.

Apagaram a história das gafieiras. Tinha a Caçamba, depois veio o Som de Cristal e o Garitão. E a mais famosa e melhor gafieira de todos os tempos era o Vinte e Oito. Não sei o nome oficial, mas todo mundo conhecia como Vinte e Oito, porque era no número 28 da Florêncio de Abreu. E era uma portinha só com uma escadaria. Uma portinha estreita e a gafieira acontecia lá no andar de cima. Aí pegou fogo um dia e morreu todo mundo. Porque não dava pra descer as escadas né? Era um corrimão estreitinho assim, um metro de largura, e pegou fogo. O Vinte e Oito. Aí ficou um tempo quieto e depois eles abriram na Rua dos Andradas. Mas aí não foi a mesma coisa, e $\log$ o fechou. 
A rapaziada que frequentava eram os crioulos da sacaria, da Santa Rosa ou lá do Largo da Banana. Onde trabalhavam aqueles negros da pesada, tudo suado, de camiseta. Aí quando chegava de sexta-feira ou sábado, punham meia de mulher na cabeça pra alisar o cabelo, né? Na sexta-feira todo mundo trabalhava com a meia amarrada na cabeça. Era engraçado. Porque quando chegava o final de semana tinha que ir pro Vinte e Oito. Passava banha na cabeça, passava uma lata de banha pro cabelo ficar esticado, ficava lumioso e punha um terno branco tipo panamá mesmo, 220. Chapéu Panamá.

As empregadas pegavam as roupas das patroas, as joias das patroas e iam tudo pro Vinte e Oito dançar. E era animado. Tinha sempre conjunto de baile com bateria e pandeiro. O pandeiro segurava sozinho. Tinha que ser bom o pandeirista de conjunto. A bateria dava o breque e era o pandeiro que mudava de ritmo. Quando dava o breque, tum e aí o pandeiro mudava de ritmo. Por exemplo, quando mudava pra bolero, era o pandeiro que mudava. Era assim. E tinha metais, guitarras e ia embora.

Em 54, 55 teve uma música que foi campeã de carnaval e virou costume tocá-la quando ia acabar o Baile. A orquestra já sabia que era a música de São Paulo que encerrava. A orquestra já vinha: Vai tocar a última, tá chegando a hora. Isso era pra avisar os caras que estavam no bar fumando, tomando uma cachacinha, outro lá conversando com a namorada na porta. Todo mundo parava o que tava fazendo pegava a mulher e corria pra pista. Cantavam assim antes de tocar a música:

Vai tocar a última, pegue o seu casaco e meu chapéu e vai me esperar lá foralAnda depressa querida, que a nossa condução já vai chegar/Quem é pobre, mora longe não espera o baile acabar/E eu vou'me embora./Vai tocar a última.

Era a última da gafieira. E a turma cantava e ia embora.

No Brás também tinha muito engraxate. Perto da estação de trem do Brás. Os caras ficavam engraxando ali. Ninguém fala disso. Tinha também. Apagaram a história do Brás. Não era só nordestino que tinha ali, tinha muita coisa, muito carnaval. No Brás era carnaval mesmo. Desfile com escolas, com carros. Tinha no Rio e em São Paulo também. E tinha muita batalha de confete.

Eu me lembro dos eventos do meu tempo, estou falando pelo meu tempo, nos anos 50, final dos anos 40. Até 50 e poucos era aqui no Parque Shangai, onde hoje é o 
Parque D. Pedro II. Era a maior diversão de São Paulo. Era uma espécie de parque de diversões. Pro Parque Shangai vinham os maiores cantores do Brasil. Francisco Alves, que era considerado o maior cantor da época. É o maior cantor do Brasil de todos os tempos! Eles vinham cantar aqui. Orlando Silva, no Parque Shangai. Era um parque muito grande. Mas sempre foi reduto de sambistas.

Dali saíram grandes escolas de samba. Saiu a escola de samba em 38, 39, Brasil Moreno, Rosas Negras. Onde o Germano Mathias começou, de 39, a Rosas Negras. Saiu do Lavapés e foi parar lá na Rua Vergueiro, onde tem o Hospital Municipal na Vergueiro, bem naquela esquina era a Rosas Negras. Na Castro Alves. Era ali a quadra. Quadra não, não existia quadra em São Paulo, há diferença de cordão e escola de samba. Cordão sempre nasceu e morreu na rua. A escola de samba primeiro tinha terreiro depois tinha quadra. Cordão não tinha nem terreiro nem quadra. Tinha assim... Você guardava os instrumentos, os caras falavam, vamos guardar os couros. Então guardava o instrumento na casa do dono do batuque. Que nem tem lá em Pirapora, a Dona Maria Esther, que é a dona do batuque, né? Aqui em São Paulo era assim, o dono do batuque. O Grupo Barra Funda era na casa do Seu Dionísio, e assim por diante.

A nossa tradição aqui em São Paulo era cordão. As escolas de samba começaram no Rio de Janeiro, no bairro do Estácio. Era um novo tipo de música que estava nascendo ali. Ficou conhecido como samba do Estácio, que é o samba carioca como vemos hoje, que veio da fusão do jongo e do lundu, principalmente o lundu, que é o pioneiro, chegando depois a fase do maxixe e o refinamento disso foi o primeiro passo para o samba. Aí ganhou a síncopa e o telecoteco, e se tornou o samba.

Esse modelo de samba, conhecido como samba do Estácio, foi o samba do Rio de Janeiro. Então você vê que foi longa a minha trajetória diferenciando o samba paulista do samba carioca. Esse samba, esse modelo, não existia. $\mathrm{O}$ que se tinha, nos mais diversos Estados, eram modelos rústicos, tanto no Maranhão, Belém e cidades portuárias, principalmente Santos. Lá é o porto mais antigo da América Latina. Por onde chegavam os escravos da África, mesmo depois da proibição dos ingleses no tráfico oceânico. E, depois, evidentemente, São Paulo, pela grande extensão de mão de obra escrava. E o samba veio dessa cultura africana, com elementos da música europeia, 
principalmente no uso de instrumentos de sopro e cordas. A fusão foi com a cultura imposta de cima.

Veja bem, esse é o meu modo de perceber as coisas, e é claro que é uma forma de ver através da sensibilidade e não do banco acadêmico, então posso ter equívocos e erros. É a minha sensibilidade que está falando. É o meu modo de ver a primeira fase. Se não dividir em três fases o samba, é impraticável fazer essa comparação que esses acadêmicos tentam fazer.

Então havia diferença, como eu fui ver em Cuba, na África e em todos os lugares que deram essa essência. Cuba tá pobrezinha! Parou, regrediu. Bloqueou há mais de 50 anos essa receptividade que o Brasil continua tendo. Mas é a mesma linha africana que estava lá, a mesma que estava aqui. A primeira a chegar foi do Congo, então essa primeira fase definia muito e criou um modelo no Rio de Janeiro por ela ter sido privilegiada, por ter sido a primeira e virou um padrão. Então, a partir dos anos 30, começou a se difundir pelo país, influenciando outras modalidades. Essa difusão se deu pelo rádio, que começou a evoluir nos anos 30. Ele nasceu nos anos 20, 22, mas o processo de evolução foi depois de 32, 33, o rádio começou a mandar essa sonoridade, na qual o Brasil foi absorvendo e mudando a sua característica de batuque, de samba.

O samba da segunda fase já está nesse processo de urbanização dos anos 1930 para cá... Mas não podemos esquecer as influências que o samba paulista tinha, não só da zona rural, mas da religiosidade. Sempre a Igreja foi a pioneira a impor para os escravos e para os índios a sua cultura. Para desmistificar o santo africano, principalmente. Havia um diferencial também na religião, porque a umbanda, que tem cento e poucos anos, é nova, e era mais praticada em São Paulo do que no Rio, no Rio teve uma forte presença do candomblé e uma pequena presença da umbanda.

A umbanda é uma religião brasileira. É a mais brasileira das religiões do mundo. Ela congrega as quatro raças, o índio, né? Você recebe o santo índio, e o negro, o pai João, o pai Joaquim, e europeia, pois incorpora o doutor Fritz, e sei lá o que mais, e recebe até o amarelo. Recebem as quatro raças que é o Brasil. O candomblé, não; o candomblé é africano, embora ele seja mais rico, ele tem oito ritmos diferentes ou nove, ele tem nas suas batidas diferenciadas, que foi influenciar o samba do Rio de Janeiro. A 
batida ligeira, o urucungo, influenciou os sambas-enredos. A lenta, por exemplo, foi influenciar no samba tipo Martinho da Vila. Essas vertentes são complicadas, para quem não entende, mas o candomblé teve forte presença no Rio através das Tias Baianas. A mais famosa delas é a Tia Ciata.

Em São Paulo, eles começam buscar a linha do café e o diabo a quatro. Eu, como sou percussionista desde moleque, há mais de 50 anos, eu começo a perceber onde está a batida e quem fez e quem não fez, né? Você tem o João da Baiana, que era macumbeiro, então era Orrã. Eu vejo como é que funcionava isso em São Paulo. Olha, eu falo como percussionista, porque eu não sou praticante de nada, eu sou um corintiano metido à besta. Então a umbanda, que só tem uma batida, ela permaneceu até hoje no samba rural, ela é uma batida mais ou menos assim: tum,tumlucuntum,tum. Essa batida gerou o que você vê que no samba de Pirapora é assim, a batida do bumbo lá, muito pesada, porque era muito bumbo e muita coisa pesada, porque, além dos atabaques, era utilizado o bumbo.

Na segunda fase do samba, nós tínhamos a influência da zona rural que acabou. Tanto o sertanejo acabou, como o samba acabou. Tudo que era da zona rural, praticamente acabou. $\mathrm{O}$ que vemos aí hoje é tudo falso... O sertanejo não existe, o sertanejo de hoje é um lixo, é uma música romântica, com um cara fantasiado de americano, cantando uma música de amorzinho, de corno e acabou. E isso acontece em todas as vertentes do samba.

O grande samba bom, de Caymmi, o samba de roda da Bahia, praticamente acabou. Foi passando por um processo de sonoridade, de mega sonoridade, modernização, com muitos metais, muita guitarra, desde Dodô e Osmar, que foram gênios criando aquele carnaval do trio elétrico para a grande massa. Igual à escola de samba hoje, é pra grande massa, é pra sociedade, não é mais pro sambista a escola de samba. Escola de samba acabou, hoje tem um grande espetáculo, pra todo mundo participar. Hoje eles acham bonitinho, você comprou sua fantasia? O cara nem sabe o endereço da escola de samba. Ah, vou dar de presente, vou comprar uma fantasia pra minha filha a fantasia da Mangueira. Essas fantasias vendem à beça, entendeu? Então, 
acabou. A mesma coisa aconteceu na segunda fase do samba, começou já o processo de evolução.

O Mario de Andrade já lamentava a transformação do samba de Pirapora, porque eu sou um dos atuantes lá em Pirapora, tem o decreto-lei número um. Eu sou cidadão 'piraporano', por decreto-lei, porque eu fazia intercâmbio lá. Tem só uma pessoa viva, se vocês pudessem falar com ela. Ela é de 1924, é a dona do samba lá... A Dona Esther, ela tá muito doente, tem muita idade, perdeu uma irmã faz dois anos. Ela é mãe de santo e é muito simples, e é a única sobrevivente; tem ela, tem o João do Pasto, que é mais novo que ela, mas já tá véio também. Mais véio que eu, um pouquinho mais que minha idade, mas o pessoal tá todo mundo indo embora. Ela é de 1924, tem a idade do Paulo Vanzolini, vai pra 87 anos. Então, se Mario de Andrade lamentava isso nos anos 30, você imagina quem somos nós pra falar agora. E quem persiste em ficar no tradicional, vai pro lixo, é simplesmente descartado. Porque hoje a exigência, tem muita faculdade de música, de arte de tudo...

Hoje show tem que ser cópia de Hollywood, é a cópia de tudo. Então você vê o pessoal falar muito. Um dia, eu tava vendo um DVD com um documentário sobre o samba e mostraram o jongo da Serrinha, e aí escutando as pessoas, que falavam eu fiquei tão brabo, xinguei! No depoimento, ela falou:

- Olha a diferença, olha o carioca lá em Madureira, o jongo.

É o maior lixo, foi o Mestre Darcy que criou isso aí. Ele morreu faz uns cinco anos, que Deus o tenha, um grande batuqueiro de jongo. Mas hoje virou vitrine pra turista. Eu assistindo e vendo o jongo tudo errado. Jongo com coreografia, os instrumentos, não tinha nenhum instrumento de jongo. Tá com instrumento cubano, como você fala que é jongo, tá com tumbadora de tarraxa de ferro. Cadê o tambu? O quinjengue, o candongueiro? Cadê? Cadê o caxambu pra bater, que é no chão, socado no tambu? Você vai por aí, no Estado de São Paulo, tem jongo primitivo, com nêgo ainda de carcanhar rachado batendo no tambu, esquentado no fogo com pinga. Não isso que eles mostram na televisão pra turista ver.

O jongo não veio da classe do Ermínio de Moraes. Então como é que você admite que isso é jongo, só porque é preto que tá cantando? Eu falei: isso não é jongo! 
Tá cantando jongo, com músicas das antigas, mas a batida está diferente. Os instrumentos não são os mesmos. Cadê a religiosidade? E cada vez vão mudando mais. Não pode mudar essa imagem, né? Então, o jongo de verdade tem uma religiosidade até na pele do instrumento. Quando você esquenta no fogo com a cachaça, pra dar a oferenda do santo, aquilo é sagrado, tem uma religiosidade, então não pode você mudar.

O samba perdeu também essa religiosidade africana. Porque a partir do momento em que já tá na... Sei lá quantas gerações... Já deve estar na quinta geração, sexta ou até mais. Muita coisa se perde, não vai passando a diante. Porque eu conheci praticamente a segunda geração e alguns da primeira geração do samba. Eu conheci, eu gravei com Ismael Silva, que foi quem ajudou a formatar esse samba do Estácio. Eu gravei com Nelson Cavaquinho, esse povo. Adoniran, então, nem se fale, né? Já é segunda geração, o Adoniran é de 1910.

Antes dessa veio a primeira geração. Essa é, ainda, antes da virada do século passado. A primeira geração do samba é a Clementina, fiz peça com ela. Esses, sim, eram filhos de escravos e fizeram jongo de verdade. Depois, quem já tá na quarta, quinta geração é mentira! Tá fantasiado de sambista. Bota terno branco, chapéu. É a primeira coisa que põe, porque agora virou moda novamente colocar chapéu, entendeu? Ih, é sambista e canta samba. Bom, cantar, todo mundo canta, samba é música, não é privilégio de ninguém. De cara que faz música com o ritmo de samba, a academia tá cheia. Foi desmistificado agora, entendeu? O samba era mistificado, agora não, acabou! Não tem mais a essência.

Hoje só fala de amor, igual à música sertaneja. Não tem mais o que dizer, porque o caipira de hoje não mora no mato, é tudo criado aqui. O Chrystian e Ralf foram criados comigo lá no Tucuruvi. Eu vi os dois ainda moleques, cantavam em coro; no começo de carreira, eles gravavam comigo. Nunca viram mato! Assim como todos os outros. Então como ele vai falar de determinada raiz que serve de remédio, que antigamente se falava? Como é que ele vai falar de determinado pássaro ou bicho do mato, que nem falava Raul Torres, o Furtado, né? O Capitão Furtado... Como falavam os maiores... Alvarenga e Ranchinho, né? Que eram caipiras de verdade, daqueles que 
se vestiam bem 'paiaço', parecendo o jeca. O próprio Mazzaropi. Nas próprias músicas, quando ele cantava no cinema, assim:

A sanfona tá tocando/Começou o arrasta-pé/Dança e tem homem com homem/E mulher com outra mulher/Esta dança que balança/mas não cansa.

Então é um caipira do mato, entende? Agora isso que tá aí é ai, amorzinho, você me deixou e bate o pé, e bate o pé e tudo com a mãozinha na calça jeans e rebolando a bunda, isso aí não é sertanejo, isso aí é pura e simplesmente entretenimento. É música, mas para entretenimento. Mas, se for comparar isso com sertanejo, é sacrilégio.

Se for comparar o samba, com o pagode, é sacrilégio. É sacrilégio puro! Aí os caras que vão pra faculdade, tem palavra bonita pra se defender, não porque é evolução... Evolução é a puta que pariu [indignado]! Nós temos que respeitar primeiramente as nossas origens, isso é você evoluir...

Porque eu sou uma pessoa atualizada, todo ano eu faço samba-enredo. Não deixam ganhar, porque 'véio' não pode ganhar mesmo, hoje é tudo manipulado. Mas eu estou bem atualizado. Viajo sempre. Tô mais atualizado que eles. Não paro, agora mesmo vou fazer, em Curitiba, a história do samba paulista, no teatro lá, entendeu?

Mês que vem, vou fazer um trabalho em Brasília. Eu não paro. Então, atualizado é isso. É você respirar todo dia música e saber o diferencial de hoje, mas respeitar o passado, respeitar quem fez, porque nós somos uma história em processo eterno de evolução. O mundo está sempre em evolução, isso tem que ser dito. Mas não pode evoluir sem perder a raiz, se não, não é evolução, é outra coisa.

E foi perdendo a raiz em São Paulo. No Maranhão, por exemplo, muita coisa se mantém, mas já também com muito verniz, embora tenha coisa muito bonita lá, como o tambor de crioula. Mas, quer queira quer não, você não pode trocar um tambu, que é um instrumento tradicional, por um instrumento de náilon, porque existia toda uma cultura religiosa por trás daquilo.

Com o samba é a mesma coisa. Ele nasceu na Bahia, se desenvolveu no Estácio e virou modelo nacional, pois, agora, é brasileiro. Ele foi refinado no Rio de Janeiro, mas nasceu na Bahia. Ele tá em constante processo de evolução. O que a gente tem que 
fazer é aceitar o que é bom, adicionar um tempero, como novos instrumentos, nova indumentária e tal, mas não ironizar ou desprezar...

Não cortar raiz, senão a planta morre. Você não pode cortar a raiz. Uma árvore você tem que adubar, você tem que cuidar dela, mas, se você cortar a raiz, já era. O dente a mesma coisa, se tirar a raiz do dente, ele fica amarelo, preto e apodrece. É a mesma coisa a nossa história, só existe o novo porque o 'véio' deu a referência... Se o cara inventou a penicilina, outro inventou o telefone, hoje tem computador, tanta coisa, mas tem que respeitar quem inventou o telefone, porque ele deu o primeiro passo, ele abriu pros outros saírem correndo atrás. O samba é a mesma coisa.

São Paulo começou a olhar com bons olhos o rádio, depois o cinema, depois do cinema a TV, a partir dos anos 50. Então, esse processo de comunicação, de comunicação imediata, foi responsável pela transformação da questão regionalista do Brasil. Então o samba ganhou força, fez um elo muito forte no carnaval através da escola de samba. No Sul tinha um instrumento chamado sopapo, tinha a pele de um lado só, e era batido com a mão, por isso que era sopapo, tinha bons tocadores que batiam muito bem, mas agora passou a tocar com baqueta que nem o carioca. Botava um surdo de primeira, um de segunda, um de corte, um de terceira. Virou escola de samba carioca, e antigamente não era, era um tambor com uma pele de um lado só batido com a mão. Existia um diferencial, mas, agora, foi copiado o padrão todinho, na íntegra.

Se a Bahia não tivesse axé, Filhos de Gandhi e outras coisas mais, estariam fazendo escola de samba também. Porque até no Paraguai tem escola de samba, A gente encontrava antigamente vários quartetos, trio de negro em turnê na América Latina. Aí você ia falar com ele:

— De onde você é?

- Yo soy da Mangueira.

O cara não era nem brasileiro. O cara era lá do Paraguai, do Uruguai, cansei de ver esse negócio. Ah, é da Mangueira é? Eu já olhava o cara, ele era do Paraguai e tocava igual brasileiro. Então não há fronteira, esse processo de comunicação leva os ritmos para todos os lugares. Primeiro o rádio, depois o cinema e a televisão. 
Aqui em São Paulo também se adotou o padrão do Rio de Janeiro. Tínhamos uma identidade própria nos dos cordões que era um cortejo imperial, na batida de marcha, de marcha sambada e de outras modalidades, como Zé Pereira. Pom, pom, pom, Zé Pereira, pom, Zé Pereira. Ia fazendo isso pelas ruas.

E perdeu tudo isso, uma riqueza imensa. Tinha trombone, clarins, tinha muitos clarins, todas essas coisas bonitas se perderam e virou tudo escola de samba de padrão carioca. Por exemplo, assim como no Sul, aqui, em São Paulo, a batida do surdo era diferente. Não tinha nada igual ao Rio, absolutamente nada. Não tinha porta-bandeira nem mestre-sala, não tinha rainha de bateria. O desfile era diferente, era um cortejo imperial, com rei, rainha, a corte, a princesa, com os cordões usando o mesmo tipo de fantasia todo ano. Não falava bateria, era batuque. Bateria era Rio de Janeiro. Aqui era batuque. Na frente do batuque, tinha uma 'rumbera'. Sacudindo aquele vestido encarnado, rodando no chão. E tinha as baliza, eu fui baliza, fui um pouco de cada coisa, então jogava aqueles pauzinhos.

A percussão do cordão era bem pesada. Além desses instrumentos de corda e de sopro que eu falei, tinha surdo e bumbo, muito bumbo de banda. Não confundir com zabumba, porque muito historiador põe zabumba. Zabumba é nordestino, é fininho, é um bumbo magro, e o bumbo é aquele gordo mesmo de banda, aquele que nem o dos fuzileiros navais. Bum, bum, bate de um lado e do outro.

Então, em São Paulo, tinha muito bumbo e a batucada era bem diferente. Como tinha muito harmônico, o bumbo é um grave pesado, e ele tem muito harmônico. O som é assim: Bum! O harmônico fica retumbante. O importante dele era a função de batida, não é repique. Quem repicava era um surdinho pequeno. Era um samba socado que o carioca dava risada da gente. Falava que era um samba duro. Então era assim, o bumbo, ele vinha sempre dois ou quatro atrás, depende do cordão.

Os maiores cordões eram Campos Elíseos, Camisa Verde e Vai-Vai. Cada um no seu tempo, então tinha aqueles bumbos grandes. Então vinham dois bumbos atrás, às vezes não vinham. Se tivesse patrocínio, poderia colocar mais bumbo. Os cordões tinham pouca miudeza. Pouco tamborim, pouca cuíca, pouco agogô, pouca frigideira e ganzá. Aqui em São Paulo era mais pesado. Esse era o diferencial. 
Os cordões possuíam influência rural e religiosa. O samba rural é um samba caipira, onde você têm várias modalidades, cururu, por exemplo, equivale ao partido alto do Rio de Janeiro, é o desafio de viola. Esse samba era presente nas cidades de Tietê, Botucatu e Capivari, todos os lugares de cururu, moda de viola, muita moda de viola. Cana verde. Cana verde é marcha, aquela marchinha de viola. Nhéi, nhéi, nhéi, nhéi, minha vó ficou sem dente de tanto morder meu pai.

A influência religiosa era da Folia do Divino e de outras festividades do interior. E era muita marcha. Era muita religiosidade, né? Porque as Folias do Divino, as congadas, são eventos religiosos e assim como os cordões, essas festividades possuíam um estandarte, herança da religiosidade jesuíta. Não tinha bandeira. Existia estandarte. Se a cultura dos cordões tivesse evoluído e não copiado o padrão carioca, deveria hoje também estar maravilhosa, com alegorias grandes. Porque o cordão não tinha alegoria, o cordão era mais animado e, apesar da batucada pesada, para dançar era mais leve... E com o fim dos cordões perdemos a riqueza regional. Perdeu!

A parte plástica dos cordões foi toda perdida. As escolas de samba têm a origem nos ranchos, que tinham alegoria. E também enredo. É uma espécie de peça teatral. Os cordões não eram peça teatral. Se fosse comparar com o teatro, seria como a festa de Cristo. Todo ano a mesma. A paixão, a morte de Nosso Senhor Jesus Cristo é sempre a mesma, todo ano. Cordão é a mesma coisa.

O principal do desfile era a corte imperial. E a motivação era a alegria. Era cantar o carnaval. Cantava músicas de rádio ou outras que eles mesmos faziam. Não era uma única música como tem posteriormente o enredo. Por exemplo, a Mangueira, este ano, tem como tema Monteiro Lobato. Já os cordões eram assim: o primeiro tema de fantasia da batucada do Vai-Vai foi de marinheiro. Teve um ano em homenagem aos russos, as fantasias de 'sordadinho' Fritz. Fritz por quê? Existia uma propaganda no jornal que era bomba de Frit pra matar inseto. Eles falavam Frit, né? Tinha a propaganda de um 'sordadinho' que tinha um chapéu russo, aquele chapéu comprido, de russo. Só que em vez dele ter uma carabina aqui na mão, ele tinha uma bomba de Fritz na mão, isso nos anos 30, 40. 
Eu me lembro disso aí. Até os anos 50 tinha a propaganda do soldadinho com uma bomba de Fritz da mão. Normalmente, era a bateria que vinha com fantasia diferente todo ano. A corte vinha igual. A mesma coroa, a capa de rei, rainha, os súditos atrás. As crianças segurando a capa da rainha, do rei. Era bonito, mas sempre a mesma coisa. O que variava era a música. Então você cantava quatro linhas, repetia várias vezes, uns dez minutos, cinco minutos, enjoava, mudava para outro tema, aí cantava uma música de sucesso de rádio. $\hat{O}$, jardineira, por que está tão triste? O cara puxava no trombone, tinha trombone, tinha pistom. Tinha muito mais instrumento de sopro do que percussão. E, além do sopro e percussão, tinha corda. Na verdade, começou com corda, depois foi introduzindo os instrumentos de banda. Estamos falando de 70 anos atrás, portanto, não existia equipamento de som. Então era o pessoal com conjunto de choro acompanhando, e a percussão tinha que ser pouco, pra não cobrir os outros instrumentos.

Então saía um regional com dois, três cavacos e um banjo. Porque o banjo grita mais alto. E violões, um pandeiro e poucos bumbos. Um ou dois, como eu falei pra vocês. Pra não encobrir os violões e a voz. Então era muito mais sonoro, mais bonito. De longe já se ouvia aquele grupinho, que vinha cantando, balançando, espontâneo. Sem aquele compromisso de ganhar um título, dinheiro e tal...

Aí veio a televisão e começou a mudar muito. Foi com a entrada da televisão e o crescimento muito acelerado das escolas que começou a industrialização dos instrumentos, porque antes era artesanal, né? Agora são 300, 400 ritmistas, não tem como fazer como antigamente. Você fazia primeiro com barrica, depois veio o processo de evolução e fazia com madeira compensada. Tinha aquele tamborzão de madeira compensada e que parecia um surdo. Era só pregar um couro ali e virava um surdo. O surdo é de madeira compensada até hoje. Então a gente inventou aquilo.

Depois veio tambor de carbureto. Era um tamborzão de lata assim, do tamanho do tronco de uma pessoa, bem grande. A gente mandava para o ferreiro ferrar uma argola aqui e quatro tarraxas. Aí já esticava e apertava o surdo, não era mais esquentado na fogueira. Que nem aqueles compensados de barrica. Cê tinha que esquentar e esticava. Dali dez minutos esfriava, aí ficava pior. O sereno molhava e aí ficava pior. 
Esquentava durante uns dois minutos e depois começa a bater, tum, tum, tum, tum, tum, tum, até ficar na afinação correta. Dali a pouco, já começava de novo. Os caras falam, endeusam muito isso. Pega um tambor murcho, esquenta ele e começa a tocar no sereno pra ver quanto tempo ele dura. Entendeu? Aí inventamos a tarraxa. Aí não precisava mais esquentar, era só apertar que a pele esticava. Isso já representou um grande avanço. Aí depois começou a industrializar. Por tarraxa nos instrumentos.

Você sabe a capa do meu livro? Tá o Germano Mathias com a primeira cuíca que eu fiz pra ele. Ele já tinha comprado uma e não deu certo. Aí ele foi até a minha casa para eu entregar a cuíca pra ele. Ele foi com o Padeirinho lá. E aí tiramos a foto, com o Germano e a cuíca. Muita gente ia até a minha casa. Germano, Padeirinho, Jorge Costa iam sempre até a minha casa. E eu fiz aquela lá. A foto a gente tirou na mesma rua, mas eu fui tirar na casa da minha comadre. O Germano paquerava a filha da minha comadre. Fui tirar em frente à casa dela. Porque minha casa era muito feia. Era um barracão. Era bonito por dentro que era obra de arte. Tudo artesanal. Eu fazia máscaras, fazia aquele rosário de Nossa Senhora. A porta na entrada do barracão era com tampinha de cervejas. Eu fazia pintura. Mas era um barracão. Eu morava na última casa do morro. Aí eu desci com o Padeirinho e com o Germano e tiramos a fotografia na porta da casa da minha comadre, que era a terceira da viela. Eu morava na última. Eu tirei de uma peça velha de bateria. Aí eu botei a pele, botei a vareta.

Não fiz muita coisa na cuíca, só fiz isso. Aí dei pra ele. Ele tocava. Tocava apito, cuíca e tocava aquela latinha, tocava tamborim. Tocava tudo. Esses instrumentos que eu fazia eram muito pobres, muito artesanais. Ainda hoje eu faço as peles e depois encouro tudo. Que eu ponho do meu jeito. O meu som é diferenciado! Modéstia à parte, eu sou quem faz o melhor som. Mas o pessoal tá me alcançando. Tá evoluindo muito, o pessoal já tá descobrindo as manhas. Hoje você compra uma cuíca e pode sair da loja tocando. Antes não, você tinha que afinar. Você comprava na loja e, dependendo da fabricação, tinha que mandar fazer de novo.

Esses regionais dos cordões fora do carnaval tocavam em festas juninas e mais nas festas religiosas católicas. Festa de Nossa Senhora Aparecida, em outubro, e outras festas de santo, como São Benedito. Todas as grandes festas religiosas. Em fevereiro, a 
festa de Iemanjá. E tinha as grandes festas tradicionais das cidades. Por exemplo, o banho da Dorotéia, que ia pra Santos, que acabou. Os juízes mandaram acabar. Eu que descobri, fui atrás pra saber.

Os caras falavam que acabou por briga política, é isso, é aquilo. É nada. A orla marítima começou a ser tomada pela elite e aí a coisa começou mudar. O pessoal não gostava muito dos farofeiros. Chegavam os farofeiros lá com um monte de ônibus. Desciam as caravanas de São Paulo, do interior de São Paulo e de tudo quanto era canto pra Santos. Pra fazer oferendas e jogar aqueles barquinhos no mar. Era uma festa bonita que se fazia. O banho da Dorotéia realizado sempre antes do carnaval. No fim de semana antes do carnaval. Aí começou a reclamar todo mundo e começaram a acabar com essas caravanas, com esse negócio. Diziam que todo mundo levava lanche, jogava lixo e garrafa na praia. Para os ricos, a cidade de Santos virava um pandemônio. Já foi a maior festa do Brasil, que superava até essas famosas festas como o Círio de Nazaré, em Belém do Pará, como festa de romaria, era em São Paulo, nas cidades próximas do rio Tietê. Nas margens do Tietê tinham as festas do Divino, eram 58 dias diretos. Subia o batelão. O batelão, você sabe o que é, né? Você vai atravessar a balsa de lá do Guarujá, aonde vai os carros em cima.

$\mathrm{O}$ rio Tietê era cheio de batelão. $\mathrm{O}$ rio Tietê era navegável, era muito barco. Então subiam os batelões e desciam os batelões. Cheios dos festeiros, dos foliões do Divino. Soltando fogos e tal... Eram 58 dias de festa. E a romaria não parava. Era uma religiosidade violenta. Cada um ficava um pouco. As cidades escolhiam qual era o fazendeiro que tinha condição de receber a Folia do Divino, pra dar pousada pra eles. Porque até hoje é famosa a Pousada do Divino.

Os fazendeiros que tinham mais posses normalmente recebiam os romeiros. Eles escolhiam uns três fazendeiros que podiam matar um boi, pra dar para o pessoal se alimentar e fazer a festa. Compravam e soltavam fogos pra receber a bandeira do divino. E hasteavam a bandeira lá, sempre tinha a bandeira do Divino Espírito Santo. Aí hasteava uma bandeira e, pra onde o vento apontasse a bandeira, era a fazenda para onde eles iriam seguir. Então a fazenda lá do Nhô Tonico ia receber os foliões da Festa do Divino. Então ia aquela caravana, pousava lá, se alimentava e aí tinha aquelas 
músicas de agradecimento: Senhora, dona da casa, agradeço a pousada. E daí eles iam visitar, por exemplo, os hospitais, os doentes.

Naquele tempo se visitava as cadeias, porque o preso antigamente não era violento que nem hoje, não era... No interior, se tinha assassino, era aquele matava que por traição, aqueles crimes passionais... Aquelas coisas de vingança... Iam visitar as cadeias, dar comida para os presos. E subiam o rio Tietê e encontravam as outras caravanas, por exemplo, de Tietê, que recebia o pessoal do rio Anhembi, de cidades diferentes que se encontravam e tocavam moda de viola. Aí fazia cururu, que eram os desafios de versos e roda de samba.

Nessas festas, eles normalmente não tocavam as músicas dos cordões, pois ninguém conhecia. Era música folclórica tradicional e muita música de rádio, a música do momento, que estivesse em evidência. E quando era regional, o regional tinha a preferência por tocar seus choros. Quando era banda, a banda tinha sua preferência. E quando era grupo improvisado, porque era mais comum isso, de várias regiões diferentes que se encontravam, todos tinham que saber a música. Por isso tocava pouca música de autoria. Porque ninguém gostava de cantar a música de autoria, pois ela não é conhecida. Até hoje é assim. Você vai fazer um show, digamos no SESC Tá lotado. Você canta uma música, por mais bonita que seja, se ela é inédita, o cara não interage, não entende. Agora você toca uma música, por mais chata, às vezes, só porque ela alcançou bastante sucesso, uma música pobre de letra, razoável, mas tem uma melodia mais ou menos, todo mundo canta.

Então a mesma coisa acontecia nos cordões. Quando estava todo mundo bêbado de madrugada, cansado de tanto tocar, aí esgotava o repertório e tocava o Zé Pereira. Quando acabava o repertório, eles não lembravam mais e ninguém puxava mais e os metais iam embora porque o bico estava cansado, tocavam o Zé Pereira. Isso aí tem mais de 300 anos, herança do Zé Pereira dos portugueses, que começou em Portugal, com o bumbo. Aí ia até chegar um mais animado, que puxava outro samba, até chegar ao destino que tinha que chegar. Então era assim, a preferência era cantar a música que agradasse que o povo cantava junto. Porque não tinha essa obrigatoriedade da escola de 
samba de decorar o samba. Não tinha nada disso. Cantava a música que empolgasse. Quem não empolgava, não cantava.

Se você cantasse uma música que você fez agora, por melhor que fosse, você chegava lá e cantava uma música que você fez agora, por exemplo: Estou cansado de pisar na passarela, ou... Nesta viela... Vou embora e cantar nos braços dela... O cara nem cantava, ficava olhando torto, pra você. Ninguém queria. Eles queriam que você cantasse uma música de rádio. Serenou, serenou/meu chapéu não molhou, nhengatuncurungundum. Aí todo mundo, vê, porque já conhecia a música. Tinha esse negócio. E como eu falei. Os cordões acabaram pelos meios de massificação. Porque é muito mais bonito você copiar o gigantismo das escolas de samba que estão fazendo sucesso do que ficar fazendo folclore. Vê se alguém quer bater folclore hoje em dia no carnaval? Ficar fazendo alguma música folclórica. Nêgo quer fazer a bateria da escola de samba do Rio. O folclórico não faz sucesso, não atrai público nem a mídia. E tudo hoje é mídia!

Tudo isso que eu falei aconteceu até os anos 40. Dos anos 40 já veio o processo de modernização que começou a apagar tudo. E começou a ir diminuindo, diminuindo. Você vê as Festas do Divino hoje, né? É muito difícil. Eu tenho muita música, eu faço muito samba rural. Muita coisa eu não tive oportunidade de gravar. Agora que eu vou gravar. Eu já liguei para um cara e vou gravar uns três discos seguidos. Vou gravar muito mais pelo registro histórico do que comércio. Eu tenho uma música que eu abro meu show, até passou ontem na televisão, na TV SESC. Foi um show gravado uns dois anos atrás. Eu até falo na entrevista, meu nome é Osvaldinho da Cuíca e tenho 70 anos.

Eu fiz para aquela abertura uma música que eu falo da influência do divino, assim no samba. No início foi muito forte. No nosso samba paulista, não; no samba carioca. No samba carioca teve influência do candomblé puro. Ele pegou um pouco de influência depois, quando surgiram os blocos no Rio tocando calango e jongo. Eu fiz um samba pra abrir meu show:

O velho batuqueiro está em festa/Pra comemorar com devoção/A paz de Deus que reina no meu peito/E a luz divina no meu coração/ $\hat{O}$ chora viola, $\hat{o}$, $\hat{o}$, $\hat{o}$ viola chora. Ô chora viola, $\hat{o}$, ô, ô viola chora [refrão] Você chora, quando eu canto/Ai, ai e a 
tristeza vai-se embora/Ô $\hat{o}$, você chora quando eu canto/Ai, ai e a tristeza vai-se embora. Como é bonito ver um bando do divino/Fazer pousada sobre a luz do candeeiro/E a festança desse povo peregrino/Com seus batuques e violeiros/Ai, ai chora viola, $\hat{o}, \hat{o}, \hat{o}$, viola chora.

Você vê que a batida tem um pouco do Divino aqui, tem um pouco da Folia de Reis. Um pouquinho. Cada um tinha sua identidade e a minha música é inspirada nisso. Em Suzano tem uma das maiores Festas do Divino com o apoio da Prefeitura. Eu fui lá cantar. Eu fiquei olhando, eles ornamentaram tudo com as bandeiras do Divino, eu brinquei com o cara. Essa bandeira tá meio fajuta, a bandeira real, mesma do Divino é vermelha, essa daí tem uns enfeites, tá mistificada, mas está bonita. As bandeiras penduradas, grande, num palco bonito. Aí eu me inspirei! A música não estava completa. Nossa, parece que eu fiquei iluminado na hora! Aí chegou no palco, eu tava com uma caixa de engraxate pra batucada. Aí eu falei:

— Eu vou pedir permissão pra vocês: eu fiz uma música aqui, agora, inspirada nessas bandeiras. Posso cantar? Só que eu não decorei ainda, porque eu escrevi agora.

Tirei o papel, e o povo:

- Pode.

Aí, eu cantei. Falei pra rapaziada que tava comigo:

- Presta atenção que não tem tom aí, me persegue.

E a turma, êêê! E, com isso, veio a terceira fase que é a padronização, que eu falei pra vocês. Hoje é tudo muito igual.

E os grupos, antigamente, quando você reporta ao passado, você tem que entender que, em São Paulo, a população era pequena e os grupos eram pequenos, saíam 30 pessoas, 20 pessoas, 40 pessoas. Hoje, 40 pessoas é a diretoria de uma escola. Grupo Especial desfila com quatro mil. Tem que entender isso pra poder compreender os cordões.

A bateria dos cordões era quinze, vinte pessoas. Hoje são 350. Então você pode botar dois bumbos. A Mocidade sempre sai com dois bumbinhos bons. Eles fizeram a medida, é bom. A Mangueira sempre tinha bumbo. Dois ou três bumbos atrás, marcando. Pra Mangueira é bom que a característica de sua bateria é de uma batida só. 
A Mangueira e a Portela têm uma batida diferenciada. A Portela bate ao contrário. Tim, tim, tum. A Mangueira é tum, tim, tim, tum. As únicas que são diferentes. Antigamente, todas eram diferentes. Não tinha toque igual. Em São Paulo é tudo igual. Os caras falam por vaidade, não. Mas é tudo igual.

Samba-enredo tá ficando a mesma coisa, tudo igual. Agora eles tão caindo na consciência e falando um pouquinho melhor, porque eu já cansei de falar isso na televisão e em todo lugar. O samba-enredo não está mais rápido pra acelerar e pra andar mais depressa, isso é mentira! Porque eu sou fazedor de samba-enredo e samba-enredo de boa qualidade. Já botei mais de 30 na avenida.

Eu sei fazer! E pra qualquer andamento. O segredo tá na divisão. Não é na melodia nem na letra. Não tem nada a ver uma coisa com outra. Então o processo de o samba ter o andamento mais rápido também veio do Rio de Janeiro, que estava no processo de evolução das escolas de samba, mas as escolas foram superadas pelos blocos em gigantismo. Tendo um horário limitado, uma hora e vinte pra desfilar, uma hora e dez, de acordo com o regulamento, você tem que limitar o número de componente. Se você tem que desfilar com 70 minutos e levar quatro mil componentes, você estoura o tempo. No Rio, que é mais folgado o tempo, com 3500, 3800, é o ideal. Então, o processo pra você desfilar nesse espaço de tempo, você tem que limitar o número de componente. Não é acelerar! Não é essa a questão.

Você sabe qual a razão dos sambas-enredos acelerarem tanto? Enquanto as escolas limitaram seus componentes, os blocos, como o Bafo da Onça e Cacique de Ramos, aumentaram. Então você vê, teve uma época que quiseram fechar o Sovaco do Cristo, porque saía 200 mil, cem mil pessoas. Onde vai caber essa quantidade de gente? Não cabe. Aí que dá o vandalismo, porque vai pela cidade andando, quebra carro e atrapalha o trânsito. Cem mil pessoas pela cidade atrapalha o trânsito. E os blocos estavam indo nesse caminho. Por causa do Bafo da Onça e do Cacique de Ramos. Então, o que aconteceu? As músicas dos blocos eram mais empolgantes, contagiavam mesmo. Tinha aquela: Essa onda que eu vou, olha a onda, iaiá. E acelerar, acelerar. E as escolas vinham: Vejam essa maravilha de cenário/É um episódio relicário. 
Tava tudo aqui quietinho, né? Balanceado. E os blocos já metendo o pau. O maior número era dos blocos. Porque antigamente era o contrário. Migraram para os blocos, o pessoal de escola de samba, pra encher os blocos. É mais empolgante o bloco com samba de embalo. E aí o samba-enredo passou a ser samba de embalo. Embalo de embalar mesmo. Essa é a verdadeira história. Não isso que contam por aí, tem que acelerar porque tem que desfilar em uma hora.

A prova é que a Império Serrano desfilou, há cinco anos, com o samba Vejam Essa Maravilha de Cenário, que é um samba antigo, lá de 64, antigo pra caramba. Como a divisão é boa, veio com a bateria atual e foi o melhor desfile do Império, melhor desfile de todos os tempos, Aquarela Brasileira.

Quem começou o movimento de escolas de samba aqui em São Paulo foi a Lavapés, fundada em 1937. Foi a primeira que vingou com o nome escola de samba. Antes dela, teve a Primeira de São Paulo, do Seu Elpídio, mas que não foi pra frente. Mas tem muita coisa que não é contada de maneira correta.

A Lavapés era da Madrinha Eunice com seu marido, o Chico Pinga. O Chico Pinga tinha o maior conjunto de São Paulo, era um dos maiores batuqueiros. A família dele toda tocava. O irmão dele tocava cuíca. O Chico Pinga tocava cavaco. Era o melhor cavaquinhista da turma e tocava cuíca também. Os irmãos dele eram Pérsio e o Vado. Se tiverem vivo, porque eu nem sei se tá mais. Um deles era motorista de praça ultimamente. Eu soube nos últimos dez anos que ele estava vivo lá não sei aonde e que era motorista de praça. A família era muito grande e todo mundo tocava.

Mulher não tocava. Elas organizavam as fantasias. A parte da batucada quem fazia era o conjunto do Chico Pinga. Tem algumas coisas que não são bem esclarecidas. Porque cada um fala o que quer. Gente de idade esquece muita coisa. Você pega o depoimento da Madrinha lá no MIS. Eu vou fazer agora no Rio de Janeiro. Até indiquei o Jota Muniz, que é a maior autoridade pra mim. É o nosso pai. Jota Muniz, de Santos. Pra mim é a maior autoridade que tem sobre samba aqui em São Paulo. Bem, você pega o depoimento da Madrinha Eunice no MIS. Ela fala assim, quem entrevistou foi o Tinhorão e uma professora. A Madrinha Eunice falou assim: 
— Ah, eu ia muito pro Rio. Tinha parente no Rio, eu fui pro Rio em fevereiro de 1937. E eu vi o Salgueiro, meus parentes eram de lá do Salgueiro. Eu fiquei impressionada com o Salgueiro. E eu vim para São Paulo para fazer uma escola de samba igual ao Salgueiro, vermelho e branco.

Não é bem assim! O Salgueiro só foi ser vermelho nos 50. Era azul e branco. Tinha três escolas do Salgueiro. A outra era verde e branco, não tinha vermelho no morro do Salgueiro. Como é que ela conta essa história? Aí fica uma verdade só, entendeu? Apagaram também o Chico Pinga da história, porque ele era muito tímido, muito calado. Eu tenho a foto dele aí. Ele com ela. Chico Pinga era italiano, branco, careca, gordo, com uma família enorme. Às vezes, é uma história mal contada que passa por verdade.

Veja bem, não havia quadra de samba, e nem escola de samba. A Lavapés tinha o nome de escola, mas era cordão. Eu tenho as fotos aqui em casa e eu até mostrei num livro meu. A foto da Lavapés eu consegui localizar na casa do Seu Zé da Caixa, irmão da Madrinha Eunice. Foi uma fase terrível! Ele e eu estávamos pra morrer. E eu ganhei a parada e ele foi. Coitado, eu fiquei! Eu tenho a foto dele doente, com a cuíca na mão, a cuíca tá até sem a vareta. Era só pra tirar fotografia.

Ele não aguentava mais tocar, tava muito doente. Eu tava com 40 quilos. Estava até meio preto, efeito da radioterapia. Eu não podia comer, fiquei quatro meses sem comer. E um ano bebendo só de canudinho. E eu com pandeiro assim e só vê os dentes. A gente tirou a foto e eu fui buscar a foto na casa dele. Estava estragada a foto. Sabe quando dobra assim em quatro a foto?

Aí eu mandei recuperar essa e uma foto da Lavapés que ele tinha quando a mãe dessa presidente tinha cinco anos de idade. A Cidinha, mãe da Rose. Eu calculo que ela tinha de quatro a cinco anos. Ela tá de baianinha, de vestidinho. Eu tenho outra foto que tem criança de marinheiro. Que se vestia muito de marinheiro. Está na foto a mãe dela, a tia dela e o filho do Seu Zé da Caixa. Então ele me deu essa foto, eu mandei recuperar e já espalhei pra muita gente. Tá no meu livro também. Você tem os meus livros, então deve ter essa foto da Lavapés. Essa foto deve ser de 48 ou 49. Porque ela, a Cidinha, é mais nova que eu. Ela parece que nasceu em 45. Então ela deve ter quatro ou cinco anos 
de idade. Então, ela tá com o estandarte. Não pode ser escola de samba. Mas está escrito escola de samba. No estandarte. No Nenê é a mesma coisa. Tem foto do Nenê lá na UESP, tem monte de fotos da Nenê. E tudo com metais, né? Embora a Nenê tenha sido a primeira a colocar bandeira, mestre-sala e enredo.

Você conheceu o Paulistinha? O nome dele é Álvaro Rosa. Primeiro mestre-sala da Nenê. Ele morreu há um tempo, lá na quadra da Nenê. Ele morava lá, era uma espécie de caseiro, porque terminou na miséria. Foi cantor de rádio e foi o primeiro mestre-sala da Nenê, primeiro compositor e diretor de bateria. Era um gênio, o Paulistinha. Naquele disco, História do Samba Paulista, eu canto música dele. Nem lembro mais, só cantei pra gravar. Era mais ou menos assim: $O$ apito trilou balançando a nossa gente/na cadência bonita do samba/De um samba indolente.

Essa é dele. Ele era um grande compositor. Muito primitivo ainda, mas um bom compositor. Eu tinha muita dó dele, porque, no final, ele morava de favor lá na quadra da Nenê. Ele ia sujo, embriagado. Perdeu o pé, por conta da cirrose. Estava andando de muleta. Sabe quando o cara tá no último degrau? Foi uma pena. Porque ele era um artista [silêncio].

A Nenê trouxe muitas inovações para o nosso desfile. Uma delas foi primeiro enredo. Casa-Grande e Senzala em 56. Mas não pode confundir e dizer que foi o primeiro samba-enredo. Pode ser o primeiro enredo, mas o samba era samba-tema. Porque ele não destrincha o enredo. Se você ouve o samba: É banzo que negro tem/É banzo que negro tem. Não conta nada. Ele tem oito linhas. Não pode ser enredo. Mas já é um protótipo do enredo. Então, realmente, o samba-enredo começou por aí, nos anos 60. O Vai-Vai, como cordão, fez o seu primeiro enredo contando a chegada da Família Real, acho que em 68. Aí, em 70, desandou. Em 71 foi um dos melhores sambas do Vai-Vai, que eu comparo com aquele samba do Mano Décio que a Elis gravou: Independência ou Morte. É um samba incompleto, que tem dez linhas ou onze, mas a história tá meio incompleta. Eu até fiz uma coreografia com o Trio Canela, fazia a coreografia diferente, eu batia no instrumento, palmas e pé. E o Vai-Vai fez em 71, valeu o sacrifício dos Andradas, foi mais bonito e mais completo. Fez sucesso no Brasil 
todo. Eu gravei tocando cuíca nesse samba. Estourou! A gravação foi pela Tapecar. Estourou e o Brasil inteiro não sabia que esse samba era enredo do Cordão Vai-Vai.

As mulheres eram imprescindíveis na parte plástica do desfile. Antigamente, o carnaval era artesanal; nós mesmos que fazíamos. Os batuqueiros ficavam com os dedos todos furados, ajudando a mulherada. As costureiras tinham dois ou três ajudantes. A gente não tinha experiência e furava tudo os dedos. Eu ia ali na Rua João Teodoro. Até hoje tem loja de chapéu lá. Pagava 200 réis a unidade, comprava aquele monte de chapéu de paia e levava pra casa pra ornamentar pro desfile. Compravam 'os tecido' nas lojas. Antigamente, a Pernambucana só vendia tecido.

Comprava aqueles tecidos baratinhos pra fazer as fantasias. Punha o chapéu e forrava. A bandeira, a gente pedia pra fulana fazer o estandarte. Bandeira não tinha. Então era aquela preocupação, tudo artesanal com purpurina. Hoje, se o cara usar purpurina, vai ser lixo. Pegar papelão e colar purpurina pra ficar bonito e brilhante. Então hoje tá aí o computador pra fazer coisas maravilhosas. Hoje é laser na avenida, é o homem voando. Tudo que é violinha, que é acústico vai acabando. Hoje o som tem que ser amplificado pra milhares de pessoas. Em São Paulo é 40 mil que vai assistir.

Então foi isso! A Madrinha Eunice copiou do Rio o termo escola de samba. Aliás, é bom deixar registrado que São Paulo copia tudo do Rio. Veja o que aconteceu recentemente lá. Acelerou o samba e repercutiu aqui. Fez Sambódromo lá, faz Sambódromo aqui. O cara dá um gritinho de guerra lá, e todo mundo copia aqui. Agora virou inferno samba-enredo. Dá saudades do Jamelão. Ele não permitia gritaria no samba. Houve meu samba aí, meu samba-enredo tá aí nesse CD que eu te dei. Pode pôr aí pra vocês ouvirem. Ele empolga pela letra, pela melodia, pela sequência lógica. Não tem gritaria.

Qualquer samba meu você entende. Salvo aquele de 82, o Oluayê, que era uma filosofia africana. É difícil você entender uma filosofia brasileira, quanto mais uma africana, né? Então, tudo bem. Mas, quando eu faço samba, você entende. Você começa pelo fio, ele vem em ordem cronológica, contando a história até o fim.

Esse ano eu fiz, tá aí. Só que não deixaram ganhar, lá na Gaviões. O enredo era pra contar a saga do povo nordestino, o sofrimento do sertão, vindo pra São Paulo e um 
representante maior, que chegou a ser presidente da nação, representando todo esse povo, com seu folclore, sua história e seu sofrimento. Vindo pra São Paulo e vencendo, que é o Lula. Ele conseguiu um monte de patrocinadores pra Gaviões falar dele. Cinco milhões. Muito bem, tá aí. Você pega meu samba, você entende. A primeira parte é ficção. Você vai ver, o maior escorpião da avenida é o abre-alas da escola. Porque ele é do signo de escorpião. Esse escorpião se transforma num gavião, porque é a Gaviões da Fiel e ele é corintiano. E vem pra São Paulo, aí que começa a luta dele que todo mundo conhece, no $\mathrm{ABC}$, até ser presidente da República. Aí vêm os processos de viajar pro Nordeste, fazendo as caravanas da cidadania, aqueles negócios, muito bem.

Esse é o enredo, agora pega o samba-enredo que ganhou. Agora você pega o meu pra você ver. Só tem rimas pobres, um senso-comum. Eu tenho percepção. Que eu sempre fui de conjunto vocal, sempre gostei de vocalizar. Então eu peguei o pessoal da Vela, umas meninas que cantam pra caramba. Peguei o Washington do Vai-Vai, o Odilon, que é um irmão meu também, desfilava comigo nos cordões. E gravamos o samba. Eu falei pra eles: 'A música é essa, só que aqui vai fazer uma oitava e aqui vai vocalizar.' No palco fizemos igual à gravação. Ensaiamos a divisão. Não quero harmonia, quero voz. Quando chegou na quadra e eu entrei com aquela turma: violão, cavaco tudo ensaiado, coro. Tinham uns oito no coro. Quando abriu o vocal, o Renê Sobral começou:

Nasceu na terra seca do sertão/pau-de-arara pés no chãolo retirante nordestino/ Viveu o sofrimento do lugar/E na cultura popular fortaleceu o seu destino/Cresceu sob a influência de escorpião/Acreditando no poder da transformação/Bateu asas e voou/E foi assim que tudo começou/Mãe coragem abençoa pra vencer/Vem pra terra da garoa a perder/Operário consciente é cidadão/É o braço forte da nação/Mãe coragem abençoa, pra quê?/Pra vencer, vem pra terra da garoa.

Escuta isso! Cara, incendiamos a quadra. Quando os caras que ganharam entraram na quadra com eco, com som mecânico, estilo Rock in Rio, sabe? Os caras puseram o som só pra eles. E proibiram as baianas de cantar meu samba. Porque são as baianas que escolhem o samba. Isso é história. Mesmo perdendo todo mundo, disse que 
esse samba tem história, esse samba é bonito. Aí começou a cair na internet. O Mestre Odilon, do Rio de Janeiro que nem tem amizade comigo. Ele falou:

- Quero conhecer sua obra. Isso que você fez é um samba antológico. Tá faltando isso pra gente revolucionar o samba de novo.

São palavras dele. Esse samba pode mudar o curso da história. Eu falei:

- Se deixar ganhar.

E não deixaram. Então, véio, o samba não é mais do sambista; ele é de uma sociedade, é de uma empresa. Mas não é do sambista. O sambista não tem vez.

Esse samba eu perdi na Gaviões. Há uns dois anos na Vai-Vai, infelizmente, foi a mesma coisa. Perdi o samba-enredo. O carnavalesco era o Chico Espinosa. Esse ano ele tá lá na Vila Maria. Ele queria meu samba. Tanto é que ele ficou um mês afastado do Vai-Vai, brabo. Porque quando ele viu meu samba, ele mudou até o enredo. Ele inspirou-se no meu samba pra fazer a escola de asas. Quando ele me viu, perguntou:

— De onde você tirou essa ideia do anjo?

Eu falei:

—Você não pesquisou direito.

Eu fui enredo lá na Vila Prudente. Conheço a orquestra Baccarelli, o símbolo da orquestra é um anjo. Não podia falar Baccarelli, porque seria propaganda. Então pus o seguinte verso: Um anjo que desceu lá na favela/E traz pra passarela um lindo sonho a realizar.

A proposta do enredo é que música e a arte acabavam com a miséria. Vê se alguém falou? Eu falei. Aí o que o Chico Espinosa fez e botou o Vai-Vai toda alada do começo ao fim. Alegoria, ala, destaque, tudo com asa. Porque eu coloquei no meu samba, do anjo que desceu lá na favela. Nenhum samba, nem mesmo o que ganhou não fala. Fazer o quê, se os caras têm muito dinheiro. Pra ganhar samba-enredo, tem que investir pesado.

O samba que ganhou de mim fez uma coisa inédita na história da disputa de samba-enredo. Nem no Rio nem em São Paulo. Puseram três puxadores, o Wander Pires, Tinga e outro, os melhores do Rio pra defender. Você costuma ver, normalmente, um puxador e seis apoios. Agora pegaram os três melhores do Rio, pagaram onze 
ônibus da Heliópolis e do Jardim Elba. Uma torcida forte pra caramba! E puseram o som e iluminação pra eles. Essas coisas eu não posso nem falar.

No ano seguinte, fiz uma obra-prima e que seria um sucesso no Brasil. Fiz a síntese de um samba deste tamanho de enredo. Pra Acadêmicos do Tucuruvi. Estava tudo certo, arrumei patrocínio, só que, na última hora, não deu certo. Tá aí o samba. Vou gravar agora. É assim: Venham ver a natureza exuberante/Juventude peito arfante, a exaltar/Vem ver.

E vai embora. É um samba que vem contando a história da cidade que a Tucuruvi ia falar. Dei até a parceria para o prefeito. Eu sempre faço sozinho, depois só acerto os detalhes com os parceiros. Eu gosto de fazer de madrugada, porque não toca telefone, ninguém vem aqui. Não tem barulho. Então, de madrugada é outra coisa. Fiz o primeiro, fiz o segundo. Tive que fazer três sambas ficarem do jeito que eu gosto. É um samba-enredo com energia que contamina. Porque o samba, quando você joga, você, na hora, percebe se vai pegar ou não. Aí como não saiu o patrocínio, não falamos da cidade na avenida e o meu samba ficou esquecido.

E não é só comigo. É com a minha geração. No ano passado, Ideval Anselmo, um dos maiores compositores de São Paulo. Ele começou em 72, tem minha idade. Só que ele veio do interior, era violeiro e começou no Camisa Verde. Fez os melhores sambas e mais conhecidos do Camisa Verde. No ano retrasado, ele faz muitos sambas fora do Camisa porque não deixam ele ganhar.

É a comercialização do carnaval. Porque a preocupação é só com verba e patrocínio. A Liga e a UESP só estão interessadas em patrocínio e em conseguir dinheiro. A que está em melhor situação, porque cuida das escolas pobres, é a UESP. Ela tem uma preocupação mais cultural. Tem um acervo. Porque passou a ser especial, você tá ferrado. É monopólio. Não tem como fugir. É patrocínio, a própria diretoria tem que ceder. Quando tem dinheiro, é outra história. Onde tiver dinheiro, tem mosca.

A Liga não tem um acervo. Tentamos começar. Eu levei muito material pra Liga e acabou ficando, assim, na chuva. No prédio novo, lá na Santos Dumont, eu vi isso. Fiquei muito bravo. Eu falei lá na Liga, pro Serginho. Ele é um trabalhador, é presidente da Vila Maria, uma pessoa dedicada, é o presidente da Liga e ele se esforçou pra fazer. 
Mas deixaram os documentos apodrecendo no tempo. Antes levasse pra UESP, que fica tudo guardado.

Outra coisa. Vê a qualidade dos CDs feitos pela Liga. Muito ruim! Eu tenho 50 anos de estudos. Você pega o meu disco e escuta o meu som. É a mesma tecnologia que todo mundo grava. Vê o som do meu disco. Vê o som desse aí, você pode levar. Aí o que acontece. Eles não ouviram a gente porque os mais jovens têm ciúmes. Eles querem assinar e fazer. Porque esses velhos querem tomar o nosso lugar. Você, com a experiência, vem para somar. Você vai fazer uma festa, você vai chamar o melhor festeiro pra sua festa ter sucesso. Não, você vai ficar com ciúmes e fazer sozinho, só que você não sabe. Eu não frequento mais nada. Eu tô disposto a cuidar só da minha saúde e da minha vida. Tenho minhas coisas pra fazer. Preciso fazer uma operação e tô preocupado, porque minha agenda tá lotadíssima.

Só participo de alguma coisa quando insistem muito! Teve a aula de jurado agora e veio o pessoal da Liga do Rio; vieram fazer aula aqui e os caras me convidaram. Teve um samba aqui no outro final de semana e veio gente do Rio e de todo lugar. Não cabia aqui, nem na rua lugar pra estacionar. Aqui é pequeno. E esse pessoal vinha aqui em casa. Eu liguei e perguntei: 'Que horas termina a aula?' 'Seis horas, mais ou menos.' Eu falei: 'Eu vou buscar vocês aí no Anhembi.' Aí fui lá pro Anhembi, mas, com medo do trânsito e da chuva, fui mais cedo. Cheguei lá cinco horas. Eles estavam tendo aula. Cheguei lá na porta do pavilhão B e o pessoal lá do Anhembi dizendo que eu não podia entrar. Porque tem jurado lá. Não pode ter acesso aos jurados e eu sou componente do Vai-Vai. Aí tudo bem, nessa situação você tem que respeitar, porque não pode ter acesso a jurados, né. Eu conheço o sistema melhor que eles, e aí uma menina, assim, de uns 20 e poucos anos, veio perguntar se eu sou convidado, ou se eu vim dar aula. Aí eu liguei:

— Ô, Nelson, eu tô aqui na sua porta, aqui, na sala de aula.

Daqui a pouco vem todo mundo. O pessoal da Liga do Rio. Todo mundo chorou, até.

- Rapaz, eu passei um filme teu agora aqui, falei de você agora aqui na aula. Mostrei um samba teu. 
— Não falei que eu vinha te buscar.

- Vamos entrar, vamos entrar. Olha quem tá aqui.

Todo mundo aplaudiu. Ele falou assim:

- Depois dessa, não estou mais em condição de dar aula. Dá aula você. Eu argumentei:

- Mas preparei nada, como eu vou fazer, eu não preparei nada, eu só vim te buscar.

— Não, aqui tá a história viva. Dá aula aqui. Bateria, samba-enredo e harmonia.

- Mas tenho que preparar, cara. Eu não sei o regulamento, muda todo ano e tal.

- Fala o que você quiser.

E foi sentar lá com os alunos. Aí eu comecei, e a Liga filmando. 'Com todo o respeito ao trabalho e ao sacrifício que vocês tiveram, gastaram muito com o disco. Eu mesmo fui três vezes lá pra gravar e nem precisava. Uma vez era o suficiente. A VaiVai me convidou e eu fui três vezes. O disco envolveu 2500 pessoas pra fazer. Eu, com 1\%, faria melhor. Com 25 pessoas. Eu faria melhor que isso aí.’

Eu comecei a aula com bateria e, quando chegou no quesito samba-enredo, eu falei tudo que tinha direito e mais um pouco. O bicho pegou! Eu falei que os jurados também têm que ser responsabilizados pela má qualidade dos sambas-enredos de hoje em dia. 'Vocês também são responsáveis, são culpados. A mídia e a comunidade, que aceita ser capacho da péssima qualidade dos sambas escolhidos. Tem samba bom, tem gente jovem competente, mas não tem espaço. Então, vocês são culpados, mas porque vocês são culpados? Porque saem por aí distribuindo dez. Dez é a perfeição.'

Eu não vejo um samba no Rio ou em São Paulo com mérito pra dez. Eu fui uma vez só julgar pra valer. Foi em última circunstância. O jurado faltou e me pegaram na avenida, eu falei: 'Não posso, eu sou Vai-Vai.' Disseram pra mim: 'Nós temos confiança.' Então eu fui lá e julguei. Eu não dou dez. Dez é a perfeição, não pode.

'Primeira coisa que vocês vão fazer. Escutar bem esse disco. Os sambas-enredos já podem vir julgados direto de casa. Oitenta por cento você já vem com a letra, melodia e a comparação com o histórico. Depois você vai julgar a divisão e o momento. O que 
não está embutido dentro do regulamento chama-se empolgação ou emoção. Isso você vai ver na avenida. É o mais fácil.

Então vocês têm capacidade de, dois meses antes do desfile, escutarem o sambaenredo. Estudar! É o único item que não justifica errar, não tem justificativa pra erro. Leia o histórico dez vezes, entendeu, entendeu. Agora vocês vão comparar com o samba. Tá na ordem cronológica? É fiel? Tem no mínimo seis ou sete quesitos importantes para o povo entender a passagem da escola? Tem, muito bem, agora vocês vão ver a facilidade de cantar o samba. Viram se não tem plágio de anos anteriores? Porque todo ano tem, é uma porcaria.'

Estoura lá um samba no Salgueiro e, logo depois, tem escola do Brasil inteiro copiando o samba. E o meu samba do Noel, esse ano e no ano passado veio bastante escolinha copiando. Porque foram distribuídos três mil discos pra São Paulo. Só pra gente do samba. Tá cheio de gente que tem o meu disquinho lá. Tá cheio de frase do meu samba. Tudo bem, é válido. O que não é válido você pegar a frase toda e pegar a melodia toda, ou pegar a letra toda. Tá errado, tem que descontar. Eu já vi três anos seguidos a mesma escola com uma frase repetida. Esse ano tem de novo.

Aí veio um cara da Liga no meu ouvido, cochichando:

— Você não pode citar o samba desse ano. Você falou Gaviões e falou Vai-Vai.

'Opa, vamos começar de novo. Então vocês peguem as letras. Neste ano, tem cinco sambas que estão falando de guerreira. Todo mundo é guerreiro agora. Guerreiro é violência, cara. É guerra. Nós estamos falando de música, de melodia, de coisas bonitas. Só tem guerreiro, guerreiro não tem outra palavra com criatividade pra buscar.' Foi quando me chamaram a atenção. Aí eu não repeti mais. O Camisa veio vários anos com o mesmo lá lá lá de Atlântida, o cinema popular. O Vai-Vai vinha todo ano com a mesma frase e todo mundo canta que se derrete. Então hoje isso é comum. Tem que prestar atenção. O samba deve merecer dez porque tem criatividade, né? Ele tem uma melodia diferente.

Outra polêmica. A questão de você exaltar a escola na primeira parte do samba. É tudo balela! Não precisa. O Silas de Oliveira dificilmente falava da escola, 
nominalmente. Eu ganhei o maior carnaval da Vai-Vai, Amado Jorge. Quando estava fazendo o samba, meu parceiro falou:

— Mas não tem Saracura? Não tem Vai-Vai e não tem Bixiga?

Eu disse a ele:

— Não tem Bixiga, mas tem o mais importante, todo o enredo. Quando anuncia lá não fala assim. Agora, a escola de samba Vai-Vai. Tem o meu pavilhão escrito VaiVai, você quer o que mais? Não tem o abre-alas escrito Vai-Vai?

— Mas e a comunidade? Nós não vamos ganhar. Mas o samba começa baixo.

- Vamos ganhar, sim. Vai lá escutar os sambas do Silas de Oliveira. Ele começa o samba dele com Vejam essa maravilha de cenário é um episódio relicário e vai subindo.

Eu comecei assim: Bahia o seu nome principia/Com o canto e a magia/Que o negro sopra pelo ar/Cantando sua terra sua gente/Seu passado presente

Resultado. Ganhei o carnaval e fui tricampeão com o Amado Jorge. Neste ano, a Mocidade vem com o mesmo tema, Jorge Amado e com a tenda dos milagres, daquele herói, Pedro Arcanjo.

O Leandro Lehart regravou esse meu samba numa coletânea dos dez melhores sambas de todos os tempos. Só que ele não conhece a história e ele gravou retratando a esperança. Não é retratando a esperança. É Pedro Arcanjo a esperança. O Tobias cantou isso e ele não entendeu isso. É o herói principal do tema da Mocidade. Então não precisa essa exaltação toda. Botar uma linha ou duas eu ponho. Na maioria das vezes, eu ponho, é uma questão de satisfazer o ego da comunidade, mas não tem necessidade. Certas coisas são vícios. Não é regulamento e não é tradição. Veja essa gritaria toda. $\mathrm{O}$ Jamelão não permitia na Mangueira que viesse caco. Caco é quando quebra telha pra lá. O velho dizia:

- Aqui não tem caco não, aqui tem samba! E é verdade mesmo, tem que cantar. Você pega a gravação, você não consegue entender o samba, com tanta gritaria em cima.

— Ô, meu presidente. - Que meu presidente. 
— Ô, minha ala de baianas. — Que ala de baianas. Deixa a ala de baianas cantar, que o papel dela é esse. Todo ano é meu presidente. Presidente entra e sai todo ano. Às vezes é uma porcaria esse presidente, afundou a escola e o cara tá puxando o saco lá na gravação. Não tem que estar gritando, não. Você tem que apresentar o sambaenredo, mostrando a letra e a música. Aí o cara sai gritando em cima. É moda agora. Chega, pô! Samba é música, não é gritaria! Outra coisa que me deixa nervoso. Soltam fogos pra caramba. No meu tempo, fogos eram na festa junina. Você tá cantando e pum, pum, pum. Aquela barulheira, ninguém escuta o samba.

Teve um ano que gravaram os sambas-enredos na RCA, com a maior mesa de gravação do Brasil. Os americanos vieram buscar de volta porque era a melhor mesa que tinha. Nenhuma era igual aquela. Gravaram lá o começo do samba e cismaram de gritar! E olha meu presidente! E chora Saracura, e queima de fogos. Tínhamos a melhor mesa de som e, se você ouvir a gravação, ficou péssima. Você ouve o barulho dos fogos, parecem tiros. Porque o cara simplesmente não põe a música aí. Quer ser mais realista que o rei. Então tem umas coisas que me contrariam, sabe? É uma barulheira danada, mas samba, que é bom, tem pouco!

Não sou contra mudança, sou contra aquela que corta raiz! Em toda a vida da gente ela vai sendo modificada. A cultura não é imóvel, ela vai se transformando. Só que, às vezes, de forma criminosa; e, às vezes, de forma inocente, e, às vezes, pela força da massificação.

Tem gente que conta mentira na história. Como aquele filme que a Globo passou sobre o Adoniran. Não lembro bem o nome, acho que era Ela Sua Vida, ou Por Toda Sua Vida. Convivi com ele nos anos 60, eu fui contratado da Record. Eu vi muita mentira sendo contada. Fui do Demônios da Garoa durante muitos e muitos anos. Saí em 99. Fui componente do conjunto original, dos velhos. Conheci a história do Adoniran de perto. Ninguém me contou, eu vi. Conheci Osvaldo Moles, que inventou o Adoniran. A maior parte das músicas compostas pelo Adoniran é em parceria com Osvaldo Moles. Ele foi o maior radialista, cronista, escritor e intelectual do rádio do Brasil. Ele que criou a história das malocas, ele que criou o personagem Adoniran. $\mathrm{O}$ 
Adoniran, antes dele, era um lugar-comum; cantava Noel, cantava marchinha. A partir dele, ele incorporou os personagens do Osvaldo Moles.

Conheci Djalma Amaral, um negro que era o Seu Dija, que era parceiro do Adoniran, que fazia aquelas radionovelas. Era um negro magro, amicíssimo meu, que ficava com o cigarro na boca, fumava que nem um desgraçado. Seu Dija, crioulo magro, que fazia o papel de crioulo na história das malocas. Ele interpretava um neguinho malandro que desviava, fazia aquelas malandragens toda. Então conheci e ele era meu amigo. Ele fazia a programação da Record e me dava, às vezes, e mandava programar música minha na Record.

Uma das mentiras contadas pela Globo é sobre a música Iracema. Tanto mentira do Adoniran, como mentira da Globo. Na verdade, foi um amigo meu que contou essa mentira pra Globo, um grande pesquisador da música brasileira. Não precisava disso, porque o nome dele já tá imortalizado na música. Ele contou que o Adoniran via a Iracema toda noite num cabaré aqui em São Paulo e paquerava ela. O Adoniran paquerava todo mundo. Não tinha vergonha na cara. Era casado, mas não podia ver menina nova, era assim mesmo, paquerador. Aí ele disse que tava paquerando, mas ela não dava bola pra ele. Aí, quando ela passou em frente dele, ele disse com raiva: 'Vou te matar, Iracema.' E fez a música Iracema, que a personagem morria atropelada na São João. Quando eu vi isso na novela, me deu vontade de quebrar a televisão de raiva. Isso é incompatível com a personalidade do Adoniran, incompatível com a letra da música.

Se você pegar a letra de Iracema, como é que ele pegou e falou assim pra tal de Iracema, numa boate, 'vou te matar'. Iracema nem era do Adoniran, era de um bêbado, que a mulher dele morreu na Consolação, nem foi na São João, atropelada. E o Toninho, membro dos Demônios da Garoa, pagava cachaça pra ele lá no ponto dos músicos. Era um bar que a gente ficava depois que saíamos dos shows e a gente esperava amanhecer pra pegar condução e ir embora ou pro serviço. Ele batia pandeiro e atrapalhava o transito. Às vezes, saía da calçada e cantava: Iracema nunca mais eu te vi. A turma dava risada daquele bêbado. Tem histórias que, se você contar hoje, você vai passar por mentiroso. Porque um milhão de mentiras da música vai se sobrepor a uma história real.

E quem podia confirmar, morreu. O Arnaldo dos Demônios da Garoa. O 
Toninho também morreu. O filho dele que cuida, que é o dono do conjunto. Aquele careca, o Serginho, entrou em 81 no conjunto, mas sabe a história. Ele sabe, mas não vai ter coragem de contar, porque o pai contou pra ele. É a mesma coisa de eu chegar na televisão e falar mal de Jesus Cristo, do Roberto Carlos ou do Pelé. Ah, nêgo cai de pau em cima de mim. Então tem esses detalhes, que são pequenos, mas a história pode ser modificada por vaidade. A minha história, quantas vezes eu vejo modificada na minha frente. O cara fala na minha frente que o Osvaldinho foi lá e não sei o que, pá, pá, pá, quebrou tudo. Eu nunca tive lá. Na minha frente, os caras falam. Meu Deus do céu, pra que isso, cara!

Como eu te falei, eu fui dos Demônios da Garoa. Também participei de um monte de outros grupos. Participei do Jogral em 71 e 72. Eu estava com Adauto Santos e Trio Canela. Eu era parte do Trio Canela. Primeiro surgiu o Trio Mocotó e, como nós tocávamos na mesma casa e nós íamos depois então, o garçom, o mâitre, começou a fazer gozação com o Trio Mocotó. E gente veio na cola do Trio Mocotó, viramos Trio Canela.

Teve uma noite que a gente estava tocando no Jogral, o Adauto Santos, P. Viola e o Trio Canela na percussão. Era eu, o Jairzinho da Portela e o Osmar, que era sobrinho do Adauto Santos, que tá no Paraná agora. A casa lotada parecia um teatrinho. O pessoal com um copinho de uísque, se alguém falava alguma coisa, todo mundo, shiiiii. E aí apareceu um cara que tava atrapalhando a apresentação, entrou de camisa aberta, meio assim, pra lá, pra cá. E o garçom pedindo silêncio. E ele atrapalhando, encostando em um e no outro. E todo mundo, shiii. Uma hora ele foi no palco, catou o microfone, o palco era bem baixinho. Os caras queriam empurrar ele pra fora toda hora. Ele pegou o microfone:

— Ô, gente, eu não quero atrapalhar ninguém, eu só quero dar o meu recado. Eu sou o Nelson Cavaquinho. Sou compositor e queria mostrar meus sambas. Sou lá da Estação Primeira de Mangueira.

Aí a turma, shiii. Pra você ver, até meados dos anos 70, não era conhecido o Cartola. Muito menos o Nelson Cavaquinho. Era difícil conseguir gravar samba. Eu mesmo tenho mais de 50 anos de carreira e vê o número de discos que eu tenho lançado. 
Foi com o Martinho da Vila, com o Germano Mathias, que o samba se popularizou nos anos 60. O Germano foi o expoente de uma safra importante pra música brasileira. Nos anos 60, o rock'n' roll e a Bossa Nova estavam invadindo. E a gente estava descaracterizando a música brasileira. Que embora todo mundo fale muito bem da Bossa Nova, você tirando algumas maravilhas da Bossa Nova, tinha muita coisa era bem jazz mesmo. Muitos não aceitavam percussão, não aceitavam a característica da música brasileira, que é percussiva. Era violãozinho. Era uma música muito individualista. O João cantava nessa intensidade: Bim, bom, bim, bom, bem baixinho. Era um porre, vamos aceitar isso!

Então o Germano Mathias veio numa fase muito boa para o samba paulista, principalmente. Ele foi para o Brasil, uma explosão. Porque só segurava o samba paulista o Demônios da Garoa e o Adoniran. É claro que tinha o Noite Ilustrada. Mas o Noite chegou depois, em 54 ou 55, em São Paulo. Era mineiro e grande parceiro meu também. Tinha a Denise, esposa dele, de Atibaia. Ela foi miss, Miss Atibaia. Tinha outros também. Grandes sambistas que apagaram da história. Tinha o Mauricy Moura de Santos, uma das maiores vozes. Ele também gravou Paulo Vanzolini. Ele tinha uma voz assim: Chorei, lá, lá, lá, lá, todos riram, fingiram, pena de mim não precisava, com uma voz bem grave.

Ele cantava assim, com uma boca deste tamanho, de caçapa. Bebia muito e morreu de tanta bebida. Ele tocava violão e cantava sozinho. Tinha que ficar internado uma temporada e uma temporada na rua. Tocava no Jogral e em grandes casas. Toquei com ele no Partido Alto, maravilhoso, né? E tocava música de outro santista também, Lúcio Cardim. A turma pensa que a música Matriz e Filial é do Lupicínio. Porque o Jamelão gravava tudo do Lupicínio. Mas é do Lúcio Cardim, grande compositor santista. Ele veio pra São Paulo, mais ou menos na mesma época, em 55. Ele era cabo da aeronáutica e tinha uma casa noturna ali na Amaral Gurgel, chamava acho que Matriz ou Filial, não lembro o nome.

Outro grande nome do samba de São Paulo que eu tive o prazer de conhecer foi Geraldo Filme. Esse tem essência. Era um pensador, tinha poucos no Brasil e em São Paulo como ele. Ele se inspirava muito no pioneiro, em Dionísio Barbosa, que 
representava uma filosofia de negro, mas não tinha a capacidade de escrever que o Geraldo tinha. O Geraldo e Seu Dionísio pra mim são o número um. Dionísio Barbosa, porque nasceu em 1891. É o pioneiro. E o Geraldo, por ser a maior cabeça pensante de todos os tempos do samba. Da raça, da periferia. Geraldo Filme falou da Revolução Constitucionalista, da Confederação dos Tamoios nos enredos. Ele falava do índio, do branco, do negro. Do pobre, com muita propriedade. Geraldo Filme era meu parceirão e amigo.

Nós entramos juntos no Solano Trindade em 1958, 1959, juntos. Foi uma trajetória que eu... E outra, muito educado, nunca levantava a voz, nunca brigava. Uma pessoa consciente. Quando ele via uma coisa que não agradava, ele levantava, saía e ia embora. Então, Geraldo Filme, pra mim, é um herói. Ele teve pouco reconhecimento. Quem abriu as portas pra ele foi o Plínio Marcos, em um show que era ele, o Zeca da Casa Verde e o Toniquinho Batuqueiro.

Com o Toniquinho eu estou brigado! Aí a gente sempre viajava junto. Com a Embaixada, em Pirapora. Eu arrumava show pra ele participar. E o Toniquinho sempre mostrava pra mim um pedacinho de música e dizia:

— Vamos fazer uma parceria aí. Nós não fizemos parceria ainda.

Aí, num dia, eu lembrei. Eu tinha um samba que falava de Angola, dos meus avós. Sobre escravidão e é no mesmo tom do Ditado Antigo, que ele gravou em $71 \mathrm{com}$ o Plínio Marcos. Eu falei pra ele:

— Tá editado aquele samba seu, o Ditado Antigo?

— Eu mesmo que editei. A editora era minha mesmo, mas não existe mais. Eu que editei. O Plínio falou pra editar e foi gravado só com ele.

É aquele samba: Mandei preparar o terreiro que já vem chegando o dia/Encourar o meu pandeiro pra entrar na folia.

Eu falei:

— Tonico, esse seu samba tem uma levada de jongo muito boa. Eu tenho um jongo que é parecido com aquele. Você quer ver como fica se emendar?

Aí botei o refrão em cima e no meio: Ei, jongueiro/bate no couro que tem festa no terreiro/ei, jongueiro/bate no couro que tem festa no terreiro. 
Eu adequei na mesma melodia do dele. Outro verso que eu botei: Meu avô preto de Angola me ensinava cantoria [cantando]. Esqueci a letra agora. Foi o Jair Rodrigues que gravou. Aí fiz outro refrão embaixo. Eu botei sete linhas e o samba dele tinha oito, o original que o Plínio Marcos gravou. Eu fiz meio jongo, meio capoeira. O Jair viu e ficou louco:

—É esse que eu quero e ele gravou no meu disco.

Tá bom! Era pro Aldo Bueno gravar, aí o Jair gravou esse daí. O Toniquinho ficou todo feliz quando ouviu. E me perguntou:

- Mas vai dar algum dinheiro?

— Dinheiro não dá mais. Antigamente, eles davam um advance pra nós. Agora disco independente não dá dinheiro.

Aí nós assinamos. Estou aqui com o contrato. Acho que tá lá no meu arquivo com os outros contratos. Aí assinamos. Botei o nome dele na frente por respeito, ele é mais velho. Porque a parceria foi igual, ele tem oito linhas e eu tenho sete. Prioridade a ele pela idade e um verso a mais. E eu entrei na melodia dele, eu mudei a melodia. Botei um lá lá iá diferente. E aquele: Ei, jongueirolbate no couro que tem festa no terreiro.

Foi o forte do samba e a segunda parte, né? No verso do Tuniquinho era assim:

No dizer de minha vó sambador não tem valia. Meu verso é diferente: Meu avô preto de Angola me ensinava cantoria/Foi herança de um passado/Fez a travessia/Capoeira quilombola derrubava e não caía.

Aí eu botei e ficamos parceiros. Aí tem uns aí que chegaram ano 2000 no samba, porque antes vivia para o rock e começou. Começaram a produzir um disco pro Toniquinho. E regravou depois de quatro anos sem o meu nome. Essa nossa parceria foi gravada em 2004. Em 2008, ele regravou a música e não colocou meu nome, aí desfiz a amizade. Ele regravou sem a minha parte e sem o meu nome. Eu, com o contrato registrado em cartório e assinado.

O menino do Kolombolo estava sentado aí, o Renato Dias. Eu falei pra ele:

- Eu não vou tomar tudo seu e mandar recolher o seu disco e exigir uma indenização. Porque você é casado com a Lígia, que eu tenho muita consideração. 
Estava aqui na gaveta o contrato e assinado com o advogado, e advogado bom. Esses que não entram pra perder. Aí diante da boa vontade do Renato em divulgar o trabalho do Toniquinho. Ele, que é uma pessoa maravilhosa, eu desisti da ideia. Eu não falei mais com esse parceiro.

Ele morreu recentemente, ligaram pra mim e eu falei: 'Não vou'. Eu ia a todos os funerais. Aliás, sou eu que batia o surdo fazendo o soca pilão. É um ritual. Tem que saber quantos passos você dá e tal. Eu deixei de fazer isso também. Começaram umas vaidades na frente, aí eu parei. Não é porque morreu que eu vou lá. Tô brigado, não foi fiel, acho que por falta de caráter, não achei legal o que ele fez comigo. Eu quando faço meu trabalho, falo pros piratas: 'Pode usar à vontade, eu não ligo pra isso'. Mas tem que ter o meu nome. Disco você não ganha dinheiro, mas divulga seu nome.

Eu tô com muito problema de saúde. Eu tinha saúde boa, mas depois eu tive câncer na garganta e acabou comigo. Foi quimio, rádio, acabou comigo. Depois veio o enfarte. Eu sou vegetariano, pressão doze por oito. Fazia exercício. Não tive sequela. Porque destruiu a rede vascular, o osso.

Aí fui ao médico na semana passada. Um grande especialista, com o avental do Sírio Libanês no braço, se vê que ele trabalha no Sírio Libanês, deve ser chefe, alguma coisa. Mas me atendeu tão mal, foi tão grosso. Como eu tô tendo alguns processos aqui, tá tendo um derrame de bílis aqui, umas dores muito fortes no céu da boca, e como eu já operei e pus prótese no céu da boca, o cachorro mordido por cobra tem medo de linguiça. Então eu fui. Na Avenida Angélica. Eu nunca vi um consultório tão chique. Com dois, três bares, vários ambientes. Com café, sala ambiente. Uma finesse. Angélica, número dois mil e quinhentos. Aí, chegou minha vez. Eu sentei.

- Doutor, o meu é uma revisãozinha na boca. Eu já tô livre do câncer desde 2003. Já me deram alta. Eu tô curado, mas eu andei sentindo umas dores ultimamente; é apenas uma revisão. O resto é outra especialidade. Eu só quero ver como tá a minha situação aqui na boca, porque é que eu estou com essas dores.

- Mas não é assim, não. Você tá pensando que as coisas se faz assim, isso aí precisa de exame. Cadê o seu diagnóstico? Cadê os exames? Precisa de uma série de coisas, não é assim, tá pensando o quê? 
Aí eu fui encolhendo na cadeira e olhando, olhando. Que eu sou pavio curto, eu fiquei olhando, mas hoje eu tenho mais bom senso. Eu pensei: 'Quem sabe ele é um bom médico, apesar de ser grosso. Vamos ver até onde chega.' Ele falou, falou, falou. E eu com tudo na mão. Porque eu trabalhei em hospital. Eu cheguei a ser chefe de enfermagem, então, eu não sou bobo. Eu conheço. Eu, com tudo, no envelope na mão. Pensei de novo: 'Não sei se fico bravo, ou se continuo na minha.' Olhei, olhei, olhei, e falei:

- Péra, um pouquinho doutor. O senhor ficou brabo porque eu falei revisãozinha, é isso? Será que o senhor ficou brabo?

—Não! É pela responsabilidade que a gente tem. Você tá pensando que é assim. Precisa dos exames, do laboratório, precisa não sei o quê. Você fez exame do quê? Quem pediu? Como é que é?

Eu falei:

— Tá aí. Eu tive alta no hospital já faz tempo, eu tô sarado.

Aí eu ia perdendo a linha com ele, mas eu pensei: 'Deixa eu manter a linha e dar uma lição nele.'

- Espera aí, doutor. O diagnóstico se faz com quatro itens, exame de laboratório, sinais, sintomas e a história do doente. Agora eu vou contar a minha história. Eu estive em Cuba, agora, recente, e peguei uma virose lá. Acabou comigo. Eu cheguei essa semana de Brasília. Eu trabalho com direitos humanos lá. Sou voluntário. $\mathrm{O}$ ar muito seco me ferrou, então eu não sei se pode ter agravado alguma coisa. Como eu tive câncer aqui, no céu da boca, e foi tudo cortado. Eu não sei se eu tô com algum processo que me atacou vesícula. Eu quero saber daqui. Eu queria fazer um exame, eu quero saber a sua opinião. Está aqui o diagnóstico, do que é sarcoma, do que é isso aqui, tá tudo aí.

Aí eu não falei mais nada, cruzei os braços, já mostrei que eu não sou ignorante. Fiquei lá olhando pro homem. Aí, ele pá, pá, pá, me deu um monte de exames.

— Você vai consultar com o doutor Ézio. — Perguntei: 
— O Ézio não é do Sírio Libanês? Eu já fui paciente dele por indicação do Dráuzio Varela, que é meu amigo. Não é? Se for o mesmo, eu fui paciente dele, porque o nome não é comum, Ézio. Aí ele continuou:

- Você vai passar pela doutora Fulana de Tal, vai passar não sei o quê, vai fazer uns exames, assim e assim, faringe e, por último, a endoscopia. Peguei os papéis, falei: 'Dá licença' e até hoje. Fui procurar outro médico. Não é assim que trata as pessoas. Graças a Deus, faz dez anos que eu tô curado do câncer. Ultimamente, enfrentei um derrame, mas, como eu me alimento bem, consegui me recuperar rápido. Venham aqui na cozinha ver aqui, é eu mesmo que preparo minha comida. Sou vegetariano, cozinho legumes, proteína. A dieta vegetariana é muito rica. Você ganha muita saúde.

Pra terminar, eu quero deixar registrado que o ser humano, hoje, está perdendo a sensibilidade. Ele tá agindo mais com interesse. Tudo é apenas interesse. Porque antes você fazia sem ganhar dinheiro. Eu canso de fazer isso. Até me atrapalha. Isso aqui tá me atrapalhando e muito. Eu deixei de fazer umas três coisas hoje. Se ponha no meu lugar, abre a tua porta todo dia para uma pessoa que você não conhece. É que nem o espírita, eu tenho uma missão, mas, pera aí, e quem paga o meu aluguel? Porque, infelizmente, é isso. Às vezes, eu passo uma temporada não atendo ninguém. O Paulo Vanzolini, não é ele que atende o telefone. É a Ana, esposa dele. O Jota Muniz não atende o telefone. É a esposa dele também que filtra tudo. Depende de quem liga, elas dizem: 'Ele não tá, está viajando. Retorna mês que vem.' Eu tenho meus empresários e eles já me proibiram, mas eu não tomo jeito! Eles me avisaram:

— Ô, Osvaldinho, tem um show no Guarujá. — Eu falei:

— Ô, rapaz, nessa sexta eu não posso.

- Mas como que você faz isso? Eles brigam comigo porque eu tenho esse costume. Então o processo de evolução nos induz a ganhar dinheiro. A gente tem que viver. Como é que eu vou pagar minhas contas? A cobrança está aí. E eu acho que é uma missão. A melhor coisa que a gente tem é isso. Divulgar o nosso samba! E que bom que temos pessoas interessadas nisso! A porta estará sempre aberta!” 


\section{Álvaro Casado}

Nome: Álvaro Ribeiro

Data de nascimento: 28/11/1940

Local de nascimento: Avaré

Profissão: Publicitário

Data da entrevista: 01/05/2012

Local: Residência do entrevistado, no município de Poá-SP

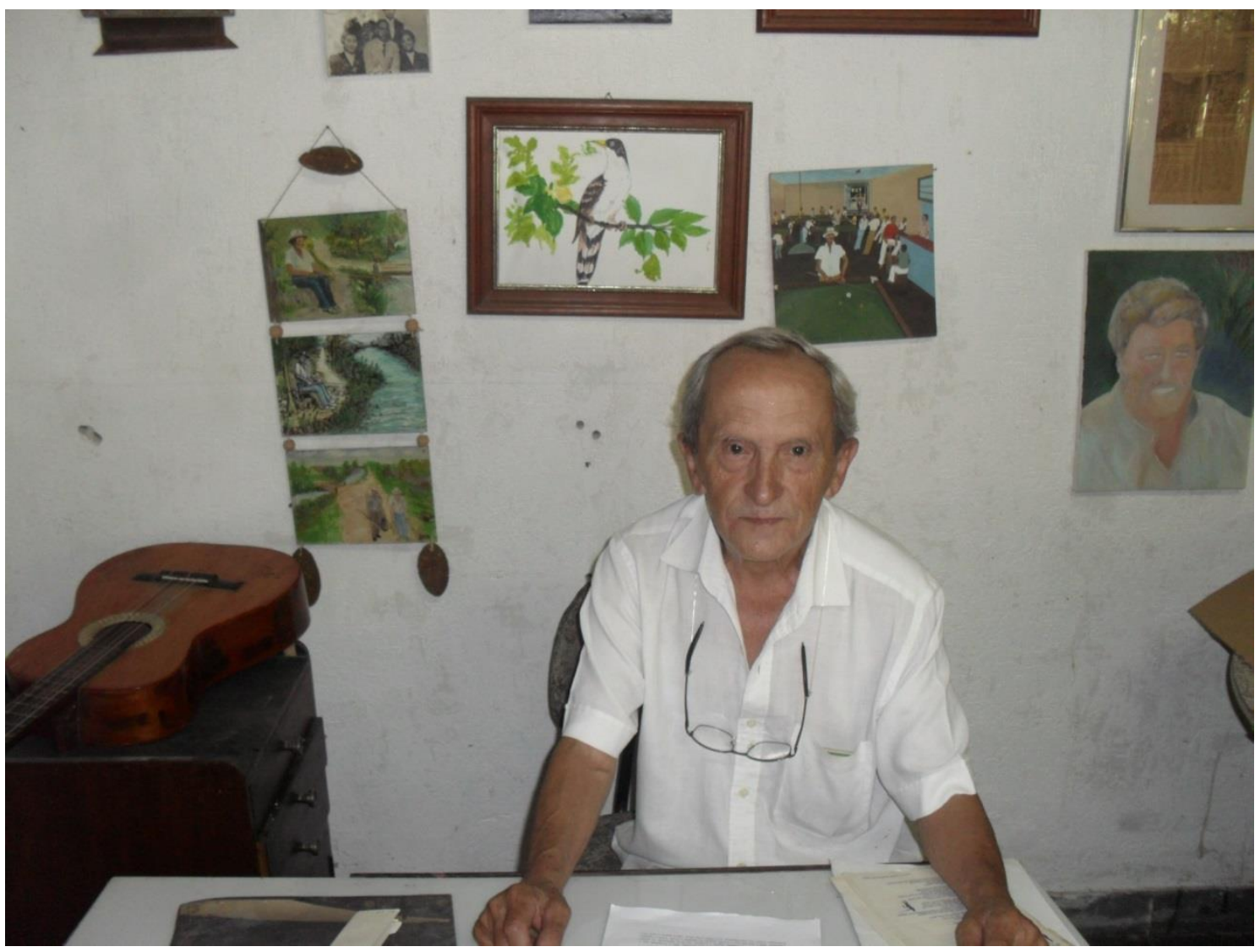

Figura 7 - Álvaro Casado

Fonte: Foto tirada pelo autor.

"Antigamente o samba era só negrada mesmo. Negro e aqueles brancos cheios de sangue preto como eu!" 
“Meu nome é Álvaro Ribeiro, sambista. Nasci em Avaré no dia 28 de novembro de 1940. Ainda jovem, me mudei com minha família pra São Paulo. Foi então que eu comecei a brincar carnaval. Primeiro no cordão Estrela Brilhante e, em 1952, eu entrei na escola de samba Garotos do Itaim, no Itaim Bibi. E, no mesmo ano, fundamos o Tatuapé. Eu sou fundador do Tatuapé. O Mala e eu. Nós fundamos o Tatuapé em 53 e desfilamos no carnaval de 54. O Mala era baliza lá no Garotos do Itaim, e lá no Garotos era azul e branco a cor. Aí o Mala arrumou uma nêga na Vila Santa Isabel e caiu pra lá. E ele levou os instrumentos.

Nós também tínhamos um pequeno grupo, que a gente batucava atrás do gol do campo do Olaria. Ele reuniu o pessoal e disse: 'Vamos fundar uma escola de samba.' Ele fundou a Primeira de Santa Isabel, mas saiu um ano só. Depois mudou pra Acadêmicos do Tatuapé, porque o bairro era Tatuapé. Nesse tempo todo, ajudei, muitas vezes, a colocar o Tatuapé na rua, desde o primeiro ano até hoje. Naquela época, nós não tínhamos apoio, existia o livro de ouro e bailinhos, mas nosso ordenado era curto e, aos poucos, foi melhorando. A gente via no Rio de Janeiro aquelas escolas grandes e sonhávamos em fazer isso aqui em São Paulo. E não tinha nem uma federação, tinha uma liga daqui, outra liga dali, estava meio dividido. Por causa dos próprios sambistas, nem tanto por política, mas por ciumeira. Por exemplo, se o Chiclé pegasse uma nêga do Mala, virava uma rixa, por causa de mulher, de namorada, até isso tinha. Entendeu? Pra participar da administração da escola ou do cordão não era mole. Os maiores cordões eram o Camisa Verde e Branco e Vai-Vai, nossa! E o Camisa era muito mais forte que o Vai-Vai. O Inocêncio era uma cabeça. O velho Mulata queimava dinheiro mesmo. O Vai-Vai, que agora está empatado, mas porque o Camisa caiu.

Mesmo com todos esses arranca-rabos, disputa por mulher, queríamos melhorar o nosso carnaval. Esse era o nosso pensamento. E, no ano de 1968, depois de batermos muito a cabeça, fomos falar com o prefeito Faria Lima. Foi uma pressão que fizemos sobre ele, que é carioca. Nós optamos por fazer uma pressão direto nele, porque o carnaval carioca estava lá no maior apogeu e o samba de São Paulo meio caído. Aí já explicamos tudo para ele... Como todo mundo queria a mesma coisa e ele pôs todo o processo pra frente. Já oficializou e fez todo o regulamento. Além do Faria Lima, outra 
pessoa muito importante nesse processo foi o Jangada. Ele era do Rio de Janeiro, mas estava trabalhando aqui, na prefeitura. Não lembro qual o órgão que ele estava, e ele era compositor do Rio, e ele veio pra cá. Era da São Clemente, eu acho. Ele atuou no processo de redação do primeiro regulamento oficial, porque ele era redator, trabalhou em jornal também. Ele que armou o esquema, fez a ata, tudo. Fizemos uma reunião, e o Faria Lima tocou tudo pra frente e unificou. Mas foi bom o prefeito fazer a coisa, por que tinha lá uns caboclos meio fora de esquadro, né? E era por aí ele que elaborava tudo. Ele veio do Rio de Janeiro, veio da São Clemente e escolheu a Lavapés. Ele chegou em São Paulo e optou pela escola mais velha. Ele era historiador, tudo, e começou a fazer samba por lá. O Lavapés tem muito samba dele. Ele que pegou o regulamento do Rio de Janeiro e mudou uma coisica só, era pouco. Se num ano não deu certo uma coisa, no outro ano, vamos mudar aqui.

Então criamos uma Federação. O Moraes Sarmento foi o primeiro presidente, depois o Evaristo, a sede era lá no Martinelli, no prédio Martinelli. Antes tinha a Ligação, Federação, União, era uma bagunça, tinha tudo e não tinha nada, porque cada um fazia apenas o que dava na cabeça. Aí, quando o Faria Lima oficializou, ele disse:

- Vamos ajeitar a casa. Para os recursos saírem, é necessário que vocês se organizem.

Aí o Moraes Sarmento entrou como presidente. Participou o Evaristo, Seu Inocêncio, o Mala, que eu te falei, que era meu cunhado, lá do Tatuapé, Pé Rachado, eu, entrou a tropa toda. Eu sou desenhista e publicitário. Agora que eu estou aposentado. A bandeira da Federação fui eu que desenhei, confeccionei. Nessa época tinha cordão e escola. Tinha o Fio de Ouro, o Camisa-Verde, o Vai-Vai, tinha outro que eu não lembro o nome, tinha uns quatro ou cinco, o resto era escola.

$\mathrm{Na}$ época do Moraes Sarmento, da Federação, andaram emitindo uns cheques sem fundo, porque chamava a escola e dava direto na mão do cara. O Mala ia e eu ia com ele e dava o cheque pra escola diretamente, pro presidente ou pro tesoureiro. Tinha cara que recebia o cheque e não desfilava. Teve uma escola de samba, veio lá da zona Leste. O presidente pegou o dinheiro e comprou carro, comprou geladeira, fogão pra nêga. E aí não saiu a escola! O que você vai fazer com um cara desse? O que vai fazer 
com esse cara? Assinou o recibo com o dinheiro e gastou e não pôs a escola na rua. Teve processo, mas o cara tava ligando pra processo. Caiu no esquecimento. E, com isso, quem ficava em descrédito era a Federação.

Por conta disso, o Evaristo depois não quis mais e tiveram vários desentendimentos, problemas com a burocracia da Prefeitura e muito ciúme. Saiu o Evaristo e o Juarez entrou, mas começaram uma política contra o Juarez, que ganhou dois carnavais seguidos, 70 e 71. Aí falaram: 'Esse cara vai subir demais.' Aí começaram a prejudicar o Juarez, pura ciumeira. E aí, tentando unificar novamente, formamos, em 73, a UESP. Como presidente, primeiro entrou o Renatão, esse que tá aí [aponta para uma foto]. O Renatão, da Globo. Mais aí o Renatão tava com problema de coração, ele tinha uns problemas de saúde, ele tava com medo de ter um enfarto [sic], porque o negócio não é fácil, não. Ele saiu e ficou sem presidente o negócio.

Aí me chamaram! Eu morava ali na Rui Barbosa. Até assustei quando vi na minha casa o Inocêncio, Pé Rachado, Chiclé. Falaram pra mim: 'Nós vamos pôr você aí. Vamos pôr o branquinho aí!' Aí eu entrei por unanimidade. Porque não foi assim, eles falaram é ele que vai. Os caciques do samba que foram lá em casa e outros, como o Juarez, me apoiaram, e aí eu entrei na presidência da UESP. Teve as chapas, para oficializar. Para não ficar uma coisa assim, pusemos o cara e pronto. E nós ganhamos, quer dizer, já estava ganho. Eu conheço todos eles desde 53. Sinval, falecido, Seu Nenê, falecido, eram caras que falavam é o Casado. Eu conheço ele desde pequeno, que eu morei na Barra Funda. O Inocêncio Mulata que sugeriu primeiro meu nome. Ele falou:

— Esse cara, eu conheço ele. Ele é sambista, pôs dinheiro do bolso no Tatuapé. A minha diretoria era eu, o vice era o Derly Marques, o fotógrafo. O Jangada. O Nelsinho. Era bom, um time bom. Tinha o Mala. Tinha muito apoio, o Pé Rachado mesmo. A maioria era branca, tinha só um preto, o tesoureiro. Apesar de todo o apoio, alguns pensavam assim: 'Nós, os brancos, sentados na mesa, e os negão lá.' Aí tinha que entrar um mediador pra tentar resolver, e sempre era o Jangada, o Derly, às vezes eu. Não podia errar. E nunca falhei um ano de 53 pra cá.

Só que a UESP não era onde está hoje... Era ali na galeria na Brigadeiro Luís Antônio. Eram duas salas ali. Tanto que quem pagava o aluguel éramos nós mesmos... 
Os diretores das escolas. Quando nós pegamos a UESP, não tinha esse negócio de enredo, sabe como é que é? Os caras nem faziam carro alegórico. Nós que unificamos. Jangada, o pessoal todo disse: 'Vamos fazer o seguinte, vamos ensinar o pessoal como é que se faz. Esse ano vamos fazer enredo pras escolas de samba.' Aí, como eu era desenhista, naquela época, desenhava os figurinos, os carros alegóricos, aquela coisa toda. O primeiro desfile da Barroca fui eu que desenhei. Eles começaram e queriam pôr ele no quarto grupo. Porque antes não tinha o acesso. Não tinha tantas escolas. E também com o nome dele, Pé Rachado, vai pôr o cara no quarto grupo? A gente sabia que vinha bem. $\mathrm{O}$ acesso estava sendo preparado. Porque já começou a entrar escola na UESP e logo formou o grupo de 20. Pô, num tem tempo pra 20 escolas. Aí começou a divisão. Porque tinha escola que vinha mal, mal, mal mesmo. Já caía ou ficava onde tava. Já o caso do Pé Rachado é diferente. A gente ia lá na escola e, em setembro, já tava fazendo tudo, já tá quase pronto. Bateria ensaiada, baiana, o cara é organizado e ele é velho de Vai-Vai. Você não vai acreditar no cara? Ele já sobe direto. Aí você pega uma Estrela Brilhante, o cara vem lá do fim do mundo e trás uma porcaria, apesar da orientação. Então a gente tinha que ajudar. Até escreviam o samba pro cara. Principalmente o Jangada e o Sílvio Modesto, montavam o samba-enredo e davam pro cara, sem cobrar nada. Eu tive no meu acervo muitas letras do Jangada. Ele digitava e eu pedia um. Eu gostava dos sambas do Jangada, dele e do Silvio Modesto. Eu pegava e punha no arquivo, aí teve um dia e encontrei com ele e falei: 'Péra aí que eu vou te dar um negócio.' Peguei e dei as letras, ele falou: 'Pô, nem eu tenho isso aí.' Falei: 'Então leva.' Porque eu sou meio rato com esse negócio de samba. Eu vô guardando. Eu tenho tranqueira pra tudo quanto é lado! As escolas grandes, como Vai-Vai, Peruche, não precisavam de nada, mas as escolinhas pequenininhas a gente ia e explicava: a escola de samba é assim, não é do jeito que vocês saem. Aí o cara montava, recebia o kit, pronto. Desenhava tudo o carnaval inteiro. Usávamos cetim, lamê. Usava muita renda. A costura era feita na casa do cara. A casa dele virava um barracão. A verdade é essa. A mulher fazendo o arroz aqui, e a outra com a máquina de costura ali. E eu visitava cada muquifo, em cada beco da cidade. As pessoas faziam pelo amor, pelo samba. Tanto é que a Rosalina, eu fiz até enredo pra ela, ela ficava de setembro até o dia do carnaval, 
costurando direto, todo dia. Junto com aquela sobrinhada, um costurava, outro alinhavava. Três máquinas de costura, direto. Era amor mesmo. Porque nós sentimos, víamos que vinham umas escolas malfeitas, sem tema, sem fantasias bonitas. Entendeu? E não era por falta de vontade, mas sim de experiência.

Aí fazíamos uma reunião no plenário e perguntava que tema você escolheu... Como é?... Embaixador, Imperador, não sei o quê... Você tem dinheiro pra escolher isso? Tem dinheiro? Se você sair como D. Pedro, vai gastar com tecido, coisa de época, você não vai bancar, não vai sair legal. Você não quer esse enredo aqui, que é mais simples. Aqui dá pra você ir. E no ano que vem, se você tiver mais dinheiro, você faz seu enredo de D. Pedro. Naquele tempo tinha Marujos, Falcão do Morro, Itaquerense, Estrela Brilhante; tinha um montão de escolas de samba, mas bem fraquinha. Aí nós começamos a encaminhar os caras. Agora tem barracão, tem profissional, tem 60 caras trabalhando. Hoje o carnaval é uma indústria.

Eu já desfilei em muitos lugares: no Parque Xangai, no bairro do Glicério. Íamos ao Ibirapuera, desfilamos até no Pacaembu, no estádio mesmo. Participei da Rádio Record, que fez uns concursos, isso foi lá em 1954. Na Rua Direita, também, mas isso faz muito tempo. Entrava na Praça Clóvis e ia até o viaduto. Mas também era escola de cem pessoas, 180. Quem ganhava sempre era o Lavapés, da Madrinha Eunice. Era uma escola forte. Depois Vale do Anhangabaú e, então, foi pra São João. Saía lá da Duque de Caxias e ia até o Correio. Chegando ali, tinha uma corda. A escola entrava e ninguém podia entrar atrás, porque tinha que disputar, mas saía dali todo mundo participava. Até guarda civil entrava no meio, polícia, era uma bagunça, mas foi o melhor carnaval que eu vi o da São João. Era tradicional. De quarto grupo pra cima. O acesso das escolinhas bem pequenininhas a gente fazia uma pré-eleição. Era tudo na São João. Os quatro grupos desfilavam lá, era uma muvuca braba. Bons tempos, na São João; pegou o finzinho da época dos cordões. Eles eram bem maiores que as escolas. As escolas grandes tinham 200, os cordões tinham mil. Aí começaram a unificar, as escolas começaram a crescer. O Seu Nenê, briguento, queria escola, o Mala, meu cunhado, queria escola. Aí, o Sinval, com a Império do Cambuci, aí todo mundo começou a pensar, vamos fazer igual. Aí começou esse pensamento, que era melhor os cordões 
virarem escola. E também pela cultura, em todo lugar era escola e cordão. Eles vinham com aquela coisa de reisado, com aquele vestidão e com a corte. Eles gastavam muito mais dinheiro que escola de samba. Porque as escolas de samba vinham com uma fantasia mais levinha. E eles optaram por virar escola. Num ano, o Vai-Vai desfilou como cordão e, no outro, já foi escola. Tanto é que eles eram Cordão Camisa Verde, agora é Grêmio Recreativo, Cultural e Escola de Samba Camisa Verde, mudou tudo. O único que não conseguiu foi o Rômulo, do Fio de Ouro, que não conseguiu virar escola. Foi caindo, caindo. Porque era muito perto do Vai-Vai, tava ali do lado, na Rui Barbosa. O Fio de Ouro ensaiava na Rui Barbosa e o Vai-Vai é na rua de baixo. Tanto que o pessoal era o mesmo. O mais forte era o Camisa, que embalava quatro anos. Como cordão e como escola. Virou escola e embalou quatro anos seguidos.

O negócio era brabo. Começava no sábado e terminava na segunda, terça-feira. Tinha escola que repetia. Porque o negócio era desfilar, era uma coisa legal. Todo sambista que você perguntar, que for mais velho, vai dizer que o melhor carnaval foi o da São João. Porque era participação popular. Todo mundo podia participar. O caboclo tava de baianinho e entrava no meio da escola e desfilava. Punha uma camisa branca e calça branca e entrava no meio da escola, empurrava carro, ajudava. Hoje, pra começar, você tem a parede e a grade. O povo aqui e a escola de samba lá dentro. Sem ingresso não entra. Na São João você andava no meio da escola. A escola vinha na São João desde lá de baixo... Era a festa. Era bem rua mesmo. Vinham bloquinhos, assim, com dez moças vestidas, rapaz e um tipo de fantasia que eles bolavam e entravam no meio da escola. Só quando chegava perto do correio que tinha a corda, a diretoria da escola já sabia quem era e quem não era. Já era uma norma, o povo já sabia, até lá eu posso, pra lá, não. Por que tinha que julgar, né? A roupa, o cara tava de azul, de vermelho e a escola é azul e branco, não pode, porque o cara tem que estar de azul e branco.

A única coisa ruim da São João é que tinha o problema de trânsito, de trilho. Ali era vazão de tudo, pô. Quem ia pra Lapa, Pinheiros, Vila Madalena, não tinha acesso. Parava os bondes, os ônibus, entendeu? E virava uma bagunça ali no centro. Tanto é que nós fizemos vários desfiles e os palanques ficavam ali no Largo do Paiçandu, em frente à igreja. E era corda, não tinha arquibancada, o carnaval era na corda. E dava uma mão 
de obra danada. E aí optamos pela Tiradentes. Eu era presidente da UESP e falamos: 'Vamos mudar.' Porque era interesse deles também, porque parava tudo ali. O bonde, carros. Aí eles mudaram pra Tiradentes, porque tinha acesso pelo outro lado, então o trânsito ficou dividido. E foi de boa, a Prefeitura estava estudando os locais, falaram na Tiradentes. Aceitamos e, no outro ano, já montamos lá. Aí que começaram as arquibancadas. Porque antes tinha arquibancada, mas era daqui ali, pequenininha. Tinha o que, 50, 60 pessoas, cada fileira. E mais o camarote... Dos jurados e das autoridades. Não tinha extensão. E também não dava, porque a São João não era tão larga e você não vai fazer uma arquibancada na porta de alguém. E o comércio? Então eles faziam ali no Vale do Anhangabaú, só naquele pedaço. Cabiam ali 500 pessoas, era tudo mais complicado. E aí foi tendo um público cada vez maior. As escolas também já estavam cada vez maiores. Na época, acho que $60 \%$ da escola a prefeitura bancava. Porque tinha interesse, porque tinha a concorrência com o Rio de Janeiro, Bahia, já estava essa muvuca de carnaval, sem bairrismo. Mas acontecia. A gente falava no Rio de Janeiro: 'A Portela saí com 3000 e aqui a gente sai com 500. Vamos aumentar isso aí.' E tivemos sucesso. O público cresceu demais. A Avenida Tiradentes ficava lotada até aqui em cima no correio. Aí as escolas começaram a se aprimorar.

Na Tiradentes que o povão mesmo começou a participar. Os estudantes, porque antigamente o samba era só negrada mesmo. Negro e aqueles brancos cheios de sangue preto como eu! Não tinha essa frequência, porque agora tem ala lá de quinhentos e é tudo branco. Vêm até japonês. Era malvisto, moça de família, o pai não gostava que ela frequentasse escola. Aí que começou uma preocupação maior com a parte visual. O carnaval subiu, o carnaval na São João era baixinho. Alegoria de mão era o que tinha mais, carro alegórico era do tamanho dessa mesa aqui. Mas tinha um problema: se o desfile era na São João, o cara tinha que vir lá de Itaquera. A alegoria tinha que ser pequena pra caber em cima de caminhão. Aí começamos a arrumar por aí. Porque as escolas do quarto grupo ou do acesso é um carrinho só. As escolas que ficavam pertinho tinha vantagem. Só pra ter uma ideia, a Nenê, pra ir pra lá, tinha que ir pela marginal, com aqueles carros alegóricos grandes, era um transtorno. Agora não, eles tão fazendo tudo lá embaixo. Teve que articular, porque, pensa, hoje em dia, parar a marginal pra 
levar um carro alegórico. A Peruche mesmo teve um ano que parou a marginal, saímos da quadra, deu uma mão de obra, não passava embaixo de viaduto. E tinha que fazer de madrugada. Meia-noite ou uma da manhã a gente saía. E era uma bagunça; agora, não, é tudo articulado. Os caros são gigantescos. Que eu não gosto muito, mas fazer o quê?

Durante a minha gestão como presidente da UESP começou a política de quadra. As escolas negociavam com a prefeitura a cessão dos terrenos. O Nenê conseguiu quadra. O Tatuapé saía num bequinho, ali onde é a Chic agora. Não dava essa área aqui do meu quintal. Ensaiava ali. Os carros alegóricos faziam na rua ou quando alguém cedia algum terreno. E punha lona em cima, aquela coisa toda. Era muito longe do centro. No dia de desfile demorávamos o dia inteiro pra chegar. Se fosse pequeno os carros iam em cima de caminhão. Já os carros maiores do primeiro grupo iam empurrados, porque carro alegórico não pode ter motor, é lei. No primeiro grupo eram três carros. Agora, o que acontece, a Chic comprou a área e nós tivemos que cair para um terreno alugado na Melo Peixoto. Dali nós fomos para um varejão que tinha no Tatuapé, no outro lado. Um varejão, uma feira, vai. E lá tinha um barracão e um banheiro. Aí nós caímos pra dentro. Depois fomos pra Guaiaúna. Aí deu uma enchente no carnaval e levou instrumento, as roupas, levou tudo.

O Acadêmicos era complicado. Teve um problema: quando o metrô veio derrubando, era ali que tava a nossa base. Dispersou todo mundo. Cada um foi pra um lado, Cohab Dois, Cohab Cinco, sumiram. Os caras vinham, mas já não com tanta frequência. Porque a nossa base era da Favela do Maranhão, lá embaixo, perto do Corinthians, no Largo do Maranhão, na Antônio de Barros. E acabaram com a favela. O cara vem morar aqui em Poá e pensa: ‘Ah, eu não vou, não. É longe, é difícil.' Apesar de que agora não, agora vem gente de tudo que é lado. Depois é que nós fomos pra debaixo do viaduto, na gestão do Jânio. Ali embaixo do viaduto. O Jânio Quadros que cedeu pra nós. Não sei se você lembra, na gestão dele, o Tatuapé era o bairro mais poluído de São Paulo e quase não tinha opção de lazer aqui na zona Leste. Foi uma jogada pra valorizar a região. Foi na época, eu cheguei nele e falei: 
- Pô, a Associação dos Comerciantes usa embaixo do viaduto pra fazer painel, faixa, essas coisas. Nós vamos usar para uma coisa cultural. Eu pedi para ele esse lugar. Aí ele cedeu e está lá até hoje.

Nessa época que estávamos no beco que eu comecei a articular e desenhar para as escolas. Porque eu acho que a base do carnaval foi essa ideia de falar: 'Vamos fazer enredo, tipo encomendado, vamos conseguir mais dinheiro para todo ano sairmos tranquilo.' Valorizou a coisa. As escolas tinham que fazer enredo sobre temas do Brasil. Isso veio do Rio de Janeiro. Nós que optamos por trazer pra cá. Porque o cara ia vir com o enredo sobre os Estados Unidos? Não tem porquê. Eu negociava direto com a Secretaria. O prefeito só assinava. Tanto é que tinha um caboclo aqui [aponta para uma foto com várias pessoas em um palanque assistindo a um desfile], o Simões Neto, que andou dando cheque sem fundo por aí, inclusive pra Tatuapé, mas isso é fofoca. Eu me dediquei bastante na UESP. Toda sexta-feira. Sempre à noite. Eu tirava as noites de sexta-feira pra UESP. Acompanhava a liberação das verbas. Era como um clube. Sinval era meu amigo, Seu Inocêncio, meu amigo. A gente tomava uns conhacão juntos no bar da galeria e depois subia pra reunião. A reunião era na sexta, mas na quinta a gente já estava lá. Às vezes na terça, pra ficar no botequim conversando. Quando sambista se reúne, a falação é só de samba, nem futebol entra. Então a gente ia pra lá, era mais fácil. Mas como eu conhecia todo mudo. Começava em setembro e ia até depois do carnaval.

Fizemos muitas coisas bonitas, só não conseguimos fazer mais por causa da divisão de nós mesmos. Eu tentei, mas na verdade foi o Geraldo Filme que conseguiu unificar. Porque, você olha pra minha cara: eu não sou preto. Então eu tava lá no plenário, eu falando, o cara não ligava. Porque eu escutava, saía uns bochichos: 'Pô, um branquinho tomando conta do samba', saía esses papos aí. Aí, quando eu passei pro Geraldo Filme, ele conseguiu. Porque era o Geraldo Filme, né, negrão, muito respeitado. Comandava na época o Paulistano da Glória, um dos melhores salões de baile. Eu ia muito nos bailes lá, com o Geraldo. Eu tenho respeito por um lado e ele tem por outro. Estava sempre no meio do tiroteio. Porque você vai falar com o representante de todas as escolas de sambas. Pensa que vai vir um negão e chega o Álvaro, um branquinho. Entendeu, tinha cara que não entendia muito bem isso aí. Mas como a 
máfia foi rodando, quando entrou o Geraldo, aí é que unificou tudo. A parte de baixo da Barra Funda, depois do rio, o Carlão, o Juarez, Seu Zezinho do Morro da Casa Verde eram de uma facção. Pé Rachado e Chiclé eram de outra. Ele conseguiu pôr todo mundo na mesa e ficar juntos. Porque quem brigava mesmo pelo samba era Geraldo, eu, Jangada, Pé Rachado, o Mala, falecido cunhado meu. Era quem brigava mesmo pela cultura. Tanto que a Prefeitura passou a mandar a verba para a UESP e a entidade repassar para as escolas.

O dinheiro era dado pela Secretaria direto para as escolas, pra mão do presidente. Depois que passou a ser centralizado na UESP. A gente cobrava do secretário, da prefeitura o dinheiro, em setembro. Porque tinha que sair em setembro pra dar tempo. Os caras davam em novembro. As escolas cobravam a gente em setembro. Era uma muvuca, os caras iam na UESP, e eu falava: 'Eu levo vocês lá.' Era assim! A Secretaria, quando entrou o Anhembi, que deu uma legalizada. Tanto é que eu te falei, o Secretário deu um cheque sem fundo. Não fui eu que dei. Eu sou UESP, quem deu o cheque foi a Secretaria. Aí o que nós tivemos que fazer: fomos no Notícias Populares e colocamos o cheque, fotografamos e saiu nos jornais. No outro dia, o Secretário tava distribuindo dinheiro lá no gabinete. Devolvemos o cheque e o dinheiro tava lá pras escolas pegarem. Teve um ano lá que atrasou muito, era dezembro e não tinha saído a verba. Aí fomos todo mundo lá. Todas as escolas lotaram a Secretaria. Aí o cara viu a pressão. Passou uns dias e teve o dinheiro na mão. Porque teve ano que a verba saiu praticamente em janeiro, pô. Teve parcela que saiu em fevereiro. Já teve verba que saiu três dias antes do carnaval, a última parcela. Aí você pega um sábado e domingo a 25 de Março fechada, não dava tempo. Agora não, sai em setembro, a verba já sai. Dos que passaram por aí, eu lembro que o Paulo Egydio foi um cara decente. Ele, junto com a Prefeitura, aumentou a verba um ano lá. Acho que a mulher dele deu uns tapas nele, ela gostava de carnaval. Oh, melhora o negócio aí. Eu lembro que em vez dele dar 70 ele deu 100. Mas no outro ano voltou pra 70 de novo.

Quando eu saí da presidência, fiquei no departamento cultural. Aquele acervo que está lá, o arquivo, fui eu que montei. Tanto é que tem tanta coisa minha lá, um monte de coisas. Doei livro, foto, tem foto aqui que eu copiei e está lá. Mas todo mundo 
vem aqui. Eu já vinha com essa ideia faz tempo. Mas, como presidente, não tinha tempo. Já vinha guardando coisa, junto com o Derly, que também é ratão nessas coisas de samba. Eu tenho parceria com o Derly nesse acervo que eu tenho aqui, e com o Jota Muniz, nós três. O Jota Muniz foi jurado muitas vezes. Na época ainda não tinha esse curso de jurados que tem hoje. Gente que nem é do samba e faz um curso e julga. Sempre dois sempre dois jurados por cabine, para não ter muita discussão. Mas sempre dava briga. Nós também colocávamos jurados diferentes em cada grupo. Nós só chamávamos personalidades, pessoas de gabarito para julgar. Porque tinha um jurado que ia julgar o grupo tal, mas ele tinha amigos na outra escola, então tinha aquela democracia. Professor de música, maestro, teve um famoso, o... Júlio Medaglia. E também teve outros. Sambistas também, que vinham de Santos. O Dráuzio, que tá aí na foto, o Jota Muniz vinha também.

Depois que o Geraldo assumiu, a gente ficou mais tranquilo e eu voltei a ficar mais perto do Tatuapé. No Acadêmicos do Tatuapé eu queria fazer só enredo paulistano, Império Tropical, Cama do Gonçalo, Amador Bueno. Eu tenho todas letras, têm alguns que eu tenho até figurino da época. Eu optei por São Paulo, aí a gente punha na cabeça dos caras, vamos falar das coisas daqui. Tem tanta coisa, Brás Cubas, vamos falar de Mogi das Cruzes. Essa parte cultural, Pirapora. Essa raiz fomos nós que implantamos. Foi a UESP que implantou. Na nossa gestão de 1973-75. A marca da nossa gestão foi isso. Tanto é que já tinha o projeto do arquivo. O meu arquivo pessoal é maior que o da UESP, da história do carnaval paulista. Eu dei as xerox e fiquei com o original. Tenho muita coisa no arquivo de aço grande.

Era difícil arrumar patrocínio. O Acadêmicos não tinha. O que tinha era malandragem. Teve uma vez que eu cheguei no Renato da Tapeçaria Chic e dizia: 'Eu vou fazer um enredo Meu Chic Tatuapé.' Eu cheguei lá no Renato com os slides, projetei: 'Ô, Renato, Meu Chic Tatuapé, tô falando da sua loja e do Acadêmicos do Tatuapé e do Tatuapé, do bairro Tatuapé.' Eu fiz isso várias vezes. Fiz com o Marengo também. A uva Marengo. Eu peguei todos, a casa da borracha. Todos comerciantes ajudaram o enredo Meu Chic Tatuapé. Eu fui no Marengo, vou sair com um cacho de uva enorme. Tanto é que saiu mesmo. O Marengo assinou o cheque. Não tinha tanto 
dinheiro mais, o bairro mesmo prestigiava. Só a verba da prefeitura e a renda da escola não eram suficientes. Vou falar pra você, eu, particularmente, pus dinheiro no Acadêmicos do Tatuapé adoidado. Eu fui diretor de arte e, depois, dono de agência de propaganda, então eu investia. Eu era sócio do Carlos Queiroz Telles. Eu desenhava o figurino e saía muito na época. As baianas, por exemplo, nós dávamos o tecido e ela confeccionava a sua fantasia. Você encontrava baianas lá na 25 de Março, comprando os vestidos dela mesmo. Era por amor mesmo. Tanto é que a minha sogra, mãe do Mala, era costureira e saiu no Anhangabaú, São João e Tiradentes. Tinha que ter amor.

Além do Tatuapé, também saí no Império Serrano, porque a gente fez um intercâmbio. Já desfilei também pela União da Ilha e pela Mocidade Independente. Porque a gente desfilava aqui no sábado, pegava o busão e ia pra lá. E eu frequentei muito quando eu morei lá em 71 e 72 . Mas, todo ano, no carnaval, eu vinha pra cá. Se desfilasse no sábado, o Império e o Acadêmicos, eu vinha pro Acadêmicos. Tanto é que, quando a gente vinha, a gente trazia o Mano Décio pra desfilar no Acadêmicos. Pra fazer o samba, ele fez vários sambas... Aí era certeza que tirava dez de samba-enredo. Eu tenho parceria com ele em dois sambas. Porque o enredo era meu, eu passei a letra pra ele e disse: 'Mano, é isso aí que tem que entrar.' Aí ele, pum, na viola, e já fazia a melodia... Também produzi o primeiro álbum do Mano Décio, pela Tapecar. Meu nome tá lá escrito na capa. Só que tá Álvaro Ribeiro, não tá Casado. Ó a história como é que foi. Tinha a gráfica Mata Velha e ele queria dar uns brindes e todo ano eu fazia os brindes de fim de ano. Porque a gráfica tinha aquele negócio: chegava no fim de ano, vou dar pros clientes a folhinha, aquele negócio. Aí chegou no fim de ano, eu falei pra ele assim: 'Vamos dar uma fita com os sambas do Mano Décio.' Ele conhecia o Mano Décio, gostava do Mano Décio. Aí fizemos a fita, mas tem que gravar, e foi gravado lá no Rio de Janeiro pela Tapecar. Aí nós fizemos esse LP aí, mas foi a Mata Velha que financiou. Nós fomos pro Rio de Janeiro, gravamos. O Mano Décio até se mijou, rapaz! Porque ele nunca tinha gravado um disco, rapaz. Aí até se mijou, coitado. Tanto é que o disco não tá muito bem gravado porque ele tava muito nervoso. Aí nós fizemos a fita e dava de presente para os clientes. Com um encarte explicando a história do Mano Décio e tal. E foi um show. Tanto é que ele até ganhou como melhor brinde entre as gráficas. 
Tem história esse LP. Eu não tenho mais porque emprestei pra um caboclo aqui em Poá e depois vim saber que o cara se mudou e levou. E é raro aquele disco. Nem o Mata Velha tem. Porque ele foi dando, dando e ficou sem. Depois é que ele gravou os outros. Depois que ele saiu da Império Serrano, quando ele desfez a parceria com o Silas. Até hoje não sei o porquê. Ele nunca me explicou. Eles são parentes. Acho que o Silas, na época, era mais famoso que o Mano Décio. E depois começou também o Mano Décio a fazer muito show. Tanto é que, quando eu morava no Rio, eu ficava sexta, sábado e domingo, não ficava nenhum dia em casa. Pegava o carro, colocava ele e a viola e um pandeirista e corria pra fazer show. Vamos pro Cacique de Ramos, vamos, São João do Meriti, era uma loucura. Ele não tinha carro e eu tinha. Era uma farra, na verdade. Tempo bom, rapaz! Ele ficou ali embaixo do pé de árvore, antigamente aqui tinha um galpão com uma churrasqueira. Ele ficou deitado ali na rede, com a viola fazendo samba. Ele vinha do Rio de Janeiro do meu lado, como meu copiloto, do lado, tocando viola, na Dutra. Eu vivi muito com o Mano Décio. Eu tenho tanta foto dele aí. Foi um dos meus melhores amigos!

Quem mudou os dias de desfile de sábado e domingo para sexta e sábado foi a Globo mesmo. Tanto é que a Globo está há tantos anos transmitindo. A Bandeirantes briga, mas não entra. A Globo fez a cabeça dos sambistas. O poder econômico fala mais alto. Vocês fecham com a gente, mas a gente quer só as melhores. Tanto é que ela não transmite o carnaval da UESP. Nem do acesso. A Globo é o problema. Mudou o dia, passou pra sexta-feira. Tudo é jogada da emissora. E o dinheiro não é pouco não e cai na mão da Liga. Aí tem uns ratão lá dentro e já viu. Apesar de que agora as escolas estão com uns presidentes mais maneiro. Opa, péra aí, vamos ver direito. Porque naquela época não tinha, o cara pegava o dinheiro e nem contava. Punha o dinheiro na mala e zarpava, ia cuidar da vida dele. Agora não, os caras sabem tudo. A Liga até empresta dinheiro pras escolas. Ela se tornou um banco. Meu compadre Valtinho, falecido, foi presidente da Peruche uma par de tempo. Ele e o Barcan. Com eles era o seguinte: os caras punham do próprio bolso sempre uns 300 contos e corria com a escola. Chegava a verba, pegavam de volta o dinheiro. $O$ único sério até hoje que eu vi. O Valtinho fazia. Ele bancava a escola antes do carnaval e depois ele tirava de volta. 
Mas ele reunia a diretoria. Eu fui diretor lá. Olha aqui, gente, a verba tá no banco, tá aqui o boleto. Os meus 300 eu vou tirar amanhã. Mas era sério, entendeu? Tem nêgo aí, tem escola que empresta dinheiro, agora de onde vem a grana eu não sei, mas que empresta, empresta.

As escolas de samba foram fundadas nas famílias. Sempre tinha uma família responsável. No Tatuapé, o Mala, a família do Mala. Na Nenê, é o Nenê. Mocidade é o Juarez. No Peruche, o Carlão. Agora não, eles põem um monte de gente e advogado que não tem nada a ver com o samba. As famílias perderam o processo. Porque sempre foi comunidade. No Tatuapé, o Mala saía, entrava eu, eu saía, entrava o Mala. Quando não entrava a Analú, aí depois entrou o filho do Mala. Tanto é que, nos documentos você lê, presidente Álvaro Casado, Osvaldo Vilaça. Mas era família, o Mala morou aqui no Jardim Alvorada, em Poá. Você vê o Império de Casa Verde, que chegou com muito dinheiro e levou todo mundo de todas as escolas. Tenho alguns amigos que eram do Peruche e estão lá na Império agora. Tem dinheiro. O Peruche tá mal porque ainda é uma das únicas escolas administradas por família. E além do mais, o pessoal foi envelhecendo. Tanto é que o Camisa tá no risco que tá agora, porque o Inocêncio morreu, depois o Tobias morreu, entrou a Magali, depois o Seu Maninho. Mas não é o Mulata, não é o cacique. O Tatuapé caiu na mão do Roberto, Zoinho, que foi tocando, montou um esquema com a faculdade, articulou lá um pessoal. Tanto é que não tem ninguém da Velha Guarda na diretoria do Acadêmicos. É outro pessoal. Ele fala: 'Casado, estou chateado.' Eu falo pra ele: 'Larga disso, rapaz!' Samba é samba. Porque você chega na quadra, eu sou fundador do Acadêmicos, não conheço ninguém. Aí o Roberto precisa anunciar no microfone, tá aqui o Álvaro Casado, fundador. Mas ele tem que indicar é aquele lá. Aí o pessoal bate palmas. [risos] É um negócio complicado, mas um pouco é relaxo meu, se eu tivesse lá direto, direto. No Tatuapé, um dia, chegaram até me barrar na porta. O segurança não me conhece, eu chego lá na porta à paisana. Se eu chego lá de faixa, de sapato branco, o cara olha e fala: 'Esse cara é embaixador, deve ser alguma coisa.' Mas se eu chego lá assim, o cara fala: 'O que o senhor quer?' 'Eu quero entrar.' 'Quem o senhor é?' 'Eu sou Álvaro Casado, fundador dessa tranqueira aqui.' 'Ah é?' Mas o cara não tem obrigação de me conhecer. 
Eu saio no Acadêmicos do Tatuapé não é tanto por gosto. Eu não gosto muito do movimento. A escola cresceu, tá saindo com 4000, eu sou contra isso, sou contra 4000. Mas tenho uma história na escola, faço parte da Embaixada e da Velha Guarda do Tatuapé. Ultimamente, só frequento na época do carnaval, vou a dois, três ensaios e desfilo. O pessoal me joga lá no fundão e eu vou embora. Eu não sei se o carnaval evoluiu. Eu me lembro que era sempre a Velha Guarda que abria o carnaval. Agora é o contrário, a Velha Guarda foi lá pra trás. A comissão de frente era aquele negócio assim, era a diretoria e a Velha Guarda. Olha, estou trazendo meus filhos aí atrás. Agora não, puseram a Velha Guarda lá no final e colocaram na frente às coreografias e quem vem primeiro é o coreógrafo. E na Velha Guarda são pessoas idosas, e, quando o desfile atrasa, quem tem que acelerar são eles. Esse ano não, eu não fui. Tive 'uns treco' aí e não fui. Aí o ano retrasado, eu tava lá e a bateria do Tatuapé é meio veloz, é meio rapidinha. Aí o que acontece, toca a sirene na avenida, opa, entra todo mundo. Vocês vão lá pro fundo da escola. Põe no meio, atrás de um carro alegórico, porque o carro vai parando e você vai de boa, né? Colocaram 'os veinho' lá em último. Chegou lá, a escola atrasou, teve que andar. Isso é cansativo pra caramba. Pra mim não, que eu ainda aguento, mas tem uns veinho lá meio balangandã. Minha parte eu já fiz, hoje eu vou pra alguns ensaios, desfilo e, depois, tchau. Vou cumprimentar todo mundo, conheço todo mundo das outras escolas e depois eu vou embora." 


\section{CONSIDERAÇÕES FINAIS}

O carnaval das escolas de samba da cidade de São Paulo passou por inúmeras transformações ao longo do século XX. Foram modificações de natureza estética, musical e também políticas e institucionais. O que começou como uma forma de diversão dos pobres nos bairros periféricos da cidade ao longo do século converteu-se em um dos principais eventos turísticos de São Paulo.

As adequações se intensificaram a partir da oficialização do carnaval das escolas de samba pela prefeitura da cidade em 1968, durante a ditadura militar. A oficialização, feita pelo Estado em um período autoritário, teve semelhanças com o processo ocorrido no Rio de Janeiro, na década de 1930, durante a ditadura do Estado Novo. Com a oficialização vieram o patrocínio e o incentivo do poder público, o que ajudou as escolas de samba a crescer cada vez mais e se popularizarem por todo o país, ao mesmo tempo em que regras e normatizações foram impostas (URBANO, 1987, p.63).

Na cidade de São Paulo, o carnaval popular negro se desenvolveu na primeira metade do século XX, principalmente devido aos cordões, que, aos poucos, foram se inspirando no modelo carioca. Logo, esses cordões foram se transformando em escolas de samba. Os sambistas paulistanos viam nos desfiles do Rio de Janeiro um modelo a ser seguido, por causa da qualidade do espetáculo e também pelo incentivo em dinheiro recebido. Inicialmente, o poder público não aceitou negociar diretamente com os sambistas, e vários radialistas e profissionais do setor de comunicação serviram de mediadores entre a Prefeitura e os sambistas. Em comum acordo, foi refundada a Federação das Escolas de Samba, que se encontrava sem atribuições. Um novo regulamento para as escolas de samba foi estabelecido, de acordo com o modelo do Rio de Janeiro. Esta imposição de um modelo carioca de desfile chocava-se com as tradições dos desfiles de São Paulo, o que acarretou na extinção dos cordões carnavalescos. Outras regras foram fixadas e modificaram a organização dos desfiles da cidade, como o fim dos estandartes, da corte carnavalesca e dos instrumentos de sopro, 
e novos elementos foram incorporados, como mestre-sala e porta-bandeira e a ala de baianas (SIMSON, 2007, p. 159).

Se por um lado, a partir da oficialização, eles abrem mão dos desfiles dos cordões carnavalescos, que já estavam em decadência para organizar uma nova modalidade de agremiação, com novos regulamentos, conseguem receber uma ajuda financeira do Estado que garantiria o funcionamento das agremiações por anos a fio. $\mathrm{E}$ como sofrem pressões e censuras em um momento histórico de ditadura militar e repressão política, os dirigentes das escolas se organizaram em uma entidade que também irá cobrar do poder público mais investimentos no carnaval.

A relação entre Estado e escolas de samba não foi construída por meio de imposições; Há uma relação em que todos são sujeitos e agentes em disputa, pois os sambistas também realizaram pressões sobre secretários e prefeitos para ocuparem mais espaço nas ruas da cidade e cobraram maior atenção do poder público para os bairros onde as agremiações estão inseridas.

A possibilidade de recebimento de uma quantia em dinheiro para a preparação dos desfiles fez com que o número de escolas de samba aumentasse a cada ano, em diversos bairros da cidade; por outro lado, isso trouxe mudanças que transformaram o cotidiano das escolas. As escolas tradicionais surgidas a partir dos cordões, representavam um espaço de lazer e sociabilidade das comunidades em diversos pontos da cidade. Apesar de o poder público funcionar como financiador das escolas de samba, muitas delas se transformaram mais do que esses espaços. Muitas escolas se tornaram verdadeiras porta-vozes dos bairros em que estão inseridos, cobrando, do poder público, melhorias como: mais escolas, creches, parques, asfaltamento e calçamento de ruas, melhorias no sistema de coleta de lixo e saneamento básico, por exemplo. Em todas as eleições é comum vereadores ou candidatos pedirem o apoio das escolas de samba, e, caso sejam eleitos, estabelecem livre trânsito em seu gabinete para a diretoria e membros das escolas. 
Ao analisar as escolas de samba existentes no Censo Samba Paulistano 2012, ${ }^{122}$ documento publicado pela SP Turismo com informações de todas as escolas de samba, é possível perceber que, no presente ano (2013), 78 agremiações carnavalescas (escolas ou blocos) desfilaram nos concursos promovidos pela Prefeitura de São Paulo. Das escolas atualmente em atividade na cidade de São Paulo, apenas onze escolas foram fundadas antes da oficialização. No período analisado pela presente pesquisa (19681996) foram fundadas 46 escolas que continuam em atividade. Mais de $50 \%$ das escolas foram fundadas nas décadas de 1970 e 1980, período de consolidação do carnaval paulistano.

Entre os anos de 1968 e 2012, nada menos que 215 agremiações desfilaram oficialmente no carnaval paulistano. Algumas desfilaram por décadas, enquanto outras se apresentaram apenas por alguns anos. Dezesseis apresentaram-se apenas um carnaval e encerraram suas atividades. Esse grande número revela que o reconhecimento oficial e o aporte financeiro da Prefeitura potencializaram a fundação de escolas de samba, caracterizadas com um misto de negócio e diversão. Assim como a própria dinâmica da cidade, que foi expulsando cada vez mais os pobres para a periferia da metrópole, o crescimento das escolas de samba também ocorreu em bairros periféricos, como, exemplo: Unidos de Santa Bárbara, no Itaim Paulista, extremo leste da cidade, e Valença de Perus, no bairro de mesmo nome, no extremo oeste da cidade, regiões de ocupação e construções mais recentes, devido a projetos habitacionais oficiais, invasões de áreas municipais e loteamentos populares, repetindo o que acontecera na Zona Norte da cidade com o Morro da Casa Verde e Parque Peruche.

Outra importante mudança ocorrida no período analisado foi a substituição do carnaval conhecido como "participação" realizado pelos cordões, blocos e escolas até a década de 1960, em São Paulo, para uma modalidade de carnaval de atores e espectadores. Esta modalidade de carnaval não se configura como uma festa, mas como um espetáculo, com ganhadores e perdedores. Os atores são aqueles que se fantasiam e desfilam por suas escolas, cujo principal objetivo é se sagrar campeã. Os espectadores,

${ }^{122}$ Censo Samba Paulistano. Coord. Geral Luiz Sales. 2. ed. São Paulo: São Paulo Turismo, 2012. 
maior parte dos envolvidos, não participam de fato dos desfiles, apenas assistem passiva, ou presencialmente ou ainda pela televisão, e admiram o espetáculo.

Desde o início de suas atividades, o concurso de carnaval passou por diversos palcos: os bairros de origem dos cordões e escolas de samba; desfiles concentrados no bairro da Lapa; no Parque do Ibirapuera; no centro da cidade; Rua Direita; Avenida Líbero Badaró; Avenida Brigadeiro Luiz Antônio; Vale do Anhangabaú; Avenida São João e Avenida Tiradentes. Todos têm em comum o fato de serem ruas e locais de grande circulação e fazerem parte do espaço público da cidade. Novamente inspirado no modelo carioca, houve, no início da década de 1990, em São Paulo, a construção de um Sambódromo. Com a sua inauguração, o carnaval deixa de ser realizado "na rua", ou seja, no espaço público, e passa a acontecer em um local privado onde as escolas ficam confinadas. Esses espaços fechados seriam uma mistura de estádio e teatro, no qual ocorre a cobrança de ingressos para o espetáculo, alijando assim a população mais pobre do carnaval espetáculo.

O confinamento do carnaval produz uma infinidade de excluídos, isto é, aqueles que não dispõem de meios para participar dos desfiles ou nem mesmo para comprar ingressos para assisti-los. Para essas pessoas, só resta acompanhar os desfiles pela televisão e por outros meios de comunicação, reafirmando, assim, a realidade do mundo capitalista, à qual exclui aqueles que não possuem recursos. O interesse da opinião pública, dos meios de comunicação e da indústria cultural é apenas pelo desfile do Grupo Especial, que reúne as maiores e mais luxuosas escolas de samba. Tomando como exemplo o futebol, cujos meios de comunicação dão reduzido espaço para os campeonatos das divisões inferiores, o concurso das escolas dos grupos inferiores não recebe grande aporte financeiro, visibilidade e atenção, gerando um abismo intransponível entre as grandes escolas e as pequenas agremiações.

Ao longo da dissertação pudemos ver que esse quadro se intensificou a partir das negociações diretas entre as escolas de samba e a indústria cultural, provocando a divisão dos próprios sambistas em duas entidades distintas. Os desfiles dos grupos superiores, organizados pela Liga, passaram a ser transmitidos pela emissora de 
televisão líder de audiência, movimentando cada vez mais recursos e produzindo um desfile cada vez mais grandioso.

Esta nova dinâmica de desfile provocou mudanças também na composição das direções das escolas de sambas. Isso ocasionou a saída de fundadores e membros históricos das escolas das funções de direção e a entrada de novas lideranças. As escolas de samba passaram a ser vistas, ao mesmo tempo, como entidades culturais e empresariais restando aos sambistas históricos restou o papel de agentes da preservação cultural, aparecendo apenas na ala da Velha Guarda. (BLASS, 2007, p. 36)

Três marcos são de extrema importância para a consolidação deste atual modelo carnavalesco consolidado na década de 1990, na cidade de São Paulo: a fundação da Liga Independente das Escolas de Samba, a construção do Sambódromo e as transmissões televisivas dos desfiles do Grupo Especial em cadeia nacional. O primeiro acontecimento foi responsável pelas negociações envolvendo o carnaval; o segundo e o terceiro impulsionaram o desfile paulistano à padronização total, à semelhança do espetáculo promovido pelo Rio de Janeiro. Nesse contexto, as grandes verbas das campanhas publicitárias, como as das indústrias de bebidas, são muito importantes para o financiamento das escolas, já que tais empresas movimentam os anúncios de imagem das transmissões televisivas, que são a grande fonte de receita das escolas de samba.

Em suma, a Liga trabalha dentro de um parâmetro empresarial capaz de negociar contratos com as emissoras de comunicação e com o poder público buscando uma maior fatia do bolo para as escolas (BELO, 2008, p. 180). Já a UESP permanece como a entidade de organização das pequenas agremiações, de comunidades mais afastadas, longe dos holofotes, trabalhando dentro do parâmetro tradicional de desfiles que as escolas realizam desde a oficialização do carnaval de São Paulo. O principal canal de financiamento são as verbas da Prefeitura de São Paulo, insuficientes para cobrir os gastos das escolas que têm na sua comunidade e na criatividade de seus membros as soluções para a escola realizar o desfile, que podem vir desde patrocínios pontuais de empresas a soluções de reciclagem e uso de sobras de materiais das grandes escolas. Depois da divisão entre as duas entidades, a UESP ficou encarregada de continuar 
fazendo o carnaval de rua em pontos mais afastados da cidade com uma ação profissional de cunho social, sem fins lucrativos e politicamente descentralizado.

O papel exercido pelo sambista pobre e negro sofreu muitas transformações ao longo do percurso pelo qual as escolas de samba atravessaram. Mas, de maneira alguma os sambistas podem ser vistos como agentes passivos que entregaram o carnaval para o Estado ou para as classes médias e, posteriormente, para as emissoras de televisão. Estas personagens procuraram parcerias e negociações porque viam nestas agremiações, fundadas ou dirigidas por elas, uma oportunidade de sair do anonimato e da carestia e alcançar algum prestígio social, como também oportunidades materiais.

Ao longo das entrevistas realizadas com os membros das Velhas Guardas, presente na segunda parte da dissertação, é possível perceber que a visão dos entrevistados seria a de que o carnaval vivenciado por sua geração seria não comercial, e o que os movia era apenas a "paixão" pelo samba e pelo desfile, mesmo que este já fosse oficializado e estabelecesse relações com o Estado. Apesar de ainda estarem ativos e participando diretamente das escolas de samba, eles veem o carnaval atual como algo produzido pelo mercado cultural, para agradar a um público mais amplo, o qual não tem ligações com as comunidades das escolas e que apenas quer se divertir na festividade. Para os entrevistados, essas pessoas só participam do carnaval porque, hoje, desfilar em uma grande escola de samba é sinônimo de status, já que elas aparecem na televisão e o evento tem ampla cobertura midiática.

Concluímos, por fim, que é inegável que o processo de negociação dos sambistas com os órgãos públicos e com a indústria cultural trouxe perdas e ganhos por parte das escolas de samba. É claro que estas negociações se deram em instâncias diferentes de poderes, com diferentes formas de pressão e imposição, como, por exemplo, a do Estado, que, para patrocinar as escolas, impôs um regulamento, mudou os desfiles de lugar diversas vezes e, de certa forma, constituiu o modelo de carnaval popular das duas cidades mais importantes do país. Esta parceria com o poder público transformou o carnaval popular em uma arte de massa, mediada pela indústria cultural.

Podemos perceber que padrões competitivos da sociedade mais ampla foram implantados dentro das escolas de samba, formando-se um "mercado do samba", com 
concorrência acirrada entre as entidades carnavalescas (SIMSON, 2007, p. 222). Algumas escolas mais antigas, ligadas a uma administração familiar, criaram esquemas para se adaptar aos novos tempos, mas, muitas delas, como a Lavapés - citada por todos os entrevistados como uma das escolas mais organizadas do passado e exemplo a ser seguido na década de 1960 — , não se adaptaram e definharam, mantendo-se viva, porém disputando os grupos inferiores e desfilando com pouco mais que uma centena de componentes.

Nesse processo de profissionalização das escolas de samba, os sambistas mais velhos estão afastados das decisões políticas das agremiações e enxergam a própria inversão, característica do carnaval comprometida, com a indústria cultural presente nos desfiles das grandes escolas, pois o sambista pobre não possui nenhum destaque nestes desfiles, são eles personagens que dedicaram boa parte da vida em prol dos folguedos e, apesar da popularidade conquistada hoje pelas escolas de samba, estão excluídas dos meios de comunicação e da indústria cultural e não conseguem sobreviver através de sua arte. Desenvolvem normalmente ofícios simples, pela pouca escolaridade que tiveram, levam uma vida com privações materiais e dedicam boa parte de seu tempo para o samba e para o carnaval, desenvolvendo este ofício voluntário e enquadrado como lazer. No entanto, não podemos esquecer que o processo histórico de se fazer samba sempre esteve vinculado às classes subalternas. Mesmo sendo hegemônicos, dentro dos festejos carnavalescos, os símbolos originais do samba não deixaram de ser comunitários e provincianos, pois tampouco se perdeu a mística do batuque e da comunicação com os símbolos espirituais da cultura afro-brasileira. Não podemos esquecer também dos sambistas idosos que mantém um papel e uma função importante e fundamental no mundo do carnaval e do samba. 


\section{BIBLIOGRAFIA:}

\section{LIVROS}

ARIAS Y ARIAS, Ricardo. La Poesia de los Goliardos. Madrid: Gredos, 1970.

ARRUDA, Maria Arminda do Nascimento. Metrópole e Cultura: São Paulo no meio século XX. Bauru: Edusc, 2001.

AZEVEDO, Clara de Assunção. Fantasias Negociadas. Políticas do Carnaval Paulistano na Virada do Século XX. Dissertação de Mestrado. São Paulo: FFLCH/USP, 2010.

BAKHTIN, Mickail. A Cultura Popular na Idade Média e no Renascimento: o contexto de Rabelais. São Paulo: HUCITEC -Editora da Universidade de Brasília, 1987.

BAROJA, Julio Caro. El Carnaval. Madrid: Alianza Editorial, 2006.

BLASS, Leila Maria da Silva. Desfile na avenida, trabalho na escola de samba: a dupla face do carnaval. São Paulo: Annablume, 2007.

BRAIA, Ana. Memórias de Seu Nenê da Vila Matilde. São Paulo: Lemos Editorial, 2000 .

BELO, Vanir de Lima. O enredo do carnaval nos enredos da cidade: dinâmica territorial das escolas de samba em São Paulo. Dissertação de Mestrado. São Paulo: FFLCH/USP, 2008. 
BONDUKI, Nabil. Crise na habitação e a luta por moradia no Pós-Guerra. In: Kowarick, Lúcio (org.). As lutas sociais e a cidade. Rio de Janeiro: Paz e Terra, 1998.

BOSI, Ecléa. Cultura Popular e Cultura de Massas. Leitura de Operárias. Rio de Janeiro: Vozes, 1972.

Memória e sociedade. Lembrança de Velhos. São Paulo: Companhia das Letras, 1994.

BOTEZELli, J.C PELÃO, PEREIRA, Arley. A Música Brasileira deste Século por seus Autores e Intérpretes. Volumes 1 a 8 . São Paulo: SESC, Serviço Social do Comércio, 2000.

BUSCÁCIO, Gabriela Cordeiro. Enquanto se samba se luta também: o Granes Quilombo nos anos 1970. IN. Carnaval em Múltiplos Planos. CAVALCANTI, Maria Laura e GONÇALVES, Renata (org.) Rio de Janeiro: Aeroplano Editora; Faperj, 2009.

CABRAL, Sérgio. As Escolas de Samba do Rio de Janeiro. São Paulo: Lazuli Editora; Companhia Editora Nacional, 2011.

CAMARGO, Haroldo. Fundamentos multidisciplinares do turismo: História. IN: TRIGO, Luiz G. (org). Turismo. Como aprender, como ensinar. São Paulo: Senac, 2001.

CANDIDA, Richard Smith. Circuitos de subjetividade. História oral, o acervo e as artes. São Paulo: Letra e Voz, 2012. 
CANDIDO, Antonio. Os Parceiros do Rio Bonito. Estudos sobre o caipira paulista e a transformação dos seus meios de vida. 9ª ed. São Paulo: Duas Cidades; Ed.34, 2001.

CASCUDO, Luis da Câmara. Dicionário do Folclore Brasileiro. $-11^{a}$ ed. São Paulo: Ed. Global, 2002.

CAVALCANTI, Maria Laura Viveiros de Castro. $O$ rito e o tempo: ensaios sobre o carnaval. Rio de Janeiro: Civilização Brasileira, 1999.

. Carnaval carioca: dos bastidores ao desfile. Rio de Janeiro: Editora UFRJ, 2006.

e GONÇALVES, Renata. (org). Carnaval em múltiplos planos. Rio de Janeiro: Aeroplano; Faperj, 2009.

CERTEAU, Michel de. Artes do Fazer: 1. A Invenção do Cotidiano. Petrópolis: Vozes, 1994.

CRECIBENI, Nelsinho. Convocação Geral: A Folia está na Rua. O Carnaval de São Paulo tem História de Verdade. São Paulo: O Artífice Editorial, 2000.

CUÍCA, OSVALDINHO e DOMINGUES, André. Batuqueiros da Paulicéia. São Paulo: Barcarolla, 2009.

CUNHA, Maria Clementino Pereira. Ecos da Folia. Uma história social do carnaval carioca entre 1880 e 1920. São Paulo: Companhia das Letras, 2001.

DAMATTA, Roberto. Carnavais, malandros e heróis: para uma sociologia do dilema brasileiro -6a ed. Rio de Janeiro: Rocco, 1997. 
DELGADO, Lucília de Almeida Neves. História Oral. Memória, tempo, identidades. Belo Horizonte: Autêntica, 2006.

DOMINGUES, Petrônio. Movimento Negro Brasileiro: alguns apontamentos históricos. Revista Tempo. Rio de Janeiro, Volume 12, No 23, Julho de 2007.

FERREIRA, Felipe. O Livro de Ouro do Carnaval Brasileiro. São Paulo: Ediouro, 2005.

FRANCO JR., Hilário. Cocanha: a história de uma país imaginário. São Paulo: Companhia da Letras, 1998.

FRANGIOTTI, Nanci. O espaço do carnaval na periferia de São Paulo. Dissertação de Mestrado. São Paulo: FFLCH/USP, 2007.

FRAUENDORF, Max Christian. Época de Transição: surgem as Escolas de Samba. IN Cultura do Samba: Sua história e sua arte; texto utilizado na exposição de mesmo nome no SESC Itaquera em 2002.

FREITAS, Sonia Maria. História Oral: Possibilidades e Procedimentos. São Paulo: Humanitas, 2006.

GUIMARÃES, Fernanda Paiva. O samba em pessoa: narrativas das Velhas Guardas da Portela e do Império Serrano. Dissertação de Mestrado. São Paulo: FFLCH/USP, 2011. 
GALVÃO, Walnice Nogueira. Ao som do samba. Uma leitura do carnaval carioca. São Paulo: Editora Fundação Perseu Abramo, 2009.

GONÇALVES, Renata de Sá. Continuidade no espetáculo da mudança: o casal de mestre-sala e porta-bandeira. IN. Carnaval em Múltiplos Planos. CAVALCANTI, Maria Laura e GONÇALVES, Renata de Sá (orgs). Rio de Janeiro: Aeroplano Editora; Faperj, 2009.

GULLAR, Ferreira. Barroco: olhar e vertigem. IN: NOVAES, Adauto (org). O Olhar. São Paulo: Companhia das Letras, 1988.

HAUSER, Arnold. História Social da Arte e da Literatura. São Paulo: São Paulo: Martins Fontes, 1997.

HOBSBAWM, Eric e RANGER, Terence (orgs).A invenção das tradições. $4^{\mathrm{a}}$ ed. São Paulo: Paz e Terra, 2006.

LADURIE, Emmanuel Le Roy. O carnaval de Romans : da Candelária à quarta-feira de cinzas 1579-1580. São Paulo: Companhia das Letras, 2002.

LE GOFF, Jacques. História e Memória. Campinas: Ed.Unicamp, 1990. e TRUONG Nicolas. Uma História do Corpo na Idade Média. Rio de Janeiro: Civilização Brasileira, 2006.

LEOPOLDI, José Sávio. Escola de samba, ritual e sociedade. Rio de Janeiro: Editora UFRJ, 2010.

LOPES, Nei. Partido Alto: Samba de Bamba. Rio de Janeiro: Pallas, 2005.

MANZATTI, Marcelo Simon. Samba Paulista do centro cafeeiro à periferia do centro. Estudo sobre o samba de bumbo ou samba rural paulista. Dissertação de Mestrado. São Paulo: PUC-SP, 2005. 
MAZOCO, Eliomar Carlos. Congo de Máscaras. Vitória: UFES, 1993.

MEIHY, José Carlos Sebe Bom. Manual de História Oral. São Paulo: Loyola, 1996.

e HOLANDA Fabíola. História Oral: como fazer, como pensar? São Paulo: Contexto, 2011.

MENISTREL, Francisco de Assis Santana. A batucada da Nenê de Vila Matilde. Formação e transformação de uma bateria de escola de samba paulistana. Dissertação de Mestrado. Campinas: Unicamp, 2009.

MÉSZÁROS, István. Para além do capital. Rumo a uma teoria da transição. São Paulo: Boitempo, 2002.

MONTENEGRO, Antonio Torres. História oral e memória. A cultura popular revisitada. São Paulo: Contexto, 2010.

MORAES, Wilson Rodrigues. Escolas de Samba de São Paulo. São Paulo: IMESP, 1978.

MORAES, José Geraldo Vinci de. As sonoridades paulistanas: a música popular na cidade de São Paulo -final do século XIX ao início do século XX. Rio de Janeiro: Funarte, 1995.

MUNIZ, J. Júnior. Do batuque à escola de samba. São Paulo: Símbolo, 1976.

MUSSA, Alberto e SIMAS, Luiz Antônio. Samba de Enredo. História e Arte. Rio de Janeiro: Civilização Brasileira, 2010.

NOVAES, Adauto (org). O Olhar. São Paulo: Editora Companhia das Letras, 1988. 
OLIVEIRA, Chirstian Dennys Monteiro de. Geografia do turismo na cultura carnavalesca: O sambódromo do Anhembi. São Paulo: Paulistana, 2007.

OLIVEIRA, Kelly Adriano. Entre o lúdico e a luta: Leandro de Itaquera, uma escola de samba na cidade de São Paulo. Dissertação de Mestrado. São Paulo: FFLCH/USP, 2002.

ORTIZ, Elsa Maria Nitsche. O sujeito do samba-enredo. Revista Linguagem \& Ensino, Rio Grande do Sul, Volume 1, N²,115-132, 1998.

ORTIZ, Renato. A moderna tradição brasileira. Cultura Brasileira e Indústria Cultural. São Paulo: Brasiliense, 1988.

PARANHOS, Adalberto. Os desafinados: sambas e bambas no "Estado Novo". Tese de Doutorado. São Paulo: PUC-SP, 2005.

PINTO, Regina Pahim. O movimento negro em São Paulo: luta e identidade. Tese de Doutorado. São Paulo: FFLCH-USP, 1993.

PUTTERMAN, Paulo. Indústria Cultural, a agonia de um conceito. São Paulo: Editora Perspectiva, 1994.

QUEIROZ, Maria Isaura Pereira de. Carnaval Brasileiro o vivido e o mito. São Paulo: Brasiliense, 1992.

RODRIGUES, Ana Maria. Samba Negro, Espoliação Branca. São Paulo: Hucitec, 1984.

SANDRONI, Carlos. Feitiço decente. Transformações do samba no Rio de Janeiro (1917-1933). Rio de Janeiro: Ed. Jorge Zahar, 2001. 
SEBE, José Carlos. Carnaval, Carnavais. São Paulo: Ática, 1984.

SEVCENKO, Nicolau. Orfeu Extático na Metrópole: São Paulo sociedade e cultura nos frementes anos 20. São Paulo. Cia das Letras, 1992.

SILVA, Zélia Lopes da. Os carnavais de rua e dos clubes na cidade de São Paulo. Metamorfoses de uma festa (1923-1938). São Paulo: Editora Unesp; Londrina: Eduel, 2008 .

SIMSON, Olga Rodrigues de Morae Von. Brancos e Negros no Carnaval Paulistano, São Paulo: Tese de Doutorado: FFLCH-USP, 1989.

Carnaval em Branco e Negro: Carnaval Popular Paulistano: 19141988. Campinas, Editora da Unicamp; São Paulo: Editora da Universidade de São Paulo; Imprensa Oficial do Estado de São Paulo, 2007.

. Mulher e Carnaval: mito e realidade. REVISTA DE HISTÓRIA, São Paulo, nº125-126, ago-dez/91 a jan-jul/92, p.7-32.

SOARES, Reinaldo Silva. O Cotidiano de uma escola de samba paulistana: o caso da Vai-Vai. Dissertação de Mestrado. São Paulo: FFLCH/USP,1999.

SOIHET, Raquel. Reflexões sobre o carnaval na historiografia - algumas abordagens. Rio de Janeiro: Revista Tempo, vol. 7, pp. 169-188, 1999.

A subversão pelo riso. Estudos sobre o carnaval carioca. Da BelleÉpoque ao tempo de Vargas. Uberlândia: Edufu, 2008.

TINHORÃO. José Ramos. Pequena História da Música Popular: da modinha a canção de protesto. Rio de Janeiro: Vozes, 1975.

. A imprensa carnavalesca no Brasil: um panorama da linguagem cômica. São Paulo: Hedra, 2000. 
THOMPSON, Paul. Voices of the Past: Oral History. Oxford: Oxford University Press, 1978.

URBANO Maria Apparecida; NABHAN, Neusa Neif; SANTOS, Yolanda Lhulier dos. Arte em desfile: escola de samba paulistana. São Paulo: EDICON, 1987.

URBANO Maria Apparecida. Carnaval \& Samba em evolução na cidade de São Paulo. São Paulo: Ed. Plêiade, 2006.

VALENÇA, Raquel. Carnaval. Pra tudo se acabar na quarta-feira. Rio de Janeiro: Relume-Dumará: Prefeitura do Rio, 1996.

VIANNA, Hermano. O mistério do samba. Rio de Janeiro: UFRJ Editora, Jorge Zahar Editor, 1995.

\section{PERIÓDICOS}

JORNAL A HORA DO POVO

JORNAL DIÁRIO POPULAR

JORNAL FOLHA DA TARDE

JORNAL FOLHA DE SÃO PAULO

JORNAL GAZETA ESPORTIVA

JORNAL NOTÍCIAS POPULARES

JORNAL O ESTADO DE SÃO PAULO 
JORNAL TRIBUNA DA LAPA

JORNAL ÚLTIMA HORA

REVISTA VEJA

REVISTA FATOS E FOTOS

REVISTA MANCHETE

\section{VÍDEOS}

Documentário: SAMBA A PAULISTA. Fragmentos de uma história esquecida, Diretor: Gustavo Mello, Produção TV Cultura, 2007.

Documentário: Seu Nenê da Vila Matilde, direção de Carlos Cortez, São Paulo, TV Cultura, 2001.

\section{DOCUMENTOS}

\section{FICHAS TÉCNICAS}

FICHA TÉCNICA 1969. Centro de Documentação e Memória do Samba, FT 1969.

FICHA TÉCNICA 1975. Centro de Documentação e Memória do Samba, FT 1975. 
FICHA TÉCNICA 1977. Centro de Documentação e Memória do Samba, FT 1977.

FICHA TÉCNICA 1978. Centro de Documentação e Memória do Samba, FT 1978.

FICHA TÉCNICA 1979. Centro de Documentação e Memória do Samba, FT 1979.

FICHA TÉCNICA 1980. Centro de Documentação e Memória do Samba, FT 1980.

FICHA TÉCNICA 1981. Centro de Documentação e Memória do Samba, FT 1981.

FICHA TÉCNICA 1982. Centro de Documentação e Memória do Samba, FT 1982.

FICHA TÉCNICA 1983. Centro de Documentação e Memória do Samba, FT 1983.

FICHA TÉCNICA 1984. Centro de Documentação e Memória do Samba, FT 1984.

FICHA TÉCNICA 1985. Centro de Documentação e Memória do Samba, FT 1985.

FICHA TÉCNICA 1986. Centro de Documentação e Memória do Samba, FT 1986. 
FICHA TÉCNICA 1987. Centro de Documentação e Memória do Samba, FT 1987.

FICHA TÉCNICA 1988. Centro de Documentação e Memória do Samba, FT 1988.

FICHA TÉCNICA 1990. Centro de Documentação e Memória do Samba, FT 1990.

FICHA TÉCNICA 1992. Centro de Documentação e Memória do Samba, FT 1992

PASTA ANHEMBI TURISMO 1989. Centro de Documentação e Memória do Samba, AHB 1989.

PASTA ANHEMBI TURISMO 1990. Centro de Documentação e Memória do Samba, AHB 1990

PASTA ANHEMBI TURISMO 1991. Centro de Documentação e Memória do Samba, AHB 1991.

PASTA ANHEMBI TURISMO 1992. Centro de Documentação e Memória do Samba, AHB 1992.

PASTA ANHEMBI TURISMO 1993. Centro de Documentação e Memória do Samba, AHB 1993. 
PASTA ANHEMBI TURISMO 1994. Centro de Documentação e Memória do Samba, AHB 1994.

PASTA ANHEMBI TURISMO 1995. Centro de Documentação e Memória do Samba, AHB 1995.

PASTA ANHEMBI TURISMO 1996. Centro de Documentação e Memória do Samba, AHB 1996.

\section{ENTREVISTAS}

MARCOS DOS SANTOS. Marcos dos Santos. Fundador da escola de samba Tom Maior e diretor do Centro de Documentação e Memória do Samba (CDMS). Entrevista realizada em 10 de agosto de 2010. São Paulo/SP.

MESTRE GABI. Gabriel de Souza Martins. Dirigente da FESEC e fundador e presidente da presidente da Associação de Mestres Sala, Porta-Bandeiras e Estandartes do Estado de São Paulo, a AMESPBEESP. Entrevista realizada em 25 de outubro de 2010. São Paulo/SP.

DONA CHINA. Emília Feliciano Ferreira. Primeira porta-bandeira do Vai-Vai, fundadora da escola de samba Unidos de Vila Carrão e da Associação de Mestres Sala, Porta-Bandeiras e Estandartes do Estado de São Paulo, a AMESPBEESP. Entrevista realizada em 09 de julho de 2011. São Paulo/SP. 
MESTRE DIVINO. Valdevino Batista da Silva. Diretor de bateria das escolas de samba Camisa Verde e Branco, Nenê de Vila Matilde e Imperial. Fundador e presidente da escola de samba Imperial e ex-presidente da União das Escolas de Samba Paulistana (UESP). Entrevista realizada em 15 de outubro de 2011. São Paulo/SP.

OSVALDINHO DA CUÍCA. Osvaldo Barro. Fundador da escola de samba Gaviões da Fiel, compositor e membro da Velha Guarda do Vai-Vai e primeiro cidadão-samba da cidade de São Paulo. Entrevista realizada em 21 de janeiro de 2012. São Paulo/SP.

ÁLVARO CASADO. Álvaro Ribeiro. Fundador da escola de samba Acadêmicos do Tatuapé e ex-presidente da União das Escolas de Samba Paulistana (UESP). Entrevista realizada em 01 de maio de 2012. Poá/SP. 
ANEXOS 


\title{
ANEXO 1
}

\author{
MINI ST BRIO DA JUSTIÇA \\ DEPARTAMENTO DE POLICIA FEDERAL \\ SUPERINTENDENCIA REGIONAL EM SRO PAULO
}

PORTARIA NN $006 / 76$.

Em, 19 de Janeiro de 1976.

O Superintendente Regional do Departamento de Policia Federal, no Estado de São Paulo, no uso de suas atribuições legais e,

CONSIDERANDO ser exclusiva competência da União, através do Departamento de Polícia Federal, prover, no Territorio Nacional, a censura de diversões priblicas (Arto 8, Item VIII, alínea "d" da Constituição Federal);

CONSIDERANDO que no âmbito dessa competência eș tá compreendida a aprovação, pelos seus 6rgãos próprios, de todas as materrias que dizem respeito à diversões públicas, bem como as apresen tações de préstitos, grupos, cordőes, ranchos e estandartes carmavalescos (Arto 4ㅇ, nํ VIII do Decreto $n \cong 20.493$, de 24/01/1946).

R E S O I V E baixar as seguintes instruções, que deverão vigorar para o Carnaval de 1976:

1 - Nenhum BAILE CARNAVAIESCO poderá ser realizado em teatrfos, cinemas, parques, clubes, associaçoses recreativas ou esportivas, salões, hotéis ou dependências adequadas, sem a devida aprovação do respectivo programa nelo Serviço de Censura de Diversões Pŕblicas da Superintendência Regional do D.P.F. em São Paulo ou pelos orgãos competentes da Divisão de Santos e das Delegacias de Bauru e Iorena.

2 - Para a aprovação de suas programações, os interessados deverão fazer requerimento em três vias dirigido ao Chefe do Serviço de Censura de Diversões Públicas, em tempo hábil, acompanhado dos seguintes documentos:

2.1. - Autorização das Sociedades Protetoras

dos Direitos Autorais;

2.2. - Contrato de trabalho dos músicos devidamente visados pela Ordem dos Mŕsicos do Brasil, Seção de São Paulo;

Continua: 
Continuação:

2.3. - Contratos de trabalho dos artistas visados pela Delegacia Regional do Trabalho, do Ministério do Trabalho em São Paulo ou Sindicato de Classe;

2.4. - A aprovaçăo do local pelo Corpo de Bombeiros;

2.5. - Alvarás de Funcionamento fornecidos pelas Prefeituras dos Municipios de São Paulo, Santos, Bauru e Lorena; 2.6. - Croquis aa Decoração dos Salões e das Alegorias a serem feitas, bem como dos figurinos e histbrico dos enredos, das Escolas de Samba, Ranchos, etc.;

2.7. - Exposição pormenorizada, em três vias, da programą̧ão a ser cumprida nos Bailes, Participantes (Núsicas e Cantores), esclarecendo os casos em que houver desfile de fantasias, em detalhe;

2.8. - Para a realização de Bailes Infantis, os responsáveis pelos mesmos deverão apresentar Alvará do Juízado de Menores.

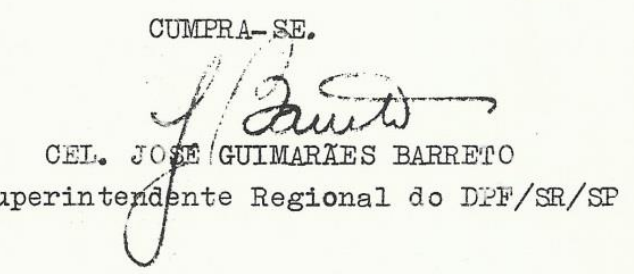




\section{ANEXO 2}

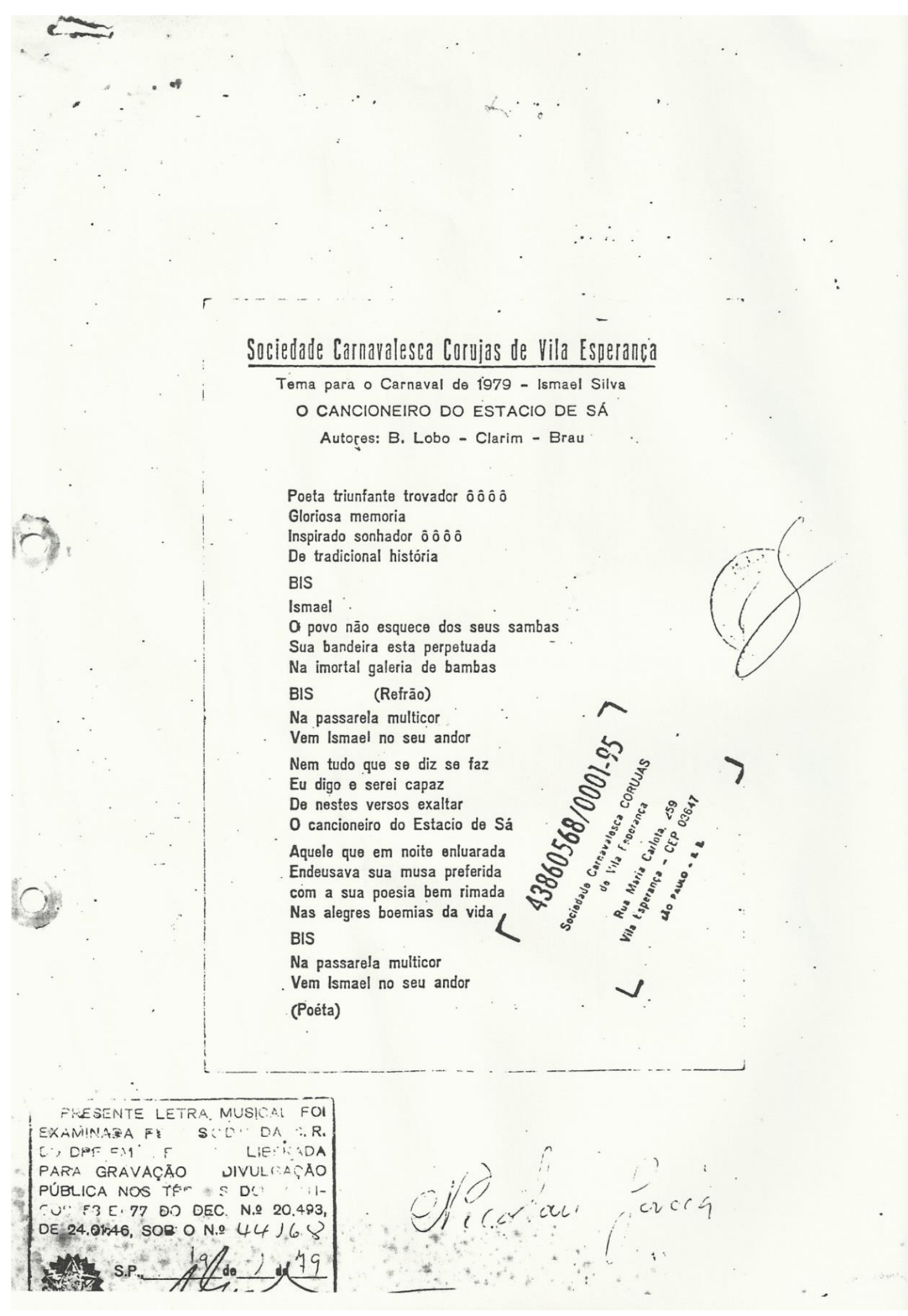




\section{ANEXO 3}

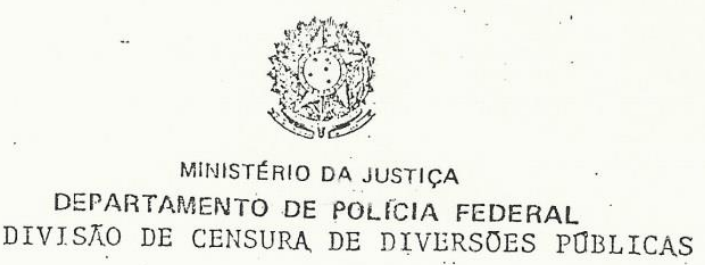

OF. $N^{9} 1.509 / 85-G A B / D C D P$

Brasília-DF

Em 03 de setémbro de 1985.

\section{Senhor Presidente,}

Em ątenção à consulta formulada ao $\mathrm{F} \times \mathrm{m}^{\circ}$. Sr. Minisiro de Estado da Justiça, atravês do telegrama datado de 05 de agosto de 1985, informaṇos a V.Sa. que este Orgão, após analisar a matéria, decidiu dispensar o exame prévio dos enredos, samba-enredo. alegorias, adereços e figurinos das Escolas de Samba, desde que as progranaçōes sejam apresentadas à Censura Federal, instruj̉as com os seguintes documentos:

1.Título do Tema do enredo e samba enre do e respectivas autorizaçōes autorais;

2.Termo de Compromisso - assinado pelo'. responsâvel - à fiel observância das normas da Censura, nö que se re fere à nudez com tapa-sexo e o uso de alegorias e adereços que, de forma alguna, sirvam de armas ou possam causar ferimentos ao püblico... testós de estima e consideração. Apresentanos, na oportunidade, nossos pro

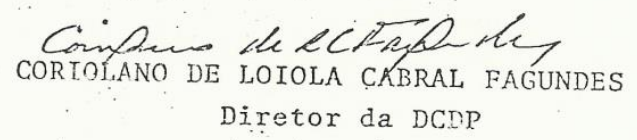

Iline $\mathrm{Sr}$.

EDUARDO JOACUIM DE OLIVEIRA

M:D. Presidente da União das Escolas de Samba Paulistanas SÃO PAULO/SP 